UNIVERSIDADE DE SÃO PAULO

FACULDADE DE FILOSOFIA, LETRAS E CIÊNCIAS HUMANAS

DEPARTAMENTO DE ANTROPOLOGIA

PROGRAMA DE PÓS-GRADUAÇÃO EM ANTROPOLOGIA SOCIAL

THAÍS CHANG WALDMAN

Entre batismos e degolas:

(des)caminhos bandeirantes em São Paulo

VERSÃO CORRIGIDA

SÃO PAULO

2018 



\section{Entre batismos e degolas: \\ (des)caminhos bandeirantes em São Paulo}

VERSÃO CORRIGIDA

Tese apresentada ao Programa de Pós-Graduação em Antropologia Social do Departamento de Antropologia da Faculdade de Filosofia, Letras e Ciências Humanas da Universidade de São Paulo, para a obtenção do título de

Doutora em Antropologia Social

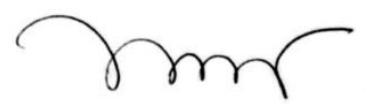

Orientadora: Prof ${ }^{a}$. Dr ${ }^{a}$. Fernanda Arêas Peixoto

\section{SÃO PAULO}


Autorizo a reprodução e divulgação total ou parcial deste trabalho, por qualquer meio convencional ou eletrônico, para fins de estudo e pesquisa, desde que citada a fonte.

Catalogação na Publicação

Serviço de Biblioteca e Documentação

Faculdade de Filosofia, Letras e Ciências Humanas da Universidade de São Paulo

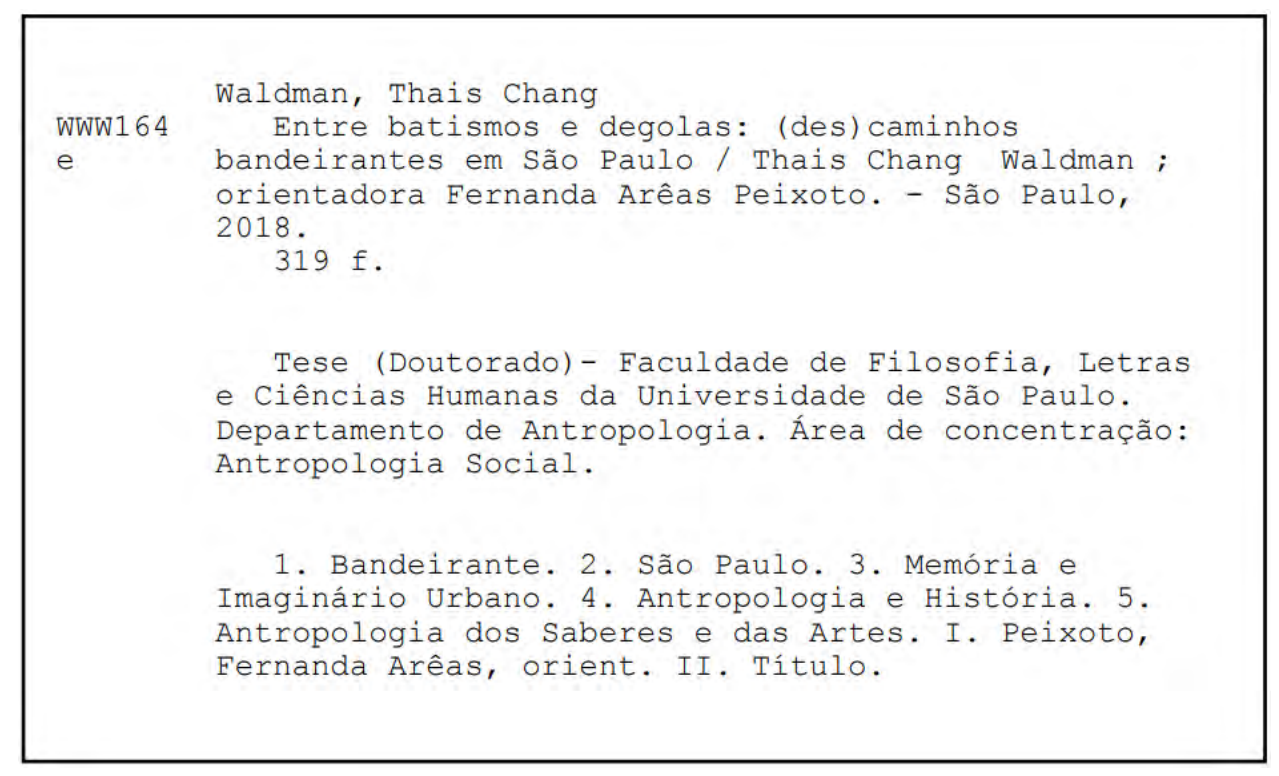


Aprovada em 9 de março de 2018:

Banca Examinadora:

Prof. a Dra. Ana Cláudia Scaglione Veiga Castro

Prof. ${ }^{a}$ Dra. Julia Ruiz di Giovanni

Prof. Dr. Paulo César Garcez Marins

Prof. a Dra. Silvana de Souza Nascimento 



\section{AGRADECIMENTOS}

Os agradecimentos começam à professora Fernanda Arêas Peixoto, presença “incontornável” na minha trajetória desde a graduação. Obrigada pela confiança e pelas parcerias, por compartilhar sua experiência e seus conhecimentos, pela orientação vital.

Aos colegas do Coletivo ASA — Artes, Saberes e Antropologia, meu principal espaço de interlocução acadêmica, a quem sou muito grata pelas constantes trocas e discussões, assim como pelo incentivo sempre afetuoso. Agradeço especialmente à Júlia Di Giovanni, por sugerir novos rumos para esta pesquisa durante o exame de qualificação e também durante a banca de defesa da tese; à Lorena Avellar, "orientadora" nos estudos e na vida; ao Alexandre Bispo, pelas inúmeras leituras interessadas que fez deste trabalho; ao Bruno Pereira, ao Bruno Zorek e ao Vinícius Spira, que também foram leitores atentos de partes fundamentais da tese e muito me ajudaram a repensar a cidade que tanto estudamos; à Júlia Goyatá, pela leitura do relatório de pesquisa antes do exame de qualificação; ao Diogo Maciel, companheiro nestes e em outros percursos; à Aline Murillo, por me cercar de carinho; ao Luís Felipe Sobral, amigo que tive a sorte de conhecer nas reuniões do ASA; e à Adriana Taets, com quem felizmente ingressei nesta jornada.

Adriana de Oliveira Silva, foi uma presença incondicional, acompanhando de perto cada passo desta pesquisa.

Nos tempos difíceis que são aqueles da conclusão de uma tese, pude contar com o apreço de Ana Martha Yano, Renata Gessullo e Rodrigo Lobo, amigos mais que queridos, que leram, comentaram e me ajudaram a revisar este trabalho.

Sou muito grata também à amizade e aos palpites de Priscila Vieira, parceira de todas horas; de Rogério Fernandes, irmão do coração; de Marília Jahnel, amiga das antigas; de Bianca Briguglio, 
mana sagaz e generosa; de Florbela Ribeiro e de Enrico Spaggiari, presentes que o mestrado me trouxe; de Stefan Klein, comparsa dos mais atenciosos; e de Alexandre Cunha e Daniela Camargo, que, apesar dos distanciamentos, sempre estiveram por perto quando precisei.

Não posso deixar de mencionar as leituras de Paula Alegria, com quem tanto aprendi sobre os estudantes secundaristas; e também as sugestões de Augusto Ventura dos Santos, Bruna Triana, Eduardo Dullo, Glaucia Destro e Marie Goulart, que acompanharam em diferentes momentos esta pesquisa.

Amigos-leitores não faltaram nesta longa empreitada, ainda bem!

Agradeço também à Camila Mainardi e ao Carlos Filadelfo, pelas ótimas conversas; assim como à Jacqueline Teixeira e à Talita DalBó, por enfrentarem comigo a reta final da escrita do doutorado.

Aos professores Ana Castro, Paulo César Garcez Marins e Silvana Nascimento, sou muito grata por terem participado da banca de defesa da tese. À Ana, obrigada também pelo estímulo desde o mestrado e pela leitura atenta do trabalho durante o exame de qualificação. Ao Paulo (cujos trabalhos são referências fundamentais para esta pesquisa), pelo incentivo contínuo, desde o dia em que nos conhecemos.

Aos professores Fernanda Pitta, Giselle Beiguelman, John Dawsey, Marina Vanzolini, Marta Amoroso, Nardo Germano, Paula Monteiro, Paulo Iumatti, Pedro Cesarino, Renato Cymbalista e Renato Queiroz, obrigada pelo apoio e pelas valiosas sugestões que me deram ao longo deste trabalho.

Ao Danilo Sato, agradeço a ajuda com os mapas. 
Aos demais colegas e professores da Universidade de São Paulo (USP), sou grata pelo convívio e aprendizado dos últimos anos.

Agradeço aos artistas interlocutores neste trabalho, em especial: Fernando Piola, Flávio Cerqueira, Francisco Carlos, Jaime Lauriano e Mario Ramiro, pelas trocas de ideias e pelas imagens e textos cedidos.

Aos funcionários do Programa de Pós-Graduação em Antropologia Social da USP e das instituições onde pesquisei, obrigada pela presteza. Sou grata, principalmente, às equipes do Arquivo Histórico Municipal Washington Luís; do Arquivo Público do Estado de São Paulo; da Biblioteca Brasiliana Guita e José Mindlin; da Biblioteca Florestan Fernandes; da Biblioteca do Instituto de Estudos Brasileiros; da Biblioteca Mário de Andrade; do Conselho de Defesa do Patrimônio Histórico, Arqueológico, Artístico e Turístico; da Pinacoteca do Estado de São Paulo; do Museu Mariano Procópio; e, principalmente, da Biblioteca e do Arquivo Permanente do Museu Paulista, em especial Flávia Urzua e Ernandes Lopes. Cabe mencionar ainda o auxílio prestativo de Sandra Brecheret Pellegrini, do Instituto Victor Brecheret; de Sonia Schaf, uma das fundadoras da Associação dos ex-alunos da Escola Estadual Fernão Dias Paes; e do Comitê Paulista de Solidariedade à Luta pelos Tapajós, grande fonte de inspiração.

Nas idas e vindas pelo Museu Paulista conheci os pesquisadores Carlos Lima Junior e Michelli Monteiro, com os quais muito aprendi. Já no Instituto de Artes da Unesp, ganhei novos amigos, entre os quais destaco: Michel Leal, Regiane Bento, Debyh Dias, Janaína Lins, Melanie Martins de Mello e Melissa Vassalli.

Talita Bedinelli, Lilian Aveiro, Beatriz Pasqualino, Melina Mesquita, Paula Pires e Rômulo Vinícius Martins me dão a solidez da amizade duradoura. Muitos anos marcados por afeto, risadas e cervejas marcaram também meu caminho e os de Adriana Depieri, Alberto D’Angelo, Amanda Spadotto, Gisleine Scandiuzzi, Luís F. Bokor (o “Alemão”), Marcela Hoenen, Pedro Suarez e das já mencionadas Mamá e Renatinha. Caminho também marcado por muitas cores com Tikka Meszaros, Feik Frasão, Glauci Miyata e Moises Souza. Obrigada pela presença constante! 
Por fim, Fábio Fujita, profissional exemplar, sou muito grata pela revisão da tese.

Agradeço, sobretudo, à minha família: aos meus pais, Chang e Eliseu, à minha irmã Tatiana e ao Nem, por muitas coisas este trabalho é dedicado a vocês.

Esta pesquisa de doutorado foi possível graças ao financiamento do Conselho Nacional de Desenvolvimento Científico e Tecnológico (CNPq). 
WALDMAN, Thaís Chang. Entre batismos e degolas: (des)caminhos bandeirantes em São Paulo. Tese de Doutorado. Programa de Pós-Graduação em Antropologia Social. Faculdade de Filosofia, Letras e Ciências Humanas. Universidade de São Paulo (USP). São Paulo. 2018.

\section{RESUMO}

Acompanhar as flutuações e os percursos bandeirantes na cidade de São Paulo, objetivo desta tese, significa balizar os usos que pessoas e grupos fazem desse personagem para dar sentido a suas experiências em momentos e lugares específicos. Produzido no interior de uma teia de práticas e discursos, o bandeirante não é uma categoria fixa, tampouco tem seu significado dado de antemão. Para além de figura histórica do período colonial brasileiro, trata-se da invenção de uma metrópole que ele mesmo ajuda a produzir, numa operação na qual sobrepõe, cruza, destrói e reinventa falas, atitudes e miradas, muitas vezes contraditórias. Ao trazê-lo para o primeiro plano (com os diferentes sentidos e formas que sua figura vai assumindo, assim como as associações que ela estabelece e que a constituem), procuro mostrar como suas tão variadas encarnações não se substituem uma à outra, em linha diacrônica, mas convivem, muitas vezes de modo tenso e ambíguo, em distintos enredos simultâneos. Sensível às transformações da cidade, o bandeirante comenta as mudanças urbanas e lhes confere sentido, não apenas expressando essas transformações, mas engendrando-as e produzindo-as. Presença incontornável na capital paulista, ele se insere em frentes, espaços e ramos diversos, sendo cultivado e recriado em um movimento permanente. Atenta às reelaborações locais e às tantas historicidades nele impregnadas, sigo os itinerários acidentados de algumas figurações desse personagem que, ao se recriar no tempo e com o tempo, condensa e articula diferentes embates, temporalidades e sentidos.

Palavras-chave: Bandeirante. São Paulo. Memória e Imaginário Urbano. Antropologia e História. Antropologia dos Saberes e das Artes. 

WALDMAN, Thaís Chang. Between baptisms and beheadings: the (mis)directions of the Bandeirantes in São Paulo. Thesis (Doctorade in Social Antropology). Faculty of Phisolophy, Languages and Literature, and Human Sciences. University of São Paulo (USP). São Paulo, 2018.

\begin{abstract}
Accompanying the moves and paths of the Bandeirantes in the city of São Paulo, the objective of this thesis, means surveying the uses that peoples and groups make of these characters in order to bestow meaning on their experiences at specific moments and in specific places. Produced within a web of practices and discourses, the Bandeirantes are not a set category, nor is their meaning preestablished. More than historical figures from the colonial period in Brazil, they are an invention of a metropolis that they themselves helped to produce in an operation in which sayings, attitudes and views, often times contradictory, are overlapped, intersected, destroyed and reinvented. By bringing them to the forefront (with the different meanings and forms that these figures assume, as well as the associations established, and which constitute them), I attempt to demonstrate how their varied incarnations do not substitute one another, in a diachronic line, but instead coexist, often in a tense and ambiguous manner, in distinct, simultaneous story-lines. Sensitive to the city's transformations, the Bandeirantes comment on urban changes and confers meaning upon them, not only expressing these transformations, but also engendering and producing them. An inescapable presence in the city of São Paulo, they are found in facades, spaces and sectors, cultivated and recreated in a permanent movement. Mindful of local redevelopments and the many historicities imbued in these characters, I follow the turbulent journeys of some of the manifestations of the Bandeirantes, which, through their self-reinvention in time and with time, embody and convey a series of conflicts, temporalities and meanings.
\end{abstract}

Key words: Bandeirante. São Paulo. Memory and Urban Imagery. Anthropology and History. Anthropology of Knowledge and Art. 



\section{ÍNDICE DE IMAGENS}

Figura 0.1 — Lambe-lambe "Fora bandeirantes do mundo", praça da República, 2016 .............................. 23

Figura 0.2 — Lambe-lambes "Fora bandeirantes do mundo", São Paulo, 2016 ............................................. 24

Figura 0.3 - Monumento às bandeiras ganha novas cores, 2016 ………………………................................. 25

Figura 0.4 — "Borba Feio"/"Borba Gato", meme compartilhado nas redes sociais, 2016 ....................... 27

Figura 0.5 - "Contra os bandeirantes de camarote", meme compartilhado nas redes sociais, 2016 _....... 28

Figura 0.6 - "Armandinho", tirinha de Alexandre Beck, 2016 …………………………………………….... 29

Figura 0.7 - Semáforos, praça Armando de Salles Oliveira, 2017 .................................................................. 33

Figura 0.8 - "Aqui, o bandeirante ideal", reprodução da tela Domingos Jorge Velho e o loco-tenente Antônio Fernandes de Abreu (1903), veiculada em 2008 na revista Nova Escola ...................................... 38

Figura 1.1 —Compêndio de bistória do Brasil (1968), de Antônio José Borges Hermida ..................................... 41

Figura 1.2 — Festejo à frente do edifício-monumento do Ipiranga, anos 1890............................................. 42

Figura 1.3 - Sala de cartografia colonial e documentos antigos. Museu Paulista, anos 1930..................... 43

Figura 1.4 - Capa do ensaio biográfico Domingos Jorge Velho (1990), de Renato Castelo Branco................ 44

Figura 1.5 — Domingos Jorge Velho e o loco-tenente Antônio Fernandes de Abreu (1903), de Benedito Calixto ... 46

Figura 1.6 - Luís XIV em indumentária real (1701), de Hyacinthe Rigaud; Luís XIV em armadura (1694), de Hyacinthe Rigaud; e Dom João IV (1817), de Jean-Baptiste Debret..................................... 50

Figura 1.7 - Manuel da Borba Gato (1921), de Nicola Rollo, e Manuel Preto (1921), de Adrian Henri Vital van Emelen

Figura 1.8 - Placa de licenciamento de veículo (1973), vaso comemorativo do IV Centenário da cidade de São Paulo (1954), chaveiro (s/d)

Figura 1.9 - Breves lições de história do Brasil (1922), de Creso Braga ............................................................... 53

Figura 1.10 - Capa do romance Domingos Jorge Velho (1930), de Mario Wanderley; cédula do bônus Pró-Constituição (1932) do Thesouro do Estado de São Paulo; Bilhete de loteria (1971) da Caixa Econômica Federal 54

Figura 1.11 — Interior do edifício-monumento: vista a partir da escadaria central, 1892 ........................... 56

Figura 1.12 - Estudo para a escadaria principal do Museu Paulista, de Adrian Henri Vital van Emelen, década de 1920

Figura 1.13 - Afonso Taunay na escadaria principal do Museu Paulista, anos 1930 .................................... 59

Figura 1.14 - Antônio Raposo Tavares e Fernão Dias Paes Leme, Museu Paulista, anos 1930. ......................... 61

Figura 1.15 - Afonso Taunay ao lado da escultura por ele encomendada, Antônio Raposo Tavares (1922), de Luigi Brizzolara 
Figura 1.16 - Antônio Raposo Tavares, de Amadeo Zani, no livro Índios! Ouro! Pedras! (1926), de Afonso Taunay......

Figura 1.17 - Ruínas da casa e capela de Antônio Raposo Tavares em Quitaúna, de João Batista da Costa, no livro Índios! Ouro! Pedras! (1926), de Afonso Taunay

Figura 1.18 - Chefe bandeirante (1929), de Henrique Bernardelli.....

Figura 1.19 - Henrique Bernardelli em seu ateliê, diante de uma das versões recusadas de sua tela Ciclo da caşa ao indio (1925)

Figura 1.20 — Os bandeirantes (1889), de Henrique Bernardelli ................................................................70

Figura 1.21 - Os bandeirantes (estudo), de Henrique Bernardelli. .............................................................74

Figura 1.22 - Ilustração de José Wasth Rodrigues para o livro Vida e morte do bandeirante (1943), de José de Alcântara Machado .......................................................................................................76

Figura 1.23 —Bandeirante e india, de Henrique Bernardelli ..............................................................................77

Figura 1.24 — Vulto retratado no fundo da tela Bandeirante e india (detalhe) ................................................79

Figura 1.25 — Sem título (Bandeirante e indio), de Henrique Bernardelli..........................................................8 80

Figura 1.26 — Retirada do cabo de São Roque (1927), de Henrique Bernardelli................................................81

Figura 1.27 — Últimos momentos de um bandeirante (1932), de Henrique Bernardelli .......................................85

Figura 1.28 — Ciclo do ouro (1922), de Rodolfo Amoedo ...............................................................................8

Figura 1.29 - Varação das canoas/ Bandeirante (1929), de Rodolfo Amoedo.................................................88

Figura 1.30 - Combate de milicianos de Mogi das Cruzes com botocudos (1920), de Oscar Pereira da Silva .........90

Figura 1.31 - Sauvages civilisés, soldats indiens de Mugi das Cruzas (Province de S. Paulo) combattant des botocudos (1834), de Jean-Baptiste Debret.................................................................................................92

Figura 1.32 - Vida e morte do bandeirante (1930), de José de Alcântara Machado..........................................94

Figura 1.33 — Breves lições de história do Brasil (1922), de Creso Braga ...........................................................95

Figura 1.34 - A partida da monção (1897), de Almeida Júnior, sala das monções, década de 1930 ..............96

Figura 1.35- Amolação interrompida (1894) e Caipira picando fumo (1893), de Almeida Júnior .......................97

Figura 1.36 — A partida da monção (1897), de Almeida Júnior .........................................................................98

Figura 1.37 — Partida de Porto Feliz, (1920-21) e Carga de canoas (1920), de Oscar Pereira da Silva ............ 100

Figura 1.38 - Benção dos canoões (1919) e Pouso no sertão-monções (1919), de Aurélio Zimmermann............ 100

Figura 1.39 - Encontro de duas monções no sertão (1920), de Oscar Pereira da Silva...................................... 101

Figura 1.40 - A partida das monções e Carga das canoas nos cartões telefônicos do Sistema Telebrás (Série Museus- 1996)........................................................................................................... 102

Figura 2.1 - Fernão Dias ganha corpo em mármore, granito e bronze em três distintos locais da

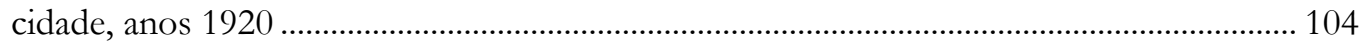

Figura 2.2 — Borba Gato se converte em monumento em Santo Amaro, anos 1960 ............................ 105

Figura 2.3 — Largo de São Bento, esquina com a rua Florêncio de Abreu, 1920.................................... 107 
Figura 2.4 - Lapide sepulcral de Fernão Dias e Maria Garcia Betim, transepto da igreja do mosteiro de São Bento; escultura em baixo-relevo de Fernão Dias, fachada exterior do mosteiro de São Bento. Anos 1920

Figura 2.5 — Parede externa do mosteiro de São Bento, rua Florêncio de Abreu, 2017

Figura 2.6 - Fernão Dias e Raposo Tavares, de Luigi Brizzolara, década de 1920.

Figura 2.7 - Fernão Dias coberto por um invólucro branco e translúcido durante a reforma do Museu Paulista, 2016

Figura 2.8 - Fotografias de Fernão Dias na exposição “Estamos Aquil”, 2017 114

Figura 2.9 - Parque da Independência, 1900/1915; Parque da Independência, 1910/1920 116

Figura 2.10 - Fernão Dias na capa da revista Manchete em homenagem ao IV Centenário de São Paulo e em um selo comemorativo dos cem anos do Museu Paulista.

Figura 2.11 - Fernão Dias e Raposo Tavares como símbolos da fraternidade ítalo-brasileira, 1922 121

Figura 2.12 - Fernão Dias no média-metragem Os bandeirantes, abertura do bloco "Ciclo do ouro e das pedras"

Figura 2.13 - Fernão Dias, de Luigi Brizzolara, na História do Brasil (1953), de Rocha Pombo, e também na História das bandeiras paulistas (1975) e em A grande vida de Fernão Dias Pais (1977), ambos de Afonso Taunay.

Figura 2.14 - J. Silveira agoniza em "Ciclo do ouro e das pedras"

Figura 2.15 - O caçador de esmeraldas, ateliê de William Zadig, Suécia, 1920 .....

Figura 2.16 - Inauguração do Monumento a Olavo Bilac, antigo belvedere da avenida Paulista, 1922 ....... 132

Figura 2.17 — Monumento a Olavo Bilac, cartão-postal, 1922... 133

Figura 2.18 - Estudantes do Centro Acadêmico XI de Agosto resgatam a escultura Beijo eterno, $1966 / 1984$

Figura 2.19 - Olavo Bilac, avenida Sargento Mário Kozel Filho, 2017

Figura 2.20 — O caçador de esmeraldas, Escola Estadual Fernão Dias Paes, 2015 ......................................... 137

Figura 2.21 — Guia dos monumentos nômades, 2015 .................................................................................... 138

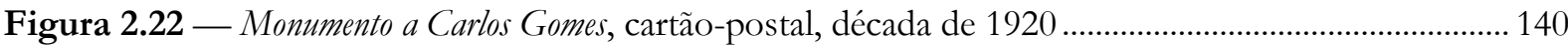

Figura 2.23 - Charge "Il dubbio di Bilac?", 1922 ………............................................................................... 145

Figura 2.24 — "Fagundes Varela, fantasiado de Álvares de Azevedo", charge de Belmonte, 1922......... 146

Figura 2.25 - A decapitação e o martírio do Monumento a Carlos Gomes, charges dos anos 1920 ............. 147

Figura 2.26 - "O leiloeiro enterrado vivo", charge de Belmonte, 1922 ...................................................... 148

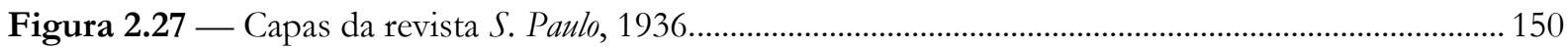

Figura 2.28 - Anhanguera, de Luigi Brizzolara, e Angelo Brunetti, detto Ciceruacchio, de Ettore Ximenes ... 151

Figura 2.29 - Anhanguera em uma propaganda eleitoral de Jânio Quadros.................................................. 152

Figura 2.30 — Deslocamentos da escultura $O$ caçador de esmeraldas............................................................. 154

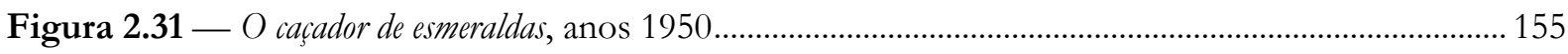

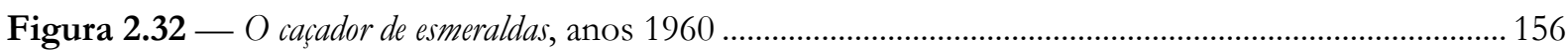


Figura 2.33 - O escoteiro, depósito municipal do Canindé, 2015 .............................................................. 158

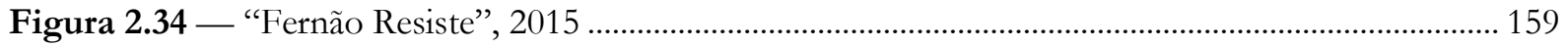

Figura 2.35- Homenagens a bandeirantes no entorno da Escola Estadual Fernão Dias Paes, 2017..... 160

Figura 2.36 - "Bandeirante e assassino", placa da rua Mourato Coelho, Pinheiros, 2017 ........................ 161

Figura 2.37 — Ensacamento de $O$ caşador de esmeraldas, 2015 …………………………................................. 163

Figura 2.38 - O caçador de esmeraldas presta solidariedade aos refugiados, 2015 ........................................ 164

Figura 2.39 - O caçador de esmeraldas resiste ao Palácio dos Bandeirantes, 2016 .......................................... 167

Figura 2.40 — Charge de Larte Coutinho, 2015 ........................................................................................... 169

Figura 2.41 - Borba Gato, de Júlio Guerra, anos 1960............................................................................. 170

Figura 2.42 — Borba Gato garoto-propaganda, anos 1970 .......................................................................... 173

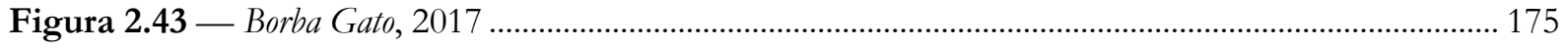

Figura 2.44 — Borba Gato na revista Chiclete com banana (1985) .................................................................. 177

Figura 2.45 — "Quem escondeu o Borba Gato?", 2007 ............................................................................. 178

Figura 2.46 - Cartazes próximos a Borba Gato, 2008 …………………………………………………....... 180

Figura 2.47 — Julgamento popular do Borba Gato, 2008 ............................................................................. 181

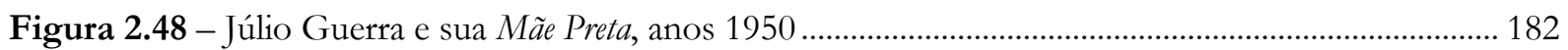

Figura 2.49 - Sobrevivência, de Eduardo Srur, 2008................................................................................... 184

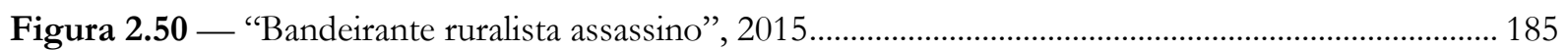

Figura 2.51 — Campanha “Quem matou Semião?”, 2015 ........................................................................... 186

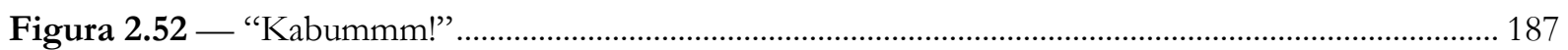

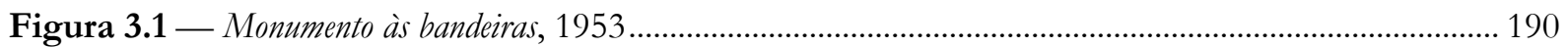

Figura 3.2 - Monumento às bandeiras, capa do álbum de cartões-postais, anos 1950 ................................... 191

Figura 3.3 - Monumento à resistência guarani, 2013 ...................................................................................... 192

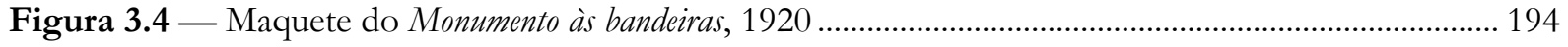

Figura 3.5 — L'eroismo dei bandeirantes ......................................................................................................... 198

Figura 3.6 - Ponte das Bandeiras (detalhe), aquarela de Prestes Maia ............................................................. 199

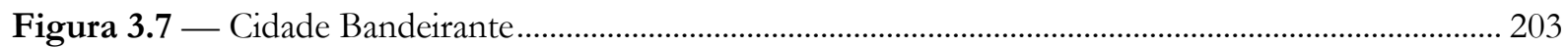

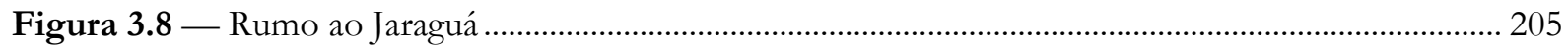

Figura 3.9 - Estudo de José Wasth Rodrigues para os painéis de azulejo com cenas históricas do bandeirismo no parque do Jaraguá, anos 1950 ……………………………………………….... 207

Figura 3.10 - Construção das fundações do Monumento às bandeiras, 1937 ................................................ 208

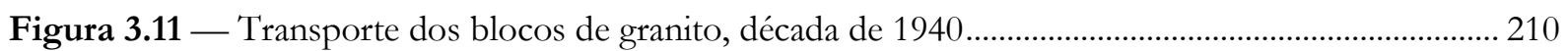

Figura 3.12 — Estudos em barro e gesso do Monumento às bandeiras, 1936 ................................................. 211

Figura 3.13 - Monumento às bandeiras na revista S. Paulo, 1936 .................................................................. 212

Figura 3.14 - Autorretrato do escultor Victor Brecheret, anos 1940......................................................... 213 
Figura 3.15 - Homem esculpindo fragmento do monumento, oficina Incerpi, anos 1940. 216

Figura 3.16 — Propaganda do hotel Comodoro, 1953 …....................................................................... 217

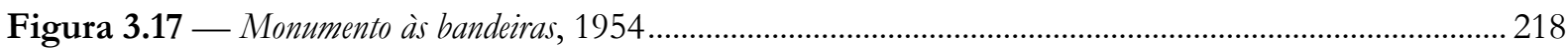

Figura 3.18 - Monumento às bandeiras durante as festas do IV Centenário..................................................220

Figura 3.19 — Rumo ao futuro, revista Manchete, 1954 _............................................................................... 221

Figura 3.20 — Propaganda veiculada durante as celebrações do IV Centenário da cidade, 1954 ............. 222

Figura 3.21 — Logradouros em homenagem a bandeirantes no entorno do parque do Ibirapuera......... 223

Figura 3.22 - Ensaio de carta geral das bandeiras paulistas, mapa de Afonso Taunay, no Monumento às

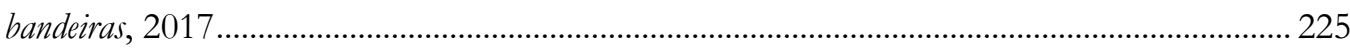

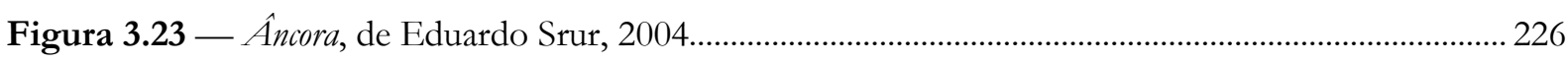

Figura 3.24 — Sala consagrada às monções, Museu Paulista, década de 1930..........................................228

Figura 3.25 — Antiga canoa, parque das Monções, Porto Feliz, anos 1930 ............................................. 229

Figura 3.26 — Inauguração do parque das Monções, 1920 ........................................................................230

Figura 3.27 — Desenho em guache do brasão de armas da cidade de Porto Feliz, anos 1920 ................2231

Figura 3.28 — Da Serra do Mar a Porto Feliz ........................................................................................ 232

Figura 3.29 — Álbum de figurinhas IV Centenário de São Paulo (1954).....................................................237

Figura 3.30 — Inauguração do Monumento às monções, parque das Monções, 1920....................................238

Figura 3.31 - 61 ${ }^{\text {a }}$ Semana das Monções, praça Matriz, Porto Feliz, 2016 .............................................. 239

Figura 3.32 — A Semana das Monções na revista O Cruð̨iro ...................................................................... 241

Figura 3.33 - Tinha que acontecer, de Flávio Cerqueira, Estação Pinacoteca, 2017 ....................................243

Figura 3.34 - Visitante interage com a obra Tinha que acontecer, Estação Pinacoteca, 2017 ..................... 245

Figura 3.35 - Fragmento: Templo de minha raça, de Victor Brecheret, Estação Pinacoteca, 2017 ............... 246

Figura 3.36 - Estudo para o Monumento às bandeiras, Paris, anos 1920 ...................................................247

Figura 3.37 — Entradas e bandeiras (1985), de Luiz Gê ..............................................................................249

Figura 3.38 - Monumento às bandeiras, de Jaime Lauriano, Estação Pinacoteca, 2017 ................................ 250

Figura 3.39 — Jaime Lauriano e seu Monumento às bandeiras, Galeria Leme, 2016 ......................................2251

Figura 3.40 — Projeto São Paulo, Estação Pinacoteca, 2017 .........................................................................255

Figura 3.41 — Projeto Bandeiras e Projeto Praça Vermelha, detalhes do Projeto São Paulo (2010) ..................... 256

Figura 3.42 - Operação Tutoia, de Fernando Piola, 36a Delegacia de Polícia, 2008/2011 ......................... 258

Figura 3.43 — Ensacamento do Monumento às bandeiras, 1979....................................................................259

Figura 3.44 — Imagem do Monumento às bandeiras ensacado no jornal Última Hora ..................................260

Figura 3.45 - Montes de lixo e estátuas cobertas com sacos de lixo no jornal Notícias Populares ............ 261

Figura 3.46 — Transeuntes observam a escultura Anbanguera ensacada, 1979......................................262

Figura 3.47 — Selo em homenagem a Victor Brecheret, 1984 .............................................................263 
Figura 3.48 - Logotipos da prefeitura de São Paulo nas gestões Reynaldo de Barros, Salim Curiati e

Figura 3.49 - Capa e contracapa do Plano Diretor de São Paulo: ao alcance de todos (1991)............................ 266

Figura 3.50 - Anhanguera é coberto com um tecido preto, avenida Paulista, 2013................................... 267

Figura 3.51 — Monumento às bandeiras se transforma no Monumento à resistência guarani, 2013 ..................... 268

Figura 3.52 — Indígenas ocupam o Monumento às bandeiras, 2013 .............................................................. 269

Figura 3.53 - Duas diagramações da mesma capa de O Estado de S. Paulo ................................................. 270

Figura 3.54 — Limpeza do Monumento às bandeiras................................................................................ 271

Figura 3.55 - Imagens e multiplicação de sentidos visuais, 2013/2017 ………………………………..... 272

Figura 4.1 — Borba Gato, loja Brasil Antigo: móveis e objetos autênticos, 2017 .................................................... 275 


\section{SUMÁRIO}

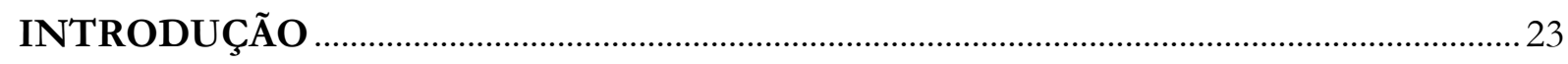

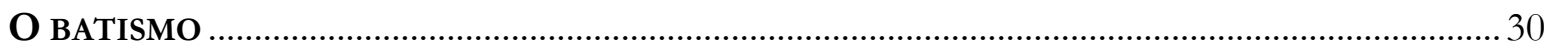

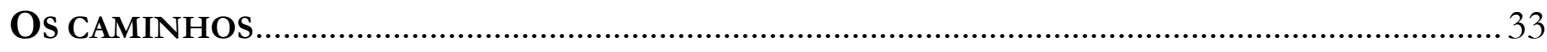

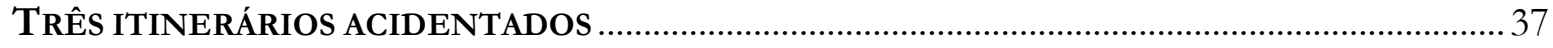

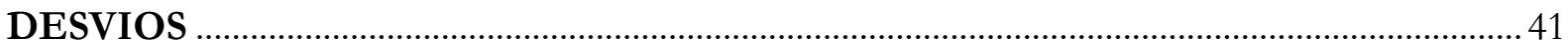

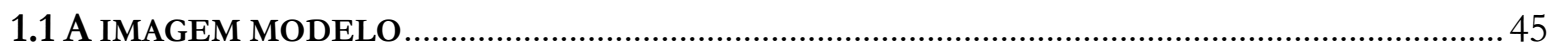

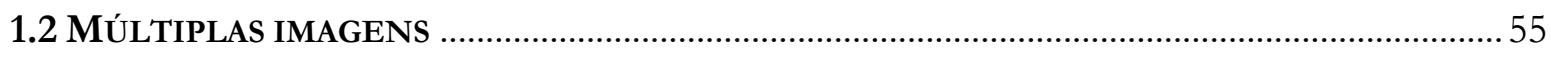

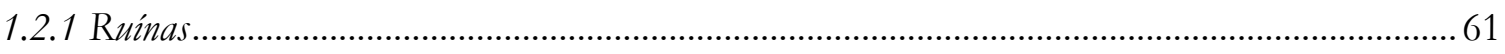

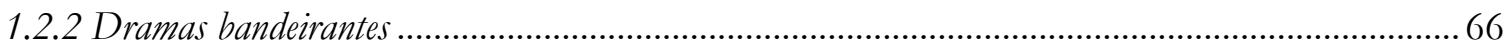

a) Saciando a sede como animais ......................................................................................... 70

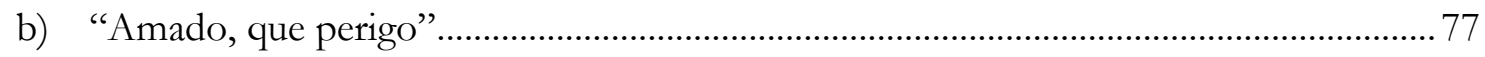

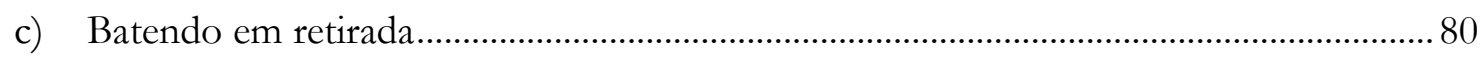

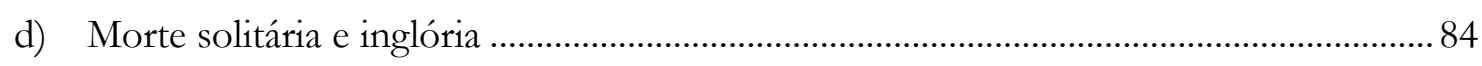

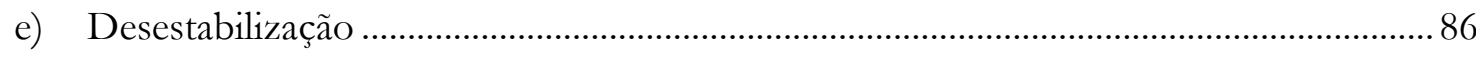

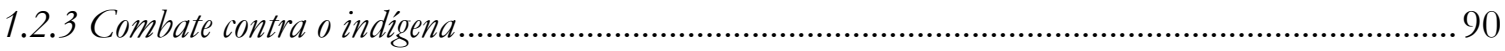

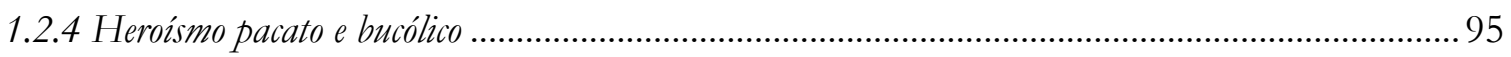

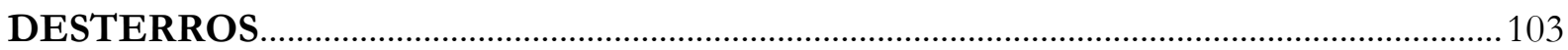

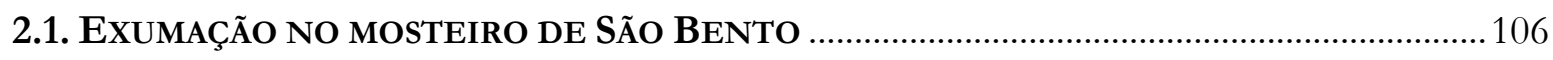

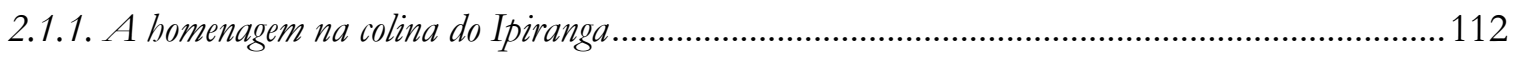

2.1.2. Do Museu Paulista ao cineteatro Odeon ……………………………………...........................122

2.2. Partida do antigo belvedere da AVEnida Paulista ..............................................129

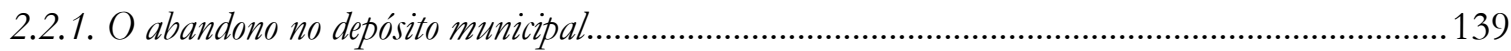

2.2.2. A transferência para a Escola Estadual Fernão Dias Paes ........................................................153

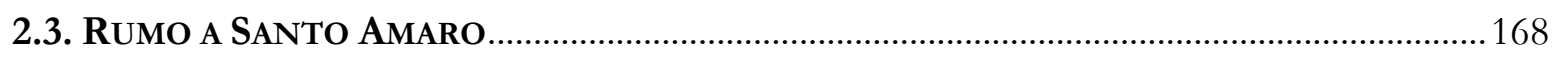

2.3.1. A (i)mobilidade na praça Augusto Tortorelo de Araújo ............................................................. 176

2.3.2. Estilhaços para muito além do antigo povoado...........................................................................186 


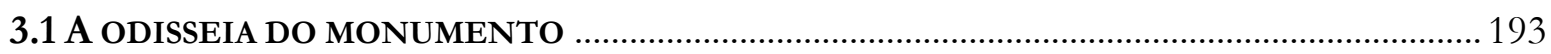

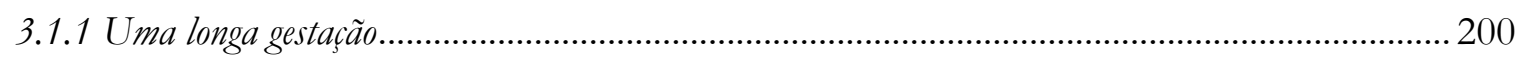

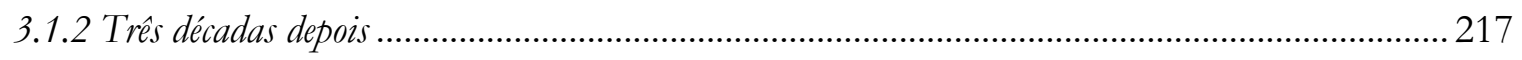

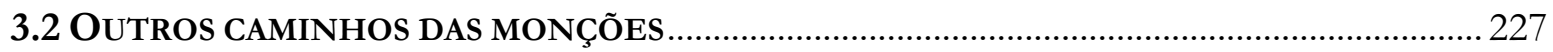

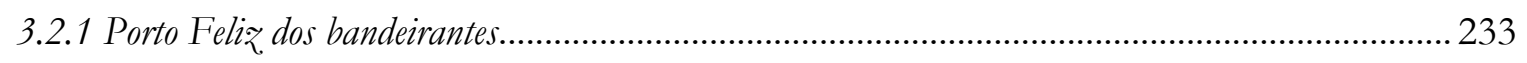

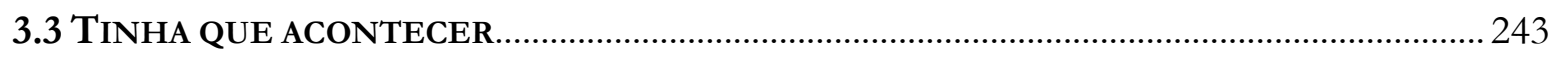

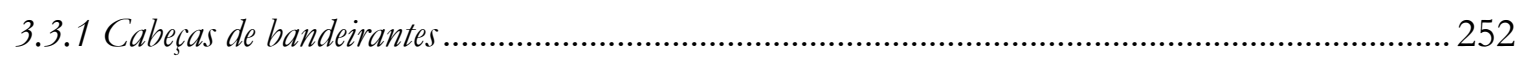

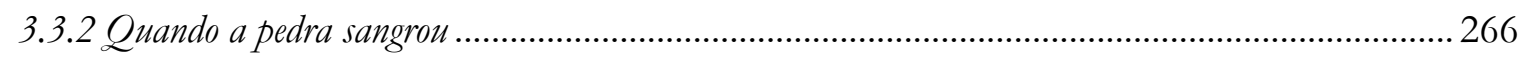

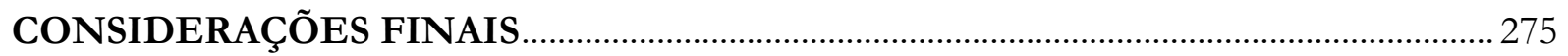

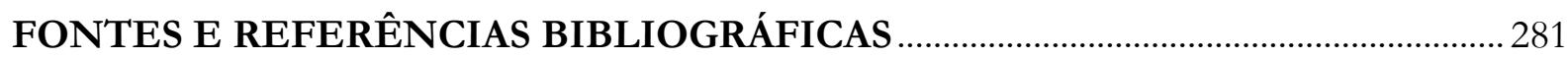

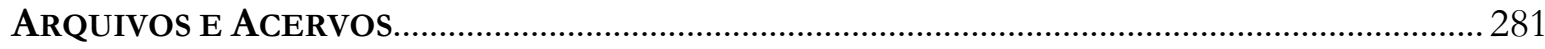

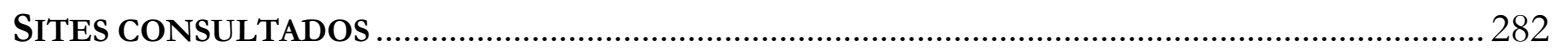

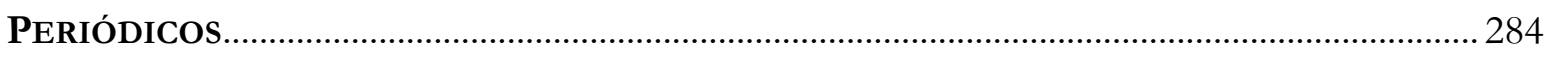

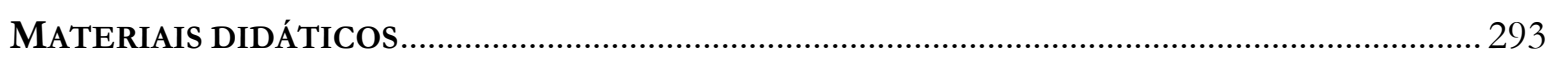

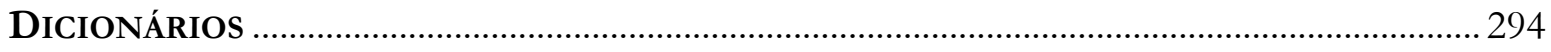

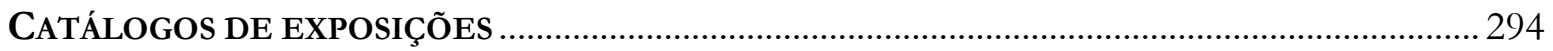

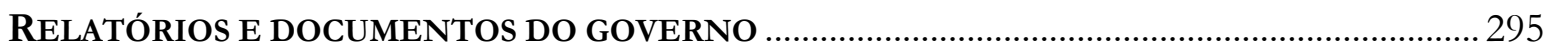

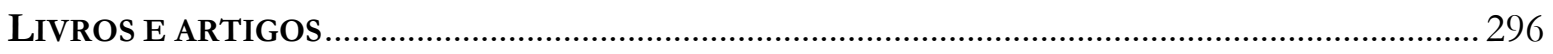

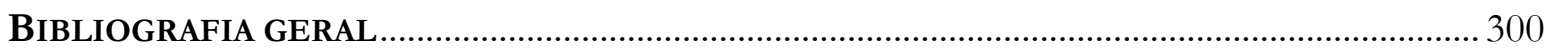




\section{INTRODUÇÃO}

"Os bandeirantes ainda estão entre nós e não são apenas estátuas que amanhecem pixadas em protesto"

(Comitê Paulista de Solidariedade aos Tapajós, 2016)

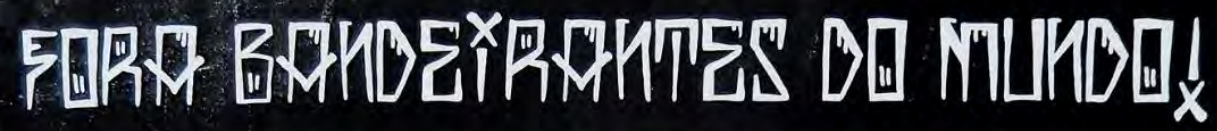

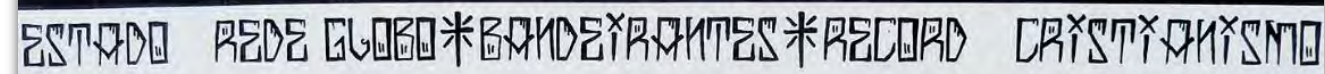

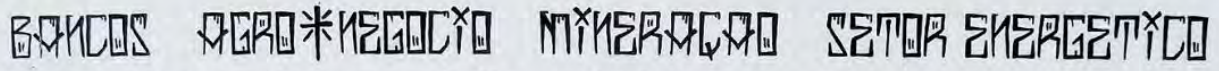

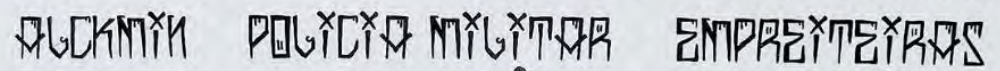

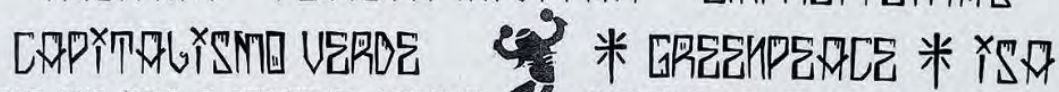

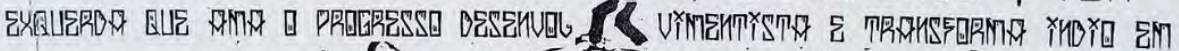

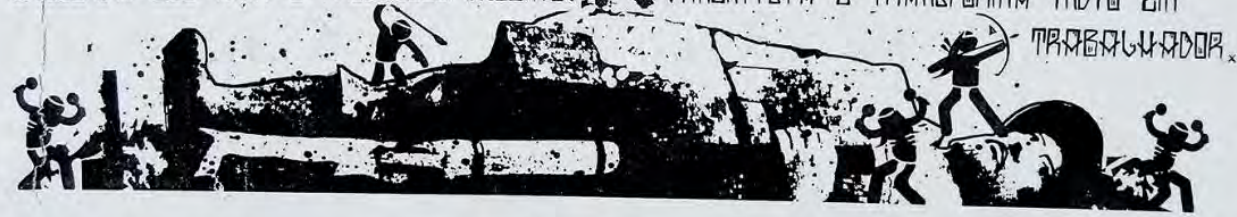

Figura 0.1 — Lambe-lambe "Fora bandeirantes do mundo", praça da República, 2016. Fonte: Acervo pessoal | Foto: Thaís Waldman.

Alguns lambe-lambes colados nos muros de São Paulo nos lembram que os bandeirantes ainda estão presentes, atuando entre nós, e não são apenas estátuas que amanhecem pixadas em protestos $^{1}$. Em 2016, por exemplo, encontrei a figura acima em mais de uma ocasião, em locais

\footnotetext{
${ }^{1}$ A grafia da palavra pixação, com "x", e não com "ch", conforme rege a ortografia oficial, alude ao modo como os próprios pixadores de São Paulo escrevem o termo que designa a sua prática.
} 
como a praça da República e a rua Augusta. Fixada nas paredes do centro da cidade pelo Comitê Paulista de Solidariedade à Luta pelos Tapajós (Comtapajós) ${ }^{2}$, a imagem retrata seis indígenas comemorando a derrubada de um grande monumento em homenagem a um bandeirante, o Borba Gato, enquanto outros bandeirantes são enumerados um a um, como se tivessem, todos eles, saído de dentro do mesmo corpo, estático, caído ao chão. "Fora bandeirantes do mundo!", diz a frase estampada no alto da imagem, e logo abaixo dela encontram-se listados: o Estado; a Rede Globo, a Bandeirantes e a Record; o cristianismo; os bancos; o agronegócio; a mineração; o setor elétrico; o então governador do estado Geraldo Alckmin; a Polícia Militar; as empreiteiras; o capitalismo verde; o Greenpeace e o Instituto Socioambiental (ISA); e a "exquerda que ama o progresso desenvolvimentista e transforma índio em trabalhador".
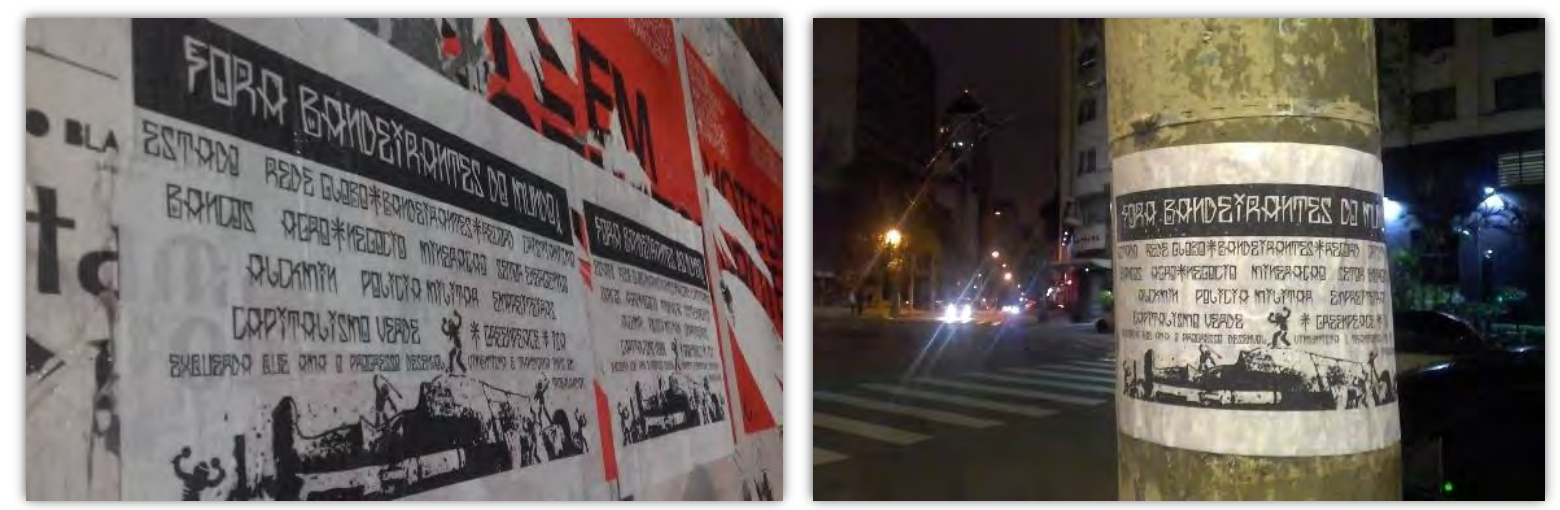

Figura 0.2 — Lambe-lambes "Fora bandeirantes do mundo", São Paulo, 2016. Fonte: Página do Facebook do Comitê Paulista de Solidariedade à Luta pelos Tapajós ${ }^{3}$.

Fotografias desses lambe-lambes foram compartilhadas nas redes sociais e apareceram na timeline do meu Facebook às vésperas das últimas eleições municipais de São Paulo, no dia 30 de setembro de 2016, mesmo dia em que dois dos maiores monumentos bandeirantes instalados na cidade foram parcialmente cobertos de tinta látex: o Borba Gato, de Júlio Guerra, derrubado na imagem dos lambe-lambes, e o Monumento às bandeiras, de Victor Brecheret. Com seus mais de dez metros de altura, Borba Gato foi inaugurado em 1963, na praça Augusto Tortorelo de Araújo, em Santo Amaro, pouco antes de ser deflagrado o golpe que instauraria a ditadura militar no Brasil, em 31 de março de 1964. Já o Monumento às bandeiras, que ocupa quase toda a praça Armando de

2 O Comitê Paulista de Solidariedade à Luta pelos Tapajós (Comtapajós) foi fundado em 2005 com o objetivo principal de apoiar as ações de resistência dos povos do Tapajós à construção de hidroelétricas na região. Trata-se de um coletivo que visa também refletir sobre o significado de ser paulista, apoiando os povos indígenas, ribeirinhos, quilombolas e camponeses na luta pela sua autonomia. Disponível em: <https://www.facebook.com/Tapajoslivre/>. Acesso em: 20 nov. 2016.

${ }^{3}$ Disponível em: <https://www.facebook.com/pg/Tapajoslivre/photos/>. Acesso em: 1 out. 2016. 
Salles Oliveira, na entrada do parque do Ibirapuera, com seus cerca de 45 metros de comprimento, foi inicialmente esboçado por Brecheret em 1920, com o apoio de diversos intelectuais e artistas envolvidos na realização da Semana de Arte Moderna de 1922, e finalizado somente por ocasião dos preparativos para as comemorações do IV Centenário da fundação da cidade de São Paulo, em 1953.

Poucas horas antes dos monumentos amanhecerem coloridos, durante o último debate eleitoral televisionado que assisti na noite anterior, o então candidato à prefeitura de São Paulo João Doria (PSDB) havia perguntado à ex-prefeita e também candidata Marta Suplicy (PMDB) qual seria a proposta dela em relação às pichações, por ele consideradas um dos grandes problemas de uma cidade, em suas palavras, "à beira do abandono completo". "Vandalismo nós não vamos permitir na cidade, sem truculência, mas não vamos permitir", respondeu a candidata, que afirmou "sentir dor" ao ver obras como o "lindíssimo" Monumento às bandeiras frequentemente pichadas. "Vandalismo tem que ser tratado pela polícia", retrucou João Doria. Coincidência ou não, durante a madrugada, os monumentos esculpidos por Victor Brecheret e Júlio Guerra ganharam novas cores, como rosa, amarelo e verde-claro. Alguns disseram que era uma retaliação de pichadores; outros, que se tratava de uma ação de grupos interessados em dinamitar a candidatura do então prefeito Fernando Haddad (PT). Independentemente da autoria, os bandeirantes sacudiram a cidade.

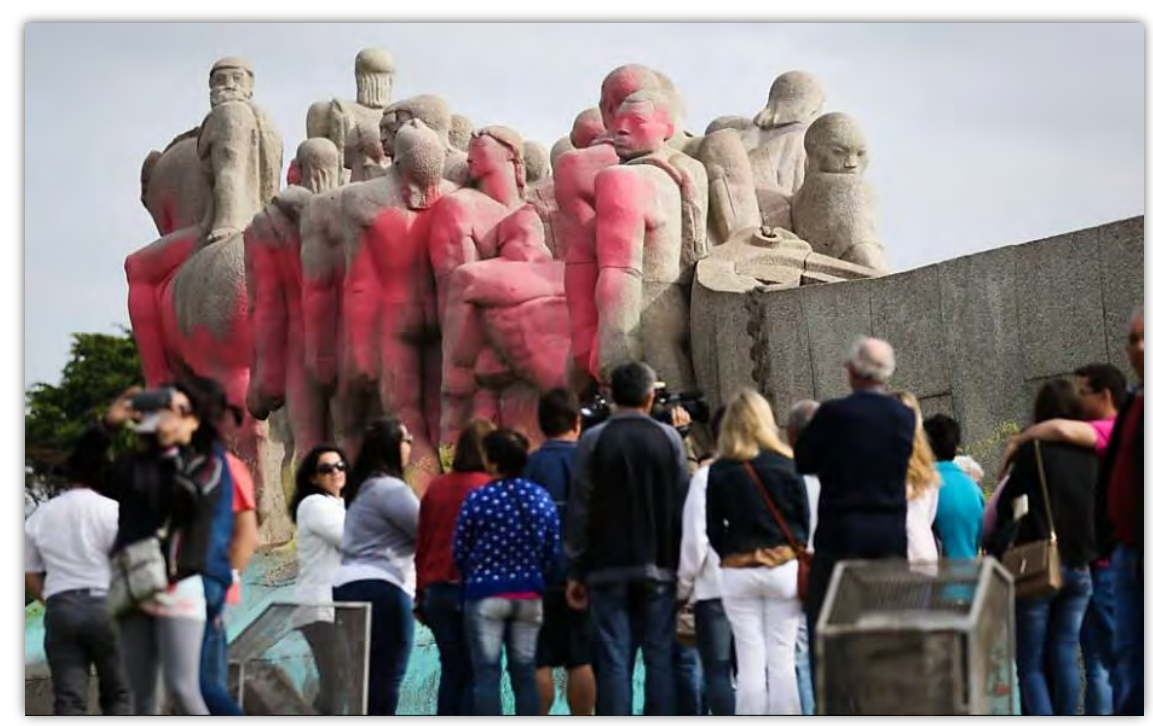

Figura 0.3 - Monumento às bandeiras ganha novas cores, 2016. Fonte: Folha de S.Paulo, 1 out. 2016, Eleições 2016, p. 2 | Foto: Zanone Fraissat. 
No dia seguinte ao debate eleitoral, o Bom Dia São Paulo, telejornal matutino da Rede Globo de Televisão, lamentou o "vandalismo", a "sujeirada", a "lambança" que haviam feito com a homenagem àqueles que "desbravaram o país", enquanto o jornal digital Brasil 247 ressaltou que esses mesmos desbravadores exterminaram povos indígenas e destruíram quilombos 5 . "É uma tristeza ver o nosso patrimônio danificado, nós [da prefeitura] vamos limpando e o monumento vai danificando", declarou ao jornal O Estado de S. Paulo à diretora do Departamento do Patrimônio Histórico (DPH), Nadia Somekh, "daqui a pouco não vai ter mais pedra" ${ }^{6}$. E se, no lugar de intervenções urbanas com um alto custo para a limpeza pública, removêssemos esses “açougueiros”, sugeriu em seu blog o jornalista Leonardo Sakamoto ${ }^{7}$. O que ocorreu nessa madrugada é uma "barbárie", acusou o engenheiro civil Victor Brecheret Filho, em entrevista à revista $V$ eja São Paulo, na qual afirmou que a tinta jogada nas esculturas equivaleria às explosões e demolições protagonizados pelo grupo extremista Estado Islâmico em monumentos na Síriå .

Nas redes sociais, como no Facebook e Twitter, a repercussão dos bandeirantes em cores se multiplicava. "Foda-se o herdeiro do escultor de bandeirantes e todos os demais comemorantes", afirmou indignado o antropólogo Eduardo Viveiros de Castro, "ato de barbárie é exatamente o que os 'monumentos' comemoram". Em poucas horas, mais de 1,2 mil internautas confirmaram a participação e 2,7 mil demonstraram interesse em um evento criado por Rafael Santos, indigenista da Fundação Nacional do Índio (Funai), para trocar a estátua de Borba Gato por uma de Gaudino Pataxó, indígena queimado vivo em 1997 enquanto dormia em um ponto de ônibus em Brasília, no Distrito Federal ${ }^{10}$. "Pixar é pouco", comentou a artista urbana Lygia Lee,

${ }^{4}$ Disponível em: <http:/g1.globo.com/sao-paulo/noticia/2016/09/monumentos-amanhecem-pichados-com-tinta-colorida-emsp.html>. Acesso em: 30 set. 2016.

5 Disponível em: <https://www.brasil247.com/pt/247/sp247/257960/Pol\%C3\%ADcia-busca-respons\%C3\%A1veis-por-jogartinta-em-monumentos.htm>. Acesso em: 30 set. 2016.

${ }^{6}$ Disponível em: <http://sao-paulo.estadao.com.br/noticias/geral,monumento-as-bandeiras-e-estatua-do-borba-gato-amanhecempichados,10000079134>. Acesso em: 30 set. 2016.

${ }^{7}$ Disponível em: <http://blogdosakamoto.blogosfera.uol.com.br/2016/09/30/ao-inves-de-pichar-que-tal-removeras-homenagens-aos-bandeirantes-em-sp/>. Acesso em: 30 set. 2016.

${ }^{8}$ Disponível em: < http://vejasp.abril.com.br/materia/filho-de-brecheret-ve-ligacao-entre-pichacao-e-debate-eleitoral/>. Acesso em: 30 set. 2016.

${ }^{9}$ Disponível em: <https://twitter.com/nemoid321/status/782201901081395200?lang=pt>. Acesso em: 1 out. 2016.

${ }^{10}$ Disponível em: <https://www.facebook.com/events/191460351289942/192326654536645/?notif_t=feedback_reaction_generic \&notif_id=1475353354816597>. Acesso em: 1 out. 2016. 
"deviam era ter arrancado a porra da cabeça" muitos internautas.

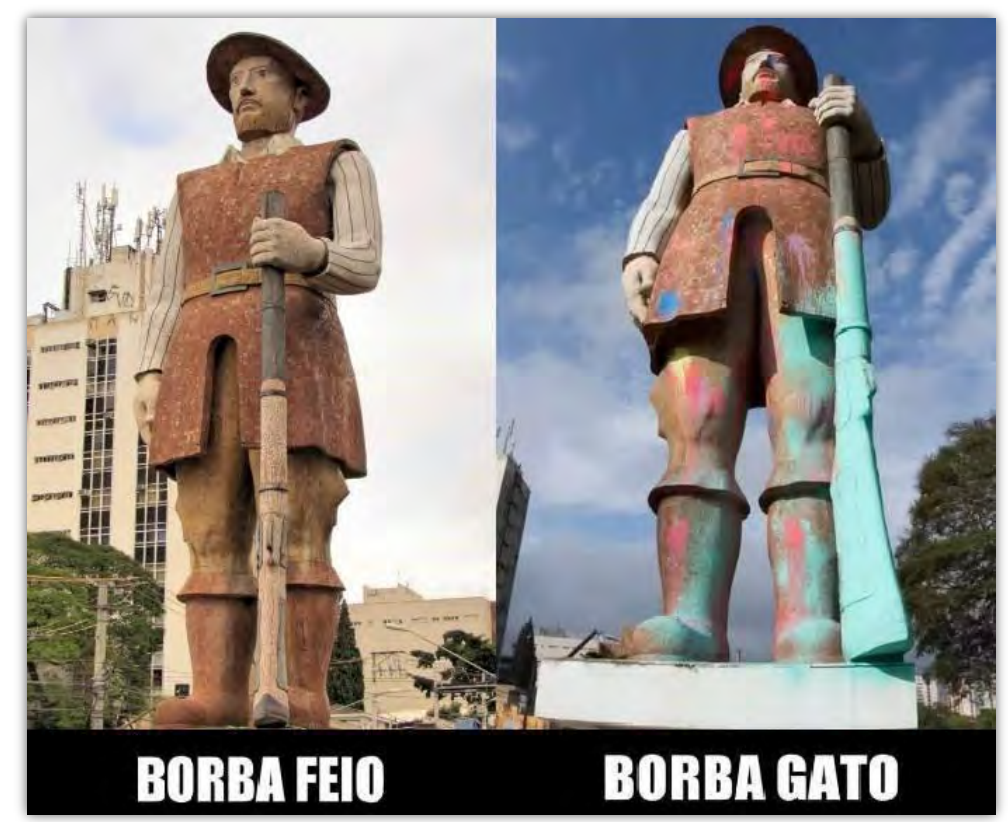

Figura 0.4 — “Borba Feio"/“Borba Gato", meme compartilhado nas redes sociais, 2016. Fonte: Página do Facebook do Movimento Mães de Maio ${ }^{12}$.

Enquanto as polêmicas proliferavam, outras imagens do personagem iam surgindo. $\mathrm{O}$ movimento Mães de Maio ${ }^{13}$ posicionou-se contra os "bandeirantes de camarote", elencando entre seus principais representantes o então candidato João Doria, associado às hashtags \#VaiTerPixo, \#Partiu, \#PrefeitoSenhorDeEscravos e \#PrefeitoCaviar. Com a ajuda de alguns internautas, o Comtapajós enumerou outros "bandeirantes [que] ainda estão entre nós", mencionando desde a classe média paulistana até o atual presidente da Turquia, Recep Tayyip Erdogan, criticado internacionalmente por restringir liberdades civis e a expressão de vozes da oposição ${ }^{14}$.

11 Disponível em: <https://www.facebook.com/photo.php?fbid=10208964974256475\&set=a.1091357439048. 2015084.1079851199\&type=3\&theater $>$. Acesso em: 30 set. 2016.

12 Disponível em: <https://www.facebook.com/maes.demaio/photos/>. Acesso em: 20 nov. 2016.

${ }^{13}$ O Movimento Mães de Maio foi fundado depois de pelo menos 564 pessoas serem mortas no estado de São Paulo, a maioria delas em situações que indicam a participação de policiais, entre os dias 12 e 20 de maio de 2006. Tratase de um movimento independente que defende a luta por "memória, verdade e justiça". Disponível em: <https://www.facebook.com/maes.demaio>. Acesso em: 20 nov. 2016. Sobre o movimento, ver também o livro Mães em luta: dez anos dos crimes de maio de 2006, organizado por André Camarante dez anos depois da chacina, e o "Vídeo-Memorial das Mães de Maio", por elas produzido em parceria com a Associação Capão Cidadão. O vídeo está disponível em: <https://youtu.be/Iw1b4zAnG6Q>. Acesso em: 20 nov. 2016.

${ }^{14}$ Disponível em: <https://www.facebook.com/Tapajoslivre/posts/1081713635269580>. Acesso em: 1 out. 2016. 
“Bandeirantes, Anhanguera, Raposo, Castelo, são heróis ou algoz?”, indagou por sua vez, o grupo de rap Inquérito, citando a letra de uma das suas músicas, ilustrada com uma imagem dos bandeirantes coloridos ao fundo, "botar o nome desses cara nas estrada é cruel. É o mesmo que rodovia Hitler em Israel”"15.

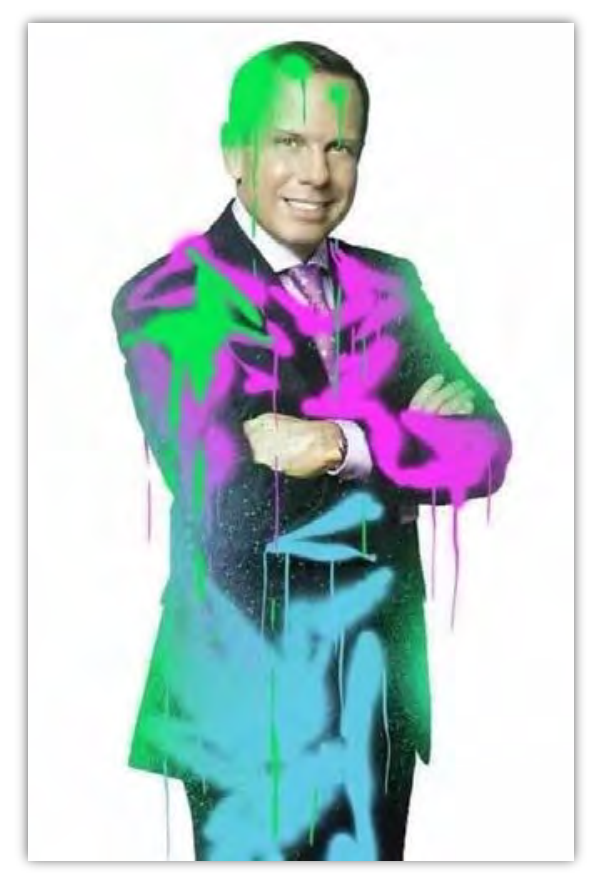

Figura 0.5 - "Contra os bandeirantes de camarote", meme compartilhado nas redes sociais, 2016.

Fonte: Página do Facebook do Movimento Mães de Maio ${ }^{16}$.

Em um vídeo gravado às vésperas das eleições municipais, durante a retirada da tinta látex do Monumento às bandeiras, João Doria, em seguida prefeito eleito da cidade ${ }^{17}$, advertira: "Cada um faz o que quer aqui em São Paulo. Comigo, não. É autoridade"18. O vídeo viralizou na internet. Sandra Brecheret pediu ao Ministério Público que oferecesse maior proteção aos bandeirantes

15 Disponível em: <https://www.facebook.com/inquerito/photos/>. Acesso em: 3 out. 2016. A música mencionada, chamada "Eu só peço a Deus", pode ser ouvida no site do grupo, no álbum "Corpo e Alma". Disponível em: <www.souinquerito.com.br>. Acesso em: 1 out. 2016.

16 Disponível em: <https://www.facebook.com/maes.demaio/photos/>. Acesso em: 20 nov. 2016.

${ }^{17}$ João Doria foi eleito prefeito de São Paulo em um inédito primeiro turno nas eleições municipais, depois de conquistar a maioria dos votos em quase todas as zonas eleitorais, com exceção de Grajaú e Parelheiros, no extremo sul da cidade, nas quais Marta Suplicy saiu vitoriosa.

${ }^{18}$ Disponível em: <https://www.facebook.com/pg/jdoriajr/videos/>. Acesso em: 30 set. 2016. 
esculpidos por seu pai $^{19}$. Já o Movimento São Paulo Independente ${ }^{20}$, que conta com mais de 40 mil seguidores no Facebook, convocou um ato cívico no Ibirapuera em defesa da "pátria bandeirante" ${ }^{21}$. Nas redes sociais, pipocaram fotos de eleitores junto a políticos que, como João Doria, foram supervisionar a limpeza dos bandeirantes (e, por extensão metonímica, da cidade como um todo $)^{22}$. O filósofo Renato Janine Ribeiro, por sua vez, elogiou a estética do monumento e comentou que isso mais parecia "uma provocação para colocar na conta da esquerda" 23 , enquanto que para o ex-ministro da Defesa, Aldo Rebelo (PCdoB), tal ato "agredia a história e a memória de São Paulo e do Brasil" 24. Ao mesmo tempo, uma tirinha do personagem Armandinho, compartilhada por mais de 22 mil pessoas no Facebook, afirmava que "vândalos" eram os próprios bandeirantes.

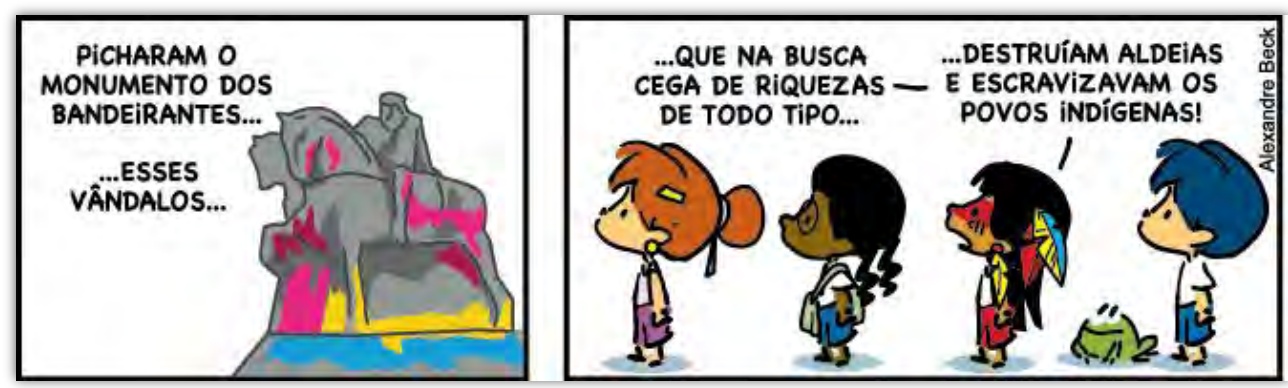

Figura 0.6 - “Armandinho", tirinha de Alexandre Beck, 2016.

Fonte: Página do Facebook de Armandinho ${ }^{25}$.

Assim que, esculpidos há décadas, os bandeirantes continuam a mobilizar a cidade e seus habitantes. Seja em uma praça em Santo Amaro ou no parque do Ibirapuera, no patrimônio

${ }^{19}$ Disponível em: <https://twitter.com/folha/status/782286461232185348>. Acesso em: 1 out. 2016.

20 O Movimento São Paulo Independente se define como um movimento nacionalista " $100 \%$ independente", fundado em 1992, com a meta de separar a "Pátria Paulista" do Brasil, "na defesa das tradições e da independência de São Paulo". Disponível em: <https://www.saopauloindependente.org/>. Acesso em: 1 out. 2016.

${ }^{21}$ Disponível em: <https://www.facebook.com/MSPIreal/photos/>. Acesso em: 30 set. 2016.

22 Um dia após ser empossado, no primeiro dia útil de janeiro de 2017, João Doria se vestiu de gari na praça Catorze Bis, no centro de São Paulo, para divulgar o lançamento do programa Cidade Linda, cujo objetivo seria "revitalizar áreas degradadas da cidade". Doria prometeu, nesse mesmo dia, varrer um ponto da cidade todas as semanas até o fim de sua gestão. Algumas das primeiras ações de sua administração tinham como foco, especificamente, apagar e tentar erradicar as pichações da cidade, como ações como a da limpeza da ponte Estaiada, na zona sul de São Paulo. Disponível em: <http://capital.sp.gov.br/noticia/prefeito-participa-da-primeira-acao-do-programa-sao-paulo-cidade-linda-1>. Acesso em: 3 jan. 2017.

23 Disponível em: < https://www.facebook.com/renato.janineribeiro/posts/1433426406672151>. Acesso em: 1 out. 2016.

${ }^{24}$ Disponível em: <https://twitter.com/aldorebelo?lang=pt>. Acesso em: 30 set. 2016.

${ }^{25}$ Disponível em: < https://www.facebook.com/tirasarmandinho/photos/>. Acesso em: 1 out. 2016. 
histórico, na grande mídia, nas redes sociais, em um lambe-lambe, na mídia alternativa, em uma história em quadrinhos, em movimentos separatistas, em letras de rap, no meio universitário, no governo municipal, em um movimento independente de combate aos crimes do Estado, no governo estadual — cuja sede, não por acaso, é o Palácio dos Bandeirantes —, no meio artístico, ou em um coletivo autônomo que busca fortalecer o processo de resistência dos povos indígenas, ribeirinhos e tradicionais, o bandeirante circula pelos mais diversos espaços. Nesses trânsitos, ele borra fronteiras temporais, entre regiões da cidade, entre diferentes formas de expressão e entre os domínios "eruditos" e "populares".

Para além de figura histórica do período colonial brasileiro, o bandeirante se destaca até hoje como uma presença incontornável em São Paulo, metrópole que o próprio personagem ajuda a produzir, emprestando-lhe inclusive um de seus mais famosos epítetos: a "capital bandeirante". Ancorada no suposto de que as ideias engendram atos e as imagens produzem efeitos sobre o mundo, tomo aqui o bandeirante, a partir de algumas de suas muitas figurações, como um personagem que produz sentidos e relações as mais diversas, por meio de operações nas quais ele sobrepõe, destrói e reinventa falas, ao mesmo tempo em que cruza atitudes e miradas, muitas vezes contraditórias.

\section{O batismo}

Os usos e as disputas em torno dos sentidos do bandeirante não constituem novidade. Criado a partir de documentos, mapas, inventários e crônicas dos séculos anteriores, ele remonta à chamada "lenda negra" dos séculos XVI e XVII, e à "lenda dourada" do século XVIII, mas é somente no final do século XIX que ele ganha um nome ${ }^{26}$. Trata-se de uma figura que começa a ser criada

\footnotetext{
${ }^{26}$ Nos séculos XVII e XVIII, os padres jesuítas, expulsos da vila de São Paulo na disputa pela exploração da mão de obra indígena, elaboraram a chamada "lenda negra", caracterizando os expedicionários paulistas do período como cruéis assassinos, inimigos dos indígenas e dos padres, e insubmissos vassalos dos reis de Portugal. Antonio Ruiz de Montoya, Francisco Jarque e Pierre-François-Xavier de Charlevoix são alguns nomes de jesuítas associados à imagem dos paulistas como assassinos de extrema crueldade. Já o fidalgo paulistano Pedro Taques e o beneditino santista frei Gaspar, linhagistas e filhos da aristocracia local, criam a "lenda dourada" no século XVIII. Acentuam então a lealdade, a magnanimidade e a nobreza dos antigos aventureiros paulistas, responsáveis pela expansão do território brasileiro para além do tratado de Tordesilhas, com base na ideia de um orgulho ancestral, do qual
} 
anos antes de seu nome, mas que só depois de batizada passa a atuar em diversas narrativas sincrônicas de uma espécie "macrodrama" paulista ${ }^{27}$. O nome bandeirante pode, assim, servir de bússola para acompanharmos o caminhar do personagem entre espaços e tempos, permitindo (re)encontrá-lo em suportes e materiais tão variados como os acima mencionados.

Tomemos como ponto de partida o seu registro oficial. Não há nenhuma menção ao bandeirante no dicionário de Antônio de Moraes Silva, publicado em Lisboa em 1789, considerado um marco inicial da lexicografia em língua portuguesa ${ }^{28}$. Já no primeiro grande dicionário brasileiro, organizado por Laudelino de Oliveira Freire entre 1939 e 1944, o termo bandeirante ganha duas acepções: "indivíduo que, no Brasil, fazia parte dos bandos destinados a descobrir minas e cativar os selvagens" e "o mesmo que paulista". Nesse sentido, ao ser batizado, é que o personagem passa a me interessar de perto, não porque a atribuição de um nome remeta a um bandeirante original, mas sim porque sua nomeação traz à tona um personagem plural que irá protagonizar em São Paulo distintos enredos simultâneos e entrelaçados com a própria noção de cidade.

Depois de procurar o vocábulo bandeirante em diferentes dicionários de língua portuguesa, Maria Isaura de Queiroz (1992) explica que é somente no início da primeira década do século XX que o termo é dicionarizado, inicialmente despido de qualquer conotação simbólica. Bandeirante, portanto, nem sempre foi sinônimo de paulista. E é durante o processo de associação entre esses dois vocábulos, que o bandeirante se torna uma das presenças mais notáveis da capital paulista ${ }^{29}$. A autora afirma que é em 1913 que o vocábulo ganha sua primeira acepção, quando o dicionário de Antônio Candido de Figueiredo, ao incluir em sua publicação brasileirismos nunca dicionarizados, o define como um "indivíduo que, no Brasil, faz parte dos bandos, destinados a explorar sertões, atacar selvagens, etc.”. Devemos, no entanto, antecipar essa data em pelo menos quatro décadas, quando o termo é dicionarizado por frei Domingos Vieira, ainda no século XIX.

afirmavam compartilhar. Sobre as chamadas "lenda negra" e "lenda dourada", cf. Abud (1985), Souza (2000) e Schneider (2016).

27 Agradeço a Julia Ruiz Di Giovanni pela sugestão oferecida, na banca de qualificação, de pensar as encarnações bandeirantes a partir de distintos enredos simultâneos de um "macrodrama” paulista.

${ }^{28}$ O dicionário de Antônio Moraes e Silva é ampliado em sua segunda edição, publicada em Lisboa em 1813. Nela também não há nenhuma menção ao termo bandeirante. Já bandeira (vocábulo que não consta na primeira edição da obra) é definida como "uma associação de homens que vão pelos sertões, debaixo de um cabeça, descobrir terras mineiras".

${ }^{29}$ Embora seja o bandeirante como sinônimo de paulista o foco de interesse desta pesquisa, não podemos esquecer que ele também fará parte do imaginário regional de outros estados brasileiros, como, por exemplo, de Goiás e do Mato Grosso, que foram integrados ao domínio português pelas expedições paulistas dos séculos XVI e XVII. 
O primeiro registro que encontrei da palavra bandeirante em um dicionário de língua portuguesa ocorre em 1871, segundo a datação, sem indicação de fonte, da última edição impressa do Honaiss, publicada em 2009. Consta ali que, desde então, o bandeirante é registrado como substantivo masculino que denomina um "indivíduo que no Brasil colonial tomou parte em bandeira ('expedição')". Ao que parece, Antônio Houaiss faz uma referência ao dicionário publicado em 1871 pelo frei Domingos Vieira, no qual bandeirante é definido como "o afiliado da bandeira, ou companhia de exploração das matas virgens”. Já a derivação desse significado por extensão de sentido, quando ele passa também a ser definido como sinônimo de paulista, é posterior.

Embora não se saiba a datação exata da segunda acepção da palavra, ao pesquisar alguns periódicos da grande mídia paulista da época - como O Estado de S. Paulo e Correio Paulistano —, notei que na década de 1920 o termo paulista já era amplamente evocado como bandeirante nas mais diferentes colunas jornalísticas, seja em discussões sobre "a moda bandeirante”, "o esporte bandeirante", "a lavoura bandeirante", "a jurisprudência bandeirante", "o meio social bandeirante", “a terra bandeirante", entre tantas outras referências que remetem a São Paulo de então e aos seus habitantes.

Sinônimo de paulista, o bandeirante não apenas ganha evidência nas colunas jornalísticas como se torna, no início do século XX, o personagem principal de diversos discursos proferidos nas rádios, nos órgãos governamentais, nas escolas e nas praças públicas; ao mesmo tempo, converte-se no protagonista de uma série de livros históricos e literários; revela-se uma estrela do cinema, do teatro, da propaganda oficial e dos anúncios publicitários privados; é entoado nos hinos patrióticos e nas músicas populares; empresta seu nome a empresas, associações, lojas, produtos comerciais e logradouros; além de ganhar dimensões, relevo, cores, formas e texturas nas pinturas, esculturas e monumentos espalhados em regiões estratégicas da capital paulista.

Mas afinal, quem é esse personagem que se insere em frentes, espaços e ramos tão diversos? Desbravador do Brasil, assassino, herói, genocida e mártir? (Des)povoador do sertão, caçador de índios, destruidor de quilombos e soldado pacificador do gentil inimigo? Ou capitão do mato, sertanista e pioneiro no garimpo do ouro e das pedras preciosas? Inimigo dos espanhóis e dos jesuítas, defensor dos interesses da Coroa portuguesa e ao mesmo tempo insubmisso vassalo do rei de Portugal? E ainda aristocrata, bruto, milionário, despojado e self-made man? Mameluco, português, indígena? Caipira, monçoeiro, tropeiro, cafeicultor? Quatrocentão, modernista, imigrante, migrante, negro e mulher paulista? 
Essas tão variadas encarnações do personagem não se substituem simplesmente, uma a outra em sucessão diacrônica, mas convivem, muitas vezes de modo tenso, em enredos simultâneos. Ao serem incorporadas ao personagem, elas são cultivadas e recriadas em um movimento permanente, pois não se constituem de forma cumulativa, basta lembrarmos a imagem dos lambe-lambes colados nas ruas de São Paulo e dos diversos bandeirantes que parecem sair do corpo da mesma estátua derrubada ao chão, como vimos no início. Produzido no interior de uma teia de práticas e discursos, o bandeirante não é uma categoria fixa, dada de antemão, mas algo que se transfigura. Nesse sentido, cada vez que ele se torna protagonista, cabe indagar quem é o personagem que conduz a narrativa e/ou é por ela conduzido. E se ele em geral não está sozinho nos enredos, é o caso de questionar também quem são os coadjuvantes que permitem compor cenas e enquadramentos.

\section{Os caminhos}
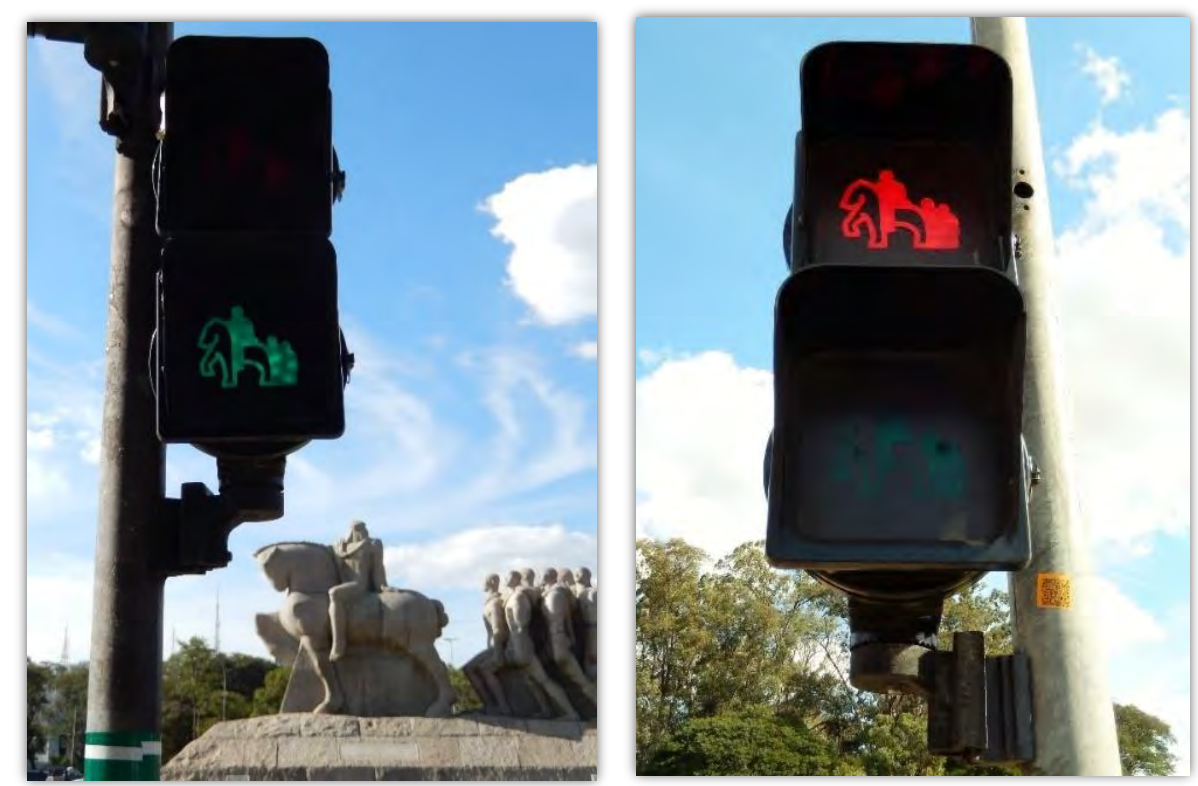

Figura 0.7 - Semáforos, praça Armando de Salles Oliveira, 2017. Fonte: Acervo pessoal | Foto: Thaís Waldman. 
No intuito de dar conta da complexidade do personagem e das dinâmicas que o envolvem, sigo aqui o que denomino de suas encarnações, aquilo que lhe dá corpo e expressão, e com elas caminharei por entre tempos, espaços e imagens. É nesse sentido encarnado, assumindo personificações díspares e às vezes incongruentes, que ele aparece como um artefato cultural moderno. Personagem-sujeito-objeto, o bandeirante mobiliza a cidade de São Paulo e seus habitantes, como sugerem as imagens estilizadas verdes e vermelhas do Monumento às bandeiras, presentes nos semáforos que sinalizam as passagens e os cruzamentos do entorno de uma das obras que, às vésperas das eleições municipais de 2016, acordou colorida.

Trazer para o primeiro plano o bandeirante (com os diversos sentidos e formas que ele assume, assim como as associações que estabelece e que o constituem) implica atentar para as suas reelaborações locais e para as tantas historicidades nele impregnadas. Trata-se também de balizar os usos que grupos e indivíduos fazem dele, instaurando um presente relativo a um momento e um lugar específicos. Que usos são esses? De que indivíduos e grupos se trata? Assumir a premissa de que os sentidos são construídos no interior de práticas específicas - como defende Michel de Certeau (1994; 2011), inspirado nas teorias performativas da linguagem, ao mostrar a relação necessária entre "modos de dizer" e "maneiras de fazer" — significa problematizar as reelaborações locais de um personagem cujos passos e movimentos são marcados pela justaposição de temporalidades.

Ao enveredar por esse caminho interpretativo, me aproximo de um conjunto de trabalhos igualmente dedicados ao personagem. Refiro-me, em especial, às teses de Kátia Abud, O sangue intimorato e as nobilíssimas tradições (1985) ${ }^{30}$; à livre-docência de Antônio Celso Ferreira, A epopeia bandeirante: letrados, instituições, e invenção histórica (1870-1940) 11 , publicada em livro em 2002; e à tese

\footnotetext{
30 Autora de um trabalho pioneiro no estudo da historiografia regional paulista, tema que poucos autores haviam abordado até então, Kátia Abud (1985) torna-se referência obrigatória sobre a temática bandeirante ao analisar a constituição do personagem desde sua "proto-história", em textos do século XVII, até a mobilização políticaideológica de 1932. Ao percorrer esse amplo recorte cronológico, seu interesse recai sobre a São Paulo da década de 1920 — “o período áureo da produção histórica sobre o bandeirantismo” (ABUD, 1985, p. 7) — e, principalmente, os textos de Alfredo Ellis Júnior, Afonso d’Escragnolle Taunay e José de Alcântara Machado.

31 Antônio Celso Ferreira (2002), preocupado em circunscrever os espaços de sociabilidade dos intelectuais de São Paulo, acompanha a experiência regional paulista entre 1870 e 1940, e um de seus principais personagens, o bandeirante, voltando-se não somente para a construção textual dos discursos históricos, mas também dos literários. Ressalta, assim, o papel central da imaginação literária na construção de uma historiografia que se pretende rigorosamente objetiva, ao mesmo tempo que analisa novelas, romances, contos e poemas embriagados de conteúdo histórico. Entre as fontes percorridas pelo autor, destacam-se o Almanaque literário e a Revista do Instituto Histórico e Geográfico de São Paulo, além de autores específicos.
} 
de Danilo Ferretti, A construção da paulistanidade: identidade, historiografia e política em São Paulo (18561930) (2004) ${ }^{32}$. Três grandes referências sobre o tema, esses estudos atentam para o exame da historiografia e da literatura regionalista, tomando o bandeirante como a principal representação paulista das primeiras décadas do século XX, um símbolo fundamental para as elites de São Paulo e para a constituição de um universo ideológico ${ }^{33}$.

Esses estudos fornecem balizas importantes para a compreensão do assunto, mostrandose fundamentais também para esta pesquisa. Entretanto, deles me distancio do ponto de vista das opções feitas aqui, inspiradas de perto nas análises antropológicas voltadas para a vida das coisas ${ }^{34}$. Ao dirigir a atenção às capacidades de abdução da agência dos objetos, como propõe Alfred Gell (1998, 2001, 2005), o olhar desloca-se do significado para a eficácia do artefato; os objetos condensam ações, relações e sentidos; é por meio deles que as pessoas agem, se relacionam e existem no mundo (LAGROU, 2010). Orientada por tais formulações, tomo o bandeirante como evocação e atualização de um conjunto de intencionalidades e ideias complexas que produz efeitos (mais ou menos eficientes) sobre o mundo.

Sem desconhecer a importância da figura como referencial simbólico para a formação e a consolidação de certo regionalismo paulista — sobre o qual parte da bibliografia se dedica —, escolhi ensaiar outro ponto de vista, atenta ao modo como as encarnações bandeirantes conduzem uma série de enredos sincrônicos, produzindo o que designei como "macrodrama” paulista. Tal escolha me obrigou a considerar as relações que o personagem estabelece com a cidade de São Paulo, sobrepondo e cruzando — de modo raramente harmônico — vozes e perspectivas diversas. Ao dar ênfase à agência desse sujeito-objeto, o partido analítico aqui adotado conduz a um relativo afastamento dos caminhos da representação. Sensível às transformações da cidade, o personagem

32 Interessado na construção de um imaginário político no qual a presença do bandeirante é constante, Danilo Ferretti (2004) revela as íntimas relações entre os universos da historiografia regional paulista e da política, entre os anos de 1856 e 1930, analisando textos como os de José Joaquim Machado de Oliveira, Capistrano de Abreu, Washington Luís, Teodoro Sampaio, Oliveira Vianna e Paulo Prado.

${ }^{33}$ Katia Abud encontra no bandeirante uma representação que serve aos interesses dos grupos dominantes, então interessados em integrar os grupos dominados aos seus projetos, tomando a elite paulista em sua unidade social. Seu trabalho se desdobra nas análises de Danilo Ferretti sobre as disputas em torno dessa representação a partir das clivagens políticas internas da elite paulista da época; o "propalado símbolo bandeirante", ressalta Ferretti (2004, p. 12), não possui um sentido unívoco. Antônio Celso Ferreira, por sua vez, encontra no bandeirante um "símbolo épico" a partir do qual estabelece relações entre a produção simbólica e o campo social das elites do período. Sobre os materiais compulsados, os marcos temporais e a escolha das problemáticas dessas referências fundamentais sobre o personagem, cf. as três notas acima.

${ }^{34}$ A respeito do debate antropológico em torno da agência e da biografia de objetos e imagens, ver os balanços bibliográficos feitos por Ingold (1994), Hoskins (2006), Gonçalves (2007) e Caiuby Novaes (2008), entre outros. 
comenta e confere sentido às mudanças urbanas, não apenas representando essas transformações, mas engendrando-as e produzindo-as ${ }^{35}$.

A literatura disponível mostra como o bandeirante se insere em diferentes espaços da cidade e como essa circulação se dá em períodos distintos. Para além dos textos históricos e literários, ele se faz presente nas telas, esculturas, documentos e objetos mobilizados pelo Museu Paulista visando as festas centenárias de 1922 (CHIARELLI, 1998; LIMA \& CARVALHO, 1993; CHRISTO, 2002; MAKINO, 2003; MATTOS, 2003; BREFE, 2005; MARINS, 2007 e 2017; PITTA, 2013, LIMA JUNIOR, 2015; NERY, 2015; OLIVEIRA, 2017); nos cartazes e panfletos, nas cédulas e nos selos emitidos durante a mobilização ideológica de 1932 (CAPELATO, 1981); nos nomes de ruas, avenidas e rodovias, tal qual o Caminho dos Goyazes, antiga trilha indígena do século XVII, nomeada rodovia Anhanguera nos anos 1940 (REIS, 2014); nos meios de comunicação, como no filme Os bandeirantes (1940), dirigido por Humberto Mauro (MORETTIN, 2013); nos anúncios publicitários que, durante as comemorações de 1954 pelo aniversário de quatrocentos anos da capital, veiculavam a imagem do “Bandeirante do progresso" (MOURA, 1994); nas festas municipais, tal qual o próprio IV Centenário da fundação da cidade de São Paulo (LOFEGO, 2004; WEINSTEIN, 2015); e nas edificações da capital paulista, como nas chamadas casas bandeiristas (ZANETTINI, 2005; MAYUMI, 2008; WEIMER, 2015; SANTOS, 2016); para ficar em alguns exemplos. Isso sem deixar de lado os monumentos públicos, como o Monumento às bandeiras (BATISTA, 1985; MARINS, 2003), que ainda hoje, mesmo tendo sido produzidos em uma São Paulo bastante distinta da atual, são capazes de sacudir a cidade, como vimos no início.

Essas indicações parecem suficientes para aferirmos a potência da figura, que continua a engendrar muitas ações e reflexões. Acompanhar suas flutuações e seus percursos, objetivo deste trabalho, significa enfrentar os modos como ela foi usada e consumida em diferentes registros e momentos, descolando-se de um contexto específico e habitando múltiplos tempos e espaços. Para isso, tomei algumas figurações do personagem como guias nessa caminhada, que se mostrou acidentada e variada, permitindo perceber não só um personagem, mas também sujeitos, disputas e uma cidade muito mais diversos do que eu imaginava em um primeiro momento ${ }^{36}$. Com a ajuda

\footnotetext{
35 Não posso deixar de mencionar aqui também as sugestões retiradas do livro Ciudades suadamericanas como arenas culturales (2016), organizado por Fernanda Peixoto e Adrián Gorelik, no qual a cidade é pensada como uma "arena cultural", quer dizer, como espaço de germinação, de experimentação e de embates.

${ }^{36}$ Caminhada que, de certo modo, há alguns anos comecei a trilhar, quando em minha dissertação de mestrado enfrentei analiticamente a produção de Paulo Prado e o contexto no qual ela foi gestada, levando a sério suas ideias e formulações, que se evidenciam em uma escrita situada entre a história e a literatura, a ciência e a arte. Seguir os movimentos do autor por lugares intervalares e intermediários permitiu que eu o enxergasse como um importante
} 
dos estudos acima mencionados, que ensinam como o bandeirante habita épocas e domínios distintos, segui sua presença em São Paulo a partir de três itinerários, que estruturam os três capítulos da tese e que apresento a seguir.

\section{Três itinerários acidentados}

Na São Paulo da década de 1920, observa Mário de Andrade, "germinavam monumentos numa floração de gestos heroicos" ${ }^{\prime 37}$. Entre aqueles que homenageiam o nosso personagem, além dos bandeirantes que começam a ser esboçados por Victor Brecheret, temos: o fragmento escultórico O caçador de esmeraldas, de William Zadig (1884-1952), inaugurado em um antigo belvedere da avenida Paulista; o busto em baixo-relevo de Fernão Dias, realizada por Adelbert Gresnigt (1877-1956) na parede externa do Mosteiro de São Bento; e as esculturas Anhanguera, no Trianon, e Fernão Dias Paes Leme e Antônio Raposo Tavares, na colina do Ipiranga, feitas por Luigi Brizzolara (1868-1937). Germinavam monumentos até mesmo dentro de monumentos, como é o caso das últimas duas estátuas e de outros seis bandeirantes em bronze - Manuel da Borba Gato, Manuel Preto, Bartolomeu Bueno da Silva, Paschoal Moreira Cabral, Francisco Dias Velho e Francisco de Brito Peixoto - encomendados pelo Museu Paulista (conhecido como Museu do Ipiranga), instituição sediada em um edifício que cumpriu inicialmente a função de monumento histórico, dentro do qual dou início a caminhada.

Esta tese toma como ponto de partida uma imagem adquirida pelo Museu Paulista em 1903: a tela Domingos Jorge Velho e o loco-tenente Antônio Fernandes de Abreu, o mais antigo retrato de um bandeirante realizado em São Paulo no período republicano, pelo que se sabe até o momento. Pintados por Benedito Calixto (1853-1927), o bandeirante que ficou conhecido como o destruidor do Quilombo dos Palmares e seu loco-tenente foram finalizados na fase embrionária de diversas narrativas que exaltariam esses personagens paulistas como heroicos desbravadores do território brasileiro, consolidadas, como veremos, entre muitos membros do Instituto Histórico e Geográfico de São Paulo (IHGSP) e da Academia Paulista de Letras (APL). Trata-se de uma obra que, como bem

\footnotetext{
mediador entre universos aparentemente díspares, nos quais é constante o aparecimento do bandeirante, personagem que de algum modo ele próprio reencena. Cf. Waldman (2014).

37 “De São Paulo”. Ilustração Brasileira, nov. 1920, p. 37.
} 
ressalta Paulo Garcez Marins, “inaugura uma longa trajetória de produção de imagens, bidimensionais e tridimensionais, que procuravam celebrar os antigos sertanistas mediante representações imponentes" (2007, p. 90) — embora essa interpretação heroica dos antigos paulistas não fosse unanimidade, observa ainda Marins. Se essa trajetória não foi linear, a partir de uma imagem considerada modelo acompanho os itinerários acidentados das imagens (plurais) bandeirantes, que nos permitem entrever diferentes modos de pensar a história e de estar na história, mostrando que a construção da imagem heroica esteve acompanhada de seu avesso.

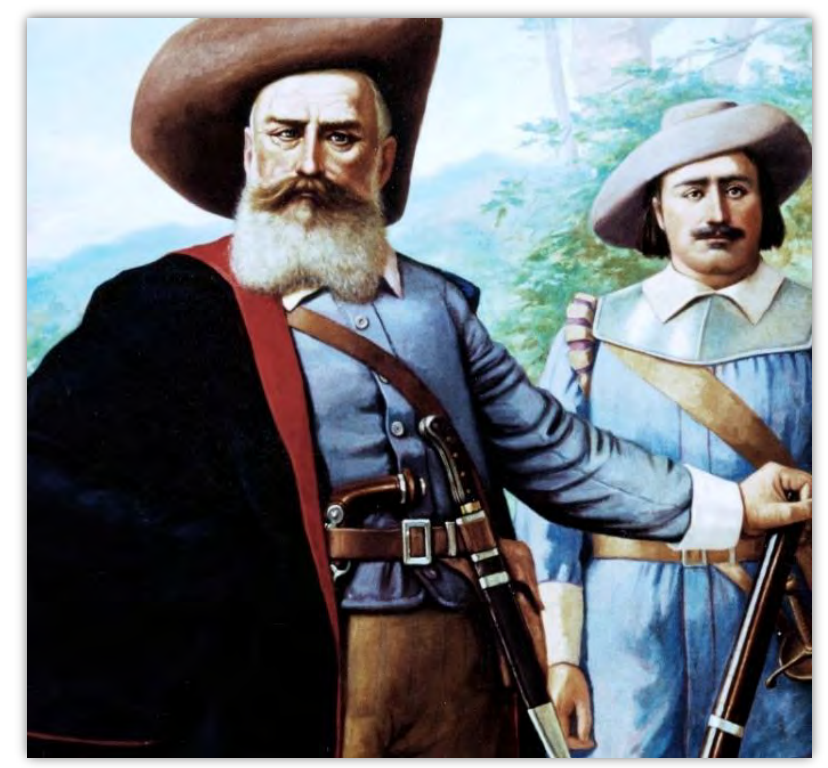

Figura 0.8 - “Aqui, o bandeirante ideal”, diz a legenda da imagem acima, uma reprodução de parte da tela Domingos Jorge Velho e o loco-tenente Antônio Fernandes de Abreu (1903), de Benedito Calixto, veiculada em 2008 na Nova Escola, revista mensal de grande circulação, que há mais de 30 anos atua na área de educação, publicada pela editora Abril ${ }^{38}$.

No capítulo inicial, intitulado "Desvios", é com Domingos Jorge Velho e o loco-tenente Antônio Fernandes de Abreu que entro no interior do edifício do Museu Paulista, um dos maiores monumentos já erguidos em São Paulo, construído às margens do Ipiranga para celebrar o local que referenciava o ato de Dom Pedro I no movimento de separação do Brasil de Portugal. Adquirida em 1903, a obra de Benedito Calixto é parte de um projeto visual que ganha força, principalmente, a partir de 1917, quando Afonso Taunay (1876-1958) é designado pelo governo paulista para a direção da instituição, tendo em vista as comemorações paulistas do Centenário da Independência do Brasil. A partir desse retrato, e procurando me desviar dele, sigo outras imagens

\footnotetext{
38 "O modelo que transpira da pose altiva, do olhar penetrante, das armas novas e da roupa impecável" do bandeirante "cristalizado no senso comum" é o de um "herói” retratado por Benedito Calixto, explica a repórter Ana Rita Martins. Cf. "Mudou a Imagem”, Nova Escola, out. de 2008.
} 
mobilizadas por ocasião das festas centenárias de 1922, que tiveram como sede oficial o próprio edifício-monumento, transformado por Taunay em uma espécie de panteão em homenagem não só à Independência do país, mas também ao protagonismo paulista.

Já no segundo capítulo, "Desterros", deixo a colina do Ipiranga, atentando às rotas traçadas nos espaços a céu aberto da cidade. É curioso notar que não são poucas as esculturas e os monumentos que literalmente se deslocam pela capital. Lembremos que Borba Gato e Fernão Dias são convertidos em bronze nos anos 1920 em O caşador de esmeraldas, uma das partes que compõem o Monumento a Olavo Bilac, inaugurado durante as comemorações centenárias em um antigo belvedere da avenida Paulista. Em 1936, porém, a obra é banida, retalhada e abandonada em um depósito municipal, no bairro do Glicério. O fragmento com os dois bandeirantes se encontra hoje na Escola Estadual Fernão Dias Paes, em Pinheiros, enquanto os demais pedaços estão espalhados por diversos lugares da capital. Deslocamentos como esses, sejam literais ou simbólicos, não só trazem à tona distintas disputas pelos espaços da cidade, como também configuram uma certa geografia bandeirante.

Em "Desfigurações", último capítulo da tese, sigo mais de perto a movimentação dessas figurações no tempo, a partir dos bandeirantes esculpidos em granito por Victor Brecheret. Projetado inicialmente em 1920, por ocasião das comemorações centenárias, o Monumento às bandeiras é inaugurado apenas em 1953, às vésperas do IV Centenário da fundação da cidade de São Paulo. Obra em constante transformação - que ao amanhecer em cores, em 2016, foi "enfrentada", nos termos da fotógrafa e ativista Elaine Campos, em uma referência ao poema "Vamos pra Palmares", do escritor e rapper Dugueto Shabazz ${ }^{39}$-, os bandeirantes esculpidos por Brecheret incorporam as mais diversas camadas de embates e sentidos, sem efetivamente apagar nenhuma delas. Por meio de seus movimentos, procuro friccionar distintas narrativas e temporalidades.

\footnotetext{
${ }^{39}$ Os versos de Dugueto Shabazz, publicados em 2006 e cantados também em rap, apareceram na timeline do meu Facebook logo após o Monumento às bandeiras e o Borba Gato sacudirem a cidade: "Mesmo que os inimigos contra nós sejam milhares. Eu vou pra Palmares. Eu vou pra Palmares. Enfrento os Borba Gato e os Raposo Tavares. Eu vou pra Palmares. Eu vou pra Palmares. Mesmo que eu tenha que cruzar terras e mares. Mesmo que eu tenha que cortar serras e ares. E que meu sangue regue o chão solo de nossos lares. Pois todos quilombolas são nossos familiares. Índios e foras da lei renegados e populares. Malquistos e malvistos vindos de vários lugares. Você não tá sozinho por que nós somos seus pares. No levante contra bandeirantes militares". "Eu vou pra Palmares”, propõe Shabazz desde o título do seu poema. E "teve gente que virou a noite enfrentando os Borba Gato e os Raposo Tavares", concluiu a fotógrafa e ativista Elaine Campos, em sua página do Facebook. Disponível em: <https://www.facebook.com/100000653163322/posts/1270984242933336/>. Acesso em: 1 out. 2016. O clipe da música "Vamos pra Palmares" pode ser acessado na página do Facebook de Shabazz. Disponível em: <https://www.facebook.com/duguetoshabazz/videos/1447262845356520/>. Acesso em: 1 out. 2016.
} 
Ao longo dessas rotas, o tom narrativo do texto se altera, como mostram os três capítulos, o que se relaciona ao recorte temático de cada um deles, aos materiais mobilizados e à bibliografia existente. A natureza e volume das fontes impõem certa deriva ao texto, impactando no tom dos capítulos. Se o primeiro está centrado em uma instituição que já foi tema de diversas análises, e em um período específico, sobre o qual também há literatura abundante, sendo mais marcado pelas citações dos estudos existentes e pelas referências aos textos mobilizados; ao sair da colina do Ipiranga, nos dois capítulos seguintes, com a ajuda de materiais de natureza distinta - como, charges, filmes, fotografias, correspondências, capas de periódicos, selos, propagandas publicitárias, histórias em quadrinhos, cartazes, desenhos, mapas, webdocumentários, cartõespostais, biografias, depoimentos, crônicas jornalísticas, postagens de redes sociais, livros didáticos, históricos e literários - pude transitar mais livremente entre tempos, imagens e espaços, seguindo os caminhos criativos e transformadores traçados pelo personagem museu afora.

A ubiquidade desse personagem também fez com que a pesquisa tivesse inúmeras frentes. Além de examinar o Arquivo do Museu Paulista; investiguei o Fundo do IV Centenário, no Arquivo Histórico Municipal de São Paulo; busquei nomes de ruas em homenagem a bandeirantes no Núcleo de denominação de logradouros públicos; procurei os processos de tombamento de bens ligados à memória bandeirante no arquivo do Conselho de Defesa do Patrimônio Histórico, Arqueológico, Artístico e Turístico; li os documentos sobre a criação da Operação Bandeirante no Arquivo Público do Estado de São Paulo; para ficar em alguns exemplos. Fui também a campo durante a ocupação estudantil, em 2015, da Escola Estadual Fernão Dias Paes; participei da 61 ${ }^{\text {a }}$ Semana das Monções, em 2016, na cidade de Porto Feliz; acompanhei os protestos guarani no parque estadual do Jaraguá, em 2017; frequentei exposições de que algum modo abordavam a temática bandeirante em diferentes instituições - como o Museu Paulista, a Pinacoteca do Estado de São Paulo, a Estação Pinacoteca, o Palácio dos Bandeirantes, o Museu de Arte de São Paulo, a Caixa Cultural da Sé, o Museu Afro Brasil, o Museu da Cidade de São Paulo, a Galeria Leme, e o Museu Nacional de Belas Artes do Rio de Janeiro, entre outras. E, assim, fui me abrindo ao que os materiais e as experiências me apresentavam. 


\section{DESVIOS}

Domingos Jorge Velho e o loco-tenente Antônio Fernandes de Abreu (1903), primeiro retrato oficial de um bandeirante realizado em São Paulo durante a República, é também a primeira tela com essa temática a ser incorporada ao acervo do primeiro museu público do estado, de acordo com os levantamentos feitos até o momento (MARINS, 2007). Pintado por Benedito Calixto de Jesus (18531927) sem nenhuma iconografia anterior que possa ter servido de suporte, o retrato de Jorge Velho com seu loco-tenente — registrado em 1903 no livro de aquisições do Museu Paulista como um quadro que representa o "vencedor do Palmares" e seu "ajudante" 40 , foi difundido museu afora como uma imagem modelar dos bandeirantes paulistas.

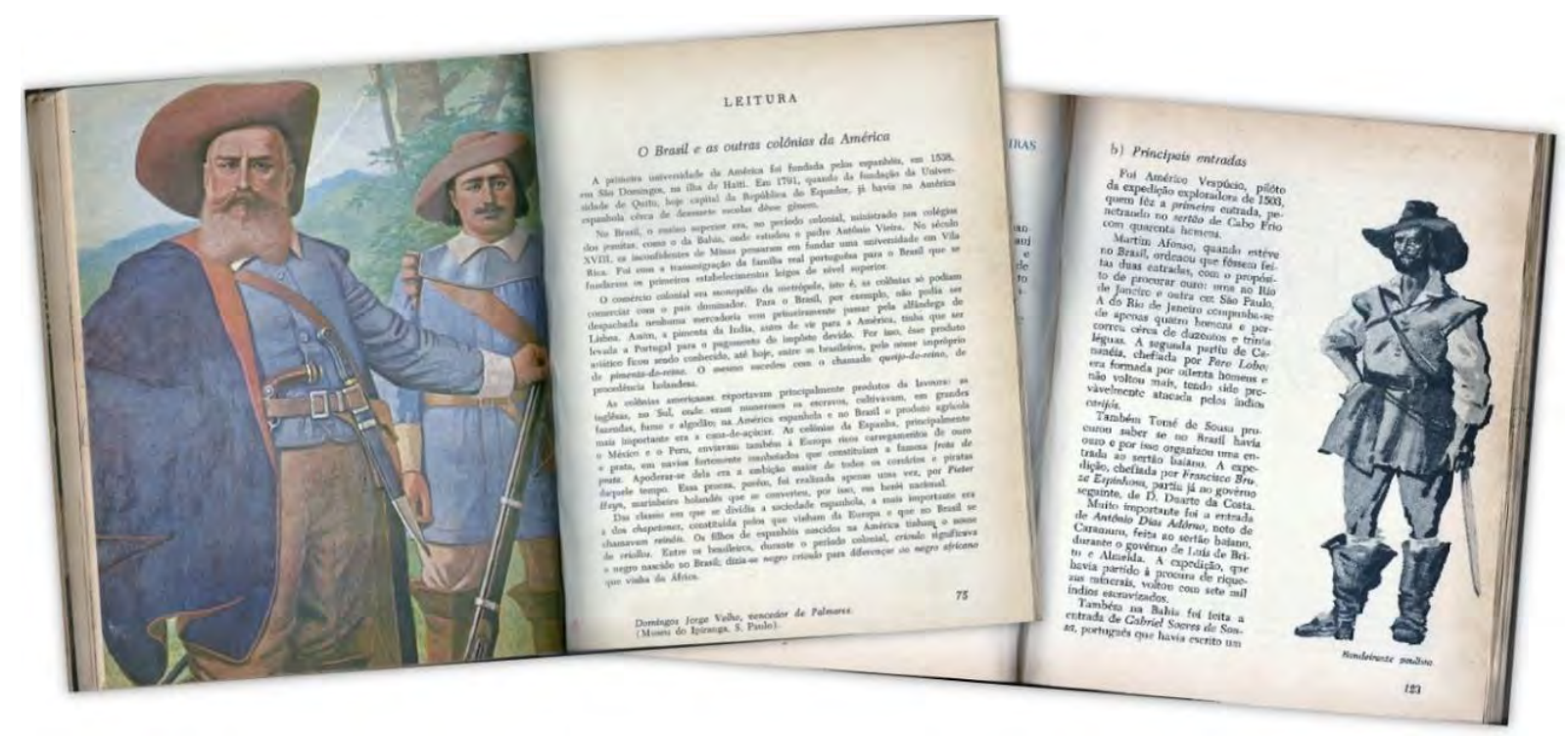

Figura 1.1 - Compêndio de história do Brasil (1968), de Antônio José Borges Hermida. Na legenda da imagem à esquerda, lê-se "Domingos Jorge Velho, vencedor de Palmares (Museu do Ipiranga)". Já na legenda da imagem à direita, "bandeirante paulista". Fonte: Acervo pessoal | Foto: Thaís Waldman.

${ }^{40}$ Livro de aquisições do Museu Paulista. APMP/FMP, livro 90. 
É com o auxílio dessa imagem que ingresso no Museu Paulista, sediado em um edifício construído pelo engenheiro e arquiteto Tommaso Gaudenzio Bezzi (1844-1915) para celebrar a Independência do Brasil. Inaugurado já durante a República, em 1893, às margens do Ipiranga, local que remete à separação entre Brasil e Portugal, o edifício se destaca como o maior monumento erguido na São Paulo do período imperial ${ }^{41}$. Sua construção delineou também a configuração de um espaço na cidade destinado às celebrações cívicas e às atividades lúdicas ${ }^{42}$.

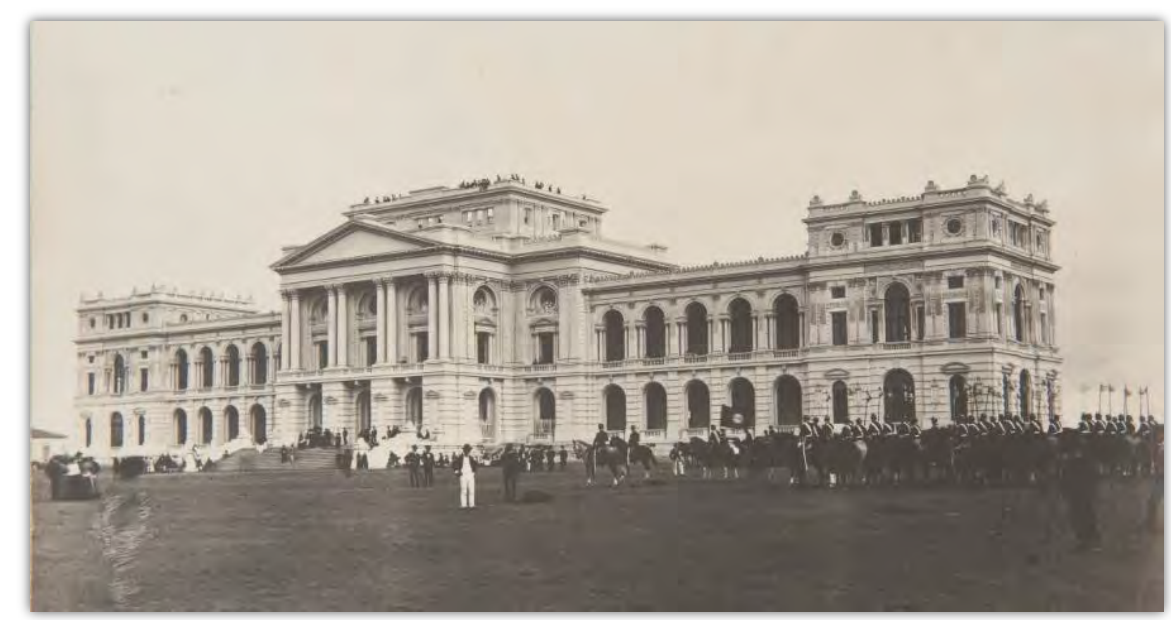

Figura 1.2 — Festejo à frente do edifício-monumento do Ipiranga, anos 1890. Fonte: Acervo do Museu Paulista da USP | Foto: Guilherme Gaensly.

O museu que ainda hoje abriga os bandeirantes retratados por Benedito Calixto foi instalado no interior do edifício-monumento em 1895, no dia 7 de setembro, a partir de um acervo inicial composto, sobretudo, por uma antiga coleção particular, o chamado Museu Sertório ${ }^{43}$. Cabe ressaltar que em seus anos iniciais, embora a instituição tenha ficado largamente reconhecida por ter desempenhado a função de museu de história natural durante a gestão do médico e naturalista

\footnotetext{
41 Até então, um dos poucos antecedentes mais longínquos de um equipamento urbano com caráter monumental implantado em São Paulo era o Obelisco de Piques, que data do início do século XIX, localizado na ladeira da Memória. Marta Rossetti Batista (2012) observa que no século XIX já era possível encontrar, além de chafarizes, algumas estátuas nos jardins paulistanos, embora nessa época a capital paulista não estivesse preocupada com um marco urbano comemorativo.

42 A ideia de se construir um monumento à Independência é praticamente contemporânea à sua proclamação, data de 1823; mas é somente na década de 1880 que temos um projeto aprovado e levado adiante pelo governo provincial. Cf. Guilhotti, Lima \& Meneses (1990), Oliveira (1999), Oliveira Filho (2003) e Barbuy (1997).

${ }^{43}$ O Museu Sertório, pertencente ao coronel Joaquim Sertório, era uma coleção particular reunida no fim do século XIX em São Paulo, bastante similar ao modelo do gabinete de curiosidades europeu, cf. Carvalho (2014).
} 
alemão Hermann von Ihering (1850-1930), que permanece no cargo entre os anos 1895 e1916, nela foram aceitos objetos ligados à temática histórica e à formação de uma galeria artística ${ }^{44}$.

Em 1917, Afonso d'Escragnolle Taunay (1876-1958), engenheiro dado aos estudos históricos e proveniente de uma família de artistas, é designado pelo governo paulista para a direção da casa e recebe a missão de enfatizar essa faceta do museu voltada à história do Brasil e, mais especificamente, à história de São Paulo ${ }^{45}$. Para isso, tendo em vista as comemorações paulistas do Centenário da Independência do país, que tiveram como sede oficial o próprio Museu Paulista, Taunay procurou formar coleções e montar exposições, mobilizando uma série de quadros, estátuas, objetos e documentos iconográficos, textuais e cartográficos que ocupariam as dependências do local ${ }^{46}$.

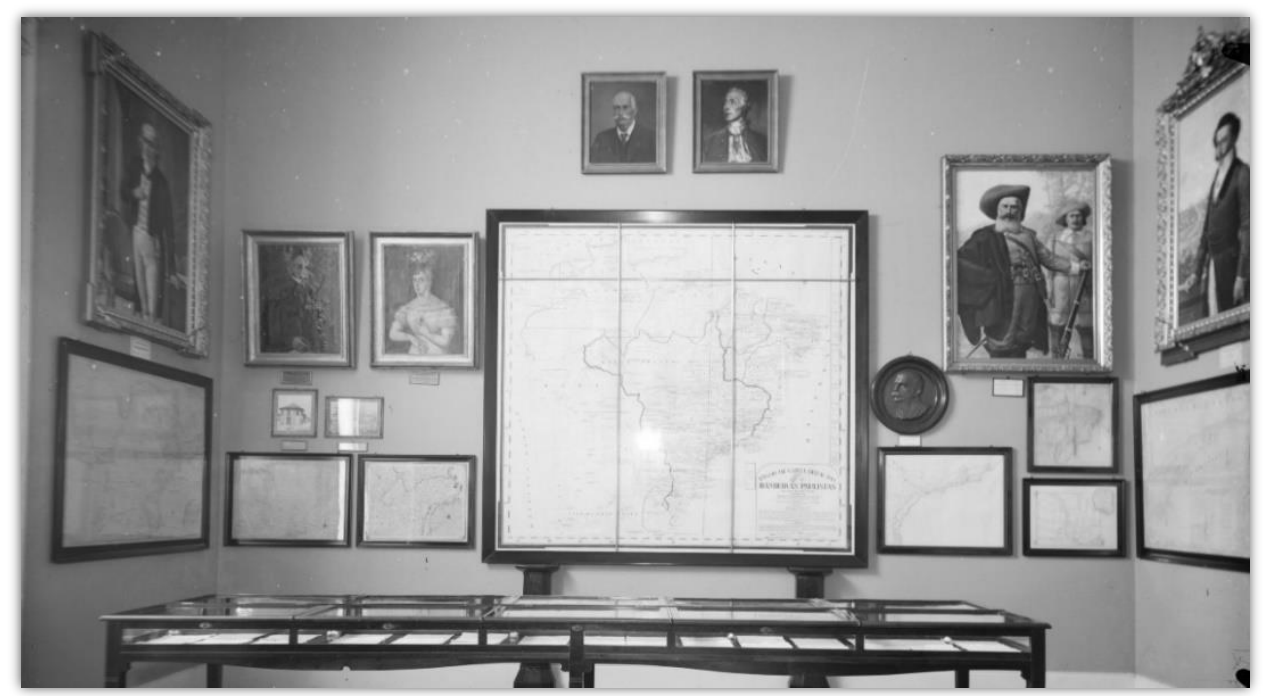

Figura 1.3 - Sala de cartografia colonial e documentos antigos. Museu Paulista, anos 1930. Ao fundo, à direita, na parte superior, vê-se a pintura Domingos Jorge Velho e o loco-tenente Antônio Fernandes de Abreu, ao lado do mapa das bandeiras paulistas, ao centro. Fonte: Acervo do Museu Paulista da USP.

Na primeira das salas inauguradas durante sua longa gestão (1917-1945) — dedicada, nos termos do próprio Taunay, a mapas e cartas territoriais e a uma série de documentos textuais sobre

\footnotetext{
44 O caráter histórico e artístico da coleção do Museu Paulista durante os primeiros anos de sua existência é analisado por Marins (2007), Miyoshi (2012), Moraes (2008), Nery (2015) e Pitta (2013; 2014). Já a ênfase na estruturação de um museu voltado, sobretudo, para as ciências naturais, foi trabalhada por Alves (2001) e Lopes \& Figueirôa (2003).

45 Para uma análise da gestão de Afonso Taunay, cf. Brefe (2005) e o livro organizado por Oliveira (2017).

46 São muitos os estudos acerca do Museu Paulista e a formação de seu acervo, entre eles ver também: Anhezini (2003), Carvalho (2014), Chiarelli (1998), Christo (2002), Dias (2013), Elias (1996), Françozo (2005), Glezer (2003), Lima \& Carvalho (1993), Lima Junior (2015), Makino (2003), Mattos (2003), Meneses (1994), Monteiro (2012), além do catálogo organizado por Piccoli \& Pitta (2016).
} 
a São Paulo do período colonial, tais como inventários de "bandeirantes ilustres", controle das remessas de ouro tirado do sertão, roteiros de minas e "autógrafos de personalidades notáveis" (entre estas bandeirantes, escritores e homens do governo) ${ }^{47}$ — foi exibido também, segundo o Guia da seção bistórica do Museu Paulista $(1937)^{48}$, o retrato imaginado de Domingos Jorge Velho e de seu loco-tenente, ao lado dos retratos como os de Dom Pedro I, José Bonifácio e José de Anchieta, todos de Benedito Calixto. Ali exposto, Domingos Jorge Velho e o loco-tenente Antônio Fernandes de Abreu ganha o status de uma imagem efetivamente documental (reproduzida, anos depois, tal qual um retrato fotográfico, na capa em preto e branco do livro escrito por Renato Castelo Branco, obra definida na sua contracapa como "um ensaio biográfico sobre a vida apaixonante de Domingos Jorge Velho e a participação dos paulistas na libertação e colonização do Nordeste"49).

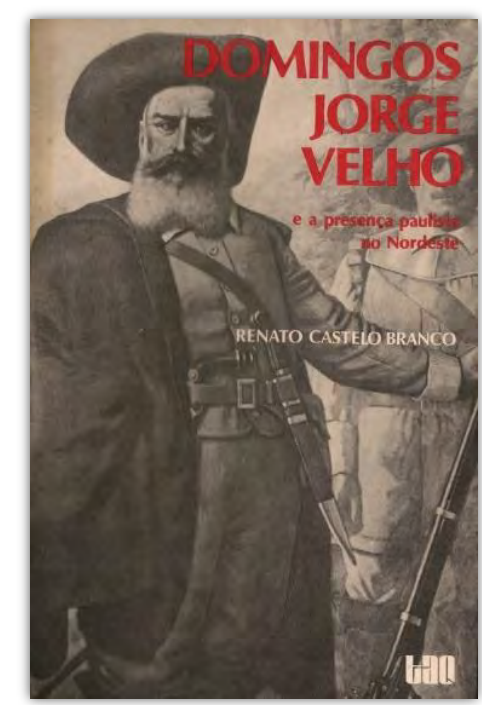

Figura 1.4 - Capa do ensaio biográfico Domingos Jorge Velho (1990), de Renato Castelo Branco. Fonte: Acervo pessoal | Foto: Thaís Waldman.

Ainda que muitas das obras mobilizadas durante a gestão de Afonso Taunay, como o retrato de Benedito Calixto, sejam até hoje percebidas como reiterações de um discurso triunfalista e afirmador da heroicidade bandeirante, estudos recentes vêm demonstrando que um olhar aproximado e com o foco, por exemplo, em obras pintadas por alguns artistas ligados à Escola

\footnotetext{
${ }^{47}$ Relatório de atividades do ano de 1917. APMP/FMP, pasta 5.

${ }^{48}$ Em seu Guia da seção histórica do Museu Paulista, publicado em 1937, Afonso Taunay descreve cada uma das salas de exposição pública da seção de história da instituição, além de apresentar um breve resumo do Ipiranga e do Museu Paulista. Algumas obras expostas durante as comemorações do Centenário, no entanto, transitaram pelo museu depois das celebrações de 1922, como é o caso do próprio retrato de Domingos Jorge Velho feito por Calixto.

${ }^{49}$ Em uma das primeiras páginas do livro, Renato Castelo Branco faz uma nota de reconhecimento aos autores dos estudos que serviram de base para seu ensaio biográfico, e o primeiro nome mencionado é o de Afonso Taunay.
} 
Nacional de Belas Artes do Rio de Janeiro, como Henrique Bernardelli (1857-1936) e Rodolfo Amoedo (1857-1941), traz à tona diferentes recriações do personagem, que deixam ver um ser cansado e vencido pela natureza e/ou envelhecido e solitário. Isso sem mencionar o bandeirante morto por uma flechada, abandonado pelo indígena no meio da mata. Entre os pintores ligados ao Liceu de Artes e Ofícios de São Paulo, como Oscar Pereira da Silva (1867-1939), é possível localizálo em linha de combate. Não podemos esquecer também dos bandeirantes caipiras e/ou monçoeiros desprovidos de heroísmo, como os das telas de José Ferraz de Almeida Júnior (18501899).

Uma imagem modelo e seus desvios, suas transformações e recriações, esse é o percurso deste primeiro momento da análise. Privilegiando certas trilhas laterais, veremos que a imagem modelar do bandeirante é contemporânea ao seu oposto: o bandeirante retratado sem teor celebratório, em linha de combate, desvalido, fatigado, moribundo, morto. A imagem gloriosa e supostamente perene, é acompanhada de seu avesso, ou seja, está sempre prestes a se corromper, a se tornar outra coisa, a se desencaminhar,

\subsection{A imagem modelo}

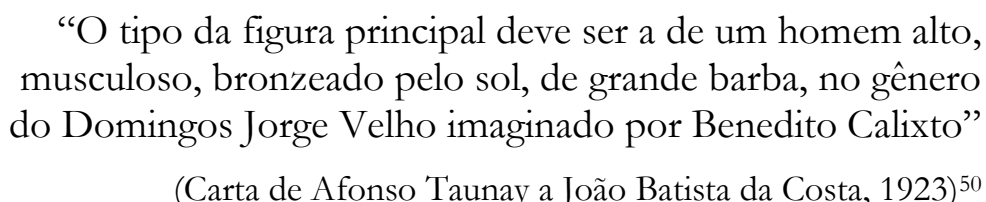

Logo no primeiro plano da tela Domingos Jorge Velho e o loco-tenente Antônio Fernandes de Abreu, a imagem posada de Jorge Velho, aprumado, com volumosas barbas brancas, bigode ruivo-escuro

\footnotetext{
${ }^{50}$ Carta escrita por ocasião da encomenda da tela Ciclo dos criadores de gado, obra que irá figurar na parede da escadaria principal do Museu Paulista, em homenagem à ação dos bandeirantes paulistas criadores de gado, responsáveis, segundo Afonso Taunay, pela fundação de enormes fazendas no alto São Francisco, em Minas Gerais, na Bahia e no Piauí. Cf. Carta de Afonso Taunay a João Batista da Costa, de 18 jul. 1923. APMP/FMP, pasta 119.
} 
e olhos verdes, se impõe. Com um chapéu marrom escuro de abas largas protegendo a cabeça, botas de cano longo da mesma cor cobrindo os pés e parte da perna, e um manto preto e vermelho sobre o ombro direito, o bandeirante perscruta aquele que o observa, ocupando grande parte da composição. O cinto de couro, prendendo as camisas azul e branca alinhadas à calça escura, na qual se pode ver faca e pistola, sugere estar ele fortemente armado, embora fora da linha de combate, impressão reforçada pela espada atrás do corpo e pela arma de cano longo na mão esquerda - elementos que irão marcar grande parte da iconografia bandeirante do período. Atrás dele, figura o loco-tenente, retratado em tons mais claros, enquanto os planos seguintes da tela, pintados em tons aquarelados, apresentam uma paisagem que parece ir se apagando, o que valoriza o bandeirante do primeiro plano.

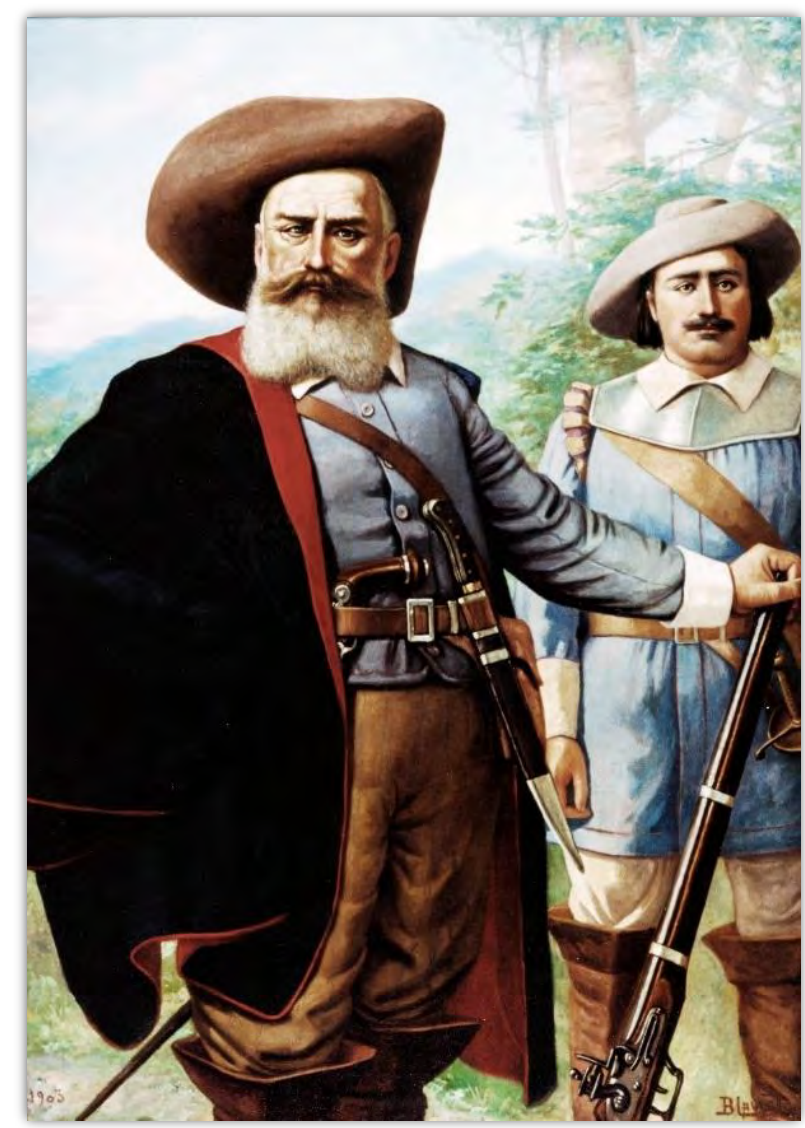

Figura 1.5 - Domingos Jorge Velho e o loco-tenente Antônio Fernandes de Abreu (1903), de Benedito Calixto.

Óleo sobre tela, $99 \times 140 \mathrm{~cm}$.

Fonte: Acervo do Museu Paulista da USP | Foto: Hélio Nobre e José Rosael.

O retrato pintado por Benedito Calixto foi finalizado na fase embrionária de diversas narrativas que celebrariam os bandeirantes paulistas como heroicos e triunfantes desbravadores do 
Brasil, ressaltando a relevância do estado de São Paulo para a história da nação brasileira. Tais narrativas se consolidaram, a partir do final do século XIX, entre muitos membros do Instituto Histórico e Geográfico de São Paulo (IHGSP), fundado ainda em 1894, e, posteriormente, também entre os membros da Academia Paulista de Letras (APL), cuja criação data de $1909^{51}$. O próprio Calixto, além de pintor foi um historiador das bandeiras paulistas ${ }^{52}$; durante a confecção da sua obra, contou ainda com a orientação de outros historiadores, como Washington Luís Pereira de Sousa (1869-1957) ${ }^{53}$, também membro do IHGSP.

Ainda no início de sua carreira como político e historiador, Washington Luís sugere em carta a Benedito Calixto a leitura do romance Os Palmares (1885), de Joaquim de Paula Souza (1833$1887)^{54}$. Sob o pseudônimo de Jorge Velho, o livro narra a destruição do Quilombo dos Palmares, em Alagoas, pelos paulistas no final do século XVII, reforçando a ideia de que São Paulo, devido ao empenho de sua gente desde a época colonial, possuiria um papel de liderança no cenário nacional.

${ }^{51}$ Fundado em um momento em que a República vive uma turbulenta luta por sua consolidação e no mesmo ano em que o primeiro presidente paulista adentra o Catete, o IHGSP enfatiza, logo no primeiro artigo de sua revista institucional, que “a história de São Paulo é a própria história do Brasil”, cf. Ferreira (2002), Ferretti (2004) e Schwarcz (1993). Busca assim redefinir a história da nação, até então construída pelo Instituto Histórico e Geográfico Brasileiro (IHGB), fundado em 1838, no Rio de Janeiro, por iniciativa de Dom Pedro II, cf. Ferretti (2004) e também Guimarães (1988) e Guimarães (2007). Desse modo, se o IHGB apresenta uma pretensão totalizante, surgem posteriormente a ele diferentes institutos históricos com falas marcadamente regionais, como é o caso do IHGSP.

${ }^{52}$ Entre as obras de Benedito Calixto destaca-se o livro Capitanias paulistas (1924). Nele, o autor do retrato de Jorge Velho reflete sobre o significado da palavra paulista: "Alguns dicionários antigos definem a palavra paulista, no sentido figurado, como sendo sinônimo de teimoso, birrento. Não deixa de ser bem aplicado o vocábulo, pois que a teimosia, a tenacidade enérgica, foi o que sempre distinguiu o caráter do bandeirante paulista. Foi com essa teimosia e tenacidade inquebrantável que o paulista conseguiu através dos sertões tornar grande e unida esta pátria que tanto estremecemos" (CALIXTO, 1924, p. 97). A trajetória de Calixto como artista e historiador foi estudada por Alves (2003).

${ }^{53}$ No mesmo ano em que Benedito Calixto finaliza sua tela, Washington Luís publica um de seus principais trabalhos, o artigo "Na capitania de São Paulo: o governo de Dom Rodrigo César de Meneses", transformado em livro em 1918, cf. Ferreti \& Capelato (1999). Vale ressaltar que, ao assumir o cargo de prefeito da capital paulista (1914-1919) e posteriormente presidente do estado de São Paulo (1920-1924), Washington Luís irá apoiar também a publicação de valiosos documentos sobre o passado bandeirante paulista, tais como: as Atas da Câmara de São Paulo, o Registro geral da Câmara de São Paulo, os Inventários e testamentos e as Sesmarias.

${ }^{54}$ Carta de Washington Luís a Benedito Calixto, 3 jan. 1903. Reproduzida em: “Os Palmares”. Correio Paulistano, 28 fev. 1903, pp. 1-2. É possível acompanhar, na mesma matéria, uma carta de Teodoro Sampaio, um dos poucos intelectuais negros a participar da fundação do IHGSP, enviada em 1892 a Calixto. Nela, Sampaio defende ser necessário "sacrificar um tanto a realidade à ficção, no intuito de conseguir maior força de expressão [na pintura]". Ambas as cartas foram publicadas no Correio Paulistano por Antônio de Toledo Piza, um dos fundadores e primeiro secretário do IHGSP, depois da finalização do retrato. Sobre o debate entre Washington Luís, Teodoro Sampaio, Toledo Piza e o pintor, tendo em vista a discussão em torno da melhor maneira de se retratar Jorge Velho, ver Marins (2007). 
Mais especificamente, a obra ressalta o protagonismo de Domingos Jorge Velho e de seu "batalhão de indígenas" no controle de "forças insurgentes" que queriam que "a raça negra subjugasse a branca, e que o Brasil se tornasse uma República do Haiti” (PAULA SOUZA, 1885, p. 9).

Lançado no Rio de Janeiro em 1885, Os Palmares começou a ser publicado em São Paulo em 1880, em formato de folhetim, no jornal $A$ Constituinte ${ }^{55}$. Logo no primeiro capítulo, a narrativa é apresentada como "um estudo dos homens e dos acontecimentos de 1694", pois "tudo que ali existe está provado", pelas obras publicadas e pela tradição transmitida de pais para filhos ${ }^{56}$. Seu livro, defende Paula Souza (1885, p. 8), forneceria "cenas novas, pinturas originais, costumes diferentes, cor local, completamente nossa, sem igual no mundo", que resultam de uma "síntese cultural" ocorrida em São Paulo, em que há um encontro entre as culturas europeia e americana, sem que haja mistura de raças.

Na mesma carta a Benedito Calixto, Washington Luís reproduz trechos do romance, nos quais Joaquim de Paula Souza descreve Domingos Jorge Velho como um homem de setenta anos de idade, "alto, robusto, de uma aparência imponente; tinha os cabelos ruivos, cortados rente, os olhos azuis, o rosto comprido, alvo, corado na pequena parte que não era coberta pelo espesso bigode, e comprida barba ruiva que lhe descia ao peito”. Já Antônio Fernandes de Abreu, o locotenente, aquele que depois do chefe pode provisoriamente desempenhar as funções deste, era, segundo a mesma carta, "meão de altura, pescoço curto e grosso, ombros largos, corpo reforçado; a cabeça era bem-feita, a testa um tanto saliente, os olhos pequenos e vivos, os bigodes aparados" 57 . Tudo indica que Benedito Calixto leu e levou a sério as sugestões de Washington Luís.

A obra de Benedito Calixto assegura a "pureza da raça" defendida pelo romancista, que não apenas deplora a presença negra na formação brasileira, como entende por paulista o branco “educado" na tradição de portugueses e indígenas, sem que haja miscigenação. Se em Os Palmares, nos termos de Paula Souza (1885, pp. 9/17), os paulistas derrotam os "pretos" tão "cheios de defeitos" e conquistam a maior parte do território brasileiro com a ajuda dos indígenas, "seus braços de todos os tempos”, não há nenhum negro e/ou indígena no retrato. É por meio de uma “união", que implica a submissão dos indígenas aos portugueses, explica Paula Souza, que surgem a força paulista e seu espírito destemido e desbravador, pois “os mestiços que [aqui] existem, não

\footnotetext{
55 “Os Palmares". A Constituinte, 16 maio 1880, pp. 2-3.

56 "Baseado na história, [o romance] não é um produto da fantasia", afirma Paula Souza. Seu livro, explica ele, tem como fontes "testamentos e velhos papéis que nos deixaram os antigos", além de relatos como os de Souza Botelho, marquês de Lavradio e Auguste de Saint-Hilaire. Cf. "Noticiário", A Constituinte, 13 maio 1880, p. 1.

${ }^{57}$ Carta de Washington Luís a Benedito Calixto, 3 jan. 1903. Reproduzida em: “Os Palmares”, Correio Paulistano, 28 fev. 1903, p. 2.
} 
são o Brasil que é filho de Portugal" (1885, p. 10). O paulista, prossegue ele, "é filho do português, há três séculos para aqui mudado, cruzando-se entre si, e com europeus” (1885, p. 11).

Cabe notar, porém, que os paulistas no romance recomendado por Washington Luís sofreram "frio, fome, intempéries”, segundo a descrição do próprio Joaquim de Paula Souza (1885, p. 8), e que a destruição do Quilombo dos Palmares durou muitos meses "em um sertão sem recursos, bravio e descaroável", de acordo com o Washington Luís na mesma carta ao artista ${ }^{58}$. Calixto, no entanto, optou por pintar um quadro, fundamentado em documentação textual e memórias orais como as que foram mobilizadas por esses dois autores, que não nos mostra nenhum resquício de sofrimento e/ou de sacrifício em um sertão que é retratado em tons claros como uma mata aberta e aparentemente acessível.

Duas matérias publicadas no Correio Paulistano, em 1903, assinadas por Aberto Sousa, nos lembram ainda que a ideia inicial da encomenda previa uma cena de batalha em grande formato, mas devido à escassez de verba estadual destinada à pintura, a obra teria se limitado a um retrato feito por suposição, já que não havia nenhuma representação visual da aparência de Jorge Velho ${ }^{59}$. Quanto à documentação que fundamentou a tela, Sousa indaga: “Arrasada sua República [dos negros de Palmares], que outros documentos ficaram para a história mais do que o testemunho suspeito e rancoroso dos exterminadores?” ${ }^{60}$. O fato, conclui ele, é que o governo do estado de São Paulo, no “justo propósito” de contratar pintores paulistas para a decoração histórica do primeiro museu público do estado, encomendou um retrato de Jorge Velho na sua qualidade de herói vencedor do episódio dos Palmares.

De acordo com a análise de Paulo Garcez Marins (2007), Benedito Calixto seguiu uma convenção pictórica característica dos retratos dos reis franceses da dinastia Bourbon, inaugurada por François José Hyacinthe Rigaud (1659-1743) nos célebres retratos que pintava de Luís XIV. Tais pinturas eram marcadas não apenas por uma suntuosa indumentária, como também por uma pose monárquica na qual a mão direita se apoia em um cetro (ou um bastão de comando militar) e

\footnotetext{
58 Carta de Washington Luís a Benedito Calixto, 3 jan. 1903. Reproduzida em: “Os Palmares”, Correio Paulistano, 28 fev. 1903, pp. 1-2.

59 “Jorge Velho". Correio Paulistano, 9 mar. 1903, p. 1/ "Jorge Velho II". Correio Paulistano, 10 mar. 1903, p. 1.

60 Alberto Sousa chama a atenção do leitor para o apaziguamento das tensões do período colonial e para o protagonismo silenciado dos "audaciosos" negros escravizados ou mortos que, "insurgidos contra as violências do bárbaro despotismo senhorial", defendiam "seus direitos naturais", tal como "a posse da liberdade". A "jornada dos Palmares" encabeçada por Domingos Jorge Velho, "arrastado pelos impulsos de seu gênio belicoso e afoito, amigo de carnificinas", seria um "ingrato e mal esclarecido episódio do nosso passado", defende o articulista. Cf. "Jorge Velho", Correio Paulistano, 9 mar. 1903, p. 1.
} 
o braço esquerdo permanece sustentado na cintura. Embora no início do século XX a pose majestática estivesse em desuso, ela era característica de retratos monárquicos e de chefes militares desde o fim do século XVII, período no qual Jorge Velho estivera em Alagoas para dar fim ao Quilombo dos Palmares.
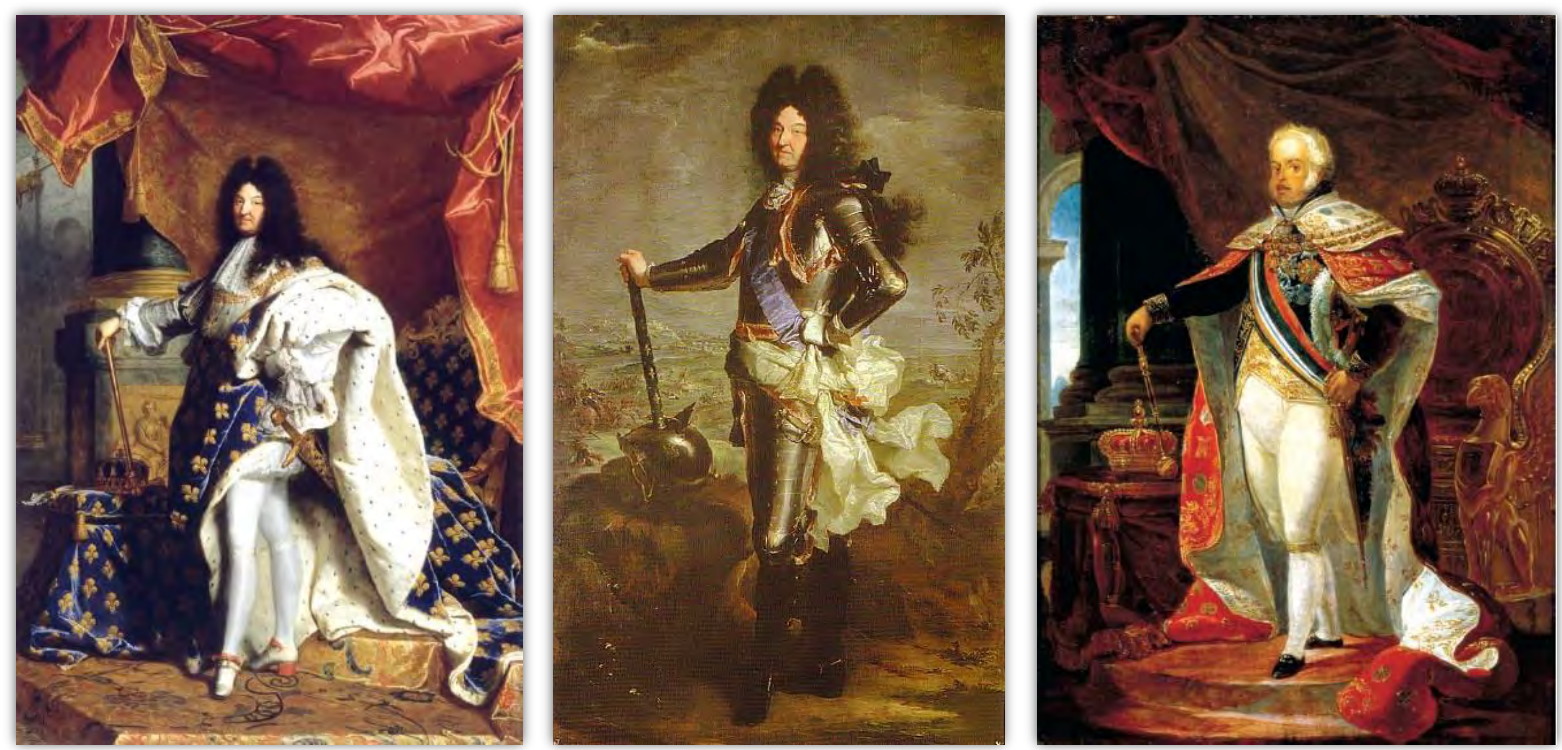

Figura 1.6 - Luís XIV em indumentária real (1701), de Hyacinthe Rigaud; Luís XIV em armadura (1694), de Hyacinthe Rigaud; e Dom João IV (1817), de Jean-Baptiste Debret. Fonte: "Nas matas com pose de reis" (2007), de Paulo Garcez Marins, pp. 224-225.

No Brasil, como aponta Elaine Dias (2006; 2013), essa convenção ganhou uma importante mediação a partir do retrato de Dom João VI, neto de Dona Mariana de Bourbon, realizado em 1817 por Jean-Baptiste Debret (1768-1848), integrante da Missão Artística Francesa que fundou a Escola Real de Ciências, Artes e Ofícios, futura Academia Imperial de Belas Artes do Rio de Janeiro. Ao servir de modelo para outras encomendas do Museu Paulista realizadas por Afonso Taunay por ocasião das festas centenárias — tais como as esculturas em bronze de Manuel da Borba Gato (1921), de Nicola Rollo (1889-1970), e Manuel Preto (1921), de Adrian Henri Vital van Emelen (1868-1943), instaladas na escadaria principal do edifício-monumento ${ }^{61}$ —, a composição

\footnotetext{
${ }^{61}$ Ambas as estátuas, Manuel da Borba Gato (Minas Gerais - 1720) e Manuel Preto (Paraná - 1853), foram dispostas na escadaria principal do Museu Paulista ao lado de outros quatro bandeirantes moldados em bronze — Bartolomeu Bueno da Silva, o Anhanguera (Goiás - 1744) e Paschoal Moreira Cabral (Mato Grosso - 1748), ambos de Amadeo Zani; Francisco Dias Velho (Santa Catarina - 1738), de Nicola Rollo; e Francisco de Brito Peixoto (Rio Grande do Sul- 1738), de Adrian van Emelen. Em cada um dos seis pedestais assinalou-se o nome do estado que teria sido alcançado pelo bandeirante e a data de sua separação do estado paulista.
} 
de Benedito Calixto se torna ela mesma uma convenção, consagrando-se como "uma das mais importantes formas de representação e dignificação dos antigos sertanistas paulistas" (MARINS, 2007, p. 80).
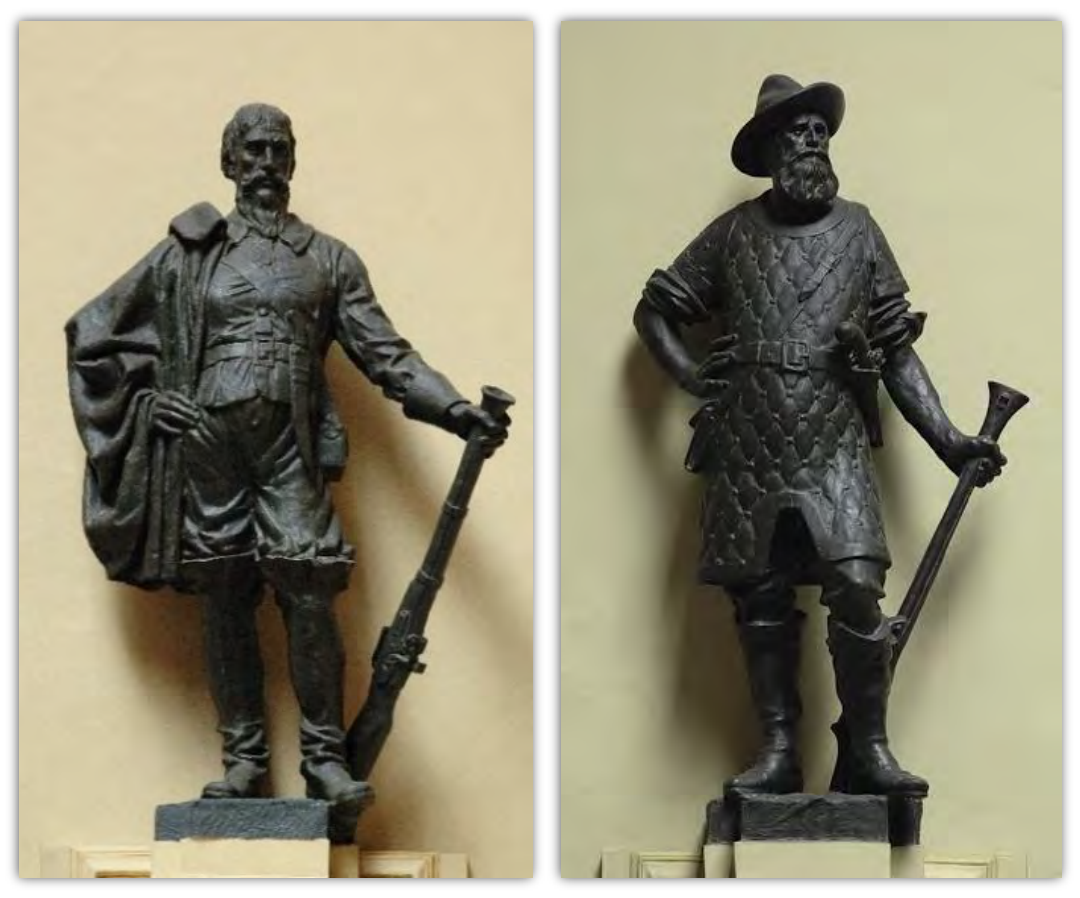

Figura 1.7 - Manuel da Borba Gato (1921), de Nicola Rollo, e Manuel Preto (1921), de Adrian Henri Vital van Emelen.

Fonte: "Nas matas com pose de reis" (2007), de Paulo Garcez Marins, pp. 231-232.

Trata-se de uma convenção que, assim como a pose majestática dos retratos de Hyacinthe Rigaud, não é seguida à risca, mas modificada segundo as conveniências do assunto ${ }^{62}$. Ao longo dos anos, imagens de bandeirantes com pose de reis estamparam diferentes suportes e materiais museu afora. Na figura abaixo, vemos, por exemplo, um chaveiro de metal sem data, um vaso comemorativo em homenagem ao IV Centenário da cidade de São Paulo e uma placa de licenciamento de veículo dos anos 1970, objetos que integraram a última exposição de longa duração do Museu Paulista. Inaugurada em 2007, a mostra "Imagens recriam a história" expôs a tela de Benedito Calixto cercada por objetos ligados à vida cotidiana, tais como porcelanas, medalhas, álbuns de figurinha, selos, postais, rótulos, embalagens e souvenires.

\footnotetext{
62 As adaptações introduzidas por Benedito Calixto ao associar a pose de Domingos Jorge Velho à majestade dos retratos monárquicos, assim como as modificações realizadas na pose estabelecida por Calixto ao ser retomada em obras encomendadas pelo Museu Paulista entre o final dos anos 1910 e meados dos anos 1920, foram analisadas por Marins (2007).
} 

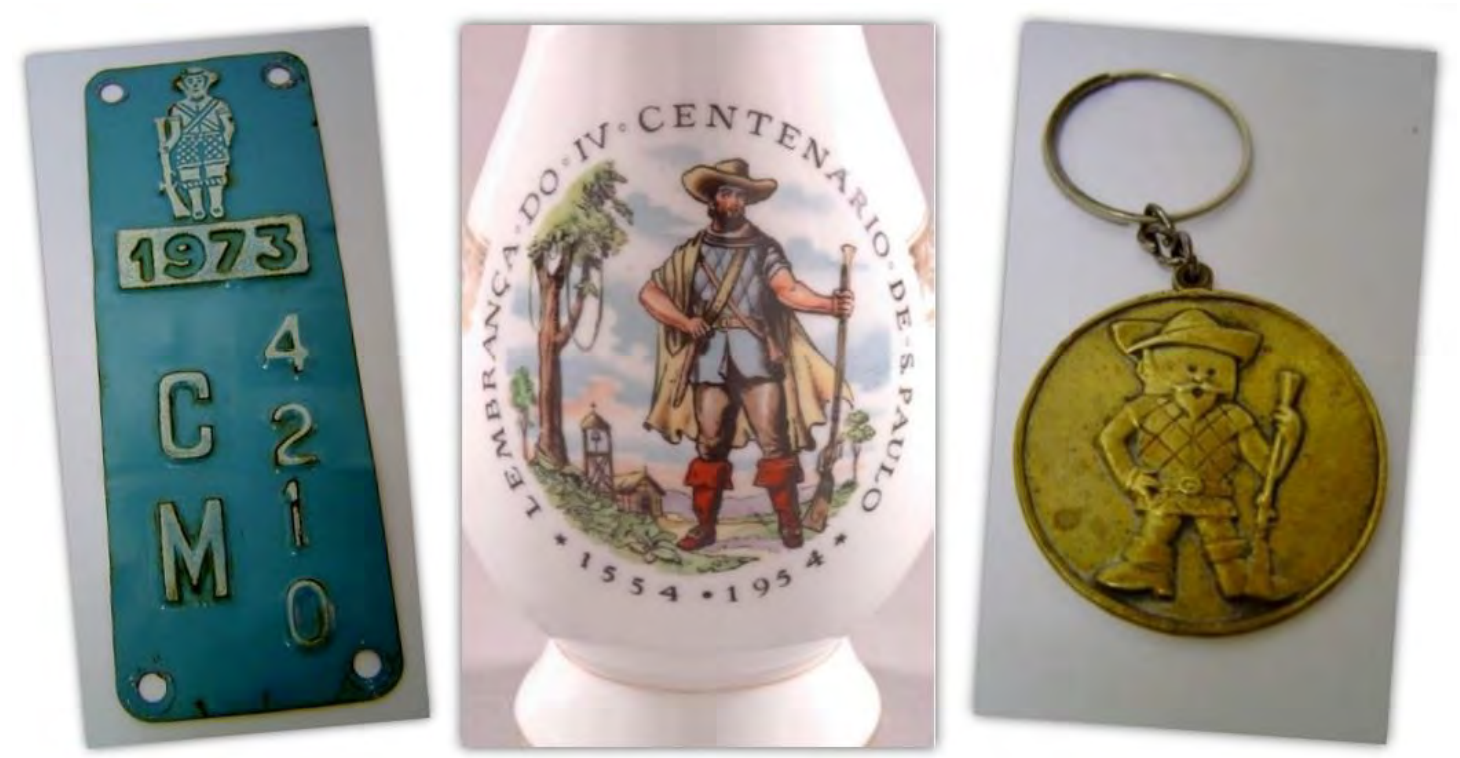

Figura 1.8 - Placa de licenciamento de veículo (1973), vaso comemorativo do IV Centenário da cidade de São Paulo (1954), chaveiro (s/d).

Fonte: Acervo do Museu Paulista da USP | Foto: Hélio Nobre e José Rosael.

Ao ser exibido no Museu Paulista, o retrato do "conquistador do Piauí e derrubador da Troia Negra" ${ }^{63}$, nos termos de Afonso Taunay, dá o pontapé inicial para a transformação do local em uma "galeria em que todos têm atitudes heroicas" 64 . Exposta com uma finalidade pedagógica, extrapolando os circuitos intelectuais a acadêmicos frequentados pelo então diretor do Museu Paulista, a obra irá também estampar diversos livros didáticos, que ajudarão a imagem do "vencedor dos Palmares" a transpor a colina do Ipiranga ${ }^{65}$. Em Breves lições de história do Brasil (1922), por exemplo, Domingos Jorge Velho, ilustrado pelo retrato feito por Benedito Calixto, é descrito por Creso Braga (1922, p. 65) como um "corajoso sertanejo" que "se ofereceu para acabar com os Palmares", destruindo o quilombo após uma longa luta que durou 10 anos. Na capa do livro, na parte inferior, há uma nota do autor informando que a obra foi aprovada em "solenes julgamentos" pelos conselhos de instrução e por outros órgãos do ensino público brasileiro, que decidiram adotála nas escolas do Distrito Federal e dos estados do Amazonas, Pará, Piauí, Ceará, Rio Grande do

\footnotetext{
63 “Identificação dos diversos Domingos Jorge Velho". Correio Paulistano, 10 jan. 1928, p. 3.

${ }^{64}$ Carta de Afonso Taunay a Henrique Bernardelli, 20 jul. 1922. APMP/FMP, pasta 117.

${ }^{65}$ Taunay não só tomou o retrato feito por Benedito Calixto como modelo para outras encomendas do Museu Paulista, como dedicou dois dos onze tomos de sua História geral das bandeiras paulistas ao estudo da destruição do Quilombo dos Palmares por Domingos Jorge Velho.
} 
Norte, Paraíba, Pernambuco, Alagoas, Sergipe, Bahia, Espírito Santo, Rio de Janeiro, São Paulo, Paraná, Minas Gerais e Mato Grosso ${ }^{66}$.

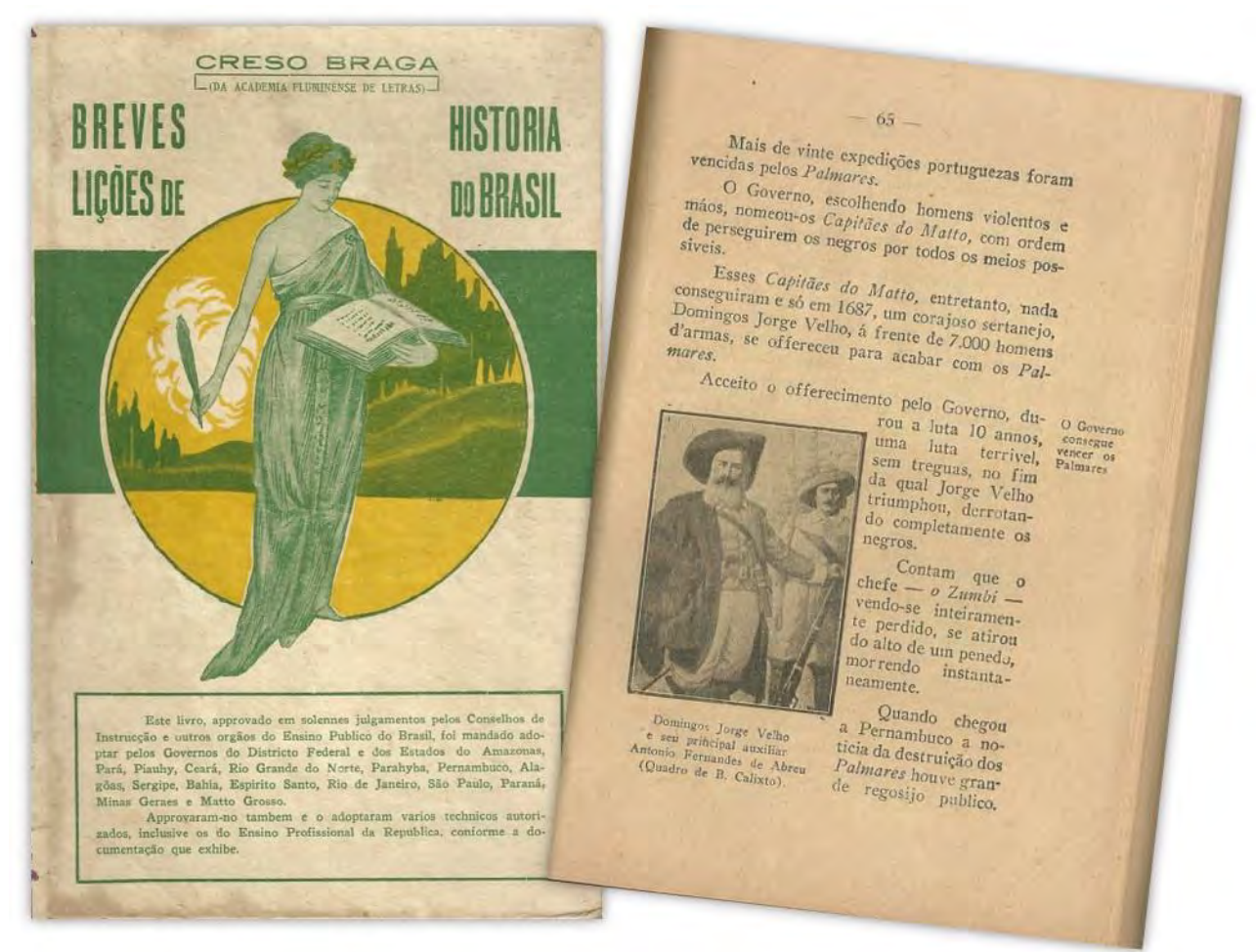

Figura 1.9 - Breves lições de história do Brasil (1922), de Creso Braga. À direita, na legenda da imagem, lê-se "Domingos Jorge Velho e seu principal auxiliar Antônio Fernandes de Abreu (quadro de B. Calixto)".

Fonte: Acervo pessoal | Foto: Thaís Waldman.

Para além dos livros de história e dos ensaios biográficos - e de textos literários como o romance Domingos Jorge Velho (1930), do alagoano Mario Wanderley —, são ainda numerosos os suportes e materiais que irão difundir não apenas a imagem dos bandeirantes com a pose monárquica, mas também a própria imagem de Jorge Velho retratado por Benedito Calixto, adaptando-a conforme as conveniências, muitas vezes excluindo a presença do loco-tenente. Temos, por exemplo, algumas cédulas do Thesouro do Estado de São Paulo, com diferentes

66 As primeiras setenta páginas do livro são destinadas às transcrições dos pareceres dos conselhos de instrução favoráveis à sua adoção, assim como a diversas congratulações de políticos e pessoas ilustres, aprovando e parabenizando Creso Braga pela referida obra. 
valores, chamadas de Bônus Pró-Constituição, emitidas em 1932 ${ }^{67}$; ou então, anos depois, um bilhete de loteria da Caixa Econômica Federal, da série "Vultos históricos", que data do ano de 1971. Em ambos, a ênfase recai sobre o rosto de Jorge Velho, desarmado (ao contrário dos negros retratados em segundo plano no bilhete de loteria ${ }^{68}$. Artefatos como esses ajudaram a disseminar uma imagem modelar.
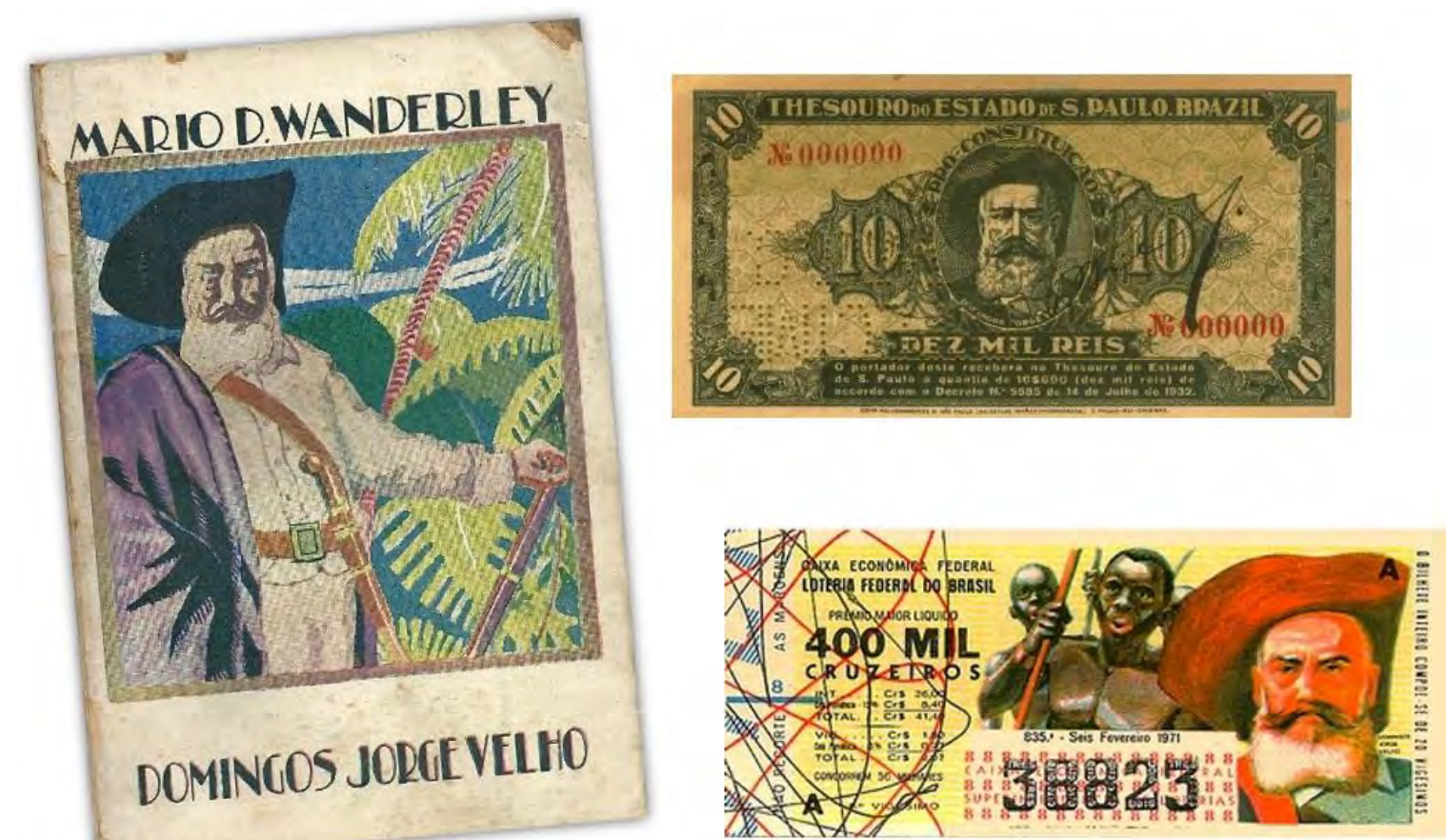

Figura 1.10 - Capa do romance Domingos Jorge Velho (1930), de Mario Wanderley; bônus PróConstituição (1932) do Thesouro do Estado de São Paulo; Bilhete de loteria (1971) da Caixa Econômica Federal.

Fontes: Acervo pessoal | Foto: Thaís Waldman/ Acervo Museu Paulista da USP | Foto: Hélio Nobre e José Rosael/ Loterofilia $^{69}$.

\footnotetext{
${ }^{67}$ As cédulas do Bônus Pró-Constituição foram impressas pela Companhia Melhoramentos de São Paulo em duas estampas, uma com o desenho do rosto de Domingos Jorge Velho e outra com o do bandeirante Fernão Dias.

${ }^{68}$ A série "Vultos históricos" é composta por doze bilhetes de loteria da Caixa Econômica Federal em homenagem a personagens históricos do Brasil, entre eles os bandeirantes Domingos Jorge Velho, Antônio Raposo Tavares, Bartolomeu Bueno e Borba Gato. Além de Tomé de Souza, Mem de Sá, Duarte da Costa, Francisco de Melo Palheta, Visconde de Cairu, Euclides da Cunha e o Dia dos Reis.
}

${ }^{69}$ Disponível em: <https://www.loterofilia.com.br/loteria-federal-do-brasil/temas/serie-vultos-historicos>. Acesso em: 10 nov. 2017. 


\subsection{Múltiplas imagens}

"E como este quadro vai figurar numa galeria em que todos têm atitudes heroicas, não será de recear que ele venha representando um homem numa situação despreocupada como quem está a fumar? Receio que daí nasça uma certa heterogeneidade com os demais quadros e estátuas"

(Carta de Afonso Taunay a João Batista da Costa, 1923) ${ }^{70}$

Em 1903, ano em que é adquirida a obra Domingos Jorge Velho e o loco-tenente Antônio Fernandes de Abreu, o Museu Paulista já se destacava das demais edificações paulistanas do período por assinalar o lugar "memorável" da proclamação da Independência do Brasil. A tela em homenagem ao bandeirante foi designada para integrar a coleção da galeria artística da instituição junto a outros retratos históricos de personagens considerados centrais para a história do país - Pedro I, José Bonifácio, padre José de Anchieta, padre Bartolomeu de Gusmão e o sargento-mor de Itu Vicente da Costa Taques Góes e Aranha — realizados por Benedito Calixto entre 1900 e $1902^{71}$. Segundo o Guia pelas coleções do Museu Paulista, lançado em 1907 por iniciativa de Hermann von Ihering, os seis retratos foram expostos em conjunto, em uma mesma sala, ao lado de objetos históricos, como uma liteira que pertenceu à Marquesa de Santos, e várias cadeiras e mesas, assim como um sofá e uma cama, que pertenceram ao Regente Feijó.

Tal inclusão de objetos históricos e obras de arte com fins celebrativos e educacionais no edifício-monumento era garantida por lei no próprio regulamento do Museu Paulista. Em 1894, durante a gestão do então presidente do IHGSP, Cesário Motta Júnior (1847-1897), frente à Secretaria de Negócios do Estado, entrou em vigor um decreto a respeito da estruturação do futuro museu e da atribuição de suas finalidades que, entre outras coisas, determinou no Art. $3^{\circ}$ que: “Além das coleções de ciências naturais - zoologia, botânica, mineralogia, etc. —, haverá no

\footnotetext{
${ }^{70}$ Carta escrita por ocasião da encomenda da tela Ciclo da caça ao indio, obra que irá figurar na parede da escadaria principal do Museu Paulista, em homenagem, segundo Afonso Taunay, ao primeiro grande ciclo bandeirante. Cf. Carta de Afonso Taunay a Henrique Bernardelli, 20 jul. 1922. APMP/FMP, pasta 117.

${ }^{71}$ Esse conjunto de retratos históricos encomendados a Benedito Calixto foi analisado por Pitta (2014).
} 
museu uma seção destinada à história nacional e especialmente dedicada a colecionar e arquivar documentos relativos ao período de nossa independência política”. Previa-se também, no parágrafo $1^{\circ}$, que nos lugares apropriados do edifício seriam colocados bustos, estátuas ou retratos a óleo de cidadãos brasileiros que tivessem prestado serviços à pátria e merecessem "a perpetuação de sua memória". Já o Art. $4^{\circ}$ estabelece um lugar para o quadro Independência ou morte (1888), de Pedro Américo (1843-1905), e para outros que fossem voltados para a história e para o costume pátrio ${ }^{72}$.

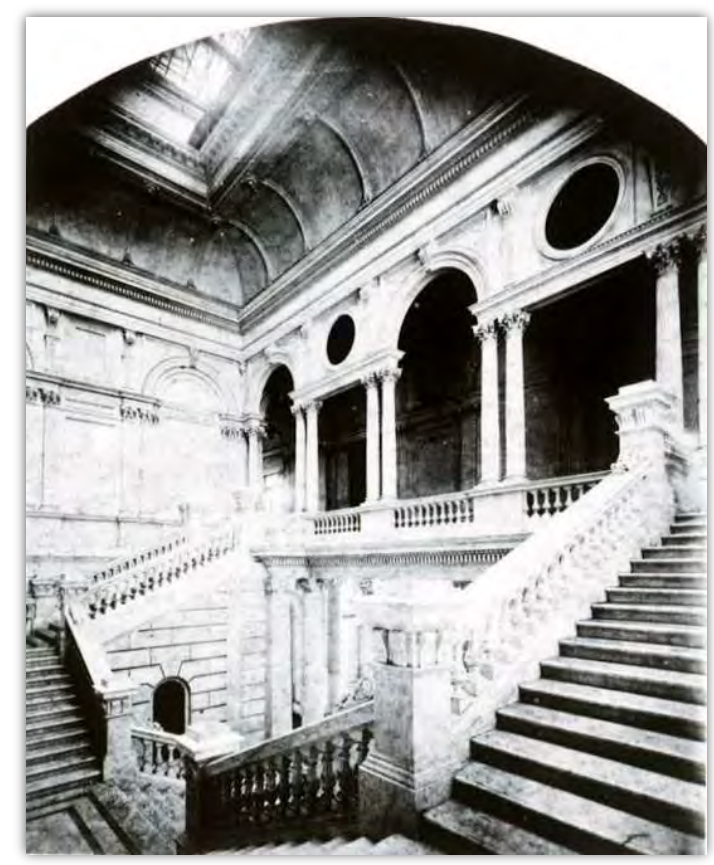

Figura 1.11 - Interior do edifício-monumento: vista a partir da escadaria central, 1892. Fonte: Acervo do Museu Paulista da USP | Foto: Guilherme Gaensly.

Embora as primeiras grandes aquisições de telas de temática histórica ligada ao passado paulista tenham ocorrido durante a gestão de Hermann von Ihering ${ }^{73}$, que inclusive era membro benemérito do IHGSP, Afonso Taunay defende que por mais de vinte anos a chamada coleção histórica do Museu Paulista permaneceu a mesma. Desde 1895 (ano da inauguração do museu) até o início de sua gestão ela teria "vegetado" confinada em duas pequenas salas de um edifício ainda “semivazio", explica Taunay (1937, p. 47). Ao anunciar no Correio Paulistano, em 1922, a inauguração do Museu Histórico e a ampliação do Museu de História Natural, Taunay descreve essas duas salas como um "irracional depósito de bric a brac", no qual "móveis velhos em detestável estado de

\footnotetext{
${ }^{72}$ Decreto no 249 , de 26 de julho de 1894, Alesp.

${ }^{73}$ Sobre a coleção de objetos do Museu Paulista ligados à temática histórica e à formação de uma galeria artística durante os primeiros anos da instituição, ver nota no 44 .
} 
conservação, amontoados, por vezes partidos, se contrapunham às joias da coleção Campos Salles, às armas antigas, e a tantas séries desconexas de cerâmicas, objetos domésticos, pinturas, retratos"74.

Sob sua gestão, o Museu Paulista irá se destacar como um importante centro de documentação sobre a história nacional do ponto de vista de São Paulo, além de ser referência fundamental para as pesquisas e publicações voltadas para essa temática ${ }^{75}$. Taunay (1926, pp. 1011) afirma ainda ter acumulado durante anos "elementos [históricos]", que agora seriam distribuídos pelas salas do museu, o que traria "um cunho de fundo regionalista justificativo do nome de nosso instituto" ${ }^{96}$. Membro atuante e presidente honorário do IHGSP ${ }^{77}$, desde jovem ele fora estimulado por seu professor, o historiador Capistrano de Abreu (1853-1927), a pesquisar a história de São Paulo, e mais particularmente sua relevância para a história nacional: "Se você está em São Paulo e quer escrever história - aconselhou-me certa vez o meu querido e saudosíssimo mestre Capistrano de Abreu [assim como ele associado ao IHGSP $^{78}$ ] - faça uma coisa: estude as bandeiras" (TAUNAY, 1927c, p. XVII) ${ }^{79}$.

${ }^{74}$ Até 1916, segundo a mesma matéria, além dessas duas salas, o Museu Paulista contava com onze salas de zoologia, uma de mineralogia, uma de numismática, uma de etnografia e um "salão de honra vazio, absolutamente vazio". Cf. "Reabertura do Museu Paulista". Correio Paulistano, 3 set. 1922, p. 3.

${ }^{75}$ Vide a criação, em 1922, dos Anais do Museu Paulista, nos quais o próprio Taunay publica grande parte de suas pesquisas sobre as bandeiras paulistas. Em carta ao secretário de Negócios do Interior, por exemplo, Taunay explica que pretendia distribuir o primeiro exemplar dos anais justamente no dia 7 de setembro de 1922. Para esse primeiro tomo, poderia fornecer numerosas cartas e papéis de negócios de bandeirantes do século XVII, além de documentos espanhóis da "mais alta valia" sobre o bandeirismo. Carta de Afonso Taunay a Alarico Silveira, 10 jun. 1921. APMP/FMP, pasta 113.

${ }^{76}$ Autor de uma vasta obra, como os onze volumes da História geral das bandeiras paulistas (editada entre 1924 e 1950 , período que coincide, em grande parte, com sua gestão no Museu Paulista), Taunay se destaca como um dos principais expoentes da onda de publicações históricas que exaltariam os bandeirantes, principalmente na década de 1920. Ver a esse respeito Anhezini (2011).

77 Entre 1913 e 1915, Taunay foi orador oficial do IHGSP, proferindo discursos fortemente marcados pelo seu interesse na construção e glorificação de uma identidade nacional paulista. Seus primeiros estudos historiográficos foram também publicados na Revista do IHGSP.

78 Avesso a títulos, condecorações ou pompas acadêmicas que a ele pudessem ser dedicadas, Capistrano de Abreu possui uma relação ambígua de hostilidade e associação aos institutos históricos. Se, por um lado, frequenta com assiduidade a biblioteca e os arquivos do IHGSP, e também do IHGB, e é sócio de ambos os institutos, por outro considera a grande maioria de seus membros "perfeitamente inúteis", desdenha das reuniões e pouco publica em suas revistas (ABREU, 1976, p. 92).

${ }^{79}$ Afastando-se do excessivo apego ao passado português que até então se confundia com a história do Brasil colonial, Capistrano centra seu interesse na formação das nossas origens como nação autônoma e inaugura uma nova perspectiva historiográfica. Sobre a concepção moderna presente na historiografia de Capistrano, ver, entre outros: Araújo (1996), Bottmann (1999), Iglesias (2000), Rodrigues (1988), Vainfas (2000), Pereira (2010) e Oliveira (2013). 
A reorganização dos espaços no interior da instituição permitiria, segundo Taunay, evocar "os grandes lances da história do Brasil revestindo o edifício do museu de uma feição de Pantheon, empolgante ao primeiro contato da vista dos visitantes com suas pinturas e esculturas" 80 . Taunay (1937, p. 22) recorda também que, entre 1890 e 1894, com o edifício-monumento desocupado, pensou-se em convertê-lo em um "Pantheon [da Independência]"; ele mesmo, porém, julgava ser “esdrúxulo" o "imperativo" de restringir o museu ao período da Independência, pois este para ele era o resultado de um processo histórico que teve início com a exploração e a conquista do território brasileiro pelos paulistas (TAUNAY, 1937, p. 46).

Nesse sentido, o retrato alusivo a Domingos Jorge Velho e Antônio Fernandes de Abreu, cumprindo a dupla função de artefato histórico e artístico, ganha uma espécie de templo para ser venerado, em um edifício-monumento consagrado não só à memória da Independência brasileira, mas também da história de São Paulo. Taunay difundiria assim a imagem do paulista "em suas várias gerações — bandeirante, tropeiro, cafeicultor — " como o responsável pelo progresso de São Paulo e consequentemente de todo o país (BREFE, 2005, p. 110).

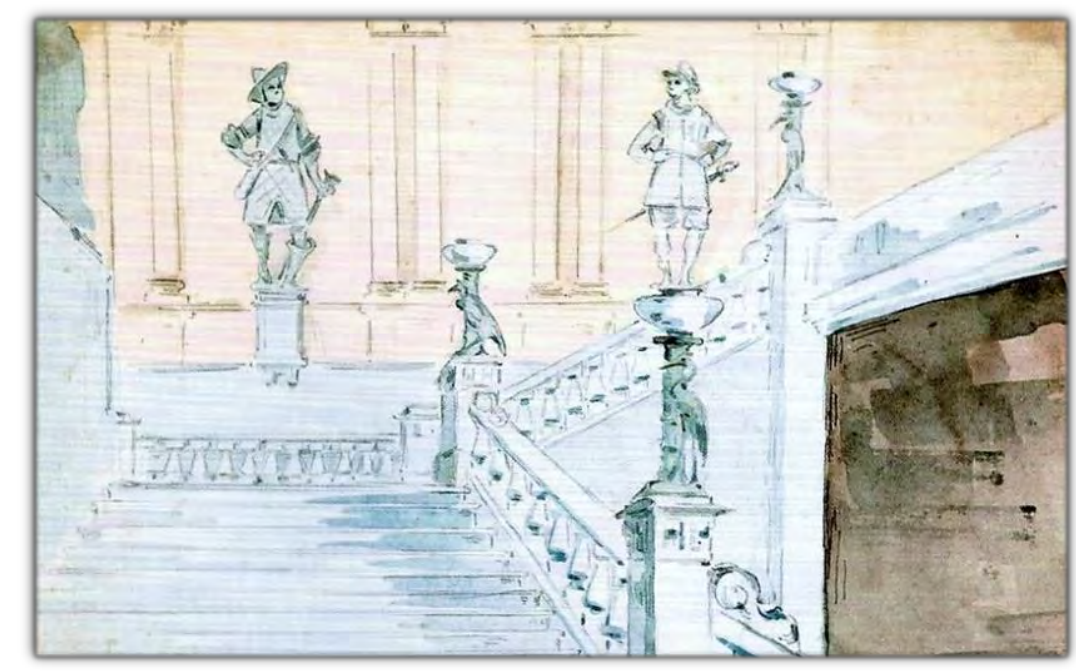

Figura 1.12 - Estudo para a escadaria principal do Museu Paulista, de Adrian Henri Vital van Emelen, década de 1920.

Fonte: Coleções em diálogo: Museu Paulista e Pinacoteca de São Paulo (2016), p. 44.

Tendo em vista as comemorações do Centenário da Independência do Brasil, o Museu Paulista amplia então suas coleções, projeto que se estende pelos anos seguintes, abrindo ao público 
novas salas consagradas, em especial, à história paulista ${ }^{81}$. Inúmeras foram as aquisições feitas no período, parte delas buscando efetivar o programa decorativo concebido para ornamentar o eixo central do edifício-monumento - hall de entrada, escadaria e o chamado salão de honra enquanto a outra iria compor exposições nas salas da seção histórica ${ }^{82}$. Pode-se dizer que as encomendas de obras de arte realizadas durante a gestão de Taunay "formam a maior e mais complexa demanda oficial de pinturas históricas e esculturas celebrativas realizadas por um museu brasileiro ao longo do século XX" (MARINS, 2017, pp. 170-171) ${ }^{83}$.

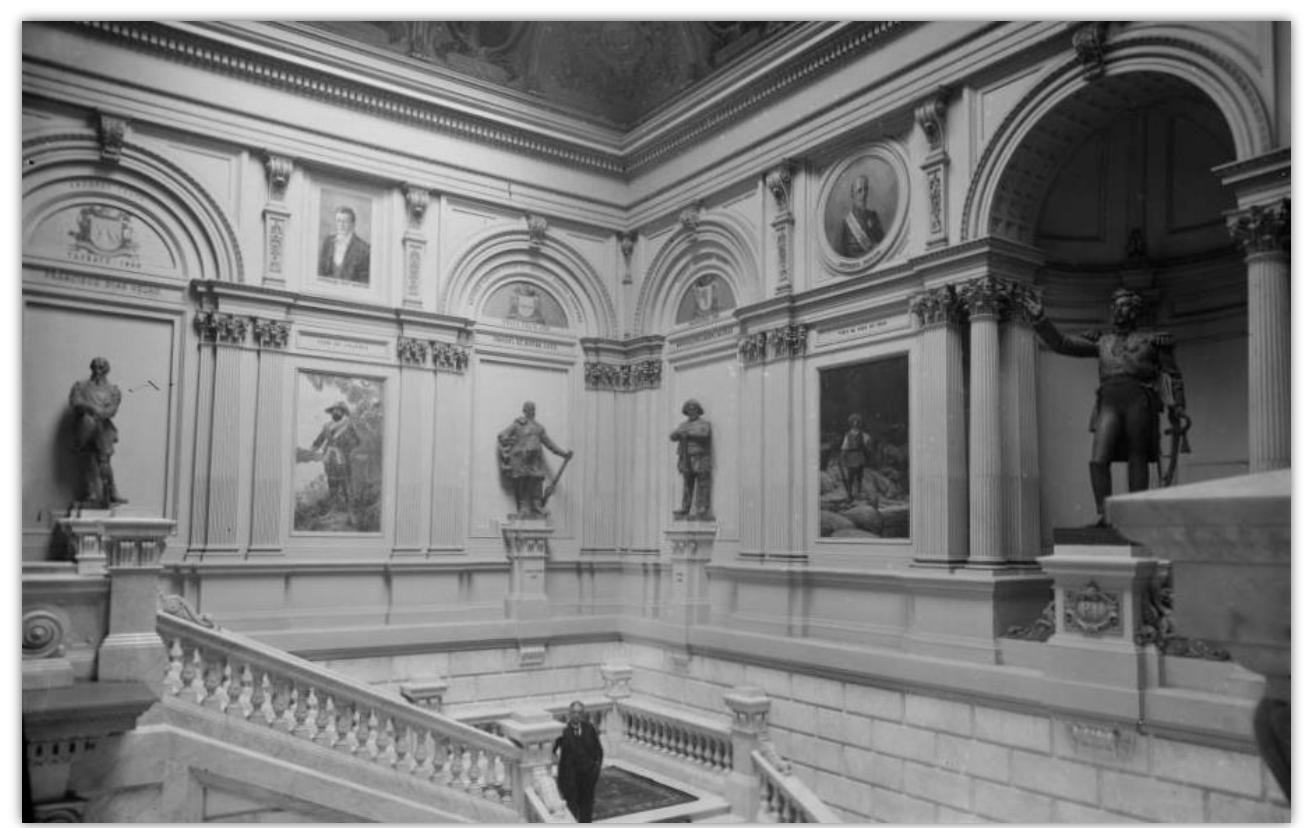

Figura 1.13 - Afonso Taunay na escadaria principal do Museu Paulista, anos 1930. Fonte: Acervo do Museu Paulista da USP.

${ }^{81}$ Para aumentar o espaço destinado à exposição dessa narrativa histórica, é criado em 1921 o Museu Republicano em Itu, uma extensão do Museu Paulista no interior do estado. Anos depois, ainda durante a gestão de Taunay, em 1939, é projetado o atual Museu de Zoologia (MZ) da Universidade de São Paulo (USP), para onde é transferida parte do acervo de zoologia. Já em 1989, a quase totalidade do acervo etnológico - que ganha uma seção após Sérgio Buarque de Holanda assumir a direção da instituição, sucedendo Taunay — é transferida para o Museu de Arqueologia e Etnologia (MAE) da USP.

${ }^{82}$ No inventário do acervo da seção de história do museu, revisto em 1925, Taunay descreve as coleções históricas de cada uma das salas abertas para exposição durante o Centenário da Independência, assim como o material conservado nos arquivos da secretaria do museu. APMP/FMP, pasta 240. Uma análise da ornamentação do museu visando as festas centenárias foi feita, entre outros, por Brefe (2003), Makino (2003), Mattos (2003) e Marins (2017).

${ }^{83}$ Nas últimas décadas, observa Miyoko Makino (2003), as pinturas encomendadas para decoração interna do prédio do Museu Paulista foram requeridas por editoras, empresas e pesquisadores com objetivos muito diversos, sendo reproduzidas à exaustão. Utilizadas de forma descontextualizada, ressalta a autora, muitas dessas imagens se disseminaram como verdades históricas. 
Ao reorganizar o museu, Taunay procurou conduzir os visitantes por um percurso expositivo que propõe uma narrativa sobre a emergência da nação brasileira como uma história protagonizada pelos paulistas ${ }^{84}$. Nesse percurso, o público é recebido no saguão de entrada pelas figuras dos bandeirantes Fernão Dias Paes Leme e Antônio Raposo Tavares, esculpidos em mármore por Luigi Brizzolara (1868-1937). Essas duas esculturas monumentais e as telas alusivas ao início da capitania de São Vicente, concluídas na década de 1930, constituem o princípio de um trajeto visual que se prolonga pela escadaria, no qual é aludida a formação econômica e territorial do Brasil por meio de esculturas de bandeirantes e pinturas dos "ciclos históricos" 85 . Percurso que se encerra no primeiro andar, no chamado salão nobre, onde os visitantes se veem diante da cena histórica do grito de Dom Pedro I, representada na tela Independência ou morte, obra finalizada em 1888 por Pedro Américo e depositada no edifício do museu em 1894, meses antes de sua abertura ${ }^{86}$.

A correspondência entre Taunay e os principais artistas encarregados da execução das estátuas e das telas que fariam parte da decoração histórica do museu visando as festas em 1922 se torna mais frequente a partir de 1920, quando o então diretor do Museu Paulista procura estabelecer os detalhes das encomendas, assim como os prazos de entrega e a negociação dos preços dos serviços. Importante ressaltar que sua intervenção na confecção dessas obras foi intensa. Taunay irá influenciar diretamente no trabalho dos artistas, fornecendo documentos históricos, opinando sobre os personagens que deveriam ou não ser retratados, sugerindo poses e movimentos, indicando as cores a serem empregadas e mesmo propondo cada detalhe das obras. Além de fornecer a fonte por meio da qual elas deveriam ser compostas, a partir de suas pesquisas históricas e das de seus pares, ele solicita informações e alterações mesmo quando elas estavam praticamente acabadas, o que nem sempre foi acatado, como veremos a seguir.

${ }^{84}$ Um ensaio topográfico da planta do edifício-monumento durante a gestão Taunay foi feito por Ana Cláudia Fonseca Brefe (2005) ao reconstruir a disposição das salas a partir de informações esparsas encontradas nos inventários do acervo da instituição e no Guia da seção histórica do Museu Paulista.

${ }^{85}$ Durante toda sua longa gestão como diretor do Museu Paulista, Taunay irá ampliar esse trajeto visual. Nos anos 1940, por exemplo, novas salas são organizadas, muitas delas dedicadas a expor telas temáticas sobre as monções, as antigas cidades bandeirantes, cenas de estrada, velhas fazendas de café. A esse respeito, cf. novamente Brefe (2005).

86 Antes mesmo da inauguração do Museu Paulista, a tela Independência ou morte, encomendada em 1885 a Pedro Américo, professor da Academia Imperial de Belas Artes, já enfatizava o protagonismo paulista no processo de independência brasileiro. Tommaso Bezzi, autor do projeto de construção do monumento que seria a sede da instituição, lhe deixara um espaço para ser fixada posteriormente na parede do edifício. A respeito da tela, ver o livro organizado por Oliveira \& Mattos (1999). Já sobre o salão nobre, cf. Meneses (1992) e Lima Junior (2016). 


\subsubsection{Ruinas}

Voltemos à entrada do Museu Paulista, na qual Antônio Raposo Tavares, que acompanharemos mais de perto neste momento, e Fernão Dias Paes Leme, que retornará no segundo capítulo, recebem os visitantes. Esculpidos em mármore de Carrara pelo italiano Luigi Brizzolara, ambos com cerca de três metros e meio de altura (ultrapassando as dimensões de Dom Pedro I, com aproximadamente dois metros de altura, encomendado a Rodolfo Bernardelli para ser exposto na escadaria central do edifício), os dois majestosos bandeirantes ocupam as paredes laterais do grande peristilo do museu, que antecede a escadaria principal. Com seus gestos e corpos vigorosos, eles se destacam, segundo Taunay, como as figuras máximas do movimento das entradas e da conquista do território nacional: Antônio Raposo Tavares, "que o admirável escultor representou na mais apropriada e estupenda das atitudes, com o braço alçado ao nível dos olhos, em um gesto de quem atento esquadrinha o horizonte infindo e hostil”, seria o principal representante do primeiro "grande ciclo bandeirante", o "ciclo da caça ao índio"; enquanto Fernão Dias "encarna o segundo grande ciclo, o da pesquisa do ouro e das pedras preciosas" (TAUNAY, 1926b, p. 22).
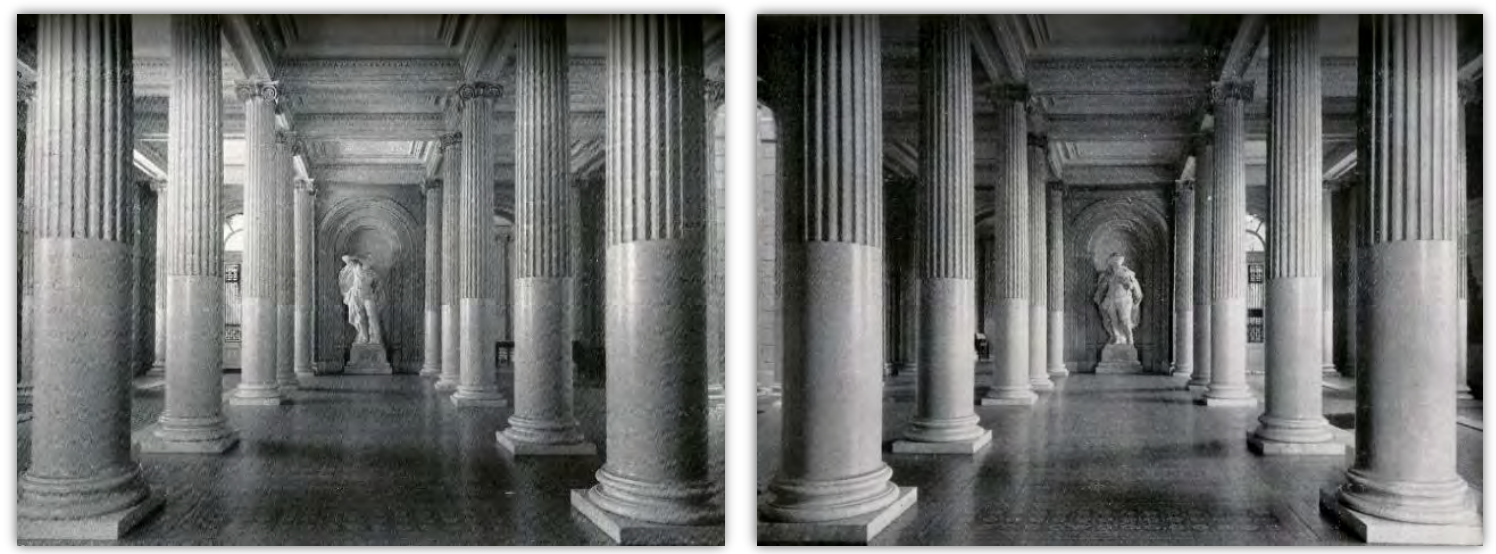

Figura 1.14 - Antônio Raposo Tavares e Fernão Dias Paes Leme, Museu Paulista, anos 1930. Fonte: Guia da sesão histórica do Museu Paulista (1937), Afonso Taunay, s/p.

Segurando um papel enrolado na mão esquerda, possivelmente um mapa, e com a mão direita sobre o rosto barbado, na altura dos olhos, Raposo Tavares fixa seu olhar na linha do horizonte, justamente em direção ao oeste, como que explorando as terras a serem conquistadas. Sua vestimenta muito se assemelha a de Domingos Jorge Velho, retratado por Benedito Calixto anos antes: chapéu de abas largas, botas de cano longo, calça e camisa alinhadas e presas na cintura 
por um cinto que carrega um facão, além de um manto sobre os ombros. Com o tronco levemente inclinado e os músculos retesados, o bandeirante joga seu manto para trás expandindo o peitoral e aumentando a imponência do personagem.

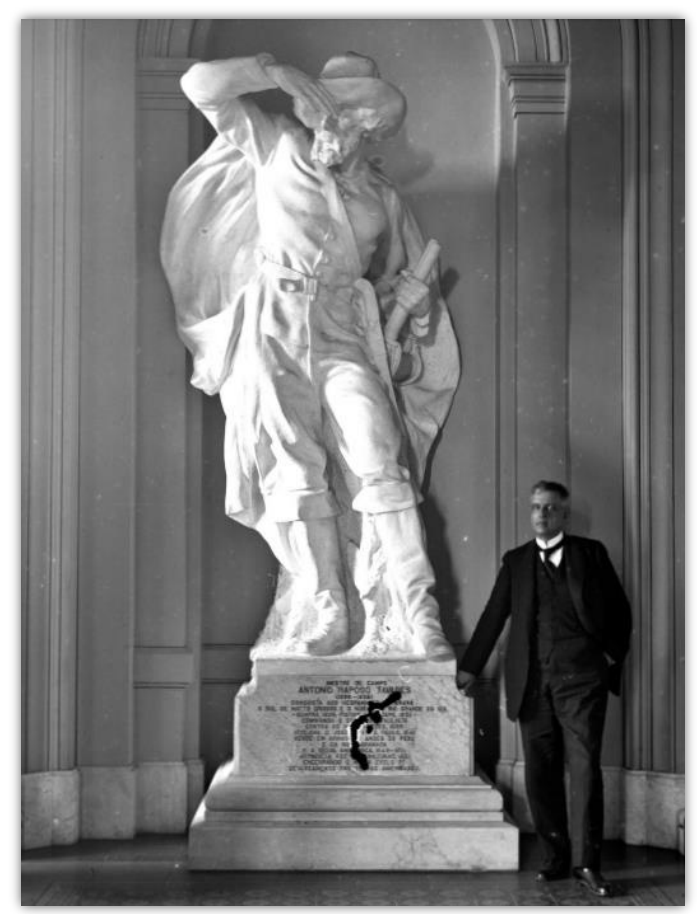

Figura 1.15 - Afonso Taunay ao lado da escultura por ele encomendada, Antônio Raposo Tavares (1922), de Luigi Brizzolara.

Fonte: Acervo do Museu Paulista da USP.

A placa abaixo do pedestal sobre o qual pisa Raposo Tavares destaca ainda aqueles que seriam seus principais feitos:

\author{
Mestre de campo \\ Antônio Raposo Tavares \\ $(1598-1658)$
}

Conquista aos espanhóis, o Paraná, o sul do Mato Grosso e o norte do Rio Grande do Sul

— Guairá, 1629; Itatins, 1632; Tape, 1636 —.

Comanda o socorro paulista contra os holandeses, 1639.

Aclama Dom João em São Paulo, 1641.

Vence em armas os andes do Peru e da Nova Granada

e a Selva amazônica, 1648-1651.

Atinge a foz do Amazonas, 1651, encerrando o maior ciclo de devassamento das terras americanas 
Em 1907, o historiador Capistrano de Abreu, a quem Afonso Taunay chamava de "mestre", questionava em seus Capitulos de história colonial o valor dessa expansão territorial, valendo-se dos relatos jesuíticos do século XVII do padre Antonio Ruiz de Montoya, sobre as práticas de violência e genocídio promovidas pelos bandeirantes nas suas incursões para apresamento dos indígenas: “Compensará tais horrores a consideração de que por favor dos bandeirantes pertencem agora ao Brasil as terras devastadas?" (ABREU, 1907, p. 104). Anos antes, em seu ensaio "Caminhos antigos e povoamento do Brasil", publicado em 1889 no jornal O Comércio de São Paulo, Capistrano já afirmava que as bandeiras não povoaram o país, pelo contrário, despovoaram, por terem causado a morte de inúmeros indígenas. O próprio Taunay irá ressaltar em seus textos que, quando jovem, Raposo Tavares teria arrebanhado para São Paulo 10 mil "servos vermelhos": uma "cena cruel", pois “cruéis eram seus intentos" (1926b, p. 7).

Olhando para o horizonte fora da linha de combate, e com a roupa toda alinhada, o bandeirante esculpido por Luigi Brizzolara não remete, todavia, a nenhuma "cena cruel", por mais que a placa comemorativa mencione a luta armada. Nesse sentido, Taunay não só encomenda uma escultura "homérica" em homenagem a Raposo Tavares, como a posiciona sobre um pedestal de mármore que celebra sua glória. Em defesa da placa, por ele escrita, e da escultura, por ele encomendada, o então diretor do Museu Paulista explica que a escravidão indígena era parte inevitável do processo de ampliação das fronteiras e da conquista do território brasileiro: a “mentalidade desses homens do século XVII" era outra, pois tinham como preocupação central a “expansão essencial do Brasil” (TAUNAY, 1926b, p. 7). O próprio Taunay (1924, p. 25) alega que muitos indígenas dispersos pelo território se tornaram um empecilho ao processo de ocupação e povoamento do Brasil; por exemplo, os tapuia, por ele descritos como "bárbaros", que "só poderiam ser vencidos com o auxílio dos paulistas" ${ }^{\$ 7}$.

A ênfase do texto da placa, no entanto, não está nas práticas de violência e genocídio, mas na conquista de territórios que pertenciam à Espanha, na luta contra a Holanda e na aclamação de Dom João em São Paulo. Obediente ao rei lusitano, Raposo Tavares é descrito no pedestal como o bandeirante responsável pelo devassamento de diversos territórios, tomando-os dos espanhóis e dos holandeses. Cabe observar, porém, que Guairá, Itatins e Tape, mencionadas no texto da placa, eram missões jesuíticas, de acordo com os próprios textos de Taunay, nos quais ele também relata que Raposo Tavares teria afastado os jesuítas, assim como os indígenas catecúmenos, para as "regiões da longínqua Mesopotâmia paraná-uruguaia", onde se julgavam "a coberto dos terríveis e

\footnotetext{
87 A maioria dos membros do IHGSP via sem estranhamento a escravização indígena realizada pelos bandeirantes, principalmente das tribos consideradas "hostis", cf. Ferreira (2002).
} 
odiados portugueses de San Pablo" (1926b, p. 7). Após esses episódios, relata também Taunay, Raposo Tavares, em reconhecimento a suas "ações de guerra”, foi promovido a juiz ordinário em São Paulo e ouvidor da capitania de São Vicente (1926b, p. 9).

Ao encomendar a escultura do bandeirante, o então diretor do Museu Paulista defende estar ele mesmo "revestindo de intensa luz" a figura de um dos "grandes chefes do afuramento da selva ignota”. Uma figura escolhida a dedo, desde as vinte letras de seu nome completo - Antônio Raposo Tavares —, que traduziriam os vinte estados da federação brasileira da década de 1920, desbravados pelos "temíveis homens vestidos de couro", que tinham como lema "O Brasil sempre a oeste!" (TAUNAY, 1926b, p. 15). Sua escultura ajudaria a revisão de uma determinada historiografia do Brasil, preocupada essencialmente com o estudo da conquista do litoral ${ }^{88}$. Havia uma grande lacuna na biografia de Raposo Tavares, defende ele, tendo o bandeirante permanecido "semiobscuro" até então devido à "ignorância dos historiadores oficiais" 89 .

É interessante notar que Taunay relembra em seus textos, como Índios! Ouro! Pedras! (1926), cuja capa é ilustrada por um desenho da imponente estátua de Luigi Brizzolara, o livro Quando o Brasil amanhecia (1919), de Alberto Rangel (1871-1945). Retomando o trabalho de Rangel, ele diz que, ao regressar de sua jornada por uma selva "cheia de espanto e terror", Raposo Tavares limpou os olhos para conferir se não estava sonhando, enquanto alguns indígenas lhe apalpavam o corpo, “devastado de magreza e moléstia”, igualmente incrédulos (1926b, pp. 14-15). Há quem diga, ainda de acordo com Taunay no mesmo livro, que o bandeirante retornou de sua expedição totalmente “desfigurado" (1926b, p. 13).

Índios! Ouro! Pedras! foi publicado por ocasião da proximidade da inauguração de outro monumento em homenagem a Raposo Tavares, inaugurado na região onde ele viveu, Quitaúna, atual cidade de Osasco. Moldada em bronze pelo italiano Amadeo Zani (1869-1944) com uma pose majestática, sem moléstias e nem magreza, a escultura foi exposta em Quitaúna sobre um pedestal com os mesmos dizeres que acompanham a estátua de Brizzolara.

\footnotetext{
88 Ao escrever sua História geral do Brasil (1854-1857), Francisco Adolfo de Varnhagen ficou conhecido como o "pai" da historiografia brasileira. Apesar de muitíssimo bem documentada, trata-se de uma história lusófila e brigantina, voltada para o estudo das comunidades do litoral. Sobre o reconhecimento de Varnhagen como o "pai" da historiografia brasileira, cf. Cezar (2007).

89 “Caso insignificante esse jornadear pela selva! Coisa mínima esse romper do sertão que oferece todas as comodidades aqueles que o devassam! É o que se depreende de tão rápidos e vulgares conceitos (...). De uns trinta anos para cá começou a assentar-se a visão dos historiadores sobre a importância colossal do movimento das entradas. Que seria sem ele o Brasil? Estrangulado pelo meridiano de Tordesilhas? Reduzido a menos de um terço do que é? E fixada a atenção sobre o surto nacional por excelência, principiou revestir-se de intensa luz a personalidade dos grandes chefes do afuramento da selva ignota”, explica Taunay (1926b, p. 3).
} 


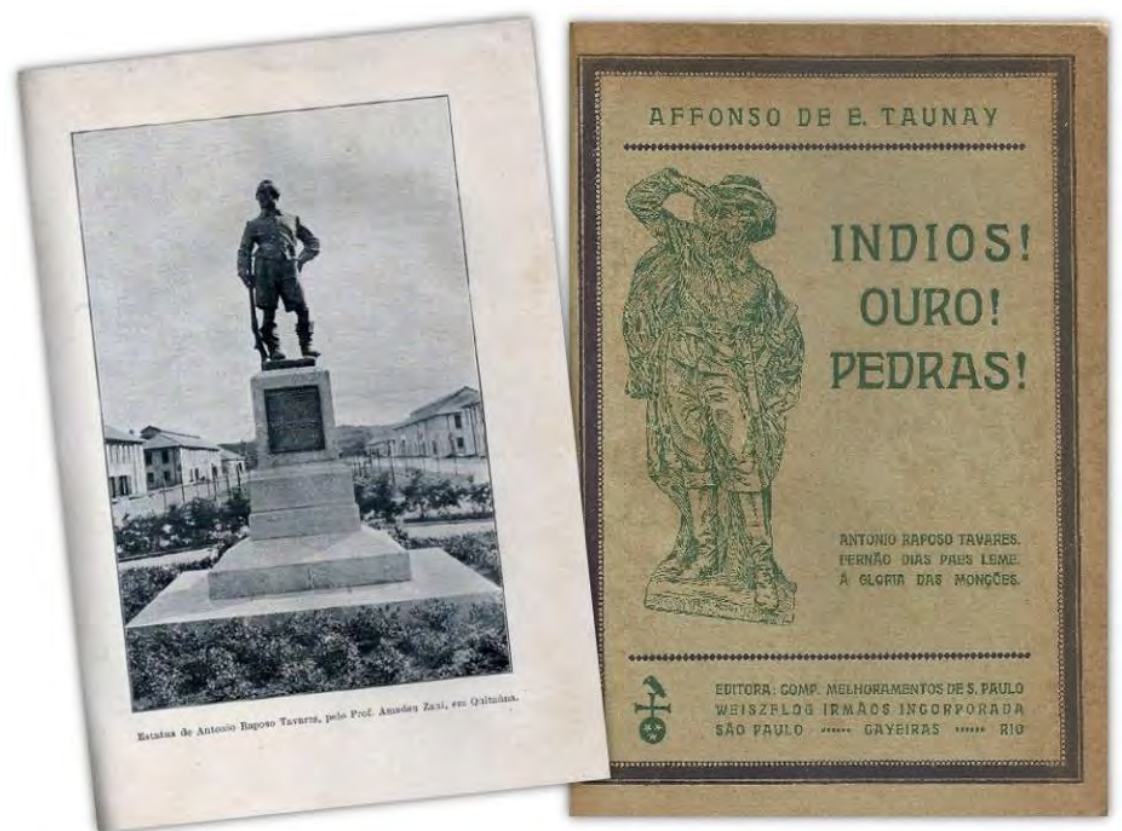

Figura 1.16 - Antônio Raposo Tavares, de Amadeo Zani, no livro Índios! Ouro! Pedras! (1926), de Afonso Taunay, cuja capa é ilustrada pelo bandeirante homônimo esculpido por Luigi Brizzolara.

Fontes: Acervo pessoal | Foto: Thaís Waldman.

Também na década de 1920, Taunay havia encomendado a João Batista da Costa uma tela retratando a casa e a antiga capela de Raposo Tavares em Quitaúna, igualmente mencionada no livro Índios! Ouro! Pedras!. Em carta enviada ao pintor em 1922, Taunay afirma ter anexado duas fotografias, uma delas de uma "estátua de bandeirante", provavelmente se referindo a escultura de Luigi Brizzolara, outra da antiga capela de Raposo Tavares ${ }^{90}$. Não se sabe ao certo que fotografias foram essas, mas a tela adquirida pelo Museu Paulista retrata duas construções de taipa de pilão, técnica que caracterizou as edificações paulistas da época colonial, em ruínas. É possível observar várias camadas de revestimentos aplicadas na parte externa da casa e nas paredes da capela, sendo que a fachada e as laterais de ambas estão bem desgastadas pela ação do tempo. Vemos aqui o final da jornada do bandeirante esculpido em mármore para as festas centenárias: sua estátua "homérica" contracenando com a pintura (de $93 \times 73,1 \mathrm{~cm}$ ) da sua casa decadente, retratada em uma das poucas encomendadas realizadas na década de 1920 pelo Museu Paulista que não possui tom celebrativo.

\footnotetext{
${ }^{90}$ Carta de Afonso Taunay a João Batista da Costa, 11 set. 1922. APMP/FMP, pasta 117.
} 


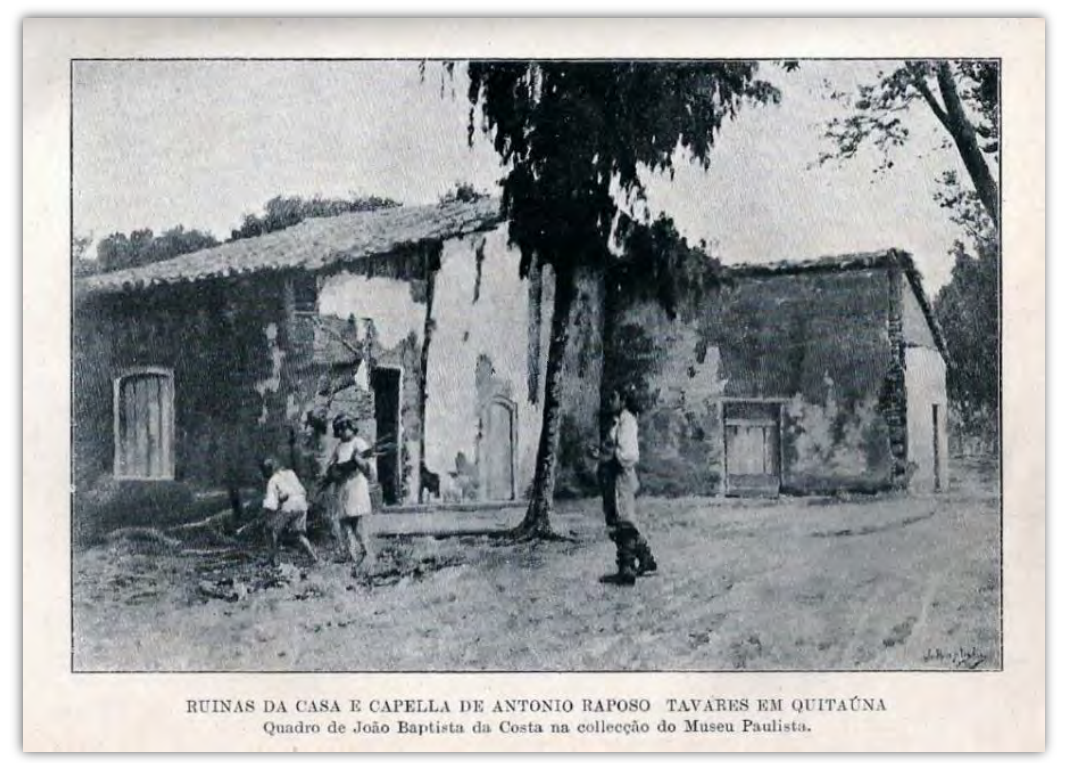

Figura 1.17 - Ruínas da casa e capela de Antônio Raposo Tavares em Quitaúna, de João Batista da Costa, no livro Índios! Ouro! Pedras! (1926), de Afonso Taunay.

Fontes: Acervo pessoal | Foto: Thaís Waldman.

\subsubsection{Dramas bandeirantes}

Entre os artistas contratados para a decoração do Museu Paulista, Afonso Taunay fez questão de convidar célebres pintores e escultores da Escola Nacional de Belas Artes do Rio de Janeiro. Entre eles, João Batista da Costa, autor de Ruinas da casa e capela de Antônio Raposo Tavares em Quitaúna, além outros como Joaquim Fernandes Machado, Rodolfo Amoedo e Henrique Bernardelli. Com uma produção bastante aclamada, esses artistas talvez pudessem ajudar a projetar São Paulo no centro da vida cultural do país com o status de artistas já consagrados da capital brasileira ${ }^{91}$.

\footnotetext{
${ }^{91}$ Rodolfo Amoedo e Henrique Bernardelli foram alunos da Academia Imperial de Belas Artes. Após voltarem de seus estudos na Europa — Amoedo em Paris e Bernardelli em Roma - se tornam renomados professores da Escola Nacional de Belas Artes, que teve como primeiro diretor Rodolfo Bernardelli, artista mexicano naturalizado brasileiro, irmão de Henrique. Além disso, participam de diversos projetos decorativos em prédios públicos cariocas, como a Biblioteca Nacional, o Theatro Municipal e o próprio edifício do Museu Nacional de Belas Artes. João Batista da Costa, por sua vez, igualmente aluno da Academia Imperial de Belas Artes, após voltar de seus estudos em Paris, assume a cadeira de pintura de Rodolfo Amoedo na Escola Nacional de Belas Artes. Já Joaquim Fernandes Machado foi aluno da Escola Nacional de Belas Artes, tendo como professores Rodolfo Amoedo e Henrique Bernardelli, e conquistou o Prêmio de Viagens em 1901, que lhe rendeu um período de estudos em Paris.
} 
Cabe notar que, no início do século Xx, São Paulo não possuía uma escola de belas-artes. Tal modelo de ensino, difundido sob a égide das Academias francesas, chega ao Brasil com a chamada Missão Francesa, em 1816, centrado na Academia Imperial do Rio de Janeiro, depois Escola Nacional de Belas Artes. O bisavô de Afonso Taunay, Nicolau Antoine, é um dos fundadores da Academia Imperial de Belas Artes, e seu avô, Félix Émile, o substitui na cadeira de pintura da mesma instituição ${ }^{92}$. Até o início do século Xx, portanto, o Rio de Janeiro era o maior e mais importante centro produtor e consumidor nacional de artes ${ }^{93}$.

Vimos que Raposo Tavares e Fernão Dias não foram os únicos bandeirantes encomendados por Taunay visando as comemorações do Centenário da Independência do Brasil. Na entrada do museu, logo depois do peristilo, seis bandeirantes menores moldados em bronze "montam guarda”, nos termos de Taunay (1926, p. 49), a outra peça em bronze, essa em homenagem a Dom Pedro I, realizada por Rodolfo Bernardelli e posicionada no nicho central da parede da escadaria principal da instituição ${ }^{94}$. Quatro telas intercalam as figuras dos seis bandeirantes, são elas: Ciclo da caça ao indio, de Henrique Bernardelli, sobre o primeiro ciclo bandeirante; Ciclo do ouro, sobre as formas primitivas de mineração, de Rodolfo Amoedo; Ciclo dos criadores de gado, destinado a lembrar a ação dos bandeirantes paulistas criadores de gado, de João Batista da Costa; e Posse da Amazônia, sobre o bandeirante que conquistou o Amazonas, de Joaquim Fernandes Machado. No topo da

92 Afonso Taunay possuía um grande interesse pela produção de seus antepassados, tendo escrito um livro sobre seu bisavô e outro sobre a Missão Francesa, além de artigos sobre Aimé Adrien, irmão de seu avô e membro da expedição Langsdorf. Sobre a missão artística de 1986, ver Schwarcz (2008).

${ }^{93}$ Em São Paulo é o Liceu de Artes e Ofícios — herdeiro da Sociedade Propagadora de Instrução Popular (1873), instituição pedagógica voltada para as artes aplicadas —, que começa a suprir essa lacuna, ainda que os artistas paulistas do período complementassem sua formação em outros centros, fosse no Rio de Janeiro e/ou nas Academias europeias, principalmente italianas e francesas. Fundado em 1882, o Liceu entra em grande atividade e expansão a partir de 1885, sob a organização do arquiteto Ramos de Azevedo. Em 1897, o Escritório Técnico Ramos de Azevedo inicia o projeto do edifício que seria a sede definitiva do Liceu, na praça da Luz, nunca concluído, mas entregue em 1900. Nesse mesmo prédio será instalada a Pinacoteca do Estado de São Paulo, na qual serão realizadas importantes exposições da década de 1910, como a primeira e a segunda edição da Exposição Brasileira de Belas Artes, que revelariam a coletividade artística da capital paulista. Criada em 1905, a Pinacoteca é inaugurada em 1911, cf. Araújo \& Camargos (2007).

94 Encomendada em 1890, a escultura feita por Rodolfo Bernardelli é entregue somente em 1923. Para as comemorações do Centenário da Independência do Brasil, o Museu Paulista teve que recorrer a um antigo busto de bronze de Dom Pedro I, emprestado temporariamente ao museu pela Escola Nacional de Belas-Artes do Rio de Janeiro. Tamanho atraso na entrega da encomenda rendeu muitos comentários: "Está bonito, vai o Sr. fazer a festa de Pedro I sem Pedro I!", teria exclamado a Taunay o então governador de São Paulo, Washington Luís, depois das festas centenárias. Taunay também afirma ter ouvido "não de um ou de dois, mas de dezenas de pessoas, pilhérias de mau gosto, conceitos desagradáveis, indiretas”. Cf. Carta de Afonso Taunay a Rodolfo Bernardelli, 16 dez. 1922. APMP/FMP, pasta 117. 
escadaria, vê-se ainda a Retirada do cabo de São Roque, também de Henrique Bernardelli, sobre um episódio de guerra entre bandeirantes e holandeses ${ }^{95}$.

Durante a encomenda do painel Ciclo da caça ao indio, Taunay pediu a Henrique Bernardelli que homenageasse o primeiro grande ciclo bandeirante por meio de um retrato de Mathias Cardoso de Almeida, "um homem de face gravibunda", com "barbas e já de certa idade" quando "andou a bater-se com índios” do Piauí, do Ceará e do Rio Grande do Norte, entre 1689 e $1694^{96}$. Taunay acompanhou de perto a realização da obra e solicitou modificações em mais de uma versão, como no estudo posteriormente intitulado Chefe bandeirante, que hoje faz parte do acervo do Museu Mariano Procópio (Juiz de Fora), por ele criticado devido à presença do cachorro ao lado de Cardoso de Almeida e do rebenque preso ao cinto do bandeirante.

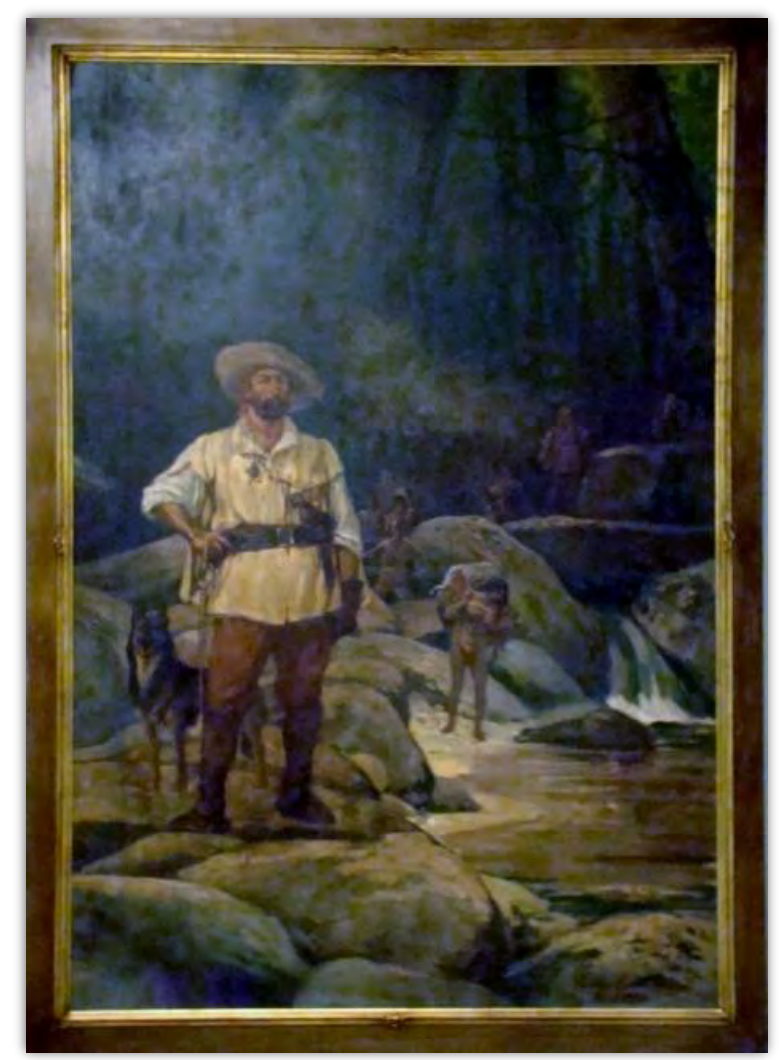

Figura 1.18 - Chefe bandeirante (1929), de Henrique Bernardelli.

Óleo sobre tela, 236 × $167 \mathrm{~cm}$ (com a moldura). Fonte: Acervo Museu Mariano Procópio.

\footnotetext{
${ }^{55}$ Cabe lembrar que em 1890, Capistrano de Abreu já anunciava, em carta ao Barão de Rio Branco, pretender escrever uma história do Brasil que abarcasse "as bandeiras, as minas, as estradas, a criação de gado", descritos por ele como “aspectos até agora menosprezados” de nossa história (apud RODRIGUES, 1977, v.1, p. 130).

${ }^{96}$ Carta de Afonso Taunay a Henrique Bernardelli, 20 jul. 1922. APMP/FMP, pasta 117.
} 
Diante de uma nova versão da tela, sem o cachorro e o rebenque, Taunay desaprova o cachimbo e a posição anti-heroica de Cardoso de Almeida que, retratado dessa maneira, fumando distraidamente à margem de um rio e de costas para os indígenas escravizados, destoaria dos demais bandeirantes do Museu Paulista e da imagem de Pedro I:

O seu quadro deve ir ao lado da estátua do seu irmão que representa Pedro I a arrancar o tópico português. Ora, poderá causar estranheza ver-se um homem, figura principal da tela, a fumar entre o Imperador nesta atitude heroica e o conquistador de Goiás, figura de Zani, apoiado no seu arcabuz em posição de combate: não pensas assim? ${ }^{97}$.
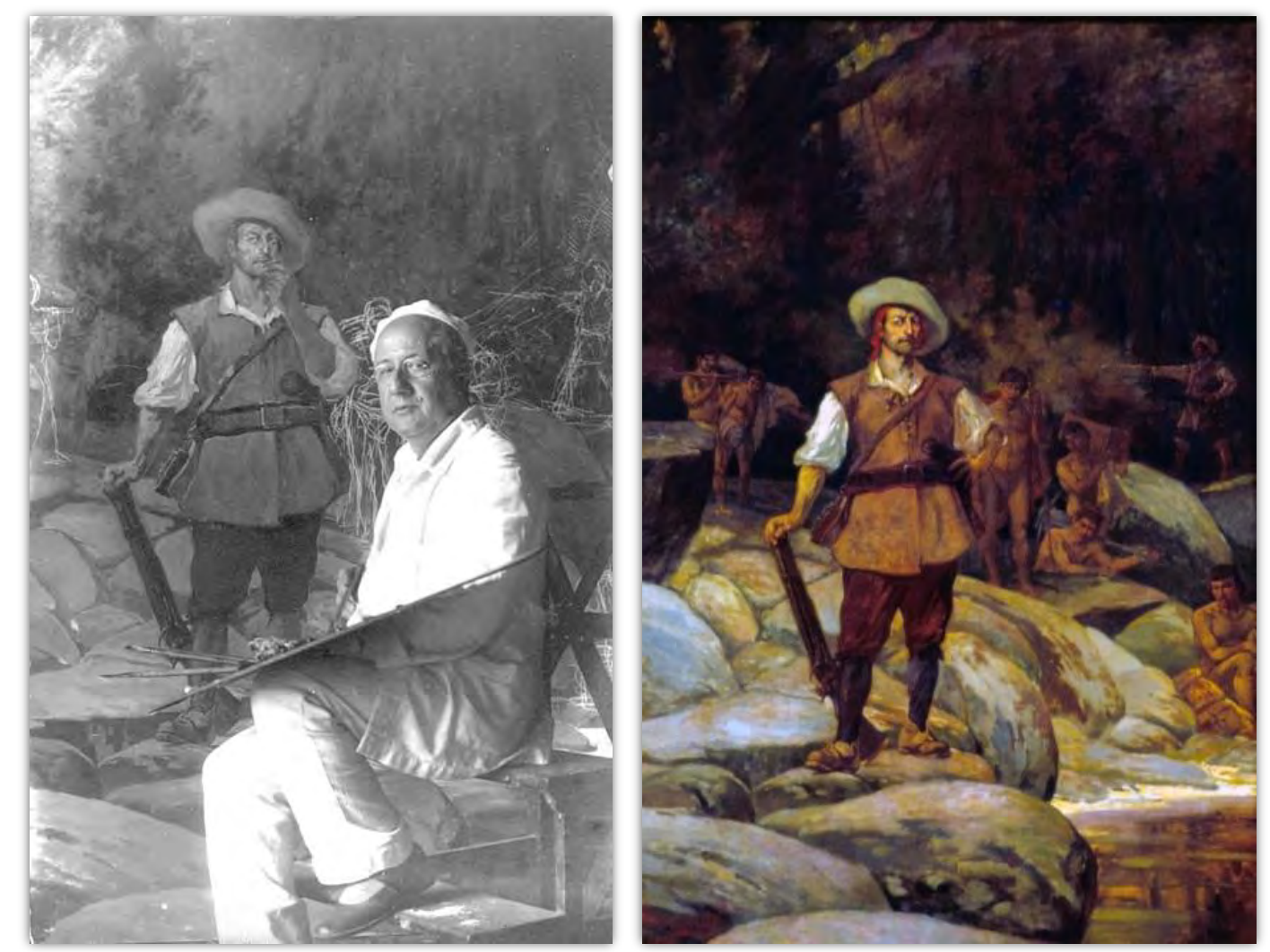

Figura 1.19 - À esquerda, Henrique Bernardelli em seu ateliê, diante de uma das versões recusadas de sua tela. À direita, Ciclo da caça ao índio (1925).

Óleo sobre tela, 233,7 x $159 \mathrm{~cm}$ (versão final).

Fonte: Acervo do Museu Paulista da USP.

Não foram poucos os estudos realizados por Bernardelli até chegar a versão final de Ciclo da caça ao indio, na qual a posição da mão esquerda do bandeirante, que antes segurava o cachimbo à boca, é alterada, seguindo a sugestão de Taunay, e passa a se sustentar na cintura de Cardoso de

${ }^{97}$ Carta de Afonso Taunay a Henrique Bernardelli, 20 jul. 1922. APMP/FMP, pasta 117. 
Almeida, retratado com o braço flexionado. Já a mão direita se mantém apoiada ao cano longo da arma de fogo. Ao fundo, de perfil, outro bandeirante dá ordens aos indígenas subjugados. Mais uma vez, temos no primeiro plano da tela a pose monárquica de Domingos Jorge Velho; entretanto, ao estudar o descompasso entre as propostas iconográficas para os bandeirantes paulistas de Taunay e Bernardelli, Maraliz Christo (2002) chama a atenção para como os bandeirantes retratados pelo artista parecem esvaziados de heroísmo, com exceção do painel Ciclo da caça ao índio.

a) Saciando a sede como animais

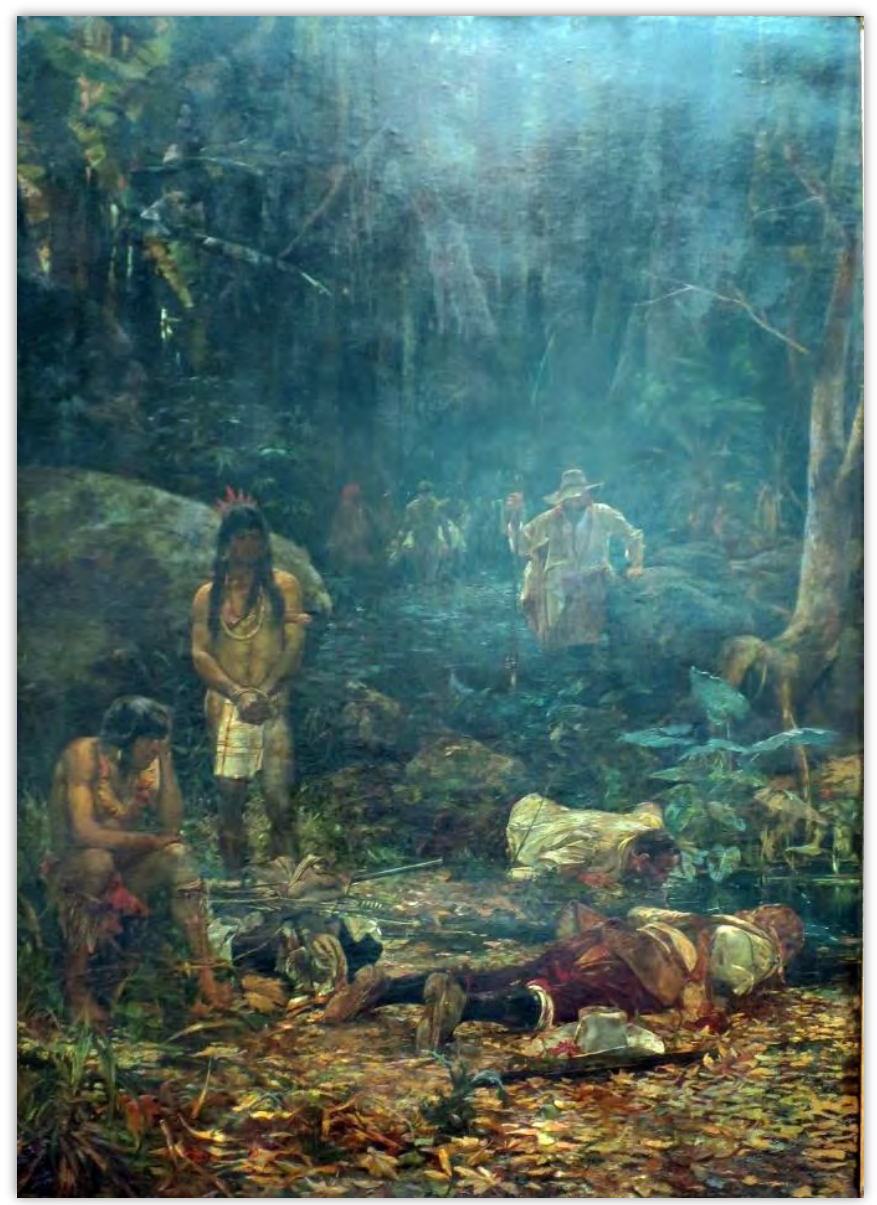

Figura 1.20 - Os bandeirantes (1889), de Henrique Bernardelli.

Óleo sobre tela, 400 x $290 \mathrm{~cm}$.

Fonte: Warburg: banco comparativo de imagens ${ }^{98}$.

${ }^{98}$ Disponível em: <http://warburg.chaa-unicamp.com.br/obras/view/11267>. Acesso em: 10 jul. 2017. 
Henrique Bernardelli irá frequentemente retratar os bandeirantes como personagens envelhecidos e enfermos, submetidos às vicissitudes da natureza, bem distantes da "virilidade heroica de Apolo ou Hércules", aponta ainda Christo (2002b, p. 33) em outro estudo, ao analisar a tela Os bandeirantes (1889), a primeira do artista sobre o tema. Anos antes das festas centenárias, Bernardelli já revelava a fragilidade dos bandeirantes, retratados em grandes dimensões sem teor celebratório, exaustos, interrompendo sua marcha no meio da mata escura para beber água diretamente de uma poça. Trata-se de um quadro destinado a exposições nos salões e ao mecenato oficial, adquirido em 1891 pela Escola Nacional de Belas Artes do Rio de Janeiro.

A tela mostra, no canto inferior à direita, dois bandeirantes deitados com o corpo inteiro ao chão, sujando suas camisas brancas com terra e folhas úmidas ao enfiarem o rosto na água ${ }^{99}$. O chapéu de abas largas e a arma de cano longo, aqui retratados muito antes de Benedito Calixto pintar Domingos Jorge Velho e o loco-tenente Antônio Fernandes de Abreu, são deixados de lado sobre a folhagem seca. Um terceiro bandeirante, mais ao fundo, ofuscado pela neblina, anda com dificuldade entre as pedras, com a ajuda de sua arma. Desse modo, se Jorge Velho e seu locotenente, retratados anos depois por Calixto, exibem seu armamento com orgulho, aqui ele parece um incômodo fardo a ser carregado, sendo utilizado como uma espécie de bengala, ou largado no chão.

Como contraponto a essas figuras, à esquerda, no primeiro plano, dois vigorosos indígenas vestem uma tanga e alguns poucos adornos, o que ressalta seus músculos definidos. Ainda que um deles esteja com as mãos amarradas, ele está levantado e parece observar aqueles que o escravizaram e estão aos seus pés com um olhar de superioridade. O outro índio, sentado em uma pedra, também fita os dois personagens sedentos. No último plano, atrás da fumaça branca, na escuridão da floresta, é possível avistar vultos de outros indígenas carregando provavelmente um bandeirante em uma espécie de maca.

Antes de ser adquirida pela Escola Nacional de Belas Artes do Rio de Janeiro - e muito antes do boom da historiografia paulista da década de 1920 sobre os bandeirantes ${ }^{100}$ — a tela de

\footnotetext{
${ }^{99}$ A força dessa imagem do bandeirante saciando a sede também será retomada por Candido Portinari, como em Descobrimentos, Desbravamento da mata, Catequese dos indios e Garimpo de ouro (1941), um conjunto de têmperas sobre quatro episódios da história do Brasil, realizado para a Biblioteca do Congresso, em Washington. Em Desbravamento da mata, no centro da tela, um homem bebe água diretamente do chão cercado por árvores e animais, cf. Fabris (1996).

100 Quase todos os historiadores da São Paulo do início do século Xx lançam versões próprias sobre o significado do movimento das bandeiras paulistas, manifestando em seus trabalhos, implícita ou explicitamente, um orgulho da linhagem a que afirmam pertencer, e que procuram reconstruir, cf. Abud (1985).
} 
Henrique Bernardelli havia sido exibida na Exposição Geral de Belas Artes, em 1890, no Rio de Janeiro. No longo texto sobre a obra, já intitulada Os bandeirantes no catálogo de 1890, consta que:

A tela celebra a audácia dos bravos expedicionários de 1600, que fizeram a descoberta das mais inacessíveis regiões do sul do Brasil, tornando-se depois infelizmente por conselho da cobiça, verdadeiros caçadores de índios para a escravidão. A invasão de suas bandeiras que não respeitavam mesmo os aldeamentos sujeitos aos missionários Jesuítas, que tinham já por esses lugares adiantando trabalhos de catequese, moveu os Padres da Companhia a reclamar providências da Santa Sé e da Corte da Espanha. Mais de trezentos mil índios, queixavam-se os emissários Jesuítas, dando ao mesmo tempo ideia da culpa e do heroísmo de tais empresas, foram entre 1614 e 1639, reduzidos à escravidão por quatrocentos Paulistas auxiliados por uns dois mil índios amigos (ESCOLA NACIONAL DE BELAS ARTES, 1890, pp. 46-47).

Os bandeirantes pintados por Henrique Bernardelli durante o período imperial são descritos pelos organizadores da Exposição Geral de Belas Artes, primeira exposição nacional do período republicano brasileiro, como "bravos expedicionários" que, consumidos pela cobiça, "infelizmente" se tornaram "caçadores de índios para a escravidão". Antes disso, em 1889, eles haviam figurado também na Exposição Universal de Paris, junto à Torre Eiffel, construída especialmente para essa ocasião ${ }^{101}$. Embora em Paris houvesse um pavilhão inteiro dedicado ao Brasil, a obra de Bernardelli conseguiu conquistar um espaço fora desse pavilhão, ao ingressar no Palácio de Belas Artes, no Champ de Mars, considerado o mais “nobre” da exposição francesa, e lá foi exposta sob o título Les Explorateurs, segundo o catálogo do evento (DAZZI, 2011) ${ }^{102}$.

Depois de passar pela Exposição Universal de Paris, em 1889, com o apoio de Dom Pedro II, e atravessar o Oceano Atlântico rumo ao Brasil e sua recém-proclamada República para figurar na Exposição Geral de Belas Artes, no Rio de Janeiro, a tela Os Bandeirantes seguiu ainda em direção ao norte da América para ser exibida na Exposição Universal Colombiana de Chicago, em 1893, nos Estados Unidos, em comemoração aos quatrocentos anos do "descobrimento" do continente,

\footnotetext{
${ }^{101}$ Embora a Exposição Universal de Paris celebrasse o centenário da Revolução de 1789, ou seja, os princípios republicanos franceses de "liberdade, igualdade e fraternidade", sobre a produção brasileira lá apresentada era possível falar em duas frentes: uma delas com foco maior nas "belas-artes", cujas obras a serem expostas, como é o caso de Os bandeirantes, foram selecionadas pela Academia Imperial de Belas Artes; a outra mais voltada para as "culturas indígenas da Amazônia”, como as coleções etnográficas do Museu Nacional, organizadas pelo botânico Ladislau de Souza Mello Netto, então diretor da instituição (BARBUY, 1996).

102 Já de acordo com Eduardo Prado e o barão de Rio Branco, o quadro Os Bandeirantes foi exibido na Exposição Universal de Paris com o nome El Dorado (PITTA, 2013).
} 
assim como a recuperação, após o grande incêndio de 1871, da cidade de Chicago ${ }^{103}$. Paradoxalmente, os "caçadores de índios para a escravidão" de Bernardelli representaram a Academia Imperial de Belas Artes na Exposição Universal de Paris, em 1889, que celebrava os cem anos da abolição da escravidão e a substituição da monarquia absolutista e, passados menos de cinco anos, irão representar também o Brasil republicano e sua recém-fundada Escola Nacional de Belas Artes na Exposição Universal Colombiana de Chicago, que rivalizava com as exposições congêneres europeias.

Importante observar que se Henrique Bernardelli opta por retratar bandeirantes (tema pouco comum na tradição de pintura de história do Brasil até então) despidos de heroísmo, ele mantém-se afeito a um repertório realista e naturalista. É possível supor, como o faz Fernanda Pitta (2013), que mesmo que se afaste de uma postura mais "idealizada", no sentido da tradicional pintura de história, recusando um tom mais edificante ao retratar os bandeirantes, Bernardelli ainda assim tivesse em mente uma possível aquisição de sua tela por parte do Museu Paulista: ao expor o que considerava serem as "qualidades humanas e prosaicas dessas figuras", o artista poderia estar preocupado com a realização de um retrato verossímil e crível, realçando o "caráter rústico, um tanto arcaico" do personagem, explica a autora (PITTA, 2013, pp. 304-306).

As disputas em torno dessas imagens e narrativas são, portanto, complexas e, às vezes, contraditórias. Maraliz Christo (2002) apresenta ainda o estudo abaixo feito pelo mesmo pintor sem datação precisa, que hoje pertence ao acervo do Palácio dos Bandeirantes. Nele não figuram indígenas se contrapondo aos quatro bandeirantes, um deles retratado com vestimentas nobres, entre as quais se destaca um rufo, uma grande gola branca engomada e franzida no pescoço, que lhe dá postura rígida ao beber a água da poça. Vimos que, na já mencionada versão final desse estudo, que hoje faz parte do acervo do Museu de Belas Artes do Rio de Janeiro, Bernardelli exclui um dos bandeirantes e o rufo. A autora aponta que se há uma filiação do pintor ao naturalismo e ao realismo ao retratar os bandeirantes na versão final da obra, os dois indígenas incluídos no

103 Rodolfo Bernardelli, primeiro diretor da Escola Nacional de Belas Artes e responsável pelo Departamento de Belas Artes da Seção Brasileira da Exposição Universal Colombiana de Chicago, foi quem selecionou na ocasião algumas obras para representar as novas tendências da arte produzida no Brasil. Possivelmente, elas foram escolhidas em acordo com os demais professores da instituição, como o próprio Henrique Bernardelli, seu irmão e professor de pintura. Não à toa, vários alunos do local, artistas ainda em formação, expuseram suas obras. Nesse sentido, Rodolfo Bernardelli parece ter feito uma escolha bastante pessoal das obras expostas. Ainda que o governo brasileiro tivesse solicitado a ele que escolhesse as "principais telas de Pedro Américo, [Victor] Meirelles, Aurélio [de Figueiredo], [Rodolfo] Amoedo, [Antônio] Parreiras, Agostinho da Motta, e das nossas principais obras de escultura desde o tempo de Luiz de Vasconcellos [Vice-rei] até as belas produções de Bernardelli” (apud DAZZI, 2011), Rodolfo Bernardelli parece ter seguindo à risca apenas a última parte da solicitação. 
primeiro plano parecem "encarna $[\mathrm{r}]$ a superioridade moral a eles destinada pela literatura romântica” (CHRISTO, 2002, p. 46).

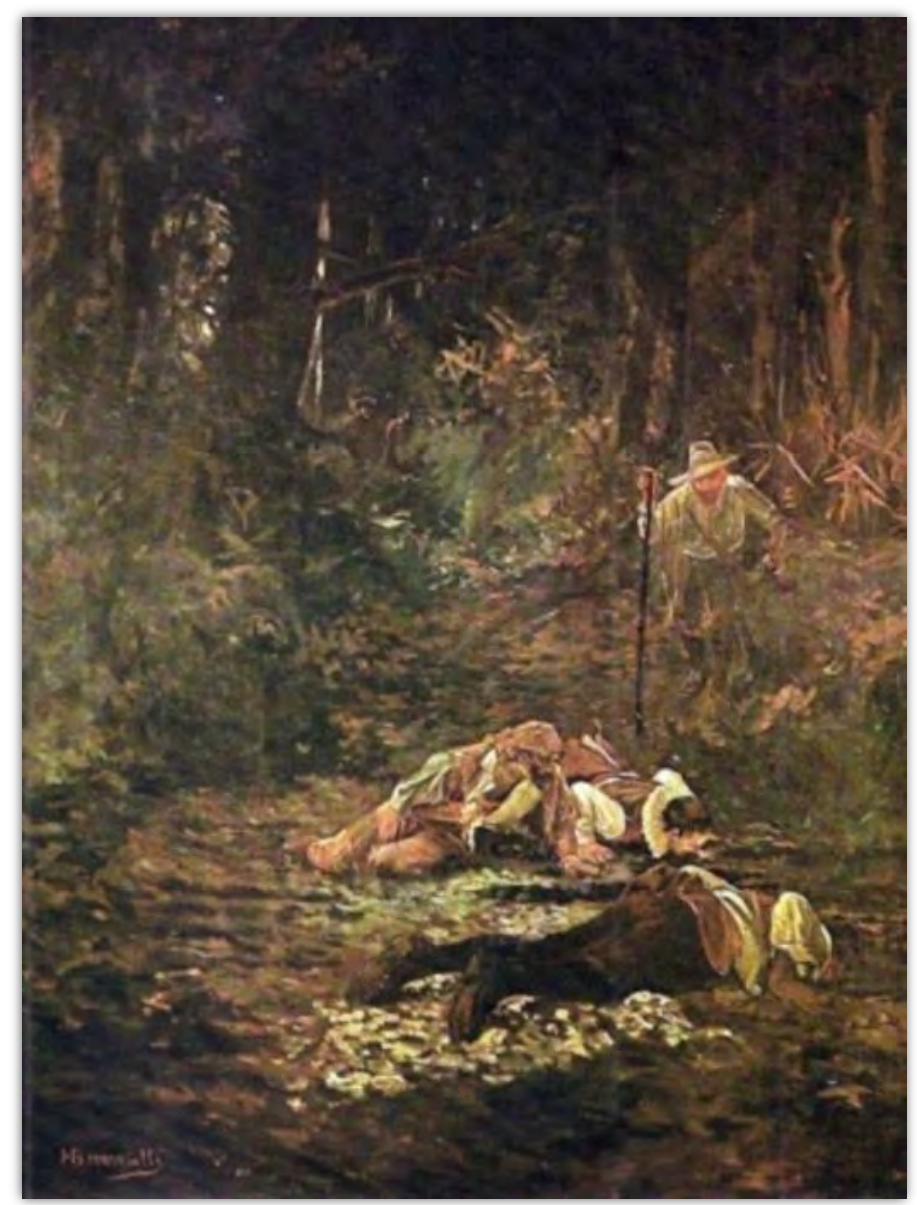

Figura 1.21 - Os bandeirantes (estudo), de Henrique Bernardelli.

Fonte: Acervo dos Palácios do Governo do Estado de São Paulo.

A ênfase dada ao gesto cotidiano de saciar a sede - que não pressupõe sorver a água diretamente de um poço, já que seria possível, por exemplo, encher alguma espécie de cantil será recuperada, trinta anos depois, por José de Alcântara Machado (1875-1941) em Vida e morte do bandeirante (1929), obra que irá se concentrar no dia a dia e na intimidade dos bandeirantes, apresentando as privações pelas quais eles passavam ${ }^{104}$. Ao pesquisar inventários e testamentos

\footnotetext{
${ }^{104}$ Kátia Abud (1985) destaca as obras de José de Alcântara Machado, Afonso Taunay e Alfredo Ellis Júnior, como a matriz do conhecimento sobre os bandeirantes produzido pela historiografia no século XX. Ao escreverem sobre nosso personagem, no entanto, os três historiadores seguem caminhos distintos, explica a autora: Ellis Júnior enfatiza sua superioridade racial, fruto do cruzamento do europeu com o indígena, já que o negro, segundo ele, era praticamente inexistente no planalto paulista; Taunay ressalta o arrojo do personagem ao estender as fronteiras do território brasileiro; enquanto Alcântara Machado, estaria mais preocupado com os detalhes e pequenos episódios da vida cotidiana.
} 
antigos organizados e publicados por iniciativa de Washington Luís quando presidente do estado de São Paulo (1920-1924), Machado afirma que: “À mingua de água para beber, [o bandeirante] se dessedenta com o sangue dos animais, o suco dos frutos, a seiva das folhas e das raízes. Mas há sertões estéreis, em que nem mesmo isso se encontra e de contínuo morre gente de fome" (1929, p. 256, grifos do autor). Entre as privações sofridas sertão adentro, segundo ele, estariam as dificuldades de abastecimento de água e de comida, tendo o bandeirante que beber água das poças do chão, quando as encontra, além de comer carnes "imundas", como as de sapos, cobras e lagartos (1929, p. 256).

Alcântara Machado apresenta os bandeirantes como rudes e pobres ${ }^{105}$. Isso levaria Sérgio Milliet, assim como Machado sócio do IHGSP, a se indagar no prefácio que escreve para a terceira edição do livro: seriam os bandeirantes "homens muito grossos de haveres e muito finos de maneiras, opulentos e cultos, vivendo à lei da nobreza numa atmosfera de elegância e fausto" como os desenha Oliveira Vianna ${ }^{106}$, ou seriam eles, como os vislumbra Alcântara Machado, "pobres e analfabetos, grosseiros de modos e de haveres parcos, vivendo quase na indigência, duros para consigo mesmos e com os semelhantes, austeros e primários, em luta permanente contra dificuldade de toda espécie, amante apavorado do sertão”? (1943, p. 8).

Reiterando a indagação de Sérgio Milliet, o próprio livro Vida e morte do bandeirante é ilustrado, a partir de sua terceira edição, por José Wasth Rodrigues (1891-1957), um dos artistas convidados por Taunay para a decoração do Museu Paulista visando as festas de $1922^{107}$. Suas ilustrações para o livro revelam um protagonista que lembra muito mais Domingos Jorge Velho, retratado por Benedito Calixto, do que o personagem descrito por Alcântara Machado. Vale lembrar que, anos antes das celebrações centenárias, Wasth Rodrigues havia criado o brasão da cidade de São Paulo ${ }^{108}$ — que ainda hoje apresenta grafada a divisa Non Ducor, Duco [Não sou

\footnotetext{
105 A recorrência do tema da pobreza colonial na historiografia sobre São Paulo foi estudada por Blaj (2002).

106 Sobre a temática bandeirante na obra de Oliveira Vianna, cf. Ferretti (2004).

${ }^{107}$ Em suas duas primeiras edições, publicadas em 1929 e 1930, Vida e morte do bandeirante é ilustrado por Yan de Almeida Prado. A única imagem de um bandeirante nessas duas primeiras edições é uma reprodução do "selvagem civilizado" da aquarela de Jean-Baptiste Debret Selvagens civilizados, soldados indígenas de Mogi das Cruzes combatendo botocudos (Provincia de São Paulo), como veremos [figura no 1.31].

108 Durante a gestão de Taunay, na configuração final da decoração interna do Museu Paulista, os brasões de São Paulo e São Vicente (primeiro núcleo de povoamento e origem de expedição de exploração do território) são fixados no alto da parede da escadaria principal, bem próximos ao salão nobre, como que em uma posição de condutores. $\mathrm{O}$ então diretor do Museu Paulista irá ainda encomendar outros sete brasões das mais antigas cidades do estado: Santos, Itu, Sorocaba, Taubaté, Parnaíba, Itanhaém e, como veremos no terceiro capítulo, Porto Feliz. Em quase todos eles, por recomendação do próprio Taunay aos prefeitos das respectivas cidades, um bandeirante aparece à
} 
conduzido, conduzo] — em parceria com Guilherme de Almeida (1890-1969), por meio de concurso público durante o governo municipal de Washington Luís, realizado em 1916, enfatizando não somente a supremacia econômica da cidade, mas também sua pretensão de conduzir politicamente o país ${ }^{109}$.

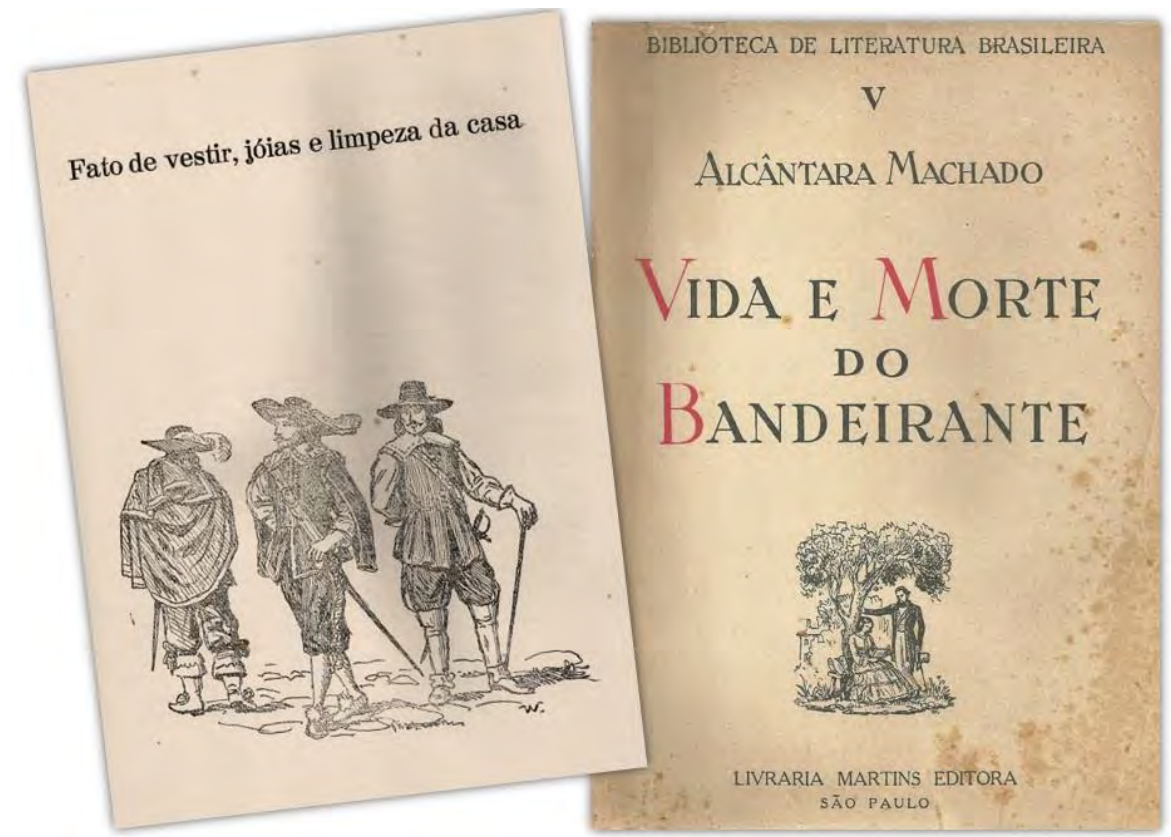

Figura 1.22 - Ilustração de José Wasth Rodrigues para o livro Vida e morte do bandeirante (1943), de José de Alcântara Machado.

Fonte: Acervo pessoal | Foto: Thaís Waldman.

Cabe notar que a obra de Alcântara Machado foi uma grande referência para os trabalhos de Sérgio Buarque de Holanda (1902-1982), como os textos da coletânea Caminhos \& Fronteiras (1957), que descrevem as técnicas e as práticas cotidianas dos bandeirantes durante a lenta ocupação territorial por eles promovida. Diretor do Museu Paulista entre 1946 e $1956^{110}$ — sucedendo Taunay -, Holanda publica Caminhos \& Fronteiras anos depois do lançamento de Vida e morte do bandeirante, mas também reconstitui, em um dos capítulos, as dificuldades de abastecimento de água nas longas jornadas sertão adentro e os esforços dos caminhantes em decifrar sinais referentes a existência de mananciais ou reservatórios naturais.

direita e/ou à esquerda do escudo da cidade, como suporte, ou dentro do próprio escudo. Além dos desenhos dos brasões, ele sugere as divisas, que ainda hoje são os lemas dessas cidades.

$109 \mathrm{O}$ bandeirismo invocaria, nesse sentido, uma adesão implícita à crença na superioridade paulista, idealizada como “a locomotiva a puxar vagões vazios", fosse no presente de hegemonia dos cafeicultores ou no passado bandeirante, cf. Love (1982).

110 Sobre a gestão Sérgio Buarque de Holanda, cf. Françozo (2005). 
b) "Amado, que perigo"

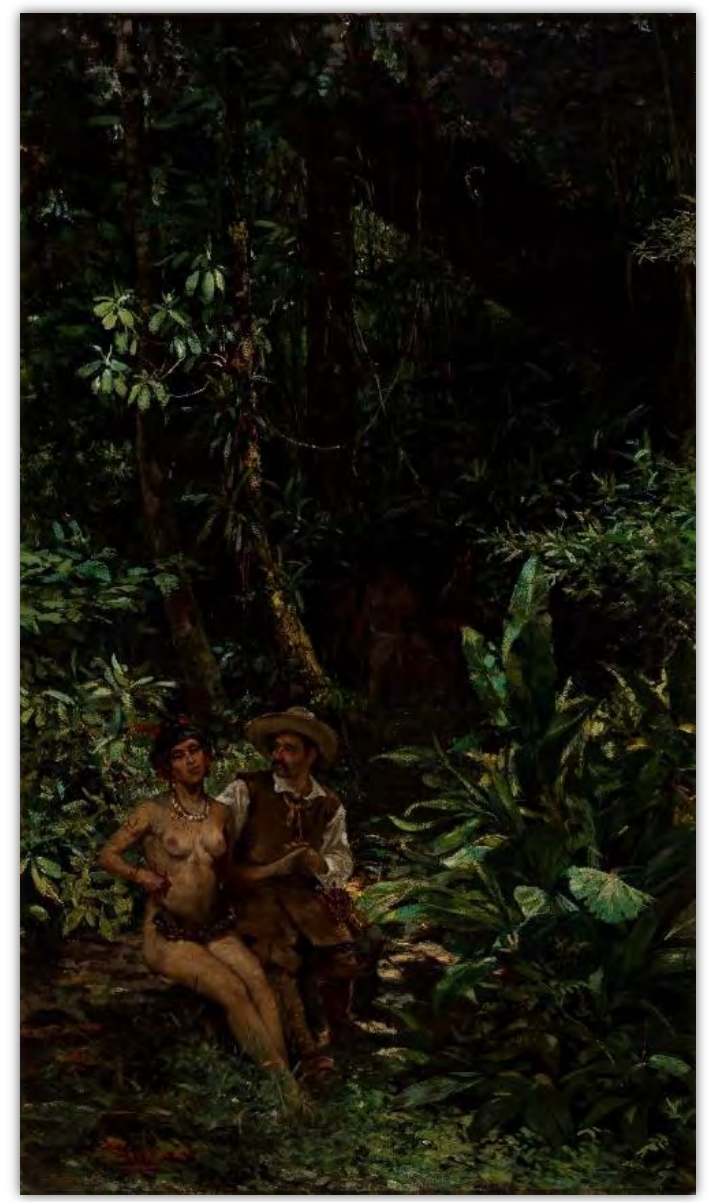

Figura 1.23 - Bandeirante e índia, de Henrique Bernardelli.

Óleo sobre tela, 88,5 x 51,5 cm.

Fonte: Acervo da Pinacoteca do Estado de São Paulo | Foto: Isabella Matheus.

Recentemente, em 2014, a obra Bandeirante e india, também de autoria de Henrique Bernardelli, foi adquirida por meio de doação pela Pinacoteca do Estado de São Paulo ${ }^{111}$. Cabe lembrar que o acervo da Pinacoteca possui hoje mais de quinhentas obras do artista, grande parte delas doadas em 1937, após a morte do pintor, como diversos desenhos por ele realizados em São Paulo, muitos deles relacionados a obras encomendadas pelo Museu Paulista. Mas o contrário

111 O título Bandeirante e india foi atribuído conforme catálogo do leilão "Lordello \& Gobbi Escritório de Arte”. Segundo o mesmo catálogo, a obra pertencia a José Adolpho da Silva Gordo Filho e foi adquirida pelo casal Lais Helena Zogbi Porto e Telmo Giolito Porto em leilão da Lordello \& Gobbi Escritório de Arte realizado em 8 de abril de 2014, na cidade de São Paulo. Cf. Ficha Catalográfica da Pinacoteca do Estado de São Paulo, RM 9695. Não foi encontrada até o momento documentação que aluda claramente aos detalhes dessa compra. 
também é válido, um esboço de Bandeirante e india encontra-se no arquivo do Museu Paulista, provavelmente doado na década de 1930, junto a outros trabalhos que fazem parte do espólio do autor $^{112}$.

O então curador da Pinacoteca, Giancarlo Hannud, atribuiu inicialmente como data da obra algo entre 1920 e 1936 (o ano de 1920 corresponderia ao início das tratativas de Afonso Taunay para a encomenda da tela Ciclo da caşa ao índio, e 1936 ao ano de falecimento de Bernardelli). Interessante notar, no entanto (como consta na própria ficha catalográfica da Pinacoteca), que a cena protagonizada pelo bandeirante e pela índia muito se assemelha ao "colóquio amoroso" descrito na tela Prólogo, cujo paradeiro ainda é desconhecido.

Segundo Maraliz Christo (2002, p. 322), Bernardelli teria produzido na década de 1910 um díptico denominado Prólogo e Epílogo, comentado pelo articulista Mattos Cardoso em crítica publicada no jornal $A$ Rua após visitar a Exposição Geral de Belas Artes de 1916: “O Prólogo tem sentimento, tem naturalidade, mas agrada-nos mais o Epílogo: é um quadro mais forte, pelo emocionante do fim trágico com que o bandeirante pagou sua ousadia, e ali jaz agora, abandonado, morto, pela selva", afirmou o articulista na época ${ }^{113}$. Porém, o jornal $A$ Noite, em notícia do mesmo período, afirma que Bernardelli expôs no evento 136 telas feitas nos últimos quinze ou vinte anos, entre elas o mesmo Prólogo e Epílogo, o que sugere que o díptico poderia ter sido produzido muito antes de $1910^{114}$.

De fato, Henrique Bernardelli pintou as duas obras ainda no século XIX. Em 1895, no periódico carioca Jornal do Commercio, há um comentário a respeito dos quadros Prólogo e Epílogo em uma matéria sobre os trabalhos do artista expostos na Exposição Geral de Belas Artes daquele ano ${ }^{115}$. Outros periódicos também divulgaram a presença de ambas as telas na mesma exposição. A Gazeta de Notícias, por exemplo, afirmou que o artista exibiu 29 quadros em 1895, sendo Epílogo

\footnotetext{
112 Sobre o espólio Henrique Bernardelli no Museu Paulista, cf. Oliveira (2000).

113 O jornal O Estado de S. Paulo igualmente destaca a presença das obras Prólogo e Epílogo entre os trabalhos expostos na Exposição Geral de Belas Artes de 1916, ao reproduzir um texto publicado no Jornal do Commercio que descreve o "drama passional em dois atos" como "cenas que devem ter ocorrido frequentemente nos primeiros tempos da ocupação portuguesa”. Cf. “Arte e artistas”, O Estado de S. Paulo, 15 jun. 1916, p. 4.

114 "Notas de Arte". A Noite, 9 jul. 1916, p. 3.

115 "Nos quadros Prólogo e Epílogo, as paisagens revelam as qualidades acima apontadas e têm figuras que se nos afiguram deslocadas e amesquinhadas pelo vigor da paisagem. No primeiro é de muito mau efeito a figura da índia, pouco característica, de postura contrafeita e com uma tanga inútil pela sua má colocação. No segundo, a figura do aventureiro português, morto por uma flecha, está colocada fora de foco do quadro, fazendo por isso a atenção desviar-se do interesse do episódio representado", diz a matéria. Cf. "Notas sobre Arte", Jornal do Commercio, 8 set. 1895 , p. 2.
} 
o mais impressionante deles ${ }^{116}$. O jornal O Paír, por sua vez, também em 1895, salientou que o quadro Prólogo "pareceria malicioso" se não houvesse um "pendant" chamado Epílogo "com o mesmo bandeirante estendido morto no chão com o peito varado por uma flecha" ${ }^{117}$.

Se voltarmos à imagem de Bandeirante e india, veremos que ao fundo, entre as árvores, quase despercebido, é possível entrever a figura abaixo: o vulto de um indígena que, ofuscado pela escuridão da floresta, observa a cena do "colóquio amoroso" de pé.

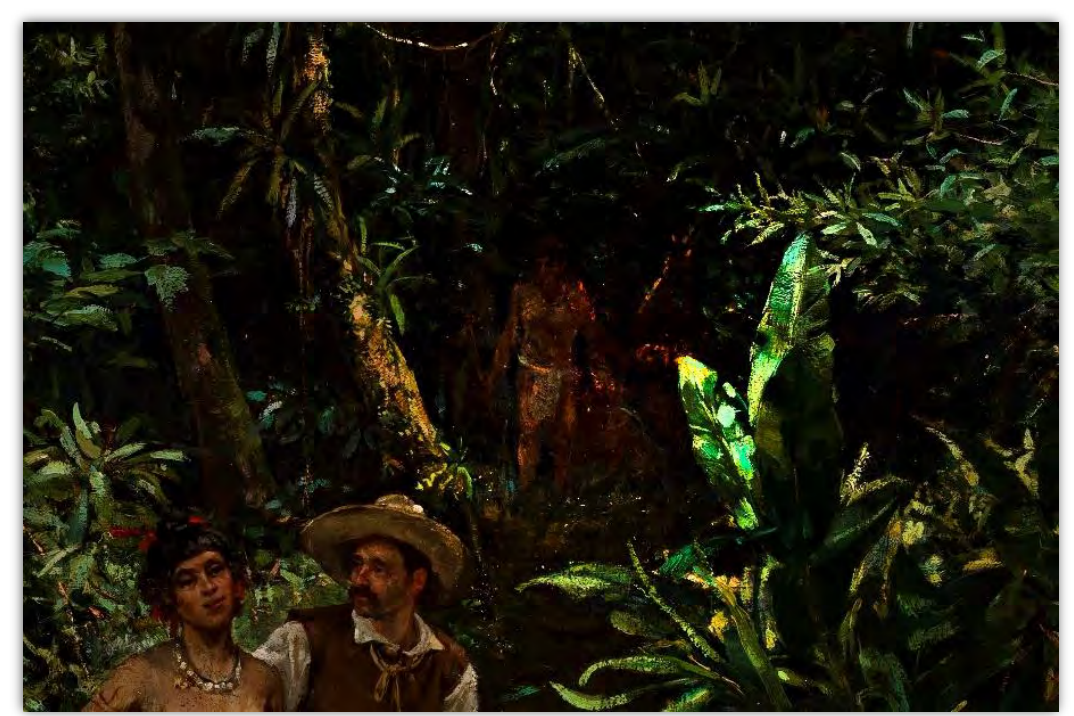

Figura 1.24 — Vulto retratado no fundo da tela Bandeirante e índia (detalhe). Fonte: Acervo da Pinacoteca do Estado de São Paulo | Foto: Isabella Matheus.

Fica então a hipótese de que Bandeirante e índia se trate da obra Prólogo, e que ela teria como complemento um Épílogo não localizado, ambos pintados no século XIX. Caso a hipótese se confirme, é preciso adiantar a data da obra Bandeirante e índia pelo menos para $1895^{118}$. Nesse caso, o pintor - já durante a República, poucos anos após finalizar sua primeira obra sobre o tema (Os bandeirantes, realizada ainda durante o Império) — ressaltaria novamente, agora em uma tela em pequenas dimensões, o vigor do indígena que, ao ver sua companheira com um bandeirante, o mata com uma flechada, deixando-o abandonado, morto, sozinho, em meio as árvores.

No arquivo do Museu Paulista há um esboço dessa tela, um desenho sem data e sem título nomeado Bandeirante e indio, de autoria de Bernardelli. O título do desenho remete ao indígena ao

\footnotetext{
116 “Exposição de Belas Artes”. Gazeta de Notícias, 1 set. 1895, p. 2.

117 “Palestra". O Paír, 8 set. 1895, p. 2.

118 A autora já sugeriu a correção para a Pinacoteca, que incluiu na ficha catalográfica da obra a informação de que o díptico foi exibido na Exposição Geral de Belas Artes de 1895, anos antes da data indicada por Maraliz Christo.
} 
fundo. Aqui é possível notar nitidamente sua cara de espanto e seus cabelos arrepiados ao flagrar o casal. Atrás dele, escondidas em meio à vegetação, surgem duas outras figuras com feições assustadas, uma delas com o mesmo cabelo espetado. Bernardelli também esboça cobras como que indicando a situação de risco. E na legenda do desenho lê-se: “(...) Amado, que perigo”. Elementos que auxiliam a corroborar, mais uma vez, a hipótese de que Bandeirante e india se trate da obra Prólogo.

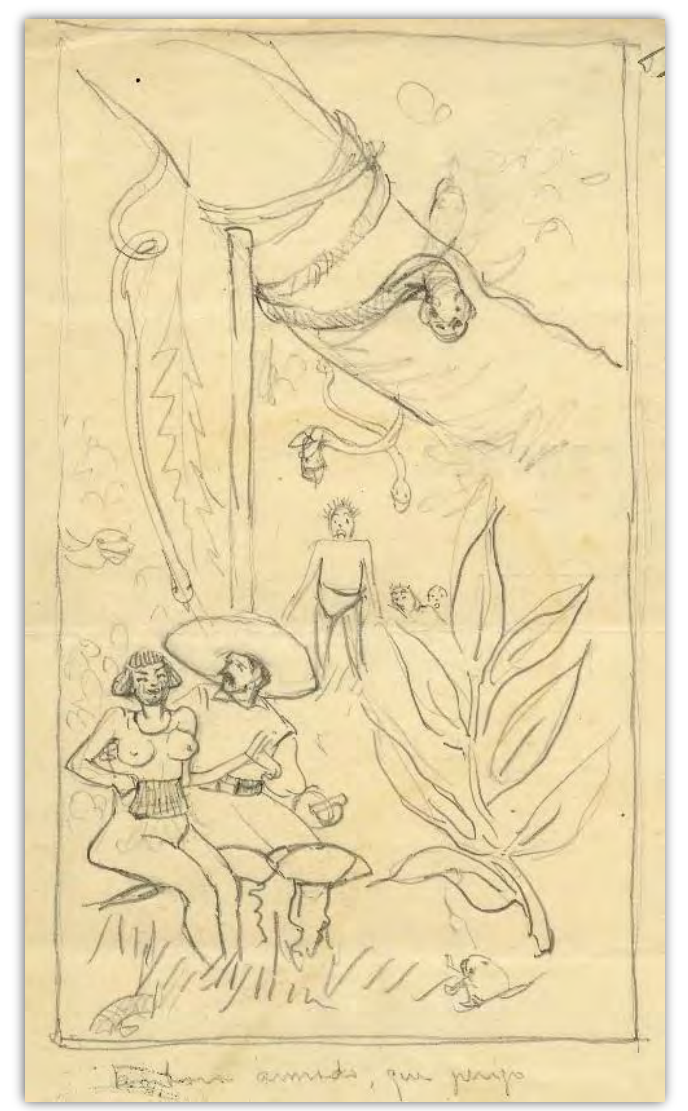

Figura 1.25 - Sem título (Bandeirante e índio), de Henrique Bernardelli. Grafite sobre papel, $15,9 \times 24 \mathrm{~cm}$.

Fonte: Acervo do Museu Paulista da UsP | Foto: Hélio Nobre e José Rosael.

\section{c) Batendo em retirada}

Pintada em grandes dimensões por Henrique Bernardelli, a tela Retirada do cabo de São Roque (1927), sobre o famoso episódio da guerra holandesa, tampouco é marcada por um tom edificante. Localizada no hall de entrada do Museu Paulista, no topo da escadaria, em face ao nicho com a 
estátua em homenagem a Dom Pedro I, trata-se de uma obra encomendada por Afonso Taunay na década de 1920, junto ao Ciclo da caça ao índio, visando narrar um dos grandes feitos dos paulistas, que estariam empenhados na contenção do elemento estrangeiro e na construção de uma identidade nacional brasileira. Taunay (1943, p. 488) explica que a encomenda é uma evocação de "um corpo de paulistas notabilizado pelos feitos e préstimos da sua prática de jornada no sertão", sob a liderança de Antônio Raposo Tavares e Luiz Barbalho Bezerra.

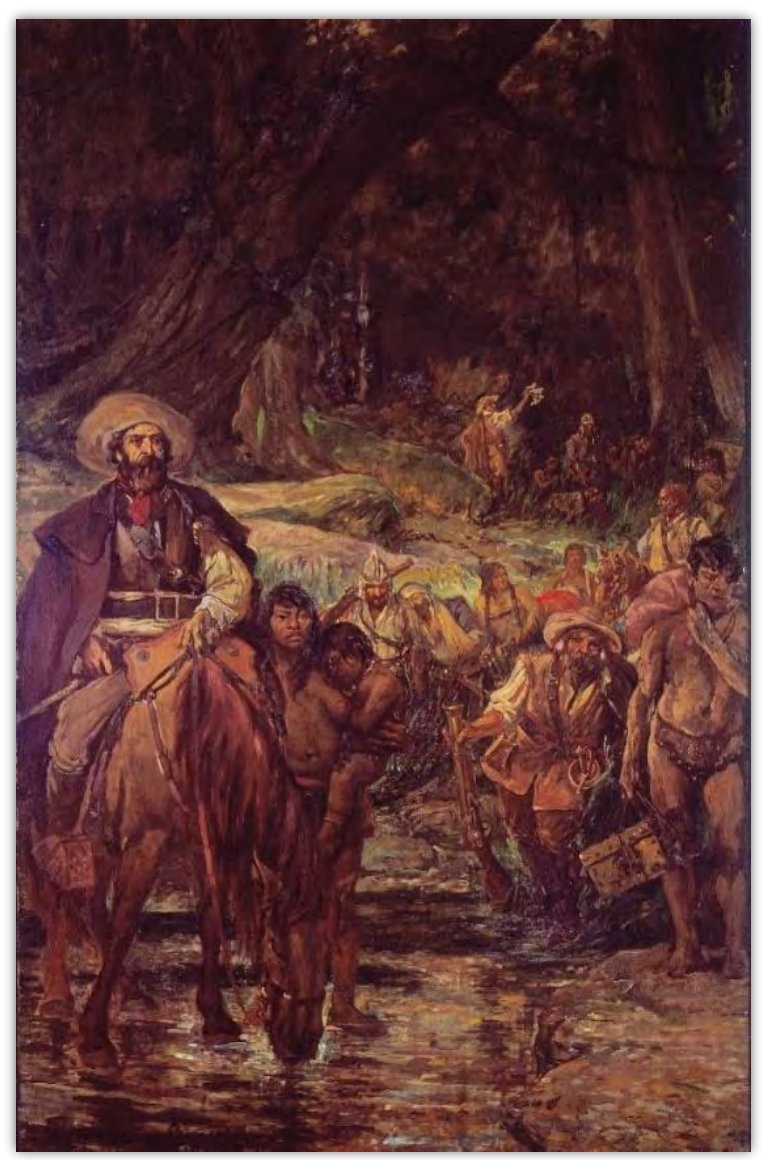

Figura 1.26 - Retirada do cabo de São Roque (1927), de Henrique Bernardelli.

Óleo sobre tela, 294,5 x $182 \mathrm{~cm}$.

Fonte: Acervo do Museu Paulista da USP | Foto: Hélio Nobre e José Rosael.

No primeiro plano da tela, atravessando uma mata semiaberta, um bandeirante a cavalo parece liderar uma retirada após uma batalha. Ainda que seus trajes sejam muito similares aos de Domingos Jorge Velho pintado anos antes por Benedito Calixto, sua feição e postura são bem distintas. Com semblante cansado, ele segura com a mão esquerda as rédeas do animal, enquanto a direita se apoia na perna. Ao seu lado, uma índia jovem caminha firme passando por cima de uma grande poça d'água, carregando uma criança sem demonstrar fraqueza. Atrás deles, um bandeirante aparenta estar semiconsciente. Em segundo plano, um outro índio, seguido por outro bandeirante. 
Robusto e com a postura ereta, o primeiro traja uma tanga, que ressalta seu corpo modelado levemente inclinado para equilibrar a grande sacola e o baú por ele carregados. O bandeirante, por sua vez, com a postura desalinhada, caminha com a ajuda de sua arma. Atrás dos dois, outros bandeirantes, a pé e a cavalo, batem em retirada, fatigados.

Depois de enviar a Afonso Taunay um esboço da Retirada do cabo de São Roque, Bernardelli foi orientado a pintar bandeirantes em armaduras, como uma couraça e um capacete, e não com roupas de pano, dando assim "um ar mais militar e menos expedicionário", já que se trata de um episódio de guerra contra os holandeses ${ }^{119}$. O artista, porém, não achou coerente bandeirantes usarem pesadas armaduras ao retornarem de uma guerra marcada por um "clima inclemente" e por "matas virgens cheias de perigos e privações de toda espécie, deixando pelo caminho muitos camaradas exânimes de sofrimento" ${ }^{120}$. Mas Taunay não renunciou ao seu ponto de vista e insistiu que as figuras do quadro estivessem armadas, reforçando seu argumento com a opinião do então presidente do estado, Washington Luís.

Responsável pela liberação da verba para a confecção da tela, Washington Luís teria afirmado que a pintura, como estava, retratava o momento de forma "desanimada senão desmoralizada". É necessário exaltar o vigor e a resistência da tropa, e não sua fraqueza e abatimento, adverte Taunay em carta ao artista, pois "assim como está não pode servir de todo ao museu”, já que para Washington Luís "ao se fazer o painel só pode ser numa cena animada de escaramuça" mostrando "que o batalhão paulista mantinha íntegra sua força de êmulo durante a retirada" ${ }^{121}$. O presidente do estado, reforça Taunay em outra correspondência ${ }^{122}$, somente admitiria no museu "uma cena combativa" e não "uma debandada" 123.

\footnotetext{
119 Carta de Afonso Taunay a Henrique Bernardelli, 24 jul. 1923. APMP/FMP, pasta 119.

${ }^{120}$ Carta de Henrique Bernardelli a Afonso Taunay, 15 set. 1923. APMP/FMP, pasta 120.

${ }^{121}$ Carta de Afonso Taunay a Henrique Bernardelli, 27 set. 1923. APMP/FMP, pasta 120.

122 Carta de Afonso Taunay a Henrique Bernardelli, 14 nov. 1923. APMP/FMP, pasta 120.

${ }^{123}$ A imagem da tropa em debandada não era novidade na época. Um no antes de Bernardelli finalizar sua tela, foi lançado o romance Os dramas da floresta virgem - Aventuras extraordinárias de um bandeirante através do sertão desconbecido. Narrativas emocionantes no coração da mata. Episódio dantesco entre feras ignoradas (1926), de Manoel Victor. Reeditado cinco vezes, e definido pelo próprio autor como uma obra "de caráter popular", o livro traz para o primeiro plano dois desertores que, fatigados, abandonam uma expedição liderada por Domingos Jorge Velho no meio do percurso. "Desemparado no ermo incomensurável do sertão", o mameluco Manuel Ubirajara "se deixara propositalmente tresmalhar do rebanho, solto no caos infernal de uma terra ingrata, batido de cansaço e coberto de feridas". Ao se afastar dos demais bandeirantes, o protagonista faz amizade com Jumbo, um negro que fugira de Domingos Jorge Velho por estar cansado de ser escravo.
} 
Lembremos que Washington Luís - com sua "alma de bandeirante", como foi caracterizado mais de uma vez na época pelo jornal Correio Paulistano - assume o governo do estado de São Paulo em 1920, momento em que a decoração histórica do Museu Paulista estava sendo amplamente realizada, contribuindo com vultosas verbas e doações feitas às coleções, ao mesmo tempo que opina sobre os elementos que deveriam fazer parte do acervo, como já havia feito anos antes durante a elaboração da tela Domingos Jorge Velho e o loco-tenente Antônio Fernandes de $A_{b r e u^{124}}$. Desse modo, se no início de sua carreira política e historiográfica ele opinara quanto à vestimenta de Jorge Velho ${ }^{125}$, a leitura dos relatórios e das correspondências do Museu Paulista revela que é precisamente quando ele toma posse do governo do estado que Taunay encontra espaço e financiamento para organizar a seção histórica da instituição, algo que pretendia realizar desde quando assumira sua direção ${ }^{126}$.

Em sua ampla produção nos jornais e em revistas da época, nos quais publica seus primeiros estudos sobre a São Paulo colonial, Taunay dá destaque à documentação que utiliza, como às Atas e aos livros de Registro geral da Câmara de São Paulo, desde o período quinhentista, assim como os Inventários e testamentos, todos publicados pelo Arquivo Municipal de São Paulo, em grande parte devido à iniciativa de Washington Luís. Taunay chega a pedir ao então presidente do estado que empreste parte desse material original para ser exposto no museu. Esse material será também amplamente utilizado por Taunay para compor seu extenso trabalho historiográfico, com destaque para o bandeirantismo, assim como para orientar muitas das encomendas que fará para o Museu Paulista ${ }^{127}$.

\footnotetext{
${ }^{124}$ A importância da relação entre Afonso Taunay e Washington Luís foi apontada por Brefe (2005).
}

125 Benedito Calixto oscilou entre pintar Domingos Jorge Velho vestido como "um militar e mestre de campo", ou seja, um oficial superior do Exército português, ou como "um sertanejo", tido como sinônimo de bandeirante e de paulista. Na época, Washington Luís sustentou que Jorge Velho "deveria estar, sem dúvida, com o vestuário clássico do sertanista, do bandeirante, que, em resumo, é o tipo glorioso de São Paulo”. Carta de Washington Luís a Benedito Calixto, 3 jan. 1903, reproduzida em "Palmares", Correio Paulistano, 28 fev. 1903, p. 2. Ver a esse respeito Marins (2007).

126 Segundo o próprio Afonso Taunay: "Sob a presidência do Dr. Washington Luís P. de Souza (1920-1924) tomou a seção histórica enorme desenvolvimento. Largos créditos lhe foram concedidos pelo novo presidente, apaixonado tradicionalista, para a apresentação condigna do Palácio do Ipiranga e suas coleções na data fausta do Centenário da Independência” (1937, p. 48). Washington Luís igualmente via em Taunay um grande interlocutor para suas próprias pesquisas. Em uma de suas cartas a Taunay, por exemplo, ele pede ao então diretor do Museu Paulista que pesquise mapas sobre o Caminho do Mar, antiga ligação entre a cidade de São Paulo e o litoral. Ainda que Taunay nada tenha encontrado sobre o assunto, ele afirma ter descoberto dois outros interessantes mapas sobre as bandeiras, e lhe envia as cópias. Carta de Afonso Taunay a Washington Luís, 21 jun. 1923. APMP/FMP, pasta 119.

127 Por exemplo: Na era das bandeiras, publicada originalmente em 1919 na Revista do IHGB e depois editada em 1920 e 1922; A glória das monções e São Paulo nos primeiros anos (ambos de 1920); São Paulo no século XVI (1921); Um grande 
Em um desabafo a Rodolfo Bernardelli, irmão de Henrique, Taunay comenta: "Creio que será difícil assentar-se um acordo de modo a tornar mais belicosa a composição que realmente é um pouco tristonha" ${ }^{128}$. Décadas depois, Tadeu Chiarelli aponta que o que mais lhe desperta interesse ao analisar essa obra é o fato de que no lugar de uma cena de heroísmo vemos "figuras cansadas, desprovidas de qualquer índice de bravura, deslocando-se num ambiente selvagem, vindo de um lugar e indo para outro" (1998, pp. 31-32). Ainda que Bernardelli tenha cedido em parte aos pedidos de Taunay, retirando da cena os holandeses a alvejar os paulistas ou retratando alguns bandeirantes ao fundo com capacetes, as figuras de que fala Chiarelli parecem refletir o cansaço de homens que estão em fuga, após uma exaustiva batalha.

A Retirada do cabo de São Roque acabou sendo fixada na moldura central da galeria do primeiro/segundo andar do Museu Paulista, que acompanha a escada principal, de frente para a estátua do imperador D. Pedro I. Embora tenha assumido a ausência de belicosidade da tela, e reconhecido o desânimo e o abatimento dos bandeirantes retratados por Bernardelli, após expor a obra Taunay (1937, p. 61) irá defini-la como um “magnífico painel” sobre "uma das mais notáveis e gloriosas páginas da história militar brasileira e onde tão notável papel coube aos paulistas".

\section{d) Morte solitária e inglória}

Alguns anos após a realização da tela Retirada do cabo de São Roque, Henrique Bernardelli novamente deixa de lado a ideia de Afonso Taunay de montar uma galeria de heróis. Em Últimos momentos de um bandeirante (1932), estudo em pequenas dimensões pintado com traços e contornos difusos, a imagem do bandeirante morrendo sozinho deitado em uma rede "é um depoimento de solidão que não permite sequer lembrança do passado glorioso”, conclui Francis Melvin Lee (1991, p. 15), ao analisar a obra do autor ${ }^{129}$. Em uma rede que se estende na horizontal, o bandeirante

\footnotetext{
bandeirante: Bartolomeu Paes de Abreu (1922) e a sua grande obra sobre o assunto, História geral das bandeiras paulistas, que começa a ser publicada em 1924.

${ }^{128}$ Carta de Afonso Taunay a Rodolfo Bernardelli, 23 out. 1923. APMP/FMP, pasta 120.

129 Anos antes, na década de 1910, Benedito Calixto, autor do retrato modelar Domingos Jorge Velho e o loco-tenente Antônio Fernandes de Abreu, já havia pintado para a igreja de Santa Cecília, a pedido do arcebispo de São Paulo, Dom Duarte Leopoldo e Silva, cenas da conversão e morte do bandeirante Pedro Correia. A imagem de Correia, convertido em membro da Companhia de Jesus e assassinado por índios carijó numa missão em Cananéia, também contrasta com a do bandeirante glorioso que o próprio Calixto ajudara a criar. Cf. Romano (2009).
} 
inerte domina quase todo o centro da pintura. Seus braços abertos semicobertos por uma camisa branca inteiramente rasgada tombam para fora da maca formando com ela uma diagonal, tal qual uma cruz [imagem que será retomada no segundo capítulo da tese, ver figura n. 2.14]. A rede, por sua vez, está pendurada nas paredes de um pequeno quarto, pintado em tons escuros, com poucos pertences $^{130}$.

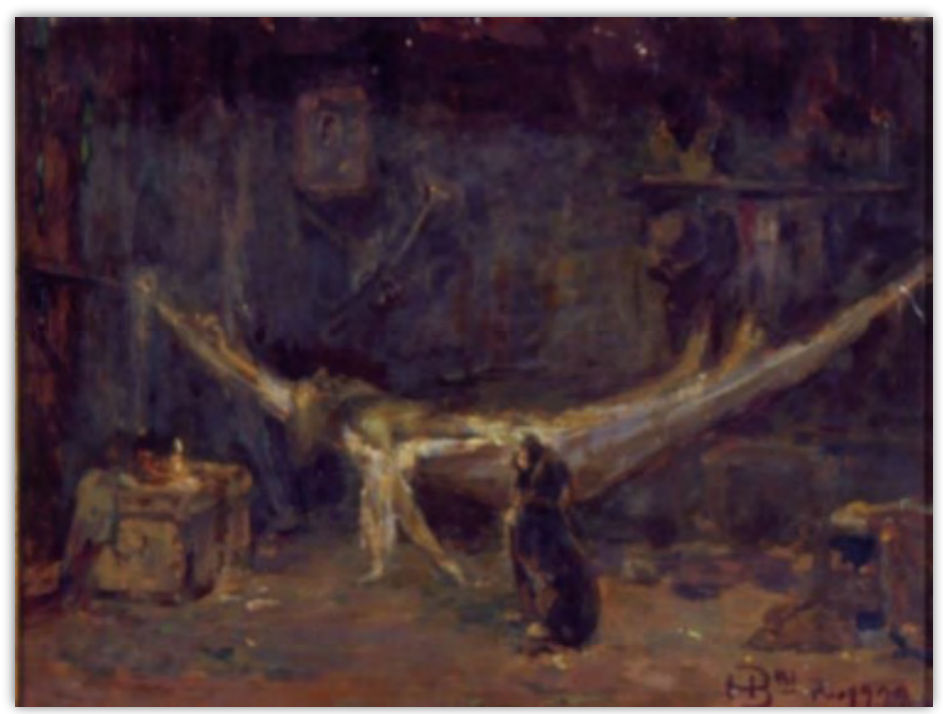

Figura 1.27 - Últimos momentos de um bandeirante (1932), de Henrique Bernardelli.

Óleo sobre papel cartão, 30,2 × $23 \mathrm{~cm}$.

Fonte: Acervo do Museu Paulista da USP | Foto: Hélio Nobre e José Rosael.

Temos novamente um bandeirante humanizado, distante do herói de Taunay. Vimos que em 1929, poucos anos antes de Bernardelli finalizar seu estudo da obra Últimos momentos de um bandeirante, Alcântara Machado havia publicado o livro Vida e morte do bandeirante, caracterizando São Paulo como uma região marcada por pobreza e carência extremadas. O livro se dedica a diversos aspectos do quotidiano bandeirante, como é possível observar nos próprios títulos dos capítulos, entre eles "Em face da morte". Machado defende ser fundamental nos concentrarmos na cultura e na vida familiar bandeirantes, nos seus hábitos de vestir, comer e morar: "Só depois de frequentá-los na intimidade e situá-los no cenário em que se moveram, estaremos habilitados a compreender-lhes as atitudes" (MACHADO, 1929, p. 29).

$130 \mathrm{O}$ corpo do bandeirante é guardado apenas por seu cão, que parece velar seu dono desassistido, quando por ocasião da execução do painel Ciclo de caşa ao índio Afonso Taunay havia reprovado a inclusão de um cachorro que Bernardelli acrescentara na primeira versão da tela, e depois suprimiu. No local onde se avistava o cachorro na tela recusada, há uma arma, na qual o bandeirante Mathias Cardoso de Almeida se apoia. Alguns anos antes, Bernardelli também havia introduzido um cachorro no fundo de sua tela Retirada do cabo de São Roque. 
Para Alcântara Machado, "reduzir o estudo do passado à biografia de homens ilustres e à narrativa dos feitos retumbantes”, como parece fazer Taunay ao decorar o Museu Paulista para as festas de 1922, "seria absurdo tão desmedido como circunscrever a geografia ao estudo das montanhas" ${ }^{131}$. Mas por mais que retrate a simplicidade dos bandeirantes, despidos de recursos materiais, o próprio autor orgulha-se profundamente de sua ascendência, a família dos Oliveira, que teria chegado em São Vicente em 1532. Não à toa, Vida e morte do bandeirante é dedicado aos seus familiares, "paulistas como eu e meus antepassados", afirma Machado (1929, p. 2).

A obra Últimos momentos de um bandeirante nunca teve sua versão final realizada, ficando apenas o estudo acima doado ao Museu Paulista na década de 1930, junto ao espólio de Henrique Bernardelli. Afinal, na galeria de heróis de Taunay a princípio não havia espaço para bandeirantes magros, maltrapilhos, desprovidos de qualquer resquício de força e bravura, como esse de Bernardelli, ainda que eles dessem um jeito de ser fazer presentes.

\section{e) Desestabilização}

$\mathrm{Na}$ escadaria principal do Museu Paulista, entre os seis bandeirantes esculpidos em bronze, seria exposta ainda a tela Ciclo do ouro (1922), do carioca Rodolfo Amoedo. Taunay havia encomendado a ele um quadro que retratasse um bandeirante escalando uma montanha aurífera e outro em que o mesmo personagem presidisse uma cena de varação de canoas, mas apenas a primeira encomenda foi aceita pelo então diretor do Museu Paulista, a segunda hoje faz parte do acervo do Museu Mariano Procópio, em Juiz de Fora (assim como a já mencionada tela Chefe bandeirante, de Henrique Bernardelli, estudo recusado para o painel Ciclo da caşa ao indio), sob a denominação Bandeirante.

As intervenções de Taunay foram constantes nas duas encomendas feitas ao pintor. Durante a elaboração do painel Ciclo do ouro, por exemplo, Amoedo lhe escrevera agradecendo o "precioso calque" de um vale mineiro ${ }^{132}$. Ao receber os esboços do artista, o então diretor do Museu Paulista lhe sugere ainda: "Em lugar da picareta, é bom pôr o almocafre às mãos dos índios;

\footnotetext{
131 "Como poderemos atingi-lo [o conhecimento do que o homem tem realizado]se concentrarmos toda a atenção em meia dúzia de figuras, esquecendo o esforço permanente dos humildes, a silenciosa colaboração dos anônimos, as ideias e os sentimentos das multidões?”, indaga Alcântara Machado (1929, p. 6).

${ }^{132}$ Carta de Rodolfo Amoedo a Afonso Taunay, 12 fev. 1922. APMP/FMP, pasta 116.
} 
neste quadro peço-lhe que ponha índios e negros"133. Amoedo acata a sugestão e desenha, no primeiro plano da tela, um bandeirante examinando uma bateia que um negro escravizado segura em pose de submissão. Cabe ressaltar que a escravização do negro, assim como a do índio, era plenamente justificada para Taunay, que ao apresentar diversos exemplos franceses, holandeses e espanhóis sobre o uso da força contra "outros povos", no primeiro tomo de sua História geral das bandeiras paulistas, conclui que sobre a "questão de extermínio dos tipos inferiores de humanidade não há nação europeia que possa atirar a outra qualquer pecha que seja” (1924, p. 65).

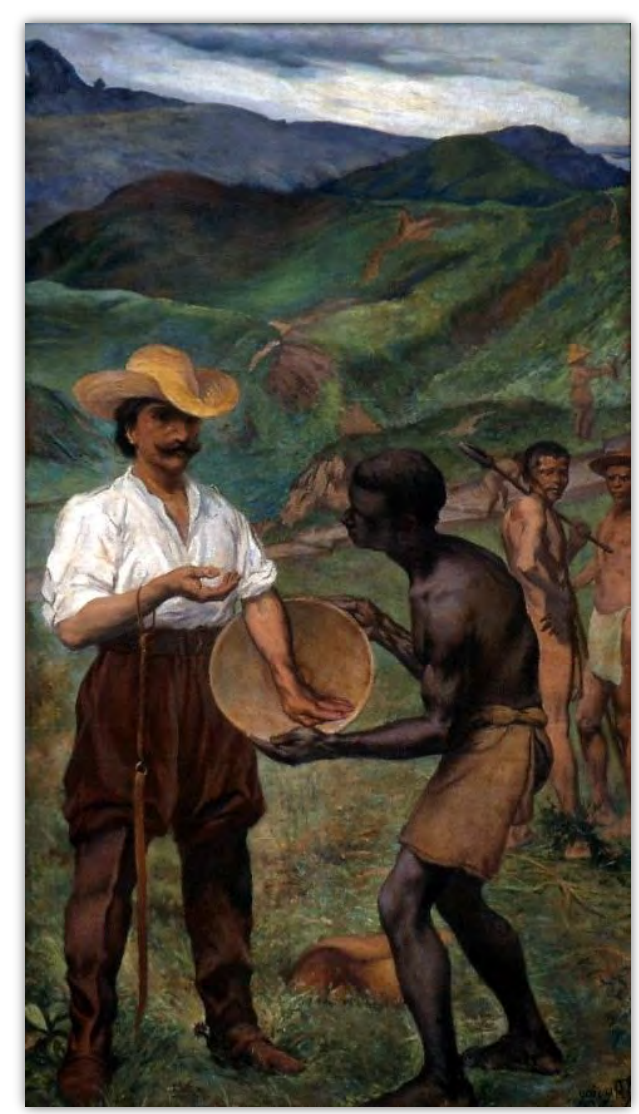

Figura 1.28 - Ciclo do ouro (1922), de Rodolfo Amoedo.

Óleo sobre tela, 232,8 x 127, $4 \mathrm{~cm}$.

Fonte: Acervo do Museu Paulista da USP | Foto: Hélio Nobre e José Rosael.

O negro é incluído no painel, em pose de escravidão, enquanto no retrato que Benedito Calixto realiza anos antes dos destruidores do Quilombo de Palmares não há nenhum negro. Encurvado e vestindo uma espécie de tanga escura, ele contrasta com o bandeirante, que veste uma camisa branca e segura um chicote. Com os ombros retos e a cabeça alinhada ao pescoço, o bandeirante não parece sequer olhar para o escravo que se curva à sua frente. Inclusive, ao dobrar

${ }^{133}$ Carta de Afonso Taunay a Rodolfo Amoedo, 13 mar. 1922. APMP/FMP, pasta 116. 
o braço direito na altura da cintura e apoiar o esquerdo na bateia, sua imagem se assemelha um pouco à pose majestática do retrato de Domingos Jorge Velho.

Se em Ciclo do ouro Rodolfo Amoedo cede às interferências do diretor do Museu Paulista, o mesmo não ocorre em Varação das canoas. Diante dos esboços do painel em que um chefe bandeirante lidera o transporte de suas canoas por terra devido à proximidade de trechos perigosos do rio, Taunay afirma ser necessário "colocar só índio e tirar toldo da canoa"134. Amoedo lhe responde que esboços são apenas pontos de partida e não possuem um caráter definitivo: "Faltam ainda muitos detalhes, mesmo dentro da canoa, que a pressa e a pequena escala não me permitiram completar" ${ }^{\prime 135}$.

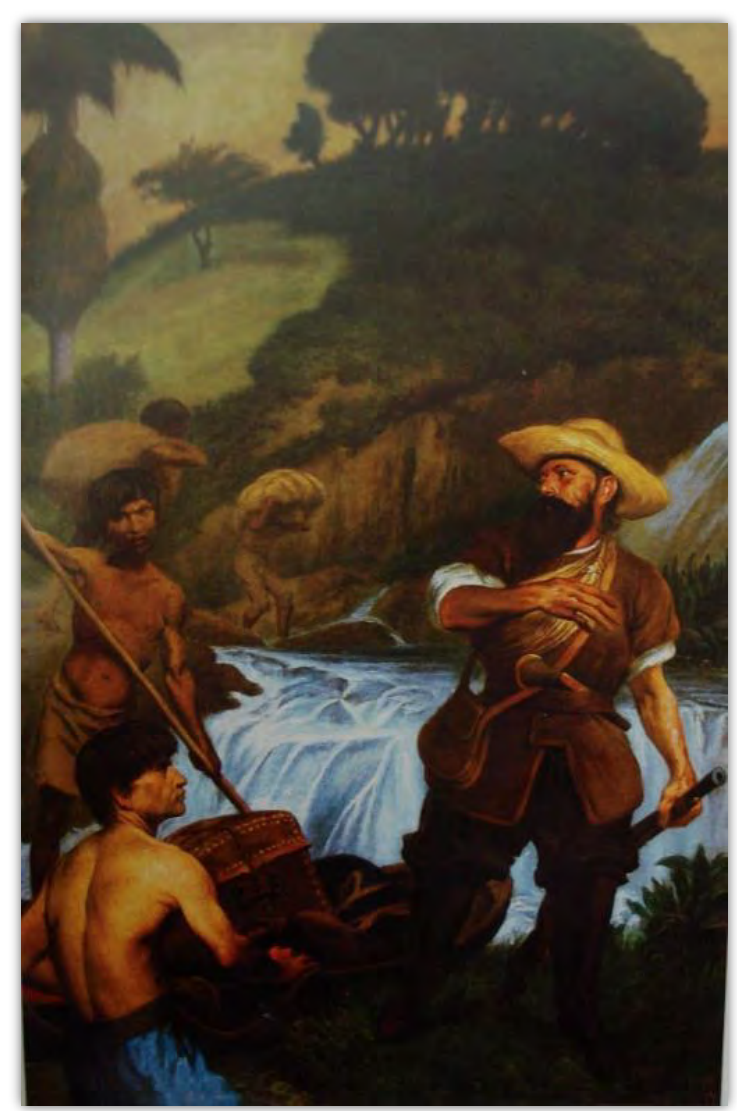

Figura 1.29 - Varação das canoas/Bandeirante (1929), de Rodolfo Amoedo. Óleo sobre tela, 232,5 x $158 \mathrm{~cm}$. Acervo do Museu Mariano Procópio.

\footnotetext{
${ }^{134}$ Carta de Afonso Taunay a Rodolfo Amoedo, 13 mar. 1922. APMP/FMP, pasta 116.

135 Carta de Rodolfo Amoedo a Afonso Taunay, 20 mar. 1922. APMP/FMP, pasta 116.
} 
Posteriormente, Amoedo irá colocar somente índios na tela e retirar o toldo da canoa, conforme sugerido por Taunay. Porém, enquanto em Ciclo do ouro o bandeirante altivo se sobrepõe ao negro submisso, o índio aqui aparece não mais como um elemento auxiliar, mas como um forte contraponto ao bandeirante ${ }^{136}$. Ao analisar os estudos de Amoedo para a realização de Varação das canoas encontrados no Museu Nacional de Belas Artes, Maraliz Christo (2002, p. 326) revela "um processo consciente de desconstrução do bandeirante como um herói absoluto".

O primeiro estudo é justamente o de um homem atirando tal qual o bandeirante central de Selvagens civilizados, soldados indígenas de Mogi das Cruzes combatendo botocudos (Provincia de São Paulo), de Jean-Baptiste Debret, obra que comentaremos no próximo tópico [ver figura n. 1.31]. Da pintura do soldado indígena realizada por Debret ainda no início do século XIX, Amoedo retira a vestimenta de seu bandeirante: o gibão de armas, o chapéu de abas largas, a camisa e a calça, as botas de cano alto, a bolsa transpassada pelo ombro, a arma de cano longo e a pistola presa ao cinto. Ao longo de outros cinco estudos, o combatente de Debret vai perdendo o vigor de seu movimento e sua atitude de comando.

Retratado em segundo plano, o bandeirante de Varação das canoas caminha com o olhar preso ao horizonte, desestabilizado, quase caindo. Assim, vai cedendo protagonismo para os indígenas carregadores e para a força do rio que cai em cascata impedindo as canoas de navegarem. Seu rosto se torna mais envelhecido, seu olhar, mais perdido, sua arma praticamente encosta no chão, enquanto seu corpo se inclina para o lado. Concluído em 1929, o painel não foi aceito por Taunay, que alegou não ter mais recursos para a encomenda entregue tardiamente, já que a verba havia sido concedida para as comemorações centenárias. Em uma entrevista realizada no mesmo ano, Amoedo desabafa: “[...] Fiz por encomenda dois bandeirantes para o Ipiranga, a mando do Taunay, fiz dois, note-se bem, para ficar junto, mesmo assim, só um seguiu seu destino, vendo-se o outro ainda por acabar, no meu ateliê, à espera de que soprem bons ventos"137.

\footnotetext{
${ }^{136}$ Não podemos deixar de lembrar que, embora Amoedo tenha sido um dos principais expoentes do indianismo quando pintou, entre outras telas, Marabá (1882) e O último tamoio (1883) —, ele também subverteu a retórica nacionalista sustentada pela Academia Imperial de Belas Artes ao ressignificar o indígena, às vésperas da Proclamação da República, diante de uma retórica de exaltação desgastada, como ressalta Richard Santiago Costa (2013). Tal ressignificação lhe daria um ar melancólico e trágico que pode ser observado tanto no último tamoio em um momento de morte, quanto na Marabá inspirada no poema de Antônio Gonçalves Dias, no qual uma índia se lamenta pelo fato de ser mestiça. Nesse sentido, se o indígena foi um tipo privilegiado de certa iconografia da Academia Imperial de Belas Artes, os significados são amplos e, às vezes, contraditórios. Sobre as representações oitocentistas de índios no Brasil, ver também Christo (2010).

${ }^{137}$ Entrevista concedida para O Jornal, 20 jun. 1926.
} 


\subsubsection{Combate contra o indigena}

Se os indígenas não aparecem em Domingos Jorge Velho e o loco-tenente Antônio Fernandes de Abreu, na tela de Rodolfo Amoedo - Varação das canoas - e nas obras de Henrique Bernardelli Os bandeirantes, Bandeirante e india e Retirada do cabo de São Roque — eles ganham protagonismo e força física. Já em Combate de milicianos de Mogi das Cruzes com botocudos (1920), de Oscar Pereira da Silva, bandeirantes e indígenas assumem no Museu Paulista o papel de combatentes ${ }^{138}$. Trata-se da única das encomendas realizadas por Afonso Taunay visando as festas centenárias na qual figura um combate. Mobilizada em diferentes exposições, ela parece ter sido sempre posicionada dentro do edifício como "uma peça acessória”, observa Paulo Garcez Marins (2017, p. 178), que desde o título de seu estudo sobre a dimensão pacífica da narrativa visual de Taunay, irá chamar a instituição, com propriedade, de "museu da paz".

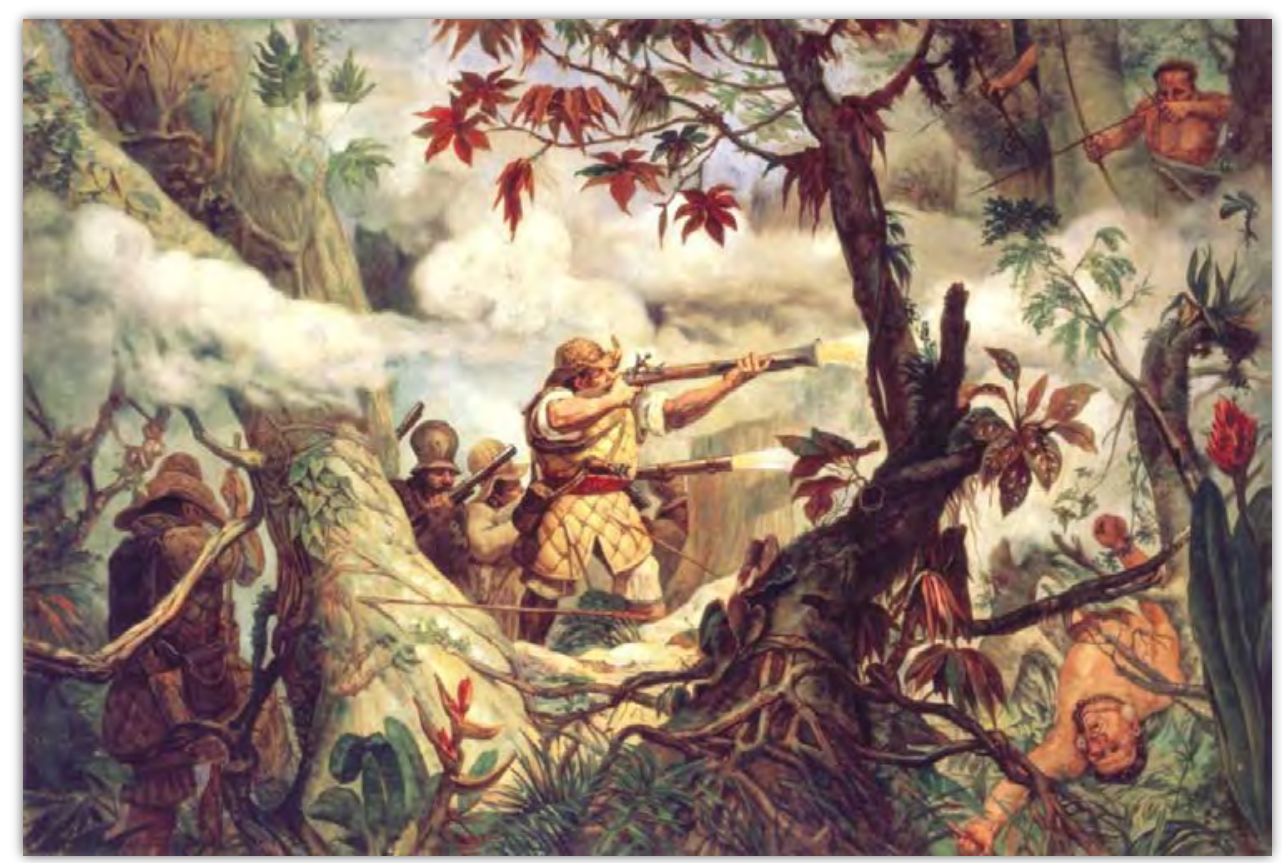

Figura 1.30 - Combate de milicianos de Mogi das Cruzes com botocudos (1920), de Oscar Pereira da Silva.

Óleo sobre tela, 150 x $100 \mathrm{~cm}$.

Fonte: Acervo do Museu Paulista da USP | Foto: Hélio Nobre e José Rosael.

138 Sobre a atuação de Oscar Pereira da Silva no Museu Paulista, entre 1920 e 1922, ver Lima Junior (2015). 
Fortemente marcada pela belicosidade, a obra de Oscar Pereira da Silva, um dos primeiros artistas plásticos a obter reconhecimento no $\operatorname{IHGSP}^{139}$, traz um indígena morto saltando ao primeiro plano no canto inferior direito da tela. No centro, temos um bandeirante em ação, num confronto armado contra indígenas, enquanto nas demais encomendas do Museu Paulista há um apaziguamento desse embate. Além de segurar uma arma que dispara quando é retratado, o bandeirante porta uma pistola presa à cintura por um cinto e tem o peito e as costas protegidos por uma espécie de armadura feita de couro na qual se encontram cravadas duas flechas. No canto direito superior da tela, dois indígenas miram suas flechas em direção aos bandeirantes. Já no centro e no lado esquerdo, é possível entrever ainda, em meio à neblina e à vegetação, outros quatro bandeirantes, visivelmente armados com mais de um tipo de arma de fogo.

Capistrano de Abreu, em seus Capitulos de história colonial (1907), já afirmava que ainda que faltem documentos para escrever a história das bandeiras, ela é sempre a mesma: "Homens munidos de armas de fogo atacam selvagens que se defendem com arco e flecha; à primeira investida morrem muitos dos assaltados e logo desmaia-lhes a coragem; os restantes, são amarrados, conduzidos ao povoado" (ABREU, 1907, p. 101). Anos antes, em seu ensaio "Caminhos antigos e povoamento do Brasil", publicado em 1889 no jornal O Comércio de São Paulo, Capistrano afirmara também que as bandeiras não eram objeto de estudo por "movivos óbvios", já que causaram a morte de inúmeros indígenas. O próprio Taunay (1912, p. 90), no discurso que faz por ocasião de sua nomeação como sócio efetivo do IHGSP, comenta que os "ferozes guaicurus e paiaguás" não conseguiram deter a marcha bandeirante pelo sertão adentro.

Foi seguindo sugestão de Taunay que Oscar Pereira da Silva tomou como base para a confecção de sua tela um desenho editado na França em 1834, Sauvages civilisés, soldats indiens de Mugi das Cruzas (Province de S. Paulo) combattant des botocudos, publicado no primeiro tomo do livro Voyage pittoresque et historique au Brésil, de Jean-Baptiste Debret, responsável, como vimos, pelo famoso retrato de Dom João VI com sua pose monárquica. Cabe lembrar que Debret chega ao Brasil em 1816, junto a outros artistas franceses, entre eles o bisavô do então diretor do Museu Paulista, Nicolas-Antoine Taunay. Em 1831, após retornar para a Europa, Debret publica uma série de desenhos sobre a formação do povo e da nação brasileira, entre eles Selvagens civilizados, soldados indígenas de Mogi das Cruzes combatendo botocudos (Provincia de São Paulo), que irá servir de base para a pintura de Pereira da Silva.

139 Oscar Pereira da Silva se associa ao IHGSP em 1909, pouco tempo depois que Benedito Calixto, que ingressa no instituto em 1905. 
No centro do desenho de Debret, vemos o "selvagem civilizado", um soldado indígena de Mogi das Cruzes, entre troncos de árvores sinuosos, portando igualmente o chapéu de abas largas, botas de cano alto e o colete acolchoado com um cinto segurando a pistola ao redor. O colete protetor possui as mesmas duas flechas espetadas. A espingarda solta fumaça ao disparar. Seus colegas também lançam fogo contra os botocudos que, por sua vez, miram suas flechas em direção aos soldados indígenas. No alto do canto direito, duas mãos empunham um arco cada e miram em direção aos soldados. Há um confronto, portanto, entre os "selvagens civilizados" e os indígenas do interior das matas fechadas. Um destes, na parte inferior à direita da tela, é atingido e retratado caindo tombado.

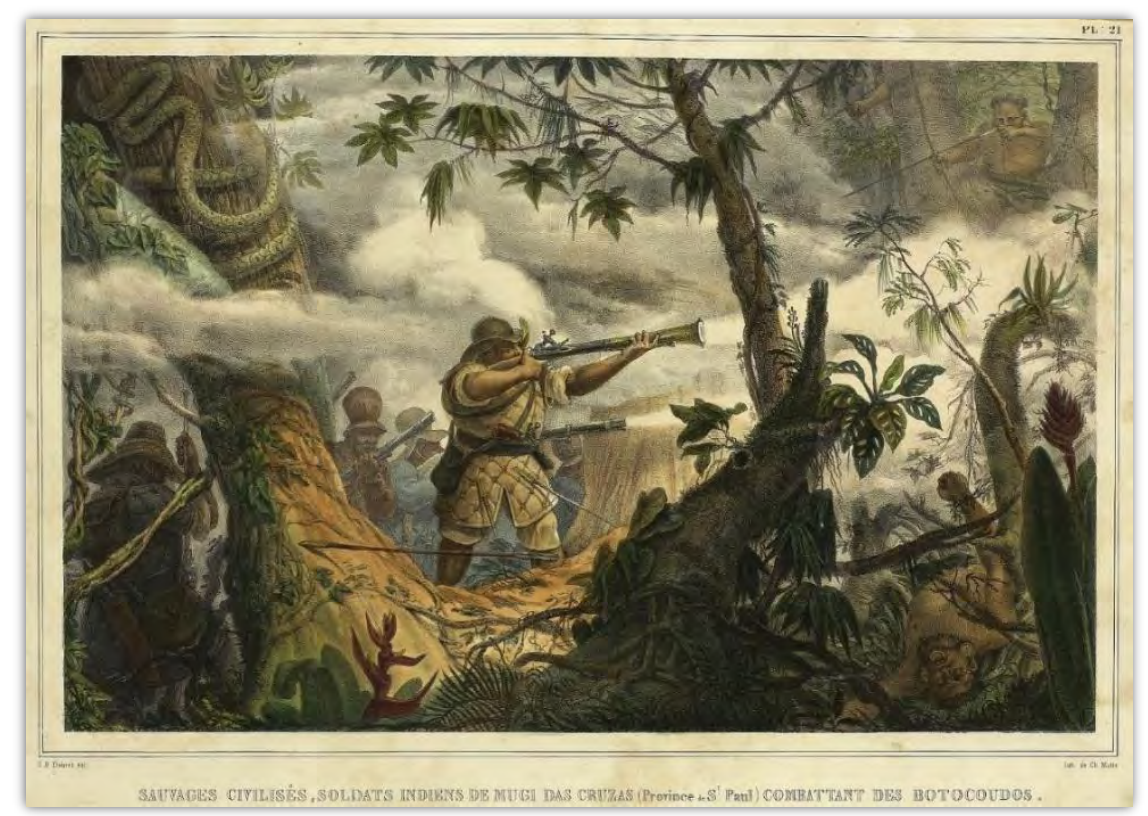

Figura 1.31 - Sauvages civilisés, soldats indiens de Mugi das Cruzas (Province de S. Paulo) combattant des botocudos (1834), de Jean-Baptiste Debret.

Litografia, $21,2 \times 32,4 \mathrm{~cm}$.

Fonte: Brasiliana Iconográfica ${ }^{140}$.

É possível supor, explica Carlos Lima Junior (2015) ao analisar ambas as obras, que a violência presente na tela de Oscar Pereira da Silva estivesse relacionada ao fato de os botocudos serem identificados como inimigos ${ }^{141}$. O autor nota ainda que os personagens ganham mais realce

140 Disponível em: http://www.brasilianaiconografica.art.br/obras/17408/sauvages-civilises-soldats-indiens-de-mugidas-cruzas-province-de-st-paul-combattant-des-botocoudos. Acesso em: 20 jul. 2017.

${ }^{141}$ Se no século XVIII Pedro Taques e frei Gaspar discordavam quanto à ascendência gentílica das elites paulistas da época - Pedro Taques, que se afirmava sobrinho-neto de Fernão Dias e descendente dos primeiros povoadores da capitania de São Vicente, frisava o sangue puramente europeu dos antigos paulistas, enquanto frei Gaspar dizia ser descendente do português João Ramalho e de Bartira, filha do chefe dos Tamoios, reconhecendo no paulista 
quando transpostos e ampliados da gravura para a tela de Pereira da Silva, tanto pelo uso de tons vibrantes, quanto pelo contorno mais definido. Além disso, o "selvagem civilizado" do centro da composição da Debret ganha um tom de pele mais claro na obra de Pereira da Silva, enquanto o botocudo tombado ao chão tem a coloração da pele mais avermelhada ${ }^{142}$.

Dois anos antes da reabertura do Museu Paulista para as festas centenárias, o "selvagem civilizado" e sua armadura acolchoada cedem lugar ao bandeirante com seu "gibão de armas", a vestimenta "essencial" de combate dos "bugreiros"143. Debret trouxe uma contribuição valiosa, defende Taunay, pois seu desenho seria o único documento iconográfico até hoje encontrado que retrata a indumentária bandeirante com "visos de autenticidade" 144 . Ainda que o ambiente da composição fosse "fantasia" e que o soldado retratado fosse um indígena oitocentista, nele encontramos o "elemento de maior valia": "o famoso gibão de armas, 'armas de algodão', 'armas estofadas', no gênero de escupil hispano americano, couraça essencial dos bandeirantes de São Paulo, do que infelizmente não subsiste um único espécime” (TAUNAY, 1949, p. 45).

Cabe observar que as duas primeiras edições de Vida e morte do bandeirante, de Alcântara Machado, publicadas em 1929 e 1930 com ilustrações de Yan de Almeida Prado (1898-1981) — as edições seguintes, como já mencionado, foram ilustradas por Wasth Rodrigues — retrataram a vestimenta dos bandeirantes a partir justamente da imagem do "selvagem civilizado" pintado por Debret nos anos 1830. Lembremos, porém, que a obra de Alcântara Machado foi uma importante referência para os textos de Sérgio Buarque de Holanda, como Caminhos \& Fronteiras (1957),

antigo a mistura luso-indígena —, no final do século XIX surge um acirrado debate em torno da busca pelo indígena "ideal" que pudesse representar a contribuição da terra para a formação do bandeirante, ver Monteiro (1992) e Ferreira (2002).

142 Nesse mesmo sentido, Solange Lima e Vânia Carvalho (1993) mostram como, ao mandar produzir uma série pictórica sobre a antiga iconografia de São Paulo para o Museu Paulista, Taunay sugeriu aos artistas que utilizassem imagens fotográficas como matrizes para as encomendas, fornecendo-lhes como modelo fotografias de Militão Augusto de Azevedo, que também tem as dimensões de suas fotos ampliadas para corresponder à monumentalidade da instituição. Em seu relatório de atividades do museu do ano de 1920, no entanto, Taunay chega a afirmar ao secretário do Interior que "foram todos os documentos rigorosamente reproduzidos pelos diversos artistas incumbidos de os transportarem para a pintura a óleo". Mas tais imagens, que registravam aspectos da cidade entre 1862 e 1887, revelam um passado anterior, privilegiando a figura do tropeiro, que seria o sucessor dos bandeirantes no desbravamento do país.

${ }^{143}$ Em seus Capitulos de história colonial, Capistrano de Abreu já mencionava a indumentária bandeirante e descrevia os "escupils" como "dalmáticas almofadas de algodão, com que vestido o soldado de pés à cabeça peleja seguro das setas, a som de caixa, bandeira tendida e ordem militar" (ABREU, 1907, p. 103).

144 Segundo Afonso Taunay (1949, p. 32), “de nenhum personagem de prol das duas primeiras centúrias existe a efígie, seja ele eclesiástico ou secular, militar ou civil. Não há um só bandeirante de que conheçamos os traços, sejam eles dos maiores ou menores". 
coletânea publicada um ano após Holanda deixar a diretoria do Museu Paulista. Mas se em Caminhos \& Fronteiras, ao falar da vestimenta dos bandeirantes, Holanda menciona a gravura de Debret - e a reproduz utilizando a legenda "sertanistas de São Paulo em luta com índios botocudos trajando um gibão acolchoado (escupil)" —, ele também reproduz em um dos textos da mesma coletânea a imagem de uma escultura do tempo das Missões, conservada em uma igreja no Rio Grande do Sul, que representa um São Miguel agreste e com feições indígenas, com o diabo prostrado aos seus pés, na figura de um bandeirante. Mas na escultura, ressalta ele, quem aparece armado com um escupil é o arcanjo, e não o bandeirante.

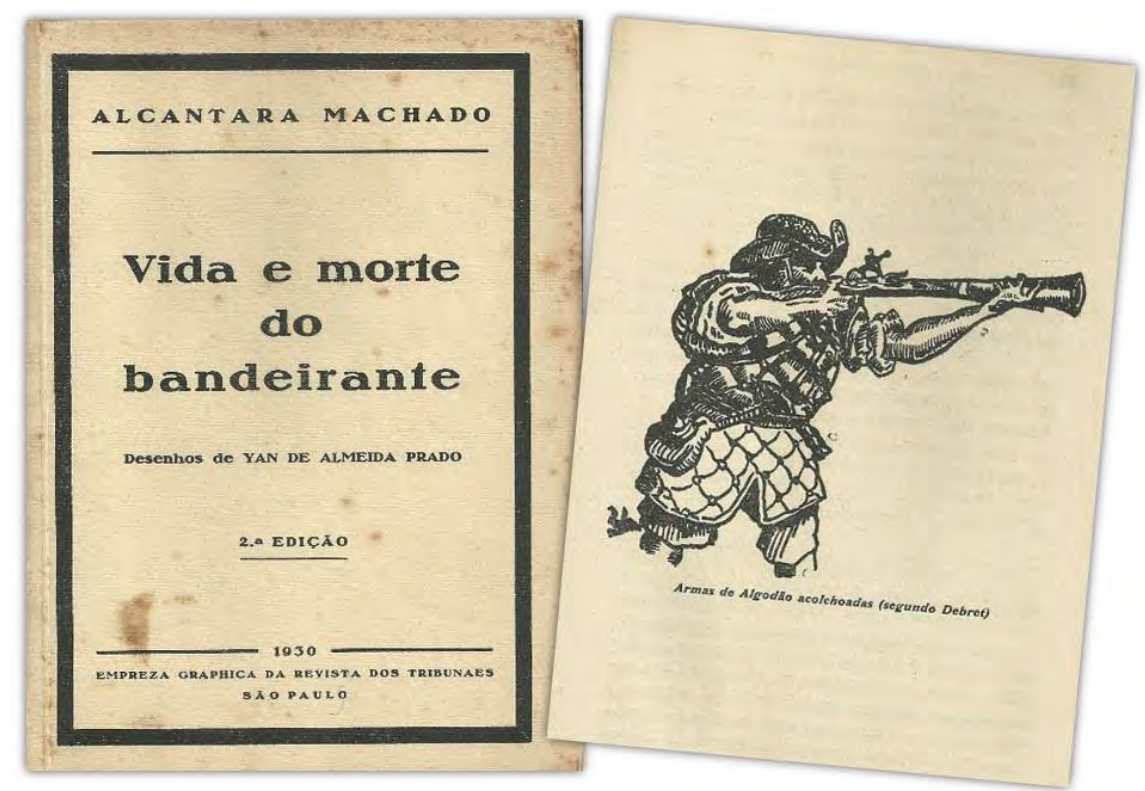

Figura 1.32 - Vida e morte do bandeirante (1930), de José de Alcântara Machado. À direita, na legenda da imagem, lê-se "armas de algodão acolchoadas, segundo Debret". Fonte: Acervo pessoal | Foto: Thaís Waldman.

Embora tenha recebido pouco destaque no programa expositivo de Taunay, a imagem do bandeirante em combate com sua "couraça essencial" é disseminada museu afora não apenas em obras como a de José Alcântara Machado e, posteriormente, a de Sérgio Buarque de Holanda, mas também em materiais didáticos utilizados por diversas escolas públicas paulistas e brasileiras do período, como no livro Breves lições de bistória do Brasil (1922), de Creso Braga, adotado em São Paulo e em outros dezesseis estados do país, como visto no início do capítulo. Além de trazer estampada, em uma lição sobre o Quilombo dos Palmares, uma reprodução do retrato modelar de Domingos Jorge Velho feito por Benedito Calixto, Braga irá ilustrar as desavenças entre bandeirantes e portugueses, ocorridas próximas a um rio, com a imagem dos bandeirantes deitados ao chão saciando a sede diretamente de uma poça, pintada por Henrique Bernardelli no século XIX, 
enquanto uma luta entre indígenas e bandeirantes é acompanhada pela reprodução da pintura dos soldados indígenas/bandeirantes combatendo botocudos.

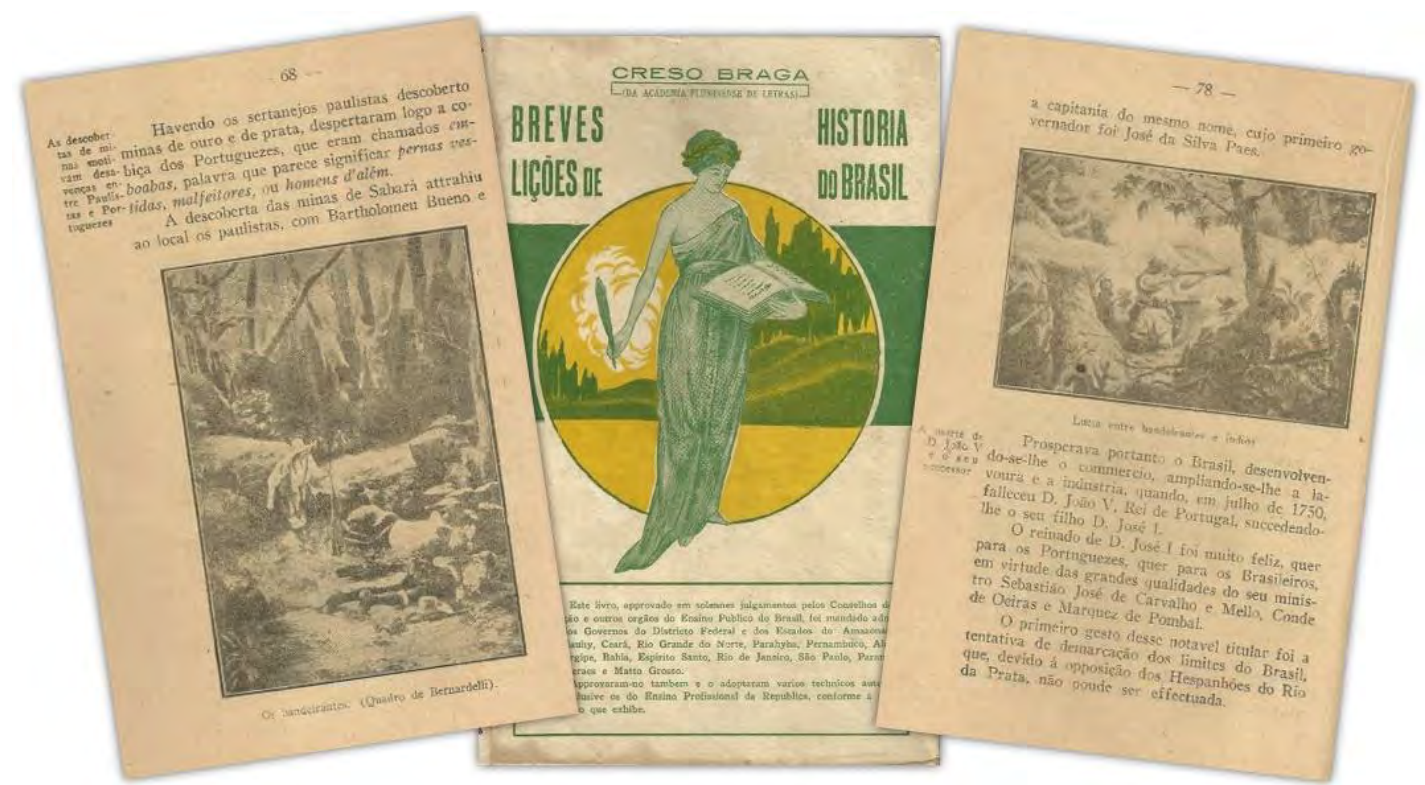

Figura 1.33 - Breves lições de história do Brasil (1922), de Creso Braga. À direita, na legenda da imagem, lê-se " $O s$ bandeirantes (quadro de Bernardelli). Já na legenda da imagem à esquerda, lê-se "luta entre bandeirantes e índios".

Fonte: Acervo pessoal | Foto: Thaís Waldman.

\subsubsection{Heroísmo pacato e bucólico}

Com a inauguração da sala das monções no Museu Paulista, em 1929, mesmo ano em que é publicada a primeira edição de Vida e morte do bandeirante, Afonso Taunay destaca o que ele chama de terceiro e último ciclo bandeirante através dos roteiros fluviais que ligavam Porto Feliz, no interior paulista, até Cuiabá, no Mato Grosso. Roteiros que ficaram conhecidos por serem utilizados pelas expedições comerciais, realizadas nos séculos XVIII e XIX, denominadas monções. Ali, o Tietê, visto como o principal caminho das entradas para o sertão, sintetizaria o caráter grandioso e desbravador dos paulistas, diretamente relacionado à alma desse rio, cujo leito acidentado só poderia ter sido cruzado e transposto pelos bandeirantes. As minas de Cuiabá, segundo Taunay (1926b, p. 88), seriam tão importantes quanto as de Minas Gerais e Goiás, que se diferenciavam por utilizar vias terrestres para se chegar a suas jazidas, daí o "colossal rush pelas águas do rio das entradas". 


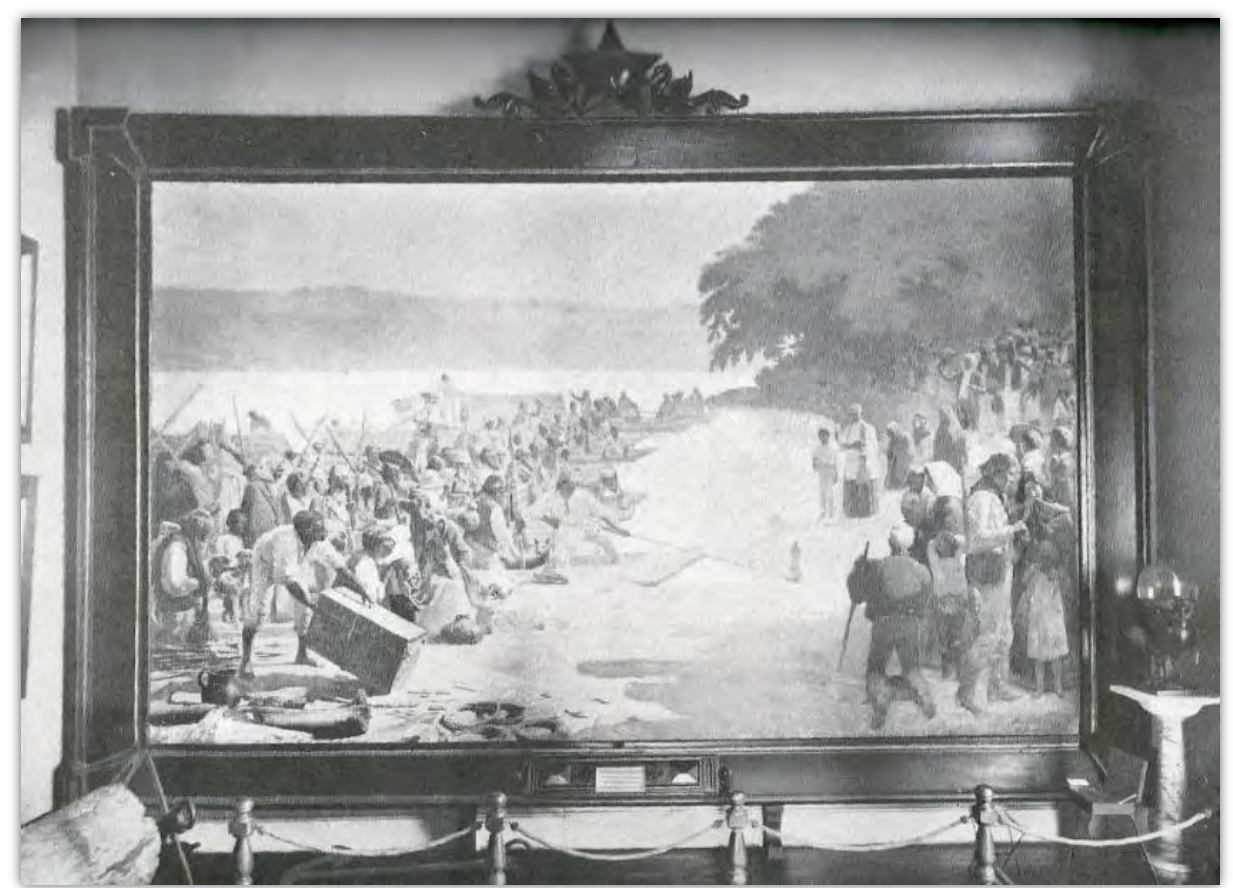

Figura 1.34 - A partida da monção (1897), de Almeida Júnior, na sala das monções, década de 1930. Nas laterais, à direita, uma ânfora, e à esquerda, pedaço do fragmento de uma canoa. Fonte: Guia da seção histórica do Museu Paulista (1937), Afonso Taunay, s/p.

$\mathrm{Na}$ sala das monções, Taunay recupera e realoca a tela em grandes dimensões $A$ partida da monção (1897), de José Ferraz de Almeida Júnior, que irá ocupar toda a parede do fundo da sala, no pavimento térreo do Museu Paulista, próxima a já mencionada sala de cartografia colonial e documentos antigos. À sua frente, além de um vaso de bronze com uma ânfora — semelhante as que pontuavam os corrimões da escadaria principal ${ }^{145}$ - contendo água do rio Tietê, é colocado um fragmento de uma embarcação fluvial, um dos poucos "vestígios" dos "canoões" que “sulcavam os rios do nosso far west”, dirá Taunay $\left(1937\right.$, p. 71) ${ }^{146}$. Adquirida pelo Museu Paulista em 1902, A partida da monção foi transferida para a Pinacoteca em 1905, junto a outras dezenove telas que saíram da colina do Ipiranga para compor a coleção da nova instituição, que ocuparia o

\footnotetext{
${ }^{145}$ Em 1928, Taunay instalou dezesseis vasos com suporte de bronze e ânforas de vidro sobre os pilares de mármore que pontuam os corrimões da escadaria principal do Museu Paulista, dois deles contendo as águas misturadas dos rios dos extremos do Brasil — Oiapoque e Chuí (norte e sul), e Javari e Capibaribe (leste e oeste) —, e os demais com as águas dos rios: Paraguai, Madeira, Amazonas, Negro, Paraná, Uruguai, Tocantins, São Francisco, Paraíba, Parnaíba, Doce, Jaguaribe, Doce, Piranhas-Assu e Carioca, cf. Marins (2016b).

${ }^{146}$ Em um discurso proferido em 1920, em Porto Feliz, publicado sob o título de A glória das monções, Taunay cita um episódio da história antiga, no qual descreve a presença de tais vasos no palácio de Persépolis, para explicar que uma ânfora com água do Tietê caberia tal qual em seu palácio do Ipiranga. Desse modo, através dos rios brasileiros, que literalmente são trazidos para dentro das ânforas, o museu tornaria presente o "conjunto do território nacional" conquistado através da navegação, já que "não há circunscrição do território nacional que não esteja representada por um curso d'água que lhe rega o solo", explica Taunay (1937, p. 60).
} 
segundo andar do edifício então pertencente ao Liceu de Artes e Ofícios, na praça da Luz, região central.

Ao analisar a transferência dessas obras, Pedro Nery (2015) observa que, para além da formação de um acervo na nova instituição, ou da falta de espaço no Museu Paulista, algumas telas permaneceram na colina do Ipiranga, como os quadros de Benedito Calixto, entre eles Domingos Jorge Velho e o loco-tenente Antônio Fernandes de Abreu. O autor recorda ainda que Almeida Júnior, artista que teve todas suas obras transferidas para a Pinacoteca na época, havia visitado o edifíciomonumento antes mesmo da abertura do Museu Paulista, quando produzia as telas Amolação interrompida (1894) e Caipira picando fumo (1893), dois quadros que se encaixam perfeitamente nas molduras de argamassa do salão nobre, ao lado da tela Independência ou morte, considerada parte integrante do edifício-monumento. Nery sugere então que a transferência das obras de Almeida Júnior para a Pinacoteca pode ser vista como uma forma de esvaziar uma narrativa na qual $A$ partida da monção, possivelmente instalada na contra parede do quadro de Pedro Américo, conectaria a Independência do país ao processo monçônico e aos caipiras, trazendo para o primeiro plano usos e costumes populares, integralizando-os à história da nação.
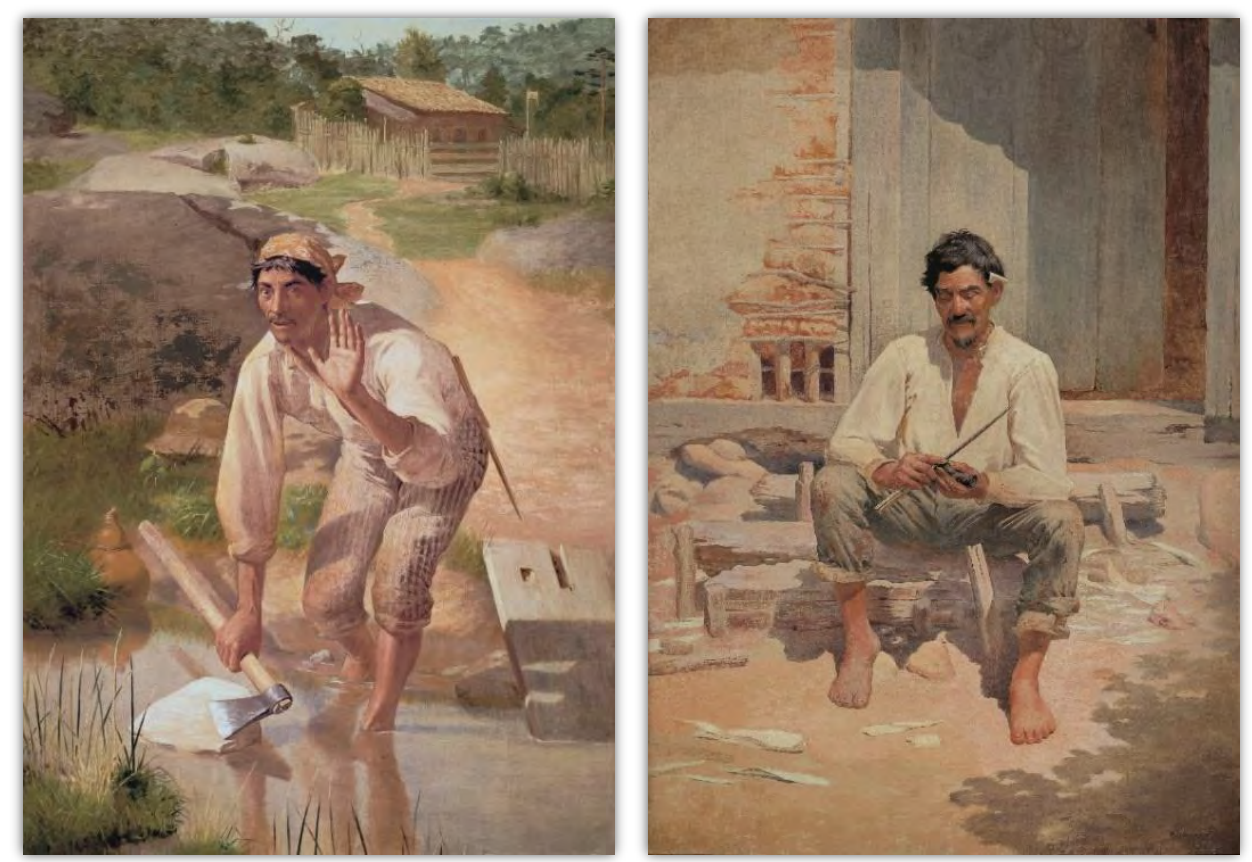

Figura 1.35-Amolação interrompida (1894) e Caipira picando fumo (1893), de Almeida Júnior. Óleo sobre tela, $200 \times 140 \mathrm{~cm} /$ Óleo sobre tela, $202 \times 141 \mathrm{~cm}$.

Fonte: Acervo da Pinacoteca do Estado de São Paulo | Foto: Isabella Matheus.

Cabe notar que $A$ partida da monção começa a ser executada um ano depois da aquisição das telas Amolação interrompida e Caipira picando fumo, as primeiras do artista a ingressarem no Museu 
Paulista, ainda durante a gestão do porto-felicense Cesário Motta Júnior (1892-1896) frente à Secretaria de Negócios do Estado ${ }^{147}$. Além do Museu Paulista ter sido criado sob sua chancela, $A$ partida da monção foi baseada, ao que parece, em um texto seu, intitulado "Porto Feliz e as monções para Cuiabá”, publicado em 1884 no Almanaque literário de São Paulo — publicação na qual, como constata Antônio Celso Ferreira (2002), os significados atribuídos ao caipira eram diversos e ambíguos, indicando sentimentos simultâneos de identificação e afastamento ${ }^{148}$.

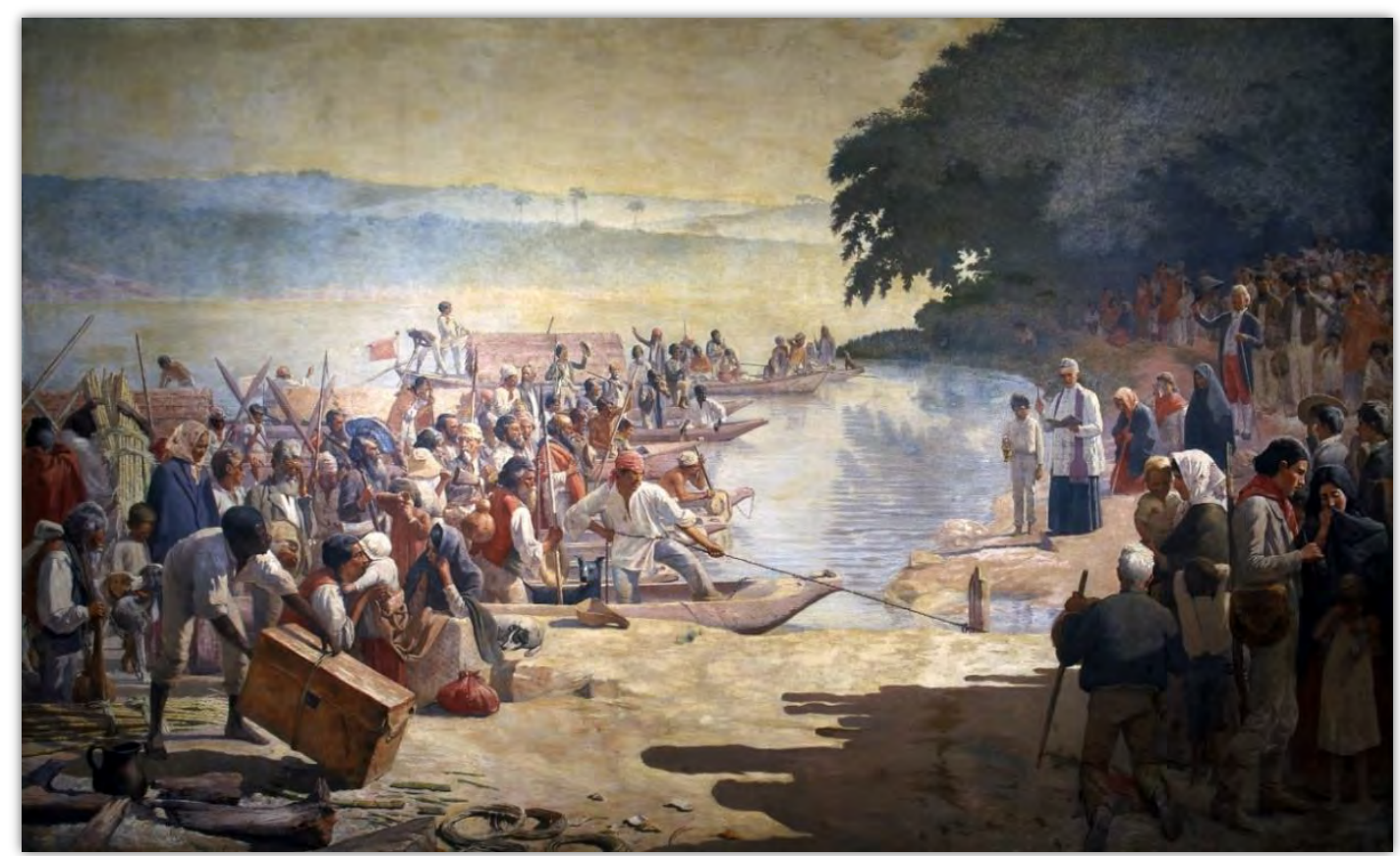

Figura 1.36 - A partida da monção (1897), de Almeida Júnior. Óleo sobre tela, 390 x $640 \mathrm{~cm}$.

Fonte: Acervo do Museu Paulista da USP | Foto: Hélio Nobre e José Rosael.

Ao contrário do retrato de Domingos Jorge Velho e seu loco-tenente, adquirido um ano depois, $A$ partida da monção não é notabilizada a partir de uma figura individual exclusiva. Conforme descrição do próprio Almeida Júnior, a tela retrata algumas "caravanas" de "destemidos e ousados

\footnotetext{
147 Projetada durante a gestão de Motta Júnior, A partida da monção foi concluída e exposta em São Paulo em 1897, em um barracão alugado pelo artista próximo ao viaduto do Chá, região central da cidade. No ano seguinte, a tela foi exposta também na Exposição Geral de Belas Artes do Rio de Janeiro. Em 1899, é aprovado um projeto de lei na Assembleia para sua aquisição pelo Estado de São Paulo, o que só se concretiza após a morte do pintor. A esse respeito, ver Pitta (2013).

148 A relação entre a obra de Almeida Júnior e o texto de Motta Júnior, no qual ele defende ter sido grande parte do sertão brasileiro conquistada pelos esforços dos paulistas, foi analisada por Pitta (2013) e Singh Júnior (2004). Lembremos também que, no início dos anos 1880, Motta Júnior já havia escrito e dirigido a peça teatral $A$ caipirinha, sobre uma jovem moça do interior forçada a ir para a cidade. A peça foi encenada diversas vezes na capital paulista entre os anos de 1917 e 1928, além de ter sido vertida ao cinema em 1919, ver Almeida (2011).
} 
sertanejos", que partiam do cais fluvial de Porto Feliz rumo a Cuiabá, descendo o rio Tietê “inspirados pelo amor ao desconhecido, descoberta das minas e civilização dos bugres"149. A crítica paulista contemporânea à obra evocou a grandiosidade dessas aventuras e seu caráter sobrehumano, e utilizou, com alguma frequência, o termo monção como sinônimo de bandeira, e monçoeiros como bandeirantes ${ }^{150}$. Taunay, por sua vez, anos depois, comenta que Almeida Júnior não só retratou bandeirantes sendo abençoados pelo vigário de Itu, como também muitos familiares e pessoas do círculo de amizades do artista ituano, como seu próprio pai ${ }^{151}$.

Observa-se ainda a ausência da figura do herói. O mais próximo dele seria o proeiro, responsável pela manutenção da embarcação que se aproxima da margem do rio e pela separação entre os que ficam e os que partem, embora ele não seja exatamente a figura que organiza as forças da composição. O capitão-mor também não se destaca como protagonista. Já o sacerdote que abençoa a expedição está posicionado discretamente à margem do rio e, ainda que muitos dos olhares dos personagens retratados tenham como ponto de convergência sua figura, Almeida Júnior insere na tela mulheres, jovens e crianças que se despedem melancólicos, dirigindo seu olhar e seu corpo para outras direções, assim como viajantes que conversam, acenam com seus chapéus, protegem o rosto com as mãos, ajeitam os instrumentos de navegação ou fazem os últimos carregamentos.

Nesse sentido, não haveria em $A$ partida da monção uma visão edificante do passado paulista, mas um heroísmo mais "pacato e bucólico", sugere Fernanda Pitta (lembrando uma expressão de Ezequiel Freire, um dos principais críticos contemporâneos à obra de Almeida Júnior), após indagar se o propósito do pintor não era justamente "interpretar a monção não tanto como uma aventura energética, mas como um evento sentimentalmente contido, melancólico e solene na sua simplicidade" (PITTA, 2013, p. 447). Almeida Júnior parece assim articular suas escolhas de modo que encontrem a contenção, o que pode oferecer um contraponto à visão enaltecedora do papel de São Paulo na história do Brasil. A autora chama nossa atenção para o fato de que os personagens de Almeida Júnior muito se assemelham aos tipos "interioranos" retratados nas telas regionalistas do artista, seja nas fisionomias, nas vestimentas, no colorido da pele ou nos gestos ${ }^{152}$.

\footnotetext{
149 “O quadro que ofereço à apreciação do público representa a partida desses heróis, que, depois da missa na igreja Nossa Senhora Mãe dos Homens, acompanhados do padre, capitão-mor e povo, embarcavam no Porto Geral, recebendo na ocasião a solene benção da partida", explica Almeida Júnior a respeito de sua obra. Cf. "Artes e artistas". O Estado de São Paulo. 1 jan. 1898, p. 1.

150 Sobe a fortuna crítica da obra, ver Singh Júnior (2004).

151 “Galeria do Museu Paulista". Jornal do Commercio, 6 de jun. 1943, p. 2.

152 Sobre os caipiras retratados por Almeida Júnior, ver também Lourenço (1980), Naves (2005) e Perutti (2011).
} 
Para valorizar o tema central de $A$ partida da monção, Afonso Taunay encomenda ainda a Oscar Pereira da Silva e ao alemão residente em São Paulo Aurélio Zimmermann (1854-1920) outras telas. São elas: Benção dos canoões (1919), Pouso no sertão-monções (1919), Carga das canoas (1920), Encontro de duas monções no sertão (1920) e Partida de Porto Feliz (1920-21) ${ }^{153}$.
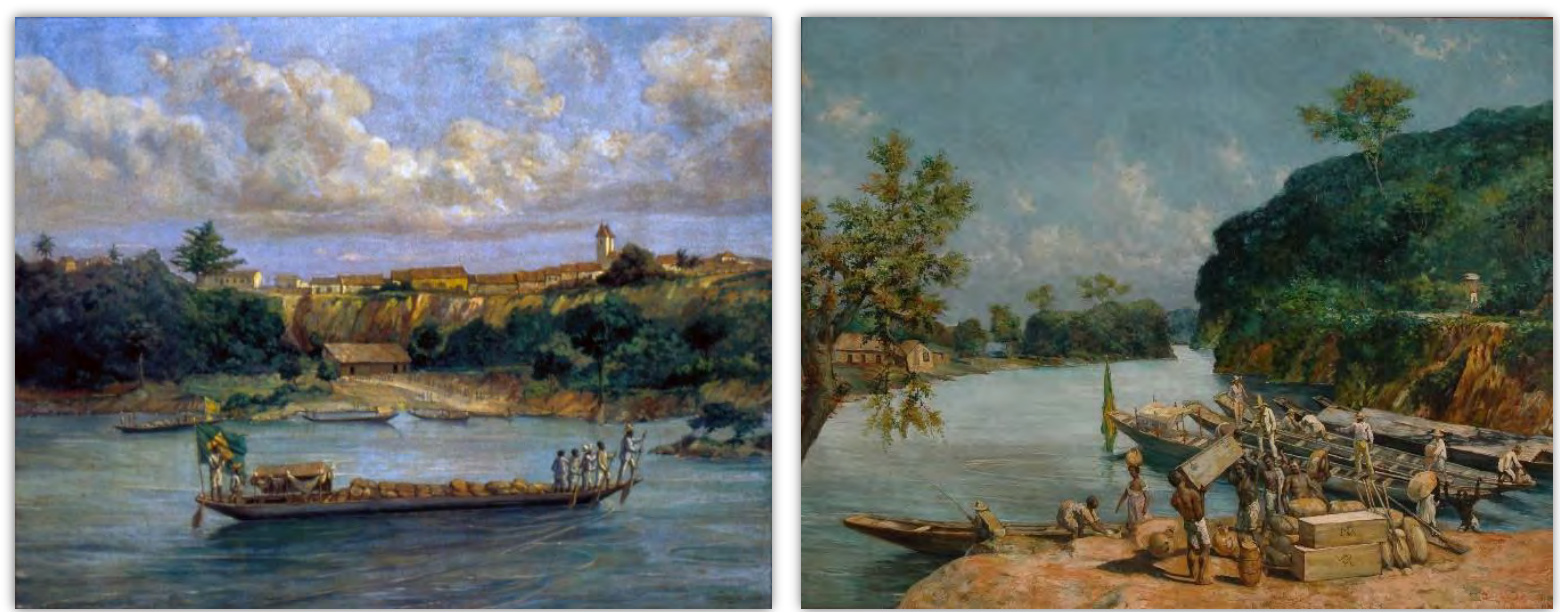

Figura 1.37 — Partida de Porto Feliz (1920-21), à esquerda, e Carga de canoas (1920), à direita, ambas de Oscar Pereira da Silva.

Óleo sobre tela, 140,5 x $110 \mathrm{~cm} /$ Óleo sobre tela, 140 x $100 \mathrm{~cm}$.

Fonte: Acervo do Museu Paulista da USP | Foto: Hélio Nobre e José Rosael.
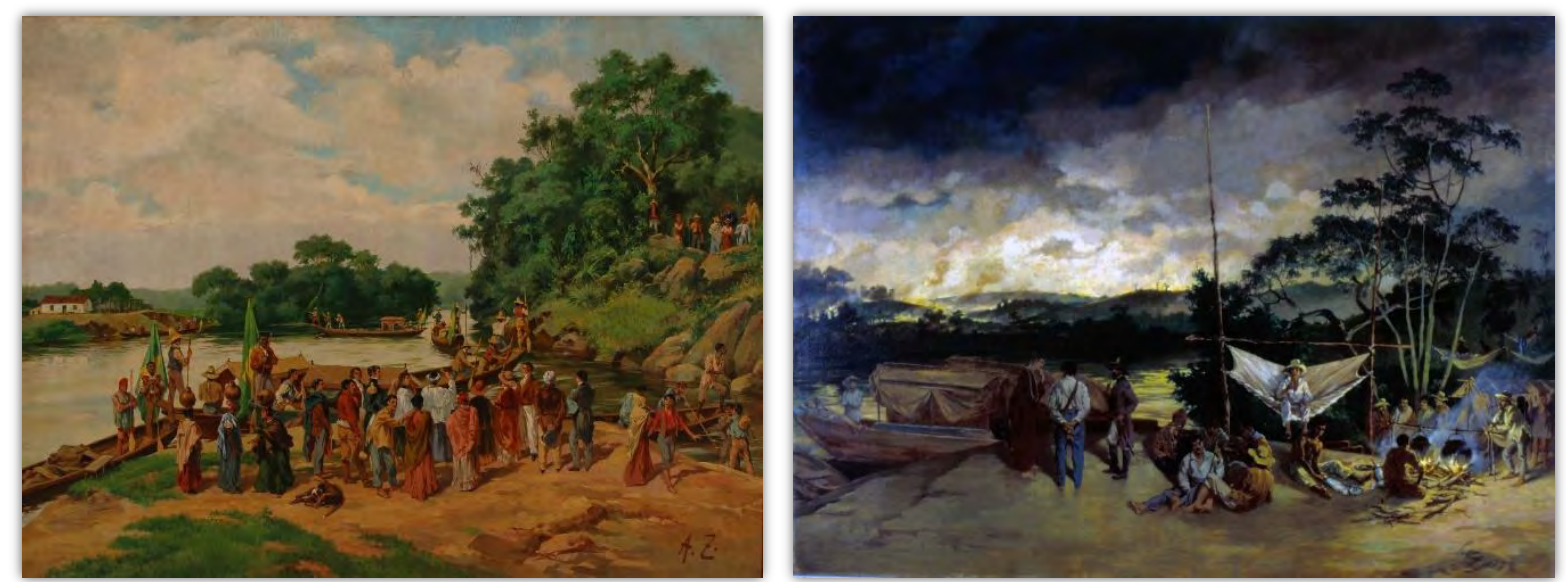

Figura 1.38 - Benção dos canoões (1919), à esquerda, e Pouso no sertão-monções (1919), à direita, ambas de Aurélio Zimmermann.

Óleo sobre tela, 134 x 101,5 cm / Óleo sobre tela, 135 x $100 \mathrm{~cm}$

Fonte: Acervo do Museu Paulista da USP | Foto: Hélio Nobre e José Rosael.

153 A respeito dessas telas, ver Lima Junior (2015). 


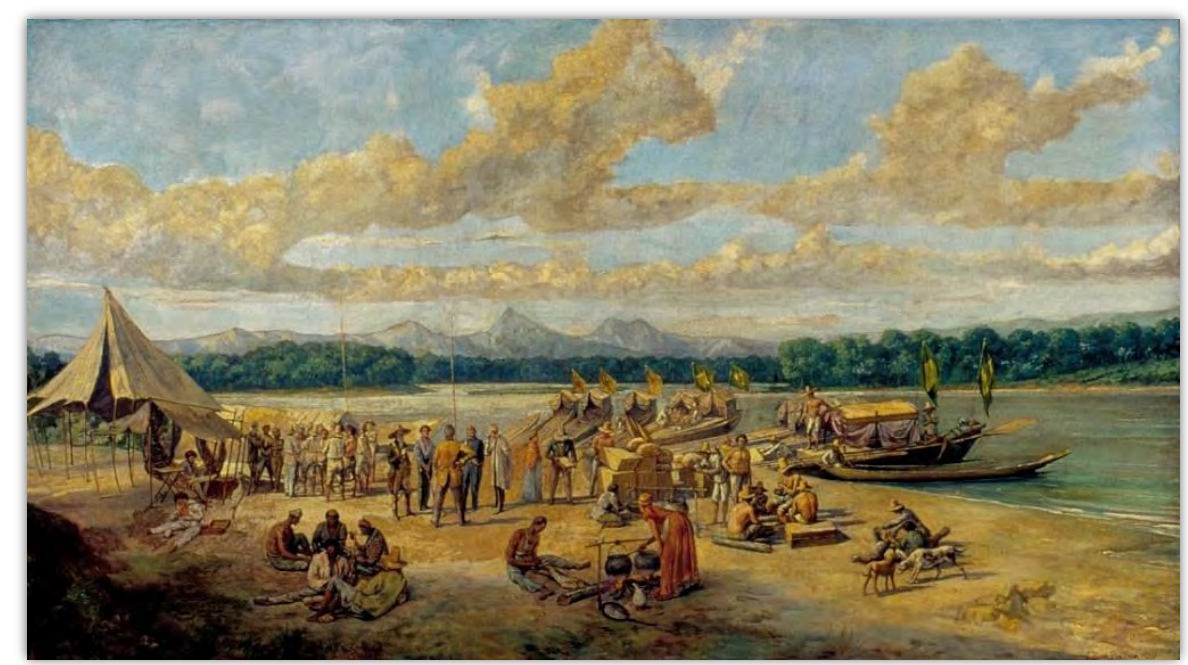

Figura 1.39 - Encontro de duas monções no sertão (1920), de Oscar Pereira da Silva. Óleo sobre tela, $173 \times 95,5 \mathrm{~cm}$.

Fonte: Acervo do Museu Paulista da USP | Foto: Hélio Nobre e José Rosael.

Inicialmente, tais telas ficaram expostas na sala dedicada à iconografia paulista antiga, até ser criada a sala das monções, onde foram instaladas de forma cronológica e temporal, possibilitando ao visitante acompanhar os passos das viagens fluviais desde sua partida até a chegada ao sertão brasileiro. Vide os procedimentos de partida e embarque, em Partida de Porto Feliz. e Carga das canoas; a religiosidade e a proteção divina para a longa jornada, em Benção dos canoões; e o sertão, em Pouso no sertão-monções e Encontro de monções no sertão. Já a tela de Almeida Júnior, A partida da monção, aglutinaria todo esse movimento.

As cinco telas deveriam ser pintadas a partir de desenhos de Hercules Florence (1804-1879) — descrito por Taunay como o "patriarca da iconografia paulista" 154 _, entre outros registrados durante a expedição chefiada pelo barão Langsdorff (1774-1852) no início do século XIX. São desenhos produzidos durante a expedição científica russa ao interior do Brasil, realizada na década de 1820, com o objetivo de registrar informações a respeito da fauna, da flora e dos costumes locais ${ }^{155}$. De acordo com o relatório do Museu Paulista referente ao ano de 1920, tais desenhos pertenciam ao governo russo, mas foram postos à disposição do Museu Paulista durante os preparativos para as comemorações do Centenário da Independência do Brasil. Vários deles, de caráter documental, tinham como base o mesmo antigo roteiro fluvial, cuja travessia seguia em grande parte o trajeto do rio Tietê.

\footnotetext{
154 “Galeria do Museu Paulista”. Jornal do Commercio, 6 jun. 1943, p. 2.

155 Sobre essas expedições, ver Belluzzo (2006).
} 
Essas imagens de expedições fluviais pelo Tietê, assim como o retrato modelar de Domingos Jorge Velho e o loco-tenente Antônio Fernandes de Abreu, serão disseminadas museu afora, seja em livros didáticos, cartões postais distribuídos às escolas públicas pela Secretaria do Interior (reestruturada em 1930, quando passa a se chamar Secretaria de Estado da Educação e da Saúde Pública), cartões telefônicos emitidos nos anos 1990 ou mesmo em latas de refrigerante, objetos que também foram exibidos na exposição "Imagens recriam a história", mencionada no início do capítulo. Desse modo, como veremos a seguir, tal qual o "rio das monções", que simbólica e literalmente é trazido para dentro do Museu Paulista, o espetáculo paulista do Centenário da Independência, e as imagens (plurais) bandeirantes, seguirão colina afora, das margens do Ipiranga para a cidade de São Paulo.
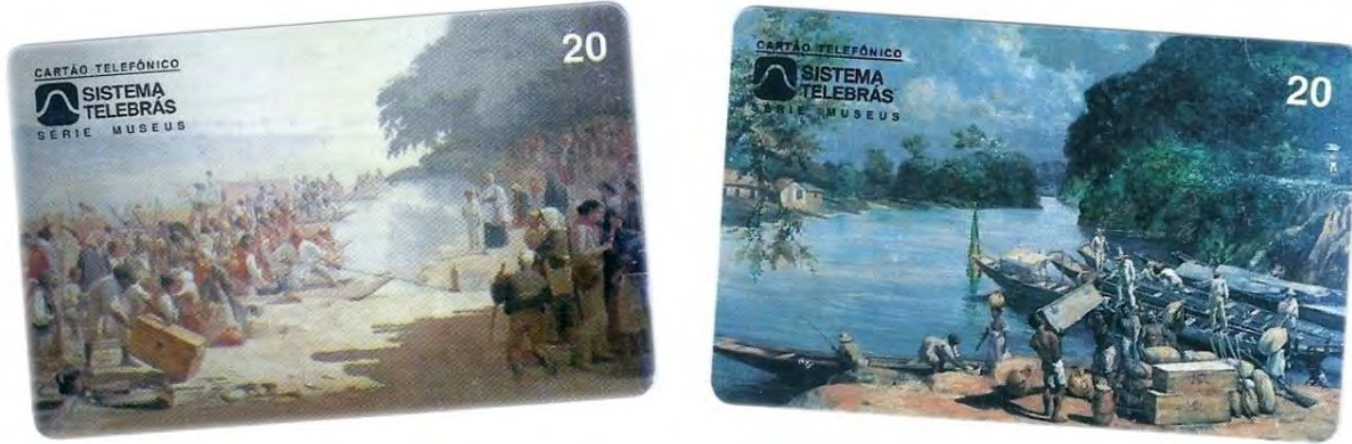

Figura 1.40 - A partida das monções e Carga das canoas nos cartões telefônicos do Sistema Telebrás (Série Museus- 1996).

Fonte: Acervo pessoal | Foto: Thaís Waldman. 


\section{DESTERROS}

Durante os preparativos para as celebrações do Centenário da Independência do Brasil, a cidade de São Paulo se agitou em torno de concursos e de projetos de esculturas e conjuntos monumentais que seriam oferecidos à cidade. "Dois monumentos: os paulistas e os portugueses renderão uma homenagem a S. Paulo" é a manchete, por exemplo, do periódico A Gazeta, em 1920 $0^{156}$. No mesmo ano, O Estado de S. Paulo anuncia um monumento ofertado pela colônia síria e outro pelo Centro Acadêmico XI de Agosto, enquanto o conjunto monumental encomendado pela comunidade italiana dá título a uma matéria publicada em Il Pasquino Coloniale ${ }^{157}$. Também em 1920, a revista $A$ Cigarra apresenta uma maquete do futuro Monumento à Independência, ao passo que o jornal Correio Paulistano lamenta a demora para a concretização de um monumento em homenagem à fundação de São Paulo ${ }^{158}$. Além do governo, patrocinador dos concursos oficiais, diversos segmentos da população procuravam marcar presença nos espaços públicos paulistanos.

Surpreso com essa multiplicação súbita de "templos cívicos" a céu aberto, um editorialista de O Estado de S. Paulo constata que uma "febre estatuária" havia grassado a cidade com uma curiosa intensidade (apud SEVCENKO, 1992, p. 99). Atingido por essa "epidemia”, o bandeirante Fernão Dias é homenageado em três locais significativos da capital, marcando a paisagem urbana ainda horizontal de São Paulo. Esculpido em mármore por Luigi Brizzolara (1868-1937), Fernão Dias se converte, na colina do Ipiranga, em uma imponente estátua exposta na entrada do Museu Paulista, em 1922, mesmo ano em que não somente se torna figura em baixo-relevo, realizada por Adelbert Gresnigt (1877-1956) na parede granítica externa do mosteiro de São Bento, como se destaca na avenida Paulista como personagem principal da escultura $O$ caçador de esmeraldas, uma das partes que compõem o Monumento a Olavo Bilac, de William Zadig (1884-1952).

\footnotetext{
156 “Dois monumentos: os paulistas e os portugueses renderão uma homenagem a S. Paulo". A Gazeta, 28 jun. 1920 , p. 1.

157 “O Centenário da Independência”. O Estado de S. Paulo, 5 dez. 1920, p. 5 / "O Monumento a Bilac". O Estado de S.

Paulo, 10 nov. 1920, p. 3/ "Il Monumento a Carlos Gomes". Il Pasquino Coloniale, 15 maio 1920, p. 15.

158 “O Monumento da Independência”. A Cigarra, 4 abr. 1920, p. 36 / "Notas". Correio Paulistano, 1 maio 1920, p. 1.
} 


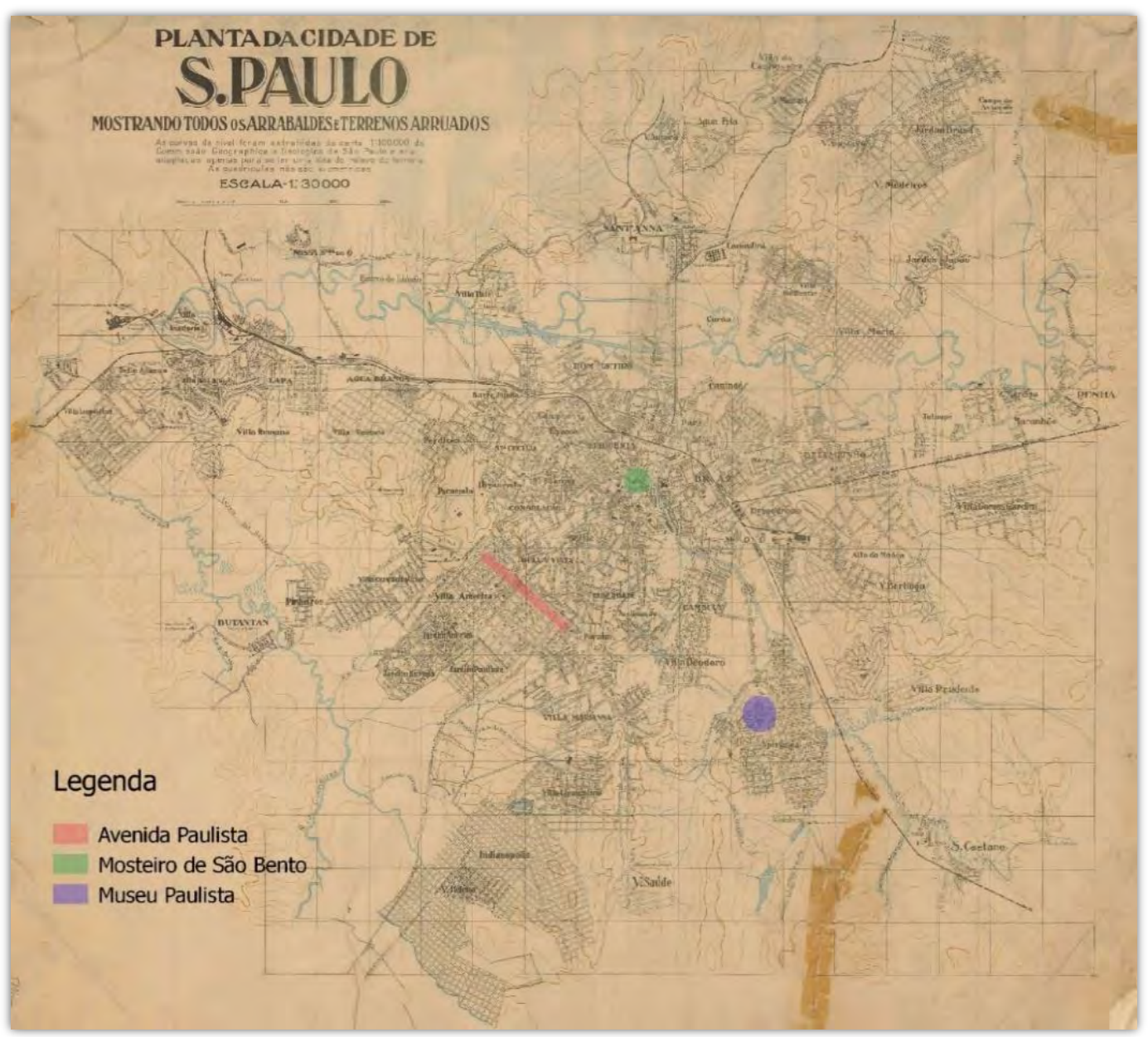

Figura 2.1 - Fernão Dias ganha corpo em mármore, granito e bronze em três distintos locais da cidade, anos 1920.

Fonte: Secretaria Municipal de Urbanismo e Licenciamento ${ }^{159}$.

Os desterros que este capítulo acompanha referem-se aos passos das esculturas (em mármore, granito e bronze) realizadas em homenagem a Fernão Dias ${ }^{160}$. São elas que irão nos conduzir; com elas caminharemos, instaurando um presente relativo a determinados lugares e a momentos específicos nos quais sua imagem é explorada, contorcida e recriada por meio de seus deslocamentos por uma capital também chamada de bandeirante. Moldado em bronze em $O$ caçador de esmeraldas ao lado de Borba Gato, Fernão Dias está sempre ladeado por seu genro, que se converte também no último grande monumento em homenagem a um bandeirante instalado em um logradouro público da cidade: realizado por Júlio Guerra (1912-2001), Borba Gato é inaugurado na década de 1960, em Santo Amaro, em uma paisagem urbana na qual a verticalidade já é rotina. São precisamente algumas dessas perambulações, cujos caminhos frequentemente se cruzam, que

\footnotetext{
${ }^{159}$ Disponível em: <http://smul.prefeitura.sp.gov.br/historico_demografico/img/mapas/1924.jpg>. Acesso em: 29 jul. 2016.

160 Tomo aqui o termo "desterro" como sinônimo de "saída do domicílio habitual para outro", conforme a última edição do dicionário Honaiss.
} 
seguiremos, trazendo à tona distintas disputas por espaços que essas próprias andanças ajudam a construir.

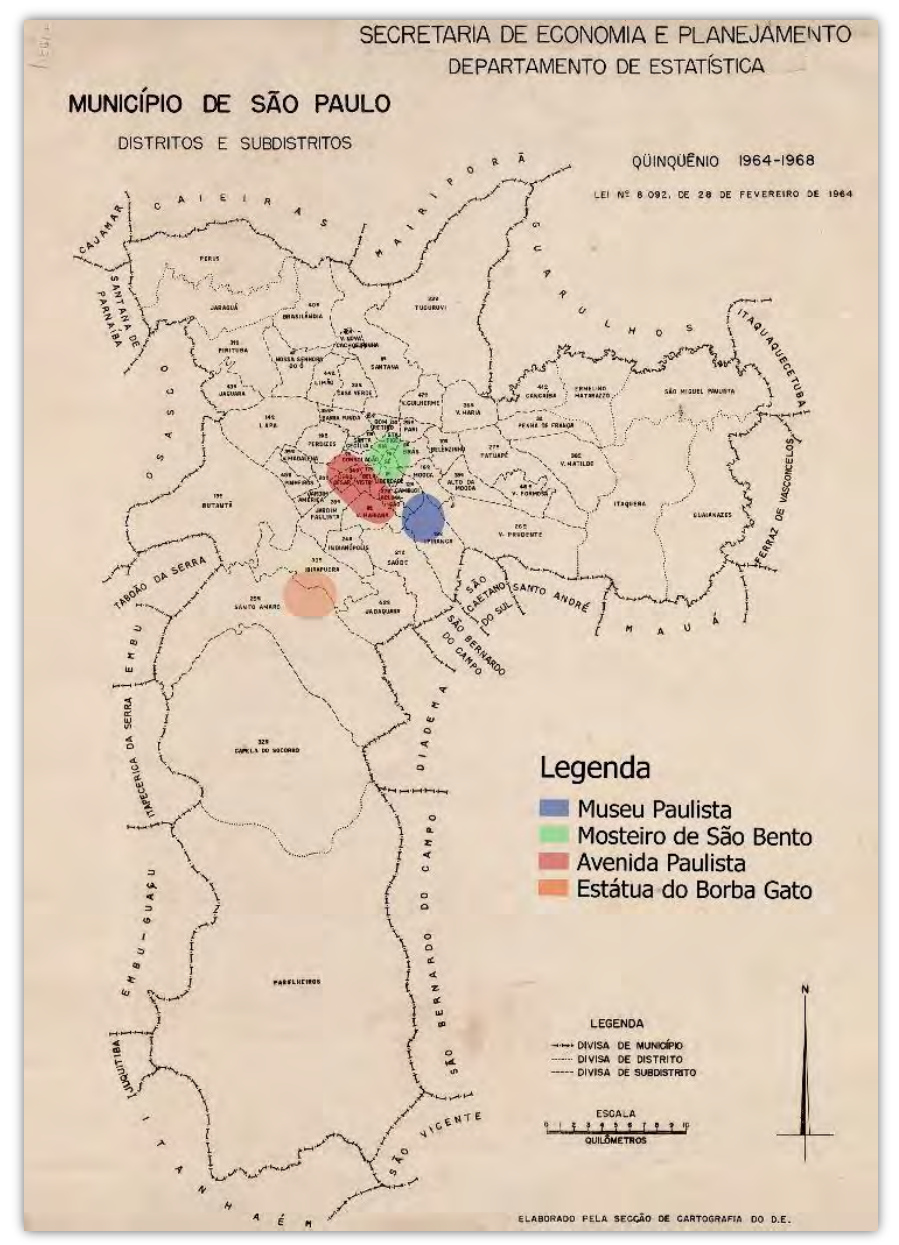

Figura 2.2 - Borba Gato se converte em monumento em Santo Amaro, anos 1960.

Fonte: Secretaria Municipal de Urbanismo e Licenciamento ${ }^{161}$.

Em 1948, o Correio Paulistano anunciava no título de uma de suas matérias "a dança das estátuas", referindo-se às esculturas que, desde pelo menos 1922, "perambulam de déu em déu", indo muitas vezes "dormir seu último sono" em um depósito da prefeitura, o "cemitério das estátuas e dos monstros" ${ }^{\prime 162}$. Pode parecer curioso, mas não são raros os episódios de esculturas que se deslocam por São Paulo, seja de modo simbólico ou literal, trilhando percursos bastante erráticos ${ }^{163}$. Constantemente ressignificadas, algumas são ainda desmembradas, sequestradas, banidas e até degoladas. Não por acaso, em um artigo publicado na Revista do Arquivo Municipal, São

\footnotetext{
161 Disponível em: <http://smul.prefeitura.sp.gov.br/historico_demografico/img/mapas/1964.jpg>. Acesso em: 29 jul. 2016. 162 “A dança das estátuas”. Correio Paulistano, 14 nov. 1948, p. 24.

163 Sobre os monumentos "nômades” da cidade de São Paulo, ver Beiguelman (2016).
} 
Paulo ganhou o epíteto de "a cidade em que as estátuas andam" (PASsOs, 1986, p. 55). Nas páginas a seguir, apresento então um itinerário acidentado, a revelar uma espécie de geografia bandeirante, que demandará do leitor uma série de idas e vindas tanto no espaço quanto no tempo.

\subsection{Exumação no mosteiro de São Bento}

"Desde os primeiros anos de S. Paulo, couberam, portanto, as terras do Ipiranga que eram caminho do mar, a três dos mais ilustres povoadores, antepassados de muitos dos mais famosos bandeirantes e personagens de prol em sua república"164 (Afonso Taunay, 1937, p. 6)

Vimos no capítulo anterior que, durante os preparativos para as comemorações paulistas de 1922, Afonso Taunay irá tomar como modelo para muitas de suas encomendas a tela Domingos Jorge Velho e o loco-tenente Antônio Fernandes de Abreu, pintada por Benedito Calixto. Em 1903, antes de ser incorporada ao acervo do Museu Paulista e de se tornar uma imagem modelar, essa obra teve sua primeira aparição pública durante uma exposição na rua São Bento, na Casa Aguiar, estabelecimento comercial localizado no chamado Triângulo Histórico de São Paulo ${ }^{165}$, cidade na qual havia inclusive um logradouro nomeado como rua Jorge Velho ${ }^{166}$. Vale ressaltar que, nessa

\footnotetext{
164 Afonso Taunay destaca que os "três mais ilustres povoadores" da região seriam Antônio de Proença, Domingos Luiz e Jusepe de Camargo, "patriarcas cuja descendência atinge hoje proporções abraâmicas” (1937, p. 5).

165 As ruas São Bento, a rua Direita e a rua XV de Novembro compõem os vértices do triângulo.

166 A rua Jorge Velho, localizada no bairro do Bom Retiro, teve seu nome oficializado pelo ato no 494 , de 26 de agosto de 1912. Antes da oficialização, seu nome era o mesmo. Não se sabe exatamente quando a rua foi nomeada, mas a base de dados do núcleo de denominação de logradouros públicos do Arquivo Histórico de São Paulo começa em 1900, com a oficialização da rua Paulo Eiró, registrada em 12 de janeiro de 1900. Pode-se dizer, portanto, que o logradouro já possuía o nome Jorge Velho quando Benedito Calixto termina a pintura de sua tela. Cf. Núcleo de denominação de logradouros públicos, AHMWL.
} 
época, a região central passava por um processo de remodelação física de seus espaços e equipamentos urbanos, que incluiria a retificação do largo de São Bento (CAMPOS, 2002) ${ }^{167}$.
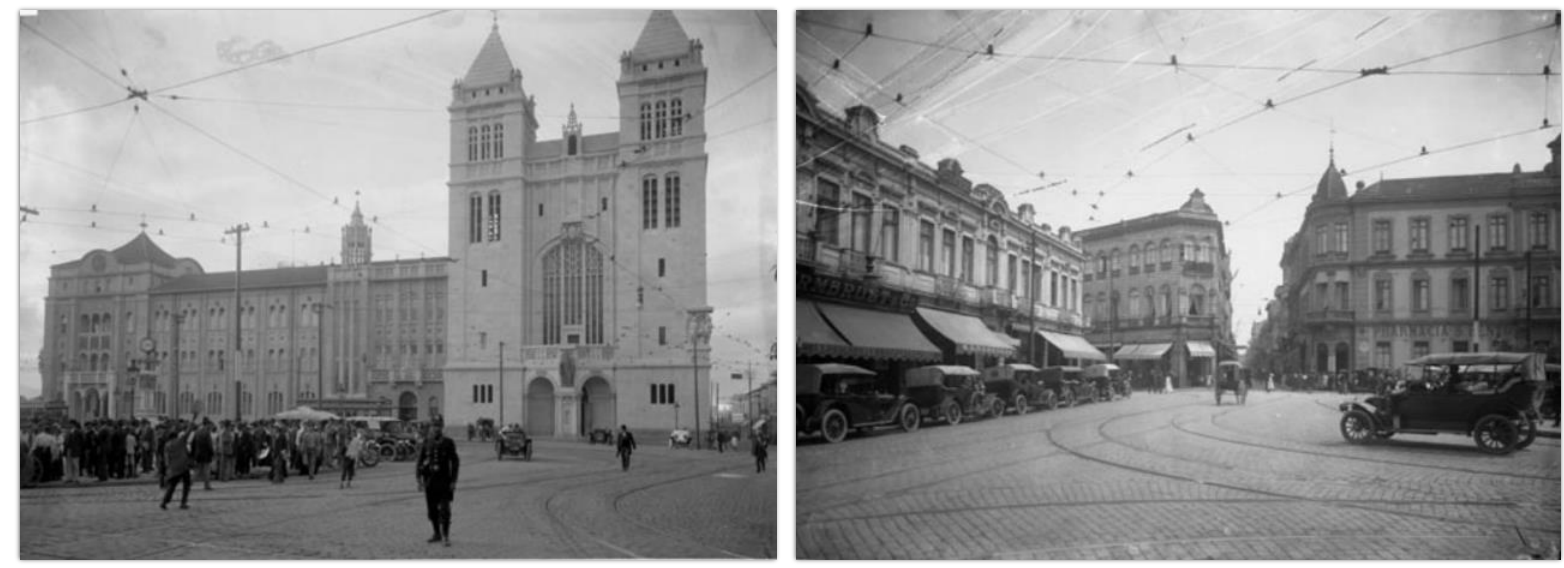

Figura 2.3 - Largo de São Bento, esquina com a rua Florêncio de Abreu, 1920.

Fonte: Acervo Fotográfico do Museu da Cidade de São Paulo | Foto: Aurélio Becherini.

Curiosamente, um dos mais antigos retratos de um bandeirante realizado em São Paulo no período republicano torna-se público em uma rua que desemboca no mesmo local onde, após a remodelação do centro da cidade, foram encontrados os ossos de Fernão Dias, o mais prestigioso e popular dos bandeirantes, segundo Taunay. Lembremos que, no início do século XX, Antônio da Silva Prado, prefeito de São Paulo durante quatro mandatos consecutivos (1899-1911), esboçara um projeto de urbanização da cidade inspirado na reurbanização de Paris, ocorrida na segunda metade do século XIX, seguindo o exemplo carioca de Francisco Pereira Passos ${ }^{168}$. Tomando como modelo as reformas urbanas projetadas por Georges-Eugène Haussmann, o primeiro prefeito da capital paulista projetou um plano de avenidas que exigia grandes desapropriações em nome da higienização e da eliminação de aspectos precários da cidade antiga ${ }^{169}$.

${ }^{167}$ Há uma extensa bibliografia, com diferentes focos, sobre as transformações da capital paulista no final do século XIX e início do XX, em seus diversos âmbitos. Cf. Morse (1970); Prado Jr. (1989); Rolnik (1981); Dean (1991); Reis Filho (1994); Homem (1996); Segawa (2000); Campos (2002), Frehse (2005; 2011); entre muitos outros. Convém também mencionar os memorialistas, como Americano (1957) e Bruno (1984).

168 Antônio Prado não foi o único a voltar sua atenção para obras realizadas no Rio de Janeiro, governado por Francisco Pereira Passos, entre 1902 e 1906. Capital do Brasil àquela altura, o Rio incorpora plenamente o papel da metrópole, centro cultural, foco do desenvolvimento e eixo de irradiação dos novos hábitos e costumes, sendo possível identificar claramente, no início do século Xx, um processo de "civilização" da sede do governo e, consequentemente, do país. Cf. Sevcenko (1989) e Needell (1993).

${ }^{169}$ Mesmo após encerrar o mandato na prefeitura, Antônio Prado não abandona seu projeto de modernização da cidade e encaminha ao governo do estado um plano que daria à capital o aspecto de uma cidade "moderna", "próspera" e "civilizada" (BRUNO, 1984, p. 912). Ainda que não pudesse realizar intervenções do mesmo porte que 
Pode-se dizer então que, ao ser exumado no largo de São Bento — local onde é construído um colégio, em 1903, uma nova abadia, em 1911, e um novo mosteiro, em 1914 —, Fernão Dias irá personificar o higienismo, a inovação e o progresso. E são ossos desse personagem que Afonso Taunay descreve ao narrar, na década de 1920, a descoberta de um antigo túmulo de um "indivíduo indubitavelmente branco", "de cabelos muito finos" e com "um fêmur de homem agigantado", encontrado em 1910 durante as obras de reconstrução da abadia e do mosteiro. Na biografia que redige sobre Fernão Dias, na época em que atuava também como diretor do Museu Paulista, ele conta que, em meio a numerosas covas de um antigo cemitério que surgiram depois do desentulho do local da velha igreja que daria lugar à basílica atual, havia um jazigo:

\begin{abstract}
Aberto o tosco jazigo foram encontrados um fêmur de homem agigantado, duas ou três vértebras do sacro, pedaços de parietais e occipitais, a que aderiam restos de cabeleira ruiva, encanecida, de cabelos muito finos, de indivíduo indubitavelmente branco. Ao lado havia duas solas de sapatos, sem salto, bem conservados, pedaços de cordão como os de São Francisco e galão de prata e, o que é mais curioso, uma grande funda de ferro, guarnecida de couro, para hérnia, apoiada numa cinta também de ferro e cujo uso deveria ser sobremaneira incômodo para indivíduos menos rudes do que o estoico bandeirante (TAUNAY, 1926b, p. 70, grifos meus).
\end{abstract}

O esqueleto encontrado na sepultura, embora fosse "rude", possuía as insígnias abaciais e estava enterrado sob a capela principal, informa Afonso Taunay, ao identificar o cadáver do “estoico bandeirante" como sendo de Fernão Dias ${ }^{170}$. Na cova ao lado havia ossos de mulher e de criança. Amparado por documentos do período colonial, Taunay explica que Fernão Dias, descrito como um homem de posses, havia sido o responsável, no século XVII, pela reconstrução do santuário, inteiramente às suas custas, utilizando mão de obra indígena, com a condição de que fosse seu protetor e tivesse na capela maior uma sepultura para ele e sua família. Impressionado com a penúria extrema em que viviam os religiosos no paupérrimo e minúsculo local, Fernão Dias teria se oferecido como benfeitor da construção de taipa dos beneditinos, ganhando em troca um jazigo.

Ainda hoje o mosteiro de São Bento reproduz essa narrativa. De acordo com o site da instituição, o local foi fundado no século XVI, em um antigo terreno pertencente ao cacique Tibiriçá,

\footnotetext{
aquelas realizadas por Pereira Passos, devido, entre outras coisas, ao baixo orçamento do governo paulistano, Prado inicia uma grande transformação no espaço da cidade, particularmente na sua área central (CAMPOS, 2002).

170 O “estoico" Fernão Dias, ressalta Afonso Taunay (1926b, p. 68), teria se mostrado resignado diante do sofrimento e do infortúnio mesmo depois de morto. Após ser embalsamado “à moda bandeirante” (enterrado a dois palmos de terra junto a uma grande fogueira, que se manteve acesa até o momento em que foi possível recolher os ossos), seus restos mortais naufragaram junto a uma canoa no caminho de volta a São Paulo e somente depois de muitos dias seus despojos foram retirados do fundo do rio Guaicuy para serem sepultados no local por ele tão desejado.
} 
o segundo melhor local da capital paulista, depois daquele onde foi edificado o colégio dos jesuítas, no alto da elevação, entre as águas dos rios Anhangabaú e Tamanduateí. Outras reconstruções vieram, ainda, antes dessa que Afonso Taunay acompanhou de perto. A mais famosa data do século XVII, informa o histórico oficial do atual mosteiro, justamente quando Fernão Dias reconstruiu o local ${ }^{171}$. Como contrapartida, o bandeirante e sua esposa, Maria Garcia Betim, têm seus restos mortais lá enterrados há mais de três séculos, tal como teriam desejado em vida. Segundo um documento setecentista citado por Taunay (1926b), Fernão Dias teria exigido que na capela maior do mosteiro fosse construída uma sepultura para ele mesmo e mais duas para seus familiares.

Exumados em 1910, os ossos de Fernão Dias e de Maria Garcia Betim tiveram que aguardar a finalização dos trabalhos de reconstrução do mosteiro de São Bento. As obras prosseguiram e a basílica só foi consagrada na década seguinte, coincidindo com o ano das festas centenárias e da reabertura do Museu Paulista. Nessa ocasião, o casal ganhou uma lápide sepulcral em bronze, instalada no transepto da igreja, logo em frente ao altar. Os dizeres nela gravados celebram o translado para o novo jazigo, em agosto de 1922, dos restos mortais do bandeirante conhecido como o "Governador das Esmeraldas" e de sua mulher.
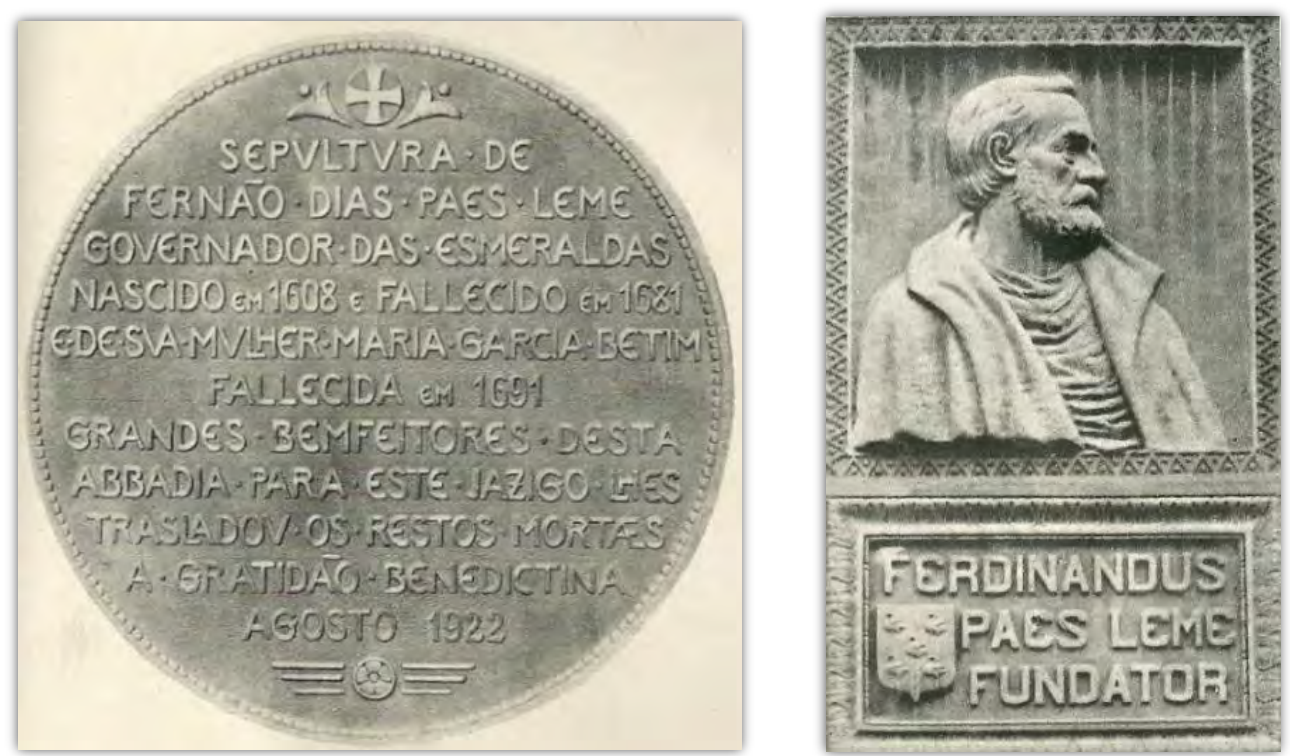

Figura 2.4 - À esquerda, lápide sepulcral de Fernão Dias e Maria Garcia Betim, transepto da igreja do mosteiro de São Bento. À direita, escultura em baixo-relevo de Fernão Dias, fachada exterior do mosteiro de São Bento. Anos 1920.

Fonte: Índios! Ouro! Pedras! (1926), de Afonso Taunay, s/p.

171 Disponível em: < http://mosteiro.org.br/o-mosteiro/>. Acesso em: 29 nov. 2017. Hoje o mosteiro também abriga uma faculdade e uma padaria, além da basílica e do colégio. 
No mosteiro reconstruído, Fernão Dias tem também seu perfil esculpido em baixo-relevo na fachada granítica exterior do edifício, pelo beneditino Adelbert Gresnigt ${ }^{172}$. Na ausência de um retrato do bandeirante, sua efígie, segundo Afonso Taunay, teve como modelo os "traços nobres e austeros de seu quinto neto, em linha varonil, Sr. Dr. Pedro Dias Gordilho Paes Leme, um dos vultos aristocráticos de realce pelas maneiras e cultura, de que se pode orgulhar o nosso segundo império" (1927, p. 74). Na base da imagem, é possível ler a frase Ferdinandus Paes Leme Fundator, inscrição que traduz para o latim a antiga homenagem dos beneditinos ao bandeirante (lembrando também que a Ordem de São Bento tem sua origem na Itália). Ao lado de Fernão Dias, são esculpidos em baixo-relevo frei Mauro Teixeira (fundador do mosteiro no século XVI), padre José de Anchieta (fundador do Colégio de São Paulo) e Amador Bueno (aclamado rei dos paulistas em $1641)^{173}$.

Ao ser esculpido na parede externa do mosteiro de São Bento, Fernão Dias passa a observar de soslaio a rua Florêncio de Abreu, uma das principais vias utilizadas no período colonial pelos paulistas que se dirigiam ao interior ${ }^{174}$. Exposta ao sol e à chuva, pichada e cercada por motocicletas, a imagem de Fernão Dias, quase cem anos depois de sua inauguração, pode ainda ser vista no antigo caminho do século XVI. O sepultamento dos ossos que supostamente pertenceram ao bandeirante, assim como a escultura em baixo-relevo em sua homenagem, só foi possível graças à iniciativa de construir uma nova abadia e um novo mosteiro, tomada por dom Miguel Kruse, abade alemão que, no início do século passado, já havia inaugurado o chamado ginásio de São Bento, fundado em 1903. Ninguém menos que Afonso Taunay, segundo o próprio texto divulgado na página oficial do atual colégio, se destacou como um dos mais "ilustres docentes" do local, que teve entre seus alunos Sérgio Buarque de Holanda, que irá suceder a Taunay na direção do Museu Paulista ${ }^{175}$.

\footnotetext{
172 O projeto da quarta edificação do Mosteiro de São Paulo é de autoria do arquiteto Richard Berndl, de Munique. Já a decoração interna, o plano e parte da execução ficaram a cargo de Adelbert Gresnigt. Cf. Silva-Nigra (1958).

173 Segundo Afonso Taunay, faltaria ainda Tibiriçá, "o velho cacique, cuja taba se erguia no local da atual abadia" (1926b, p. 71). Já Maria Garcia Betim, é homenageada apenas nos dizeres da lápide no mosteiro. Ao comentar a decoração do Museu Paulista para as festas centenárias, Taunay já havia mencionado sua intenção de "variar o tom geral da ornamentação" do Salão de Honra, rendendo homenagem, ao nível do quadro de Pedro Américo, "ao vulto de mulheres patrióticas", embora os "atributos de firmeza e coragem", segundo ele, geralmente não fossem "o apanágio do seu sexo" (TAUNAY, 1923, p.13). Sobre o pequeno conjunto de duas telas, encomendadas por Taunay visando as comemorações do centenário de 1922 no Museu Paulista, nas quais figuras femininas são alocadas na condição de protagonistas da história nacional, cf. Simioni \& Lima Junior (2018).

174 Agradeço ao professor Paulo Garcez Marins pelas indicações.

175 Disponível em: <http://colegiodesaobento.com.br/>. Acesso em: 29 jul. 2016. Em 1911, como docente do mosteiro de São Bento, Afonso Taunay apresentou na conferência de abertura do curso de História Universal alguns
} 


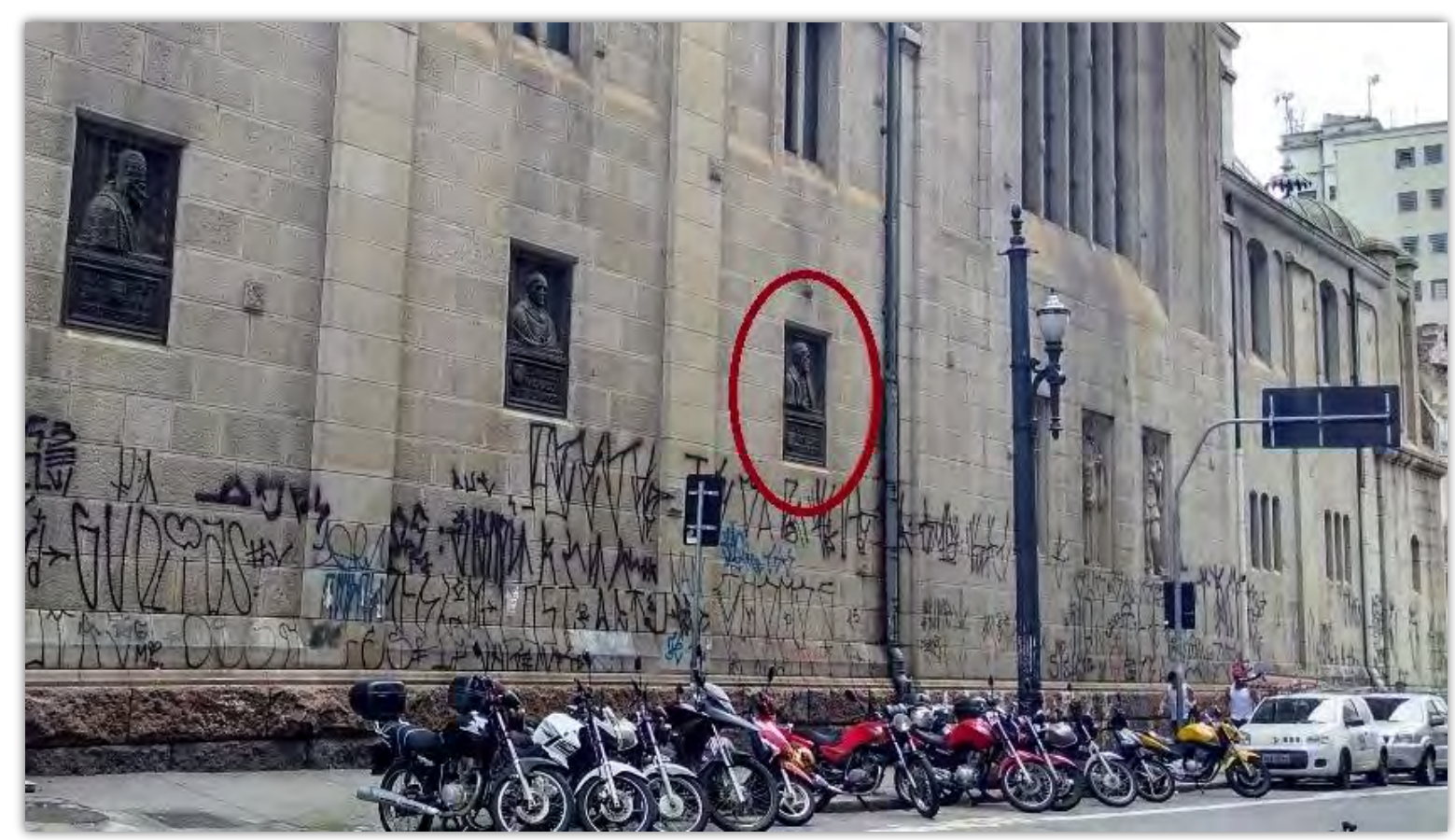

Figura 2.5 - Parede externa do mosteiro de São Bento, rua Florêncio de Abreu, 2017.

Fonte: Acervo pessoal | Foto: Thaís Waldman.

Assim como Fernão Dias, Taunay possuía uma estreita ligação com o mosteiro de São Bento $^{176}$. Interessante notar que enquanto Adelbert Gresnigt esculpe na rua Florêncio de Abreu um bandeirante idoso, desarmado e com ar cansado, vestindo apenas um casaco aberto e uma camisa desalinhada, os inabaláveis restos mortais encontrados no túmulo no mosteiro, parecem ser esculpidos em mármore por Luigi Brizzolara. No alto da famosa colina, no Museu Paulista, trajando uma vestimenta que muito se assemelha à do majestoso Domingos Jorge Velho retratado anos antes por Benedito Calixto, o Fernão Dias Paes Leme de Brizzolara, "agigantado" e "indubitavelmente branco", examina um mineral, talvez uma de suas cobiçadas esmeraldas, com a mesma postura vigorosa com que Antônio Raposo Tavares, disposto à sua frente, explora o horizonte, como vimos no capítulo anterior.

princípios que fundamentaram a sua narrativa da fundação de São Paulo e de outras obras que produziu nas décadas posteriores, cf. Anhezini (2011).

176 A formação de Afonso Taunay foi marcada pelo contato cotidiano com os beneditinos desde 1897, quando se hospedou por três anos no mosteiro de São Bento do Rio de Janeiro, enquanto cursava a Escola Politécnica. Poucos anos depois, em 1899, Taunay mudou-se para São Paulo e passou a acompanhar o dia a dia do mosteiro paulistano. Nos anos 1920, já então diretor do Museu paulista, Taunay irá publicar o livro História antiga da abadia de São Paulo (1598-1772). 

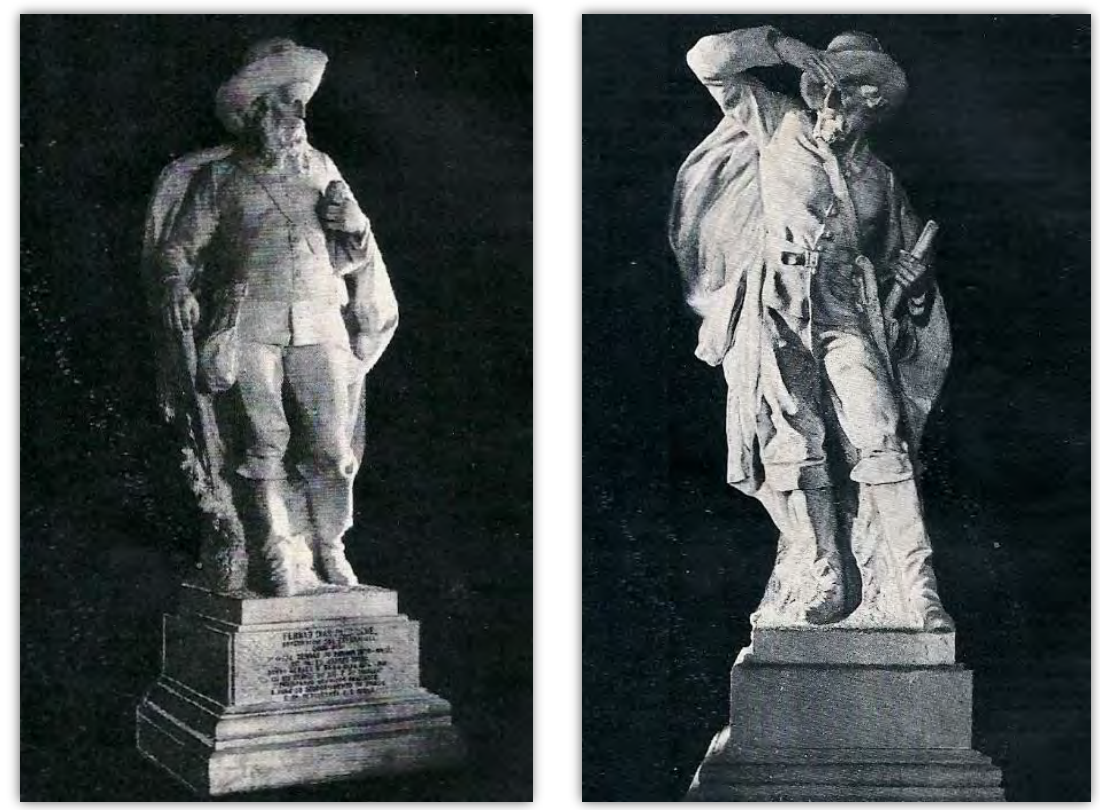

Figura 2.6 - Fernão Dias e Raposo Tavares, de Luigi Brizzolara, década de 1920. Fonte: Índios! Ouro! Pedras! (1926), de Afonso Taunay, s/p.

\subsubsection{A bomenagem na colina do Ipiranga}

Encomendada a Luigi Brizzolara no século passado por Afonso Taunay, a escultura em homenagem a Fernão Dias ainda se encontra no Museu Paulista. Embalada da cabeça aos pés por um invólucro branco e translúcido, e encurralada por pilhas de caixas, a obra foi descrita em 2016 pela Folha de S.Paulo como uma "obra-fantasma"177. Cuidadosamente empacotado para não sofrer danos, Fernão Dias Paes Leme permanece eloquente, mesmo com sua silhueta encoberta, enquanto

\footnotetext{
177 "Memórias do subsolo". Folha de S.Paulo, 27 jan. 2016, p. C1. O fantasma de que fala a matéria talvez seja muito mais um aspecto da presença bandeirante na cidade. Não à toa, recentemente, o dramaturgo Francisco Carlos dirigiu a peça Sonata fantasma bandeirante, que ficou em cartaz no Sesc Ipiranga em 2016, dialogando diretamente com a historiografia da década de 1920. Desde seu título, a peça traz o bandeirante como um fantasma que assombra até hoje a cidade. Interessante notar que a atriz Alessandra Negrini, que faz na peça o papel da esposa do bandeirante, já havia feito nos anos 2000 o papel de Isabel, sobrinha do bandeirante Dom Brás, única mulher a enfrentar a mata e as batalhas no meio dos homens na minissérie $A$ muralha, baseada no livro homônimo de Dinah Silveira de Queiroz, publicado em 1954 em homenagem aos quatrocentos anos de São Paulo. O romance foi um grande sucesso de público, lançado também na forma de folhetins na revista semanal O Cruzeiro. Traduzido para diversos idiomas, visando as colônias imigrantes no Brasil, A muralha foi lançado como quadrinhos em 1957, além de ser adaptado para a televisão em 1961, na rede Tupi, em 1968, na Excelsior, e em 2000, na Globo. Sobre a minissérie, cf. Almeida (2012),
} 
aguarda o início da reforma do museu, para restauro e ampliação da área da instituição de modo a garantir a acessibilidade. A previsão é de que o altivo bandeirante que tomou forma em mármore em 1922 volte a ser exposto ao público apenas em 2022, não por acaso com vistas às comemorações do Bicentenário da Independência do Brasil.

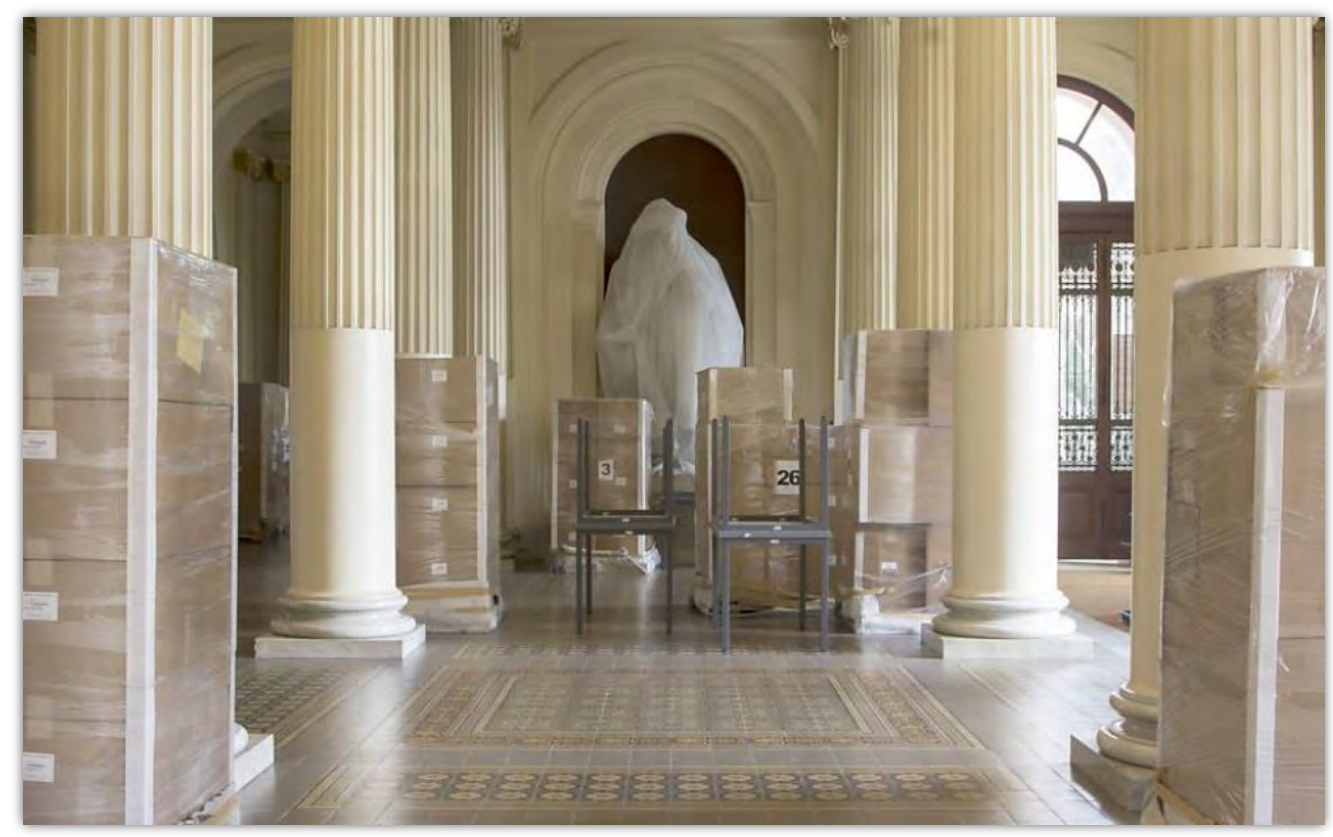

Figura 2.7 - Fernão Dias coberto por um invólucro branco e translúcido durante a reforma do Museu Paulista, 2016.

Fonte: Folha de S.Paulo, 27 jan. 2016, p. C1 | Foto: Rogério Canella.

Em 2017, imagens da mesma escultura foram dispostas em tapumes que cercam a escadaria central da área externa do Museu Paulista, integrando uma série de exposições chamada "Estamos aqui!", cuja proposta é justamente dar visibilidade ao acervo da instituição durante o restauro do edifício-monumento, além de informar à população sobre o andamento das reformas. "Bandeirantes: um personagem em debate" foi a quarta exposição da série ${ }^{178}$. Fotografias de Fernão Dias foram expostas em painéis retangulares, ao lado de outros painéis com imagens que acompanhamos no capítulo anterior: Raposo Tavares e Manuel de Borba Gato, esculpidos respectivamente por Luigi Brizzolara e Nicola Rollo; as telas Domingos Jorge Velho e o loco-tenente Antônio Fernandes Abreu, Ciclo da caça ao indio e Combate de milicianos de Mogi das Cruzes com botocudos,

178 A série de exposições "Estamos aquil" teve início em 2016, no dia da Independência do Brasil. Disponível em: <http://mp.usp.br/chamadas/estamos-aqui>. Acesso em: 29 jun. 2017. 
respectivamente pintadas por Benedito Calixto, Henrique Bernardelli e Oscar Pereira da Silva; além de outras imagens que fazem parte do acervo do museu, ou que dialogam com elas ${ }^{179}$.
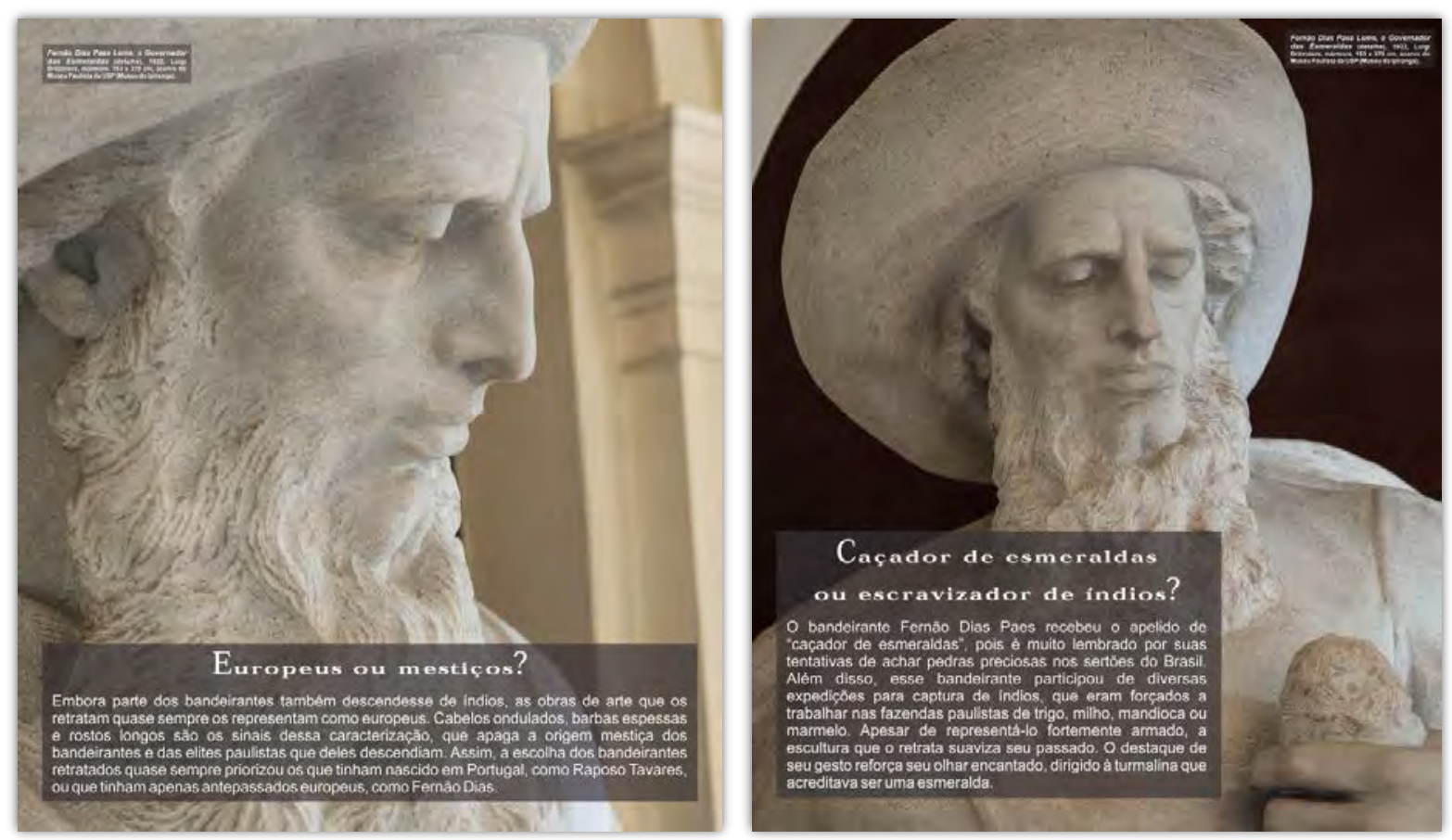

Figura 2.8 - Fotografias de Fernão Dias na exposição "Estamos Aqui!", 2017. Painéis retangulares, de $146 \mathrm{~cm} \times 172 \mathrm{~cm}$.

Fonte: Museu Paulista da USP.

Se as legendas da exposição ressaltam que a glorificação dos bandeirantes tem sido frequentemente questionada e condenada - "Europeus ou mestiços?", pergunta o texto que acompanha um dos painéis, enquanto o outro indaga "caçador de esmeraldas ou escravizador de índios?" - Fernão Dias foi encomendado nos anos 1920 para combater uma "densa treva" que, segundo Afonso Taunay, então diretor do Museu Paulista, encobria as ações e a personalidade dos bandeirantes (1926b, p. 3). Tal obscurecimento remontaria ao século XVIII, quando um incêndio ocorrido em Lisboa destruiu dois terços dos manuscritos da obra setecentista do sobrinho-bisneto de Fernão Dias, o genealogista Pedro Taques, autor da Nobiliarquia paulistana - escrita no século XVIII, a obra é uma longa genealogia que glorifica e traça uma linha de continuidade entre os

\footnotetext{
${ }^{179}$ No último dos painéis é apresentada a imagem de um bandeirante que não faz parte do acervo do Museu Paulista, o Borba Gato, de Júlio Guerra. Nele, temos o julgamento de Borba Gato, realizado em 2008, como veremos no final deste capítulo [ver figura $\mathrm{n}^{\circ}$ 2.47]. As imagens dos painéis e suas descrições podem ser encontradas no site do museu. Disponível em: < http://mp.usp.br/chamadas/estamos-aqui-bandeirante-um-personagem-em-debate $>$. Acesso em: 29 jun. 2017.
} 
bandeirantes dos séculos XVI e XVII e seus descendentes paulistas ${ }^{180}$. É somente no final do século XIX, como vimos no primeiro capítulo, que grande parte dos intelectuais paulistas irá começar a se deter ao estudo das expedições bandeirantes.

Mas retornemos ao largo de São Bento. Em 1900, anos antes de os ossos de Fernão Dias serem desenterrados na antiga capela do mosteiro beneditino, no centro da cidade, o primeiro bonde elétrico partia do mesmo largo, compartilhando o espaço da rua com um número cada vez maior de transeuntes na São Paulo pós-abolição ${ }^{181}$. À luz de um complexo conjunto de reformas urbanas, acompanhadas pela substituição da iluminação a gás e dos bondes com tração animal por sistemas elétricos, o bonde da Light em sua quarta linha chega até o local em que foi proclamada a Independência brasileira ${ }^{182}$. No entanto, apesar de as linhas terem sido estendidas até a entrada do Museu Paulista, o Ipiranga continuava sendo um local distante, cortado por charcos considerados insalubres e com pouquíssimas ruas pavimentadas e/ou iluminadas ${ }^{183}$.

Estar na colina do Ipiranga significava estar tão próximo de São Paulo e ao mesmo tempo se sentir em pleno campo. Por mais que no século XVI já houvesse diversas referências nas Atas e no Registro geral da Câmara de São Paulo à "Colina Sagrada", o documento iconográfico mais antigo encontrado por Afonso Taunay (1937, p.16) retratava o local como completamente deserto. No século XIX, a região era constantemente descrita em uma palavra: “solidão” (BARRO; BACELLI, 1979, p.55). Em 1882, momento de lançamento da pedra fundamental do edifício-monumento que sediaria o Museu Paulista, a área não passava de um descampado. Com poucas e pequenas casas rurais, limitava-se a um ponto de parada obrigatório para dar água aos animais, às margens do Caminho do Mar, antiga ligação entre São Paulo e o litoral, cuja estrada estava abandonada havia

\footnotetext{
${ }^{180}$ Mencionamos na nota 141 que o genealogista Pedro Taques, que se afirmava descendente dos primeiros povoadores da vila de São Vicente, conhecida como a primeira vila fundada pelos portugueses na América, frisava em sua obra o sangue nobre (como indica o título do livro) e puramente europeu dos antigos paulistas. Sobre a construção, no século XVIII, de uma identidade literária regional paulista baseada na ideia de "orgulho ancestral", ver Candido (2002). No século XX, em 1953, o próprio Afonso Taunay será o responsável pela segunda edição, revista e ampliada, do livro Nobiliarquia paulistana.

${ }^{181}$ Para uma análise das imagens da virada do século XX que tematizaram o fascínio pelo bonde nas ruas aparentemente mais modernas da área central da cidade, cf. Frehse (2005).

182 Responsável desde 1899 pela implantação das redes de energia elétrica, de iluminação e de bondes elétricos, a empresa canadense The São Paulo Tramway, Light \& Power Company, mais conhecida como Light, possuía estreitos vínculos com o IHGSP e desempenhou um papel decisivo na economia regional paulista. Cf. Beiguelman \& Faria (1986).

${ }^{183}$ Sobre o bairro do Ipiranga e o local do museu, cf. Barro \& Bacelli (1979) e Reis Filho (1990).
} 
vinte anos. No ponto mais baixo da região, o córrego do Ipiranga seguia se alastrando como um lameiro, atravessado somente por carros de boi com toras de madeira (REIS FILHO, 1990).

Com a aproximação das festas centenárias, o córrego é canalizado e coberto. O jardim em estilo francês implantado em frente ao Museu Paulista durante a gestão de Antônio Prado, por sua vez, é ampliado até a altura da recém-construída avenida Dom Pedro I, ligando o futuro parque da Independência ao centro da cidade ${ }^{184}$. Além disso, um grande corte no terreno à frente do museu irá isolá-lo no alto da colina, devido à canalização do riacho, aos pés da colina. Ampliava-se, desse modo, a monumentalidade do edifício que, na década de 1920, irá acolher a escultura Fernão Dias Paes Leme. Segundo o ex-aluno do colégio de São Bento e então chefe de obras da prefeitura, Francisco Prestes Maia, o ponto mais íngreme do ainda pouco povoado bairro do Ipiranga fora atingido por um corte de catorze metros de altura, ressaltando, assim, a grandeza do edifíciomonumento (REIS FILHO, 1990) ${ }^{185}$.
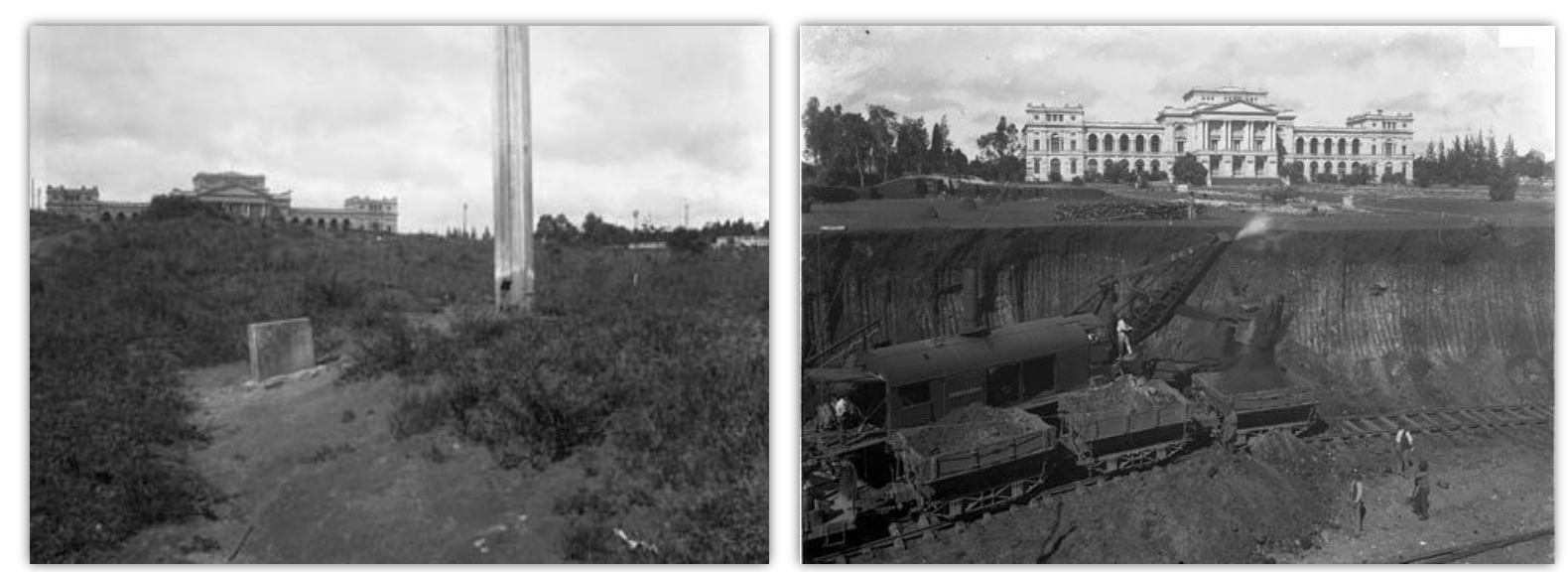

Figura 2.9-À esquerda, parque da Independência, 1900/1915. À direita, obras no parque da Independência, 1910/1920.

Fonte: Acervo Fotográfico do Museu da Cidade de São Paulo.

Deslumbrado com a repercussão da reabertura do Museu Paulista durante as comemorações do Centenário, Afonso Taunay chega a afirmar, no relatório anual de atividades da

\footnotetext{
${ }^{184}$ Considerado marco histórico nacional, o parque da Independência hoje abriga o Museu Paulista, o Monumento à Independência e a Casa do Grito, e é tombado pelo Conselho Municipal de Preservação do Patrimônio Histórico, Cultural e Ambiental da Cidade de São Paulo (Conpresp), pelo Conselho de Defesa do Patrimônio Histórico Arqueológico, Artístico e Turístico (Condephaat) e pelo Instituto de Patrimônio Histórico e Artístico Nacional (Iphan).

${ }^{185}$ Na década de 1920, há um progressivo crescimento das fábricas, do comércio e das habitações do bairro no Ipiranga. Ainda assim, as fotografias tomadas do Museu Paulista sobre o parque indicam que o crescimento do bairro ocorre nas décadas de 1930 e 1940, com a instalação das indústrias (REIS FILHO, 1990).
} 
instituição referente ao ano de 1922, que o número de visitantes foi tamanho que houve quem se sentisse flutuando. Entre setembro e dezembro daquele ano, segundo o mesmo relatório, cerca de 120 mil pessoas visitaram as salas de exposição da instituição — dez vezes mais que a população inteira do bairro do Ipiranga que, segundo o recenseamento de 1920, somava aproximadamente 12 mil moradores (BARRO; BACELLI, 1979). Já nas páginas da imprensa paulista que registrou as festividades, muito se falou sobre as ruas inundadas e sem pavimentação que levavam ao Ipiranga, cercando a colina com um imenso atoleiro ${ }^{186}$. Mesmo marcado por enchentes e lama, o evento parece ter sido um sucesso de público, reunindo pessoas das mais diversas regiões em torno dos bandeirantes encomendados por Taunay ${ }^{187}$.

Ao longo dos anos, o afluxo de visitantes e as repercussões midiáticas permitiram que Fernão Dias, do alto de seu pedestal de mármore na colina do Ipiranga, se aproximasse cada vez mais da cidade e de seus habitantes. Por ocasião do centenário do Museu Paulista, em 1995, é sua imagem que irá estampar um selo comemorativo ao lado (e não dentro) do edifício-monumento, o que lhe possibilitaria se movimentar facilmente devido às dimensões portáteis do selo, e também se descolar da arquitetura da instituição, libertando-se de seu nicho. Décadas antes, em 1954, a escultura do bandeirante já havia comemorado os quatro séculos da fundação da cidade de São Paulo, ou "quatrocentos anos sem rugas", conforme o título da matéria de capa da revista Manchete. Semanário de grande circulação da época, o periódico associa a imagem de Fernão Dias a umas das "mais modernas cidades do mundo", uma São Paulo quadrissecular cujas "ruínas" não denunciam sua idade, já que "todo o seu passado arquiteto nico foi varrido" pela "picareta do progresso" 188 .

186 Por ocasião da reabertura do Museu Paulista, segundo um articulista da Folha da Noite, logo na matéria de capa do jornal: "Nenhuma grata recordação do 7 de setembro de 1922 há de ter o paulista da atual geração". A "balbúrdia daquela multidão", que muito cedo se dirigiu ao Ipiranga, daria ao turista estrangeiro "apenas uma ideia da desordem e do caos", além "do desleixado espetáculo das vias públicas ainda não terminadas" e da "confusão inevitável de uma reunião ao qual compareceram milhares e milhares de pessoas", conclui o articulista. Cf. "As festas". Folha da Noite, 8 set. 1922 , p. 1.

${ }^{187}$ De acordo com o relato do jornal Folha da Noite, de 7 de setembro de 1922, "pela rua da Independência e adjacências, pelas fraldas da colina, por toda parte de onde se pudesse divisar a solenidade, o povo se insinuava, numeroso. Todos os arredores estavam inteiramente ocupados pela multidão". Cf. "O centenário". Folha da Noite, 7 set. 1922 , p. 2. Já o Correio Paulistano, um dia após o início das celebrações, relata que "dos palácios vistosos e das casas humildes de operários, saíam levas de gente entusiastas, que formigavam nas ruas, atulhavam os bondes, que mobilizavam todos os automóveis, todos os veículos disponíveis na praça, dirigindo-se rumo à Colina Sagrada". Cf. “O centenário”. Correio Paulistano, 8 set. 1922, p. 4.

188 A matéria afirma que "o orgulho dos paulistas jamais será o de possuir a Igreja de São Francisco, como os baianos, e sim o de construir seis casas por hora e sustentar o título de cidade que mais cresce no mundo". As únicas quatro construções antigas da capital, segundo o periódico, estariam na "zona periférica" da cidade — o convento da Luz (1627), a casa no Tatuapé do padre Mateus (1650), a chácara São Bento (1702) em Santana, e a casa grande de uma fazenda no Jabaquara (1762) — e "nada mais" havia: “Todo casario geralmente apontado pelo povo como 

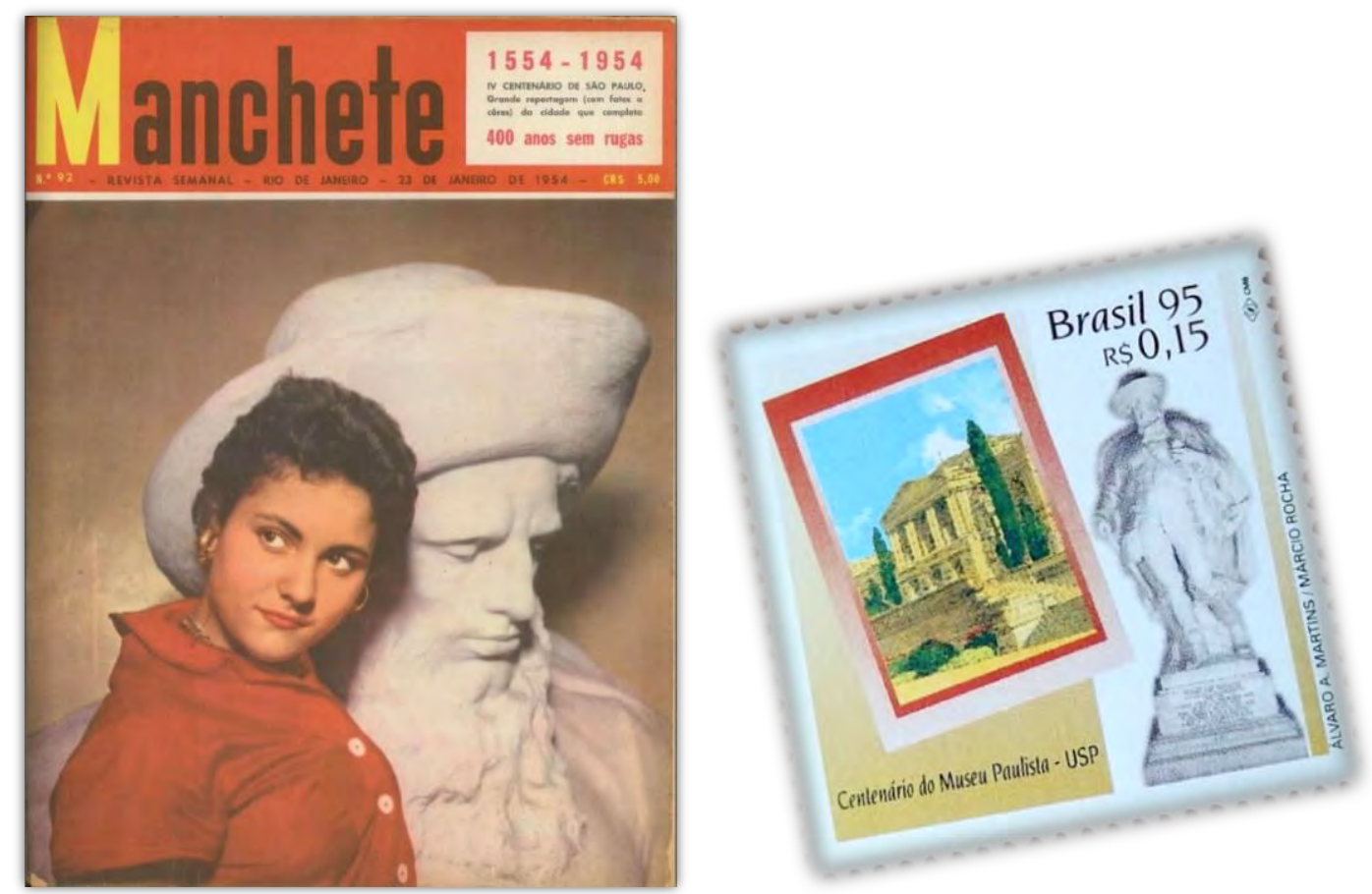

Figura 2.10 - Fernão Dias na capa de uma edição da revista Manchete em homenagem ao IV Centenário de São Paulo e em um selo comemorativo dos cem anos do Museu Paulista. Fonte: Acervo pessoal | Foto: Thaís Waldman.

Fernão Dias foi encomendado para se sobressair como uma das "figuras máximas" do movimento das entradas paulistas e da conquista do território nacional e, mais especificamente, como a escultura que encarna em mármore no Museu Paulista "O segundo grande ciclo bandeirante", voltado para a busca do ouro e das pedras preciosas, dirá Afonso Taunay (1926b, p. 22). Se os "elementos fixadores" da sua "grande memória" se encontravam dispersos, a reabertura do museu durante as comemorações de 1922 seria parte da quitação de "uma grande dívida" com aqueles que repeliram o meridiano de Tordesilhas para o longínquo Oeste, ainda nos termos de Taunay (1926b, p. 1). No texto que escreve para a placa comemorativa do pedestal da estátua, o então diretor do Museu Paulista também elenca os principais feitos do bandeirante, enfatizando aquelas que seriam suas maiores realizações:

Fernão Dias Paes Leme (1608-1681)

Governador das Esmeraldas

antiquíssimo não terá mais de oitenta anos”. Cf. “400 anos sem rugas”. Manchete, 23 jan. 1954, pp. 14-18. Lembremos ainda a famosa frase "cinquenta anos em cinco", lema do governo Juscelino Kubitschek (1956-1961), que tem início pouco tempo depois. 


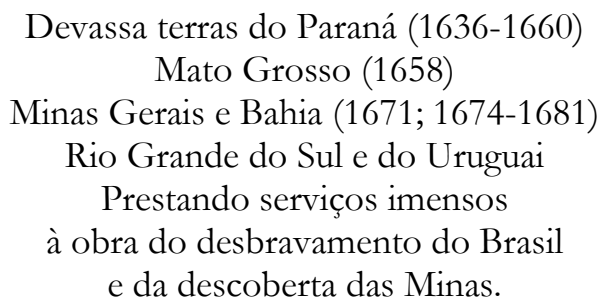

Ao conferir ao bandeirante o título de "Governador das Esmeraldas", designação atribuída a Fernão Dias poucos dias antes na lápide do mosteiro de São Bento, o texto do pedestal da estátua salienta a importância das bandeiras para o desbravamento do Brasil, destacando entre os principais feitos do personagem a descoberta das minas, daí a razão de o bandeirante esculpido por Luigi Brizzolara contemplar uma pedra que segura com a mão direita. O texto que acompanha a escultura aponta ainda que é em 1671 que Fernão Dias, quase septuagenário, parte para Minas Gerais em busca de pedras preciosas, de onde retorna apenas em 1681, dez anos depois, embora o bandeirante de Brizzolara pareça ser muito mais jovem (um personagem sem "rugas", dirá anos depois a revista Manchete).

Do mesmo modo que o Raposo Tavares disposto à sua frente (tido por Taunay como principal representante do "primeiro grande ciclo bandeirante"), Fernão Dias é esculpido como um “indivíduo indubitavelmente branco" ${ }^{189}$, ou seja, não aparenta ser descendente dos patriarcas euroamericanos dos bandeirantes de que fala Taunay ao expor um retrato de João Ramalho e outro de Tibiriçá no saguão de entrada do Museu Paulista, junto as duas esculturas de Brizzolara ${ }^{190}$. Na placa comemorativa também não há nenhuma menção à luta contra os jesuítas ou à escravização indígena, embora Taunay afirme em outros textos de sua autoria que Fernão Dias exigiu que os jesuítas saíssem da vila em 1640, além de ter reformulado e ampliado o antigo mosteiro beneditino

189 O próprio Taunay irá afirmar que Fernão Dias pertencia aos mais antigos clãs vicentinos, provenientes das primeiras levas de colonos de Martim Afonso, deixando de lado a questão da mestiçagem (1926b, p. 19). Não se sabe ao certo onde nasceu, explica o então diretor do Museu Paulista, mas sem dúvida teria sido em São Paulo ou em suas cercanias, sendo "aparentado com a melhor gente da Madeira", "descendente do descobridor da ilha", "um dos melhores elementos angariados por Martim Afonso de Souza para a nascente colônia vicentina" (1927, tomo III, pp. 333-334).

190 As duas telas juntas, uma espelhando a outra, representariam o ponto de origem de uma nova "raça", responsável pela formação do território paulista e brasileiro. Segundo Taunay, os retratos desses "vultos essenciais do quinhentismo" relembram: "os patriarcas europeu e americano dos mais velhos troncos vicentinos" (TAUNAY, 1937, p. 57). 
com a ajuda de indígenas escravizados ${ }^{191}$. Ademais, enquanto as telas Cacique Tibiriçá e Neto e João Ramalho e Filho foram pintadas no Brasil por José Wasth Rodrigues, Raposo Tavares e Fernão Dias viraram mármore na Itália, local em que também surge a Ordem de São Bento.

Embora residente em Gênova, Luigi Brizzolara executou várias encomendas para patronos de São Paulo no período, sendo considerado um dos “escultores-viajantes” que se deslocavam à procura de trabalhos na América (BATISTA, 2012) ${ }^{192}$. Ao que parece, Taunay entrou em contato com Brizzolara depois de um concurso realizado em 1919 para a construção de um monumento em homenagem à independência do Brasil, que ficou a cargo de outro italiano, Ettore Ximenes ${ }^{193}$. Construído nas margens do Ipiranga, o Monumento à Independência teve seu projeto aprovado por uma comissão da qual fazia parte o próprio Taunay, que na ocasião chegara a sugerir a inclusão de uma escultura em homenagem aos bandeirantes na maquete de Ximenes ${ }^{194}$. A leitura das correspondências de Taunay nos permite concluir que, cerca de um mês após a deliberação do resultado do concurso, que legou a Brizzolara o segundo lugar, o então diretor do museu o convida para trabalhar na ornamentação da instituição, convite aceito pelo escultor.

A forte ligação com a Itália fez com que Fernão Dias e Raposo Tavares passassem a ser igualmente considerados símbolos da "fratellanza italo-brasiliana", tal como sugere a capa do periódico Il Pasquino Coloniale, em uma edição comemorativa publicada por ocasião das festas centenárias $^{195}$. Feita pela comunidade imigrante ítalo-paulistana, e dirigida por ela mesma, essa edição especial do periódico não só reproduz as imagens das duas esculturas bandeirantes, como relembra que o museu que as abriga foi construído por um engenheiro italiano, Luigi Pucci, a partir de um projeto de outro engenheiro italiano, Tommasso Gaudenzio Bezzi ${ }^{196}$. No mesmo periódico,

\footnotetext{
${ }^{191}$ Em Índios! Ouro! Pedras!, por exemplo, Taunay relata que Fernão Dias ficou conhecido como o Anjo da Paz, depois de negociar, em nome do povo da vila, um acordo para que os jesuítas inacianos voltassem ao colégio de São Paulo, após terem sido expulsos de lá pelos próprios paulistas, entre eles Fernão Dias.

192 Sobre a história da escultura brasileira paralelamente a de “escultores-viajantes” europeus, cf. Araujo \& Laudanna (2010).

193 O grande fluxo de imigrantes na cidade ajudava a consolidar um contexto favorável à vinda de artistas estrangeiros em busca do crescente mercado para as artes que se desenvolvia na capital paulista, muitos deles interessados nos grandes concursos internacionais para criação de monumentos comemorativos, promovidos devido à proximidade do primeiro Centenário da Independência do Brasil, como é o caso de Luigi Brizzolara. Cf. Lopes (2012).

${ }^{194}$ Sobre o concurso para a construção de um monumento em homenagem à independência brasileira, cf. Monteiro (2017).

195 Il Pasquino Coloniale é um dos quase trezentos periódicos, identificados por Angelo Trento (1989), publicados em italiano até 1940 na cidade de São Paulo.

196 “Architetti Italiani in Brasile". Il Pasquino Coloniale, 9 set. 1922, p. 31.
} 
Brizzolara é descrito na década de 1920 como “l'Huomo che incarna, e rappresenta in Brasile le piu' belle virtu' della nostra razza [O homem que encarna e representa a mais bela virtude da nossa raça]"197.
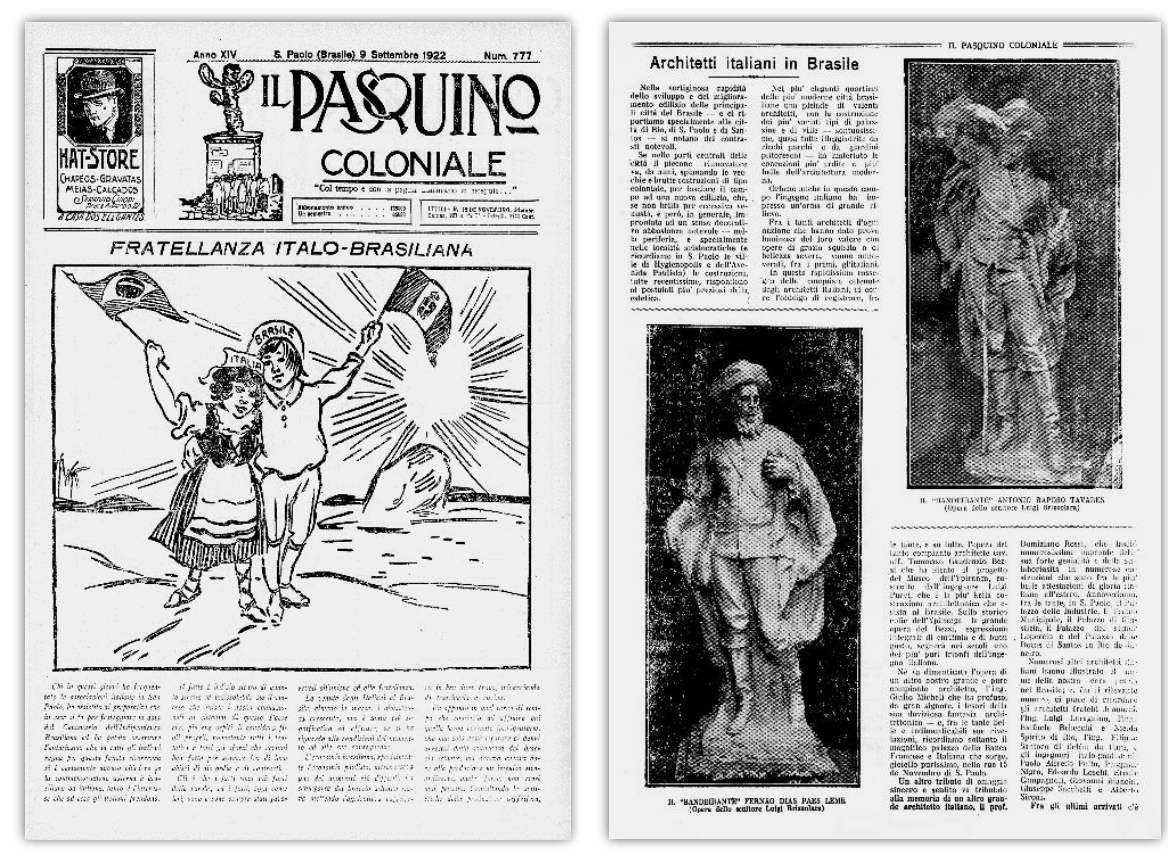

Figura 2.11 - Fernão Dias e Raposo Tavares como símbolos da fraternidade ítalo-brasileira, 1922. Fonte: Il Pasquino Coloniale, 9 set. 1922.

A imagem de uma irmandade entre a Itália e o Brasil incorporada por Fernão Dias e Raposo Tavares na década de 1920 não era novidade. No começo do século Xx, os italianos já somavam $50 \%$ da população da capital, muitos deles estabelecendo-se nas vizinhanças das fábricas (HALL, $2004)^{198}$. Essa presença marcava também a toponímia paulistana: ainda em 1905, na planta geral da cidade de São Paulo, próxima à rua Jorge Velho, havia a rua dos Italianos, no bairro operário do Bom Retiro ${ }^{199}$. Mas se muitos eram os italianos que circulavam pelo Bom Retiro, sua relação com

197 “Arte italiana in Brasile”. Il Pasquino Coloniale, 13 mar. 1926, p. 12.

198 Sobre a diferenciação entre os bairros de elite e os bairros operários na São Paulo do período, cf. Rolnik (1981); Paoli (1991); Sevcenko (1992); Homem (1996); Campos (2002), entre outros.

199 A rua dos Italianos foi oficializada pelo ato no 972, de 24 de agosto de 1916, mesmo ato que irá nomear a rua dos Bandeirantes, também no Bom Retiro. Se a pesquisa realizada por Oscar Egídio Araújo (1940), baseada em dados da década de 1930, conclui que os italianos estavam espalhados pela cidade, atualmente, além da rua dos Italianos, temos ainda a praça Itália, no bairro de Pinheiros; a avenida Itália, em Socorro; três ruas chamadas Itália, respectivamente nos bairros de Pinheiros, Guaianazes e Cursino. O antigo estádio Palestra Itália (atual Allianz Park), fundado em 1914, também não ficou de fora, e hoje ainda batiza a rua defronte a ele em Perdizes. Já no Jardim Paulista, temos a praça do Imigrante Italiano. Diversas são também as homenagens a cidades italianas: a rua Roma, na Lapa; as ruas Florença e Calábria, em Santo Amaro; a rua Palermo, na Saúde; a praça Cidade de Milão, em Moema; a rua Veneza, no Jardim Paulista; a travessa Pisa, em São Miguel; a avenida Bolonha, no Jaguaré; a rua Verona, no Tremembé; a travessa Siena, na Freguesia do Ó; duas ruas chamadas Turim, uma na Cidade Líder e 
os brasileiros nem sempre foi fraterna; violentos conflitos de rua já haviam explodido no bairro desde o final do século XIX ${ }^{200}$. Quer dizer, a boa convivência entre eles era só aparente.

\subsubsection{Do Museu Paulista ao cineteatro Odeon}

Quase duas décadas depois de ser esculpido em mármore, os bandeirantes de Luigi Brizzolara participariam do primeiro filme histórico produzido pelo Instituto Nacional do Cinema Educativo (Ince), dirigido por Humberto Mauro (1897-1983), um dos pioneiros do cinema brasileiro $^{201}$. Visando promover e orientar a utilização do cinema para a educação popular, o Ince foi criado em 1936, pouco antes da instauração do Estado Novo (1937-1945), com o apoio de Gustavo Capanema, ministro da Educação e Saúde, e a aprovação do presidente Getúlio Vargas ${ }^{202}$. Sob a égide do Ince, Humberto Mauro abandona sua produção ficcional para realizar filmes com um propósito explicitamente educativo, após se tornar diretor técnico da instituição ${ }^{203}$.

Valendo-se da estrutura do Ince, a imagem de Fernão Dias Paes Leme (assim como a de seu companheiro Antônio Raposo Tavares) é difundida cinematograficamente por intermédio, mais uma

outra no Tremembé; as ruas Pádua e Mântua, em Socorro; as ruas Agrigento e Amalfi, no Jardim Ângela; a travessa Ferrara, na Casa Verde; a rua Orvieto, no Jabaquara; a rua Trieste, em Itaquera; a rua Perúgia, na Vila Maria; a via de pedestre Catânia, na Vila Medeiros; as ruas Parma, Messina, Nápoles e Gênova, todas no Tucuruvi; e a via de pedestre Ancona, no Cursino. Isso sem mencionar várias homenagens a personalidades italianas, como os próprios Tommasso Gaudenzio Bezzi, Luigi Pucci e Ettore Ximenes, que também irão nomear logradouros em distintos bairros da capital paulista. Cf. Núcleo de denominação de logradouros públicos, AHMWL.

${ }^{200}$ Sobre o bairro do Bom Retiro, cf. Dertônio (1971).

${ }^{201}$ Humberto Mauro iniciou sua carreira na cidade mineira de Cataguases, onde dirigiu ficções como $O$ tesouro perdido (1927), Braza dormida (1928) e Sangue mineiro (1930). Seu primeiro filme sonoro, Ganga bruta (1933), realizado no Rio de Janeiro pela produtora Cinédia, é tido por muitos como uma das principais obras do cinema brasileiro. Cf. Gomes (1974).

202 Entre 1936 e 1966, o Ince produziu mais de quatrocentos curtas e médias-metragens voltados para a educação popular e para a divulgação de ciência e tecnologia. Para além da história, sua produção abrangia diversas áreas, tais como: medicina, botânica, engenharia, química, física, biologia, astronomia, ciências sociais, literatura, educação, música e teatro. Sua criação já estava prevista no decreto no 21240, de 1932, que nacionaliza a censura e institui o Instituto Brasileiro de Cinematografia Educativa. Mas é por meio do decreto $n^{\circ} 378$, de 1937, que deu nova organização ao Ministério da Educação e Saúde, que o Ince é definitivamente incluído no quadro dos serviços públicos.

203 Entre 1936 e 1964, Humberto Mauro produziu mais de 350 filmes para o Ince, sobressaindo-se como o principal cineasta do instituto. Cf. Viany (1978) e Schvarzman (2004). 
vez, de Afonso Taunay, responsável pela supervisão histórica do média-metragem Os bandeirantes $(1940)^{204}$. Em 1939, último ano de seu longo mandato como diretor do Museu Paulista, Taunay escreveu ao abade do mosteiro de São Bento solicitando permissão para que Humberto Mauro registrasse de dentro da basílica alguns aspectos importantes para as filmagens, como a própria sepultura de Fernão Dias ${ }^{205}$. Tais cenas acabaram não sendo incluídas, mas o bandeirante esculpido por Luigi Brizzolara - com uma pose ainda mais grandiosa devido ao enquadramento da câmera baixa que acentua sua imponência — ganhará protagonismo na abertura do último, e principal, bloco do filme gestado e controlado pelo Ince.

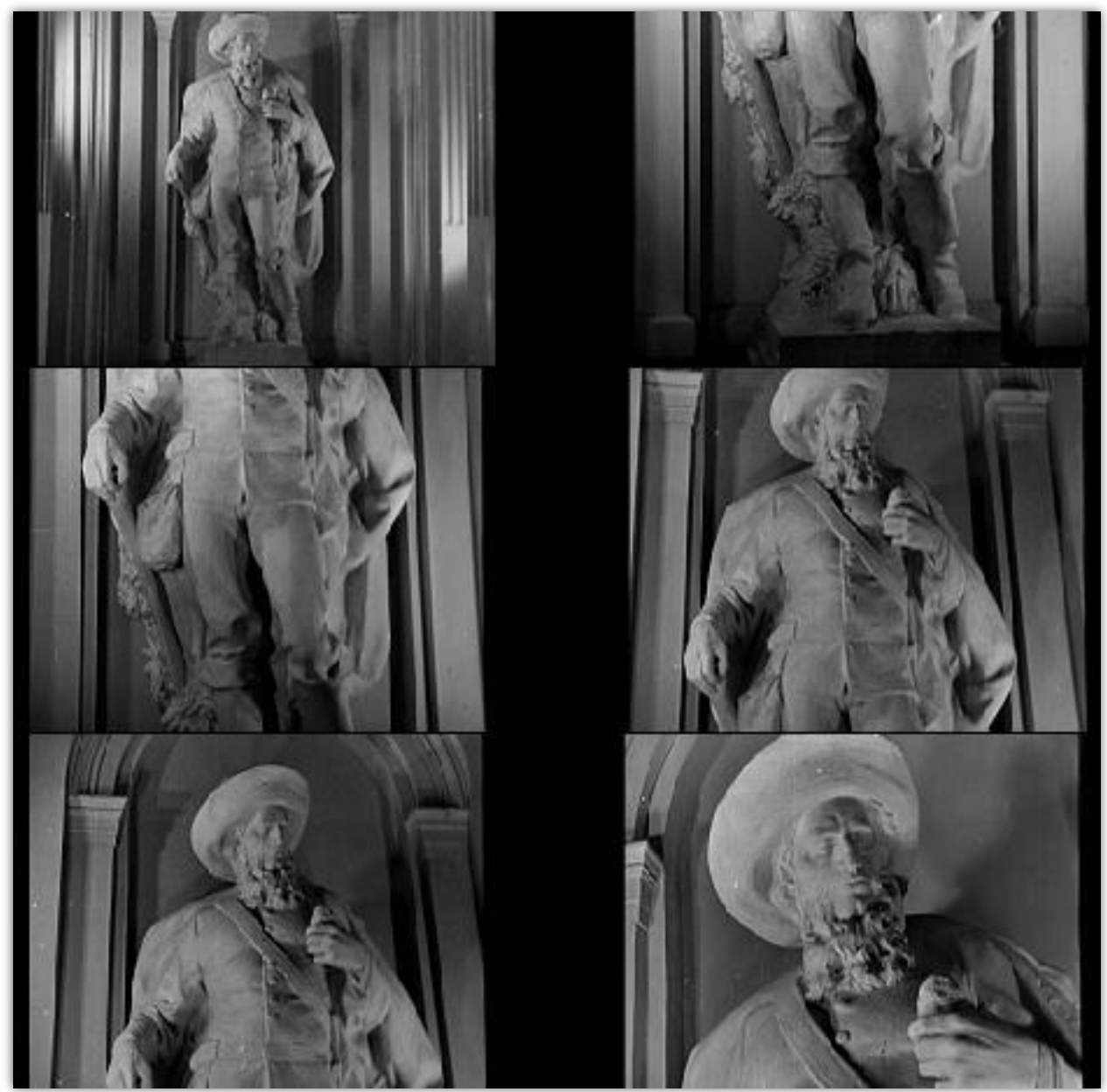

Figura 2.12 - Fernão Dias no média-metragem Os bandeirantes, abertura do bloco "Ciclo do ouro e das pedras".

Fonte: Filme Os bandeirantes (1940), de Humberto Mauro.

\footnotetext{
204 Sobre Humberto Mauro e as relações entre cinema e história, cf. Morettin (2013).

${ }^{205}$ Carta de Afonso Taunay ao abade do mosteiro de São Bento, 22 nov. 1939. APMP/FMP, pasta 176.
} 
Notemos que a constituição do Ince atendia às demandas feitas desde a década de 1920 por educadores em defesa da criação de um órgão oficial que cuidasse da produção e da exibição de filmes educativos ${ }^{206}$. Nessa mesma época, Afonso Taunay já afirmava que uma das principais propostas do Museu Paulista era fornecer mensagens de patriotismo, mesmo para o mais leigo dos visitantes. Desse modo, anos antes de estrear um filme voltado para a educação popular, a escultura Fernão Dias Paes Leme já estaria instalada, desde as festas centenárias, nessa “espécie de Versalhes paulista", não apenas por seus belos jardins em estilo francês, mas por ser uma galeria que, desde sua construção, visava a finalidade pedagógica, conforme o descreve a revista carioca Eu sei tudo, ainda em $1922^{207}$. Um ano depois da criação do Ince, Taunay torna público seu desejo, já projetado, de concretizar o primeiro filme histórico com temática bandeirante ${ }^{208}$. Destinado às escolas públicas brasileiras, esse filme educativo teria algumas sequências filmadas no Museu Paulista, levando assim imagens como a de Fernão Dias Paes Leme para as salas de aula ${ }^{209}$.

Tal vínculo do Museu Paulista com estabelecimentos de ensino, porém, dá-se em diversas frentes. Assim como o filme, o selo e os periódicos, os livros didáticos e os livros de história contribuíram para divulgar, ao longo do tempo, uma imagem heroica das esculturas encomendadas por Afonso Taunay para muito além dos limites do museu. Muitas escolas irão adotar livros de história do Brasil como os que começam a ser produzidos na década de 1940 por Roberto Jorge Haddock Lobo, lançados pela editora Melhoramentos, que se somam à já clássica História do Brasil de Francisco da Rocha Pombo, publicada pela editora W. M. Jackson Inc. Anos depois, a editora

\footnotetext{
${ }^{206} \mathrm{Na}$ década de 1920, as produções cinematográficas de gênero histórico eram na maioria das vezes recusadas e até mesmo desprezadas pela crítica da época e pela faixa de público mais politizada (MACHADO, 1989).

207 A revista explica que o "povo", ao visitar o Museu Paulista, "vê, aprende, recorda comenta, armazena ideias acima do sofrimento diário. Museus como esse completam admiravelmente a escola na qual professores patrióticos se esforçam por tornar as crianças patrióticas”. Cf. “Aspectos de S. Paulo: o Ipiranga”, Eu sei tudo, no 64, set. 1922, pp. 24-28.

${ }^{208}$ Carta de Afonso Taunay a Cantídio de Moura Campos, secretário de Educação e Saúde Pública do estado de São Paulo, 2 abr. 1937. APMP/FMP, pasta 165.

209 Ainda que Taunay afirme, na mesma carta mencionada em nota anterior [nota no 207], que a obra de Humberto Mauro, por ele supervisionada, é o primeiro filme histórico com temática bandeirante, O caçador de diamantes, do italiano Vittorio Capellaro, havia sido lançado em 1933 como “uma epopeia das bandeiras dos fins do século XVIII”, segundo sua sinopse, cf. Barro (2004). Histórico ou não, explica Rubens Machado (1989), O caçador de diamantes é um filme nacional remanescente do gênero histórico, que representou, sobretudo nos anos 1910, uma parcela considerável da produção ficcional brasileira, em grande parte inspirada em obras literárias. Anos antes, o fotógrafo franco-brasileiro Marc Ferrez, envolvido em alguns projetos vinculados a instituições imperiais, já havia dirigido na capital carioca o filme $O$ caçador de esmeraldas (1915), com o subtítulo Episódio da vida dos bandeirantes, ganhando destaque por ser um dos primeiros a retratar o contato com grupos indígenas brasileiros, ainda que da perspectiva do desbravador bandeirante.
} 
Melhoramentos reeditaria obras como A grande vida de Fernão Dias Pais e História das bandeiras paulistas, ambas escritas por Taunay.

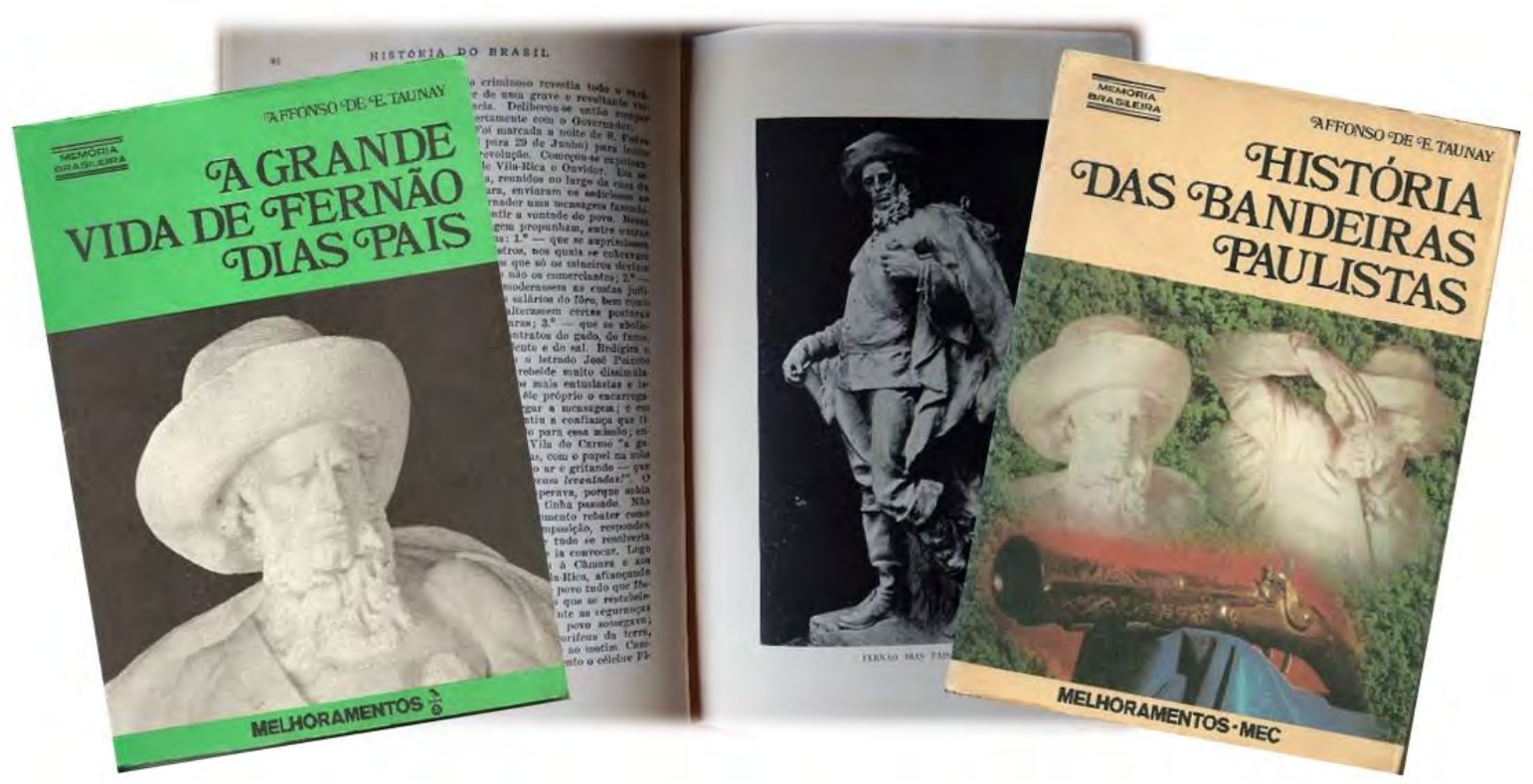

Figura 2.13 - Fernão Dias, de Luigi Brizzolara, na História do Brasil (1953), de Rocha Pombo, e também na História das bandeiras paulistas (1975) e em A grande vida de Fernão Dias Pais (1977), ambos de Afonso Taunay.

Fonte: Acervo pessoal | Foto: Thaís Waldman.

Consultor dos dados históricos do roteiro de Os bandeirantes, Afonso Taunay é apresentado pelo locutor, logo no início do filme, como "o historiador das bandeiras". Lembremos que antes de dirigir o Museu Paulista, ele lecionara na Escola Politécnica Paulista, mantendo desde cedo um grande interesse pelas ciências humanas, em especial pela história. Retratado de saída como o intelectual que irá endossar a veracidade da narrativa a ser apresentada no filme, "o historiador das bandeiras" também comentará o roteiro elaborado por Humberto Mauro, ainda em fase de preparação, e fornecerá o material iconográfico que servirá de base para o filme.

Contratado em 1936 como diretor técnico, Humberto Mauro precisou se sujeitar, do roteiro às referências iconográficas de Os bandeirantes, às ingerências de Taunay que, segundo o relatório da diretoria do Museu Paulista relativo ao ano de 1939, acompanhou os trabalhos de filmagem durante as sequências rodadas na instituição. Não por acaso, nos créditos de abertura do filme o nome de Taunay aparece antes do de Mauro; além disso, ele figura nas cenas iniciais como protagonista do primeiro bloco, chamado “Comentário". Sentado atrás de uma mesa de escritório, "o historiador das bandeiras" é filmado consultando livros, papéis e documentos, como se indicasse 
o embasamento histórico das imagens que dariam continuidade ao filme, entre elas a de Fernão Dias, esculpido por Luigi Brizzolara, que irá protagonizar o último bloco ${ }^{210}$.

Dividido em cinco partes — "Comentário", "Fundação de São Paulo”, "Anchieta”, "Ciclo do desbravamento" e "Ciclo do ouro e das pedras" —, o filme Os bandeirantes dá ênfase aos dois últimos blocos, que ligam a expansão territorial brasileira e a ocupação econômica do centro sul à ação dos bandeirantes. Juntos, esses segmentos consomem mais de três quartos do tempo de duração da película, sendo que o último segmento, aberto pelo majestoso Fernão Dias, ocupa mais de metade da obra. Nele, a escultura do bandeirante encomendada por Taunay para recepcionar os visitantes no Museu Paulista recebe também o público fora da colina do Ipiranga, contrariando sua fixação obrigatória como objeto de decoração do edifício-monumento.

Por ocasião do lançamento do filme, Taunay explica que o epílogo de Os bandeirantes é a máxima de Getúlio Vargas "recordando a imperiosidade dessa marcha para o oeste, do Brasil hodierno de que foi Fernão Dias um dos precursores" ${ }^{211}$. Como sabido, Vargas havia anunciado,

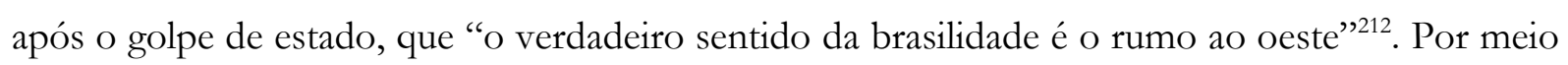
de um movimento de conquista e expansão, ocupando os espaços localizados especialmente na Amazônia e no Centro-Oeste, o governo federal pretendia alargar as fronteiras econômicas e humanas do Brasil, tal qual os bandeirantes do período colonial ${ }^{213}$. O interessante, porém, é que

210 Poucos anos antes, Taunay já havia participado de outro filme do INCE, Academia Brasileira (1937), no qual faz um pequeno discurso sobre sua obra Ensaio geral das bandeiras paulistas.

211 "História de um filme", Jornal do Commercio, 22 set. 1940, p. 3. Essa associação nas telas do cinema entre a imagem dos bandeirantes e uma "marcha para o oeste" já havia aparecido anos antes, ainda na década de 1920, quando é lançado o filme The Covered Wagon (1923), produzido pela Paramount Pictures sob a direção do ator e cineasta James Cruze. Trata-se do primeiro western épico estadunidense, gênero que, como diria o crítico André Bazin, "é o cinema americano por excelência" (2014, p. 17). O filme, sobre "a grande marcha da caravana [em direção ao oeste estadunidense] através de florestas e rios", explica um articulista do Correio Paulistano, foi lançado no Brasil justamente com o título Os bandeirantes. Cf. "No país das sombras”, Correio Paulistano, 6 abr. 1925, p. 4.

212 Disponível em: <http://www.biblioteca.presidencia.gov.br/presidencia/ex-presidentes/getulio-vargas/discursos/>. Acesso em: 12 nov. 2016.

${ }^{213}$ No início da década de 1930, porém, o próprio Taunay e o IHGSP, ao qual ele e grande parte dos intelectuais paulistas do período eram associados, assumiram uma posição favorável ao levante contra o governo de Getúlio Vargas. Durante esse movimento, o IHGSP esteve praticamente fechado, conforme pode ser verificado no volume 30 do relatório dos trabalhos e ocorrências sociais da revista da instituição, que felicita o retorno de seus membros: “Atingidos todos os paulistas pelo turbilhão da luta, teve o Instituto também vários dos seus membros, inclusive alguns da Diretoria, nas trincheiras distantes da capital, [.... levados por um idealismo sadio e alto a oferecer suas vidas preciosas para o bem de São Paulo” (RIHGSP, 1935, p. 118). Nessa mesma ocasião, um retrato de Fernão Dias (assim como a imagem modelar de Domingos Jorge Velho) irá estampar algumas cédulas do Tesouro do Estado de São Paulo, de diferentes valores, chamadas de Bônus Pró-Constituição de 1932, enquanto uma das frentes de combate ao governo provisório de Vargas será chamada de Batalhão Fernão Dias. 
embora Os bandeirantes seja definido pelo catálogo do Ince como uma grande "epopeia" em busca de ouro e de pedras preciosas, a ênfase do filme recai sobre as privações de Fernão Dias, como bem observa Eduardo Morettin (2013).
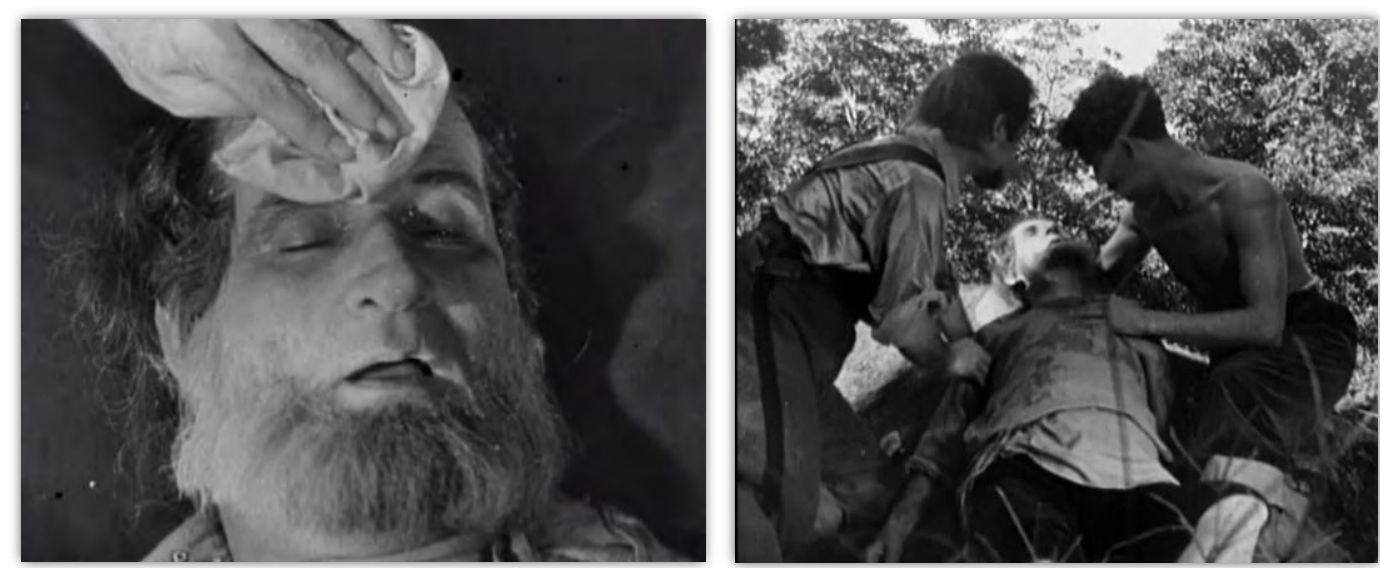

Figura 2.14 - J. Silveira agoniza em "Ciclo do ouro e das pedras". Fonte: Filme Os bandeirantes (1940), de Humberto Mauro.

Tomando como fio condutor as expedições em busca de esmeraldas, que tem início com a apresentação da escultura de Luigi Brizzolara, o filme prossegue com o ator Joel Silveira no papel do bandeirante. Depois de vender todo o ouro e a prata da família, executar o próprio filho e adoecer, Fernão Dias revela que sua busca por minas de ouro e esmeraldas foi uma empreitada que lhe trouxe muitas privações e sofrimento ${ }^{214}$. Assim, por mais que o locutor o caracterize como um “desbravador inquebrantável”, que a imagem da estátua esculpida por Luigi Brizzolara enfatize o seu vigor, e que Afonso Taunay divulgue o média-metragem exaltando "a grandiosa jornada esmeraldina de Fernão Dias" ${ }^{215}$, o que o filme mostra é um bandeirante abatido, desanimado, sem nenhuma recompensa material, e cada vez mais solitário. Trata-se de um bandeirante que explora a terra "dia e noite sem esmorecer", enfatiza o narrador, "sem pólvora e sem balas, sem ferro e sem aço, sem sal e sem azougue, empregado na pesquisa do ouro".

${ }^{214} \mathrm{Na}$ biografia que redige sobre Fernão Dias, Taunay já descrevia como "angustiosa a situação da grande entrada esmeraldina, desfalcadíssima de homens e elementos" (1926b, p. 58). Taunay explica que o bandeirante teve que pedir a sua mulher que vendesse toda prata e todo ouro da família, a fim de obter recursos, diante de uma "sombria desesperação" que levaria alguns membros da expedição à “diabólica sugestão” de assassinar Fernão Dias antes que perdessem as próprias vidas na mata (1926b, p. 55). Essa “diabólica sugestão” torna-se também, na década de 1920 , o mote da peça O governador das esmeraldas, do dramaturgo Carlos Góes.

215 Ao divulgar o filme Os bandeirantes, Taunay explica que os dois últimos blocos tratam dos "dois episódios máximos" da descoberta e da conquista do Brasil: "o prodigioso périplo continental de Antônio Raposo Tavares e a grandiosa jornada esmeraldina de Fernão Dias Paes”. Cf. “História de um filme”, Jornal do Commercio, 22 set. 1940, p. 3. 
Se no segmento fílmico dedicado a Raposo Tavares temos uma expedição bandeirante subjugando as ameaças externas — a mata, os rios, os animais selvagens e os indígenas -, o foco do último bloco, indica Eduardo Morettin (2013), são as ameaças internas à expedição, como o cansaço e a falta de recursos. Humberto Mauro filma a expedição de Fernão Dias interior adentro, rumo à exuberante lagoa Vapabuçu. Esta, porém, revela-se igualmente traiçoeira: a lagoa conhecida por esconder as tão desejadas esmeraldas acobertava a febre terçã, explica o locutor, referindo-se à malária. A câmera se aproxima, então, de um Fernão Dias fraco e doente, que delira cambaleante ${ }^{216}$. Em um de seus delírios, o bandeirante chega a cair ao chão com os braços abertos, em formato de cruz, tal qual o solitário moribundo retratado por Henrique Bernardelli na década de 1930, em Os últimos momentos de um bandeirante, visto no primeiro capítulo.

"Subjugando o olvido, através das idades, violador de sertões, plantador de cidades, dentro do coração da pátria viverás!", declama ao fim do bloco o locutor, ao ler um trecho de "O caçador de esmeraldas" (1902), poema escrito por Olavo Bilac em homenagem a Fernão Dias. Ao som de uma variação do Hino à bandeira nacional, com música de Francisco Braga e letra também escrita por Bilac, a morte do bandeirante é prenunciada. Para aumentar o sofrimento de Fernão Dias, descobrimos no final que as cobiçadas esmeraldas que ele acreditava ter encontrado eram meras turmalinas, pedras sem grande valor.

Humberto Mauro foi contratado para trabalhar no Ince a convite de Edgard RoquettePinto, primeiro diretor-geral do instituto ${ }^{217}$. Responsável pela supervisão de Os bandeirantes, o antropólogo, em discurso de recepção a Afonso Taunay na Academia Brasileira de Letras, diria em 1930 o que o historiador Paulo Prado já afirmara anteriormente: não ser Fernão Dias “o sonhador de riquezas fabulosas" que a "lenda" criou (ROQUETTE-PINTO, 1930, p. 298) ${ }^{218}$. As poucas e imprecisas informações existentes sobre o bandeirante que viveria para sempre na memória pátria — tal como declama o narrador do filme na leitura de um trecho do poema de Olavo Bilac permitiriam diversas suposições, defende Prado, endossado por Roquette-Pinto ${ }^{219}$.

\footnotetext{
${ }^{216} \mathrm{Um}$ bandeirante que pouco se assemelha, portanto, ao bandeirante pintado por Antônio Parreiras na década de 1920 em A morte de Fernão Dias. Sobre Parreiras, cf. Stumpf (2014).

217 Sobre a trajetória de Roquette-Pinto e sua experiência com o cinema brasileiro dos anos 1930, cf. Almeida (1999).

218 Paulo Prado afirma ainda ser Fernão Dias "o bandeirante por excelência", e que "talvez para ele se tivesse criado esse próprio termo desconhecido nos velhos documentos e nos autores clássicos da história de São Paulo”, encontrado pela primeira vez por Prado no livro Corografia brasilica (ou, Relação histórico-geográfica do reino do Brasil), escrito por Manoel Ayres de Cazal em 1817 (PRADO, 1925, p. 121).

219 Além de criticar a imagem de Fernão Dias como "o sonhador de riquezas fabulosas", Paulo Prado se opõe à "mania nobiliárquica" e às "justificações do sangue limpo" que ocultavam da biografia do bandeirante um "longínquo cruzamento com indígena”, o que daria a Fernão Dias o "cunho mameluco que é a nota aristocrática do paulista
} 
Se não há dúvidas de que muitas são as versões de Fernão Dias, o bandeirante idoso, exausto e desamparado projetado por Humberto Mauro foi um fracasso de público (MORETTIN, 2013). Sua estreia nas telas do cinema ocorreu na rua da Consolação, no cineteatro Odeon, um dos primeiros cinemas do país a ter duas salas de projeção. O filme foi lançado na Sala Vermelha, com maior capacidade de espectadores, além de ser mais requintada que a Sala Azul, pois exigia o uso de trajes de gala ${ }^{220}$. Mas a despeito do tamanho da sala e de toda a pompa envolvida, o filme protagonizado pela escultura entra em conflito com o personagem excessivamente realista vivido por Silveira, cujo efeito parece não ter agradado ao público, talvez por apresentar um bandeirante humano demais ${ }^{221}$.

\subsection{Partida do antigo belvedere da avenida Paulista}

(frase escrita em uma grande faixa de tecido exposta no muro da Escola Estadual Fernão Dias Paes, durante as ocupações estudantis de 2015)

Em 1922, anos antes da estreia de Os bandeirantes no cineteatro Odeon, outra escultura de Fernão Dias é inaugurada nas proximidades da rua da Consolação, mais especificamente no antigo

puro" (1925, p. 122). Mas se o Fernão Dias de Os bandeirantes pouco se assemelha a um "sonhador de riquezas fabulosas", ele também está longe de ser "mameluco".

${ }^{220}$ Em 1939, a Sala Vermelha tinha capacidade para 2510 espectadores, somando a plateia, as frisas e os balcões. Disponível em: <http://www.arquiamigos.org.br/bases/cine3p/historico/00387.pdf>. Acesso em: 29 nov. 2016.

221 Posteriormente são lançados ainda dois outros filmes em homenagem a Fernão Dias, dessa vez sem o protagonismo da estátua esculpida por Luigi Brizzolara. Em 1957, temos a estreia de Fernão Dias, o governador das esmeraldas, dirigido por Alfredo Roberto Alves, e produzido pela Cine Produtora Campineira, empresa que teve curto tempo de existência (1954-1960). O filme conta os feitos heroicos do bandeirante paulista, mas teve uma trajetória marcada por problemas de distribuição e dificuldades financeiras. Anos depois, ocorre o lançamento de $O$ caçador de esmeraldas (1979), de Oswaldo Oliveira. Trata-se de um filme que também irá contar com o apoio do governo federal e até hoje é reprisado na televisão brasileira. Além de ter em seu elenco atores que na época faziam muito sucesso como Jofre Soares, no papel de Fernão Dias, e Tarcísio Magalhães Sobrinho e Nilcedes Soares Guimarães, mais conhecidos como Tarcísio Meira e Glória Menezes - , a narrativa tem um final grandioso, no qual o bandeirante encontra as tão esperadas esmeraldas. Cf. Gonçalez (1999). 
belvedere que tinha início em uma das extremidades da avenida Paulista, atual praça Marechal Cordeiro de Farias, conhecida na época como praça dos Expedicionários. Convertido em bronze, Fernão Dias é calorosamente recebido em um mirante próximo à rua Minas Gerais — homenagem ao estado que teria sido por ele desbravado ${ }^{222}$ - , onde segue festejando colina abaixo as comemorações do Centenário da Independência do Brasil, fazendo uma ligação simbólica entre as duas regiões da cidade, o Ipiranga e a Paulista ${ }^{223}$.

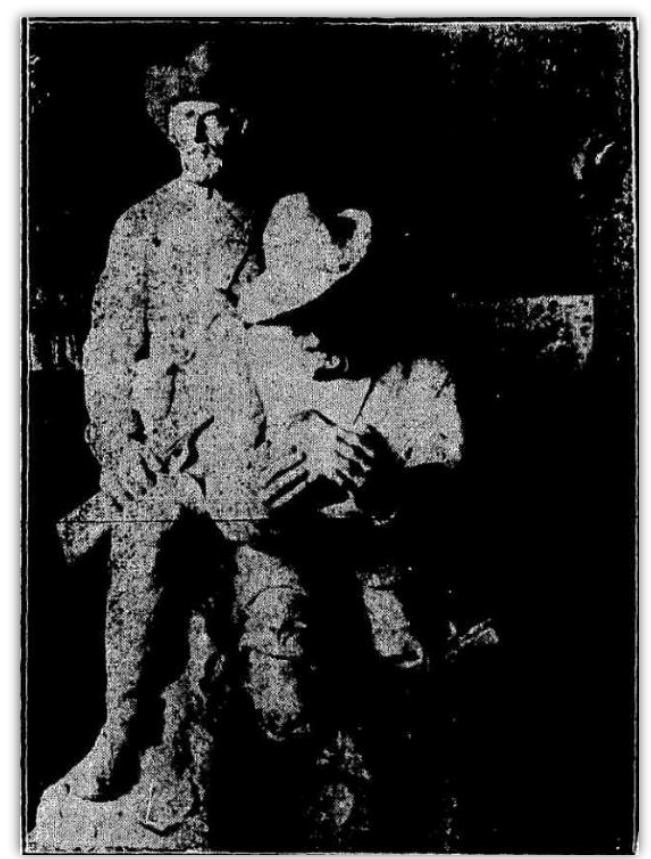

Figura 2.15 - O caçador de esmeraldas, ateliê de William Zadig, Suécia, 1920. Fonte: O Estado de S. Paulo, 10 nov. 1920, p. 3.

Fernão Dias é o principal personagem de $O$ caçador de esmeraldas, fragmento escultórico que compõe o Monumento a Olavo Bilac, encomendado ao sueco William Zadig a pedido da Liga

\footnotetext{
222 A rua Minas Gerais teve seu nome oficializado pelo ato no 972 , de 24 de agosto de 1916. Cf. Núcleo de denominação de logradouros públicos, AHMWL.

${ }^{223}$ Embora na prática a prefeitura tenha cuidado apenas do embelezamento do distante e ainda pouco povoado bairro do Ipiranga, deixando o resto no esquecimento, durante os preparativos para as festas de 1922 cogitou-se até mesmo tornar a avenida Dom Pedro I, que ligava o Ipiranga ao centro de São Paulo, uma imitação da avenida Paulista. Máximo Barro e Roney Bacelli, em texto sobre o Ipiranga premiado pelo Arquivo Municipal de São Paulo, no concurso de monografias sobre a história dos bairros da capital paulista, indagam: "Se Eugenio Lima [engenheiro responsável pela abertura da avenida Paulista], nos começos do século, através de hábeis manobras publicitárias e conchavos nos corredores palacianos, conseguira lotear todo espigão à nascente plutocracia industrial e à decadente geração dos barões do café, por que não fazer o mesmo no Ipiranga com a 'classe média'?’' (1979, p. 62). Porém, segundo os autores, tudo ficou na tentativa, apesar de as propagandas imobiliárias enfatizarem desde a importância histórica do local até os baixos preços do metro quadrado.
} 
Nacionalista de São Paulo (LNSP) ${ }^{224}$. Fundada em dezembro de 1916, por alunos, ex-alunos e professores da Faculdade de Direito do largo de São Francisco, a LNSP homenageia na obra o poeta falecido em 1918, tido como "o patrono nacionalista", segundo a diretoria do Centro Acadêmico XI de Agosto $^{225}$. Fernão Dias é moldado em bronze ajoelhado em primeiro plano, observando (assim como a escultura do Museu Paulista) uma pedra, que segura com as duas mãos. Atrás dele, de pé, no mesmo fragmento, está seu genro Borba Gato, com as mesmas barbas longas, empunhando uma espingarda na mão direita e trazendo uma arma menor na cintura. A vestimenta trajada por ambos remete à indumentária de Domingos Jorge Velho, retratado anos antes por Benedito Calixto: botas de cano alto, gibão de armas, cinto e chapéu de abas largas.

Presidente honorário da LNSP, Olavo Bilac havia publicado, na segunda edição de Poesias (1902), de 1888, o famoso poema “O caçador de esmeraldas”, sobre a expedição de Fernão Dias (texto que na década de 1940 servirá também de mote ao filme Os bandeirantes) ${ }^{226}$. Se Fernão Dias viveria para sempre no coração brasileiro, conforme os versos do poema de Bilac, o poeta, ele próprio, assim como Fernão Dias, marcará a memória paulistana. Antes de se tornar figura em bronze, Bilac é homenageado em uma outra praça no centro da cidade, no bairro de Santa Cecília, que não só leva seu nome como podia na época ser observada do antigo belvedere da avenida Paulista (com vista para o Pacaembu) no qual é inaugurado o Monumento a Olavo Bilac ${ }^{227}$. Já seu poema "O caçador de esmeraldas" dará nome, anos depois, a uma rua no bairro do Ipiranga, perto da colina em que foi edificado o Museu Paulista ${ }^{228}$.

A inauguração do Monumento a Olavo Bilac, de acordo com O Estado de S. Paulo, reuniu tanta gente "no recanto da aristocrática avenida", que a "massa popular", de tão compacta, teve que ocupar todo o trecho entre o cruzamento da avenida Angélica e a rua da Consolação, avançando

${ }^{224}$ Cerca de três meses antes da fundação da Liga Nacionalista de São Paulo, em 7 de setembro de 1916, Olavo Bilac, Pedro Lessa e Miguel Calmon já haviam fundado, no Rio de Janeiro, a Liga de Defesa Nacional (LDN), estimulando o surgimento e o desenvolvimento de associações congêneres em outros pontos do país, como a própria LNSP, na capital paulista. A LDN tinha como principal objetivo "congregar os sentimentos patrióticos dos brasileiros", segundo o seu próprio estatuto. Sobre os usos políticos da memória de Olavo Bilac no século XX, cf. Hansen (2015).

225 “Olavo Bilac”. Correio Paulistano, 25 abr. 1920, p. 3.

${ }^{226} \mathrm{Na}$ primeira década do século Xx, Olavo Bilac também escreve o prefácio do livro de poesia Os bandeirantes (1906), editado três vezes em menos de quatro anos, no qual Manuel Batista Cepelos exalta sua terra natal e os feitos heroicos dos antigos bandeirantes que teriam dado origem à nação brasileira.

227 A praça Olavo Bilac é oficializada pela lei no 2.172, de 17 de fevereiro de 1919. Anos depois, Bilac batizará também uma rua na zona leste, em Ermelino Matarazzo. Cf. Núcleo de denominação de logradouros públicos, AHMWL.

228 A rua Caçador de Esmeraldas teve seu nome oficializado pelo decreto no 2.688, de 20 de setembro de 1954 . Cf. Núcleo de denominação de logradouros públicos, AHMWL. 
até o monumento, onde as autoridades policiais tentavam contê-la ${ }^{229}$. Durante as festas centenárias, explica o Correio Paulistano, a mesma "multidão polimorfa e policroma" de homens e mulheres que havia se deslocado, no dia 7 de setembro, para o Ipiranga, dirigiu-se na sequência para as proximidades da rua Minas Gerais ${ }^{230}$. Em meio a essa euforia, ao retirarem o grande envoltório que cobria o conjunto monumental de William Zadig, Fernão Dias e os demais homenageados no monumento são ovacionados por uma "multidão que se estendia aos seus pés", relata a Folba da Noite, e praticamente se mistura a ela ${ }^{231}$.

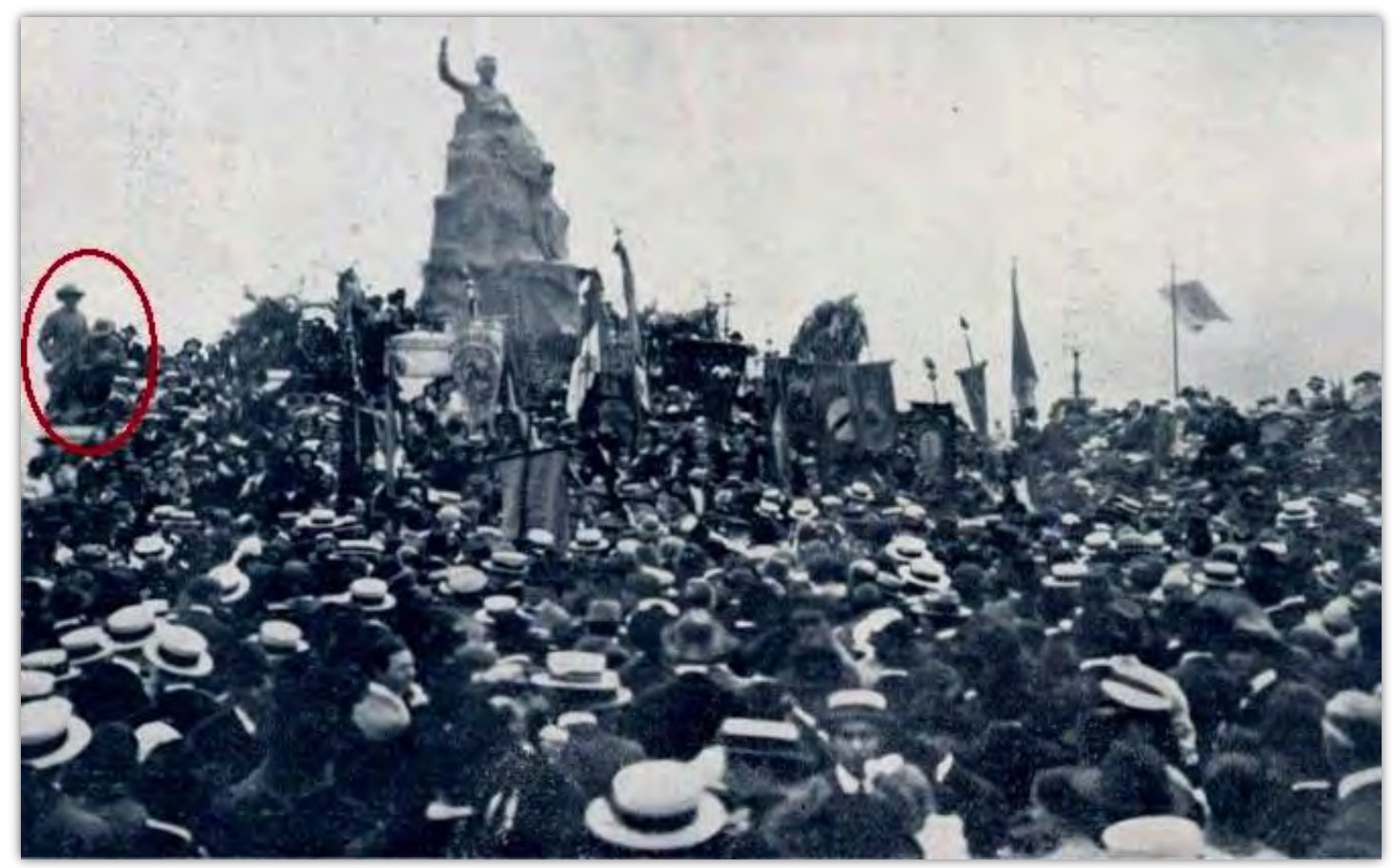

Figura 2.16 - Inauguração do Monumento a Olavo Bilac, antigo belvedere da avenida Paulista, 1922.

Fonte: A Cigarra, 1 out. 1922, p. 16.

Aberta em 1891, em um local ainda ermo, a avenida Paulista seguia o caminho de um alto espigão, e logo se torna um dos cartões-postais da cidade. De um dos pontos mais elevados de São Paulo, a escultura de Fernão Dias poderia observar a capital paulista e ser vista sem barreiras. Se isso é verdade, o grande homenageado pelo escultor William Zadig é Olavo Bilac. Esculpido no topo do pedestal central do grande conjunto, o busto de Bilac é acompanhado por alguns dos

\footnotetext{
229 "O Centenário da Independência”. O Estado de S. Paulo, 8 set. 1922, p. 2.

230 "O Centenário”. Correio Paulistano, 8 set. 1922, p. 4.

231 “O Centenário". Folha da Noite, 7 set. 1922, p. 2.
} 
personagens relacionados aos seus mais importantes escritos patrióticos, como Fernão Dias do poema "O caçador de esmeraldas" (1902), à sua direita, e o europeu e a indígena do "Beijo eterno" (1888), à sua esquerda. Embora tenham se tornado, assim como a própria avenida Paulista, cartãopostal da cidade, nenhum deles permaneceria espreitando São Paulo do grande espigão por muito mais que uma década ${ }^{232}$.

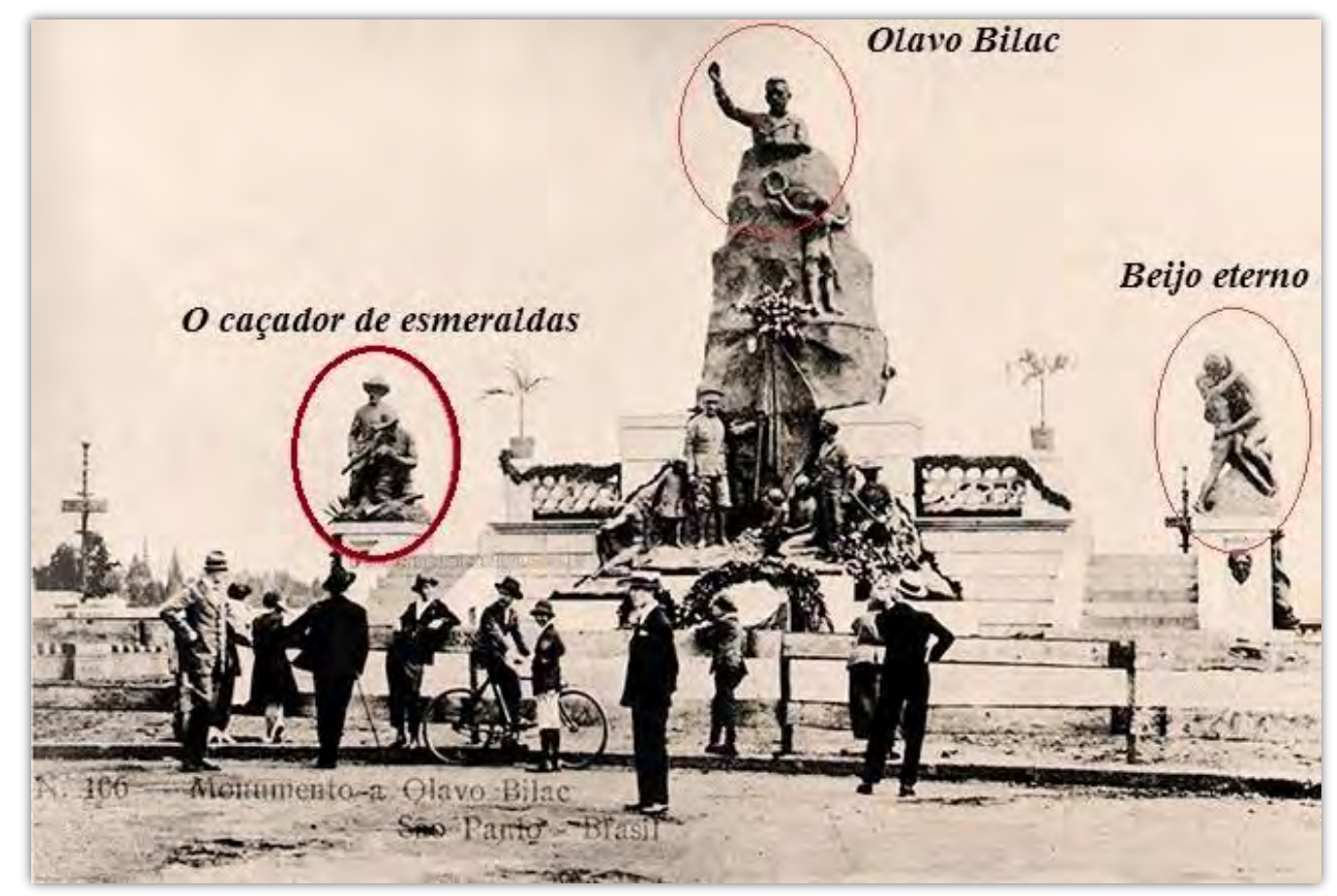

Figura 2.17 - Monumento a Olavo Bilac, cartão-postal, 1922. Fonte: São Paulo Antiga ${ }^{233}$.

Em 1936, durante o governo de Fábio da Silva Prado (1934-1938), sobrinho de Antônio da Silva Prado, o Monumento a Olavo Bilac é removido do antigo belvedere. Desmembrado, o conjunto é levado para o depósito municipal da Várzea do Carmo, no Glicério. O argumento para sua fragmentação e remoção foi o de que obras viárias estavam sendo realizadas na região da avenida

232 'Num dos seus percursos/circuitos pela cidade, Mario [de Andrade] descortina no poema 'Parada' um monumento hoje ausente", observa Maria Elvira Federico (2005, p.19), em uma referência ao Monumento a Olavo Bilac: Escrito em 7 de setembro de 1922, o poema publicado no livro O losango cáqui (1926) descreve uma parada de soldados desfilando pela avenida paulista, na qual o poeta aparece com uma nova vestimenta: "Olhe a conversão! Conversão de S. Paulo. Todos convergem pra esquerda. Lá está Bilac estreando a fatiota de bronze. Pátria latejo em ti..." (ANDRADE, 1926, s/p).

${ }^{233}$ Disponível em < http://www.saopauloantiga.com.br/monumento-a-olavo-bilac/>. Acesso em: 10 fev. 2017. Uma reprodução dessa mesma imagem foi exposta na mostra "Avenida Paulista”, que entrou em cartaz em 2017, no Museu de Arte de São Paulo, trazendo na legenda as informações: impressão sobre papel prata/gelatina, 9 x 15cm, coleção João Batista Monteiro da Silva, cf. o catálogo organizado por Pedrosa \& Toledo (2017). 
Paulista, além de reclamações frequentes quanto ao trânsito do local e em relação à nudez de uma das partes que o compunham. Intitulado Beijo eterno, ou Idílio, o fragmento trazia a imagem de um europeu e uma indígena, nus, beijando-se "com o mesmo ardente amor" do poema homônimo, que integra a primeira edição do livro Poesias (1888), ao qual será incorporado posteriormente o poema “O caçador de esmeraldas". O polêmico Beijo eterno mostrou-se efêmero: acabou esquecido durante vinte anos, depois de ter insultado pudores na avenida Paulista e de lá ser expulso.

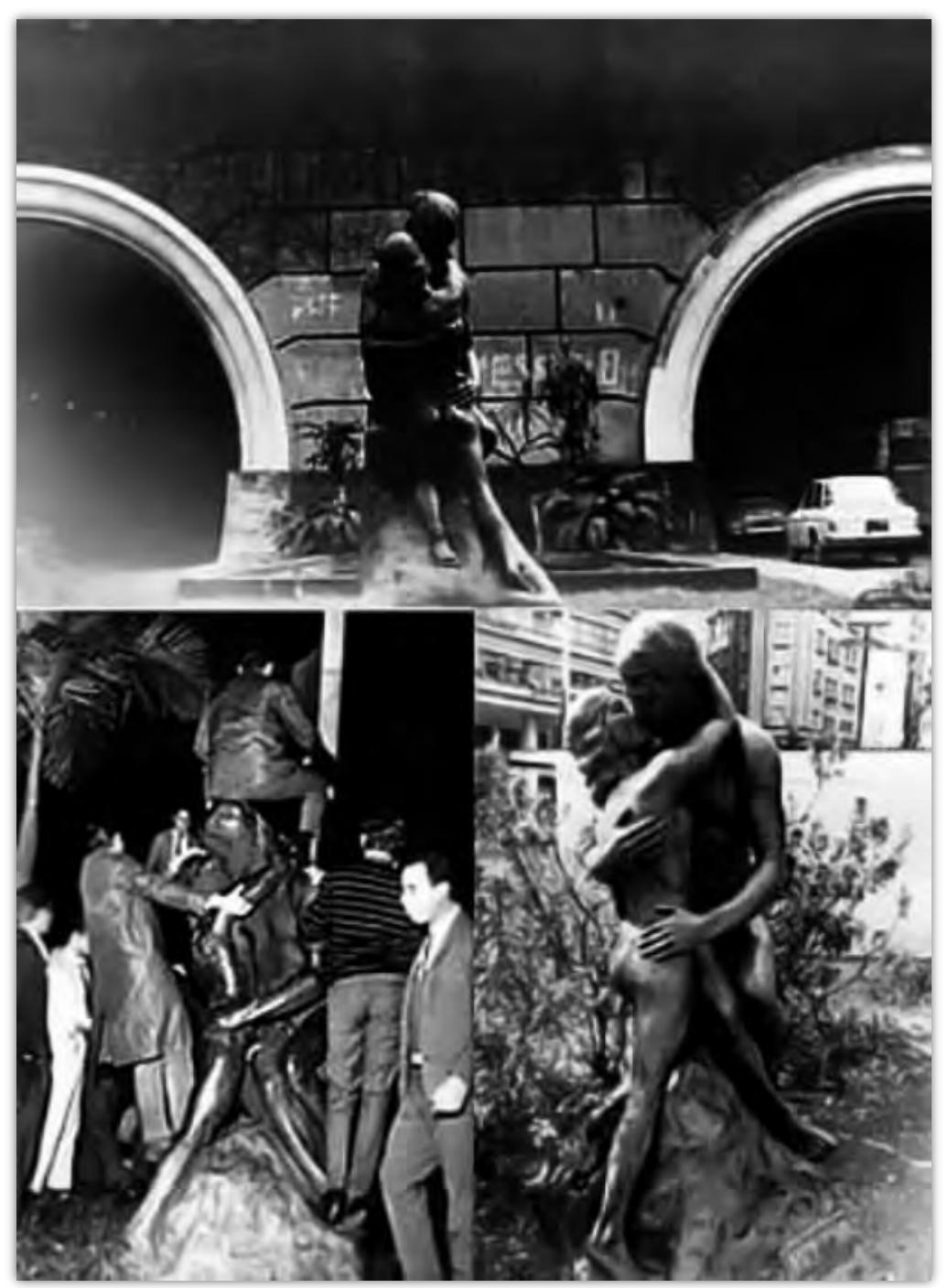

Figura 2.18 - Estudantes do Centro Acadêmico XI de Agosto resgatam a escultura Beijo eterno, $1966 / 1984$.

Fonte: Almanaque da Folha de S.Paulo234.

${ }^{234}$ Disponível em: <http://almanaque.folha.uol.com.br/monumento_beijo.htm>. Acesso em: 10 fev. 2017. 
Em 1956, Beijo eterno é reinstalado pelo então governador Jânio Quadros, do Partido Trabalhista Nacional (PTN), no largo do Cambuci. "Morei no bairro [Cambuci] e por isso conheço seu esquecimento por parte da prefeitura, vamos repará-lo”, teria dito Jânio Quadros na ocasião (FERREIRA, 1971, p. 130). Taxada mais uma vez de indecorosa pelos moradores, a escultura logo foi banida e abandonada novamente em um depósito da prefeitura. Em 1966, o casal é enxotado para a avenida Nove de Julho, porém alguns residentes da área, apoiados por um vereador da Aliança Renovadora Nacional (Arena), solicitam ao prefeito José Vicente de Faria Lima, também da Arena, que aquele "verdadeiro acinte ao decoro e aos bons costumes do povo paulistano" 235 sumisse dali ${ }^{236}$. Antes que isso acontecesse, alguns estudantes do Centro Acadêmico XI de Agosto - lembrando que no início do século xx a campanha civilista de Olavo Bilac encontrou muitos adeptos na Faculdade de Direito — resgatam os amantes para evitar que, mais uma vez, acabassem $\operatorname{confinados}^{237}$. Após passarem a madrugada transportando a obra de quatrocentos quilos, os estudantes afirmaram ironicamente que se o Beijo eterno, até hoje na entrada da Faculdade de Direito no largo de São Francisco, fosse de lá retirado, todas as figuras que aparecessem nuas em estátuas da cidade teriam de se vestir ${ }^{238}$.

Outras partes do Monumento a Olavo Bilac foram também remanejadas mais de uma vez, como é o caso do próprio busto do poeta. Jânio Quadros, então prefeito pelo Partido Trabalhista Brasileiro (PTB), novamente irá intervir ao determinar a restauração do busto de Bilac, que passa a viver em 1988 na avenida Sargento Mário Kozel Filho, no Ibirapuera, atrás da Assembleia Legislativa do Estado de São Paulo (Alesp) ${ }^{239}$. Uma placa de mármore em seu pedestal, localizado

235 "Pedida a retirada da estátua". O Estado de S. Paulo, 8 out. 1966, p. 34.

${ }^{236} \mathrm{Na}$ justificativa do processo protocolado pela Câmara Municipal de São Paulo, o vereador Armando Simões Netto (Arena) explica que: "Não se trata de aquilatar ou discutir o valor artístico ou não que a referida estátua pode representar. Trata-se sim de exigir que as coisas sejam colocadas em lugares certos. Uma obra artística representativa do demônio não deve ter lugar num santuário”. Cf. processo nº 4535 de 1966, CMSP.

${ }^{237}$ Em 1936, mesmo ano em que Beijo eterno foi desmembrado do Monumento a Olavo Bilac e retirado da região da Paulista, alguns alunos da Faculdade de Direito roubaram a estátua José Bonifácio, o moşo de um depósito da prefeitura e a levaram de volta ao largo de São Francisco. A obra do escultor francês Georges Engrand havia sido inaugurada no largo de São Francisco em 1890, sobre um alto pedestal, em frente à igreja. Em 1935, a prefeitura previu em seu plano de remodelação do local o deslocamento de José Bonifácio, o moşo para outro ponto da praça. Um ano depois, os alunos solicitaram ao prefeito Fábio Prado que reinstalasse a obra. Diante da recusa do prefeito, a estátua foi roubada do depósito municipal e levada ao saguão da Faculdade de Direito, cf. Grola (2012).

238 "XI de Agosto quer a estátua". O Estado de S. Paulo, 19 out. 1966, p. 28.

${ }^{239}$ Segundo as Atas e os Anais da Câmara Municipal de São Paulo, na década de 1960 o vereador Ary Silva já havia reivindicado em mais de uma sessão ordinária que o busto de Olavo Bilac fosse retirado dos "depósitos de lixo da prefeitura" e instalado em uma praça no bairro de Santana, zona norte da cidade, onde residia. Cf., por exemplo, os registros das sessões ordinárias n 221, n² 227, n 317, realizadas entre 1965 e 1966. 
em uma área que pertence ao Comando Militar do Sudeste, cercada por grades altas e arames farpados, saúda o "príncipe dos poetas brasileiros", também conhecido como "patrono do serviço militar". Seu remanejamento evidencia um processo de invisibilidade quase tão violento quanto seu abandono em um depósito municipal depois de ter sido retirado do antigo belvedere da avenida Paulista.

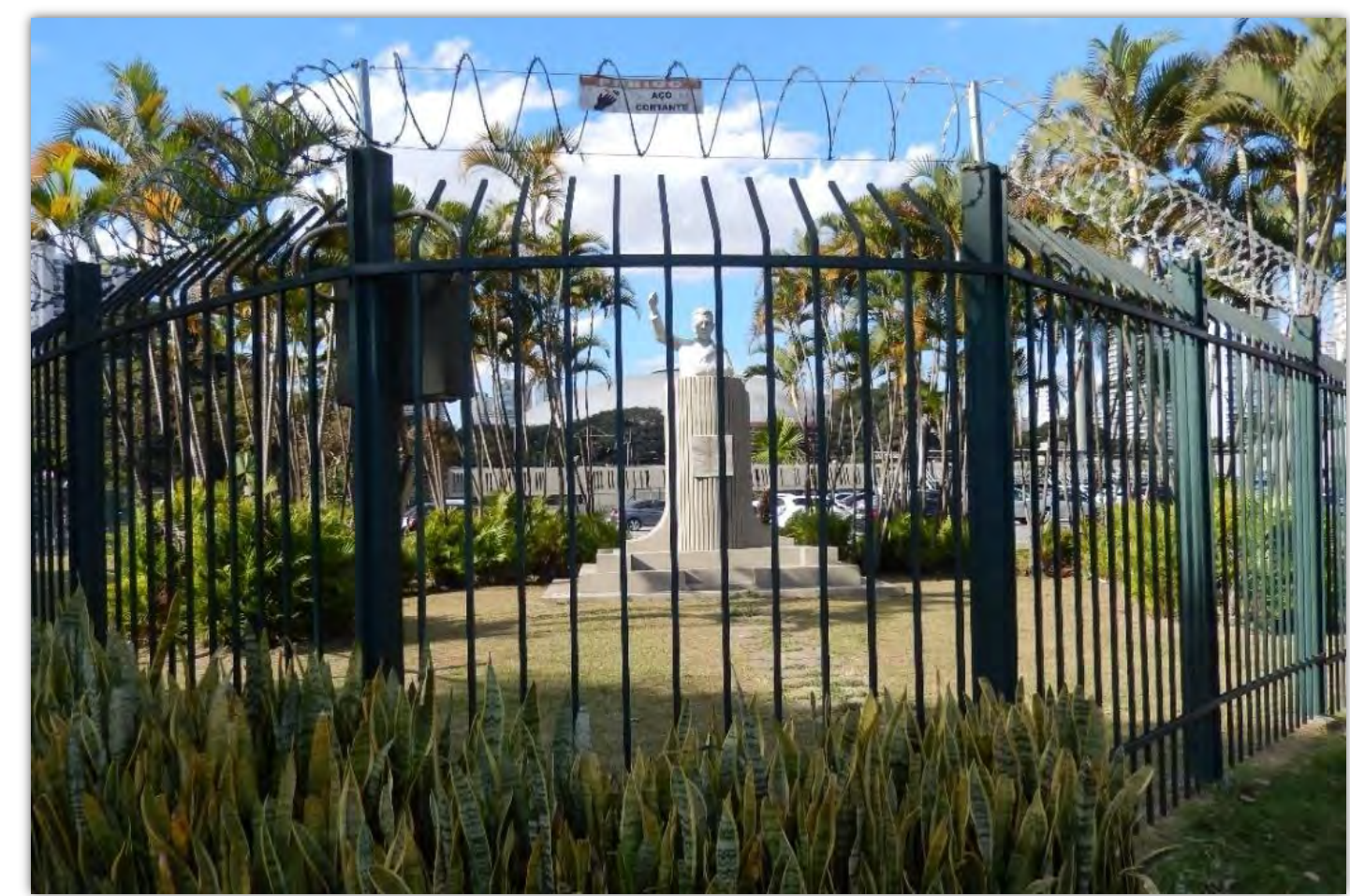

Figura 2.19 - Olavo Bilac, avenida Sargento Mário Kozel Filho, 2017. Fonte: Acervo pessoal | Foto: Thaís Waldman.

Atualmente, os demais pedaços do Monumento a Olavo Bilac encontram-se dispersos pela capital paulista. A escultura $O$ caçador de esmeraldas, por exemplo, em 1936, após o início da polêmica suscitada pelo Beijo eterno, foi desmembrada do Monumento a Olavo Bilac e abandonada em um depósito municipal até ser realocada, anos depois, no jardim de um dos colégios públicos mais tradicionais da zona oeste da cidade, fundado em 1948 como Ginásio Estadual de Pinheiros, hoje rebatizado de Escola Estadual Fernão Dias Paes. Os fragmentos da obra de William Zadig nos mostram que enquanto alguns monumentos passam décadas em um mesmo local, despercebidos, mesmo sob olhares cotidianos, outros geram paixões e aversões a ponto de serem banidos em 
depósitos, ou sequestrados na calada da noite. Essas peregrinações pelos espaços públicos de São Paulo nos ajudam a pensar, portanto, nas “esculturas errantes" de que fala Aracy Amaral ${ }^{240}$.

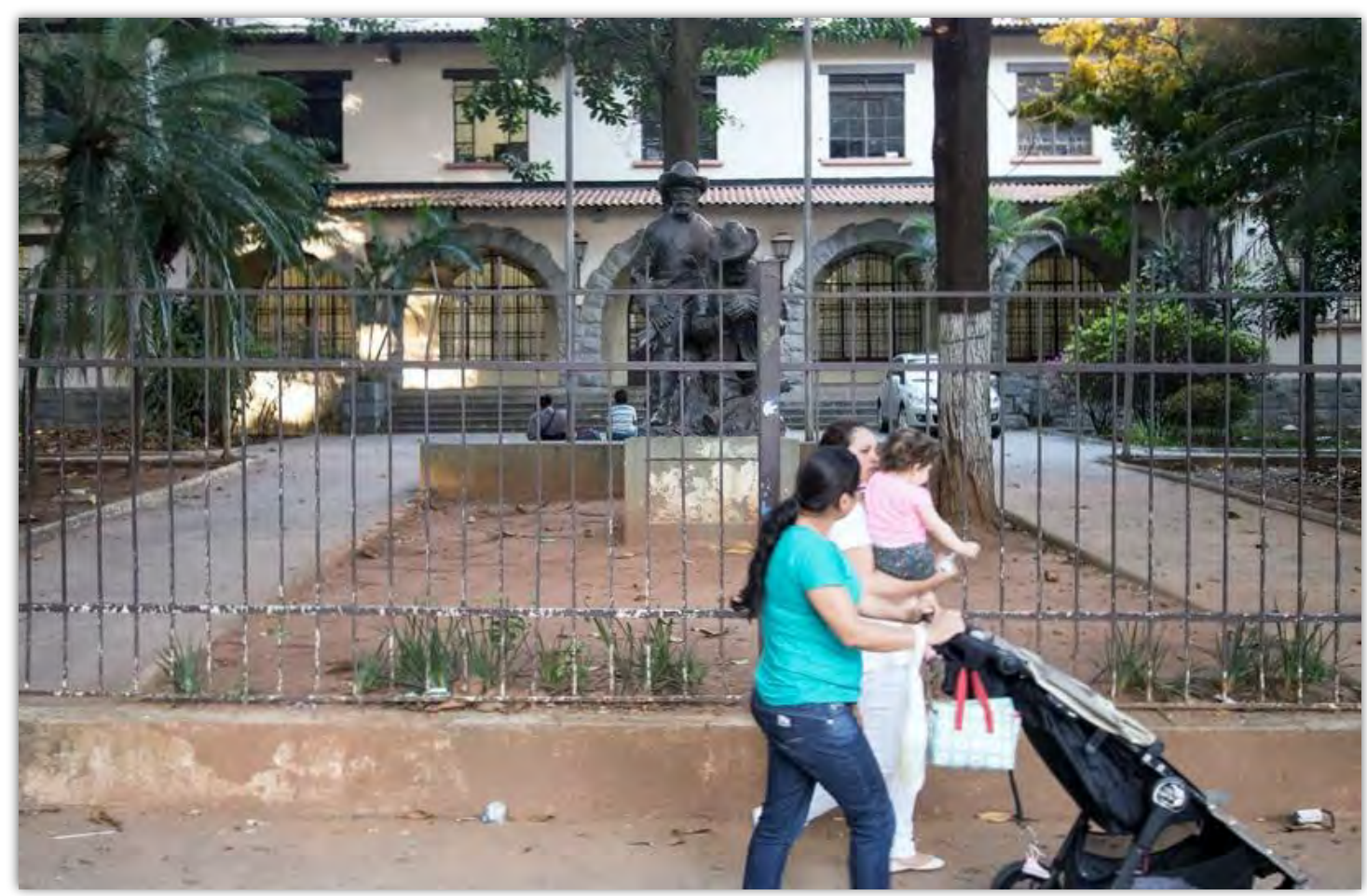

Figura 2.20 - O caçador de esmeraldas, Escola Estadual Fernão Dias Paes, 2015. Fonte: Memória da Amnésia | Foto: André Turazzi ${ }^{241}$.

Os deslocamentos dessas obras podem ser acompanhados virtualmente pelo Guia dos monumentos nômades, espécie de roteiro online desenvolvido pelo projeto Memória da Amnésia, realizado entre os anos de 2015 e $2016^{242}$. De acordo com os dados por ele levantados, existem 63 monumentos registrados na capital paulista que foram alterados de lugar pelo menos uma vez, não raro realocados por mais de três vezes, todos eles catalogados pelo Departamento de Patrimônio

${ }^{240}$ Em 1995, Aracy Amaral sugere que as “esculturas errantes” que circulam pelos espaços públicos da cidade "daria[m] bem o tema para um ensaio” (2006, p. 368).

${ }^{241}$ Disponível em: <http://www.desvirtual.com/mda/2016/03/08/fragmentos-do-monumento-a-olavo-bilac/>. Acesso em: 10 fev. 2017.

242 O projeto Memória da Amnésia discute a memória pelo prisma do esquecimento a partir de duas principais ações: uma intervenção artística, que consistiu no translado de monumentos de um depósito da Secretaria Municipal de Cultura para o Arquivo Histórico de São Paulo; e um mapeamento dos monumentos que mudaram de lugar na cidade de São Paulo. O Guia dos monumentos nômades foi desenvolvido por Giovanna Casimiro e Marina Lima. Disponível em: <http://www.desvirtual.com/mda/>. Acesso em: 26 jan. 2017. 
Histórico do município (DPH), no Inventário de obras de arte em logradouros públicos da cidade de São Paulo $^{243}$, junto a outros 375 monumentos ${ }^{244}$. Giselle Beiguelman, coordenadora do projeto, pergunta, com propriedade: "Afinal, quem decide o que deve ser esquecido, como deve ser esquecido e quando deve ser esquecido?”. Os monumentos desimplantados, explica ela, formam um acervo de outra história da capital paulista, uma história que pode revelar desde "encomendas aleatórias até memórias fantasmagóricas e indesejadas"245.

\section{4] Conheca os deslocamentos das estátuas por São Paulo e siga o seu monumento}

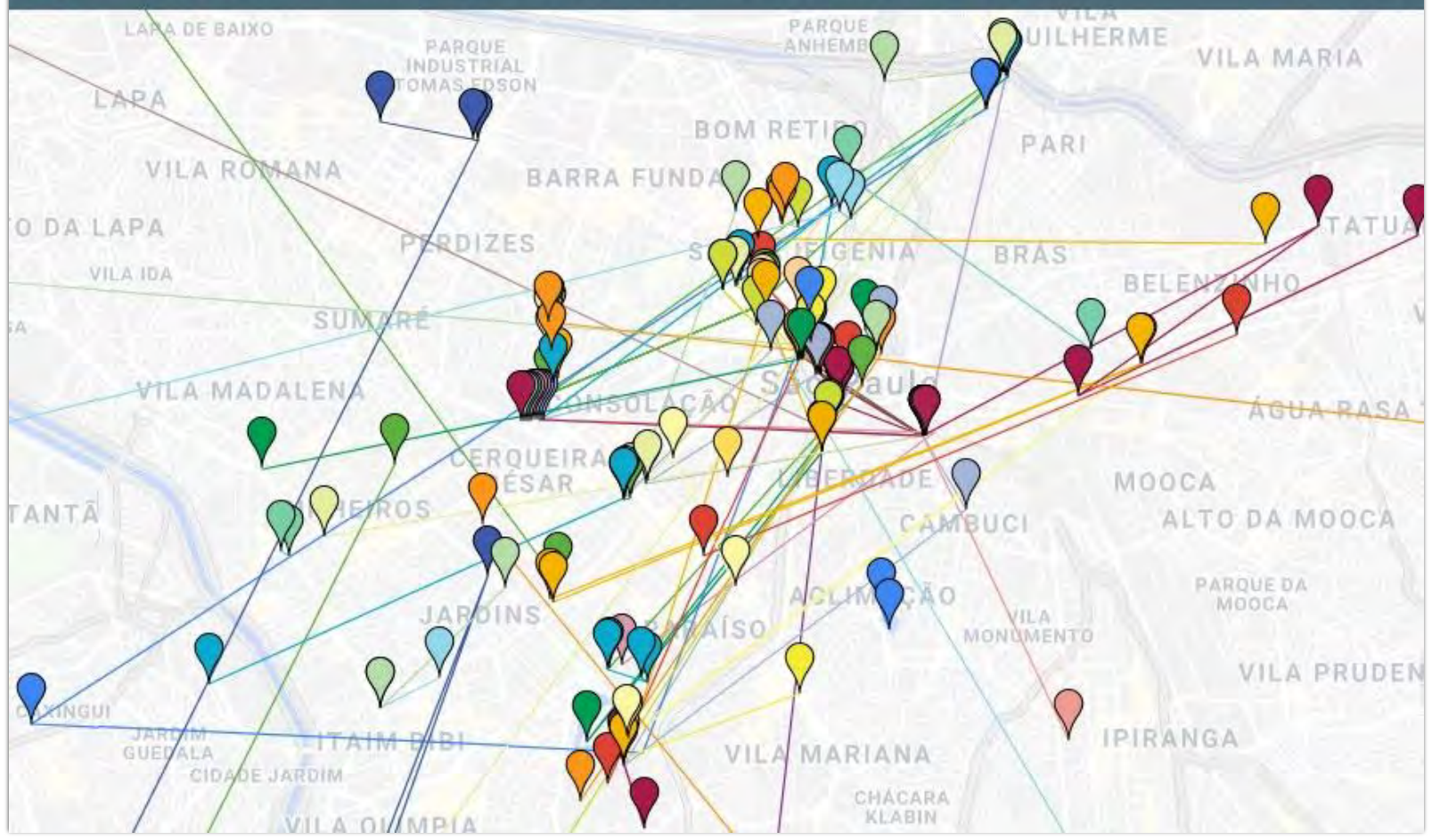

Figura 2.21 - Guia dos monumentos nômades, 2015.

Fonte: Memória da Amnésia246.

243 O livro Inventário de obras de arte em logradouros públicos da cidade de São Paulo está disponível em: $<$ http://www.prefeitura.sp.gov.br/cidade/secretarias/cultura/patrimonio_historico/adote_obra/index.php?p=4484>. Acesso em: 10 jan. 2017.

${ }^{244}$ Desse total de 438 obras, 43\% dos monumentos retratam figuras humanas, "trazendo um forte caráter de homenagens a personalidades individuais que, ocupando o espaço público em escala incompatível com a paisagem, em pouco tempo se tornam, em sua maioria, anônimos”. Além disso, 44\% estão localizadas no centro da cidade. Disponível em: <http://www.desvirtual.com/mda/2016/03/08/arte-espaco-publico-e-memoria/> Acesso em: 26 jan. 2017.

245 Disponível em: <http://www.desvirtual.com/mda/wp-content/uploads/2016/03/MDA_folder_low.pdf>. Acesso em: 26 jan. 2017.

${ }^{246}$ Disponível em: <http://www.desvirtual.com/mda/guia-dos-monumentos-nomades/>. Acesso em: 10 fev. 2017. 


\subsubsection{O abandono no depósito municipal}

Foi igualmente em 1922, ano da inauguração do Monumento a Olavo Bilac, da reabertura do Museu Paulista e da finalização dos trabalhos de reconstrução do mosteiro de São Bento, que os monumentos públicos começaram a se deslocar literalmente pela capital paulista. Os primeiros a abandonarem o sedentarismo foram três estátuas em mármore, reproduções de obras de artistas franceses, inauguradas em 1914 no centro da cidade, na antiga esplanada do Theatro Municipal de São Paulo, atual praça Ramos de Azevedo ${ }^{247}$. São elas: Leão, cópia da escultura de Prosper Lecourtier (1851-1924); Amor materno, de Charles Louis Eugene Virion (1865-1946); e A menina e o bezerro, de Pierre Robert Christophe (1880-1971) ${ }^{248}$. Adquiridas junto a empresas francesas durante a gestão de Raymundo Duprat (1911-1914) ${ }^{249}$, elas foram retiradas em 1922 da região do Anhangabaú, quando o local é escolhido para abrigar o Monumento a Carlos Gomes, encomendado pela colônia italiana visando as comemorações do Centenário da Independência do Brasil ${ }^{250}$.

A então denominada antiga esplanada do Theatro Municipal, onde é inaugurado o monumento encomendado pela colônia italiana, é mais um exemplo de obra motivada pela reurbanização do centro da cidade no início do século $\mathrm{XX}^{251}$. Para pôr São Paulo em sintonia com

\footnotetext{
247 Após a morte de Ramos de Azevedo, em 1928, a antiga Esplanada é renomeada em sua homenagem, por ter sido ele um dos responsáveis pela construção do Theatro Municipal. Além de dar nome a uma praça, Ramos de Azevedo ganha um conjunto escultórico em sua homenagem que também se torna “errante”. Esculpido pelo italiano Galileo Emendabili, o Monumento a Ramos de Azevedo é inaugurado em 1934 na avenida Tiradentes, zona norte da cidade, em frente ao edifício da Pinacoteca do Estado, outra importante obra do arquiteto. A partir do final dos anos 1960, a obra permaneceu desmontada no parque da Luz, no centro da capital, até ser reimplantada na Cidade Universitária, zona oeste, em 1974, em uma praça que também leva o nome de Ramos de Azevedo, próxima à Escola Politécnica da Universidade de São Paulo, instituição que o arquiteto ajudou a criar. Sobre os deslocamentos do Monumento a Ramos de Azevedo, cf. Freire (1997) e o livro organizado por Fabris (1997).
}

248 As três esculturas francesas foram reimplantadas em diferentes lugares do centro da cidade: a escultura Leão, no parque Dom Pedro II; Amor materno, no jardim da Luz; e A menina e o bezerro, no largo do Arouche. Mas o percurso das três estátuas pela capital paulista não para por aí. Devido às reformulações viárias no parque Dom Pedro II, Leão é transferida no final da década de 1960 para o parque do Ibirapuera, próxima ao local em que será instalado o busto de Olavo Bilac, enquanto Amor materno vai parar no largo do Arouche em data desconhecida, voltando a se encontrar, assim, como A menina e o bezerro.

${ }^{249}$ Sobre a obra urbanística de Raymundo Duprat e as transformações do Anhangabaú, cf. Toledo (1989).

250 Para uma análise do Monumento a Carlos Gomes, cf. Lopes (2012).

${ }^{251}$ Sem uma "vida social”, justifica Antônio Prado, a cidade "nunca passaria de um quieto burgo do interior" (PRADO, 1929, p. 376). Havia uma pretensão de se construir algo mais ostensivo que o Theatro Municipal do Rio de Janeiro, inaugurado em 1909 como símbolo da coroação da avenida Central carioca. A ideia de uma avenida que atravessasse o centro, porém, era de difícil viabilização em São Paulo, em virtude da topografia da cidade e da carência de recursos, o que impossibilitava aos paulistanos a aquisição de "um espaço vitrine de civilização e progresso à europeia" de impacto semelhante ao carioca (CAMPOS, 2002, p. 84). Ainda assim, as promessas e utopias que 
as principais tendências artísticas e culturais das grandes metrópoles da Europa, o governo de Antônio Prado autoriza, em 1903, a construção do Theatro Municipal, cuja inauguração se dá oito anos depois ${ }^{252}$. Nesse sentido, a praça inspirada na reurbanização de Paris, traçada pelo arquitetopaisagista Joseph Antoine Bouvard, diretor dos Serviços de Arquitetura, Passeios, Viação e Plano de Paris, estava povoada por obras de três escultores franceses. Tais esculturas, no entanto, conforme mencionado, serão banidas do local para ceder espaço a uma encomenda da comunidade italiana, feita a um escultor italiano, em homenagem ao primeiro compositor brasileiro a ter suas obras apresentadas no Teatro alla Scala, famosa casa de ópera inaugurada em Milão no século XVIII.

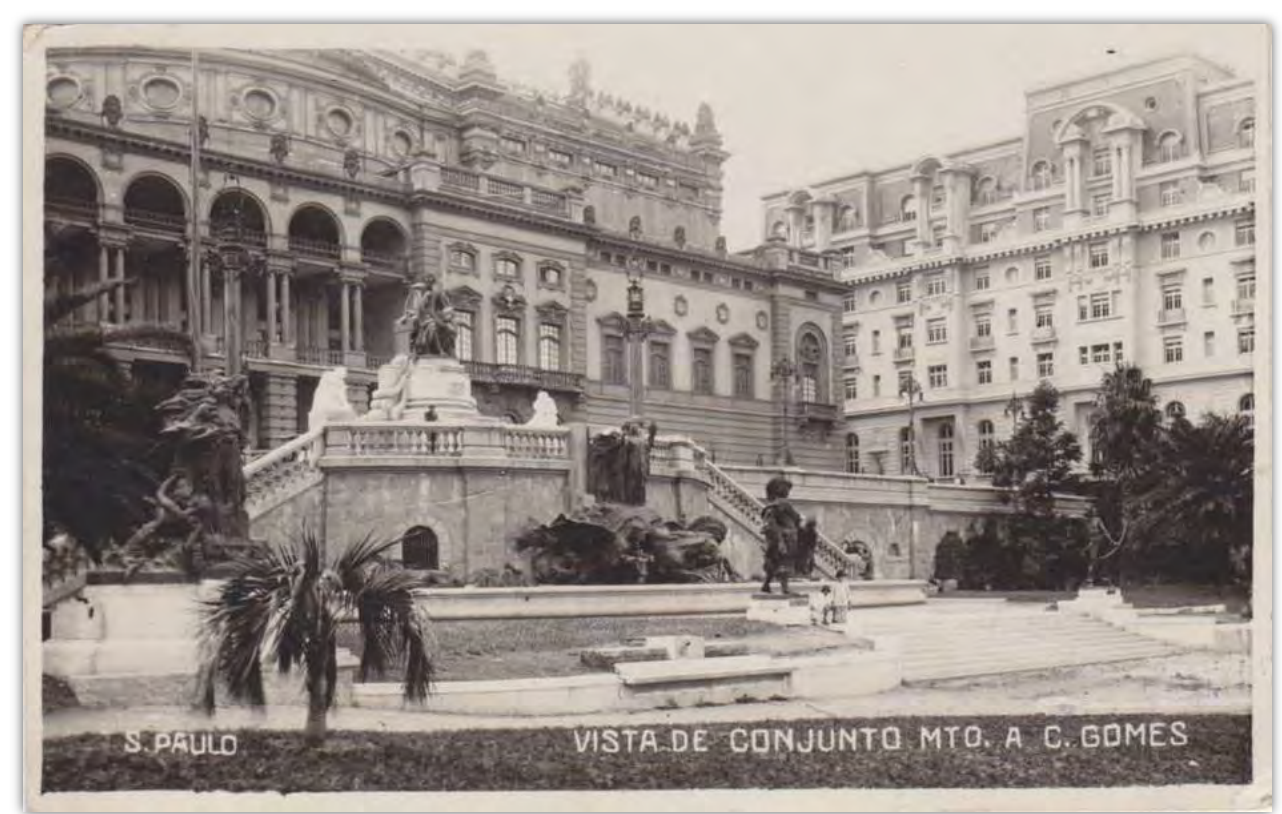

Figura 2.22 - Monumento a Carlos Gomes, cartão-postal, década de 1920. Fonte: Sampa Histórica ${ }^{253}$.

fundamentavam as iniciativas de transformação urbana de ambas as cidades eram semelhantes. Vista como um marco, a edificação do Municipal no centro da capital paulista é o primeiro monumento assumido pelo poder público, implicando muitas desapropriações e a urbanização de uma grande área central da cidade para viabilizá-lo (SEGAWA, 2000). Sobre a história do Theatro Municipal de São Paulo, ver também Amaral (2006).

252 Além de contar com exposições e espetáculos estrangeiros que reforçariam a imagem da cidade progressista à europeia, o Theatro Municipal de São Paulo, no final da década de 1910, abrirá espaço para a montagem dramáticomusical do texto $O$ contratador de diamantes, obra póstuma de Afonso Arinos, que em 1915 já havia proferido no mesmo local a conferência "Lendas e tradições brasileiras". Segundo o jornal O Estado de S. Paulo, em 1919, dias antes da estreia da peça, "não se fala[va] em outra coisa nas rodas artísticas e mundanas da nossa capital (...) [que não fosse] pôr em cena aqueles admiráveis quadros do Brasil colonial, do Brasil das bandeiras e das minas, do Brasil heroico" (apud SEVCENKO, 1992, p. 240).

253 Disponível em: <https://sampahistorica.wordpress.com/2013/08/02/monumento-a-carlos-gomes/>. Acesso em: 10 fev. 2017. 
Encomendado a Luigi Brizzolara, que na mesma época esculpia Fernão Dias e Raposo Tavares para o Museu Paulista, o Monumento a Carlos Gomes é inaugurado na atual praça Ramos de Azevedo, fixando em bronze e mármore sua presença na cidade no dia 12 de outubro, data em que também é comemorada a chegada do italiano Cristóvão Colombo à América. Ainda no século XIX, Carlos Gomes já havia dado nome a uma praça no bairro da Liberdade, no centro da capital, tal como aparece no mapa da cidade de 1895; enquanto Cristóvão Colombo, na mesma década de 1890 irá batizar outra via na região central, na Sé254. A obra de Brizzolara irá homenagear um compositor que não apenas apresentou suas obras na Itália, como também lá as compôs, além de ter dedicado aos italianos a ópera Salvador Rosa (1874), homenagem ao pintor, poeta, ator e músico napolitano homônimo do período barroco.

Anos antes, na década de 1910, a comunidade italiana já havia se organizado para inaugurar um monumento em homenagem ao professor de Carlos Gomes, Giuseppe Verdi. Moldado em bronze por Amadeo Zani — também responsável por dois dos bandeirantes em bronze da escadaria principal do Museu Paulista, Paschoal Moreira Cabral e Bartolomen Bueno da Silva (o Anhanguera), mencionados no primeiro capítulo —, Giuseppe Verdi é inaugurado em 1921 na praça Verdi, região central, em frente ao prédio dos Correios. A homenagem ao compositor brasileiro, no entanto, não só é mais opulenta do que o tributo a um dos pais da ópera italiana, como até hoje se encontra na praça Ramos de Azevedo; Giuseppe Verdi, por sua vez, foi expulso de sua praça e levado ao parque do Anhangabaú em 1948, onde permanece timidamente exposto junto às escadas de acesso à rua Líbero Badaró ${ }^{255}$.

Mas os italianos não foram os únicos a marcarem presença na capital paulista durante as comemorações do Centenário da Independência do Brasil ${ }^{256}$. A colônia espanhola domiciliada em São Paulo, por exemplo, promove a Festa da $\operatorname{Flor}^{257}$. O dinheiro arrecadado durante o evento é

\footnotetext{
${ }^{254}$ A rua Cristóvão Colombo foi oficializada pela resolução no 03, de 24 de outubro de 1892. Já Carlos Gomes, não somente aparece como nome de uma rua no mapa da cidade de 1895, como no século seguinte irá nomear uma rua no Tucuruvi, zona norte da cidade, oficializada pela lei $\mathrm{n}^{\circ} 4.371$, de $1^{\circ}$ de janeiro de 1953 . Cf. Núcleo de denominação de logradouros públicos, AHMWL.

255 Entre os primeiros monumentos paulistanos, temos também um busto em bronze doado pela comunidade italiana em homenagem ao compatriota Giuseppe Garibaldi. Já aqui os laços entre Itália e Brasil estavam presentes. Giuseppe Garibaldi é esculpido por Emilio Gallori e inaugurado em 1910 no jardim da Luz. Disponível em: <http://www.prefeitura.sp.gov.br/cidade/upload/Inventario_de_Esculturas_1261586685.pdf>. Acesso em: 7 fev. 2017.

${ }^{256}$ No último censo demográfico do século XIX, a capital paulista somava cerca de 240 mil habitantes, oito vezes mais em relação ao censo anterior; já em 1920, São Paulo chega a aproximadamente 580 mil habitantes, em grande parte devido aos imigrantes recém-chegados que, naquele ano, somavam cerca de 205 mil. Dados disponíveis em: <http://smdu.prefeitura.sp.gov.br/historico_demografico/index.php>. Acesso em: 23 jan. 2017.

257 “Olavo Bilac y el Centenario”. Diario Español, 30 ago. 1922, p. 1.
} 
revertido em benefício da conclusão das obras do Monumento a Olavo Bilac ${ }^{258}$. Os sírio-libaneses, que formavam a quarta colônia em número de imigrantes, oferecem um monumento para enfatizar sua amizade com os brasileiros, encomendado a Ettore Ximenes, na mesma época em que o escultor fazia o Monumento à Independência ${ }^{259}$. Trata-se da obra Amizade sírio-libanesa, que assim como tantas outras se deslocará pela cidade depois de ser instalada em 1928 em frente ao Palácio das Indústrias, atual Museu Catavento ${ }^{260}$. Já a colônia japonesa doa ao Museu Paulista uma série de armas medievais $^{261}$. Enviadas do Japão, elas compunham a armadura completa de um samurai para comemorar a passagem do centenário ${ }^{262}$.

Os monumentos e seus movimentos revelam assim distintos embates que ora ocultam ora evidenciam diferentes narrativas ${ }^{263}$. Vimos que várias entidades e segmentos da população, que não

258 Se, por um lado, a colônia espanhola ajudou na década de 1920 a financiar o Monumento a Olavo Bilac, inaugurado nas
proximidades da rua da Consolação, o próprio bairro da Consolação irá abrigar na mesma época uma rua chamada
Espanha, aceita e declarada entregue ao trânsito público no ano de 1924, por meio do ato no 2.455 , de 20 de
setembro. Atualmente, temos além dela a praça Comunidade Espanhola, no bairro de Santo Amaro; a rua dos
Espanhóis, na Vila Guilherme; e a travessa Espanhola, no Iguatemi. Assim como as ruas Madri, Burgos, Vigo e
Málaga, na Vila Prudente; a rua Barcelona, no Butantã; a rua Sevilha, no Tucuruvi; a rua Salamanca, no Grajaú; a
travessa Oviedo, em Vila Formosa; as ruas Bilbao e Ávila, no Jabaquara; a rua Golfo de Cádiz, em Anhanguera; a
travessa Santander, em Parelheiros; a rua Toledo, em Tremembé; entre outras homenagens a localidades da
Espanha. Isso sem mencionar as personalidades espanholas. Cf. Núcleo de denominação de logradouros públicos, AHMWL.

${ }^{259}$ Carta de Fares Nagm a Firmiano de Morais Pinto, 24 out. 1921. APMP/FMP, pasta 115.

${ }^{260}$ Em 1988, o monumento Amizade sírio-libanesa foi deslocado para a praça Ragueb Chohfi, no início da rua 25 de Março, com o argumento de que a proximidade de estabelecimentos comerciais evitaria que ele fosse depredado. Disponível em: <http://www.prefeitura.sp.gov.br/cidade/upload/Inventario_de_Esculturas_1261586685.pdf>. Acesso em: 7 fev. 2017.

${ }^{261}$ Carta do ministro e secretário da Fazenda Rafael de Abreu Sampaio Vidal a Afonso Taunay, 24 out. 1924. APMP/FMP pasta 122.

${ }^{262}$ Em meio a um movimento na Europa que previa a política da eugenia, São Paulo impôs graves entraves à introdução de mão de obra asiática no país. Tais entraves podem ser igualmente observados nos espaços da cidade. Ao que parece, nas primeiras décadas do século XX não há nenhum monumento público em homenagem ao Japão ou à comunidade japonesa. O Jardim japonês, no largo da Pólvora, data de 1974; o Monumento aos pioneiros da imigração japonesa, no parque do Ibirapuera, de 1975; o Setenta anos da imigração japonesa e o Sonho e gratidão: monumento em bomenagem ao centenário da imigração japonesa, ambos no parque do Carmo, datam respectivamente de 1978 e 2008 ; enquanto o Oitenta anos da imigração japonesa, localizado na avenida 23 de Maio, remonta a 1988. Disponível em: <http://www.prefeitura.sp.gov.br/cidade/upload/Inventario_de_Esculturas_1261586685.pdf>. Acesso em: 7 fev. 2017.

263 Para além dos monumentos, de acordo com O Estado de S. Paulo e a Folha de S.Paulo, em 1922, durante o bailado do centenário organizado pelo secretário do Interior, tivemos, por exemplo, o samba concorrendo com apresentações de danças francesa, sueca, holandesa e oriental. De modo similar, na festa paralela organizada no largo do Cambuci, as barracas comemorativas das quermesses receberam denominações como Brasil, Portugal, Síria, Itália, Alemanha, Suíça, França, Inglaterra, Americana, Bélgica e Espanha. Os marujos ingleses que se encontravam em São Paulo por ocasião das comemorações organizaram uma partida de futebol com o Club Athletico Paulistano. O Cercle Français de São Paulo promoveu um sarau musical e literário em homenagem às festas centenárias. A Maison Suisse fez uma 
estavam diretamente ligados à Comissão Oficial dos Festejos Comemorativos do Centenário, também irão se envolver com os preparativos para as festas paulistas. Todavia, se São Paulo "ganhou uma porção de presentes" durantes as celebrações de 1922, alguns foram vistos como "bons, dignos, apresentáveis", obras que "a gente põe logo no salão de visitas ou no living room”; outros foram considerados "envergonhantes, difamatórios, comprometedores", desses que "a gente coloca na dispensa, entre restos de cebola e latas de feijão", dirá um texto publicano no Diário Nacional, assinado por Urbano ${ }^{264}$.

No final dos anos 1920, na primeira página do jornal Progresso - mensário que declarava ter como finalidade "propugnar pelos oprimidos" e como diretriz "elevar o nome da (...) Raça [negra] (...) cuja escravidão é uma mancha na história da nossa civilização"265 — João Eugênio da Costa constata que "só nós pretos (...) não temos ainda numa praça um homem que na mudez do bronze fale do valor do negro que [a Princesa] Isabel fez ingressar na sociedade que o relegava"266. $\mathrm{Na}$ mesma época, um grupo de intelectuais e ativistas vinculados ao mesmo jornal lidera uma campanha pública pela construção de uma herma em homenagem ao abolicionista Luiz Gama ${ }^{267}$. Inaugurada em 1931, no largo o Arouche, a obra esculpida por Yolando Mallozzi (1901-?) permanece como uma das poucas homenagens à presença negra em logradouros públicos paulistanos, ao lado da Mãe Preta, que data dos anos 1950, como veremos ${ }^{268}$.

Em meio às disputas pelos espaços da cidade, Afonso Taunay é um dos convidados para integrar o júri que avaliaria o projeto de erigir um monumento na cidade em homenagem a Carlos

reunião da colônia para celebrar a data. O colégio Sírio-Brasileiro, uma sessão cívica solene. Já o aviador italiano Robba, ao sobrevoar a cidade, lançou 30 mil folhetos contendo saudações das associações italianas da capital, para ficarmos em apenas alguns exemplos.

264 “Monumentos". Diário Nacional, 4 mai. 1925, p. 4.

265 “O 'Progresso"”. Progresso, 23 jun. 1928, p. 1.

266 “Nosso dever". Progresso, 26 set. 1929, p. 1.

${ }^{267}$ Sobre a trajetória da campanha pela construção de uma herma em São Paulo em homenagem a Luiz Gama, cf. Domingues (2016).

${ }^{268}$ Luiz Gama irá nomear também uma rua no Cambuci, centro de São Paulo, cuja denominação remonta à década de 1880. Em 1884, a Câmara Municipal recebeu um abaixo-assinado, cuja solicitação foi aprovada, pedindo que a rua aberta entre a Glória e a Mooca recebesse o nome de Luiz Gama. Tal logradouro teve seu nome oficializado pelo ato $n^{\circ} 479$, de 13 de julho de1933. Legislações anteriores: ato $n^{\circ}$ 972, de 24 de agosto de 1916. Um pequeno trecho desse logradouro foi considerado, no início dos anos 1930, parte integrante da rua Carneiro Leão, revoltando moradores, que exigiram o retorno da antiga denominação devido à "notória fama" da rua Carneiro Leão, conhecida por seus "cortiços", habitados por muitos imigrantes. Lembremos que a São Paulo do período passa a concentrar não somente proprietários industriais de origem estrangeira, como também pequenos e médios fazendeiros, e uma grande população operária, constituída na maior parte por imigrantes, em especial italianos, portugueses e espanhóis. Cf. Núcleo de denominação de logradouros públicos, AHMWL 
Gomes $^{269}$. Ironicamente, parte da elite paulista que se considerava (como Taunay ${ }^{270}$ ) descendente dos antigos bandeirantes irá apelidar uma das esculturas que compõe o conjunto monumental em homenagem ao compositor, chamada Guarany — em referência à ópera homônima, em italiano, de 1870 —, como “o índio milanês do Sr. Brizzolara" (PRADO, 1923, p. 290). Mas tudo isso não impediu que, no dia 7 de setembro de 1922, uma fila se formasse para assistir no cineteatro República a "um dos mais brilhantes" espetáculos da data centenária, segundo a Folha da Noite: justamente a sinfonia O Guarany, de Carlos Gomes ${ }^{271}$. Ao ser inaugurado, o Monumento a Carlos Gomes irá trazer à região do Anhangabaú um conjunto de esculturas em bronze e mármore, como o já mencionado Guarany.

Luigi Brizzolara optou por povoar a área ao redor de Carlos Gomes, esculpido em uma posição central e elevada, com algumas esculturas de personagens de suas óperas, como já havia feito William Zadig ao pôr, ao redor de Olavo Bilac, O caçador de esmeraldas, entre outros fragmentos em homenagem à obra do poeta. Embora Carlos Gomes seja exibido de corpo inteiro, enquanto Bilac segue uma tradição que se assemelha a herma de um homem público, é possível que Brizzolara tenha tomado conhecimento do projeto de Zadig antes de esboçar seu conjunto monumental, pois a maquete de Zadig lembra muito o primeiro esboço de Brizzolara (LOPES, 2012). Não por acaso, a comparação entre os dois conjuntos monumentais foi frequente nos periódicos da época, extrapolando, inclusive, a semelhança física das obras.

Poucos dias depois da inauguração do conjunto monumental de Brizzolara, por exemplo, o jornal Il Pasquino Coloniale publica a charge "Il dubbio di Billac! [A dúvida de Bilac]", na qual a figura escultórica do poeta é retratada se indagando do alto de seu pedestal: "Dio Mio! Se han tagliato la testa a [Carlos] Gomes, che cosa faranno della mia statua? [Meu Deus! Se cortaram a cabeça de Gomes o que farão com minha estátua?]" ${ }^{272} \mathrm{O}$ questionamento é uma referência à escultura central em homenagem ao compositor, que havia causado certo desconforto entre a comunidade italiana de São Paulo devido a uma possível semelhança com o político brasileiro José Gomes Pinheiro

\footnotetext{
${ }^{269}$ Carta do vice-prefeito a Afonso Taunay, 18 mar. 1922. APMP/FMP, pasta 116. Anos depois, o próprio Taunay terá um busto em sua homenagem instalado no largo do Arouche. Esculpido em bronze por Claudie Dunin, Afonso d'Escragnolle Taunay é inaugurado em 1965 ao lado das esculturas francesas Amor materno e $A$ menina e o bezerro, retiradas em 1922 da praça Ramos de Azevedo para dar lugar ao Monumento a Carlos Gomes. Disponível em: <http://www.prefeitura.sp.gov.br/cidade/upload/Inventario_de_Esculturas_1261586685.pdf>. Acesso em: 7 fev. 2017.

${ }^{270}$ Em sua História Geral das Bandeiras Paulistas, Taunay afirma ser ele mesmo descendente, por parte de mãe, dos primeiros povoadores da vila de São Paulo, os “patriarcas” João Ramalho e Tibiriçá.

271 “O centenário". Folha da Noite, 7 set. 1922, p. 3.

272 “Il dubbio di Billac!”. Il Pasquino Coloniale, 28 out. 1922, p. 4.
} 
Machado, cujo assassinato a punhaladas em 1915 causou grande comoção na época, o que levou Brizzolara a refazer a cabeça de Carlos Gomes.

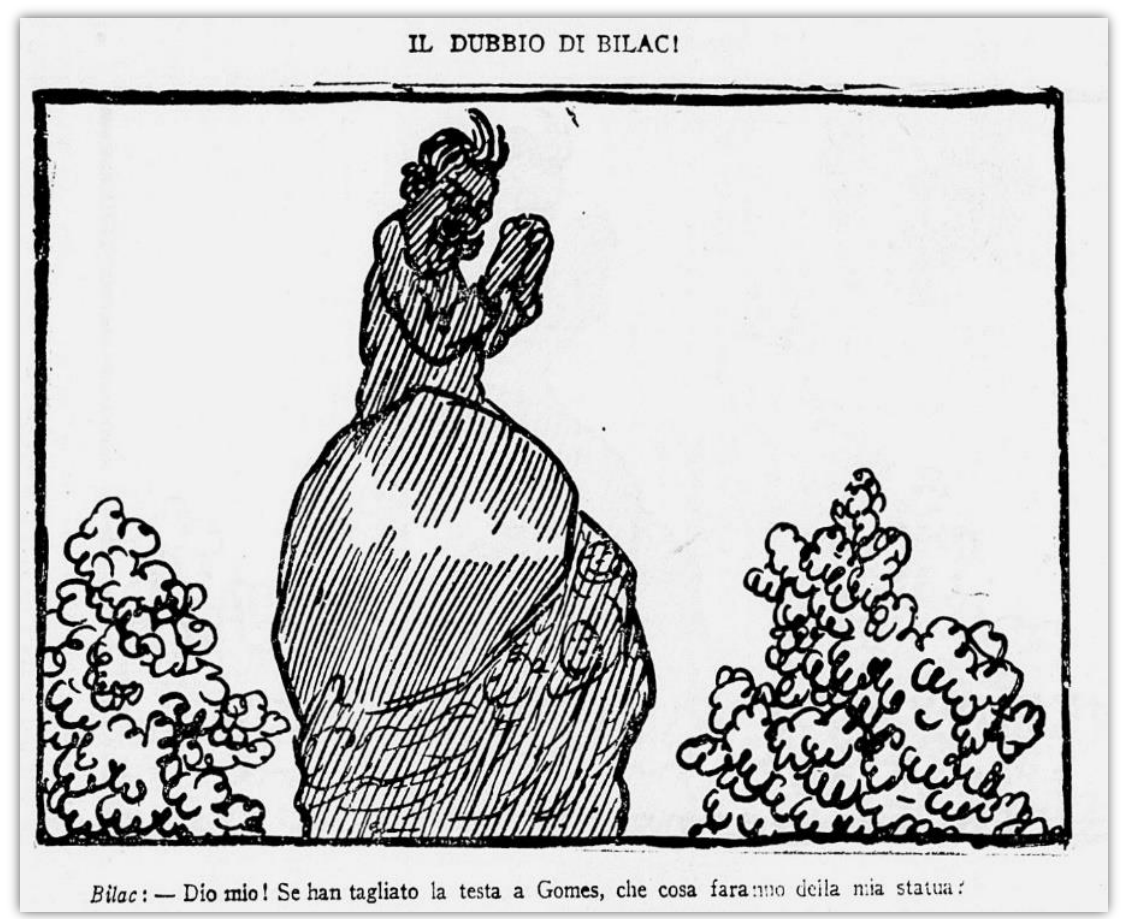

Figura 2.23 - Charge “Il dubbio di Bilac?”, 1922. Fonte: Il Pasquino Coloniale, 28 out. 1922, p. 4.

A semelhança entre Carlos Gomes e Pinheiro Machado não passou despercebida pela imprensa paulista: a Folha da Noite, por exemplo, de pronto tratou de debochar da situação ${ }^{273}$. Uma charge publicada na capa do periódico no mesmo dia em que é inaugurado o Monumento a Carlos Gomes, intitulada "As nossas estátuas", de Benedito Carneiro Bastos, conhecido como Belmonte (autor, no década seguinte, do livro No tempo dos bandeirantes, por ele ilustrado), relembra um episódio parecido que ocorrera anos antes por ocasião da inauguração de outra escultura, ao apresentar um busto com a seguinte legenda: "Fagundes Varela, fantasiado de Álvares de Azevedo, exibe duas folhagens onde deveria ter os braços e as mãos"274. Assim como o Monumento a Olavo Bilac, a escultura Alvares de Azevedo foi uma encomenda de alunos e ex-alunos da atual Faculdade de Direito do largo de São Francisco. Moldado em bronze pelo italiano Amadeo Zani, o busto de

\footnotetext{
${ }^{273} \mathrm{O}$ mesmo periódico irá criticar o fato das estátuas do conjunto monumental em homenagem a Olavo Bilac estarem espalhadas pelo jardim ao afirmar ainda que os fragmentos "não dão a ideia de pertencer ao mesmo monumento, separados como estão uns dos outros”. Cf. “O monumento a Olavo Bilac”, Folha da Noite, 18 out. 1922, p. 1.

274 “As nossas estátuas”, Folha da Noite, 12 out. 1922, p. 1.
} 
Álvares de Azevedo foi inaugurado na praça da República, em 1907, causando muita polêmica ao ser confundido com a figura de outro poeta, Fagundes Varella ${ }^{275}$.

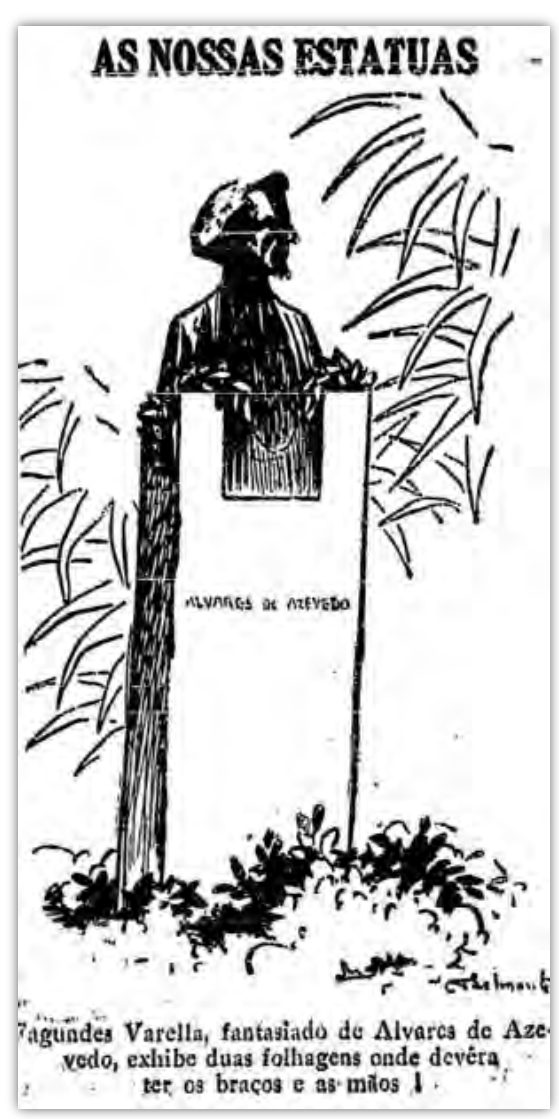

Figura 2.24 - "Fagundes Varela, fantasiado de Álvares de Azevedo", charge de Belmonte, 1922. Fonte: Folha da Noite, 12 out. 1922, p. 1.

Outra charge, "La decapitaz̧ione di... Carlos Gomes [A decapitação de... Carlos Gomes]", publicada em Il Pasquino Coloniale, prevê a literal degola da estátua que, no desenho, é observada por um jornalista da Folha da Noite. Literal porque depois da troça iniciada pela imprensa paulista, que incomodou membros da colônia italiana, Luigi Brizzolara se dispôs a refazer a cabeça do compositor, deixando-o acéfalo na esplanada do Theatro Municipal durante um mês, em janeiro de 1926, quando novamente chama a atenção do periódico. Na ocasião, mais uma charge, "Un'altra

\footnotetext{
275 Nos anos 1950, depois de uma longa polêmica acerca da semelhança do retrato esculpido de Álvares de Azevedo com Fagundes Varela, a obra foi levada para um depósito municipal, onde permaneceu até o começo da década de 1980, quando foi transferida para a praça Fagundes Varela. Em 1985, a escultura retorna para a praça da República, de onde é retirada em 2006 para ser instalada no largo de São Francisco, próxima ao Beijo eterno, de William Zadig. Disponível em: <http://www.prefeitura.sp.gov.br/cidade/upload/Inventario_de_Esculturas_1261586685.pdf>. Acesso em: 7 fev. 2017.
} 
testa tagliata! [Outra cabeça cortada]", é publicada em Il Pasquino Coloniale, dessa vez com o busto decapitado de Carlos Gomes que, carregado por dois homens, se pergunta: "Quando finirá il mio martirio? [Quando terminará meu martírio?]"276.
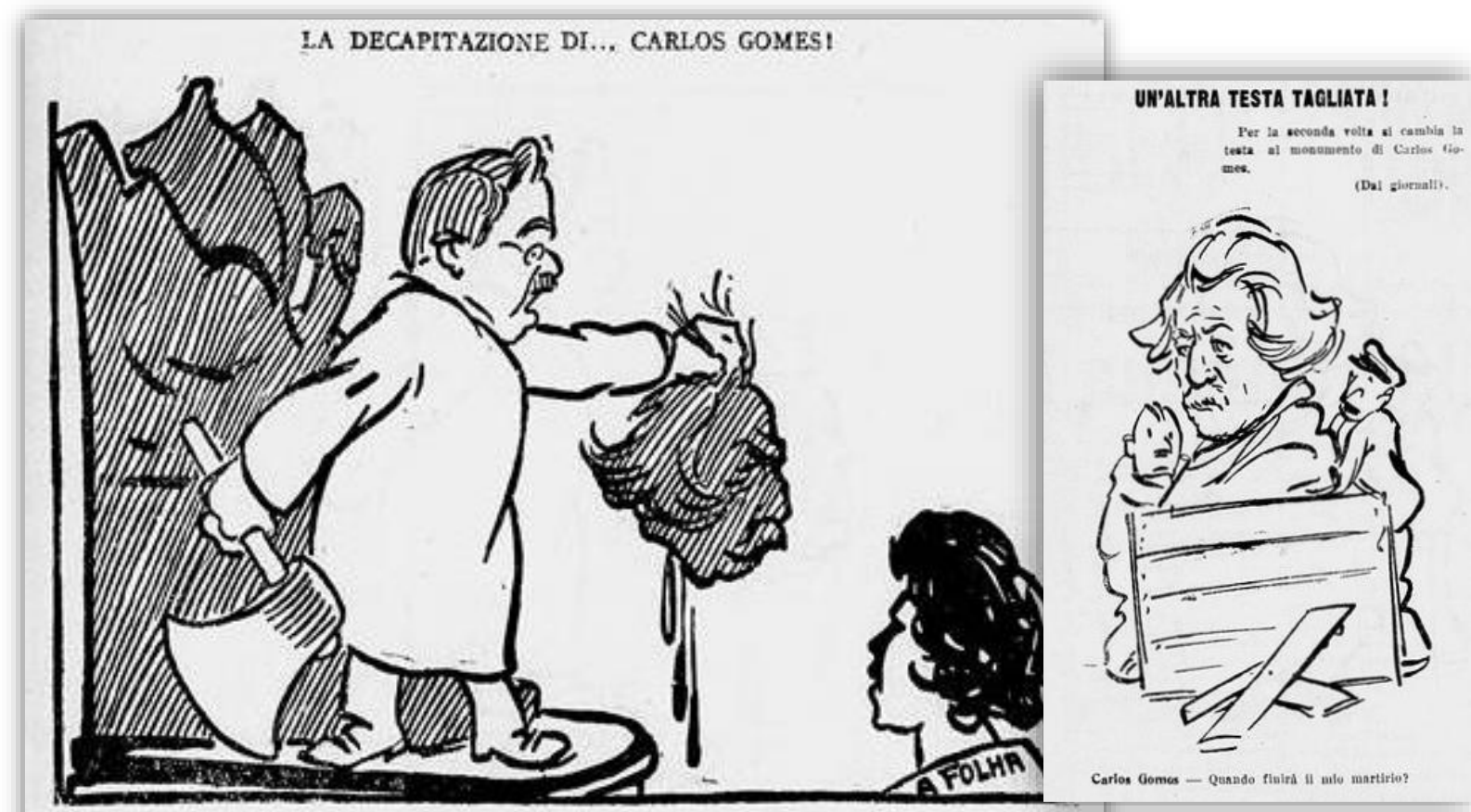

Brissoiura (rivolto alla "Folha da Noite") : - Placati, crudele, col suo sangue!

Figura 2.25 - A decapitação e o martírio do Monumento a Carlos Gomes, charges dos anos 1920. Fonte: Il Pasquino Coloniale, 28 out. 1922, p. 3 / Il Pasquino Coloniale, 30 jan. 1926, p. 6.

Ao relembrar o ocorrido, Afonso Taunay (1939, p. 70-71) explica que o escultor havia se inspirado inicialmente em uma fotografia do compositor, tirada nos anos 1870 (mesmo ano da estreia da ópera O Guarani na Itália), que pouco parecia com a "efígie de Carlos Gomes tal qual estamos acostumados a reconhecer-lhe os traços". Taunay afirma ter ele mesmo providenciado outra efígie, que teria sido tomada como modelo por Bizzolara, "deixando efetuada a metamorfose" que deu origem a atual cabeça da escultura central do monumento, assim "reintegrando Carlos Gomes magnificamente", nos termos de Taunay (1930, p. 71).

Embora não tenham sido degolados, os personagens do Monumento a Olavo Bilac também passaram por um longo martírio. "Policiais severos" faziam a guarda do monumento em homenagem ao poeta, protegendo-o "contra pretensos iconoclastas ou gente com isso parecida",

276 “Un'altra testa tagliata!”. Il Pasquino Coloniale, 30 jan. 1926, p. 2. 
relata nos anos 1920 um articulista do periódico carioca $O$ Imparcia $^{277}$. Tal qual ocorrera com o Monumento a Carlos Gomes, foram constantes os ataques à obra de William Zadig desde sua inauguração. A Gaz̧eta, por exemplo, inicia em 1922 uma campanha contra o "aleijão" de umas das mais "lindas e aristocráticas avenidas de S. Paulo" e acusa o "trambolho" esculpido por Zadig de ser um "atentado à memória", de modo que deveria ser destruído ou refundido ${ }^{278}$.

Poucos dias depois do início da campanha contra o "aleijão da avenida", o jornal Folha da Noite publica outra charge de Belmonte, intitulada "As nossas estátuas", na qual o cartunista compara ironicamente a figura de Olavo Bilac a de um leiloeiro com um martelo em punho apregoando o maior lance ${ }^{279}$.

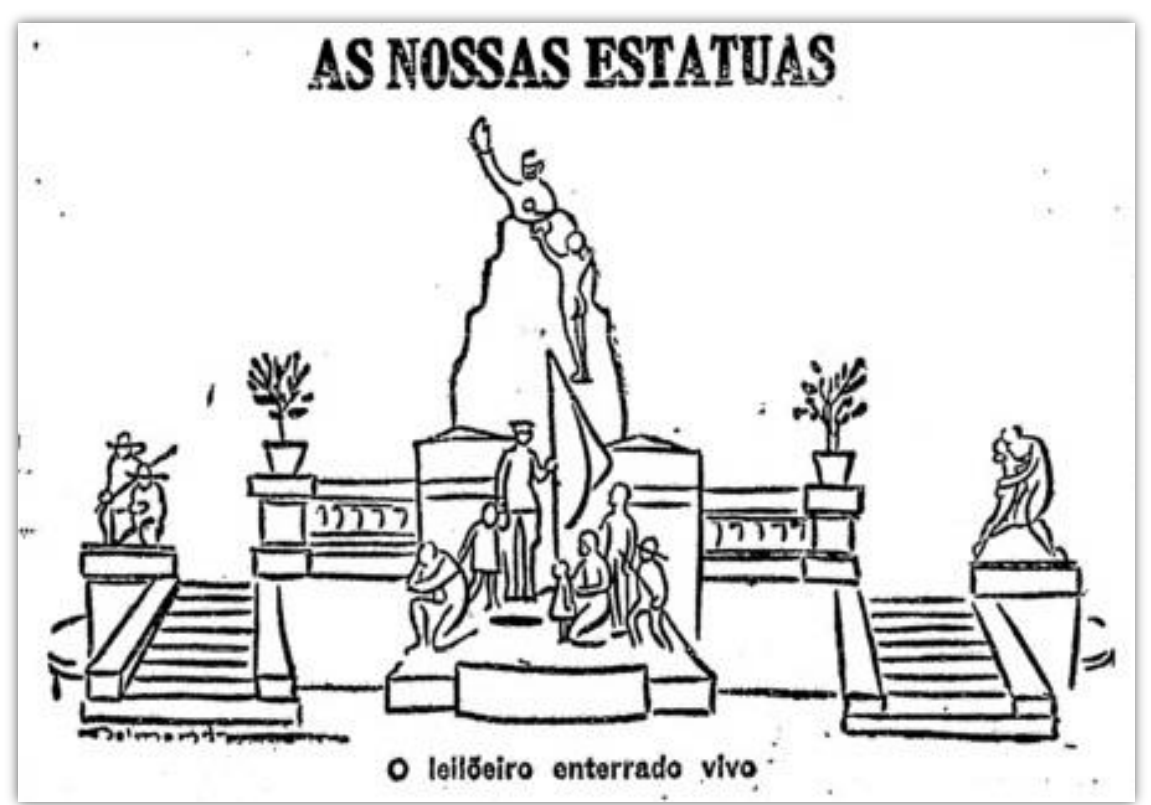

Figura 2.26 — “O leiloeiro enterrado vivo", charge de Belmonte, 1922. Fonte: Folha da Noite, 18 out. 1922, p. 1.

Em 1936, porém, o conjunto monumental em homenagem a Olavo Bilac é removido da primeira via da cidade batizada como "avenida”, ocasião em que é retalhado e encaminhado para um depósito municipal. Nesse sentido, enquanto o Museu Paulista é visto como um Palácio de Versalhes em terras bandeirantes e o mosteiro de São Bento como uma importante

\footnotetext{
277 "Bronzes paulistas". O Imparcial, 18 jan. 1923, p. 2.

278 "O aleijão da avenida". A Gaz̨eta, 7 nov. 1922, p. 1. Em novembro de 1922 foram publicadas mais de dez matérias sobre o mesmo assunto no jornal $A$ Gazeta, todas elas intituladas "O aleijão da avenida".

279 “Nossas estátuas". Folha da Noite, 18 out. 1922, p. 1.
} 
obra de remodelação da cidade inspirada na reurbanização de Paris, a avenida Paulista é uma reelaboração paulistana das consagradas avenues parisienses, para onde se deslocaram numerosos imigrantes que haviam feito fortuna na segunda metade do século XIX. Recorrentemente lembrada como um local privilegiado dos "barões do café" e de seus descendentes, cujas genealogias se estenderiam até os bandeirantes do período colonial, trata-se de uma avenida marcada pela construção de residências de imigrantes, palco de afirmação das novas fortunas e, sobretudo, de disputas a partir de uma condição estrangeira ${ }^{280}$.

Pouco antes de $O$ caçador de esmeraldas ser enviado ao depósito na Várzea do Carmo, outra escultura bandeirante irá desbravar a avenida, já marcadamente imigrante, a partir de outro antigo belvedere, o Trianon, atual Museu de Arte de São Paulo (Masp). Trata-se de Bartolomeu Bueno da Silva, conhecido popularmente como Anhanguera. Esculpida em mármore pelo mesmo Luigi Brizzolara a pedido do governo do estado de São Paulo, a obra foi inaugurada em 1924 nos jardins do Palácio dos Campos Elíseos, próxima à rua Anhanguera ${ }^{281}$. Na década de 1930, a estátua Anhanguera é transferida para as vizinhanças da residência Villa Virgínia, construída nos anos 1890 para o italiano Francisco Matarazzo, criador do maior complexo industrial da América Latina do início do século $\mathrm{Xx}^{282}$. Um dos mais célebres imigrantes a residir na Paulista, Matarazzo havia se comprometido com a realização do Monumento a Carlos Gomes, além de ter encomendado a Brizzolara um mausoléu colossal para sua família, no cemitério da Consolação ${ }^{283}$.

280 As elites imigrantes que lá residiam no período adotaram vocabulários arquitetônicos alinhados com suas respectivas origens nacionais e étnicas, diferentemente do que ocorreu nas avenues parisienses e em seus congêneres europeus e americanos. Cf. Marins (2016) e Homem (1996).

281 A rua Anhanguera foi nomeada pelo ato no 972, de 24 de agosto de 1916. Cf. Núcleo de denominação de logradouros públicos, AHMWL.

282 Enquanto o prefeito Antônio Prado se preocupava com a remodelação do centro da cidade, Francisco Matarazzo preparava os terrenos alagadiços da zona oeste para erguer suas indústrias. Anos depois, Matarazzo se tornará, ele mesmo, figura em bronze, além de nomear, na década de 1950, uma importante avenida na Água Branca. Logo após Anhanguera ser levado para a região da Paulista, o artista italiano Giandomenico de Marchis presenteou a família Matarazzo com uma estátua em homenagem ao fundador das Indústrias Reunidas Matarazzo. Inaugurada no final dos anos 1930 em frente aos portões de entrada das fábricas Matarazzo, na zona oeste da cidade, a escultura Conde Francisco Matarazzo foi transferida nos anos 1980, com a falência da empresa, para a praça Souza Aranha, na mesma região. Atualmente, a obra se encontra na praça Raízes da Pompeia, cercada e fechada com cadeado, o que lhe rendeu em 2014 a manchete "Estátua de conde vai parar atrás das grades na Pompeia, em SP", no jornal Folha de S.Paulo. Disponível em: <http://www1.folha.uol.com.br/cotidiano/2014/03/1420342-estatua-de-conde-vai-parar-atras-dasgrades-na-pompeia.shtml>. Acesso em: 7 fev. 2017.

283 O mesmo espírito que presidiu na década de 1920 a implantação de diversos monumentos em logradouros públicos atinge também a "cidade dos mortos", em especial o cemitério da Consolação. Os túmulos monumentais, como o da família Matarazzo, evidenciam a produção de esculturas nos cemitérios da cidade, grande parte deles encomendados a artesãos ou artistas de origem italiana. Cf. Valladares (1972). 
Em 1935, Anhanguera deixa a avenida Rio Branco e segue rumo ao parque Tenente Siqueira Campos, pouco antes de sua imagem estrear na capa da revista $S$. Paulo, periódico que também homenageará Fernão Dias e Raposo Tavares, igualmente esculpidos por Brizzolara, em outras edições publicadas em 1936:

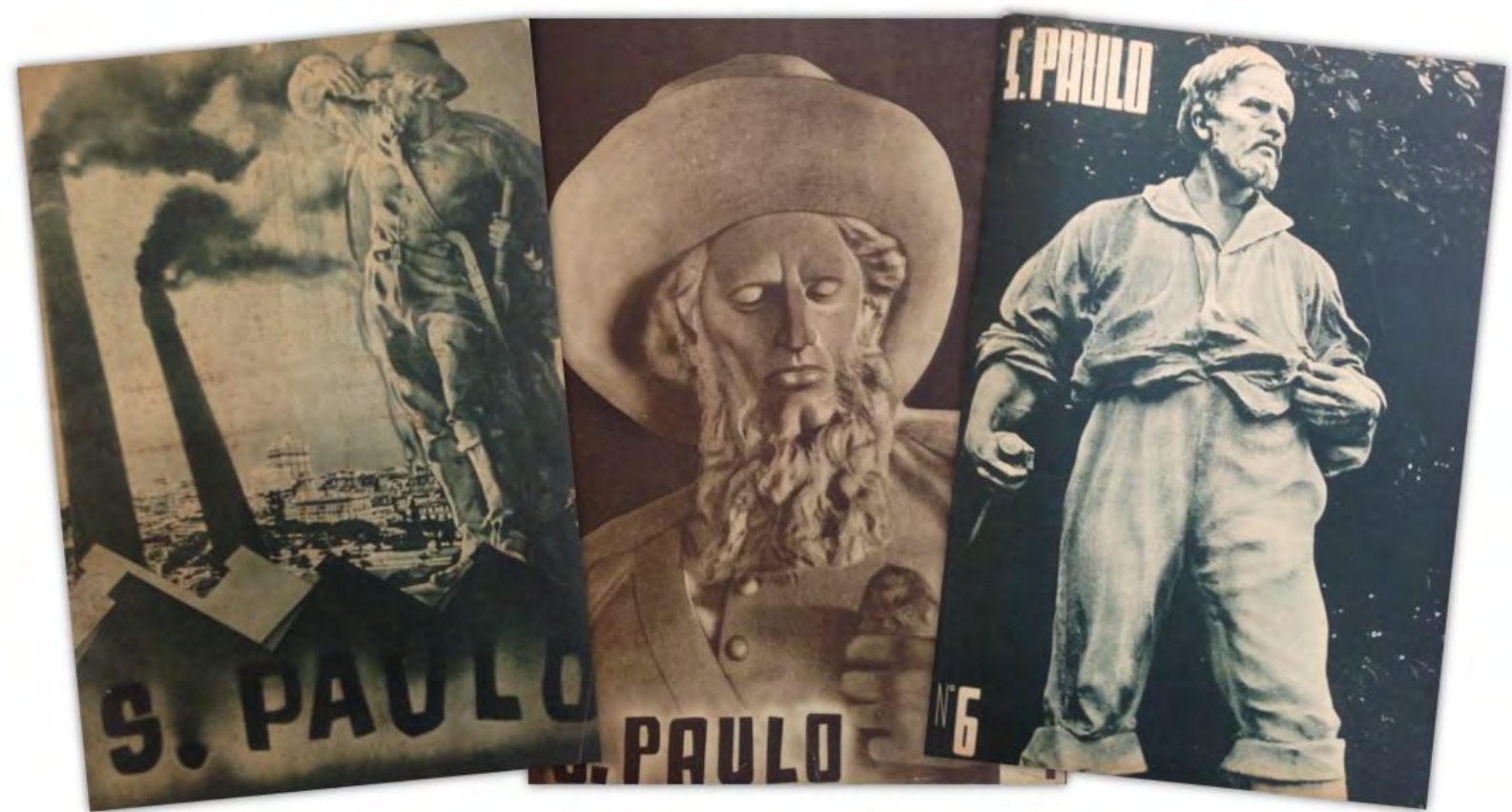

Figura 2.27 - Capas da revista S. Paulo, 1936. À esquerda, Raposo Tavares, à direita Anhanguera, e ao centro Fernão Dias, todos esculpidos por Luigi Brizzolara. Fonte: Acervo Pessoal | Foto: Thaís Waldman.

Diferente dos demais bandeirantes de Brizzolara, Anhanguera não usa chapéu de abas largas, nem gibão de armas, cinto ou manto, tampouco empunha arma de cano longo ou mesmo alguma faca ou pistola. Sua mão esquerda se aproxima do corpo, na altura da cintura, onde uma camisa amassada e semiaberta parece ter sido enfiada às pressas para dentro da calça, enquanto a mão direita segura uma adaga, arma pouco maior e mais larga que um punhal ${ }^{284}$. Fanny Tâmisa Lopes (2012) observa que Anhanguera se assemelha sensivelmente às esculturas que celebram heróis italianos, como o monumento Angelo Brunetti, detto Ciceruacchio, esculpido por Ettore Ximenes em homenagem ao mártir da unificação italiana e inaugurado em Roma em 1907.

${ }^{284}$ Já faz algumas décadas que a adaga de Anhanguera se encontra quebrada. Cristina Freire (1997) comenta que a arma parece ter sido tirada da mão da estátua por um homem que feriu seu rival nos anos 1970 em uma disputa pela mesma namorada. 

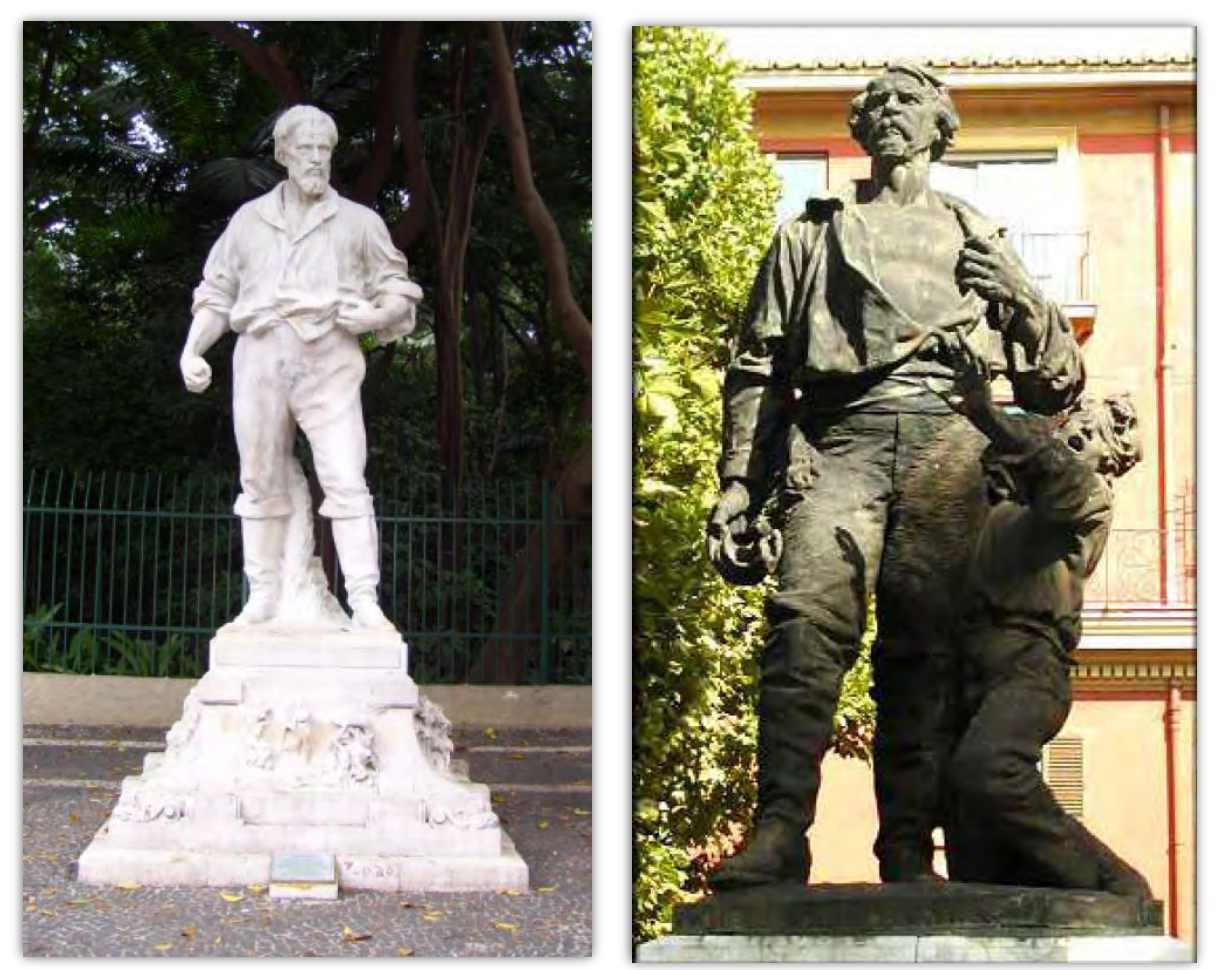

Figura 2.28 - À esquerda, Anhanguera, de Luigi Brizzolara. À direita, Angelo Brunetti, detto Ciceruacchio, de Ettore Ximenes.

Fonte: Cenografia e paisagem urbana: um estudo de caso na cidade de São Paulo (2012), de Fanny Tamisa Lopes, p. 206.

Na década de 1960, quando a sede do governo e a residência oficial do governador de São Paulo são transferidas à zona sul da cidade, para o Palácio dos Bandeirantes, localizado em um antigo terreno no bairro do Morumbi que pertencia a ninguém menos que a família Matarazzo, Anhanguera já tinha sido removido, havia muito, dos jardins do Palácio dos Campos Elíseos. Inclusive, durante a construção do edifício do palácio — quando a rodovia estadual Anhanguera atinge sua capacidade máxima e desbrava mais caminhos para originar o Sistema AnhangueraBandeirantes ${ }^{285}$ —, a imagem da estátua assinada por Luigi Brizzolara abandonará seu provincianismo paulistano para ganhar dimensão nacional. Em 1960, em uma propaganda eleitoral de Jânio Quadros (PTN), eleito presidente pouco depois com uma expressiva vitória, o bandeirante

285 A via Anhanguera, que liga São Paulo à região norte do estado, teve sua primeira pista pavimentada inaugurada em 1948, atingindo sua capacidade máxima por volta de 1960, quando a rodovia Bandeirantes é planejada visando justamente uma capacidade muito maior, dando origem ao Sistema Anhanguera-Bandeirantes. Sobre a antiga trilha indígena do século XVII, o Caminho dos Goyazes, nomeada rodovia Anhanguera, cf. Reis (2014). Cabe notar também que o primeiro acesso da capital ao oeste paulista, inaugurado em 1937, é nomeado rodovia Raposo Tavares nesse mesmo período, em 1954. 
aparece diante de duas bandeiras, uma do estado de São Paulo e outra do Brasil, e afirma ser a vez de São Paulo comandar o país.

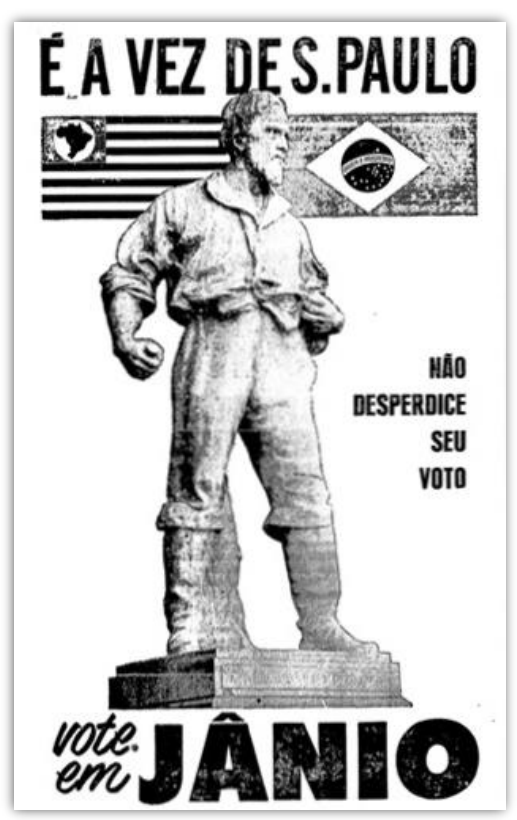

Figura 2.29 - Anhanguera em uma propaganda eleitoral de Jânio Quadros ${ }^{286}$. Fonte: Folha de S.Paulo, 1 out. 1960, p. 4.

Durante sua gestão como governador de São Paulo (1955-1959), também pelo PTN, assim como durante sua segunda gestão como prefeito (1986-1988) da capital paulista, pelo PTB, Jânio Quadros procurou devolver à cidade fragmentos do Monumento a Olavo Bilac. Depois de longa estada no depósito na Várzea do Carmo, O caçador de esmeraldas, Beijo eterno e Olavo Bilac não foram as únicas partes do conjunto monumental esculpido por William Zadig a acumularem idas e vindas pela cidade $^{287}$. No final da década de 1980, quando Bilac virou bronze no Ibirapuera, Jânio Quadros realocou dois outros fragmentos da obra, que faziam parte do pedestal central com o busto do poeta no topo: Tarde foi levado para o parque da Independência, e Pátria e família, instalado no cruzamento das avenidas Salim Farah Maluf e Celso Garcia. Tarde permaneceu no Ipiranga, na

\footnotetext{
286 Agradeço a Ricardo Assumpção pela indicação da imagem.

287 Outra obra de William Zadig também protagonizou uma grande peregrinação pela cidade. Trata-se de João Mendes, escultura em bronze inaugurada em 1913 na praça João Mendes, em homenagem ao advogado, jornalista e líder abolicionista. Transferida em 1943 para o largo Sete de Setembro, a obra foi abandonada em 1953 em um depósito municipal. Depois de ser realocada em 1960 no largo de São Francisco, João Mendes termina seu périplo em 1988, ao voltar para a praça João Mendes, não sem antes ter passado novamente, em 1986, pelo largo Sete de Setembro. Disponível em: <http://www.prefeitura.sp.gov.br/cidade/upload/Inventario_de_Esculturas_1261586685.pdf>. Acesso em: 7 fev. 2017.
} 
entrada do Museu Paulista; já Pátria e família ainda circularia pela região da Mooca (em 1999, foi transferida para a praça Kennedy e, em 2000, para a praça José Moreno).

Com base no banco de dados do Departamento de Patrimônio Histórico do município (DPH) é possível afirmar que o Monumento a Olavo Bilac foi o primeiro a vagar por depósitos municipais da cidade. Banidos da "aristocrática" avenida e relegados ao esquecimento durante anos, O caçador de esmeraldas e os demais pedaços do conjunto em homenagem ao poeta foram levados a uma região bem menos nobre. Embora o parque Dom Pedro II e suas alamedas arborizadas construídos na Várzea do Carmo, onde estava localizado o depósito municipal ${ }^{288}$ — tivessem sido entregues em 1922 à população, o lugar ainda era marcado por frequentes enchentes e problemas de insalubridade devido ao despejo de lixo e dejetos ${ }^{289}$.

\subsubsection{A transferência para a Escola Estadual Fernão Dias Paes}

O caçador de esmeraldas, separado dos demais fragmentos que compõem o Monumento a Olavo Bilac, ocupa hoje os jardins da Escola Estadual Fernão Dias Paes. Nesse sentido, se pensarmos na relação entre as partes e o todo, os fragmentos da obra de William Zadig se autonomizaram, pois parece haver uma passagem entre o monumento entendido como um conjunto e seus fragmentos como objetos autonômos ${ }^{290}$. É possível dizer, assim, que as imagens de Fernão Dias e Borba Gato desceram do antigo espigão da avenida Paulista, terminando por se aproximarem das margens do rio Pinheiros. Depois de anos de abandono, os dois bandeirantes vão parar em um local que leva o nome do protagonista do poema de Olavo Bilac, e isso ao se deslocarem da Paulista para um

\footnotetext{
288 Segundo as Atas e os Anais da Câmara Municipal de São Paulo da década de 1960, após serem levados para o depósito da Várzea do Carmo, alguns fragmentos do Monumento a Olavo Bilac passaram também por um depósito no Viveiro Manequinho Lopes, no Ibirapuera. Cf., por exemplo, os registros das sessões ordinárias $n^{\circ} 221, n^{\circ} 227, n^{\circ} 318$, realizadas entre 1965 e 1966, CMSP.

${ }^{289}$ Em 1892, anos antes de pintar Domingos Jorge Velho e o loco-tenente Antônio Fernandes de Abreu, Benedito Calixto já havia terminado outra tela pertencente ao acervo do Museu Paulista, intitulada Inundação da Várzẹa do Carmo, em referência à região que até hoje é conhecida por inundar durante as cheias do rio Tamanduateí. Sobre essa tela, cf. Meneses (1990).

290 Ao analisar os monumentos no imaginário urbano contemporâneo, Cristina Freire (1997, p. 255) observa a respeito do Monumento a Olavo Bilac que "um dia [as partes da obra] estiveram juntas num único lugar; hoje, dispersa, essa família simbolista traça destinos individuais para cada parte do monumento”.
} 
depósito no Glicério, e de lá para a zona oeste de São Paulo. Esquecidos durante anos na Várzea do Carmo, eles são transferidos para um dos bairros mais antigos da cidade.

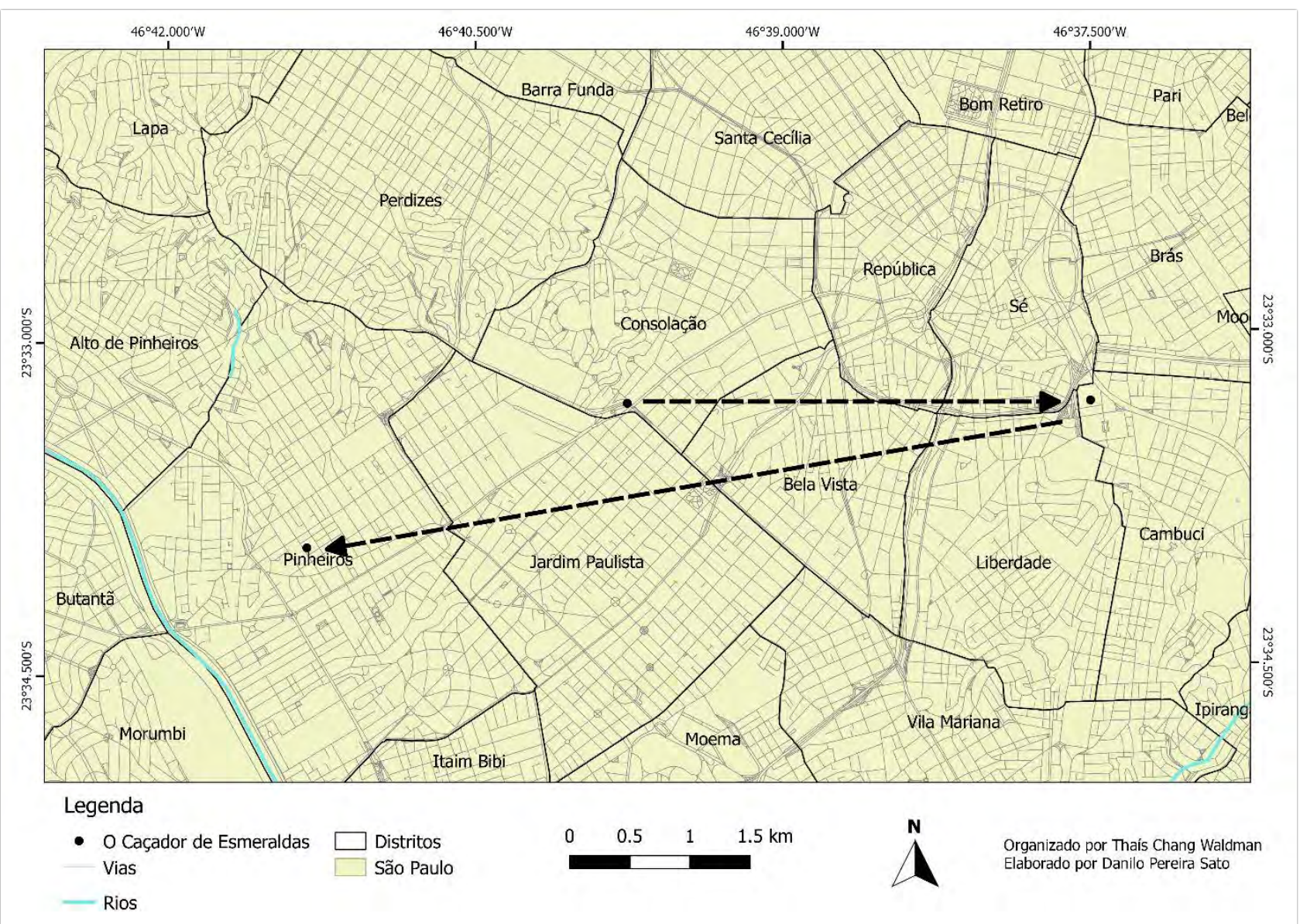

Figura 2.30 - Deslocamentos da escultura $O$ caçador de esmeraldas.

Fonte: GeoSampa e Memória da Amnésia ${ }^{291}$.

A escola que acolheu o fragmento escultórico leva nome de Fernão Dias por ter sido construída no local que fora a sede do sítio do Capão, propriedade que pertenceu à família do bandeirante (AMARAL, 1969). O caşador de esmeraldas revisita esse terreno (que se estendia desde a Vila Mariana até Pinheiros, passando pela Paulista no século Xx), não somente quando o Monumento a Olavo Bilac é inaugurado no antigo belvedere, mas também quando seu fragmento é levado para a escola estadual. Ao se deslocar ao longo dessa extensa propriedade que um dia pertencera à sua

${ }^{291}$ Disponível em: <http://www.prefeitura.sp.gov.br/cidade/secretarias/urbanismo/dados_abertos/> e <http://www.desvirtual.com/mda/guia-dos-monumentos-nomades/>. Acesso em: 5 fev. 2017. 
família, a imagem de Fernão Dias acaba nos jardins de um colégio batizado em 1950 em sua homenagem $^{292}$.

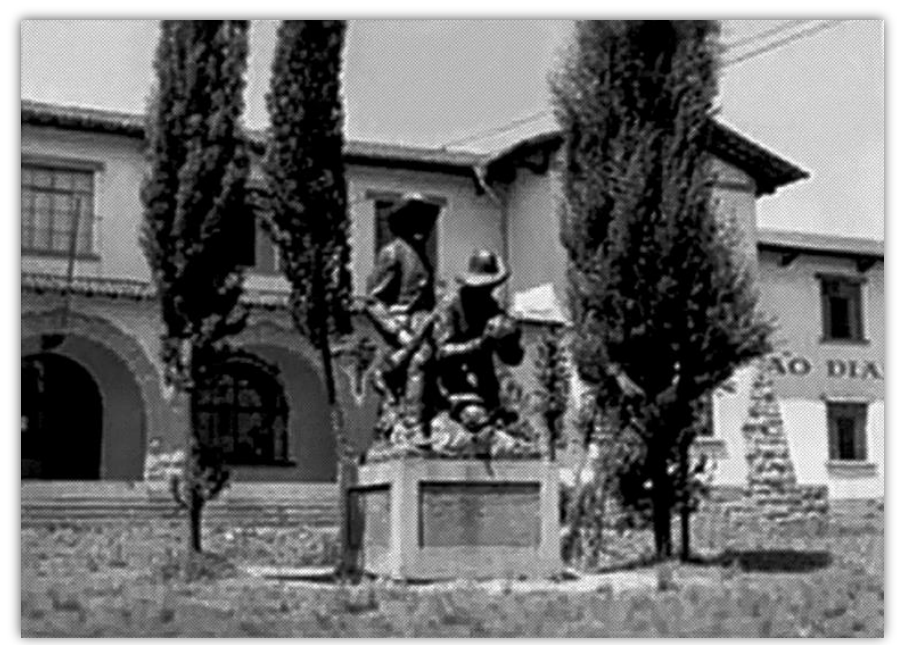

Figura 2.31 - O caçador de esmeraldas, anos 1950.

Fonte: Acervo da Associação dos Ex-alunos da Escola Estadual Fernão Dias Paes.

Não se sabe exatamente quando $O$ caçador de esmeraldas foi transferido da Várzea do Carmo para Pinheiros, nem quanto tempo ele ficou relegado ao depósito municipal. Pelas imagens disponíveis, e pelos depoimentos que obtive com alguns dos membros da associação dos ex-alunos do colégio ${ }^{293}$, é possível afirmar que desde meados dos anos 1950 — pouco antes o bandeirante reaparecer, em 1959, dando nome à rodovia que hoje liga São Paulo a Minas Gerais — a peça já se encontrava ali, em meio a alguns pinheiros plantados em homenagem ao bairro. Independente da data exata, o fato é que na década de 1920 Fernão Dias já havia sido convertido em mármore na colina do Ipiranga com uma função pedagógica; se ainda hoje o Museu Paulista é uma das instituições mais lembradas pela população $0^{294}$, em especial quando se trata de visitas museológicas

292 O Ginásio Estadual de Pinheiros recebe a denominação Fernão Dias em 1950. Cf. Decreto no 19.166, de 8 de fevereiro de 1950, Alesp. Um ano antes, em 1949, o paradeiro do Monumento a Olavo Bilac já havia se tornado pauta na Câmara Municipal de São Paulo: “1) Onde se encontra o Monumento a Olavo Bilac, retirado, por volta de 1934, da avenida Paulista? 2) Caso tenha sido vendido o bronze desse monumento, de autoria do escultor Zadig, qual a importância apurada? 3) Se for positiva a resposta do quesito anterior, desejamos saber se foi adotada, para a venda, o critério da concorrência pública. 4) De 1934 a esta parte, tomou a prefeitura qualquer providência no sentido de substituir o referido monumento?”. Cf. Requerimento 1513-49 da sessão ordinária no 232 da Câmara Municipal de São Paulo, assinado pelos vereadores Derville Allegretti, José de Moura e Ângelo Bôrtolo, CMSP.

${ }^{293}$ A Associação dos Ex-alunos da Escola Estadual Fernão Dias Paes foi criada em 2004 visando a melhoria da qualidade do ensino e a revitalização do colégio, além do compartilhamento de lembranças.

294 O Museu Paulista foi destaque da pesquisa Datafolha, publicada em 30 de março de 2015, sobre as marcas de serviço mais citadas na cidade de São Paulo pelas classes A e B, alvos do estudo. Disponível em: 
com fins didáticos ${ }^{295}$, O caşador de esmeraldas irá habitar, décadas depois de sua inauguração, justamente um estabelecimento de ensino - poucos anos antes de outro fragmento do Monumento a Olavo Bilac, o Beijo eterno, ser levado para a Faculdade de Direito.
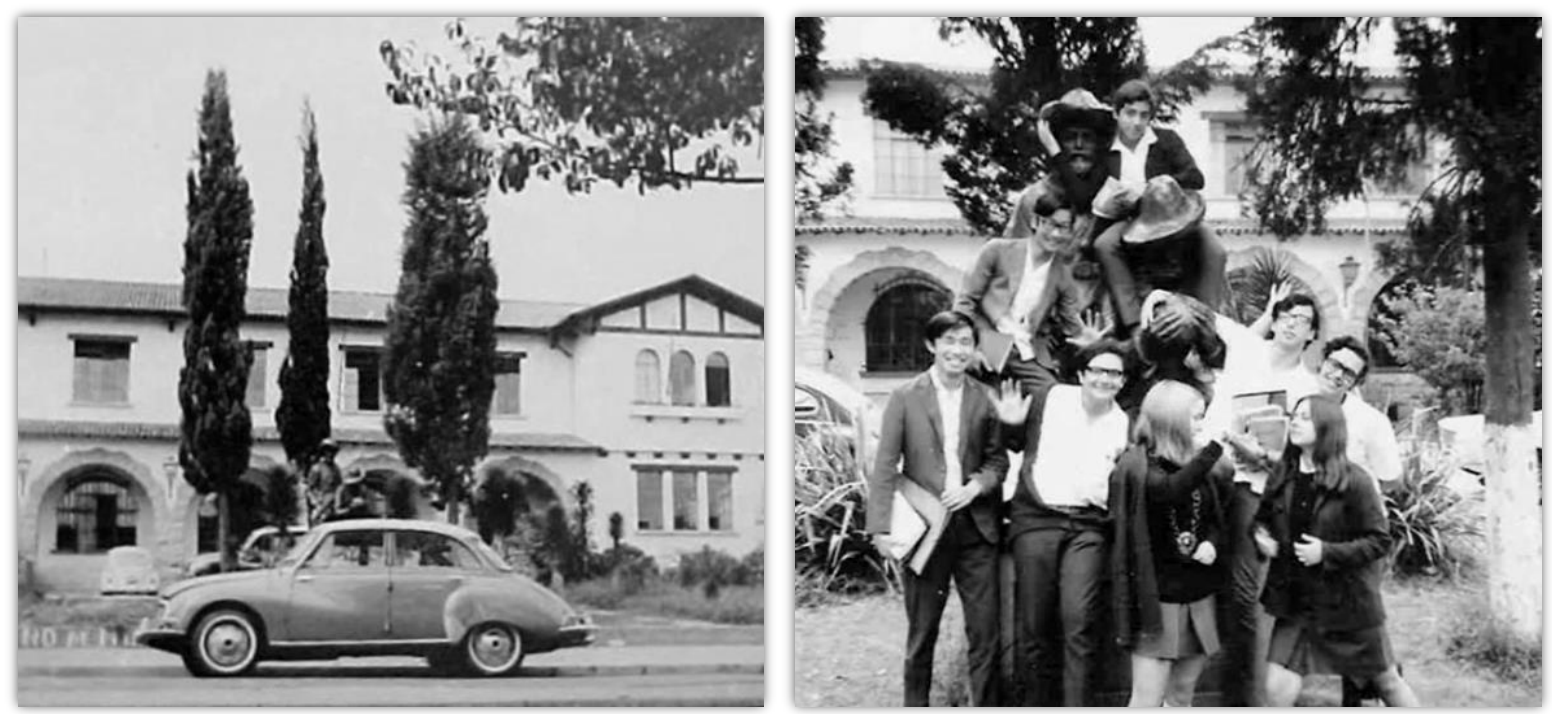

Figura $2.32-O$ caçador de esmeraldas, anos 1960.

Fonte: Acervo da Associação dos Ex-alunos da Escola Estadual Fernão Dias Paes.

Antes mesmo das esculturas em homenagem ao bandeirante serem encomendadas a Luigi Brizzolara e a William Zadig, Olavo Bilac (1924, p. 60) afirmara ser a escola "o primeiro reduto da defesa nacional; a menor falha do ensino, e o menor descuido do professor podem comprometer sem remédio a segurança do destino do país". O poeta, grande homenageado no conjunto monumental de Zadig, era considerado um dos grandes expoentes do civismo patriótico do início do século xx. Defensor da escola e do quartel como solução para o antipatriotismo, Bilac teve os versos de muitos de seus poemas patrióticos (como “O caçador de esmeraldas") declamados por distintas gerações de alunos das escolas paulistas, visando a celebração de um passado nacional (BITTENCOURT, 1990).

<http://www1.folha.uol.com.br/saopaulo/2015/05/1633981-fechado-ate-2022-museu-do-ipiranga-eo-preferido-dos-paulistanos.shtml>. Acesso em: 7 fev. 2017.

295 Segundo Adriana Mortara de Almeida (2004), no ano de 2003, 48,9\% dos visitantes do Museu Paulista consideraram que os benefícios de uma visita a esse local eram educacionais, seguidos por $27 \%$ daqueles que consideraram os benefícios de cunho cultural. Dos entrevistados, 46,8\% possuíam ensino superior completo/incompleto, seguidos por $24,9 \%$ com ensino médio completo/incompleto. 
Os princípios cívicos e militares de Olavo Bilac incentivaram também a formação de muitos grupos de escoteiros pelo Brasil. A Liga Nacionalista de São Paulo, responsável pela encomenda do Monumento a Olavo Bilac, tinha como uma de suas principais bandeiras de luta do escotismo ${ }^{296}$. $O$ escoteiro, um dos fragmentos que compõem o Monumento a Olavo Bilac, é também uma referência à prática do escotismo, visto no período como um movimento extraescolar que fazia frente à insuficiência das escolas brasileiras na "formação do caráter" (ZUQUIM; CYTRYNOWICZ, 2002, p. $45)^{297}$. No livro Escotismo para rapazes (1908), o próprio fundador do escotismo, o inglês Robert Baden Powell, afirma tratar-se de "uma escola de cidadania através da destreza e da habilidade em assuntos mateiros" 298 .

Disciplina escolar, geralmente em substituição às matérias de educação cívica, higiene e ginástica, ou aos exercícios militares, o escotismo se tornou, ainda na década de 1920, uma das atividades preferidas dos filhos das classes médias urbanas ${ }^{299}$. Segundo um articulista da época, “o escoteiro não é senão o bandeirante dos nossos dias" ${ }^{300}$. Em 1937, a prática do escotismo é institucionalizada e diretamente subordinada à Diretoria de Ensino, tendo seu programa definido pela legislação educacional (BITTENCOURT, 1990). A despeito de tudo isso, a figura abaixo mostra que $O$ escoteiro de William Zadig, no centro da fotografia, circulou durante décadas, até os anos

296 Além do escotismo, as principais bandeiras de luta da Liga Nacionalista de São Paulo eram a defesa nacional, o serviço militar obrigatório, a educação primária e profissional, a educação cívica patriótica e o voto secreto e obrigatório. Cf. Bandecchi (1977).

297 Em 1917, o presidente Wenceslau Brás Pereira Gomes estabelece, no artigo $1^{\circ}$ do decreto no 3.297, que as associações brasileiras de escoteiros passam a ser consideradas, a partir de então, de "utilidade pública". Disponível em: <http://www.planalto.gov.br/ccivil_03/decreto/historicos/dpl/DPL3297-1917.htm>. Acesso em: 26 jan. 2017.

298 O Movimento Escoteiro foi criado em 1907, por Robert Baden Powell, em Londres, na Inglaterra. Alguns anos depois da fundação da Associação Brasileira de Escoteiros, em 1914, surge o Movimento Bandeirante no Brasil, em 1919, voltado ao escotismo feminino. Também fundado por Baden Powell, com o auxílio de sua irmã, Agnes Baden Powell, primeira presidenta da associação feminina, o movimento recebe a denominação de Girls Guide na Inglaterra, em uma referência às mulheres “que abrem caminhos, que vão à frente e abrem passagem para outras". No Brasil, o movimento é nomeado Bandeirante como forma de preservar o sentido original. Disponível em: <http://site.bandeirantes.org.br/index.php/historico/>. Acesso em: 5 out. 2016.

${ }^{299}$ Em 1922, durante a reabertura do Museu Paulista, aproximadamente 10 mil escoteiros homenageavam o Centenário da Independência nos campos do Ipiranga. É possível também observar, nas correspondências do Museu Paulista, que Afonso Taunay sugere, depois das comemorações centenárias, longas listas de nomes de bandeirantes — em grande parte aceitas — para servirem de patronos das Comissões Regionais de Escoteiros Paulistas, criadas com a regulamentação do escotismo no Brasil. Somente para a Comissão Regional de Escoteiros de Araraquara, por exemplo, Taunay envia mais de trezentas sugestões de nomes, ainda que, segundo ele mesmo, não houvesse tantas "celebridades" entre os nossos bandeirantes, o que fez com que ele incluísse alguns de "arraia miúda". Carta de Afonso Taunay a Fausto Lex, 31 ago. 1923. APMP/FMP pasta 119.

300 “Os escoteiros de Natal". O Estado de S. Paulo, 5 set. 1923, p. 4. 
2010, por diferentes depósitos municipais, o último deles no Canindé, junto a outros fragmentos que compunham, abaixo do busto de Bilac, a parte central do monumento ao poeta ${ }^{301}$.

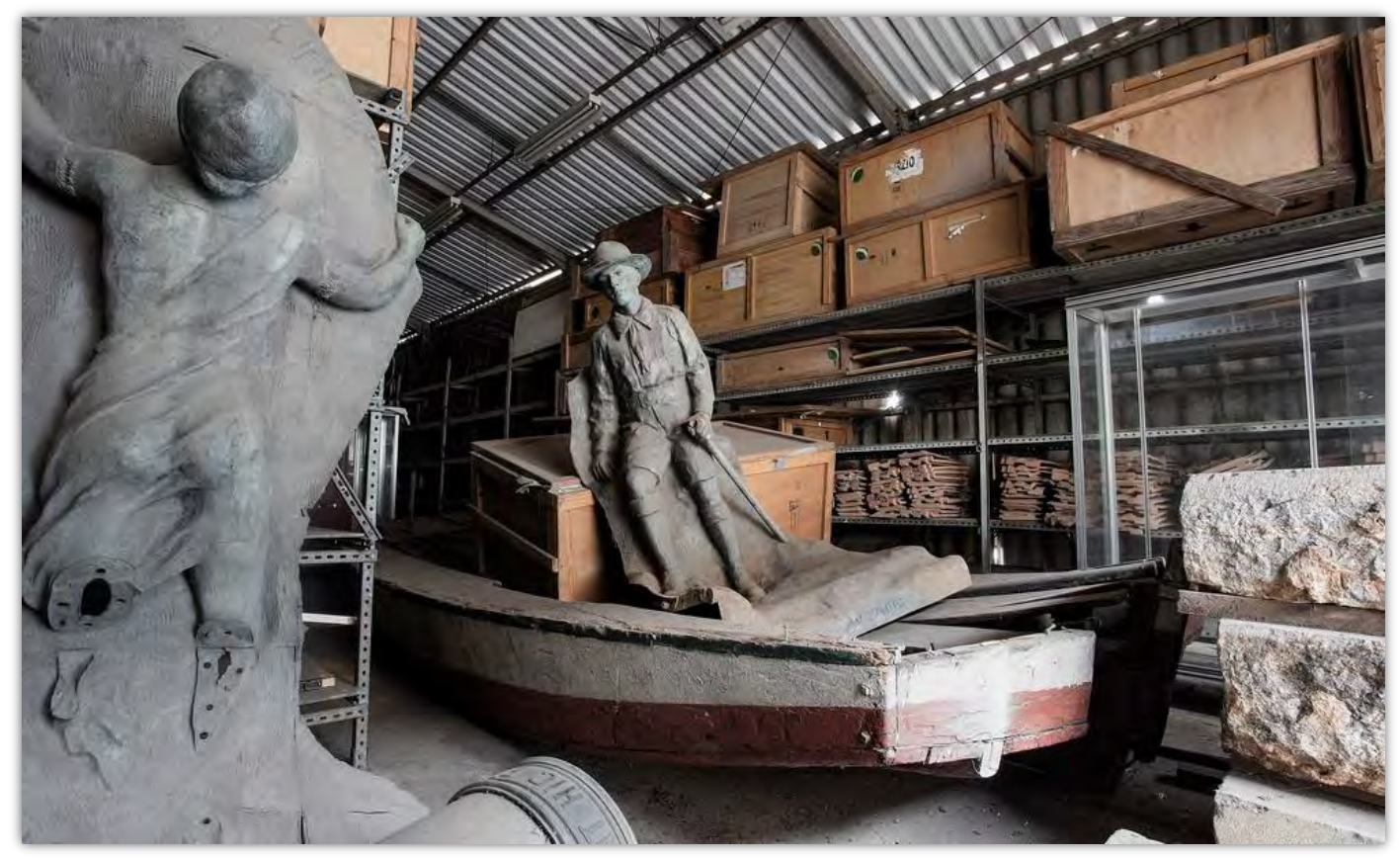

Figura 2.33-O escoteiro, depósito municipal do Canindé, 2015.

Fonte: Memória da Amnésia | Foto: Ana Ottoni 302.

Enquanto O escoteiro segue apartado da vida social, O caçador de esmeraldas ganhou destaque recente na mídia brasileira, e na imprensa internacional, por se fazer presente em uma escola pública que ficou famosa em 2015 por seu pioneirismo: a Fernão Dias Paes, conhecida como um dos colégios precursores durante as ocupações estudantis das escolas da rede estadual de São Paulo. Durante o início de sua ocupação, que abriu caminho para muitas outras, O caçador de esmeraldas esteve escondido no jardim do colégio, em meio a árvores, atrás de uma grade coberta por uma extensa faixa de tecido branco com os dizeres “Fernão Resiste!”, posicionada em frente à estátua 303.

301 Ao que parece, após anos de abandono, o próximo destino de O escoteiro será a praça Dom José Gaspar, na República Cf. “Emendas apresentadas ao PL 424/2012”, Diário Oficial da União, 13 dez. 2013, p. 167.

302 Disponível em: <http://www.desvirtual.com/mda/2016/03/08/fragmentos-do-monumento-a-olavo-bilac/>. Acesso em: 10 fev. 2017.

303 No total, 196 escolas estaduais foram ocupadas no final do ano de 2015, assim que o governador Geraldo Alckmin (PSDB) anunciou o fechamento de 94 instituições da rede estadual e o remanejamento de mais de 300 mil alunos como parte de um "rearranjo" das unidades de ensino. Chamado de "reorganização" pelo governo, o projeto, segundo a Secretaria de Educação, pretendia remanejar os alunos para que eles estudassem com colegas da mesma faixa etária. Primeira escola estadual a ser ocupada na capital, no dia 10 de novembro, a Fernão Dias Paes destacouse também como o segundo colégio no estado de São Paulo a ser ocupado pelos secundaristas, logo depois do 


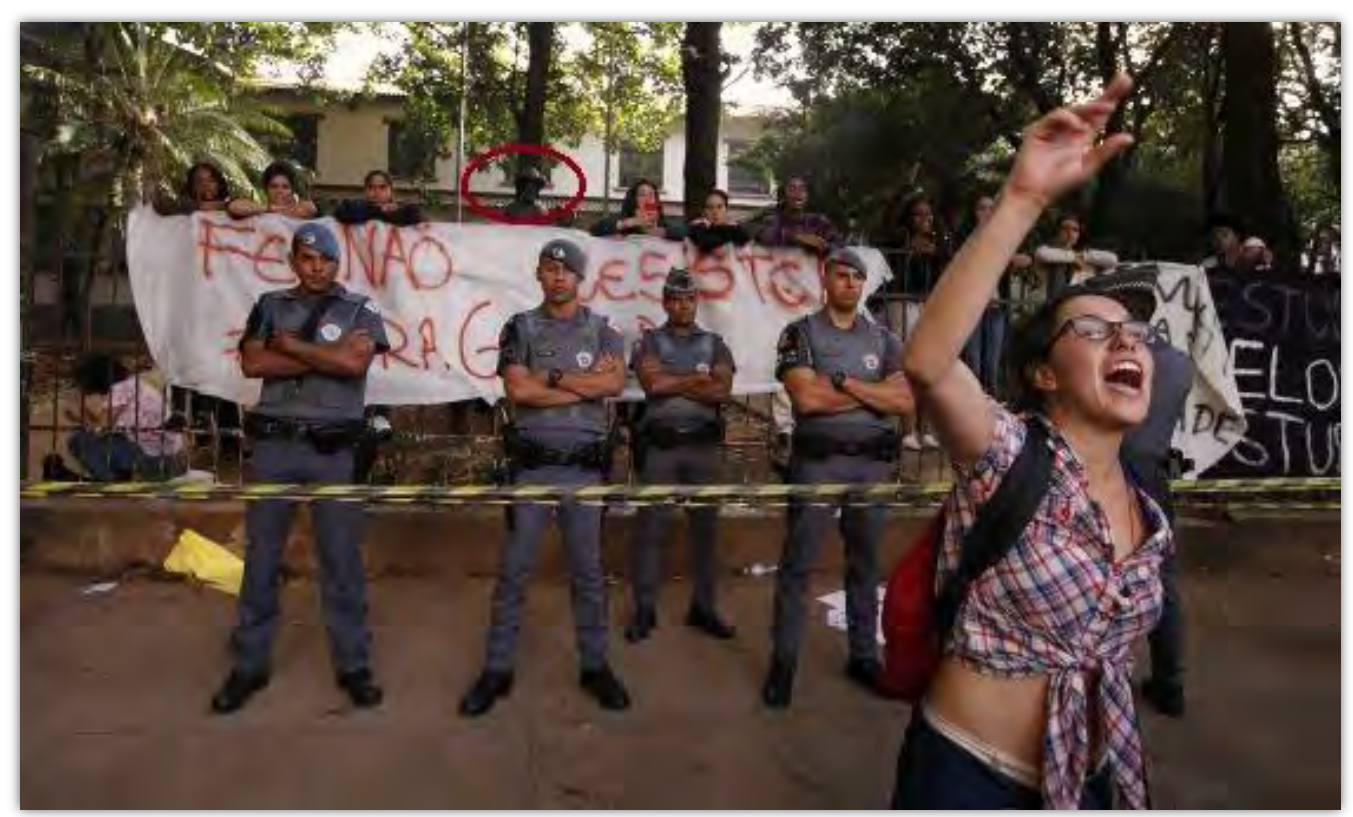

Figura 2.34 — “Fernão Resiste", 2015.

Fonte: El Pais Brasil | Foto: Rivaldo Gomes/ FOLHAPRESS ${ }^{304}$.

Embora a escultura de Fernão Dias ocupasse uma escola - ela própria ocupada por alunos $^{305}$ - o bandeirante que resistia aos policiais militares que cercavam o colégio era associado à imagem de "matador de índios", nos termos de uma estudante. Diz ela a um repórter do jornal O Estado de S. Paulo: "Essa escola não pode ter mais esse nome" ${ }^{306}$. Outro estudante, de acordo com a mesma matéria, sugere trocar o nome Fernão Dias pelo da avenida da entrada principal do colégio, Pedroso de Morais, mas depois de uma rápida pesquisa na internet, conclui: “Também era

colégio Professor Delcio de Souza Cunha, em Diadema, na Grande São Paulo. Sobre as ocupações das escolas estaduais públicas de São Paulo em 2015, cf. Campos \& Medeiros \& Ribeiro (2016).

304 Disponível em: <http://brasil.elpais.com/brasil/2015/11/11/politica/1447273812_584840.html>. Acesso em: 10 fev. 2017.

305 A ocupação da Escola Estadual Fernão Dias Paes não era unanimidade entre os alunos. Dentro e fora do colégio havia estudantes da rede estadual que discordavam das ocupações. Em 2016, inclusive, foi criado o movimento Desocupa, formado por alunos que pediam a retomada das aulas.

$306 \mathrm{O}$ debate sobre a alteração do nome do colégio está inserido em um contexto muito mais amplo. Em dezembro de 2013, a prefeitura de São Paulo começou a mapear os nomes das ruas da capital cruzando-os com os de torturadores e autoridades do período militar brasileiro. Em 2015, com o lançamento do programa Ruas da Memória, a Secretaria Municipal de Direitos Humanos e Cidadania da prefeitura de São Paulo propôs a alteração dos nomes das vias de São Paulo que homenageassem pessoas vinculadas à repressão do regime militar (1964-1985). Em 2016, ao fim de seu mandato, o então prefeito Fernando Haddad (PT) sancionou uma lei que mudou o nome do elevado Costa e Silva, conhecido como Minhocão, para Elevado Presidente João Goulart. Disponível em: <http://www.prefeitura.sp.gov.br/cidade/secretarias/upload/direitos_humanos/LEI\%20N\%2016525.pdf>. Acesso em: 26 jan. 2017. 
matador de índios, sem chance" ${ }^{307}$. Ainda que tivessem optado por Antônio Bicudo, nome da rua de acesso aos fundos da escola, a resposta seria a mesma.

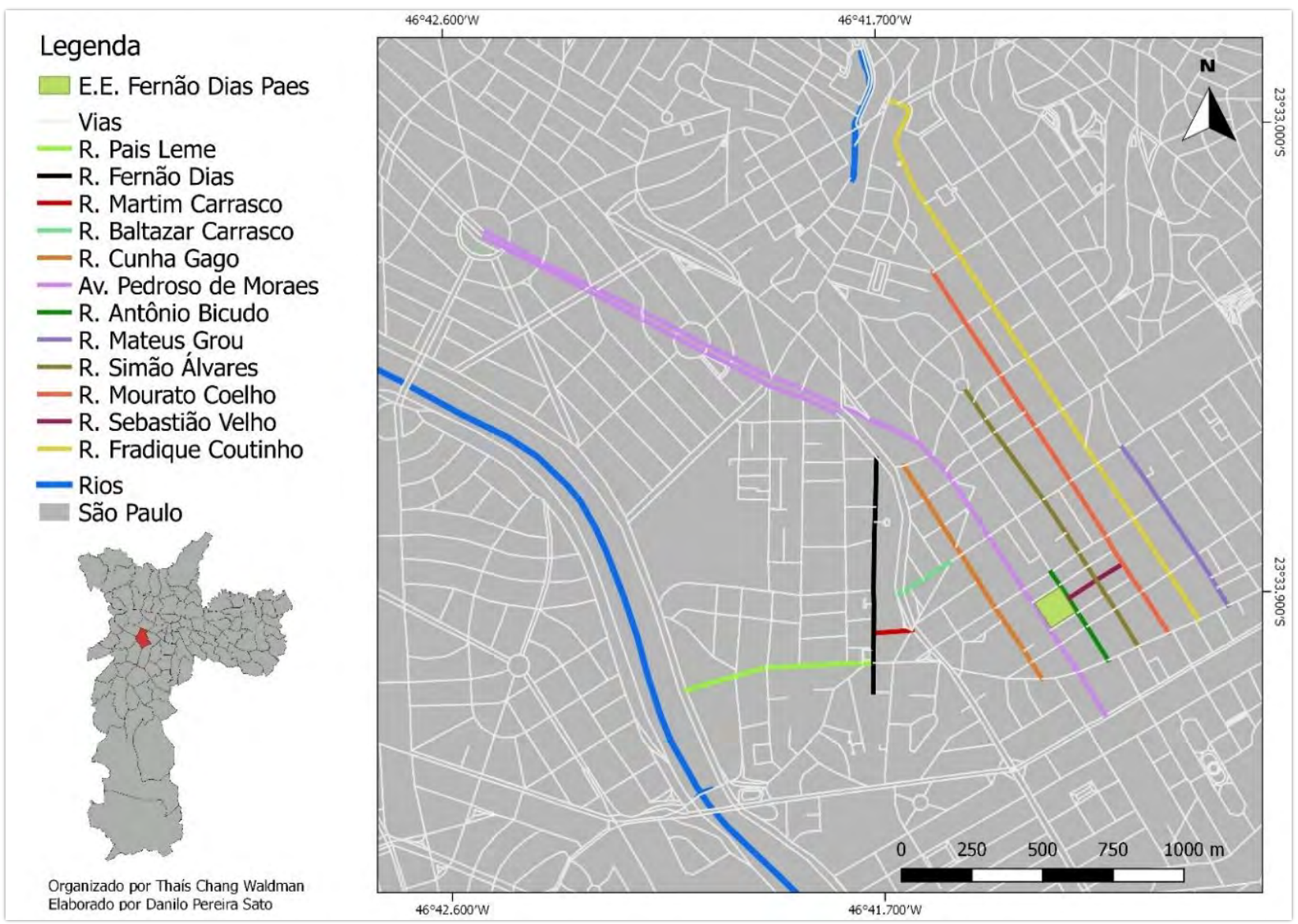

Figura 2.35- Homenagens a bandeirantes no entorno da Escola Estadual Fernão Dias Paes, 2017. Fonte: GeoSampa: dados abertos geoespaciais ${ }^{308}$.

Pedroso de Morais e Antônio Bicudo tornaram-se oficialmente nomes de logradouros no bairro de Pinheiros em 1914. No mesmo ano, outras ruas no entorno do colégio também foram nomeadas em homenagem a bandeirantes, como Mateus Grou, Fradique Coutinho, Simão Álvares, Cunha Gago e Mourato Coelho. Em 1915, é a vez do próprio Fernão Dias e de sua família Paes Leme batizarem dois logradouros, no mesmo bairro. Posteriormente, são ainda nomeadas ruas como a Baltazar Carrasco e a Martim Carrasco, ambas em 1930. Mesmo depois da inauguração da escola, há ainda, por exemplo, a oficialização do nome da rua Sebastião Velho, em 1950. Todos

\footnotetext{
307 Disponível em: <http://sao-paulo.estadao.com.br/noticias/geral,a-historia-da-escola-ocupada-que-fez-93-ficarem -abertas--imp,1807504>. Acesso em: 1 out. 2016.

${ }^{308}$ Disponível em: <http://www.prefeitura.sp.gov.br/cidade/secretarias/urbanismo/dados_abertos/>. Acesso em: 20 jun. 2017.
} 
esses logradouros prestam homenagens a bandeirantes em uma região que, séculos antes, pertencera à família de Fernão Dias. Isso sem falar nas ruas Bartira e João Ramalho, que desde 1910 marcavam presença na zona oeste da cidade ${ }^{309}$.

Recentemente, em 2017, adesivos foram colados nas placas de algumas dessas ruas, descrevendo os bandeirantes homenageados como assassinos responsáveis pela escravização de indígenas.

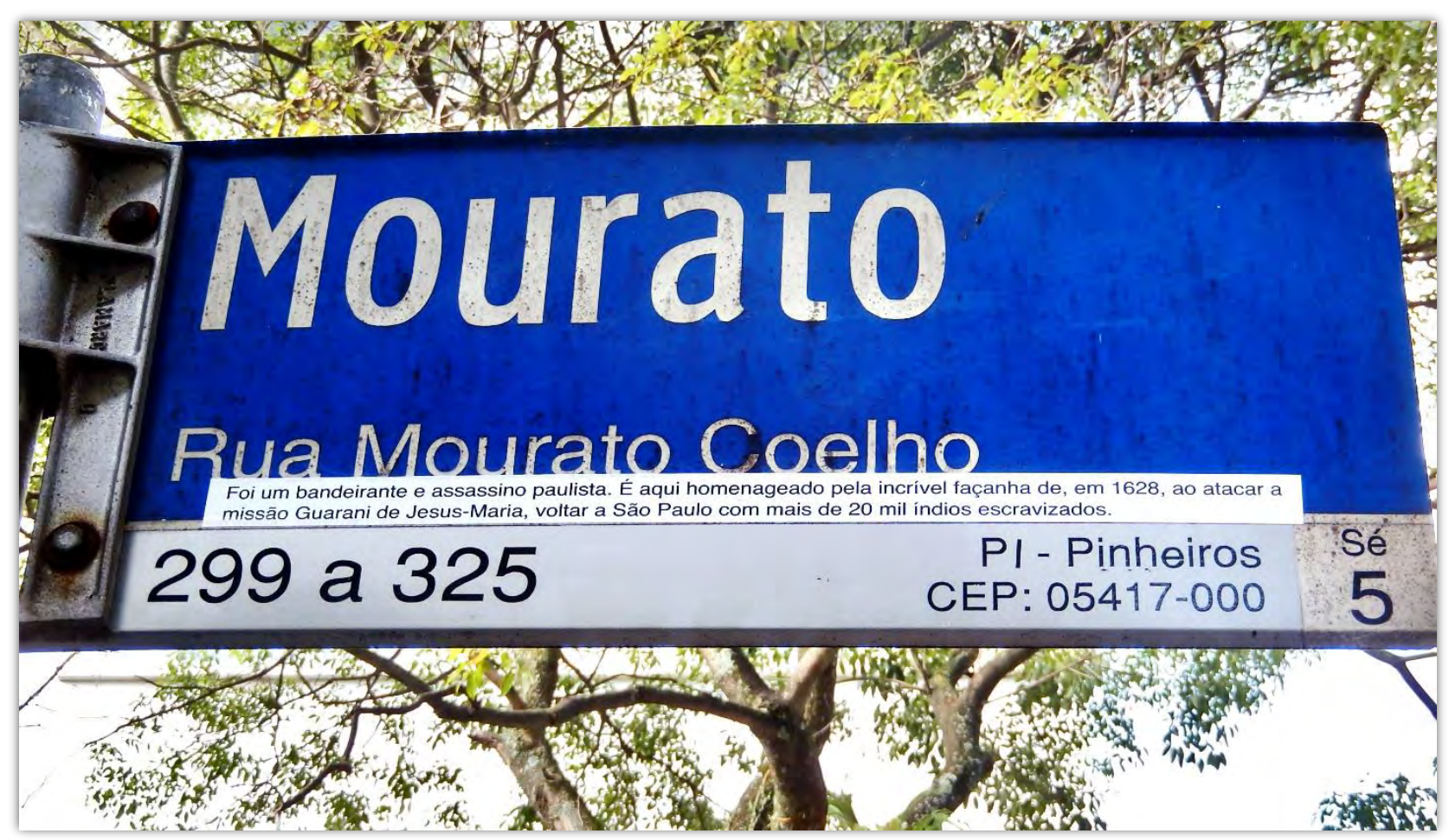

Figura 2.36 - "Bandeirante e assassino", placa da rua Mourato Coelho, Pinheiros, 2017.

Fonte: Acervo pessoal | Foto: Thaís Waldman.

Cabe notar que diversas ruas das redondezas da Escola Estadual Fernão Dias homenageavam indígenas muito antes da fundação do colégio, nomeando alguns dos lugares que foram deles tomados e jamais plenamente restituídos ${ }^{310}$. Temos, por exemplo, as ruas

\footnotetext{
309 As ruas Pedroso de Morais, Antônio Bicudo, Mateus Grou, Fradique Coutinho, Simão Álvares, Cunha Gago e Mourato Coelho foram nomeadas pelo ato n 740 , de 28 de dezembro de 1914. Já a rua Fernão Dias tem seu nome oficializado pelo ato no 810, de 28 de outubro de 1915. Baltazar Carrasco e a Martim Carrasco são nomeados pela lei $\mathrm{n}^{\circ}$ 3.476, de 10 de abril de 1930, enquanto Sebastião Velho tem seu nome oficializado pela lei $\mathrm{n}^{\circ} 3.916$, de 7 de julho de 1950. Cf. Núcleo de denominação de logradouros públicos, AHMWL.

${ }^{310}$ Em 2013, ativistas do Greenpeace já haviam realizado uma intervenção urbana nos bairros de Perdizes, Moema e Lapa, colando adesivos que diziam "sob ameaça” nas placas de quarenta ruas com nomes indígenas, além da hashtag \#DireitosIndígenas.
} 
Morás, Coropé, e Jupuá, ou então as ruas dos Macunis, dos Miranhas, dos Omaguás, dos Tamanás, todas elas tendo seus nomes oficializados nos anos $1920^{311}$. Lembremos também que O caçador de esmeraldas é transferido para a avenida Pedroso de Morais, precisamente em uma esquina com a rua Teodoro Sampaio, homenagem ao intelectual negro que, no início do século XX, foi um importante interlocutor de Benedito Calixto durante a execução de seu retrato modelar Domingos Jorge Velho e o loco-tenente Antônio Fernandes Abreu ${ }^{312}$. Calixto, por sua vez, dará nome a uma praça localizada na junção entre a rua Teodoro Sampaio e a Cardeal Arcoverde ${ }^{313}$.

Ao encarnarem dois “matadores de índios”, Fernão Dias e Borba Gato tornam-se alvos de um grupo de alunos que se referiam, durante uma das visitas que fiz ao colégio, a $O$ caçador de esmeraldas como "a estátua dos safados", termo que ouvi mais de uma vez na ocupação 314 . Desse modo, se no primeiro dia das ocupações Fernão Dias erguia um cartaz com os dizeres "Estamos tomando o que é nosso por direito", poucos dias depois a cabeça do bandeirante, agora "safado", estava coberta por um saco de lixo preto. Os estudantes constroem, assim, diferentes narrativas servindo-se de uma convenção visual já dada ${ }^{315}$. Tendo escapado da decapitação sofrida pelo Monumento a Carlos Gomes na década de 1920, os bandeirantes do Monumento a Olavo Bilac têm suas cabeças cobertas quase cem anos depois, tal como já havia ocorrido nos anos 1970 com diversas obras (como o Anhanguera, de Luigi Brizzolara, e o Monumento às bandeiras, de Victor Brecheret) durante uma intervenção do grupo 3Nós3, como veremos no próximo capítulo.

\footnotetext{
311 As ruas Morás, Coropé, e Jupuá, e as ruas dos Macunis, dos Miranhas, dos Omaguás e dos Tamanás, foram todas nomeadas através do ato $\mathrm{n}^{\circ}$ 2.096, de 26 de junho de 1923, cf. Núcleo de denominação de logradouros públicos, AHMWL.

312 A rua Teodoro Sampaio teve seu nome oficializado pelo ato no 972, de 24 de agosto de 1916. Cf. Núcleo de denominação de logradouros públicos, AHMWL.

${ }^{313}$ Logradouro oficializado através do ato n 1.065 , de 16 de abril de 1936. Cf. Núcleo de denominação de logradouros públicos, AHMWL.

${ }^{314}$ Conversa com os alunos realizada durante incursão coletiva à Escola Estadual Fernão Dias Paes, realizada pela autora em dezembro de 2015, junto à professora Silvana Nascimento e aos colegas do Programa de Pós-Graduação em Antropologia Social da Universidade de São Paulo: Arthur Fontgaland, Lucas Bulgarelli, Cibele Assenssio e Maria Izabel Zanzotti.

315 O que se aproxima nitidamente da noção de tática de Michel de Certeau: "Diante de uma produção racionalizada, expansionista, centralizada, espetacular e barulhenta [Bandeirante!], posta-se uma produção de tipo totalmente diverso, qualificada como "consumo", que tem como característica suas astúcias, seu esfarelamento em conformidade com as ocasiões, suas 'piratarias', sua clandestinidade, seu murmúrio incansável, em suma, uma quaseinvisibilidade, pois ela quase não se faz notar por produtos próprios (onde teria o seu lugar?), mas por uma arte de utilizar aqueles que lhe são impostos" (CERTEAU, 1994, p. 94).
} 

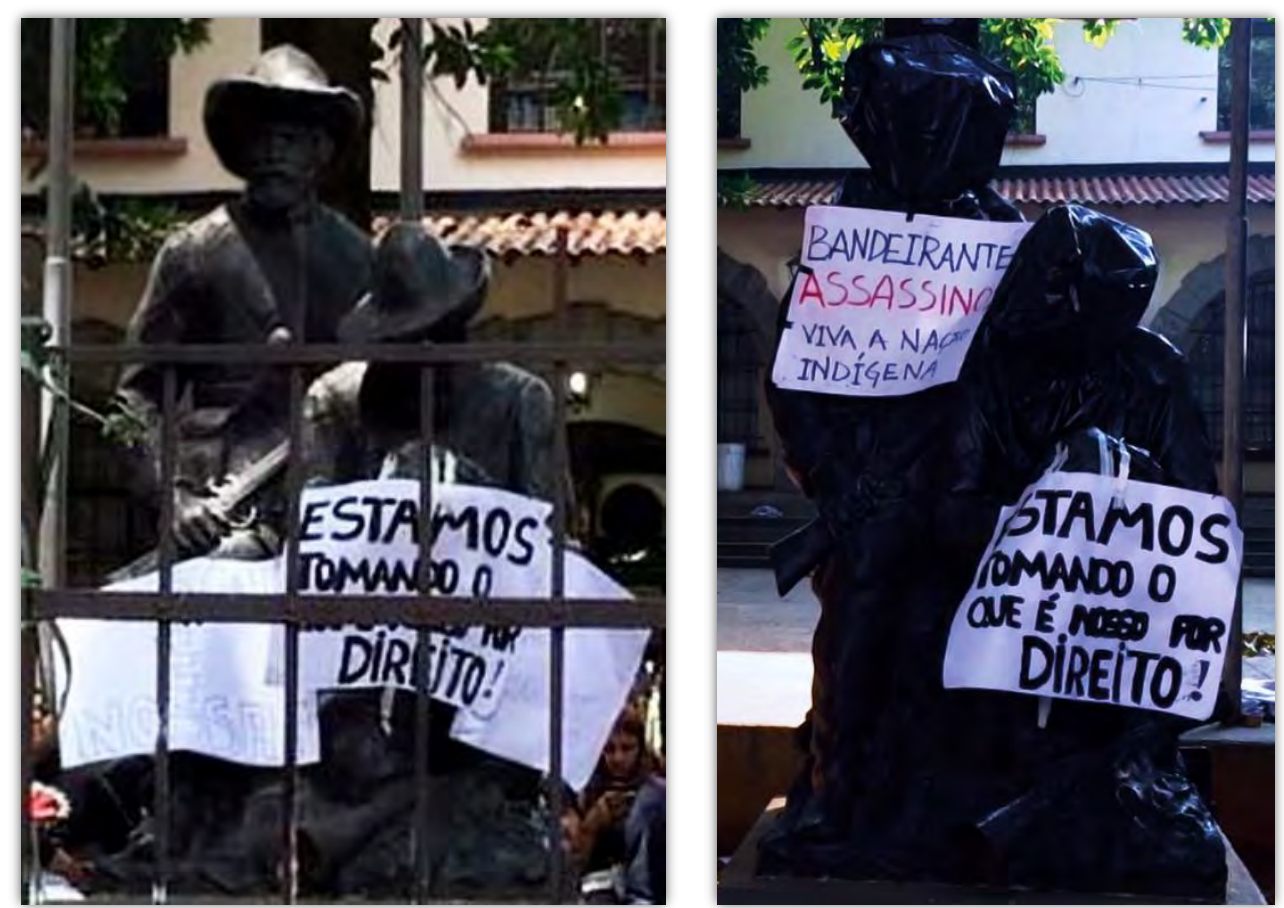

Figura 2.37 - Ensacamento de $O$ caçador de esmeraldas, 2015.

Fonte: Página do Facebook do Ocupa Fernão ${ }^{316}$.

Encapuzado, O caçador de esmeraldas oferece também sua solidariedade aos refugiados sírio/palestinos, lembrando que a Síria foi o principal país de origem dos refugiados no Brasil em 2015, ano das primeiras ocupações estudantis ${ }^{317}$. Engajado em diversas lutas, o bandeirante empunha então uma bandeira da Palestina, com os dizeres "Fora Alckmin" 318. Logo abaixo, há a inscrição “Ocupação Leila Khaled”, em solidariedade ao Movimento Terra Livre ${ }^{319}$, que havia emitido uma nota em apoio às ocupações estudantis ${ }^{320}$. Semanas antes, o Terra Livre recebera refugiados que participavam do Movimento Palestina Para Tod@s, nas proximidades do

316 Disponível em: <https://www.facebook.com/OcupaFernao/>. Acesso em: 20 jan. 2017.

317 Segundo dados do Comitê Nacional para os Refugiados (Conare), em 2014 a Síria passou a ser o principal país de origem dos refugiados do Brasil, posição mantida no ano de 2015 . Disponível em: <https://pt.slideshare.net/justicagovbr/refgio-no-brasil-51820929>. Acesso em: 17 fev. 2017.

${ }^{318} \mathrm{Na}$ grade do colégio, diante de Fernão Dias, havia ainda uma faixa em apoio aos trabalhadores da Usiminas de Cubatão, devido a possível demissão de pelo menos 4 mil funcionários da siderúrgica.

319 Movimento popular brasileiro que surge em 2005 com o objetivo de lutar por reforma urbana, reforma agrária e produção sob o controle dos trabalhadores. Disponível em: <http://www.terralivre.org>. Acesso em: 1 nov. 2016.

${ }^{320}$ Logo após as primeiras ocupações, o Terra Livre soltou nas redes sociais uma nota afirmando em letras maiúsculas: “SE ESTUDAR É UM DIREITO, OCUPAR É UM DEVER!”, num jogo de linguagem com uma das principais bandeiras do movimento (“SE MORAR É UM PRIVILÉGIO, OCUPAR É UM DEVER”). Disponível em: <https://www.facebook.com/refugiadosnaocupa/posts/1076009255751066>. Acesso em: 1 nov. 2016. 
monumento Amizade sírio-libanesa, em um prédio ocupado na região central, nomeado Leila Khaled em homenagem à militante da Frente Popular para a Libertação da Palestina ${ }^{321}$.

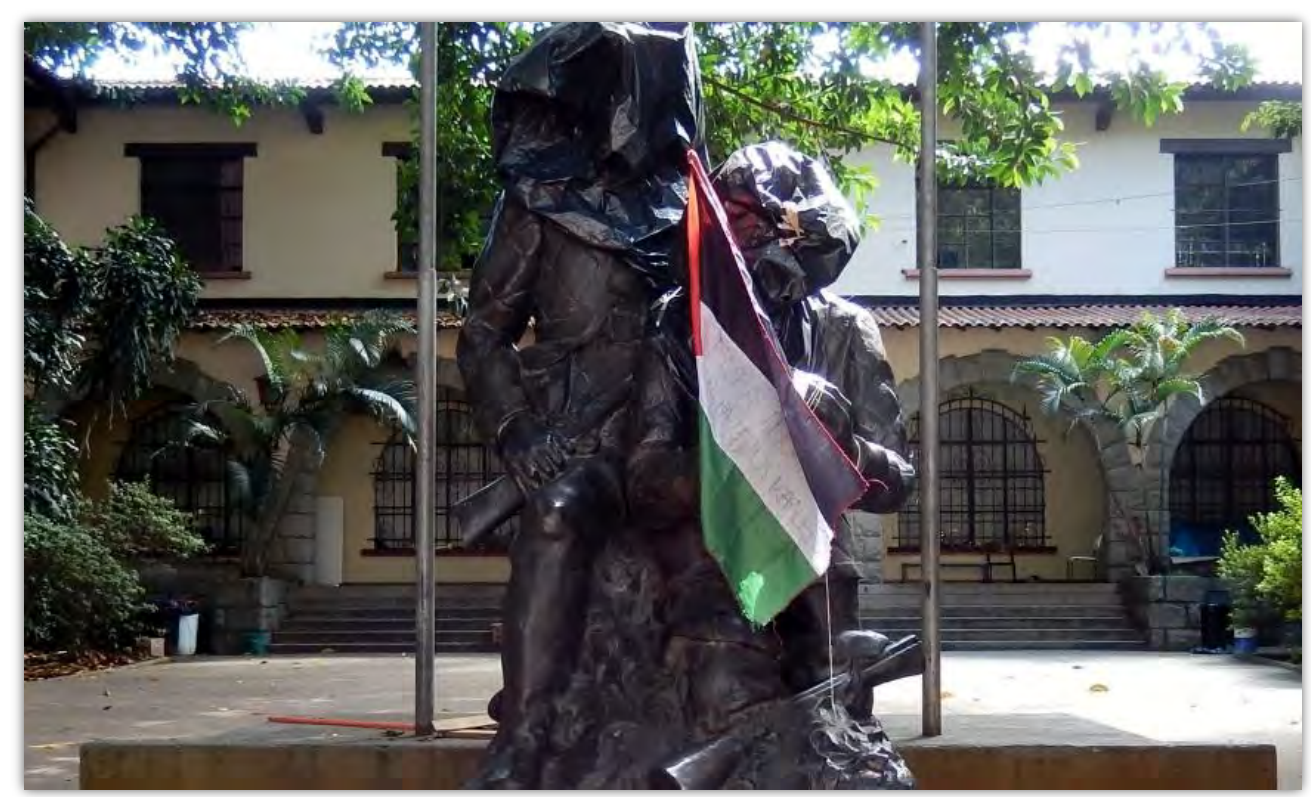

Figura 2.38 - $O$ caçador de esmeraldas presta solidariedade aos refugiados, 2015. Fonte: Acervo pessoal | Foto: Thaís Waldman.

As ocupações estudantis geraram, assim, uma dinâmica de organização coletiva inédita que produziu uma estreita interação com o espaço e, no caso da Escola Estadual Fernão Dias Paes, com a escultura $O$ caçador de esmeraldas. Voltemos à figura n. 2.37, na qual Borba Gato parece vigiar o horizonte no início das ocupações, com uma espingarda e uma arma menor a postos, como que montando guarda ao seu sogro e à própria escola ocupada pelos alunos. Ao mesmo tempo, aos seus pés há um cartaz recém-escrito com os dizeres “A escola é nossa!”. Poucas horas depois, a escola não mais pertencia a Borba Gato, o cartaz é retirado e o bandeirante, com a cabeça coberta por um saco preto, passa a segurar uma faixa com os dizeres "Bandeirantes assassinos. Viva a nação indígena!”.

Ao ocuparem a escola pública e ensacarem a escultura de Borba Gato, os estudantes encontram uma maneira de marcar presença em uma cidade que, sistematicamente, se recusa a lhes oferecer algum espaço. Enquanto a Secretaria de Educação enfatizava que a nova política para o ensino, chamada pelo governo estadual de "reorganização" da rede, era uma forma de

${ }^{321}$ Disponível em: <http://terralivre.org/2015/09/boas-vindas-aos-refugiados-siriospalestinos/>. Acesso em: 1 nov. 2016. 
diminuir a quantidade de salas ociosas, os alunos respondiam por meio dos cartazes dispostos na grade em frente a escultura $O$ caçador de esmeraldas: "Ocupar, ocupar, ocupar, até o Alckmin recuar" ${ }^{322}$. Ao combaterem aquilo que consideravam ser uma "desorganização", os alunos atribuíram à sua instituição o epíteto "Escola de luta". Na porta das escolas — assim como nas manifestações ${ }^{323}$ - os estudantes frequentemente eram encontrados cantando em coro o mais novo hit:

O Estado veio quente, nóis já tá fervendo (2x) Quer desafiar? Não tô entendendo, mexeu com estudante, vocês vão sair perdendo O Fernão é escola de luta! Andronico é escola de luta! Ana Rosa é escola de luta! Fica preparado, que se fecha, nóis ocupa...

Trata-se de um trecho da música "Escola de luta", uma versão politizada do funk "Baile de favela", lançado poucas semanas antes ${ }^{324}$. Enquanto em "Baile de favela" MC João apresenta Brasil afora as comunidades de Heliópolis, da Marconi e de São Rafael, cantadas no refrão de sua música, em "Escola de luta" a dupla MC Foice e Martelo traz para o primeiro plano a Escola Estadual Fernão Dias Paes, entre outras diversas "escolas de luta" ocupadas, como a Escola Estadual Anhanguera, nomeada igualmente em homenagem a um bandeirante paulista, e também localizada na zona oeste da cidade ${ }^{325}$. Em cada local em que a letra era cantada, os estudantes substituíam o nome da escola ocupada pelo da sua própria.

322 Além do encerramento das atividades letivas em 94 escolas, a nova política para o ensino, que seria posta em prática a partir de 2016, faria com que outras 754 escolas tivessem seus ciclos encerrados, fosse do ensino fundamental ou médio. A Fernão Dias, por exemplo, continuaria aberta, porém os alunos do ensino fundamental seriam transferidos para a Godofredo Furtado, no mesmo bairro, enquanto as turmas do ensino médio da Godofredo iriam para a Fernão Dias. Desse modo, segundo a Secretaria de Educação, o número de escolas que recebem estudantes dos três ciclos (ensino fundamental 1, 2 e ensino médio) diminuiria e todos estudariam com colegas da mesma faixa etária.

323 Antes do início das ocupações estudantis, milhares de estudantes já haviam ido às ruas protestar contra a "desorganização" da rede. Nas seis semanas anteriores às ocupações, os estudantes foram às ruas em quase duzentas ocasiões (CAMPOS; MEDEIROS; RIBEIRO, 2016).

${ }^{324} \mathrm{Em}$ Baile de favela, MC João inicia sua música com os seguintes versos: "Ela veio quente, e hoje eu tô fervendo/ Ela veio quente, hoje eu tô fervendo/ Quer desafiar? Não tô entendendo/ Mexeu com o R7 vai voltar com a xota ardendo". Lançada em setembro de 2015, em poucas semanas a música se tornou uma das mais ouvidas em streaming.

325 Mais ao norte da cidade, Anhanguera irá ainda nomear um distrito e um parque. O parque Anhanguera não só se destaca como o maior parque da cidade como, juntamente com o parque estadual do Jaraguá, constitui 
O Borba Gato esculpido por William Zadig, dessa vez não foi convidado para o baile ${ }^{326}$. Ensacada depois do cerco policial, a escultura do bandeirante, agora tachado de assassino, não mais poderia montar guarda à escultura de Fernão Dias e, metonimicamente, à escola de mesmo nome, que permaneceu ocupada por 55 dias. O cartaz com os dizeres “A escola é nossa!” é arrancado de seus pés, enquanto os alunos arrumavam outros aliados ${ }^{327}$. Vide parte da sociedade civil, em especial os segmentos de esquerda, cujo apoio às ocupações foi se tornando mais expressivo, aumentando a repercussão midiática do desafio de que fala a letra do funk ${ }^{328}$. O governador Geraldo Alckmin, cuja popularidade chegara ao menor índice já registrado, anunciou então, no Palácio dos Bandeirantes, a suspensão da "reorganização" em toda a rede de ensino do estado até o ano de $2016^{329}$.

$\mathrm{Na}$ sequência, ao desocuparem os colégios, os alunos esclareceram que não estavam abandonando a luta. Foram três conquistas, afirma um dos estudantes: "O governador ter recuado publicamente, o MP [Ministério Público] ter conseguido uma liminar proibindo o processo de reorganização e o diálogo com a diretoria de ensino por gestão participativa. Estamos deixando a

o maior complexo de preservação ambiental da região urbana de São Paulo. Disponível em: <http://www.dicionarioderuas.prefeitura.sp.gov.br/PaginasPublicas/ListaLogradouro.aspx>. Acesso em: 29 out. 2016.

326 O mesmo ocorreu com a Escola Estadual Manuel Borba Gato, na zona sul, que não foi ocupada pelos alunos e, consequentemente, não foi cantada nos versos da música.

327 A jurada do reality show MasterChef Brasil, Paola Carosella, por exemplo, cozinhou para os estudantes do colégio Fernão Dias Paes, notícia que foi amplamente divulgada nas mídias sociais. Além dela, a escola recebeu diversas visitas, tais como as do cineasta Carlos Pronzato, que exibiu e debateu seu documentário Carlos Marighella; do então secretário municipal de Direitos Humanos, Eduardo Suplicy; do cantor Chico César, que cantou suas músicas com os alunos; da cartunista Laerte Coutinho, que junto do ator e escritor Gregório Duvivier promoveu um debate sobre educação; do professor de filosofia da Universidade de São Paulo Paulo Arantes, que ministrou uma aula pública junto ao professor Tonhão, exonerado da rede estadual após a greve de 2000; do ator Pascoal da Conceição, o famoso Dr. Abobrinha do programa infantil Castelo Rá-tim-bum; entre outras. Muitos vizinhos também se solidarizaram com o movimento, doando alimentos, oferecendo oficinas e aulas voluntárias.

328 Além do já mencionado Movimento Terra Livre, no decorrer das ocupações os estudantes do colégio Fernão Dias contaram com o apoio do Movimento Passe Livre, dos trabalhadores sem-teto, das torcidas organizadas do Corinthians e do São Paulo, da vizinhança da escola e de vários ativistas e pessoas famosas que foram pessoalmente prestar seu apoio às ocupações; dois manifestos circularam também nos primeiros dias de dezembro, assinados por quase duzentos "intelectuais, artistas e figuras públicas" e 25 organizações ligadas em sua maioria à educação, reivindicando a suspensão imediata dessa "guerra contra os estudantes" (CAMPOS; MEDEIROS; RIBEIRO, 2016, p. 260).

${ }^{329}$ Segundo pesquisa do Instituto Datafolha publicada no mesmo dia em que Geraldo Alckmin anunciou a suspensão da nova política para o ensino, 28\% dos entrevistados consideraram seu governo ótimo ou bom (na anterior, o percentual era de 38\%). Dois fatos, ainda segundo a mesma pesquisa, influenciaram essa queda: a crise hídrica e a "reorganização" escolar. Disponível em: <http://www1.folha.uol.com.br/cotidiano/2015/12/1714813-popularidade-dealckmin-atinge-pior-marca-aponta-datafolha.shtml>. Acesso em: 30 jul. 2016. 
escola, mas não a luta" ${ }^{" 330}$. No ano seguinte, poucos meses depois, com um cartaz na entrada escrito "Sob nova direção", o colégio Fernão Dias Paes é novamente ocupado, dessa vez em um protesto contra a qualidade da merenda escolar e em apoio aos estudantes das Escolas Técnicas do Estado (Etecs $)^{331}$. A imagem antes contestada de $O$ caşador de esmeraldas é desensacada, assumindo o papel de porta-voz da escola ocupada.

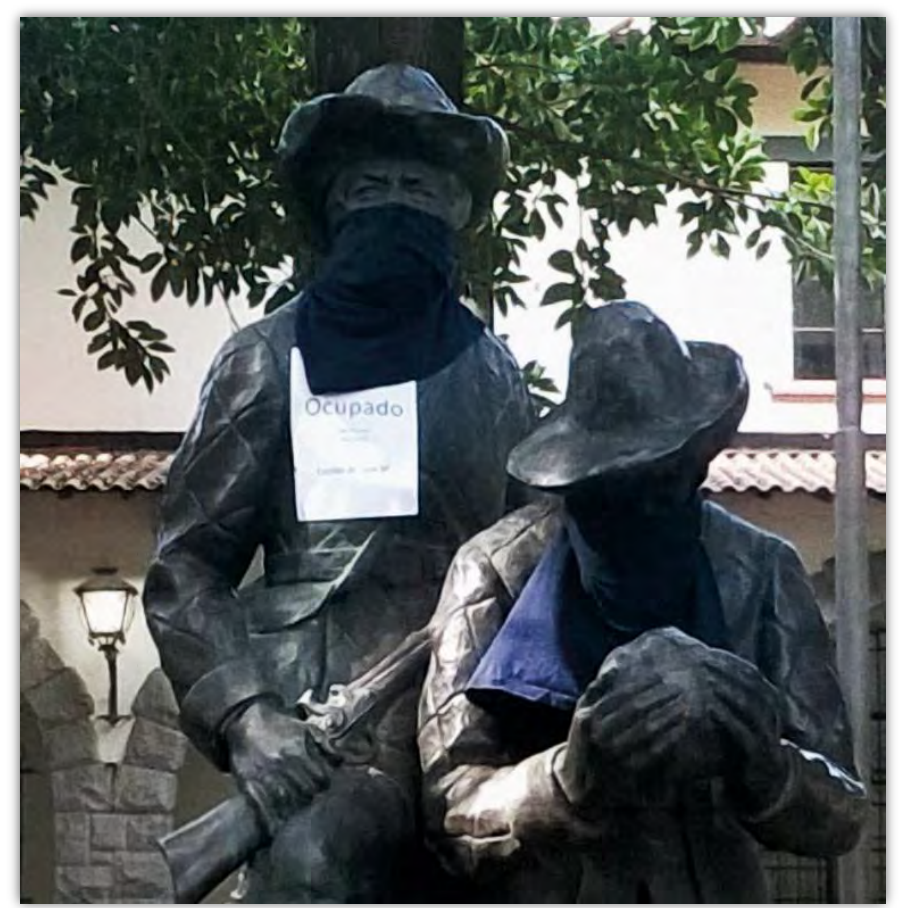

Figura 2.39-O caçador de esmeraldas resiste ao Palácio dos Bandeirantes, 2016. Fonte: Página do Facebook Ocupa Fernão ${ }^{332}$.

As figuras em bronze de Fernão Dias e Borba Gato surgem então com a boca e o rosto cobertos com um pano preto, enquanto os estudantes, com o apoio dos bandeirantes - agora black blocs ${ }^{33}$ - dão um passo no sentido de abrir uma investigação sobre a chamada "máfia da

330 Disponível em: <http://g1.globo.com/sao-paulo/escolas-ocupadas/noticia/2016/01/estudantes-da-fernao-diasentregam-chaves-e-desocupam-escola-em-sp.html>. Acesso em: 27 jul. 2016.

331 Desde abril do mesmo ano, devido aos cortes na merenda, os estudantes das Etecs ocupavam um prédio administrativo do Centro Paula Souza, autarquia do governo estadual responsável pela administração das unidades de ensino, no bairro do Bom Retiro, região central de São Paulo. Na época, diversas escolas técnicas da rede estadual estavam sem merenda ou com o fornecimento irregular desde o início do ano letivo de 2015. Em algumas unidades, os alunos recebiam apenas bolachas, barra de cereal e suco, enquanto em outras não havia fornecimento de nenhum alimento.

332 Disponível em: <https://www.facebook.com/OcupaFernao/>. Acesso em: 20 jan. 2017.

333 Julia Ruiz Di Giovanni (2007, p. 48-9), em análise sobre o movimento antiglobalização, explica que as manifestações de 1999 contra a Organização Mundial do Comércio, em Seattle, foram o momento da aparição midiática dos black 
merenda", depois de ocuparem a Assembleia Legislativa de São Paulo (Alesp). A grande pedra que Fernão Dias segura com as duas mãos, mais se assemelha a uma arma do que a uma pedra preciosa. Paradoxalmente, as esculturas dos bandeirantes tornam-se símbolos da resistência ao Palácio dos Bandeirantes, tal qual os adeptos da tática de guerrilha urbana anticapitalista black bloc que, no ano anterior, tentaram tomar a sede do governo estadual em apoio às ocupações das escolas do estado de São Paulo, mas foram dispersados da avenida Morumbi pela Polícia Militar.

\subsection{Rumo a Santo Amaro}

"Este sujeito vai fazer parte do seu endereço. Este sujeito é o Borba Gato!" (campanha publicitária veiculada na década de 1970)

“É uma questão política, não de polícia!", dizia um dos cartazes expostos no muro da Escola Estadual Fernão Dias Paes, ainda durante as ocupações de 2015, enquanto nas passeatas pelas ruas da cidade e no interior dos próprios colégios os estudantes eram recebidos pela tropa de choque com bombas de gás lacrimogênio 334 . "Sem educação não há democracia”, explicava outro cartaz, exposto no mesmo muro. A repressão policial chamou a atenção da cartunista Laerte Coutinho (1951- ), antiga aluna do colégio, que publicou uma charge na Folha de S.Paulo. Na

\footnotetext{
blocs: "Grupos de manifestantes vestidos de negro da cabeça aos pés [que] foram identificados como responsáveis pelo incêndio de latas de lixo, barricadas e pela destruição de vitrines, muitas vezes recriminados por outros manifestantes, que clamavam por 'não violência'. Esses grupos ficaram conhecidos, a partir de então, como os Black Blocks, os Blocos Negros, frequentemente encapuzados e com os rostos cobertos, quase sempre responsáveis pela dose 'violenta' dos protestos". No Brasil, os chamados blocos negros ganham popularidade com as manifestações de 2013, contra o aumento das tarifas de ônibus e metrô.

${ }^{334}$ Logo no início das ocupações, segundo o jornal El País Brasil, mais de cem policiais militares surgiram nos portões da Escola Estadual Fernão Dias Paes ao sitiarem o quarteirão inteiro do colégio, junto a dezenas de viaturas, segundo dados da corporação. Os policiais impediram o trânsito de alunos na escola, proibindo até mesmo a entrada de água e comida. Do lado de fora do colégio, cercados por um cordão de isolamento que impedia o acesso ao local, um grupo de alunos gritava slogans contra o fechamento das escolas e em apoio à ocupação: Disponível em: <http://brasil.elpais.com/brasil/2015/11/11/politica/1447273812_584840.html>. Acesso em: 27 jul. 2016.
} 
imagem, o Estado figura como um bandeirante agigantado, empunhando uma arma três vezes maior que os estudantes desarmados, cujas alturas não ultrapassam nem mesmo as botas do bandeirante, parecendo ainda menores ao se sentarem e olharem para cima.

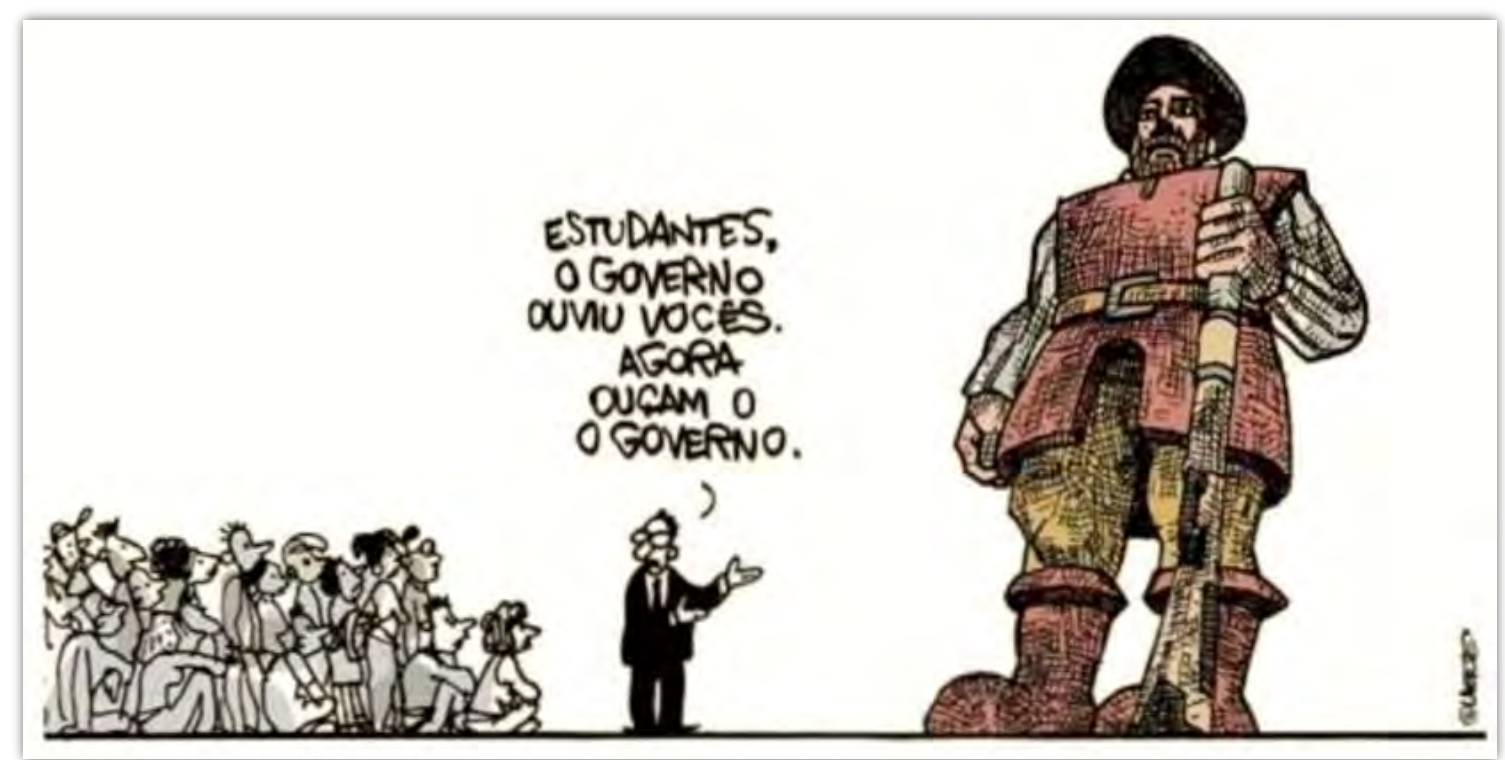

Figura 2.40 - Charge de Larte Coutinho, 2015.

Fonte: Folha de S.Paulo, 1 dez. 2015, p. A2.

Poucos dias antes de publicar sua charge, Laerte havia participado de uma roda de debates no colégio Fernão Dias Paes, quando ofereceu aos estudantes secundaristas um livro francês ilustrado sobre movimentos contestatórios, Un siècle de dessins contestataires (1974), de Jacques Sternberg e Henri Deul ${ }^{335}$. Durante o debate, alguns alunos se mostraram indignados com a intransigência do governo estadual que, segundo eles, não abriu espaços para negociações com os estudantes. Já Laerte, ao lembrar a época em que estudou no Fernão Dias, no final da década de 1960, quando o movimento estudantil se torna um dos principais protagonistas da luta contra a

335 Além da cartunista, muitos voluntários deram aulas e palestras sobre diferentes temas, inclusive sobre a história dos movimentos secundaristas no Brasil. \#DoeUmaAula, dizia a hashtag da campanha virtual dos alunos para que as ocupações mantivessem atividades culturais e aulas de matérias formais. Um coletivo chamado HubLivre se dispôs a organizar também um canal de oferta gratuita de aulas para as escolas ocupadas, defendendo assim o uso de uma tecnologia livre. Por meio de um formulário online, um banco de dados de aulas e oficinas foi alimentado e compartilhado com todas as escolas. Em dois dias, o número de propostas já beirava 2,5 mil (CAMPOS; MEDEIROS; RIBEIRO, 2016). 
ditadura brasileira, comenta: "Somos vizinhos no tempo, porque também vivi neste espaço e tive problemas relativamente parecidos" ${ }^{336}$.

O enorme bandeirante desenhado por Laerte remete à imagem de uma estátua esculpida pouco antes de ser instaurado o regime militar no país, o Borba Gato (1963), de Júlio Guerra. Tratase da última grande escultura de um bandeirante instalada em um logradouro público na cidade de São Paulo.

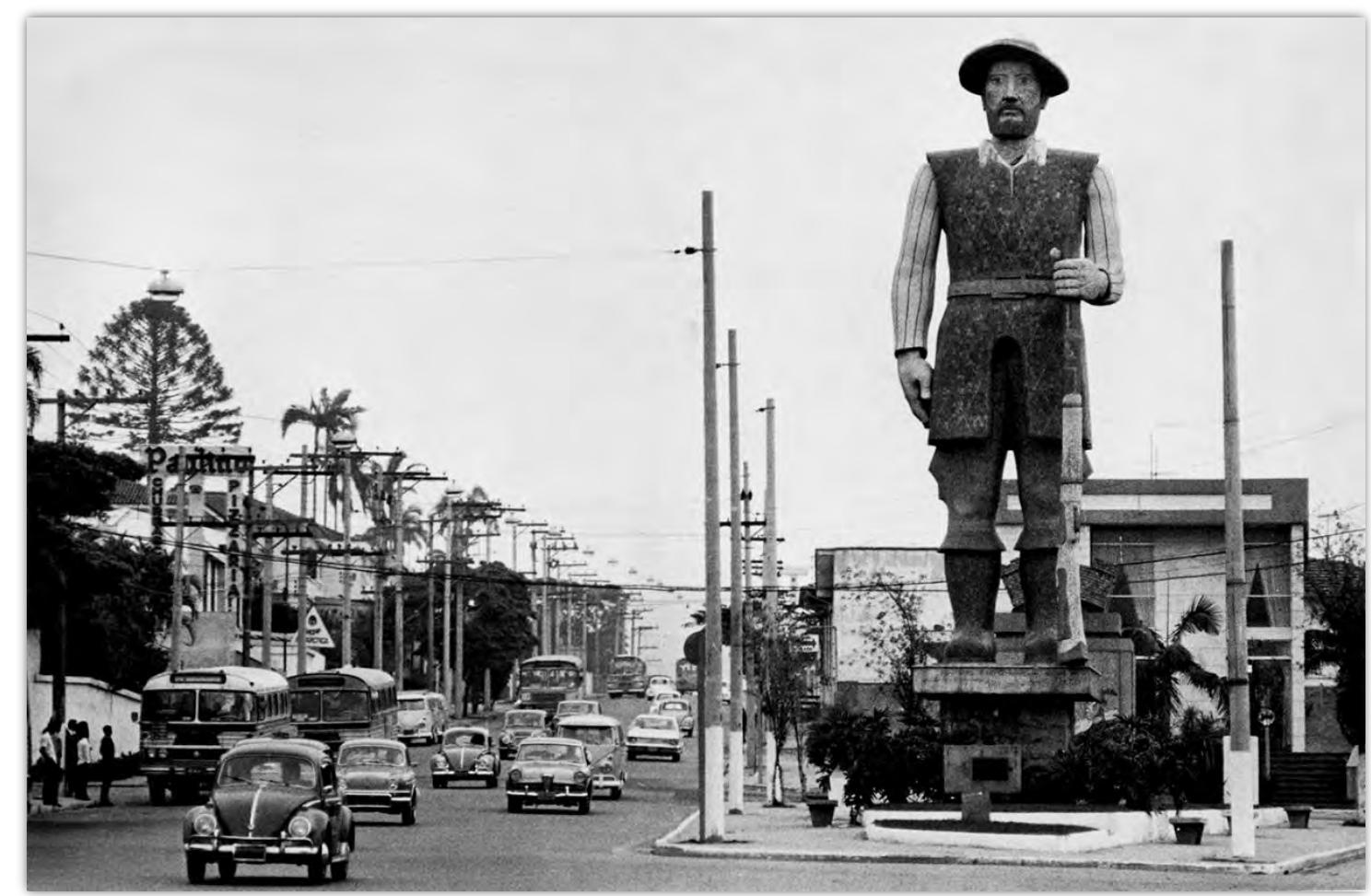

Figura 2.41 - Borba Gato, de Júlio Guerra, anos 1960.

Fonte: São Paulo Antiga ${ }^{337}$.

Com seus dez metros de altura, e arma em punho, a obra de Júlio Guerra, artista que nascera em Santo Amaro quando o atual bairro ainda era um município autônomo, é inaugurada em 1963, visando a comemoração do IV Centenário de Santo Amaro, na atual praça Augusto Tortorelo de Araújo, zona sul da cidade ${ }^{338}$. Localizada na fronteira que se tornou simbólica entre São Paulo e o

\footnotetext{
336 Disponível em: <http://www.ebc.com.br/educacao/2015/11/em-escolas-ocupadas-em-sp-rotina-de-alunos-inclui-limpeza-eaulas-abertas>. Acesso em: 24 maio 2017.

${ }^{337}$ Disponível em: <http://www.saopauloantiga.com.br/borba-gato/>. Acesso em: 20 mar. 2017.

338 Sobre o bairro Santo Amaro, cf. Berardi (1981).
} 
antigo município (anexado na década de 1930 à capital paulista por meio de um decreto estadual), a figura do bandeirante parece vigiar o povoado no qual nascera, como indica a inscrição no pedestal da estátua: "Aqui em Santo Amaro em meados do século XVII nasceu Borba Gato" 339.

Décadas depois dos supostos ossos de Fernão Dias serem desenterrados no largo de São Bento, nas proximidades da praça da Sé, centro geográfico de onde as medições de distâncias das placas toponímicas paulistanas se iniciam, Borba Gato se converte em uma enorme escultura em um bairro que possui seu próprio marco zero, a catedral de Santo Amaro, construída como uma pequena capela no século XVI, a partir da qual ainda hoje são numerados os edifícios e as casas da região. Além disso, a obra encontra-se rodeada por ampla toponímia bandeirante, a começar pela rua Borba Gato, cujo nome foi oficializado pela antiga prefeitura de Santo Amaro. Na mesma região, nos deparamos também com a rua Sabarabuçu — local onde Borba Gato teria encontrado ouro depois da morte de Fernão Dias - e a rua Vapabuçu — referência à lagoa na qual se acreditava existirem esmeraldas —, igualmente nomeadas pela antiga prefeitura. Isso sem falar na rua Tibiriçá, na zona sul da cidade ${ }^{340}$.

Apelidado de "Bonecão", "Boi Parado", "Monstromento", "Big Boy”, “Cristo Redentor", "Monstro Gato", "Borbagatão", entre outras alcunhas, o bandeirante causou muita polêmica desde sua inauguração $0^{341}$. Em 1963, o jornal Folha de S.Paulo registra que "a gente simples, os moradores de Santo Amaro, e os que vivem na cercania acharam Borba Gato um 'monumento de primeira ordem", enquanto para outros a imensa estátua de "40 mil quilos" não passava de "um enorme boneco a olhar indiferente para a cidade" ${ }^{342}$. Na mesma reportagem, Júlio Guerra explica que seu objetivo era fazer uma escultura que chegasse ao alcance do povo e fosse por ele entendida, o que

\footnotetext{
339 Atrás de Borba Gato, a cerca de 25 metros de distância, quatro painéis de mosaico coloridos, com cenas evocativas de personalidades e fatos ligados à história de Santo Amaro, recobrem uma estrutura em forma de cubo. Os painéis retratam: o jesuíta José de Anchieta e o indígena Caiubi, tendo ao centro o brasão de Santo Amaro e o rio Jurubatuba; o casal João Paes e Suzana Rodrigues doando a imagem de Santo Amaro, que emprestou o nome àquela região, à nova capela do local; os primeiros colonos alemães a se fixarem em Santo Amaro e a primeira fábrica de ferro da América do Sul; e, por fim, o poeta santo-amarense Paulo Eiró e o sacerdote jesuíta padre Belchior de Pontes.

340 As ruas Borba Gato, Sabarabuçu, Vapabuçu e Tibiriçá tiveram seus nomes oficializados pelo ato no 23 , de 14 de julho de 1934. Cabe notar que Tibiriçá não só dá nome a uma rua na zona sul da cidade, como anos antes também já havia nomeado outra rua, no Bom Retiro (próxima à rua Jorge Velho), de acordo com o ato nº 972 , de 24 de agosto de 1916. Cf. Núcleo de denominação de logradouros públicos, AHMWL.

341 Os diversos apelidos aparecem frequentemente na grande mídia do período, como em O Estado de S. Paulo e na Folha de S.Paulo.

342 “Com 12m de altura, a estátua de 40t tem seus prós e contras”. Folha de S.Paulo, 7 fev. 1963, Ilustrada, p. 1.
} 
o artista acreditava ter realizado ${ }^{343}$. Em um poema de sua autoria, Guerra de algum modo tenta explicar sua obra:

Fiz o Borba Gato

Diferente

Não parece túmulo e não tem o pedestal enfeitado E quando fazia esquecia de Policleto e lembrava de Aleijadinho

E dos bonecos da arte popular

Depois de pronto eu gostei

E o povo da minha terra também gostou

Fizeram festa

E os romeiros recordaram o Santo Amaro das chácaras e das poesias

Muitos olhos umedeceram

E os letrados, que Leonardo já ironizava, xingaram o Borba Gato

De Bonecão

Boi Parado

Monstromento

E que era feito de pastilhas

Mas não é. Ele é feito de pedras e mármores (apud BERARDI, 1981, pp. 124-125)

Com estrutura construída a partir dos trilhos dos bondes que deixavam de funcionar naquele momento, o "diferente" Borba Gato não é moldado em bronze, como os bandeirantes de O caçador de esmeraldas; tampouco é decorado com pastilhas, tal qual as fachadas dos prédios da época: ele é revestido com basalto e mármore, formando uma espécie de mosaico tridimensional montado com pedras coloridas provenientes de distintos lugares do Brasil e também de Portugal, pedras que o próprio escultor quebrou, cortou e poliu ${ }^{344}$. Júlio Guerra esclarece ainda que procurou afastar sua obra dos "modelos importados", aproximando-a de uma manifestação tradicional de arte "primitiva", como a do escultor negro Antônio Francisco Lisboa, o Aleijadinho, e a dos bonecos populares, de modo a "quebrar a rotina dessas estátuas escuras, que só servem para ornamentar túmulos"345. Feita para o "povo", sua obra desagradou os "letrados", afirma o escultor.

\footnotetext{
343 Em outra matéria, publicada na Gazeta de Santo Amaro, Júlio Guerra explica: "Muitas vezes, no início da obra, chamei gente anônima para ver e dar opinião sobre o que criava. E notei que todos me apoiavam, apenas uma ou outra vez surgia divergência”. Cf. Gazeta de Santo Amaro, 7 fev. 1963.

${ }^{344}$ Em Barbeiro Anédes, um livro igual à estátua de Borba Gato: também diferente (s/d), Júlio Guerra também enfatiza seu interesse por aquilo que considera fora do comum. O personagem que dá título ao livro, Anédes Nemendes de Aragóia y Navaja, é novamente homenageado pelo artista em um painel — de alvenaria de tijolos, concreto e mosaico de pedras — feito nos anos 1960, na mesma década em que esculpe Borba Gato. Intitulado Barbeiro Anédes, o painel está instalado na praça Marcos Manzini, na rua Visconde Taunay, zona sul da cidade, próximo a Borba Gato. 345 “A poluição através da paisagem”. Folha de S.Paulo, 18 mar. 1973, 1 Caderno, p. 11.
} 
O futuro diretor da Pinacoteca do Estado de São Paulo, Delmiro Gonçalves, ao descrever nos anos 1960 Borba Gato como um "trambolho" e um "atentado à estética", referese ao bandeirante de Júlio Guerra como uma "coisa" ${ }^{346}$. Já a galeria Collectio — espaço que teve um importante papel na formação do mercado de arte brasileiro (RODRIGUES, 2015) , ao anunciar um de seus leilões artísticos na década seguinte, afirma que qualquer um que viva cercado em uma São Paulo poluída por construções tais como o "Borbagatão" deveria ter em casa inúmeros quadros para que ao menos pudesse ter algum contato com algo belo. O publicitário Neil Ferreira, redator do texto, defende ainda que "o sujeito que fez aquele negócio [Borbagatão] deveria pagar um imposto pela obra, só por estar poluindo a cidade" 347 . Júlio Guerra retruca: "Eu não esperava tanta promoção e acho que o Borba Gato deveria pagar imposto pela propaganda que está fazendo e não pela poluição visual que muitos lhe atribuem" 348 .

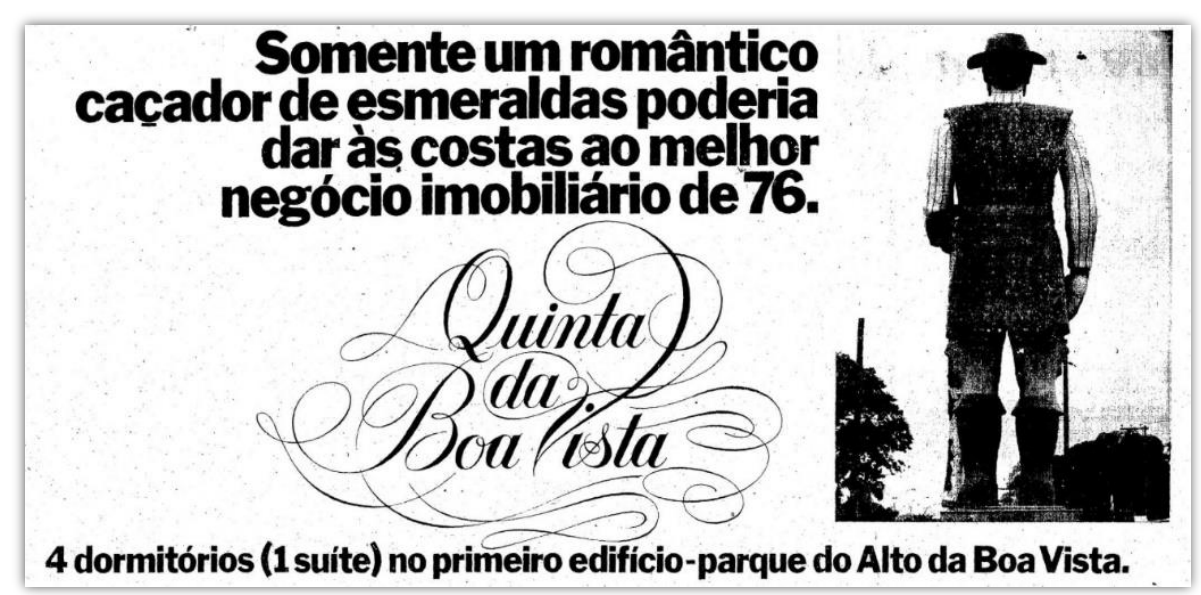

Figura 2.42 - Borba Gato garoto-propaganda, anos 1970.

Fonte: O Estado de S. Paulo, 16 maio 1976, p. 11.

De um modo ou de outro, Borba Gato se torna uma referência na capital paulista. As campanhas imobiliárias dos anos 1970 exaltam o personagem. Ninguém, a não ser sua enorme

\footnotetext{
346 "Quem ama o feio, bonito lhe parece". O Estado de S. Paulo, 9 dez. 1966, p. 44. Nessa mesma ocasião, em resposta a uma leitora do jornal O Estado de S. Paulo — que teria justificado a "feiura" de Borba Gato afirmando que sua mãe jamais seria Miss Brasil, mas ainda assim era a mulher mais bela do mundo —, Delmiro Gonçalves explica que "não é pelo fato de se amar um monstrengo que se deve achá-lo bonito".

347 “A poluição através da paisagem”. Folha de S.Paulo, 18 mar. 1973, 1 Caderno, p. 11.

348 Ibidem, p. 11.
} 
figura, "poderia dar as costas" a um ótimo negócio imobiliário como o anunciado, dirá uma delas $^{349}$. Se Fernão Dias Paes Leme, esculpido em mármore por Luigi Brizzolara, não podia ser visto de costas por estar instalado contra uma das paredes do Museu Paulista, Borba Gato, fincado em uma praça ao ar livre, não apenas podia ser observado de diversos ângulos, como "poderia dar as costas" a quem quisesse.

Este sujeito vai fazer parte do seu endereço. Este sujeito é o Borba Gato!”, afirma outra propaganda $^{350}$. Segundo periódicos da época - como a Folha de S.Paulo e o Estado de S. Paulo —, Borba Gato deu ainda nome a imobiliárias, clubes, colégios, postos de gasolina e lojas no bairro em que nasceu. "Quando qualquer pessoa diz que mora em Santo Amaro, logo perguntam: antes ou depois do Borba Gato?”, defende Júlio Guerra, que em meio a acaloradas discussões que cercaram sua obra, lamenta que os monumentos fossem vistos como “entulhos" 351 . Tanto o povo quanto os administradores preferem árvores a estátuas nas praças públicas, explica o escultor. O próprio Júlio Guerra é autor de uma escultura, encomendada durante a gestão de José Vicente de Faria Lima (1965-1969), que sumiu do mapa ${ }^{352}$. Nomeada São Paulo apóstolo, a obra foi inaugurada em 1969, na face norte do túnel Nove de Julho, próxima ao local de onde fora removida a escultura Beijo eterno. Em 1972 (mesmo ano em que foi inaugurada em Pinheiros uma estátua em homenagem ao próprio Faria Lima), São Paulo apóstolo foi transferida para um depósito da prefeitura ${ }^{353}$.

\footnotetext{
349 “Quintal da Boa Vista”. O Estado de S. Paulo, 16 maio 1976, p. 11.

350 “A poluição através da paisagem”. Folha de S.Paulo, 18 mar. 1973, $1^{\circ}$ Caderno, p. 11.

351 “Você sabe a última da estátua?”. Folha de S.Paulo, 15 maio 1975, Local, p. 19.

352 Júlio Guerra reclama ainda de duas estátuas que, depois de serem inauguradas, foram "levadas não se sabe para onde" como se fossem lixo: a já mencionada escultura de Amadeo Zani em homenagem a Álvares de Azevedo, confundida com a imagem de Fagundes Varela, e uma estátua em homenagem ao Regente Feijó, do francês LouisJoseph Convers, inaugurada em 1913 no largo da Liberdade. “A poluição através da paisagem”. Folha de S.Paulo, 18 mar. 1973, $1^{\circ}$ Caderno, p. 11.

${ }^{353}$ Em 1972, Faria Lima ganhou uma estátua em bronze e granito em sua homenagem, instalada no canteiro central de uma avenida que também leva seu nome, próxima à Escola Estadual Fernão Dias Paes. Esculpida por Luiz Morrone a pedido da Associação Amigos de Faria Lima, a obra foi nomeada Homenagem ao imortal prefeito de São Paulo. Na mesma época, Fundadores de São Paulo, também esculpido por Morrone, circulará pela cidade. Encomendado por representantes da colônia portuguesa, o conjunto escultórico protagonizado por jesuítas e representantes do governo português, ao lado da índia Bartira e de João Ramalho, havia sido inaugurado em 1963 na praça Clóvis Bevilácqua, na região da Sé. No começo dos anos 1970, a obra é transferida para a rua Manuel da Nóbrega, próxima à avenida Sargento Mário Kozel Filho, no Ibirapuera, onde também será instalado Olavo Bilac, de William Zadig. Disponível em: <http://www.prefeitura.sp.gov.br/cidade/upload/Inventario_de_Esculturas_1261586685.pdf>. Acesso em: 7 fev. 2017.
} 
A avenida Nove de Julho ficou então conhecida, não por acaso, como o "lugar das estátuas malditas" 354 . Em matéria intitulada "Você sabe a última da estátua?", publicada na década de 1970 na Folha de S.Paulo, Júlio Guerra afirma de forma irônica não saber o paradeiro de sua obra: " $\mathrm{Na}$ prefeitura me disseram que levaram meu São Paulo para dar um banho"355. Mas nada justificaria um banho tão prolongado, reclama o escultor ao explicar que suas pesquisas lhe revelaram um santo fisicamente disforme, devido às doenças, e miseravelmente vestido, por conta da pobreza: "Eu poderia ter feito um São Paulo grego, eu poderia ter feito um São Paulo romano, seria muito mais fácil. Mas fiz um São Paulo como era, procurando acrescentar-lhe um caráter popular”. Sem aviso prévio, a prefeitura retirou o "São Paulo torto e colorido" para limpeza e nunca mais o devolveu, denuncia outra reportagem, publicada na mesma época em O Estado de S. Paulo ${ }^{356}$. Foi somente em 1993 que São Paulo apóstolo reapareceu, quando foi instalado no largo Los Andes, em Santo Amaro, perto de ninguém menos que Borba Gato, esculpido pelo mesmo artista.

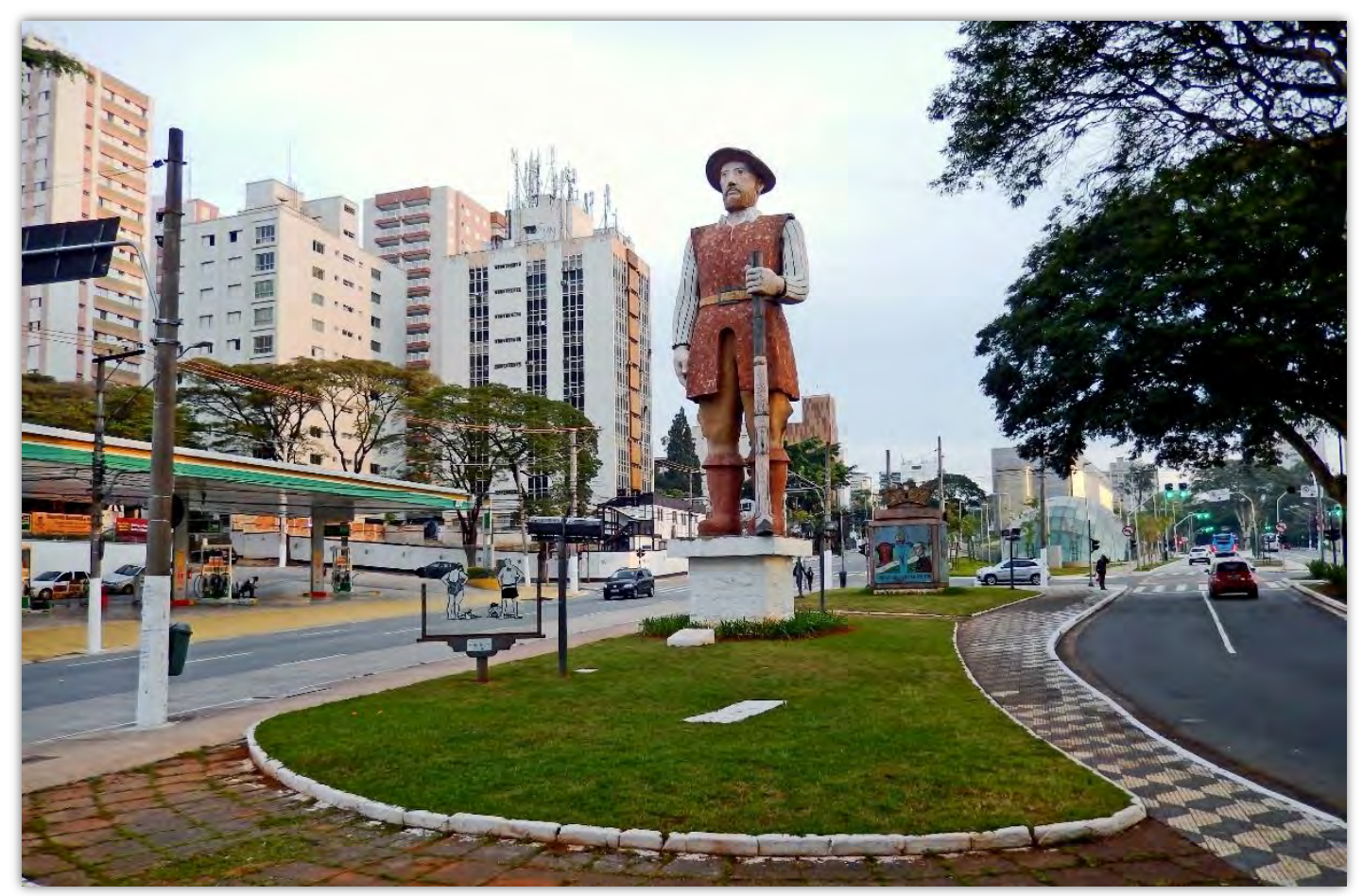

Figura 2.43 - Borba Gato, 2017.

Fonte: Acervo pessoal | Foto: Thaís Waldman.

\footnotetext{
354 Disponível em: <http://acervo.estadao.com.br/noticias/acervo,avenida-9-de-julho-o-lugar-das-estatuas-malditas,11834,0.htm>. Acesso em: 1 fev. 2017.

355 "Você sabe a última da estátua?". Folha de S.Paulo, 15 maio 1975, Local, p. 19.

356 "Prefeitura retira mais uma estátua da cidade". O Estado de S. Paulo, 19 nov. 1972, p. 64.
} 
A estátua do bandeirante, que em sua origem parecia anunciar a verticalização da zona sul da cidade, se mantém até hoje em posição ereta, no centro da praça Augusto Tortorelo de Araújo, como podemos observar na figura acima. Cercado por árvores e prédios que ultrapassam sua altura, Borba Gato já não pode mais dar as costas a quem quiser, como anunciava a propaganda imobiliária dos anos 1970. Mas ele continua a ser referência, ligando-se a outros espaços, como a estação Borba Gato (da linha 5-Lilás do metrô paulistano), inaugurada em 2017 pouco metros atrás do bandeirante esculpido por Júlio Guerra.

\subsubsection{A (i)mobilidade na praça Augusto Tortorelo de Araújo}

Ainda que não se movimente como as demais estátuas que foram parar nos depósitos municipais, o bandeirante esculpido por Júlio Guerra carrega e traz à tona distintos modos de mobilidade. Na década de 1980, “o Borba Gato de 10m [que] dominará Santo Amaro”, como dizia a manchete publicada em 1962 na Folha de S.Paulo ${ }^{357}$, literalmente desaparece, em uma história em quadrinhos, da paisagem da qual foi protagonista durante longo período. Em Entradas e bandeiras (1985), de Luiz Geraldo Ferrari Martins (1951- ), mais conhecido como Luiz Gê, o pedestal da obra de Júlio Guerra, na confluência da avenida Santo Amaro com a Adolfo Pinheiro, parecia não mais suportar o bandeirante: estava vazio ${ }^{358}$. "A cidade dos parques, jardins e monumentos, dos bandeirantes, do cidadão, havia desaparecido já há algum tempo, desde o início dos anos 1960 aproximadamente", defende Luiz Gê (1993, p. 11): “Agora era a cidade dos carros" (a imagem da escultura em 1963 [figura n. 2.41] é reveladora dessa articulação que já ocorria entre verticalização e automóvel).

\footnotetext{
357 “Borba Gato de 10m dominará Santo Amaro". Folha de S.Paulo, 7 abr. 1962, Ilustrada, p. 10.

${ }^{358}$ Luiz Gê é também autor de uma história em quadrinhos feita sobre o corpo de um manequim comercial comum, a Borba Gata, nome da personagem e título de sua história tridimensional. Borba Gata versa, segundo o próprio autor, “(...) sobre um embate — desejo/aversão - entre uma figura feminina erotirânica, com características de super-heroína, e um rato chauvinista, numa luta mais ou menos sadomasoquista que remete para a problematização do corpo e da condição feminina/masculina com a massificação do gosto através de modelos comerciais representados pelo próprio manequim" (GÊ, 2007, p. 145).
} 
Em Entradas e bandeiras, a estátua esculpida por Júlio Guerra, cujas dimensões apontavam para o futuro, está atrasado ${ }^{359}$. Correr contra o tempo, bem o sabemos, é uma das maiores marcas da vida moderna e a escultura de Borba Gato, ao abandonar seu pedestal e andar pela cidade dos quadrinhos, parece buscar se afirmar e voltar a ser impor na paisagem urbana. Vemos na figura abaixo o gigante caminhando, com pressa e sem olhar para o chão, seguindo até as imediações do parque do Ibirapuera, em direção aos bandeirantes esculpidos por Victor Brecheret, que acompanharemos no próximo capítulo. No percurso, a alguns quilômetros de distância de seu lugar de origem, seus pés enormes pisam um automóvel que, igualmente apressado, ultrapassa o farol vermelho no cruzamento entre a avenida Brasil e a Brigadeiro Luís Antônio. Se a "cidade dos carros" havia esmagado Borba Gato - tal qual as enormes letras vazadas de seu nome, enunciadas em forma de grito, gradativamente diminuindo de tamanho —, na obra de Luiz Gê é a estátua do bandeirante que irá esmagar o veículo e seus passageiros. Assim, a figura é retomada na sua vocação andarilha, nômade e destruidora.

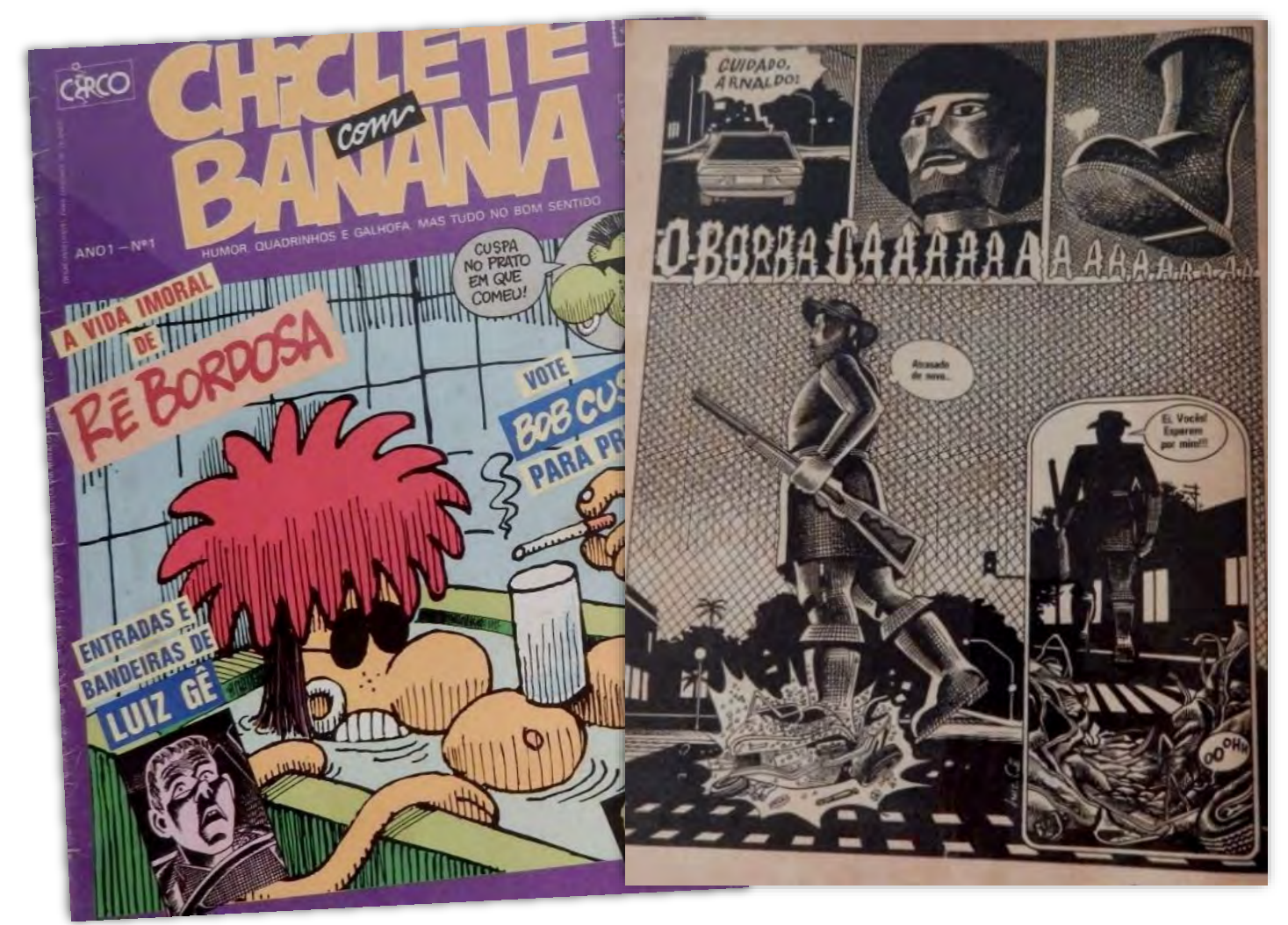

Figura 2.44 - Borba Gato na revista Chiclete com banana (1985).

Fonte: Acervo pessoal | Foto: Thaís Waldman.

359 “O povo paulistano caminha ligeiro, apressado, e no seu olhar, sombrio e parado, já não há demonstrações de lirismo”, dizia Erasto Toledo ainda nos anos 1930, ver Correia (2000). 
Entradas e bandeiras foi publicada na revista Chiclete com banana, que circulou entre 1985 e 1990, chegando a vender 80 mil exemplares de histórias e tiras criadas e desenhadas por jovens quadrinistas brasileiros daquela geração, como Luiz Gê e Laerte (SANTOS, 2014). Anos depois do sucesso dessa publicação, a movimentação de Borba Gato seguia em pauta. Em 2007, a escultura do bandeirante desaparece mais uma vez. Ao se tornar personagem de Alternative Reality Game (ARG), na época pouco conhecido no Brasil, Borba Gato se liberta outra vez do pedestal que o suportava ${ }^{360}$. A ambientação desse jogo, cuja versão paulista recebe o nome "Quem escondeu o Borba Gato?", teve como cenário São Paulo. Na história, a escultura é descrita como uma obra ignorada e malcuidada, tanto pelo poder público quanto pela população. O objetivo do jogo era resgatar, por meio de pistas espalhadas nas mais diversas mídias e nas próprias ruas paulistanas, a estátua escondida atrás de tapumes espelhados. Os jogadores eram os próprios moradores da cidade, que se cadastravam num site criado para resolver o enigma.

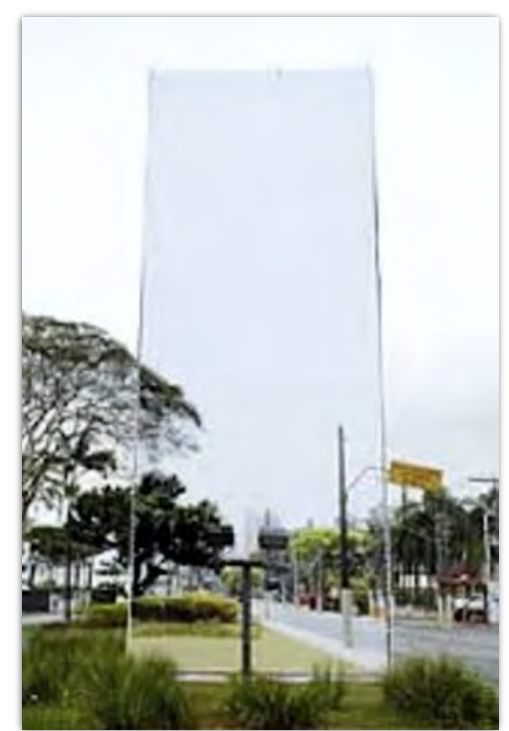

Figura 2.45 - “Quem escondeu o Borba Gato?”, 2007. Fonte: Terra ${ }^{361}$

Encoberto por espelhos, Borba Gato foi parar nos "escombros do infinito", deslocandose por outras mídias ${ }^{362}$. Lembremos que, no mesmo ano de 2007 , começou a circular o vídeo

\footnotetext{
360 Sobre os ARGs, cf. <https://www.argn.com/>. Acesso em: 20 mar. 2017.

361 Disponível em: <http://diversao.terra.com.br/fotos/0,OI55306-EI25,00-Estatua+de+Borba+Gato+some+em +SP.html>. Acesso em: 20 mar. 2017.

${ }^{362}$ Estratégico, o sumiço de Borba Gato também divulgou uma exposição sobre Júlio Guerra, em cartaz na mesma época no Sesc Santo Amaro. Disponível em: < https://extra.globo.com/noticias/brasil/borba-gato-some-vira-personagem-dejogo-inedito-no-pais-654403.html>. Acesso em: 15 abr. 2017.
} 
Borba Gato, o bagulho maravilha (2007), visualizado mais de 53 mil vezes no Youtube. Criticando, por meio do humor, a escolha dos monumentos apontados como possíveis maravilhas do mundo moderno, o vídeo propõe retirar "o nosso Colosso de Rodes" dos "escombros do infinito" "363. Em tom de sátira, o "bagulho maravilha" é lançado como candidato paulista para as "novas sete maravilhas do mundo", mas quem saiu vitorioso foi o carioca Cristo Redentor ${ }^{364}$. Com narração de Paulo César Pereio, o vídeo foi produzido pela Galeria Filmes como parte da campanha "Vote Borba Gato" (www.voteborba.com.br), que ganhou também uma página de apoiadores no extinto Orkut - rede social na qual a escultura seguia dividindo opiniões em comunidades como "Devotos do Borba Gato", "Playmobil gigante", "Eu tenho medo do Borba Gato" e "Vamos explodir o Borba Gato".

Sempre polêmico, o Borba Gato associado ao gosto popular não só perdeu para o Cristo Redentor uma eleição aberta ao povo (realizada por meio de votos pela internet e de chamadas telefônicas), como foi condenado no ano seguinte por um júri igualmente popular, encenado por atores, produtores culturais e ativistas de movimentos sociais ${ }^{365}$. Em 2008, um cartaz aos pés da estátua do bandeirante informava o que acontecia na confluência das avenidas Santo Amaro e Adolfo Pinheiro, em 19 de abril: o julgamento de Borba Gato. Era Dia do Índio e outros cartazes estavam dispostos no local. Um deles descrevia o julgamento como um "movimento no falso monumento", enfatizando que "estuprador, homicida, explorador não merece estátua"; outro afirmava que os atos do bandeirante seguiam sendo reproduzidos na história atual — “Estupra, mas não mata!”, dizia o texto, relembrando a frase proferida por

\footnotetext{
363 "Nosso Colosso de Rodes [estátua grega do deus Sol erguida em 280 a.C.] enfrentou carrapatos, mosquitos, sanguessugas, na saga dos emaranhados silvícolas da nação brasileira. O orgulho de São Paulo, mais ereto que Brasília. Olha só como ele brilha! É o nosso redentor! O Bagulho maravilha!”, diz o locutor Paulo César Pereio. Disponível em: <https://youtu.be/58MqDfb5kbk> Acesso em: 10 fev. 2017.

${ }^{364}$ Inaugurada em 1931, a estátua do Cristo Redentor foi anunciada em Lisboa, em 2007, como uma das "novas sete maravilhas do mundo" - uma revisão de caráter informal e recreativo da lista original das "sete maravilhas", idealizada por uma organização suíça chamada New Open World Corporation (NOWC) —, ao lado da Grande Muralha da China; da cidade helenística de Petra, na Jordânia; da cidade inca de Machu Picchu, no Peru; da pirâmide de Chichén Itzá, no México; do Coliseu, antiga arena de combates em Roma; e do túmulo do Taj Mahal, na Índia. Sobre as ocorrências que cercaram a eleição do Cristo Redentor entre as "novas maravilhas do mundo", cf. Giumbelli \& Bosisio (2010).

${ }^{365}$ Formavam o júri: frequentadores do sarau da Cooperifa e do sarau do Binho, ambos na zona sul da cidade; o coletivo Arte na Periferia; produtores culturais como Graça Cremon, envolvida com o chamado teatro de guerrilha; o grupo de samba Band'Doido; membros do Instituto das Tradições Indígenas (Ideti); o coletivo Epidemia; a banda Os mamelucO; os grupos de teatro Cia Antropofágica, Núcleo do 184 e Kiwi Companhia de Teatro; e ativistas socioculturais como Dulce Muniz, uma das fundadoras do PT, na época do julgamento filiada ao PSTU; entre outros.
} 
Paulo Salim Maluf em 1989, durante sua campanha à presidência pelo Partido Democrático Social (PDS) (em 2008 ele concorreria à prefeitura pelo Partido Progressista [PP]); enquanto um terceiro cartaz, colocado depois do julgamento, trazia o veredito: "Julgado, condenado e preso, fato inédito para um branco e rico".
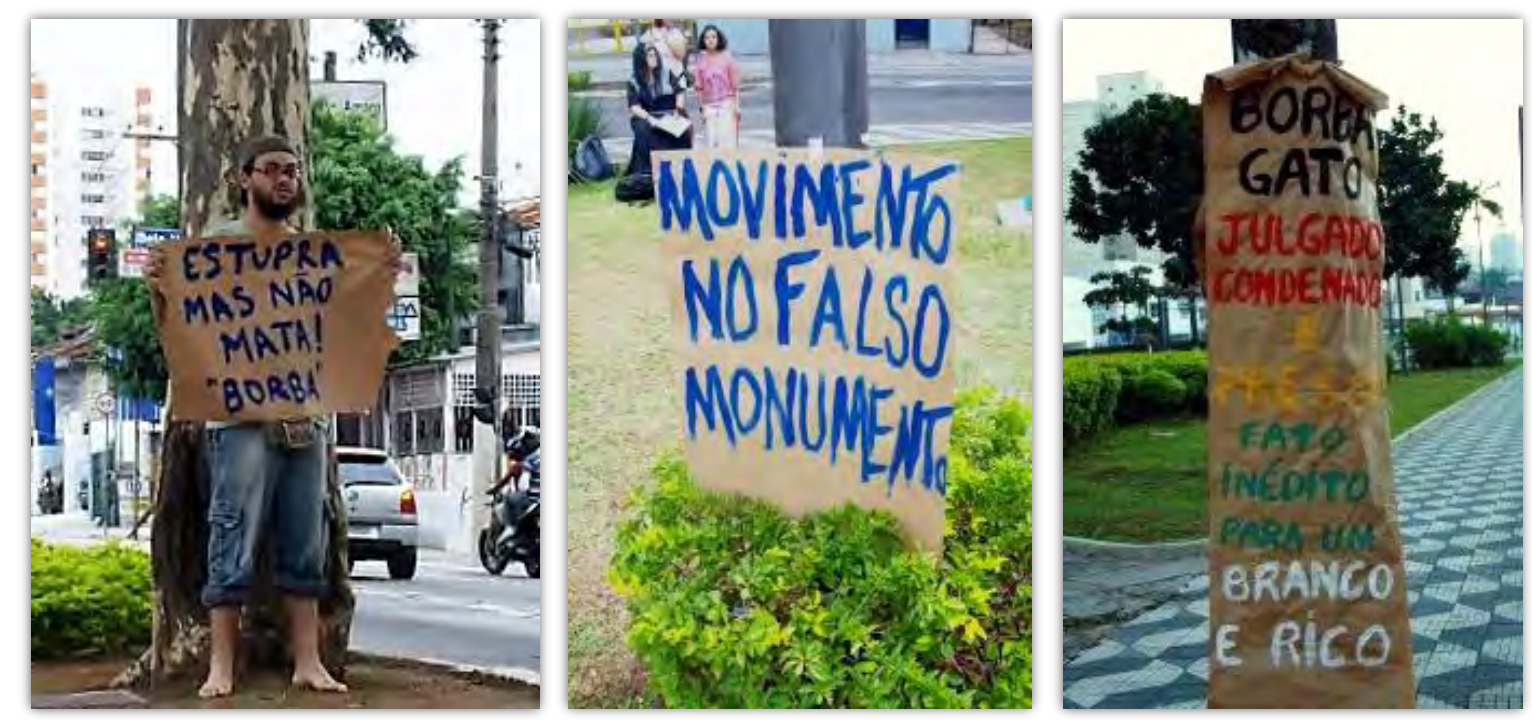

Figura 2.46 - Cartazes próximos a Borba Gato, 2008.

Fonte: Núcleo de Comunicação Alternativa ${ }^{366}$.

O júri popular declarou Borba Gato culpado pelos seguintes crimes: homicídio qualificado de negros, índios e brancos; promoção de trabalho escravo de negros e índios; estupro de mulheres negras e índias; apropriação indébita de riquezas e poder; e porte indevido e ofensivo de armamento pesado em espaço público. A defesa rebate - "Povo ingrato! Povo ingrato! O acusado de fato merece trato de herói! Tudo aquilo que constrói, que o progresso traz de fato, veio com esse cidadão, que chamamos Borba Gato" —, mas o juiz decreta: "Quem decide aqui é o povo, isso é júri popular!". Sua sentença? Segundo o blog Anonimato $S / A$ (Histórias de quem não entra para a história), alguns sugeriram que ele deteriorasse sob o cocô dos pássaros. Outros, que grades fossem colocadas ao seu redor (atitude frequente por parte do poder público em relação à proteção de vários monumentos da cidade). Teve ainda quem propusesse que os pedágios das avenidas que levam nome de "jagunço" revertessem o valor arrecadado para as nações indígenas ${ }^{367}$.

\footnotetext{
366 Disponível em: <http://ncanarede.blogspot.com.br/2008/04/> . Acesso em: 15 abr. 2017.

${ }^{367}$ Disponível em: <http:/ /anonimatosa.blogspot.com.br/2008/04/> . Acesso em: 15 abr. 2017.
} 
Borba Gato acabou sendo condenado à imobilidade por toda a eternidade na praça Augusto Tortorello de Araújo, logradouro nomeado em homenagem a um jovem paulista que morrera em 1968 na Operação Rondon. A pena foi rapidamente executada: um mês depois, a estátua do bandeirante apareceu acorrentada. Inerte, preso a uma corrente "de nióbio, material altamente resistente", Borba Gato com sua "couraça essencial" ficou impossibilitado de usar a grande arma de cano longo que segura com a mão esquerda, apesar de sua pose imponente. "Nossos heróis são outros e não estes que nos apresentam! Queremos mais. Podemos muito mais...", exclama o Núcleo de Comunicação Alternativa (NCA), lembrando que corre no sangue do povo brasileiro a ancestralidade indígena e negra ${ }^{368}$.
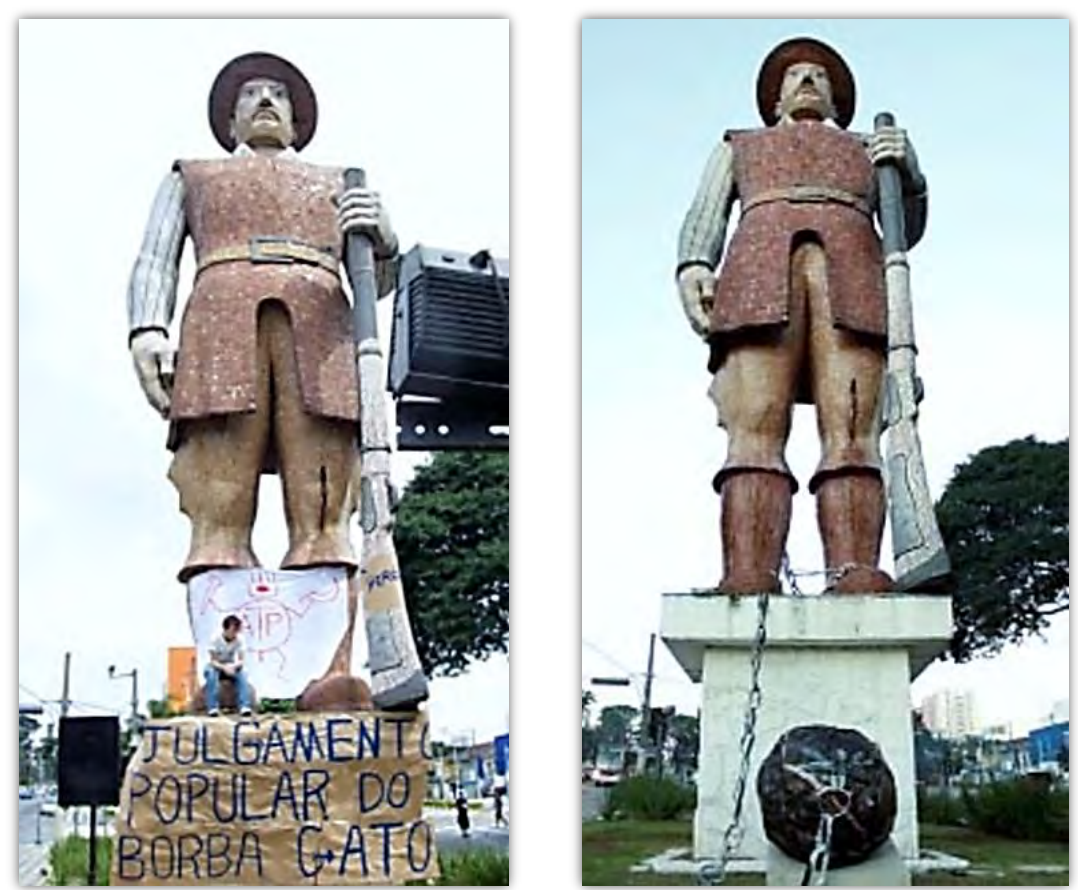

Figura 2.47 - Julgamento popular do Borba Gato, 2008.

Fonte: Núcleo de Comunicação Alternativa ${ }^{369}$.

Importante notar que Júlio Guerra também é autor de outra polêmica escultura, a Mãe Preta, obra que inscreveu a memória da escravatura no espaço público a partir da iniciativa de uma entidade que congregava agremiações negras do estado de São Paulo, o Clube 220. Segundo a Folha da Noite, em 1953, uma década antes da inauguração de Borba Gato, um memorial escrito pelo Clube 220, "entidade que congrega a família de cor de São Paulo", foi entregue à Câmara Municipal

\footnotetext{
${ }^{368}$ Disponível em: <http://ncanarede.blogspot.com.br/2008/>. Acesso em: 20 mar. 2017.

${ }^{369}$ Disponível em: <http://ncanarede.blogspot.com.br/2008/05/> . Acesso em: 15 abr. 2017.
} 
sugerindo a ereção de um busto em homenagem à "lendária babá dos primórdios da colonização do Brasil, quando a família de cor teve destacado papel" ${ }^{370}$. O memorial ressaltava ainda que, entre os monumentos públicos da cidade, não havia nenhum que remetesse à era da pré-abolição da escravatura no Brasil, já que o busto do negro abolicionista Luiz Gama, erguido no largo do Arouche nos anos 1930, partiu de uma iniciativa particular.

Inaugurada em 1955 na região central, no largo do Paissandu, próxima à igreja Nossa Senhora do Rosário dos Homens Pretos - desde o começo do século XX um ponto de referência para a comunidade afrodescendente de São Paulo ${ }^{371}$-, a Mãe Preta causou discórdia entre os militantes negros do período ${ }^{372}$.

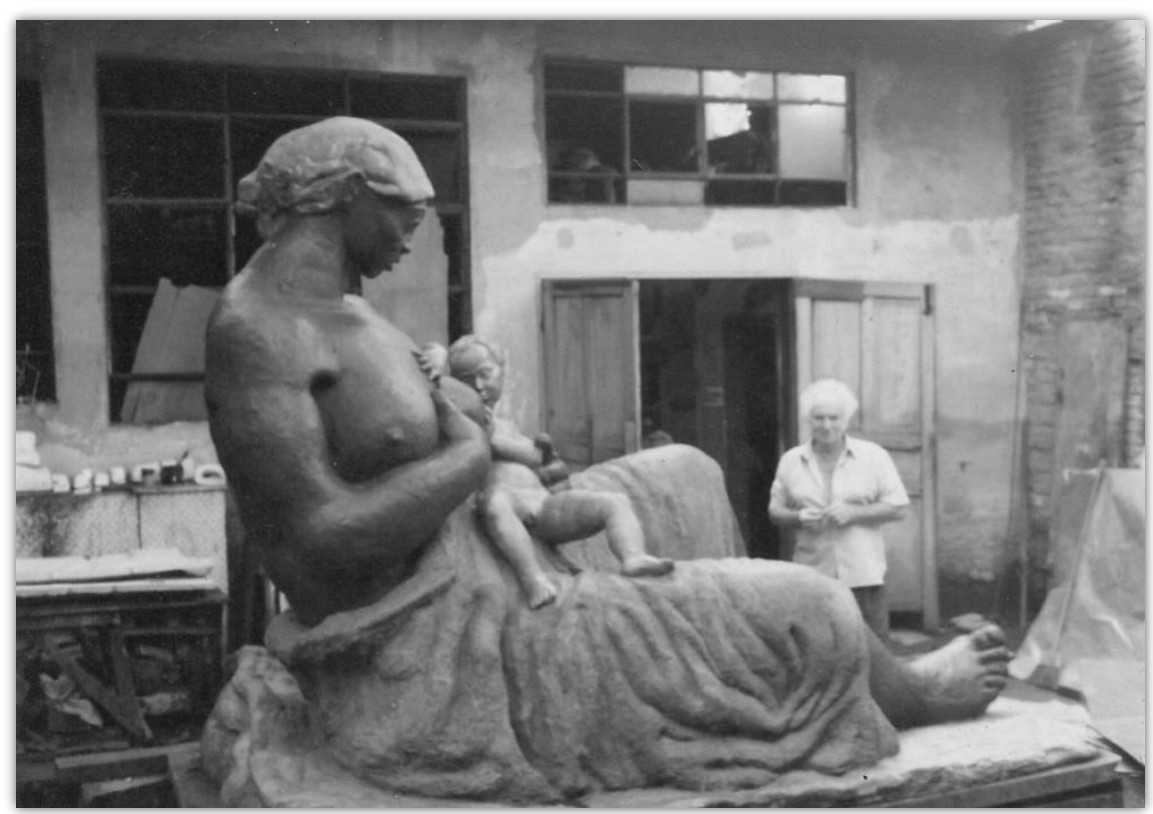

Figura 2.48 - Júlio Guerra e sua Mãe Preta, anos 1950.

Fonte: Júlio Guerra de Santo Amaro ${ }^{373}$.

370 “A ereção do busto da Mãe Preta”. Folha da Noite, 30 jan. 1953, p. 1

${ }^{371}$ Lembremos que no início do século XX, o antigo largo do Rosário, renomeado praça Antônio Prado, só é ampliado e regularizado após a transferência da antiga igreja Nossa Senhora do Rosário dos Homens Pretos para o largo do Paissandu, também remodelado e ajardinado. Livre desse "estigma" — polo de atração da comunidade negra —, a praça se torna o centro social e empresarial de São Paulo (CAMPOS, 2002, p. 83). Recentemente, em 2016, foi inaugurada na praça Antônio Prado uma estátua em homenagem a Zumbi dos Palmares, esculpida por José Maria dos Santos.

372 Sobre o debate em torno da ereção do monumento em homenagem à Mãe Preta nos jornais e nos depoimentos de ativistas negros do período, cf. Lopes (2007).

${ }^{373}$ Disponível em: < https://julioguerradesantoamaro.wordpress.com/tag/paco-cultural-julio-guerra/\#jp-carousel-10>. Acesso em: 15 jul. 2017. 
Incomodado com a ausência de "traços bonitos" na obra, o jornalista e escritor negro José Benedito Correia Leite, cofundador e diretor do jornal O Clarim da Alvorada, afirmara na época: "Se fosse branca não permitiriam que um artista fizesse uma figura deformada como aquela", ao lembrar que a ama de leite precisava ser "muito bonita, muito limpa, muito direitinha” (apud CUTI, 1992, p. 99). Mas a polêmica em torno da Mãe Preta não parou por aí. Nos anos 1970, por exemplo, o Jornegro, periódico publicado pela Federação das Entidades Afro-Brasileiras do Estado de São Paulo, irá defender em um texto não assinado que a imagem da ama de leite remete à figura da "vaca leiteira em benefício dos europeus e de seus filhos", enfatizando a exploração do negro desde seu nascimento, quando ainda bebê ficava com as sobras do leite materno ${ }^{374}$.

Em mais de uma ocasião, Júlio Guerra afirmou que "o que mata é a indiferença” e não as controvérsias em torno de sua obra ${ }^{375}$. Foi esse desinteresse que chamou a atenção do artista Eduardo Srur (1974- ) que, conhecido por suas intervenções urbanas, procurou reativar visualmente alguns monumentos da cidade por meio de uma intervenção. Eduardo Srur instalou enormes coletes salva-vidas de cor laranja com fita reflexiva não apenas no Borba Gato, de Júlio Guerra, mas também em outros quinze monumentos públicos da capital paulista, entre eles o Anhanguera, esculpido na década de 1920 por Luigi Brizzolara ${ }^{376}$. Sua proposta era a de que São Paulo voltasse a olhar para si mesma ${ }^{377}$. O maior deles, com seis metros de altura, feito de espuma, alumínio e náilon, é justamente o de Borba Gato. De salva-vidas, a escultura do bandeirante esperou por dois meses a salvação.

374 “Cartas”. Jornegro, maio 1978, p. 2.

375 “Paixão por Santo Amaro inspira escultor". O Estado de S. Paulo, 19 jan. 2001, p. 80.

${ }^{376}$ Foram também "salvos pelo colete" as seguintes obras: Monumento à Independência (1922), de Ettore Ximenes, no Parque da Independência; Monumento ao Duque de Caxias (1960), de Victor Brecheret, na praça Princesa Isabel; Monumento a Carlos Gomes (1922), de Luigi Brizzolara, na praça Ramos de Azevedo; Rui Barbosa (1930), de José Cucê, na praça Ramos de Azevedo; Camões (1942), também de José Cucê, na praça Dom José Gaspar; Doutor Luiz Pereira Barreto (1922), de Galileo Emendabili, na praça Marechal Deodoro; José Bonifácio de Andrada e Silva (1972), de Alfredo Ceschiatti, na praça do Patriarca; Ibrabim Nobre (1972), de Luiz Morrone, no parque do Ibirapuera; San Martin (1980), de A. Berna, na praça General San Martin; Monumento às musas da escultura e da engenharia, instalado em 2008, de Galileo Emendabili, na praça Luiz Carlos Paraná; Cristóforo Colombo (1992), de Luiz Morrone, na praça Panamericana; Semeador (1969), de Caetano Fracarolli, na praça Apecatu; Armando de Salles Oliveira (1977), de Bruno Giorgi, no portão 1 de acesso à USP; e Vitória (2000), de Odette Eid, na avenida Santos Dumont.

377 "O colete simboliza o salvamento, mas também vai além disso", explica Eduardo Srur, que intitulou seu trabalho Sobrevivência: "Não é só o problema do monumento, mas também daquele que passa pelo monumento. A gente caminha anestesiado. Então proponho um resgate dos sentidos para quem se desloca por São Paulo". Cf. "Srur veste coletes salva-vidas em estátuas de SP”. Folha de S.Paulo, 17 out. 2008, p. E6. 

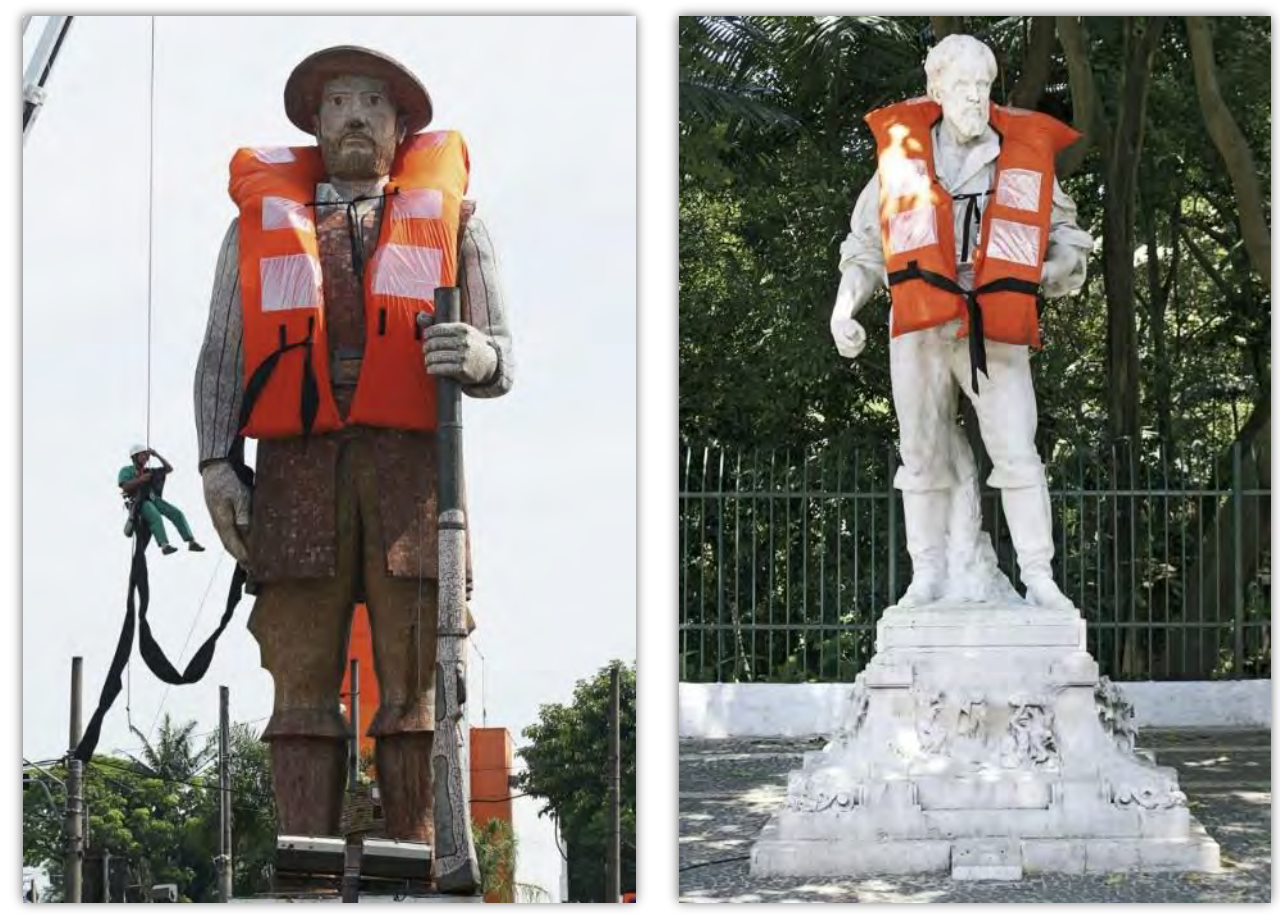

Figura 2.49 - Sobrevivência, de Eduardo Srur, 2008.

Fonte: Acervo Eduardo Srur | Foto: Hilton de Souza ${ }^{378}$.

Ao contrário da intervenção de Eduardo Srur, que foi autorizada pelos órgãos públicos e pelos detentores dos direitos das obras, o julgamento popular de Borba Gato, ocorrido no mesmo ano, não obteve repercussão na grande imprensa, mas em 2015 o bandeirante esculpido por Júlio Guerra ganhou não só as páginas da revista Veja São Paulo, no dia 7 de setembro, como também novas camadas de sentido. "A obra foi vítima de vandalismo", anuncia a Veja São Paulo: coberto com tinta vermelha e com os dizeres "Bandeirante ruralista assassino" gravados em seu pedestal, Borba Gato celebrou "ensanguentado" o aniversário da Independência do Brasil ${ }^{379}$. O bandeirante encarna novamente o genocida, agora em uma grande manifestação contra a PEC 215/2000, proposta de emenda constitucional que pretende passar do Executivo para o Legislativo a demarcação dos territórios indígenas, além de homologar apenas os territórios que estavam ocupados em 1988 e autorizar empreendimentos de impacto nessas áreas ${ }^{380}$.

\footnotetext{
378 Disponível em: <http://www.eduardosrur.com.br/intervencoes/sobrevivencia > . Acesso em: 20 mar. 2017.

${ }^{379}$ Disponível em: <http://vejasp.abril.com.br/cidades/estatua-borba-gato-pichada/>. Acesso em: 27 mar. 2017.

380 Sobre os protestos relacionados às iniciativas do Legislativo federal para restringir os direitos indígenas (especialmente os territoriais) entre 2011 e 2016, ver Ricardo \& Ricardo (2017).
} 


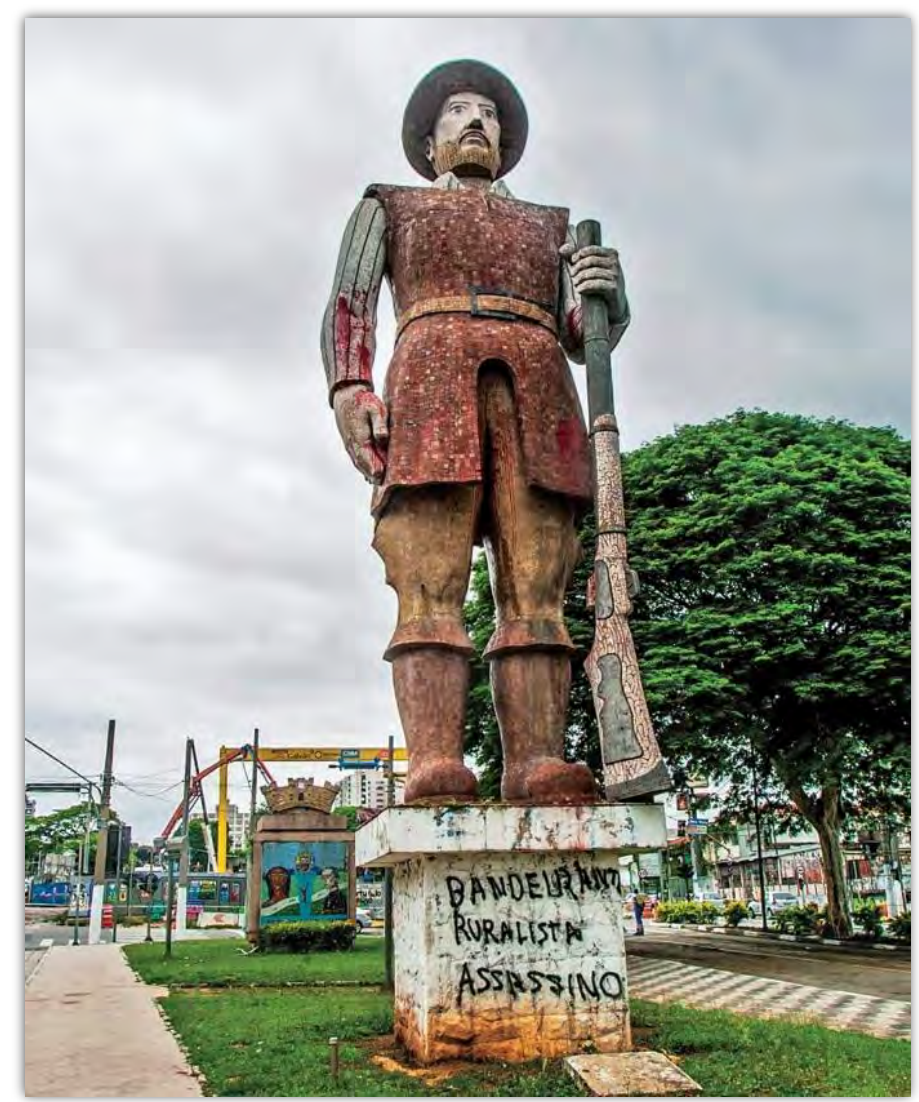

Figura 2.50 - “Bandeirante ruralista assassino", 2015.

Fonte: Veja São Paulo ${ }^{381}$.

Amanhecer "ensanguentado" parece ter sido pouco. No mesmo ano de 2015, a quilômetros de distância da praça Augusto Tortorelo de Araújo, um confronto entre indígenas e fazendeiros culminou na morte do guarani-kaiowá Semião Fernandes Vilhalva, no município de Antônio João, no Mato Grosso do Sul, estado com a segunda maior população indígena e a pior distribuição de terras do país ${ }^{382}$. Nas redes sociais e em protestos de rua, começou então a circular a campanha “Quem matou Semião?”, protagonizada pelo Borba Gato “ensanguentado”, exigindo que o culpado pela morte do líder indígena fosse identificado e condenado pelo crime ${ }^{383}$. Mas Semião não foi o

381 Disponível em: <http://vejasp.abril.com.br/cidades/estatua-borba-gato-pichada/>. Acesso em: 27 mar. 2017.

382 Em 2005, os guarani-kaiowá, no município de Antônio João, conseguiram a homologação da Terra Indígena Nande Ru Marangatu, por meio de um decreto assinado pelo presidente Luiz Inácio Lula da Silva (PT), mas ainda não têm o direito de usufruí-la, pois o processo está parado na Justiça Federal. No mesmo ano, o decreto foi suspenso por uma liminar concedida pelo ministro do Supremo Tribunal Federal (STF) Nelson Jobim, e até hoje aguarda decisão da Suprema Corte. Desde então, os guarani-kaiowá ocupam uma pequena área dos mais de 9 mil hectares homologados, enquanto o restante foi dividido em fazendas, em posse de latifundiários do estado. Disponível em: $<$ http://www.funai.gov.br/terra_indigena_2/mapa/index.php?cod_ti=30301>. Acesso em: 28 mar. 2017. Os conflitos pela posse da Terra Indígena Nande Ru Marangatu foram analisados por Eremites de Oliveira (2015).

${ }^{383}$ Sobre a luta pela terra guarani-kaiowá, cf. Pimentel \& Moncau (2011), Pimentel (2013) e Pereira (2017). 
único indígena a perder a vida em meio às disputas por terra na região, o que inseriu a campanha em um contexto mais amplo ${ }^{384}$ : um requerimento foi protocolado na Assembleia Legislativa de Mato Grosso do Sul pedindo a instauração de uma Comissão Parlamentar de Inquérito (CPI) para investigar o genocídio dos povos indígenas ${ }^{385}$.

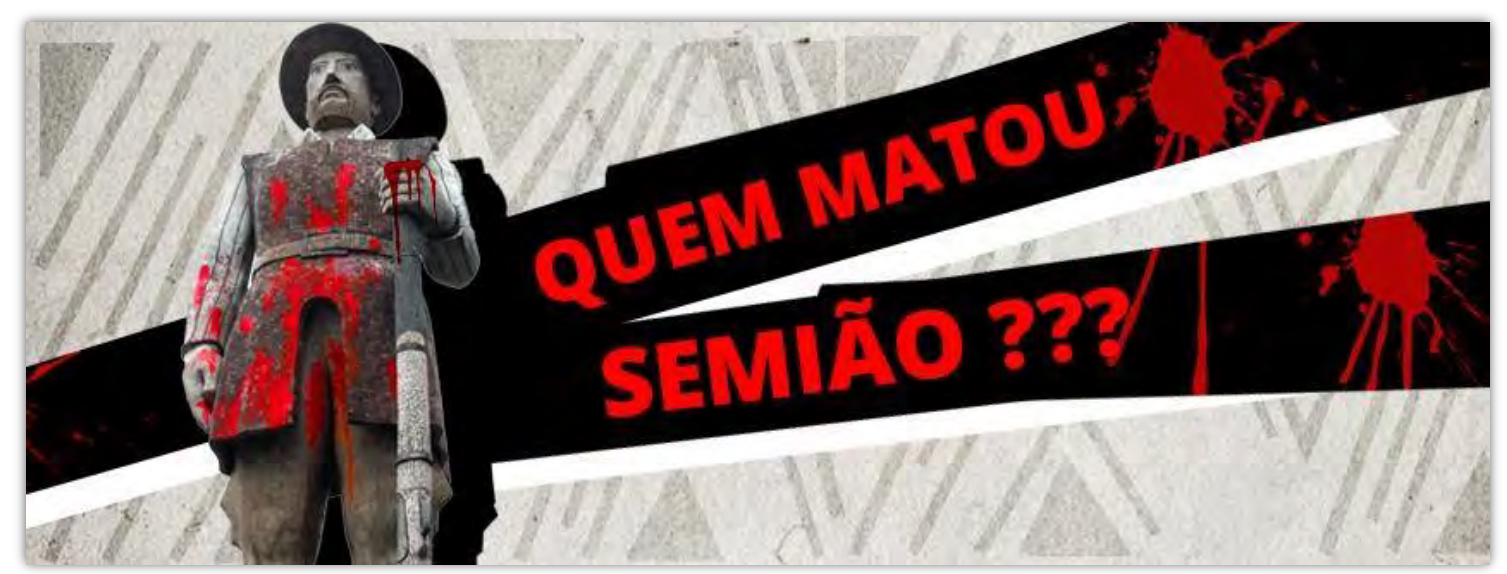

Figura 2.51 - Campanha “Quem matou Semião?”, 2015.

Fonte: Página do Facebook de Tenonderã Ayvu ${ }^{386}$.

\subsubsection{Estilhaços para muito além do antigo povoado}

Embora o Borba Gato da campanha “Quem matou Semião?” esteja foragido, a escultura de Júlio Guerra continua a render novas criações. Em 2016, enquanto os ataques aos guarani-kaiowá

\footnotetext{
384 Segundo os dados do Relatório de violências contra os povos indígenas, escrito pelo Conselho Indigenista Missionário (Cimi), entre 2003 e 2015 foram assassinados 426 indígenas no estado do Mato Grosso do Sul e outros 752 cometeram suicídio. Em 2015, foram registrados no Mato Grosso do Sul mais de dez ataques paramilitares contra várias comunidades guarani-kaowá e, segundo dados oficiais, 36 homicídios, entre eles o de Semião Vilhalva, atingido por um tiro no rosto quando tentava salvar seu filho em meio ao conflito por terras. Disponível em: <https://cimi.org.br/pub/relatorio/Relatorio-violencia-contra-povos-indigenas_2015-Cimi.pdf>. Acesso em: 7 mai. 2017.

${ }^{385}$ Em 2016, a partir de relatórios do Cimi e da Comissão Pastoral da Terra (CPT), produzidos entre 1985 e 2015 , a Fundação Rosa Luxemburgo lançou uma plataforma chamada Cartografia de Ataques Contra Indígenas (Caci), na qual organiza em um mapa online registros de assassinatos de indígenas no Brasil, entre eles o de Semião Vilhalva, além de dossiês com análises de casos emblemáticos, como o assassinato em massa dos guarani-kaiowá no Mato Grosso do Sul. Disponível em: <http://caci.rosaluxspba.org/\#!/> . Acesso em: 2 set. 2017.
}

386 Disponível em: <https://www.facebook.com/pg/tenonderaayvu/photos/>. Acesso em: 20 mar. 2017. 
com munições letais em conflitos por terras do Mato Grosso do Sul prosseguiam, Borba Gato protagonizava em São Paulo o webdocumentário Mobiliário urbano. Financiado pelo Programa de Ação Cultural (ProAC) da Secretaria da Cultura do Estado de São Paulo, o vídeo é uma produção coletiva dedicada à capital paulista e à morte dos próprios bandeirantes, como indica o texto de apresentação do site no qual ele foi disponibilizado: “À cidade! Morte aos bandeirantes! Kabummm! Pela reescrita da História. Pela nova fala da memória”387.

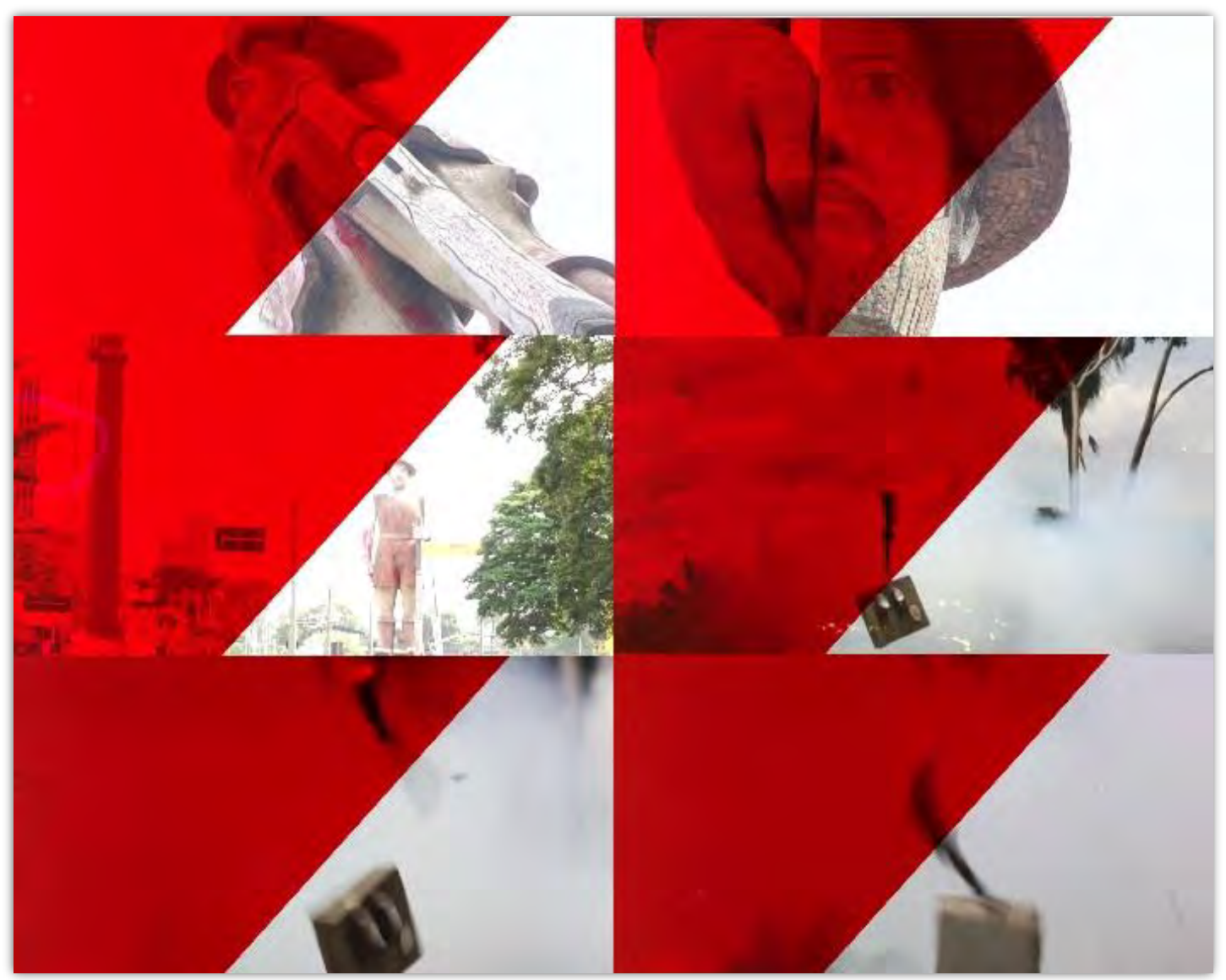

Figura 2.52 - “Kabummm!".

Fonte: Webdocumentário Mobiliário urbano.

No final de Mobiliário urbano, o que resta de Borba Gato são estilhaços espalhados em todas as direções. A demolição do bandeirante de Júlio Guerra procura abrir espaço para diversas vozes silenciadas ("fala negra, fala morador, fala macumbeira, fala povo, fala imigrante") a quem o vídeo busca dar protagonismo (“fala e deixa registrado na memória para todos verem, para todos saberem

387 O webdocumentário foi produzido por André Teles Alves, Eduardo Liron, Frederico Moreira, Renan Vasconcelos e Mirrah Iañez Gonçalves da Silva. Esta última, em 2013, produziu seu primeiro curta-metragem documental chamado Estátuas vivas, voltado precisamente para o universo dos monumentos e sua relação com o centro da cidade de São Paulo. Disponível em: <https://moburb.org/>. Acesso em: 9 mar. 2017. 
que naquele lugar tem cova!”). De dentro do monumento destruído emergiria assim a evidência de outros enredos silenciados, ou seja, o monumento "desterrado" continuaria se deslocando. Alberto Goyena (2013, p. 30) nos lembra que no latim o vocábulo demolir é tomado como sinônimo de "destruir" apenas em seu sentido figurado e, embora essa definição tenha se perdido no uso corrente do português, em sua primeira acepção demolitio é definido como "a ação de descender uma estátua de seu pedestal, retirar do nicho”, de modo que ela seguirá se movimentando. 


\section{DESFIGURAÇÕES}

Contagiados pela "febre estatuária" dos anos 1920, trabalhada no capítulo anterior, os "paulistas" oferecem a São Paulo um monumento em homenagem ao Centenário da Independência do Brasil, o Monumento às bandeiras, do italiano Victor Brecheret (1894-1955) ${ }^{388}$. O Correio Paulistano anuncia a maquete da obra, pouco antes de ser apresentada ao público pela primeira vez. Nela, abusando de "linhas simples e grandiosas", o escultor presta um tributo à “epopeia das bandeiras", informa O Estado de S. Paulo; enquanto uma matéria publicada no Diário Popular ressalta que sua "concepção original" não se atém às "convenções de escola", nem às "ficções acadêmicas"389. O plano da obra sugere que são outros os bandeirantes homenageados em gesso por Brecheret; não mais Fernão Dias que era, nessa mesma época, convertido em granito, mármore e bronze em três distintos locais da cidade. Ao contrário das esculturas de Fernão Dias, as figuras plasmadas na maquete não remetiam a personagens individualizados: eram todos anônimos, além de desprovidos de vestimentas e adornos.

Em afirmação peremptória publicada na revista Ilustração Brasileira, Mário de Andrade diz que nada deteria esses "seres gigantescos e desnudos", que "arrastam a barcaça que as corredeiras impediram de passar", embora o Correio Paulistano preveja a "morte" do Monumento às bandeiras 390 , em texto assinado por Menotti del Picchia na mesma época. De fato, nos anos 1920, em meio ao alvoroço para dotar a cidade de homenagens, nem todas as propostas apresentadas foram executadas. Ainda que a primeira maquete em gesso de Brecheret não tenha sido fundida em bronze, como previa o projeto, e que tenham sido muitas as versões do monumento, ele é inaugurado durante os preparativos para as comemorações do IV Centenário da fundação de São Paulo $^{391}$. Última de várias obras realizadas pelo escultor, e a primeira a ser esboçada, o Monumento

\footnotetext{
388 “Monumento das Bandeiras". Correio Paulistano, 27 jul. 1920, p. 3.

389 “O Centenário da Independência”. O Estado de S. Paulo, 28 jun. 1920, p. 3 / "Maquete dos Bandeirantes”. Diário Popular, 31 jul. 1920, p. 1.

390 “De São Paulo". Ilustração Brasileira, nov. 1920, p. 37/ “A vitória de um patrício”. Correio Paulistano, 10 nov. 1921, p. 4.

391 Sobre a história do monumento, de 1920 a 1953, ver Batista (1985).
} 
às bandeiras ocupa hoje quase toda a praça Armando de Salles Oliveira, na entrada do parque do Ibirapuera, com seus cerca de 45 metros de comprimento e onze de altura.

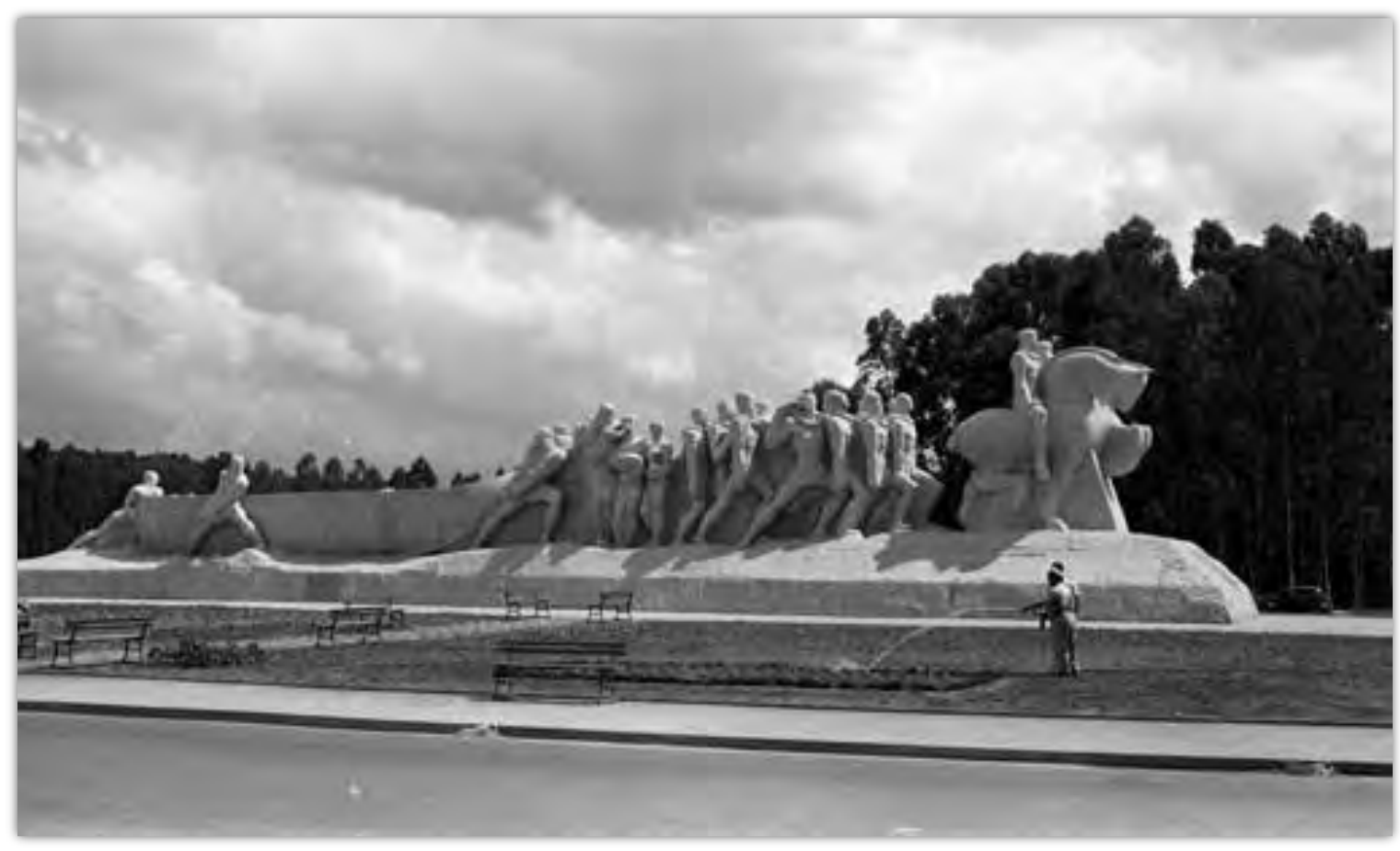

Figura 3.1 - Monumento às bandeiras, 1953.

Fonte: Acervo Fotográfico do Museu da Cidade de São Paulo | Foto: Gabriel Zellaui.

Nas semanas anteriores a sua inauguração, mais de três décadas depois do Centenário da Independência do Brasil, o mesmo Correio Paulistano que havia prenunciado em 1920 a "morte" do Monumento às bandeiras irá aclamar os "trinta anos de vida [de Brecheret] junto do maior bloco de granito do mundo" ${ }^{392}$. Antes, portanto, de surgirem em 1953 em meio às árvores, numa praça recém-criada na zona sul da cidade, os personagens esculpidos por Brecheret (entre eles o próprio escultor, que nos anos 1930 se autorretrata na obra) já marcavam presença na capital paulista. Constantemente evocados pela mídia desde a maquete, os bandeirantes de Brecheret adquirem fama Brasil afora ${ }^{393}$. Não à toa, em 1946, Nelson Rockefeller, presidente do Museu de Arte Moderna (MoMA) de Nova York, em umas de suas vindas a São Paulo, fez questão de visitar em

\footnotetext{
392 "Trinta anos me custou tudo isso. Quero ver o trabalho inaugurado logo, antes de morrer", teria dito Victor Brecheret no início dos anos 1950. "Trinta anos de vida junto do maior bloco de granito do mundo". Correio Paulistano, 21 dez. 1952, suplemento Pensamento e Arte, p. 16.

393 Sandra Brecheret Pellegrini (1976) reproduziu em livro diversas reportagens, crônicas e manuscritos sobre o Monumento às bandeiras e outras obras de seu pai, escritos entre 1916 e 1976.
} 
um "passeio sem protocolo", segundo a revista Elite, os moldes em gesso da obra cuja imagem se tornaria um dos mais famosos cartões-postais da cidade ${ }^{394}$.

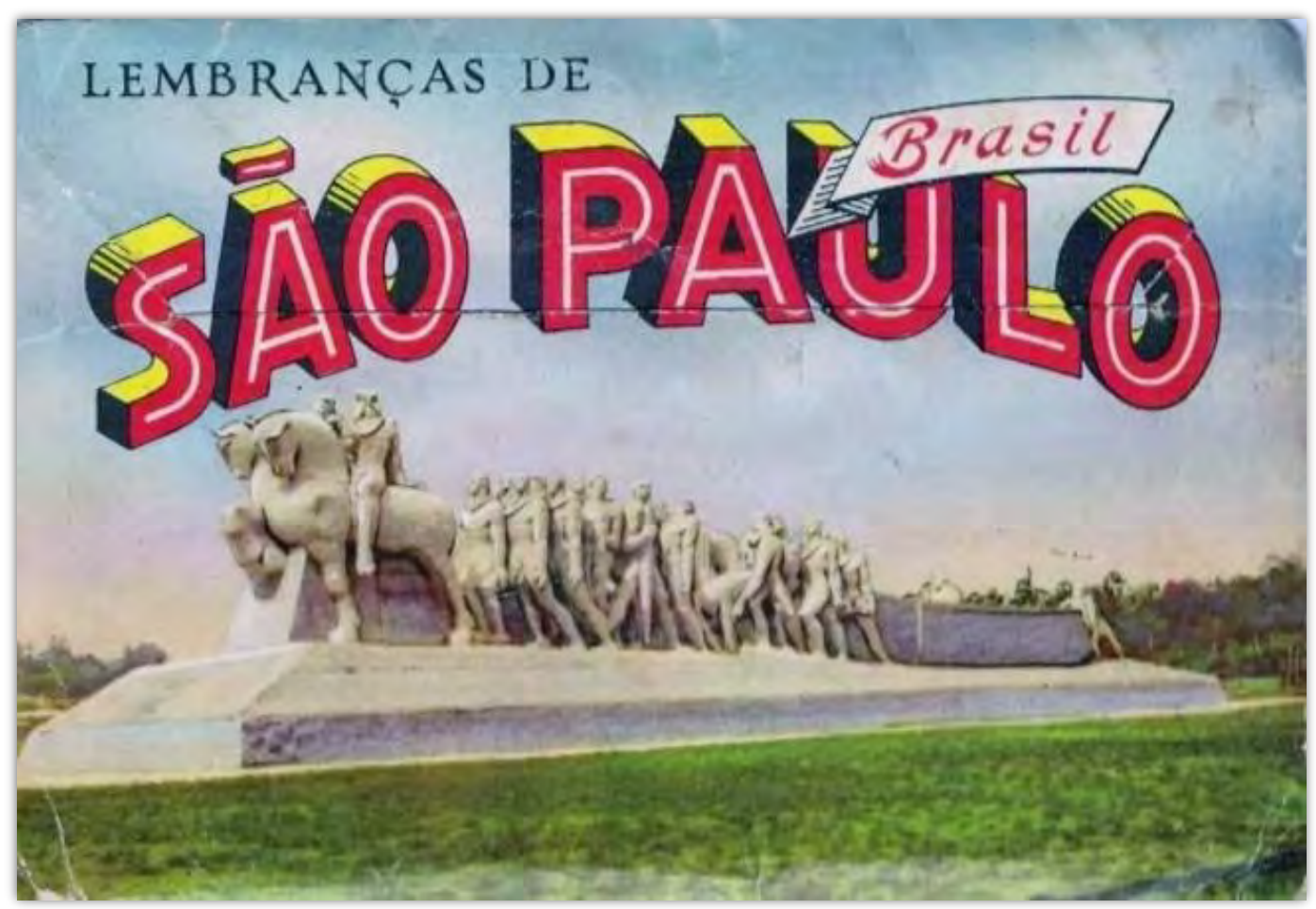

Figura 3.2 - Monumento às bandeiras, capa do álbum de cartões-postais, anos 1950. Fonte: Sampa Histórica ${ }^{395}$.

Longe de ser estático, o Monumento às bandeiras adquire significados distintos, no tempo e no espaço, passando por constantes transformações e apropriações, e imprimindo novas direções e sentidos à história. Lembremos que, nos anos 2010, a cabeça de alguns de seus personagens foi desfigurada ao ser coberta por tinta vermelha (prontamente removida pela prefeitura na manhã seguinte) durante a Semana Nacional de Mobilização Indígena. Aquilo que era pedra "sangrou" por um dia, defende o guarani mbya Marcos Tupã, transformando-se no Monumento à resistência

\footnotetext{
${ }^{394}$ Nelson Rockefeller, segundo a mesma matéria, “como um garoto que salta no quintal do vizinho para pegar a bola, pulou o muro do ateliê [de Brecheret] e ali permaneceu durante longo tempo". "O prisioneiro do parque do Ibirapuera". Elite, 1947, reproduzido em Pellegrini (1976, pp. 80-82). Rockefeller veio dez vezes ao Brasil, a terceira delas em 1946, engajando-se na criação dos museus de arte moderna do Rio de Janeiro e de São Paulo, entre outros projetos, ver Tota (2014).

${ }^{395}$ Disponível em: <https://sampahistorica.wordpress.com/2015/08/05/heranca-da-vovo/>. Acesso em: 29 jun. 2017.
} 
guarani $^{396}$. Continuamente ressignificada, vemos uma obra que, desde seu projeto inicial, concentra significações discordantes, permitindo pensar em temporalidades justapostas. Sobreposição de blocos de granito, nos termos de Brecheret ${ }^{397}$, o Monumento às bandeiras sobrepõe também camadas de tensões e disputas.

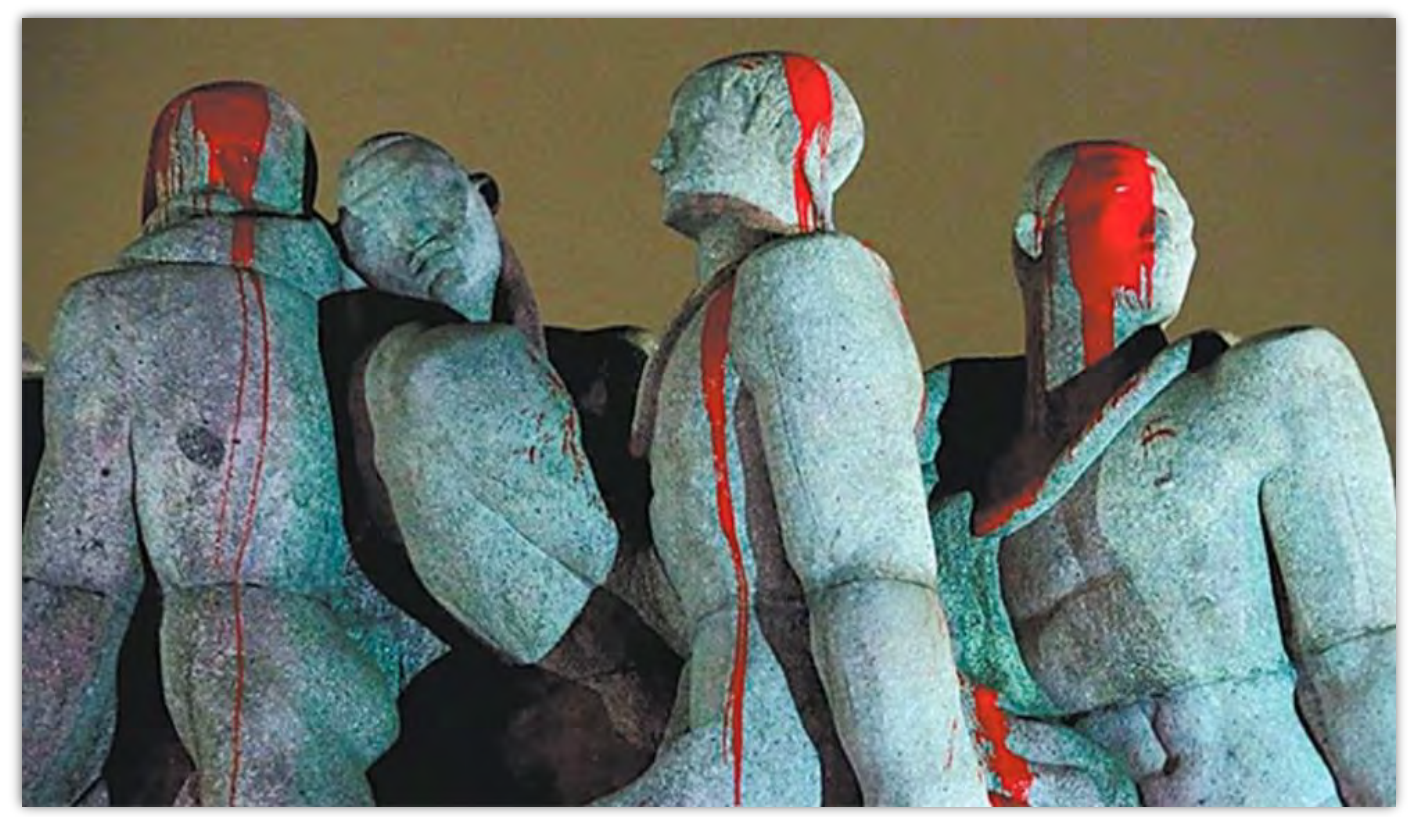

Figura 3.3 - Monumento à resistência guarani, 2013.

Fonte: Brasil de Fato, 9 out. $2013^{398}$.

Heróis e anti-heróis; símbolos da ditadura e de governos de orientação democrática; retratos do progresso e do retrocesso; imagens do passado e do futuro; as encarnações das figuras esculpidas pelo artista são as mais diversas e, muitas vezes, paradoxais. Marcada assim por uma multiplicidade de sentidos, trata-se de uma obra que habita distintas memórias e transita entre diferentes usos, reações e interpretações. Assumindo a premissa de que um monumento, desde a

${ }^{396}$ Carta aberta do guarani Marcos Tupã divulgada durante a Mobilização Nacional Indígena, em outubro de 2013. Disponível em: <https://trabalhoindigenista.org.br/monumento-a-resistencia-do-povo-guarani/>. Acesso em: 15. jul. 2017.

397 "Imaginei uma grande rocha de granito esculpida; como não havia nenhuma no local, precisei criá-la superpondo bloco sobre bloco", explica Brecheret ao falar sobre a concepção de sua obra. Cf. "O Monumento às bandeiras". Gazeta, 31 dez. 1952, reproduzido em Pellegrini (1976, p. 112).

398 Disponível em: <https://www.brasildefato.com.br/node/26228/>. Acesso em: 24 out. 2017. 
sua concepção, é uma forma em constante movimentação, seguiremos neste capítulo esse "projeto em movimento" que o Monumento às bandeiras exemplifica à perfeição ${ }^{399}$.

\subsection{A odisseia do monumento}

"A odisseia do Monumento às bandeiras começou quando Washington Luís afirmou: 'Para evitar discussões, guardem esse trabalho na Pinacoteca"'

(Correio Paulistano, 21 dez. 1952, p. 16)

Apresentada ao público em julho de 1920, a maquete do Monumento às bandeiras é exposta na Casa Byington ${ }^{400}$, estabelecimento comercial localizado no centro da cidade, na rua Quinze de Novembro ${ }^{401}$. Em sua primeira aparição pública, sob o olhar de Washington Luís, estudioso das bandeiras, a maquete teve boa cobertura da imprensa. Contou também com o apoio de intelectuais e artistas envolvidos na realização da Semana de Arte Moderna, como Menotti del Picchia (1892-1988) e Monteiro Lobato (1882-1948), ambos membros do IHGSP 402 respectivamente vinculados a grupos que giravam em torno dos jornais Correio Paulistano e $O$ Estado de S. Paulo, o que aumentou seu alcance midiático. Junto a Oswald de Andra de (1890-

399 Da mesma maneira que um edifício - como o Martinelli em São Paulo, conforme mostram Fernanda Peixoto e Alexandre Bispo (2016), em análise inspiradora —, o Monumento às bandeiras não é um "objeto estático", mas sim um "projeto em movimento", nos termos de Latour \& Yaneva (2008).

400 Especializada em artigos elétricos, a Casa Byington destacou-se nos anos 1920 como um dos estabelecimentos comerciais nos quais eram realizadas com frequência exposições de arte, cf. Rossi (2003).

401 Antiga homenagem a um bandeirante que ali residia no século XVII, o logradouro consta nos registros da documentação oficial da cidade desde 1668, quando era chamado rua Manoel Paes Linhares. A partir de 1715, com a construção da igreja Nossa Senhora do Rosário dos Homens Pretos, na atual praça Antônio Prado, o local ficou conhecido como rua do Rosário. Em 1846, quando São Paulo recebe a visita da família imperial brasileira, a Câmara Municipal altera o nome da rua do Rosário para rua da Imperatriz. Posteriormente, com a proclamação da República, a rua da Imperatriz passa a ser chamada rua Quinze de Novembro, lembrando a data em que foi proclamada a República. Cf. Núcleo de denominação de logradouros públicos, AHMWL.

402 Sobre as narrativas a respeito da cidade de São Paulo, do IHGSP as comemorações do IV Centenário, ver Silva (2013). 
1954), que escrevia para o Jornal do Commercio, Menotti e Lobato haviam encabeçado uma comissão responsável pela organização do projeto de um monumento paulista em homenagem aos bandeirantes, ofertado à cidade por ocasião das comemorações do Centenário da Independência do Brasil; Brecheret, que acabara de voltar a São Paulo depois de uma temporada de estudos na Itália, foi escolhido para realizar tal obra.

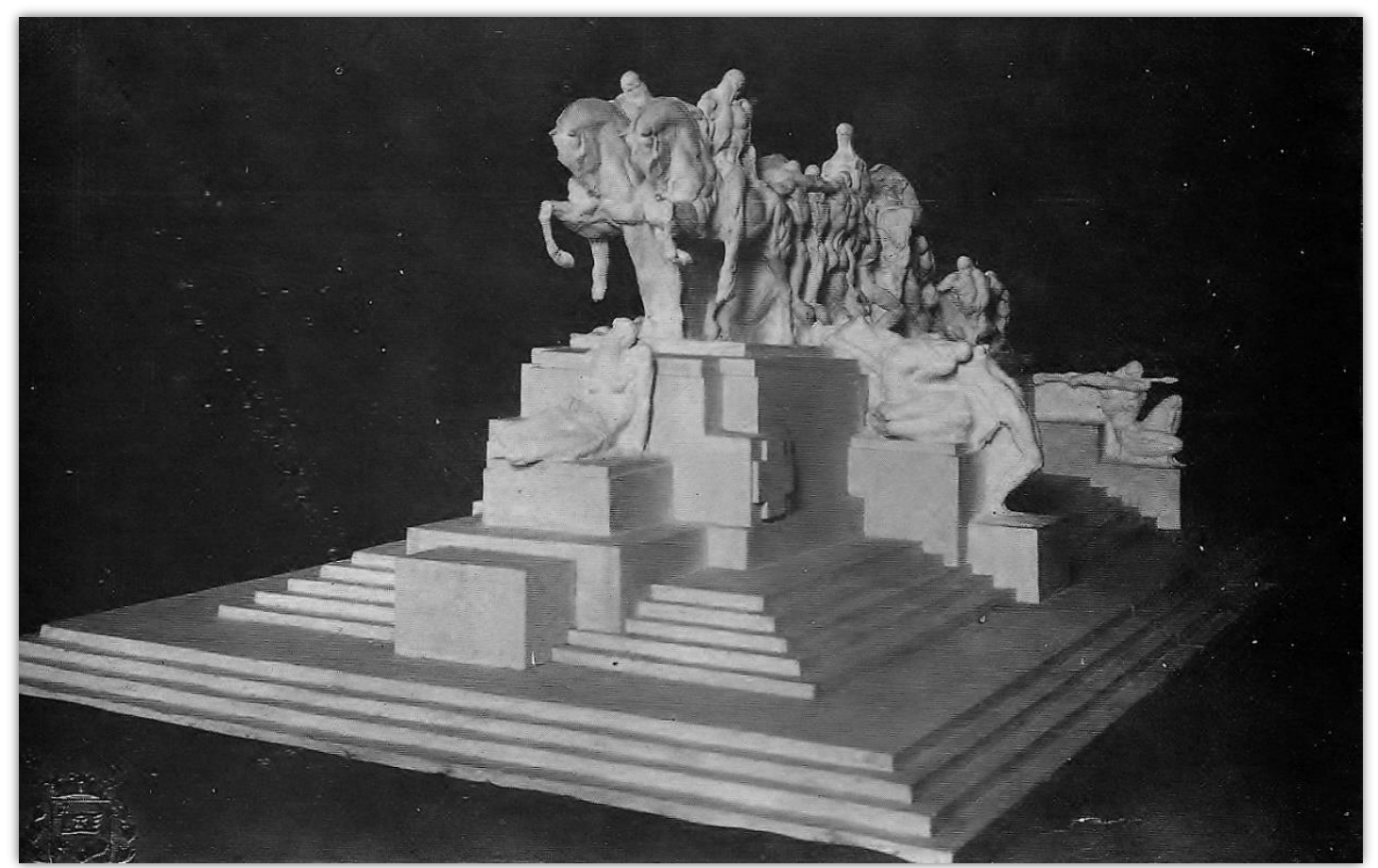

Figura 3.4 - Maquete do Monumento às bandeiras, 1920.

Fonte: Brecheret, 60 anos de noticia (1976), organizado por Sandra Brecheret Pellegrini, p. 21.

De acordo com o memorial explicativo que acompanha a maquete, assinado pelo escultor $^{403}$, o modelo apresentado em 1920 se dispõe sobre um eixo horizontal um pouco mais elevado no lado esquerdo, de onde partem os bandeirantes rumo ao sertão. O que se observa nessa "épica história do desbravamento da terra", segundo o memorial ${ }^{404}$, não são os "episódios" — como a "caça das esmeraldas" —, mas "o impulso do gênio da nacionalidade nascente,

\footnotetext{
${ }^{403}$ Em suas memórias, Menotti del Picchia (1972) não somente declara ter sido ele, e não Victor Brecheret, o autor do texto explicativo, como afirma que o escultor, antes de conceber sua maquete, "tudo ignorava da nossa história", cabendo a Menotti lhe explicar "a gesta das entradas e das monções, seu sentido na posse da terra, na dilatação das fronteiras, façanha que superou o périplo de Jasão e que forneceu à pátria uma epopeia não igualada pelas homeríadas" (PICCHIA, 1972, pp. 118-119).

404 O memorial explicativo foi distribuído aos visitantes da exposição e divulgado pelos periódicos da época, entre eles, o Correio Paulistano cf. "Monumento das Bandeiras", Correio Paulistano, 28 jul. 1920, p. 1.
} 
alargando e fixando o solo sagrado de uma pátria" ${ }^{405}$. No corpo escultórico central, vê-se uma bandeira em marcha encabeçada por dois homens a cavalo: os "gênios", dirá o mesmo texto, citando como exemplo as famílias de Fernão Dias e Borba Gato; ambos guiam outros homens, como eles também "guerreiros nus e bravios", que arrastam uma grande canoa "destinada a singrar o Tietê histórico" "406. Mas, ao contrário das esculturas de Fernão Dias e Borba Gato, as enormes e corpulentas figuras plasmadas pelo artista não possuem nome próprio, nem adereços ou indumentária.

O memorial explica ainda que na escadaria que antecede a parte central do conjunto, um nu feminino reclinado remete à terra brasileira a ser conquistada. Na escadaria traseira, uma ânfora iria conter uma porção das águas do rio Tietê, que literalmente acompanhariam a marcha dos bandeirantes. Nas laterais, dispostos em nível inferior ao da escadaria, veem-se quatro blocos sobre bases retangulares. Nos dois primeiros, à esquerda e à direita dos homens a cavalo, as insídias enfrentadas e superadas pelos bandeirantes, simbolizadas por mulheres, igualmente nuas. As “insídias da ilusão", dirá o texto explicativo, se referem às esmeraldas que Fernão Dias nunca encontrou, assim como as prometidas minas de prata de Robério Dias e o lendário mundo das Amazonas do explorador espanhol Francisco de Orellana. Já as “insídias do sertão” dizem respeito às febres, à fome, às emboscadas, às feras e à morte. Por fim, nos dois últimos blocos, a guarda do monumento é confiada aos indígenas ${ }^{407}$.

Ao ser exposto na Casa Byington, o projeto do monumento é submetido à crítica e ao público. Segundo O Estado de S. Paulo, a abertura da exposição foi um sucesso ${ }^{408}$. Washington Luís não conteve seu entusiasmo, relata o Correio Paulistano ${ }^{409}$. O Estadinho, por sua vez, destaca que "a bela e audaciosa obra" se afasta dos moldes até então correntes, enquanto o Diário Popular ressalva apenas que a "epopeia dos bandeirantes" careça de "linhas mais desafogadas", pois o escultor teria "sacrificado um pouco a silhueta" dos "nossos antepassados" 410 . O que parece ter causado “estranheza”, destaca Marta Rossetti Batista, é o fato de não haver ali um “personagem-herói”,

\footnotetext{
405 Sobre o sertão e a construção de uma "geografia imaginária” bandeirante, cf. Oliveira (1998; 2000) e Rêgo (2016).

406 Monumento das Bandeiras", Correio Paulistano, 28 jul. 1920, p. 1.

$407 \mathrm{O}$ único personagem esculpido com um adereço é um indígena na lateral direita da maquete, que porta uma lança, "mais que tudo, para definir uma horizontal de expansão do monumento fechado sobre si mesmo", ressalta Marta Rosetti Batista (1985, p. 28).

408 "Monumento das Bandeiras". O Estado de S. Paulo, 29 jul. 1920, p. 4.

409 “Arte Nova”. Correio Paulistano, 29 jul. 1920, p. 3.

410 “Maquete dos Bandeirantes”. Diário Popular, 31 jul. 1920, p. 1 / O Estadinho, 28 jul. 1920, reproduzido em Batista (1985, p. 28).
} 
caracterizado, especificado e nomeado, o que fazia as figuras, tanto masculinas quanto femininas, parecerem sem "atrativos" ou sem "precisão" (BATISTA, 1985, p. 31). Oswald de Andrade se indigna com "diversos imbecis" que não compreendiam que os personagens do monumento fossem diferentes daqueles que andavam pelas ruas, afastando-se, assim, de uma "inútil reprodução de exemplares da zoologia" (apud PELLEGRINI, 1976, p. 29); enquanto Menotti del Picchia, em uma referência ao personagem criado por Monteiro Lobato em Urupês (1918), lamenta que a obra "moderna, pujante, revolucionária" — talvez não fosse compreendida pelo "nosso encoscorado jeca-tatuísmo" 411 .

Visto e comentado, o projeto de Victor Brecheret enfrenta concorrências. No mesmo ano em que é apresentado ao público, a colônia portuguesa radicada em São Paulo oferece à cidade outro monumento em homenagem ao Centenário da Independência do país, com a mesma temática bandeirante, executado pelo escultor lusitano António Teixeira Lopes (18661942). Nesse caso, as resistências a um artista estrangeiro logo se fazem notar. Indignado, Menotti del Picchia afirma que o projeto do Monumento às bandeiras já estava pronto e que seu autor, Brecheret, era paulista, o que aumentava o mérito da obra ${ }^{412}$. Mário de Andrade também corrobora a proposta de Brecheret — um "brasileiro" que, segundo ele, "renova o passado" e se destaca no "concerto internacional" - ao relembrar que, na mesma época, assim como Teixeira Lopes, o italiano Ettore Ximenes “de longe veio" para "infelicitar” a colina do Ipiranga com uma obra "clássica" (o Monumento à Independência), que parecia um "colossal centro de mesa de porcelana de Sévres" $" 413$.

Em meio a um debate que envolvia tanto a preferência dada a artistas estrangeiros no cenário brasileiro quanto o caráter figurativo e representacional da arte, o escultor italiano (nascido Vittorio Brecheret, em Farnese, na província de Viterbo) e sua obra (marcada pela simplificação dos detalhes e pelas linhas estilizadas) tiveram sua "paulistanidade" exaltada pela imprensa da época. "Paulista, o sr. Brecheret fez uma obra muito nossa", ressalta o Diário Popular, em 1920, mesmo ano em que a Tribuna o descreve como "um nome feito na terra da arte; no Brasil, sua pátria, São Paulo"414. Nas páginas do Correio Paulistano, por sua vez, Menotti del Picchia, também descendente de família italiana, define a si próprio e ao escultor como "filhos de São

\footnotetext{
411 “Um monumento que não se ergueu”. Correio Paulistano, 30 mar. 1921, p. 3.

412 "Dois monumentos". A Gazeta, 28 jun. 1920, p. 1.

413 “De São Paulo". Ilustração Brasileira, nov. 1920, p. 37.

414 “Maquete dos Bandeirantes". Diário Popular, 31 jul. 1920, p. 1 / "Brecheret". Tribuna, 22 jun. 1920, reproduzidos em Pellegrini (1976, pp. 16-20).
} 
Paulo"; enquanto Monteiro Lobato, em O Estado de S. Paulo, se refere a Brecheret como "nosso conterrâneo" 415 . Apesar de trazer "apensa ao nome uma recordação estrangeira", trata-se de um legítimo artista nacional que reata uma tradição artística iniciada pelo "gênio inculto", o escultor negro Aleijadinho, explica ainda Mário de Andrade, na revista Ilustração Brasileira ${ }^{416}$. Diante das polêmicas suscitadas, Washington Luís adia a execução de ambos os monumentos (BRITO, 1997). Menotti del Picchia lamenta então que a proposta "paulista" tivesse ficado apenas na maquete devido à falta de apoio de "bandeirantes modernos"

Nota-se, no entanto, que o próprio Washington Luís irá cobrar de outro estrangeiro, o italiano Nicola Rollo, a concretização de um monumento em prol das bandeiras paulistas, que seria erigido na esplanada do Museu Paulista e chamado Heroísmo dos bandeirantes ${ }^{418}$. Em entrevista concedida décadas depois, Rollo afirma que o monumento lhe fora encomendado por Altino Arantes, pouco antes de Washington Luís assumir o governo do estado (AMARAL, 1998) ${ }^{419}$. Em 1922, o jornal Il Pasquino Coloniale divulga uma fotografia de Rollo ao lado de uma imagem da maquete da obra a ele encomendada, cuja legenda explica que o monumento L'eroismo dei bandeirantes seria inaugurado diante da entrada principal da mesma instituição que havia lhe encomendado as esculturas de Manuel de Borba Gato e Francisco Dias Velho ${ }^{420}$. Os heroicos bandeirantes de Rollo, como indica o título da matéria, são tomados pelo periódico como símbolos da fraternidade ítalo-brasileira (imagem igualmente associada, na mesma edição de Il Pasquino Coloniale, aos bandeirantes esculpidos por Luigi Brizzolara, Fernão Dias Paes Leme e Antônio Raposo Tavares, como mencionado no capítulo anterior) ${ }^{421}$.

\footnotetext{
415 "Brecheret". Correio Paulistano, 26 fev. 1920, p. 1. / "Monumento aos Andradas". O Estado de S. Paulo, 19 set. 1920 , p. 4. 


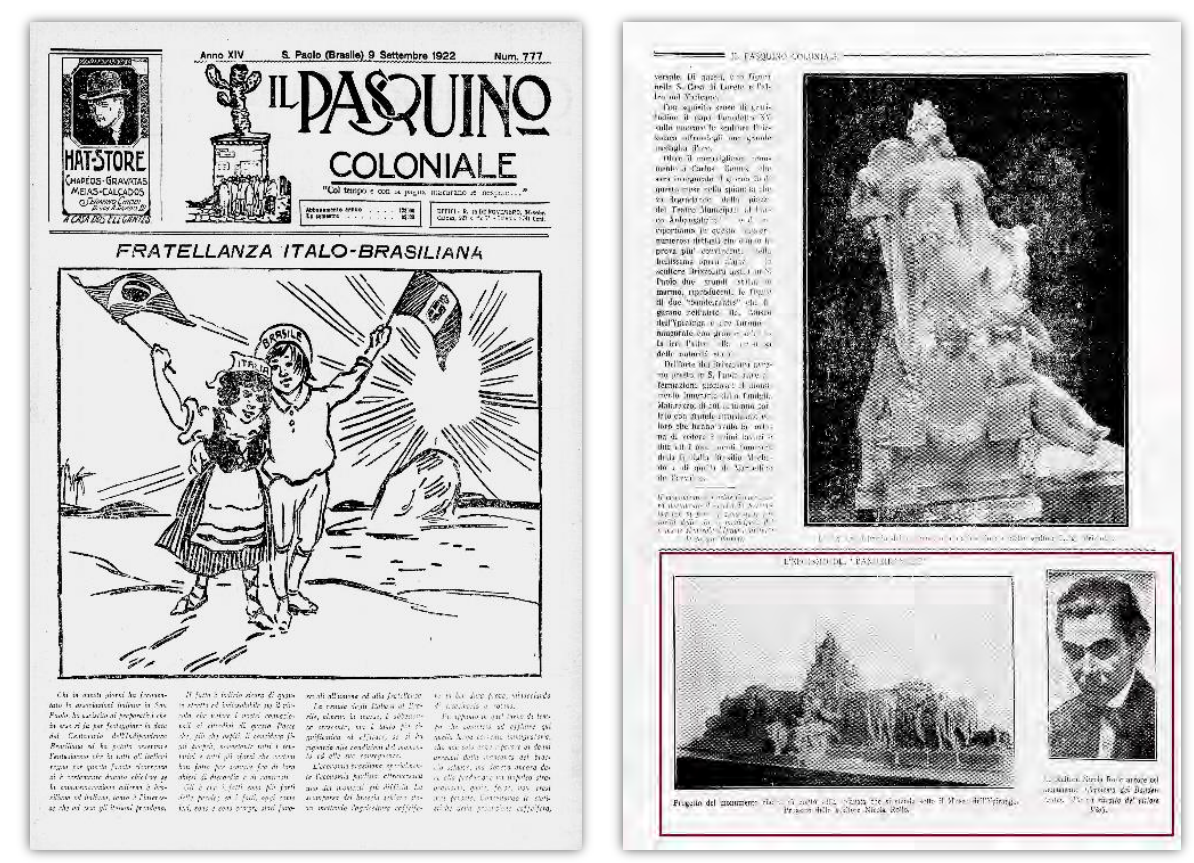

Figura 3.5 - L'eroismo dei bandeirantes.

Fonte: Il Pasquino Coloniale, 9 set. 1922.

Não foram poucos os projetos de monumento em homenagem às bandeiras oferecidos à cidade de São Paulo durante os preparativos para as comemorações do Centenário da Independência do Brasil. Em visita ao ateliê de Nicola Rollo, localizado no parque Dom Pedro II, no Palácio das Indústrias (onde também havia se instalado Brecheret antes de doar sua maquete para a Pinacoteca), Washington Luís chegou a criticar, em 1922, o "excessivo nu dos componentes do grupo escultórico"; mas, ao contrário do que ocorreu com as figuras desnudas de Brecheret, o projeto de Rollo foi aprovado de imediato, embora não tenha sido executado (AMARAL, 1998, p. 91). Ao que parece, o escultor e sua família abandonaram a cidade durante a Revolução de 1924, quando o Palácio das Indústrias foi ocupado pelo Exército e o projeto ainda em barro acabou secando. $\mathrm{O}$ barro devia ser umedecido constantemente e, devido às grandes dimensões do trabalho e aos inúmeros detalhes que ele apresentava, o processo era lento e trabalhoso (KUNIGK, 2001). Para compensar o prejuízo e o adiantamento financeiro recebido, Rollo foi encarregado da execução de outro monumento em homenagem às bandeiras.

Em seu Estudo de um plano de avenidas para a cidade de São Paulo (1930), Francisco Prestes Maia propõe a criação desse segundo projeto encomendado a Nicola Rollo e prevê a sua localização no alto de uma ilha artificial, construída no meio da futura ponte das Bandeiras (antiga ponte Grande), 
sobre o rio Tietê, no Bom Retiro, região central da capital ${ }^{422}$. Desse modo, explica ele, o monumento não ficaria nas margens do Tietê, mas no centro do rio, tal qual "uma grande proa a emergir das águas, voltada para jusante, justamente na direção do sertão” (MAIA, 1930, p. 351).

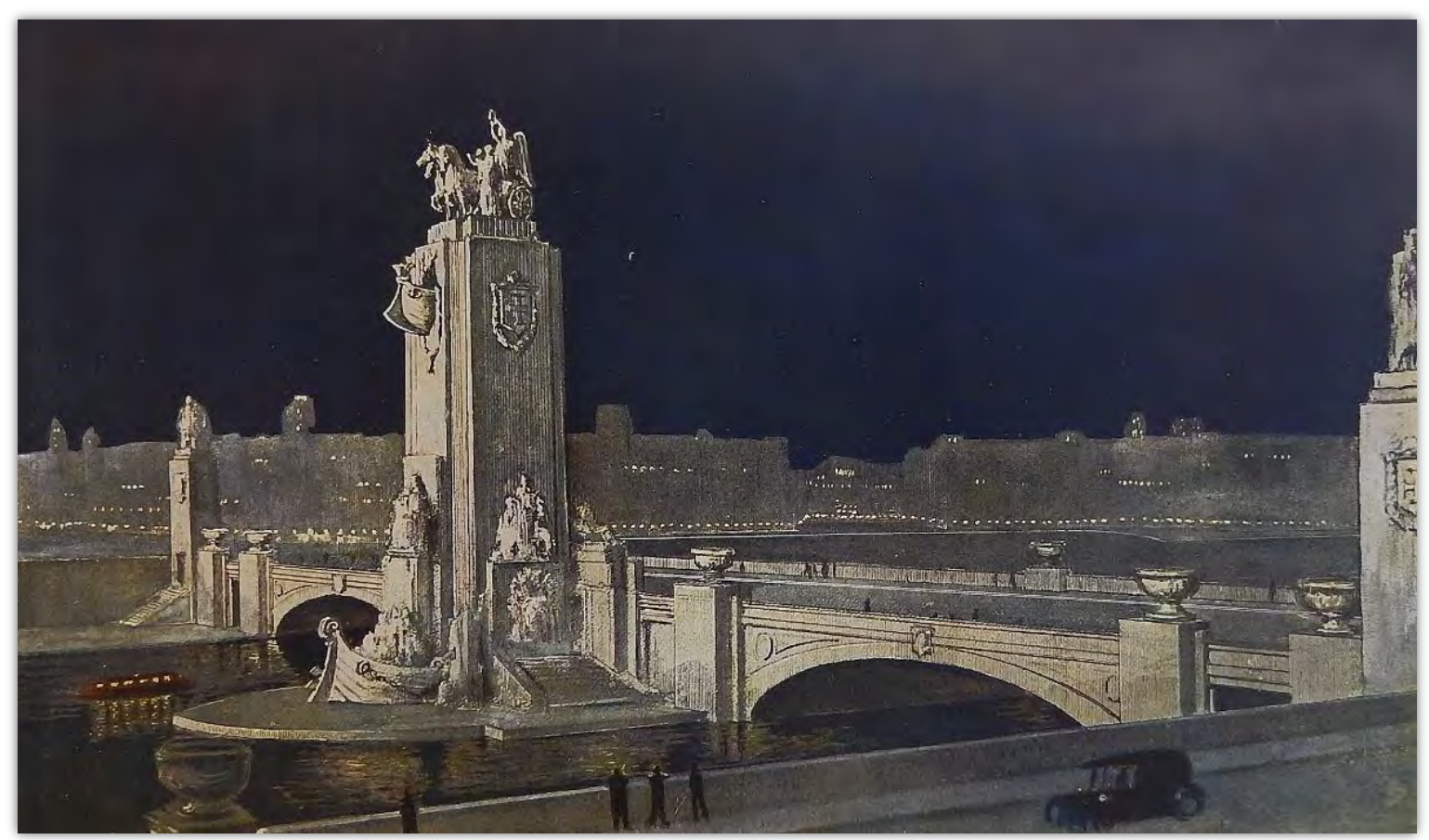

Figura 3.6 - Ponte das Bandeiras (detalhe), aquarela de Prestes Maia.

Fonte: Estudo de um plano de avenidas para a cidade de São Paulo (1930), de Prestes Maia, s/p.

A ponte monumento seria uma espécie de portal de entrada da cidade que Prestes Maia desejava impactante ${ }^{423}$. Ainda que a ponte tenha sido inaugurada durante primeira gestão de Prestes Maia (1938-45) como prefeito de São Paulo (quando é nomeado pelo interventor de Getúlio Vargas, Adhemar Pereira de Barros), a proposta do monumento em seu interior também não foi levada adiante por Rollo ${ }^{424}$. Coincidência ou não, a ponte das Bandeiras está localizada nas

422 Sobre os projetos idealizados por Francisco Prestes Maia, cf. Leme (1990), Toledo (1996) e Carpintéro (1998).

423 “A dois passos da Estação geral, do aeroporto e do porto fluvial, [a ponte] será verdadeiramente a 'principal entrada da cidade'. Acrescentemos a circunstância de transpor o Tietê, o curso histórico das penetrações sertanejas, e fica explicado porque erigimo-la em 'memorial bridge', que comemorará ainda as obras do Tietê, a conquista e a urbanização da várzea”, explica Prestes Maia (1930, pp. 350-51). Não à toa, nos anos 1940 Prestes Maia é considerado "um verdadeiro bandeirante urbano" pelo jornal A plateia, cf. Ribeiro (2018).

${ }^{424}$ Inaugurada em 1942, dez anos depois da Revolução de 1932, a ponte das Bandeiras tem como braços as avenidas Nove de Julho e 23 de Maio, ambos os símbolos da Revolução de 1932. O nome ponte das Bandeiras foi oficializado pelo decreto no 15.777 , de 29 de março de 1979. Cf. Núcleo de denominação de logradouros públicos, AHMWL. 
proximidades da rua dos Bandeirantes, logradouro cuja nomeação data dos anos 1910 . Independentemente do que tenha motivado as decisões de Washington Luís, o fato é que, na ausência de financiamentos públicos ou privados para a concretização de sua obra, Victor Brecheret ofereceu seu estudo em gesso ao governo do estado ${ }^{426}$. Menotti del Picchia ironiza a situação: "Para gáudio nosso, estará na pinacoteca pública a sua extraordinária maquete" ${ }^{427}$. No ano seguinte, o projeto de Brecheret é anunciado, no título de uma matéria do Correio Paulistano, como "um monumento que não se ergueu" ${ }^{228}$. Em outro artigo publicado no mesmo periódico, sob o pseudônimo de Helios, Menotti del Pichia evoca o monumento com a mesma temática oferecido pela colônia portuguesa (ignorando o projeto encomendado a Rollo) e afirma que a proposta de Brecheret se transformara no "monumento que os portugueses mataram sem o substituir" ${ }^{\wedge 29}$. Contrariando as previsões, o monumento não morreu, embora muitas tenham sido suas versões ${ }^{430}$.

\subsubsection{Uma longa gestação}

$\mathrm{Na}$ década de 1930, às vésperas da centralização político-administrativa promovida pelo Estado Novo, o projeto de Victor Brecheret encontra uma atmosfera mais propícia à sua retomada. No âmbito municipal, durante o governo de Fábio Prado (1934-1938), dá-se a criação do

\footnotetext{
425 A rua dos Bandeirantes foi oficializada pelo ato no 972, de 24 de agosto de 1916. Cf. Núcleo de denominação de logradouros públicos, AHMWL.

${ }^{426}$ No ano seguinte, Victor Brecheret expõe, na mesma Casa Byington, a escultura Eva, visando não somente a aquisição da estátua pela municipalidade, como também a obtenção de uma bolsa de estudos. Adquirida pela prefeitura de São Paulo, Eva é sua primeira obra exposta em um jardim público da cidade, o vale do Anhangabaú (embora hoje seja exibida no Centro Cultural São Paulo). O escultor parte então rumo à Europa, em 1921, para estudar com uma bolsa patrocinada pelo governo do estado. No início da década de 1930, depois de receber na França a condecoração de Cavaleiro da Legião de Honra, Brecheret decide retornar definitivamente para São Paulo.

427 “Um monumento que não se ergueu”. Correio Paulistano, 30 mar. 1921, p. 3.

428 Ibidem, p. 3.

429 “A vitória de um patrício". Correio Paulistano, 10 nov. 1921, p. 4. Sobre as crônicas publicas diariamente por Menotti del Picchia no Correio Paulistano ao longo dos anos 1920, ver Castro (2008).

${ }^{430} \mathrm{Em}$ A escada (1934), último volume da trilogia Os condenados (1941), de Oswald de Andrade, o escultor Jorge d'Alvelos (inspirado em Victor Brecheret e no próprio Oswald) destrói seu projeto de uma escultura monumental em homenagem a São Paulo (FERREIRA, 2002).
} 
Departamento de Cultura (DC), sob a direção de Mário de Andrade (1935-1938), grande entusiasta do trabalho de Brecheret ${ }^{431}$. Destinado não apenas a organizar a instrução pública e as atividades de recreação da cidade, mas também a fundamentar o governo estadual de Armando de Salles Oliveira (1935-1936), o DC era uma espécie de laboratório para a ação governamental (VALENTINI, 2013). Na esfera estadual, Salles Oliveira, antigo interventor federal que, em 1934, havia participado da criação da Universidade de São Paulo, é eleito governador pela Assembleia Constituinte.

No dia 9 de julho de 1936, aniversário do movimento Constitucionalista de 1932, Salles Oliveira explica, em mensagem à Assembleia Legislativa, que pela entrada principal do parque do Ibirapuera, onde seria construída uma praça, na avenida Brasil - logradouro que dá acesso aos grandes caminhos de penetração para o sertão, como o Tietê e as estradas que levam ao sul, ao Mato Grosso, a Minas Gerais e a Goiás —, sairiam os bandeirantes “a serviço da pátria” (OLIVEIRA, 1936, p. 120). O então governador ressalta ainda que a praça estaria localizada "no ponto em que nasce a avenida Brasil, à entrada do parque do Ibirapuera e na intersecção da rua Manoel da Nóbrega. A reunião destes nomes — Brasil, Ibirapuera e Manoel da Nóbrega —, na praça dos Bandeirantes, tem alguma coisa de predestinado" (OLIVEIRA, 1936, p. 119).

Cabe lembrar que foi precisamente durante a mobilização ideológica de 1932, a "Revolução de São Paulo pelo Brasil”, como aclamavam os articuladores do movimento, que se fez "reviver" o bandeirante "em toda sua plenitude" (CAPELATO, 1981, p. 40). Fosse nas publicações, nas cédulas e nos selos emitidos, nos cartazes e panfletos, nas transmissões de rádio ou nos discursos, aqueles que se dispusessem a partir para a luta pela derrubada do governo provisório de Getúlio Vargas eram evocados como bandeirantes. No centro da cidade, por exemplo, enquanto um alto-falante anunciava a "São Paulo de Borba Gato" e a "São Paulo de Anhanguera", batalhões da Legião Negra assumiam a linha de frente dos combates, enfermeiras ajudavam os feridos e índios guarani eram empregados em tarefas auxiliares. Havia ainda batalhões formados por italianos, portugueses, espanhóis, sírio-libaneses, entre muitos outros, como o das crianças, que desfilavam uniformizadas pela cidade. Desse modo, o movimento de 1932 conferiu ao bandeirante uma conotação muito mais ampla, embora, na prática, nem todos os combatentes recebessem o mesmo tratamento ${ }^{432}$.

\footnotetext{
431 Mário de Andrade revela, no balanço que faz do movimento modernista nos anos 1940, ter sido "sacudido" pela obra de Victor Brecheret (ANDRADE, 1974, p. 233). Assim como um "gatilho", explica Mário, o trabalho do escultor disparou os versos do livro Pauliceia desvairada (1922).

432 Visto, muitas vezes, como um personagem aglutinador, o bandeirante traz imbricado traços de desagregação e exclusão. Sobre a participação do operariado, dos negros, dos indígenas e das mulheres na Revolução de 1932, cf. Almeida. B. (1999), De Paula (1998), Domingues (2003) e Weinstein (2015).
} 
Victor Brecheret apoiou o movimento de 1932, contribuindo com uma escultura em gesso do soldado constitucionalista (PECCININI, 2015). A despeito dos paulistas terem sido derrotados em 1932, é um paulista, Salles Oliveira, o interventor nomeado por Getúlio Vargas para o estado de São Paulo. Em 1936, depois do antigo interventor ser eleito governador pela Assembleia Constituinte, o Monumento às bandeiras por fim tem seu plano de localização aprovado ${ }^{433}$. No ano seguinte, o escultor italiano Galileo Emendabili (1898-1974) e o engenheiro Mario Eugênio Pucci (1908-1985) vencem um concurso público, do qual fazia parte do júri o próprio Brecheret, para a construção do Monumento e mausoléu ao soldado constitucionalista de 1932, igualmente inaugurado no futuro parque do Ibirapuera, alinhado ao eixo da avenida 23 de Maio (data do estopim do movimento de 1932$)^{434}$.

Entre os assessores de Armando de Salles Oliveira, estavam Cassiano Ricardo (1895-1974) e Menotti del Picchia, que além de formarem juntos, ao longo dos anos 1920, a vertente verdeamarela do movimento modernista, defenderam na década seguinte a candidatura do antigo interventor na campanha eleitoral à presidência e propuseram a criação de um "Estado Bandeirante", ao organizarem, em 1936, o movimento Bandeira (VELLOSO, 1993). As principais propostas dos idealizadores desse movimento estavam expressas na revista S. Paulo, periódico que circulou em 1936 sob a direção de Cassiano Ricardo, Menotti del Picchia e Levém Vampré ${ }^{435}$. "Bandeira intelectual quer dizer pensamento em ação", tal qual "as arrancadas para a fixação do Brasil", afirma o editorial da revista S. Paulo em junho de $1936^{436}$, lembrando que no discurso do dia 9 de julho daquele mesmo ano, Salles Oliveira havia descrito o Monumento às bandeiras como "uma arrancada de bandeirantes" que revela "o pensamento dominando a ação":

Os homens, surpreendidos numa saída, caminham para o alto: é o idealismo paulista em ação. Alguns homens ajudando com o braço a puxar o batelão, com outro sustêm companheiros desfalecidos de fadiga ou de febre: é a solidariedade indispensável para o triunfo. Dois bandeirantes, os chefes, vão na frente, a cavalo:

\footnotetext{
433 O plano de localização do monumento é aprovado pela lei no 3.543, de 10 de dezembro de 1936. Cf. AHMWL. Para uma análise do bairro do Ibirapuera e de seu parque, cf. Torres (1977) e Barone (2007).

434 Juntas, as edificações da exposição comemorativa do aniversário da cidade, a obra de Victor Brecheret e a de Galileo Emendabili/ Mario Eugênio Pucci se destacariam como três dos maiores empreendimentos artísticos de caráter monumental realizados até as comemorações do IV Centenário da cidade de São Paulo. Sobre a construção desses elementos monumentais, erguidos no parque do Ibirapuera entre as décadas de 1930 e 1950, e o forjamento de uma identidade paulista, cf. Marins (2003).

435 No ano seguinte, em 1937, Cassiano Ricardo e Menotti del Picchia (junto a Cândido Motta Filho) irão dirigir o jornal Anhanguera, periódico que também irá divulgar as ideias do movimento Bandeira.

436 S. Paulo, jun. 1936, n. 6, s/p.
} 
é o princípio da autoridade, o mais forte esteio da civilização que o comunismo tenta destruir. As figuras decrescem em tamanho: é a hierarquia, inseparável da disciplina e um dos mais belos princípios da organização social, porque permite ao que está no ponto mais baixo ascender por si mesmo à posição mais alta. $\mathrm{Na}$ frente do grupo a grande figura de mulher que representa a terra virgem, em cuja conquista os bandeirantes partem, mostra que eles sabem o que querem e para onde vão" (OLIVEIRA, 1936, p. 119).

Ao divulgar um estudo da localização do Monumento às bandeiras em relação às avenidas da capital, a revista menciona as avenidas Nove de Julho e Brasil, e também a São João (cujo nome, defende o periódico, deveria ser modificado para avenida das Bandeiras) e a Rebouças (homenagem a Antônio Pereira Rebouças Filho, engenheiro responsável, no século XIX, pela construção de diversas estradas e rodovias brasileiras).

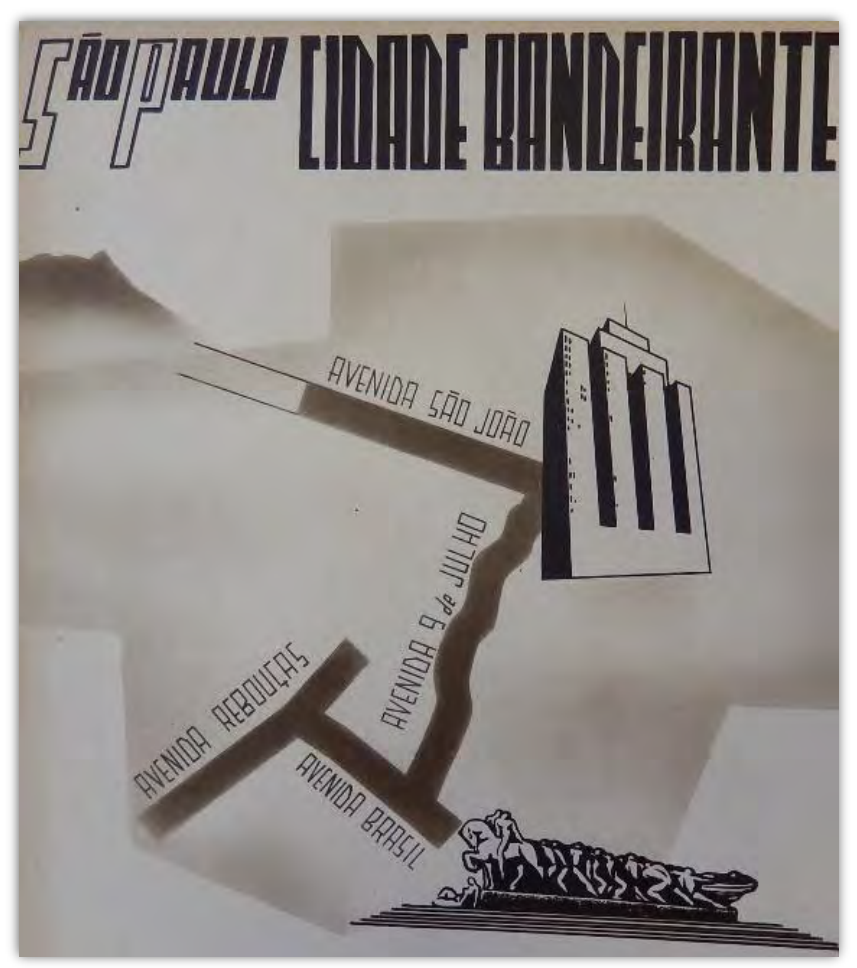

Figura 3.7 - Cidade Bandeirante.

Fonte: S. Paulo, ago. 1936, n. 8, s/p.

Na década de 1920, a prefeitura já havia apresentado, durante a gestão de José Pires do Rio (1926-1930), a proposta da construção de um imenso parque nos terrenos públicos das terras do Ibirapuera (antiga várzea de Santo Amaro), prevendo a abertura de um sistema viário entre a cidade de São Paulo e o antigo município que, na década de 1960, teria como guardião a escultura do 
bandeirante Borba Gato, de Júlio Guerra ${ }^{437}$. Com tamanho "igual ao do Hyde Park de Londres" ou "igual à metade do Bois de Boulogne de Paris", nos termos de Pires do Rio (1927, p. 10), uma vasta área verde ocuparia essa região "vazia de construções", tornando-a "útil à higiene da população urbana". O parque foi também delineado no Estudo de um plano de avenidas para a cidade de São Paulo (1930), de Prestes Maia, que concebia a construção da ponte das Bandeiras, publicado ainda durante o governo de Pires do Rio. "Devido à proximidade de bairros mais fidalgos, o relevo moderado e seu caráter artificial, pois aí tudo está por fazer", o parque seria concebido com muita "arte e delicadeza", explica Prestes Maia (1930, p. 344).

Conhecida como uma região alagadiça, a área do parque do Ibirapuera é drenada no final dos anos 1920, quando um viveiro de plantas da Água Branca é transferido para o local ${ }^{438}$. Visando arborizar a cidade, o viveiro deu início ao plantio de espécies destinadas ao embelezamento dos logradouros paulistanos, além de fornecer gratuitamente mudas às pessoas interessadas ${ }^{439}$. Pode-se dizer, nesse sentido, que esse viveiro promoveu uma aproximação entre a antiga região alagadiça e a população da capital. Por outro lado, nos anos 1950, antes da inauguração do parque, o engenheiro responsável pelas obras de infraestrutura pediu a remoção das "favelas" que haviam se formado na região, incompatíveis com a imagem de uma cidade que o governo desejava monumental, tal qual a obra de Victor Brecheret ${ }^{440}$.

Em meio à expansão de São Paulo para a região sul, marcada por intervenções higienistas, o Monumento às bandeiras seria enfim erguido, como se partisse rumo ao Jaraguá, ponto focal das antigas bandeiras, território ocupado pelos guarani desde pelo menos 1950, de acordo com o Relatório circunstanciado de delimitação e identificação da Terra Indígena Jaraguá $(2002)^{441}$.

\footnotetext{
${ }^{437}$ Anos depois, em um balanço sobre a construção do Monumento às bandeiras, Cassiano Ricardo indagará a respeito da escolha do local. "Que adiantaria abrir grandes avenidas se de modo algum estivessem ligadas à perspectiva histórica de São Paulo?”, cf. "Brecheret e sua obra máxima”. O Estado de S. Paulo, 14 mar. 1970, p. 15.

438 Disponível em: <http://parqueibirapuera.org/arquivos/livreto_viveiro_manequinho_lopes.pdf >. Acesso em 18: jul. 2017.

${ }^{439} \mathrm{O}$ viveiro, posteriormente chamado Manequinho Lopes, foi utilizado também como um depósito municipal, para o qual muitas estátuas "desterradas" eram enviadas, como alguns dos fragmentos do Monumento a Olavo Bilac, vistos no capítulo anterior.

440 Carta de Luiz Giannechini a Francisco Matarazzo, 15 out. 1952. Consta no processo do Arquivo Histórico Municipal a remoção de 186 "barracos”, que abrigavam 204 famílias. Cf. Fundo do IV Centenário, processo no $1267 / 52$, caixa 62, AHMWL.

441 O Relatório circunstanciado de identificação e delimitação da Terra Indígena Jaraguá é o resultado dos estudos determinados pelas Portarias Presidenciais da Fundação Nacional do Índio (Funai) n 659, 1178 e 1415, publicadas no Diário Oficial da União nos dias $1^{\circ}$ de julho e 29 de setembro de 2009, e 13 de dezembro de 2012, respectivamente. Em 2015, foi publicada a portaria declaratória no 581, da Funai, que reconhece cerca de 532 hectares no Jaraguá como Terra Indígena Jaraguá. Segundo o texto: “Fica o órgão indigenista federal autorizado a pactuar junto ao órgão
} 


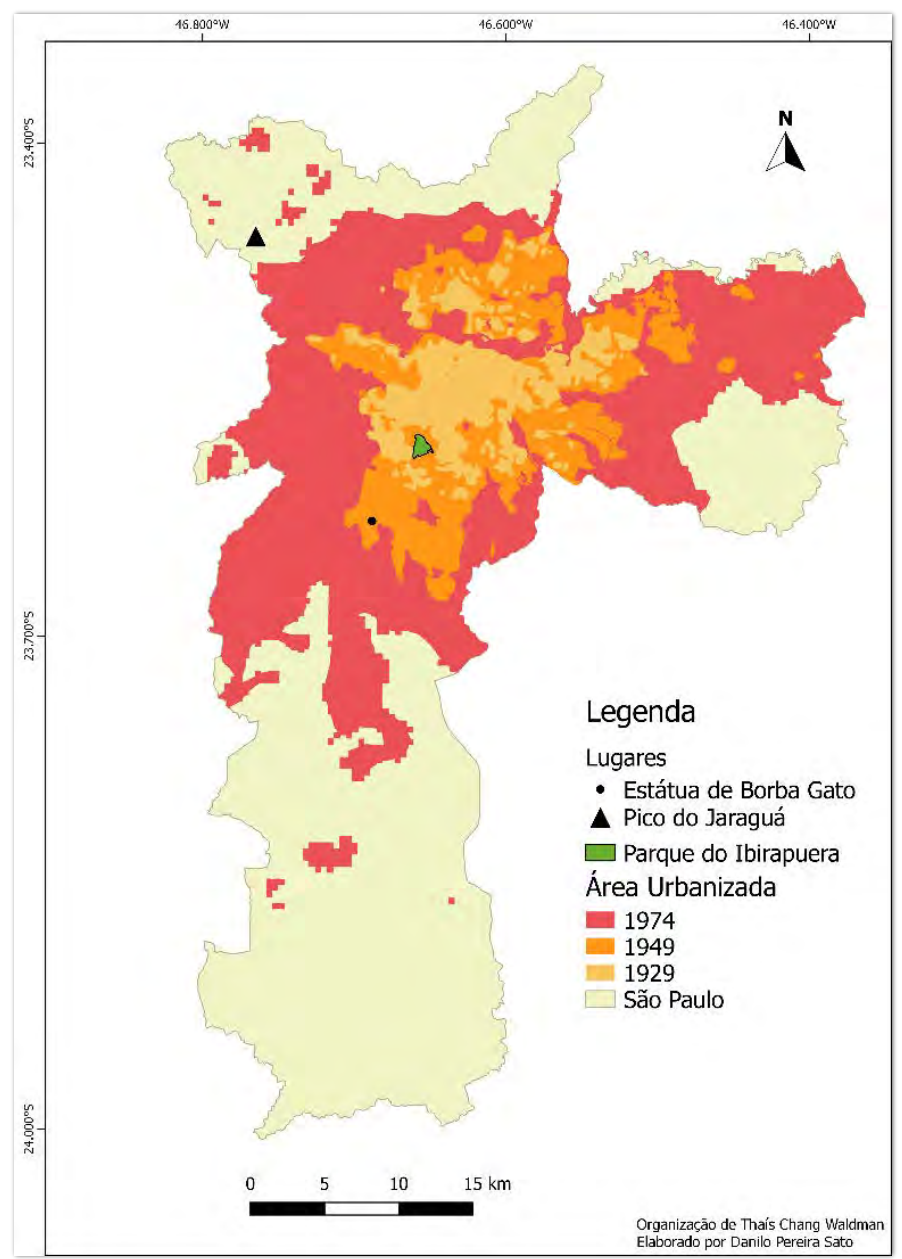

Figura 3.8 - Rumo ao Jaraguá.

Fonte: GeoSampa e Atlas of urban expansion ${ }^{42}$.

Adquirido pelo governo do estado em 1939 e declarado parque estadual em 1961, o parque do Jaraguá (localizado entre as atuais rodovias dos Bandeirantes e Anhanguera) foi tombado pelo

ambiental estadual a gestão compartilhada da área sobreposta da Terra Indígena Jaraguá com o parque estadual do Jaraguá, mediante a elaboração e implementação de plano conjunto de administração, assegurada a participação da comunidade indígena guarani" (Cf. "Portaria no 581, de 29 de maio de 2015". Diário Oficial da União, 1 jun. 2015, p. 33). Até então, eram reconhecidos apenas 1,7 hectares, demarcados pelo decreto $\mathrm{n}^{\circ} 94.221$ (Cf. "Decreto no 94.221, de 14 de abril de 1987”. Diário Oficial da União, 15 abr. 1987, p. 5457). Depois de décadas de luta guarani, em 2017, por meio da portaria declaratória no 683, o ministro da Justiça Torquato Jardim alegou “erro administrativo" e revogou a decisão de 2015. (Cf. "Portaria n 683, de 15 de agosto de 2017". Diário Oficial da União, 21 abr. 2017, p. 21) “O povo guarani foi despertado por mais um tiro, disparado pelos mesmos bandeirantes que sempre nos perseguiram”, denunciou em nota a Comissão Guarani Yvyrupa: “O parágrafo $4^{\circ}$ do artigo 231 da Constituição é cristalino: 'As terras indígenas são inalienáveis e indisponíveis, e os direitos sobre elas, imprescritiveis'. (...) A palavra dos brancos é difícil, truncada, mas nós que não temos o português como nossa língua materna, não temos dúvida que o que diz a Constituição é o mesmo que os nossos rezadores sempre disseram, é o que nos dizem as divindades, que muitos brancos não sabem ouvir: somos os primeiros habitantes dessas terras e por isso não há lei ou portaria que possa revogar nossos direitos sobre elas". Disponível em: <http://www.yvyrupa.org.br/blog/2017/08/21/fora-temer-o-jaragua-e-guarani/>. Acesso em: 25 ago. 2017.

442 Disponível em: <http://www.prefeitura.sp.gov.br/cidade/secretarias/urbanismo/dados_abertos/> e <http://www.atlasofurbanexpansion.org/>. Acesso em: 5 fev. 2017. 
Conselho de Defesa do Patrimônio Histórico, Artístico, Arqueológico e Turístico (Condephaat) em 1983. No processo de tombamento — que omite a presença guarani ao falar da "importância cultural" do bem a ser tombado —, o local é descrito como um "ponto de referência dos viajantes, tanto os antigos como os de hoje", nomeando os antigos viajantes como bandeirantes ${ }^{443}$.

Desde os anos 1940, existia o projeto de um parque turístico "altamente educativo e de profunda evocação histórica" no local, idealizado por uma comissão da qual fazia parte Afonso Taunay ${ }^{444}$. O parque do Jaraguá abrigaria em sua entrada doze estátuas de bandeirantes paulistas e, no cume do pico, um dos lugares mais altos da cidade, de onde os visitantes poderiam observar a expansão da capital à sua volta, uma escultura monumental, com mais de setenta metros, de São Paulo (com seus doze apóstolos bandeirantes) ${ }^{445}$. No pedestal de São Paulo, seria construído um panteão com urnas contendo os restos mortais de Fernão Dias (enterrados no mosteiro de São Bento) e os de Tibiriçá (que se encontram na cripta da catedral da Sé ${ }^{446}$ ). O projeto previa também a criação de um museu com material ligado à vida quinhentista e seiscentista ${ }^{447}$.

\footnotetext{
${ }^{443}$ Processo no 20437/78, Condephaat.

444 Anos depois, o decreto no 47.692, de 30 de janeiro de 1967, dispõe sobre a criação do Museu das Bandeiras, com sede no parque do Jaraguá, e afirma que caberia ao museu "registrar a história e a evolução dos feitos das bandeiras e divulgar o seu significado para o desenvolvimento econômico e a formação social do estado de São Paulo e do País", cf. Alesp.

445 Consta no plano de urbanização do Jaraguá, de acordo com a resolução governamental no 255, de 6 de dezembro de 1949, que "no ponto mais alto do maciço do Jaraguá, a 1134 metros, dominando todo o vale do Tietê, de Santo Amaro a Jundiaí, de Sorocaba às fronteiras de Minas, se elevará como marco comemorativo ao IV Centenário da fundação da cidade, o imponente monumento ao Apóstolo São Paulo que, pelas suas proporções, deverá ser o maior monumento católico do mundo". A figura do apóstolo teria cerca de 54 metros de altura e sua base, vinte metros. No seu pedestal, haveria ainda um salão de quatrocentos metros quadrados, revestido externamente de pedra e internamente de mármore, no qual seria instalado um panteão evocativo de São Paulo. Cf. Fundo do IV Centenário, processo no 68/51, caixa 68, AHMWL.

${ }^{446} \mathrm{Na}$ mesma cripta está enterrado Dom Duarte Leopoldo e Silva, primeiro arcebispo de São Paulo. Ao anunciar o projeto da nova catedral da Sé, em 1913, dom Duarte já fizera um discurso no qual associa o sentimento religioso à "fibra do bandeirante": "Queremos uma catedral que seja uma escola de arte e um estímulo a pensamentos mais nobres e mais elevados, queremos uma catedral opulenta, que, testemunhando a fartura de nossos recursos materiais, seja também um hino de ação de graça a Deus Nosso Senhor. Saibam os paulistas de amanhã que a fibra do bandeirante, lutador e intimorato nas asperezas da selva, não se enfraqueceu nos confortos da vida moderna, como não se entibiou sua fé nos esplendores da ciência e da civilização" (DAMANTE, 1971, p. 86).

${ }^{447} \mathrm{O}$ museu seria instalado no antigo solar de Afonso Sardinha, construído em 1590, abrangendo a reforma e a reconstituição do prédio e de suas dependências, com especial atenção, segundo o plano de urbanização do Jaraguá, a tudo que se referisse e evocasse "a epopeia das bandeiras", tais como "roteiros, altar, armas, roupagens, apetrechos de caça e pesca, mineração, utensílios e figuras de cera representativas dos personagens da época", além de maquinários relativos aos ciclos econômicos do ouro, do açúcar e do café. Ao seu lado haveria ainda um restaurante em "estilo rústico" chamado Pouso das Bandeiras. Cf. Fundo do IV Centenário, processo no 68/51, caixa 68, AHMWL.
} 
$\mathrm{Na}$ década seguinte, às vésperas das comemorações do IV Centenário de São Paulo, José Wasth Rodrigues executou esboços para o parque claramente inspirados no programa proposto em 1940, mas que não saíram do papel (CAMPOS, 2011). Ainda que o parque tenha sido criado nos anos 1960, a proposta do conjunto escultural e do museu evocando a “epopeia das bandeiras" não foi levada adiante, embora ainda hoje, lá do Ibirapuera, os bandeirantes esculpidos por Victor Brecheret apontem para o Jaraguá ${ }^{448}$.

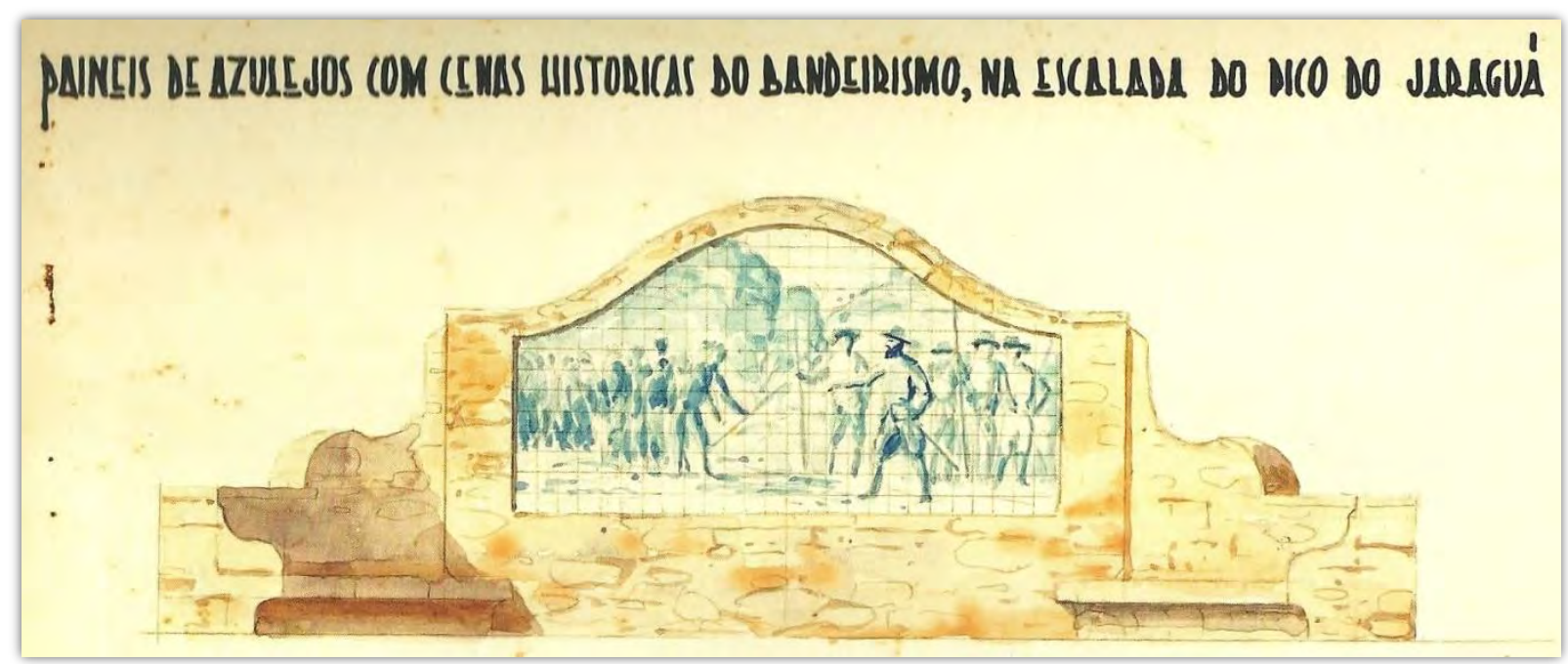

Figura 3.9- Estudo de José Wasth Rodrigues para os painéis de azulejo com cenas históricas do bandeirismo no parque do Jaraguá, anos $1950^{449}$.

Fonte: Arquivo Histórico de São Paulo: história pública de São Paulo (2011), organizado por Eudes Campos, p. 273.

Em 1937, finalmente é construída a base do Monumento às bandeiras, cuja localização havia sido aprovada apenas na década de 1930.

448 No processo de tombamento do Condephaat, consta ainda uma proposta, apresentada nos anos 1980, de construir no local uma grande estátua em homenagem ao padre José de Anchieta, cf. processo n 20437/78, Condephaat.

${ }^{449}$ Muitos anos antes, Wasth Rodrigues já havia sido convidado para fazer os painéis decorativos em azulejos para os monumentos inaugurados na Serra do Mar durante as festas de 1922. Lembremos que ao longo do percurso da antiga ligação entre o planalto paulista e o litoral santista, via Cubatão, foram inaugurados quatro monumentos Cruzeiro Quinhentista, Marcos do Lorena, Serra da Maioridade e Rancho de Paranapiacaba — que são também pontos de descanso para os automóveis, que exigiam paradas durante o percurso íngreme e sinuoso da serra. O conjunto de monumentos foi construído pelo arquiteto franco-argentino Victor Dubugras, por encomenda de Washington Luís visando as comemorações do Centenário da Independência, ver Toledo (1966). Nessa ocasião, segundo a Revista do IHGSP, em pleno século XX, os automóveis passariam ao lado daqueles que "palmilhavam praias, vadeavam rios, varejavam florestas, escalavam serras, penetravam e desvendavam o segredo do sertão e vão estabelecer o seu posto avançado nos campos de Piratininga" (RIHGSP, 1922, p. 75). Também por ocasião das comemorações do Centenário da Independência, Wasth Rodrigues e Dubugras participam da reforma do Largo da Memória, no centro da cidade de São Paulo, que previa um novo chafariz com pórtico de azulejos. 


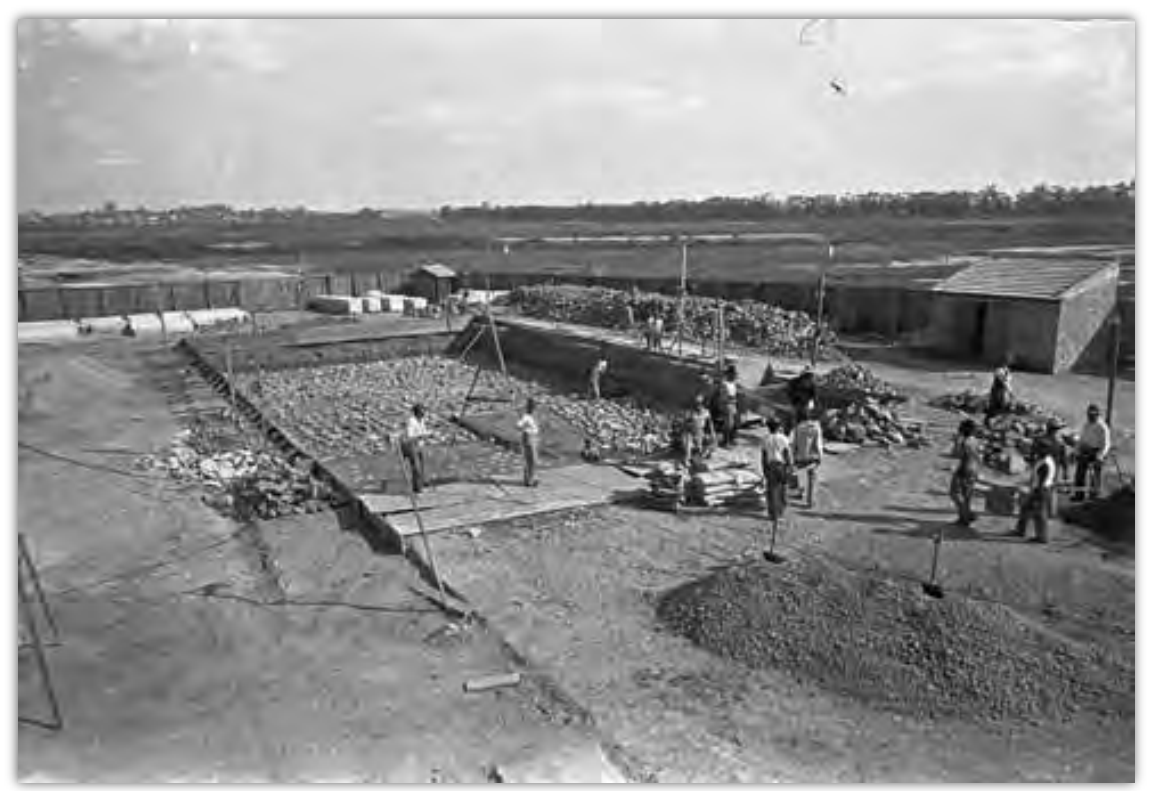

Figura 3.10 - Construção das fundações do Monumento às bandeiras, 1937.

Fonte: Acervo Fotográfico do Museu da Cidade de São Paulo | Foto: Benedito Junqueira Duarte.

O mesmo ocorreu com diversas obras do artista, que não foram executadas tendo de antemão sua futura localização, como o Monumento ao Duque de Caxias, moldado em bronze nos anos 1940, quando o escultor ainda executava o seu Monumento às bandeiras ${ }^{450}$. Brecheret aventara a hipótese de erguer sua homenagem ao patrono do Exército brasileiro na praça das Bandeiras, e não no largo do Paissandu (como planejado no contrato), mas a obra acaba instalada na praça Princesa Isabel, devido as suas grandes dimensões (LOPES, 2017) ${ }^{451}$. Com seus mais de quarenta metros de altura - Brecheret é apenas um "ponto pequenino" ao lado de seu Monumento ao Duque de Caxias, observa Tarsila do Amaral ${ }^{452}$ —, a obra é inaugurada somente nos anos 1960, na confluência da avenida Duque de Caxias com a Rio Branco.

450 Sobre o Monumento ao Duque de Caxias, cf. Lopes (2017).

${ }^{451}$ Um articulista do jornal $A$ Noite reclama nos anos 1940 da localização "errada" dos monumentos na cidade de São Paulo: "Na avenida Tiradentes não está o monumento a Tiradentes, e sim o dedicado a Ramos de Azevedo; na praça Ramos de Azevedo, não está o deste e sim o de Carlos Gomes, aliás, já no começo do parque Anhangabaú"; porém, mais importante do que fazer coincidir o nome dos logradouros públicos com as respetivas estátuas, ainda de acordo com a mesma matéria, é atentar para a desproporção entre a localização dos monumentos, suas dimensões e as personalidades por eles evocadas. O enorme conjunto monumental da avenida Tiradentes, por exemplo, não foi erguido em homenagem a Fernão Dias ou a Raposo Tavares, como se poderia pressupor, mas sim ao arquiteto Ramos de Azevedo, queixa-se o articulista. “A cidade espera as estátuas das Bandeiras e de Caxias". A Noite, 19 abr. 1947, reproduzido em Pellegrini (1976, p. 79).

452 "Uma visita a Brecheret". Diário de S. Paulo, 10 abr. 1949, p. 10. Um ano antes, em uma matéria não assinada publicada no Correio Paulistano, o Monumento ao Duque de Caxias é comparado ao cavalo de Troia, já que em seu ventre, segundo a matéria, caberiam 33 pessoas. “A dança das estátuas”. Correio Paulistano, 14 nov. 1948, p. 15. 
Também na década de 1940, outro personagem é esculpido em granito por Victor Brecheret, o Fauno (1942), encomendado pela prefeitura de São Paulo. Sua figura em terracota, com patas e chifres caprinos, encantara o então prefeito Prestes Maia, que planejou alocá-lo nos jardins da nova biblioteca municipal, nas matas do antigo palácio Episcopal, atual praça Dom José Gaspar ${ }^{453}$. Fauno, no entanto, acabou expulso dali, dando lugar a uma grande cruz de granito: "Aquela cruz mortuária, que se cravou no local onde ele surgia, dava ideia de que ali fora soterrado algo de vivo e jovial", lamenta Menotti del Picchia ${ }^{454}$. A transferência da obra (que hoje se encontra na praça Tenente Siqueira Campos) causou bastante polêmica na época. "Fulano faz uma estátua que vai para determinado jardim. Mas como tudo tem fim neste mundo, lá vem um dia em que administração muda. E vem uma nova autoridade que não gosta da arte de Fulano. Em consequência, a estátua de Fulano sai do jardim...”, reclama outro articulista, "agora imaginemos que isso se desse com o [colossal] Monumento às bandeiras, do mesmo Brecheret"? ${ }^{455}$

Desde os primórdios da "dança das estátuas", examinada no capítulo precedente, muitos monumentos foram concebidos sem que tivessem um local pré-determinado de enraizamento no tecido urbano paulistano (BATISTA, 2012) ${ }^{456}$. Esse é o caso de várias obras de Victor Brecheret. Nos anos 1940, um texto publicado no Correio Paulistano afirma que, diferente do que ocorria em outras partes do mundo, somente no Brasil se encomenda a um artista um trabalho para, depois de executado, "colocá-lo a trouxe-mouxe [desordenadamente] em qualquer canto" ${ }^{457}$. No caso do Monumento às bandeiras, segundo o jornal Última Hora, foram tantos os pesados blocos de granito

\footnotetext{
453 Segundo outra matéria publicada na mesma época no Correio Paulistano: “O ex-prefeito da capital que rasgou tantas avenidas, que alargou as ruas estreitas da antiga província imperial, que demolindo casarões antigos provocou a construção de edifícios amplos e modernos, que tornou a cidade acanhada de ontem na urbs esplêndida de que tanto se orgulha o paulista de hoje, o sr. Prestes Maia teria verificado que alguma coisa não estava certa nas nossas praças. Que adiantaria o vale do Anhangabaú com seu repousante tapete de grama verde, e a praça da República, com seus plátanos cheios de poesia, e o parque Siqueira Campos com seus arvoredos frondosos, suas sombras tão acolhedoras? Que adiantaria tudo isso se não houvesse, em meio às obras de arte da natureza, as obras de arte criadas pelo homem?”. Cf. "Estátuas de bronze e pedra serão colocadas nos jardins públicos da capital”, Correio Paulistano, 27 dez. 1947, p. 8.

454 “A vingança de Pan”. A Gaz̧eta, s/d, reproduzido em Pellegrini (1976, p. 76).

455 Texto sem menção ao nome do autor e ao nome do periódico, provavelmente publicado em 1946, reproduzido em Pellegrini (1976, p. 78).

456 Vimos no capítulo anterior por que São Paulo ganhou o epíteto de “a cidade em que as estátuas andam”, em um artigo homônimo sobre a atribuição da responsabilidade pelas obras de arte dos logradouros públicos, veiculado na década de 1980 na Revista do Arquivo Municipal. Nesse texto, a autora levanta uma questão pertinente: "Ora, como proteger, ou restaurar, uma obra de arte que hoje está aqui, mas amanhã poderá estar em outro canto da cidade?” (PASSOS, 1986, p. 58). Além de ser oneroso, o processo de transporte e instalação de um monumento, com frequência cimentado à sua base, pode danificar os logradouros da cidade e a obra de arte.

457 “A dança das estátuas”. Correio Paulistano, 14 nov. 1948, p. 24.
} 
transportados em caminhões da prefeitura, de um lado a outro, em uma cidade com um relevo marcado por grandes desníveis, que um sulco fora traçado no asfalto da avenida Brasil ${ }^{458}$. Remetendo também a pesada indústria paulista, que transformaria a cidade no centro manufatureiro hegemônico do país, alguns desses blocos, estimados em um total de mais de 527 $\mathrm{m}^{3}$, pesavam cinquenta toneladas, chegando a medir até $8 \mathrm{~m}^{3}$ (BATISTA, 1985).
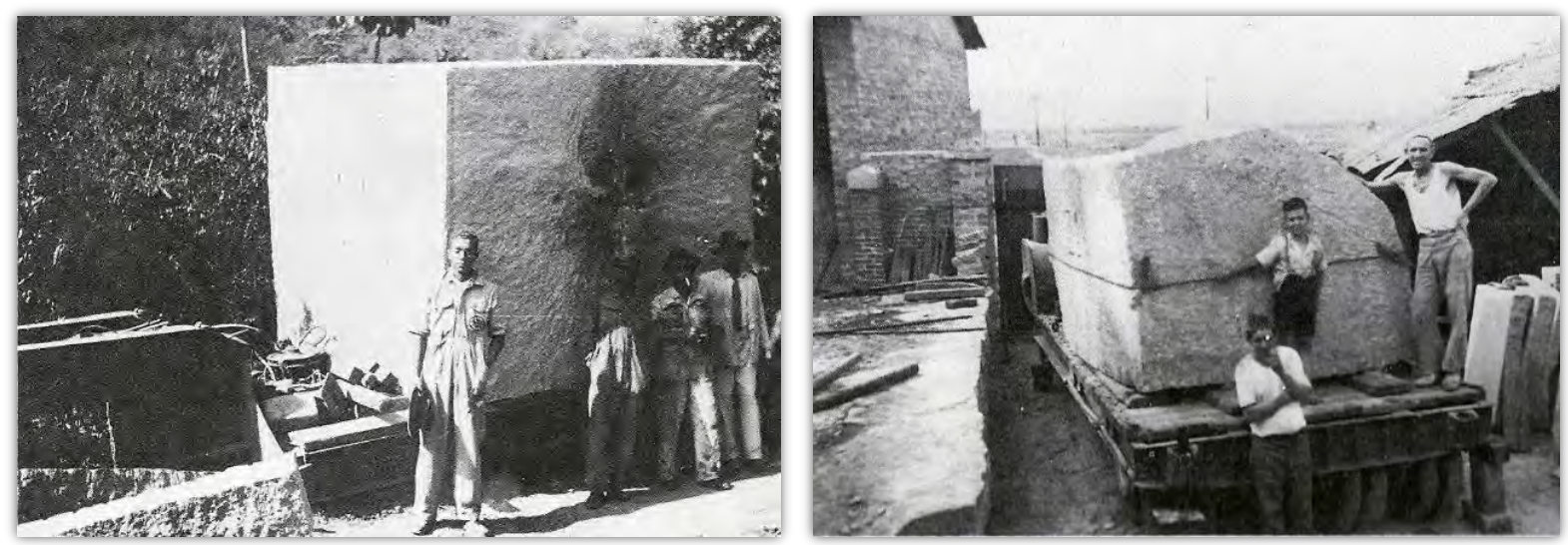

Figura 3.11 - Transporte dos blocos de granito, década de 1940. Fonte: Bandeiras de Brecheret (1985), de Marta Rossetti Batista, pp. 105/108.

"Brecheret desprezou o bronze, o mármore, a madeira — também o ouro e o marfim, que poderiam lembrar a munificência da época de Phidias - e preferiu o lindo granito de sua terra", ressalta um articulista do jornal $A$ Noite ${ }^{459}$. O granito vinha de Mauá (município da região metropolitana de São Paulo) e apresentava uma composição mais grossa e mais porosa, o que tornava o desbaste do Monumento às bandeiras menos penoso e facilitava sua retirada, se comparado ao resistente granito de Itaquera, oferecido pelos concorrentes e usado por Brecheret, entre 1937 e 1938, nos degraus da escadaria e do patamar sob os quais se assentaria o monumento (posteriormente modificados devido à paralisação das obras). Proprietários da pedreira em Mauá, os irmãos Milanezi já estavam fornecendo a mesma pedra para a execução dos relevos do alto pedestal do Monumento ao Duque de Caxias, então em andamento (BATISTA, 1985).

Antes da passagem do modelo à pedra, as figuras que se insinuavam no corpo central compacto da maquete de 1920 começam a adquirir feições e atributos em barro e gesso, no interior de galpões construídos no Ibirapuera, onde é instalado o ateliê do artista. Os blocos alegóricos (as

\footnotetext{
458 "Trinta anos de trabalho no maior monumento do mundo". Última Hora, 21 nov. 1952, reproduzido em Pellegrini (1976, p. 111).

459 “Surpresa e Comoção". A Noite, 5 nov. 1939, reproduzido em Pellegrini (1976, p. 56).
} 
“insídias da ilusão" e as "insídias do sertão”) dispostos nas laterais da obra e presentes na maquete de 1920 são eliminados, enquanto as figuras ganham rosto, cabelo, barba e ornamentos, como colares, pedaços de pano e crucifixos. Entre elas, temos: as duas que abrem a marcha a cavalo; a que carrega uma criança no colo; as que seguram uma bateia para a exploração de minério; aquela que porta uma lança; a que cai exausta e aquelas que a carregam; além da última figura do grupo, que arrasta penosamente a canoa das monções. "São portugueses barbados, índios tatuados, negros atléticos", observa entusiasmada Tarsila do Amaral, em 1949, depois de uma visita ao ateliê do $\operatorname{artista}^{460}$.
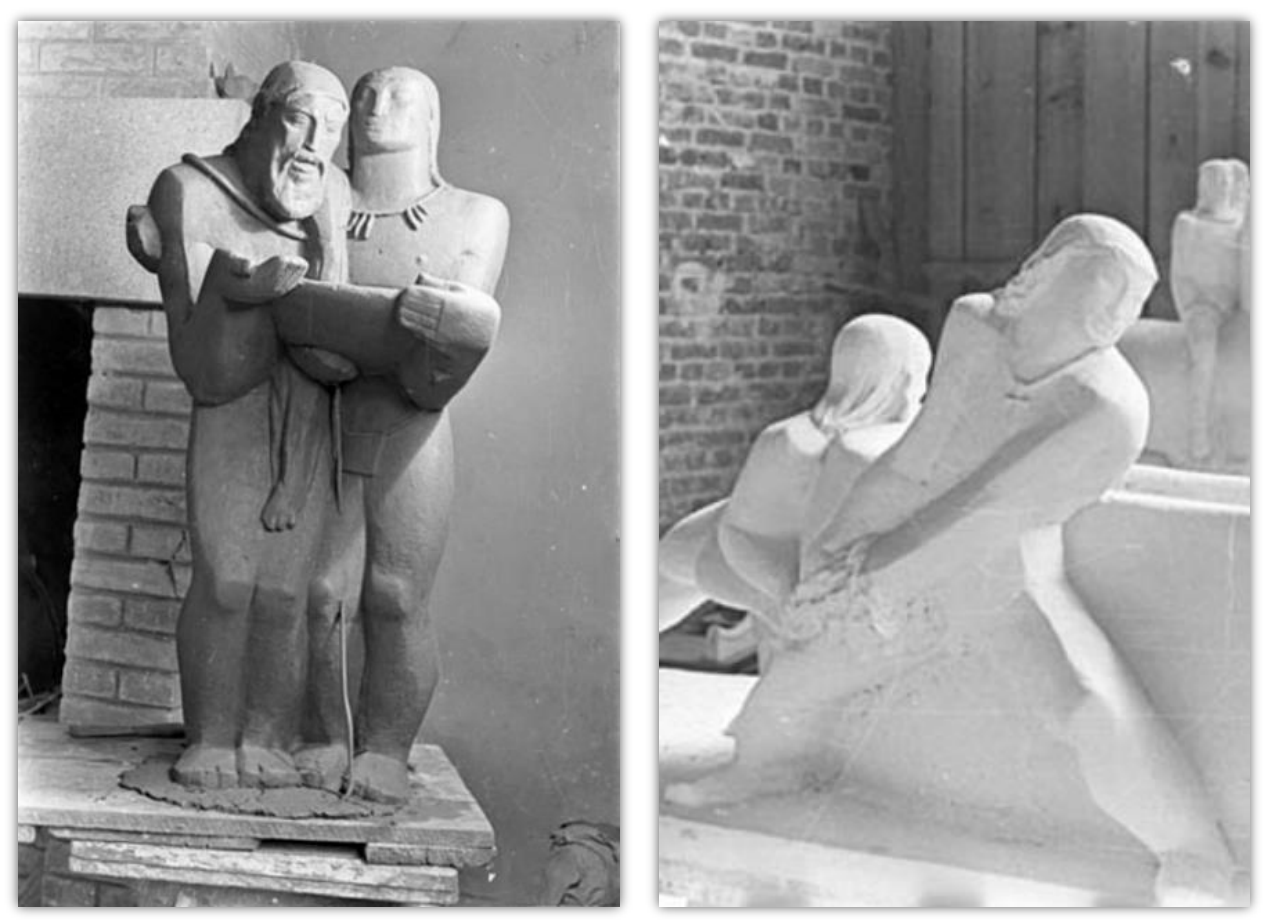

Figura 3.12 - Estudos em barro e gesso do Monumento às bandeiras, 1936.

Fonte: Acervo Fotográfico do Museu da Cidade de São Paulo | Foto: Benedito Junqueira Duarte.

Os "guerreiros nus e bravios" do grupo escultórico central, que nos anos 1920 não apresentavam distinção étnica, já haviam sido designados pelo próprio escultor, em entrevista concedida no início da década de 1940 para a revista Dom Casmurro, como "o índio, o negro, o mameluco e o português" ${ }^{461}$. Atribuindo um caráter amplo e elástico a sua obra, Brecheret afirma

460 “Uma visita a Brecheret”. Diário de S. Paulo, 10 abr. 1949, p. 10. Lembremos que nos anos 1930 Tarsila do Amaral irá esculpir a famosa tela Operários (1933), na qual procura caracterizar as figuras que desenha na sua multidão anônima de operários, cf. Amaral (2003).

461 “São Paulo escreve no granito a história do Brasil”. Dom Casmurro, 24 jan. 1942, n 235, p. 7. Interessante notar que entre os movimentos negros já havia um debate sobre o reconhecimento e a defesa de uma "raça [negra] mártir" 
que sua homenagem não diz respeito aos bandeirantes como figuras históricas, mas ao "espírito das bandeiras", por ele definido como o "ímpeto nacional" que arrastou os bandeirantes para os sertões $^{462}$. É possível acompanhar a conversão desse “espírito" em barro e gesso nas páginas da revista S. Paulo, que irá apresentar o Monumento às bandeiras como um "templo" (tal qual o Museu Paulista de Afonso Taunay) para exaltar a "fé nos destinos de S. Paulo e do Brasil" ${ }^{463}$. As imagens veiculadas nesse periódico indicam ainda a presença, na frente dos homens a cavalo, do nu feminino reclinado, que remete à terra brasileira a ser conquistada, mencionado na maquete de 1920, enquanto a guarda do monumento permaneceria confiada aos indígenas.

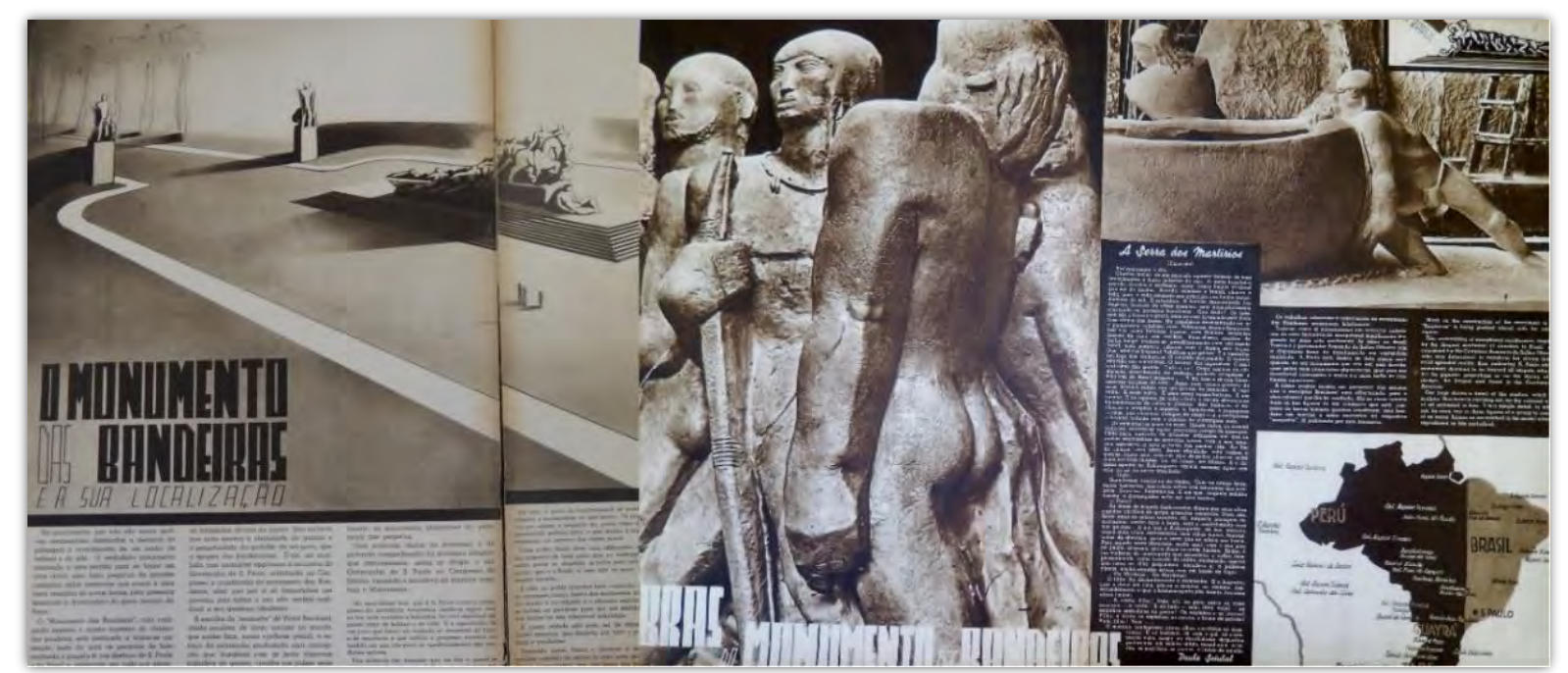

Figura 3.13 - Monumento às bandeiras na revista S. Paulo, 1936.

Fonte: Acervo pessoal | Foto: Thaís Waldman.

Lembremo-nos da "Raça Cósmica", de Cassiano Ricardo que, anos antes, em Martim Cererê (1928), escrevera um longo poema em que o índio, o negro e o branco dão origem ao "Gigante de Botas" ${ }^{464}$. Um dos editoriais da revista S. Paulo, dirigida pelo autor de Martim Cererê, relembra que a

que morreu para erigir São Paulo, como mostra Virgínia Leone Bicudo (2010) ao examinar os documentos e matérias publicadas no mensário da Frente Negra Brasileira, que existiu entre 1931 e 1937.

462 “São Paulo escreve no granito a história do Brasil". Dom Casmurro, 24 jan. 1942, no 235, p. 7.

463 S. Paulo, jul. 1936, n. 7, s/p. S. Paulo, ago. 1936, n. 8, s/p.

${ }^{464}$ Em sua "marcha para oeste", o bandeirante de Cassiano Ricardo toma posse e inventa um novo país, remetendo assim ao livro La raza cósmica (1925), no qual o mexicano José de Vasconcelos celebra o caldeamento dos povos e das raças como fator determinante no futuro da América Latina e do mundo. Em 1962, na 11a edição de Martim Cererê, ilustrada por Tarsila do Amaral, Cassiano Ricardo afirma que Victor Brecheret modificou a concepção da primeira maquete de sua obra para melhor caracterizar seus personagens. Segundo o poeta, no projeto inicial "as figuras eram todas do mesmo tipo racial; teria sido um erro, que [Brecheret] corrigiu a tempo, incluindo no monumento todos os elementos étnicos que entraram na constituição da bandeira histórica. E isso porque lera 
"Raça Cósmica" começa com o índio e chega no imigrante, cuja roupa, "em remendos variegados", traz "o mapa de todas as pátrias" 465 . Na mesma época, dois anos antes de seu pai publicar a obra Vida e morte do bandeirante (homenagem aos seus familiares que teriam chegado em São Vicente em 1532), Antônio de Alcântara Machado (1901-1935) dedica Brás, Bexiga e Barra Funda (1927) aos “novos mamelucos", nomeando entre eles imigrantes como Brecheret e Menotti del Picchia ${ }^{466}$. São os "filhos de outros bandeirantes transatlânticos dos nossos tempos" que, na década de 1920, já somavam mais de um terço da população da cidade, conforme descreve, em 1919, um redator de O Estado de S. Paulo (apud SEVCENKO, 1992, p. 57).

Não à toa, entre os personagens esculpidos em granito também consta um italiano, ninguém menos que o próprio escultor.

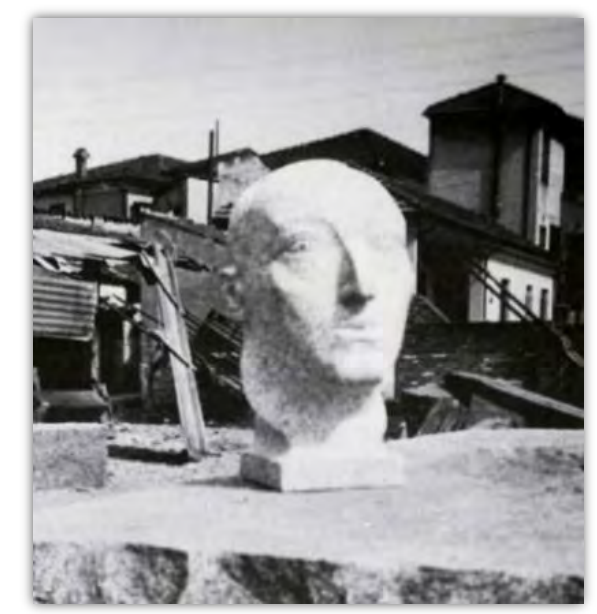

Figura 3.14 - Autorretrato do escultor Victor Brecheret, anos 1940.

Fonte: Bandeiras de Brecheret (1985), de Marta Rossetti Batista, p. 98.

Além de usar como modelos para o Monumento às bandeiras seus próprios amigos e conhecidos (tal qual Almeida Júnior, em $A$ partida da monção, como visto no primeiro capítulo),

Martim Cererê" (RICARDO, 1962, p. 268). O bandeirante reapareceria mais tarde nos ensaios históricos de Cassiano Ricardo, como “O Brasil no original” (1936) e "Marcha para oeste” (1940).

465 Editorial da revista S. Paulo, ago. 1936, n.8, s/p. Cabe notar que Victor Brecheret, Menotti del Picchia e Cassiano Ricardo aderem à Sociedade Paulista dos Amigos da Itália, em 1936, celebrando, assim, seu "carinho" pela "mãe ancestral da latinidade”. Cf. "Pró-Itália", O Imparcial, Rio de Janeiro, 2 abr. 1936, p. 8.

${ }^{466}$ Em uma de suas crônicas de Brás, Bexiga e Barra Funda, sobre o cotidiano ítalo-paulistano, Alcântara Machado nos conta ainda que "durante muito tempo a nacionalidade viveu a mescla das três raças que os poetas xingaram de tristes" até que "os transatlânticos trouxeram da Europa outras raças aventureiras. Entre elas uma alegre que pisou a terra paulista cantando e na terra brotou e se alastrou como aquela planta também imigrante (...) [e] nasceram os novos mamelucos" (MACHADO, 1927, p. 9). Sobre obra de Antônio de Alcântara Machado e as diversas dimensões da cidade de São Paulo que ela traz à tona, cf. Maciel (2017). 
Brecheret — descrito nos anos 1920 como um "brasileiro paulista" 467 — toma-se a si próprio não apenas como um dos bandeirantes de sua obra, mas como o único nomeado: na sua figura é inserida a inscrição "Autorretrato do escultor Victor Brecheret (02/10/1937)". Ainda assim, o artista enfatiza a existência de uma coletividade: seja índio, negro, mameluco, português ou imigrante, todos são bandeirantes, nos termos do escultor, e juntos constituem uma grande "massa escultural" ${ }^{468}$. No entanto, o artista dá uma forma e uma hierarquia precisa a essa massa. Se diversas são as figuras que compõem o monumento, inclusive uma mulher e uma criança, nenhuma delas parece ser tão eloquente quanto o próprio autorretrato do escultor, o único bandeirante que podemos reconhecer pela face. Esculpido logo no primeiro grupo depois dos cavaleiros, com eles Brecheret irá liderar a bandeira e os demais personagens.

No fim de 1937, com o golpe que instaurou o Estado Novo (1937-1945), quando Armando de Salles Oliveira é preso e exilado, as obras começam a caminhar lentamente diante da escassez de verbas, em um momento no qual as manifestações de cunho regionalista eram desestimuladas, ao mesmo tempo que eclodia a Segunda Guerra Mundial. O próprio fiscal da obra, no relatório do monumento, havia feito um “caloroso apelo" para que o governo não deixasse "perecer" o trabalho do escultor ${ }^{469}$. O Monumento às bandeiras acaba então "paralisado" devido à escassez material, explica Brecheret em 1942, em uma entrevista à revista Dom Casmurro, periódico que irá então descrevê-lo como um "pobre artista" que "deixou o conforto do lar" para residir num "barracão" no Ibirapuera, "velando carinhosamente” pela “epopeia de Fernão Dias”470.

Brecheret passa então a se dedicar a outras encomendas, como o já mencionado Monumento ao Duque de Caxias $^{471}$. Os processos de construção de ambas as obras foram, todavia, contrastantes, uma vez que este último contou com amplo apoio político. A proposta de erguer em São Paulo, durante o Estado Novo, uma estátua equestre ao militar conhecido como o "Pacificador da Pátria", atribuía a Luís Alves de Lima e Silva, mais conhecido como Duque de Caxias, um papel de destaque na manutenção da unidade do país. No memorial que escreve para a obra, o próprio Brecheret faz

\footnotetext{
467 “Brecheret”. Correio Paulistano, 26 fev. 1920, p. 1.

468 “São Paulo escreve no granito a história do Brasil". Dom Casmurro, 24 jan. 1942, no 235, p. 7.

${ }^{469}$ Relatório do Monumento às bandeiras desde seu início em 20 ago. 1936 até 30 abr. 1941. Cf. Processo no 87.293/45, AHMWL.

470 “São Paulo escreve no granito a história do Brasil". Dom Casmurro, 24 jan. 1942, no 235, p. 7.

${ }^{471}$ Luis Martins, membro da comissão que julgou a maquete do Monumento ao Duque de Caxias, ao acompanhar o andamento da obra em um dos galpões em que Victor Brecheret trabalhava, relata ao jornal O Estado de S. Paulo que o escultor parecia um "pigmeu" diante do "colossal" Caxias que criara. Cf. "O Monumento a Caxias", O Estado de S. Paulo, 21 dez. 1955, p. 8.
} 
questão de apontar que esculpiu o personagem propositalmente em trajes militares, e não com ponchos característicos das campanhas do Sul (LOPES, 2017). Além disso, em entrevista ao Diário de S. Paulo, em 1941, o escultor define sua homenagem ao patrono do Exército brasileiro como um trabalho "clássico, do ponto de vista grego", uma obra idealizada segundo concepções tradicionais $^{472}$.

A pedra fundamental do Monumento às bandeiras - com uma urna contendo "documentos relativos à vida da cidade de São Paulo", entre eles livros autografados por Afonso Taunay, relata O Estado de S. Paulo ${ }^{473}$ — é lançada apenas em 1946, primeiro ano pós-governo Getúlio Vargas, no aniversário da capital paulista, quando a prefeitura providencia também o início da construção definitiva da obra. Cabe notar que nesse mesmo ano, quando a prefeitura publica os editais para a execução da obra, os concorrentes foram submetidos a uma prova de capacitação da qual a oficina vencedora foi dispensada, pois ao ser escolhida anteriormente para executar o granito do Monumento ao Duque de Caxias já havia passado por um teste similar, no qual teve que transferir para a pedra uma escultura determinada por Brecheret e por ele julgada: justamente seu autorretrato em gesso (BATISTA, 1985).

Em 1947, a oficina de cantaria Incerpi, sediada no Bom Retiro, é contratada para a execução do monumento em granito. "Uma oficina de titãs", descreve uma matéria publicada no periódico $A$ Época ${ }^{474}$. Os "titãs" provocaram a admiração dos visitantes que se deslocavam até o centro da cidade para visitá-los na rua Javaés, logradouro nomeado em homenagem a um grupo indígena escravizado no passado por bandeirantes, no qual estava localizada a oficina ${ }^{475}$. Ao serem transportados até o parque do Ibirapuera, os fragmentos da obra seriam ainda testados sobre o novo suporte do monumento, que agora possuía uma base com as laterais quase na vertical, no lugar da escadaria, como se o conjunto escultural surgisse da rocha (BATISTA, 1985).

\footnotetext{
472 "Parece que via o duque de Caxias nos instantes decisivos de sua vida solar". Diário de S. Paulo, 4 dez. 1941, p. 1. 473 “O $392^{\circ}$ aniversário da fundação da cidade de S. Paulo". O Estado de S. Paulo, 27 jan. 1946, p. 7.

474 "Para o segundo semestre do próximo ano a inauguração do Monumento das bandeiras". A Época, 28 jul. 1949, reproduzido em Batista (1985, p. 113).

475 A rua Javaés teve seu nome oficializado pelo ato $\mathrm{n}^{\circ}$ 972, de 24 de agosto de 1916, mesmo ato que irá nomear a rua dos Bandeirantes, também na região do Bom Retiro. Cf. Núcleo de denominação de logradouros públicos, AHMWL.
} 


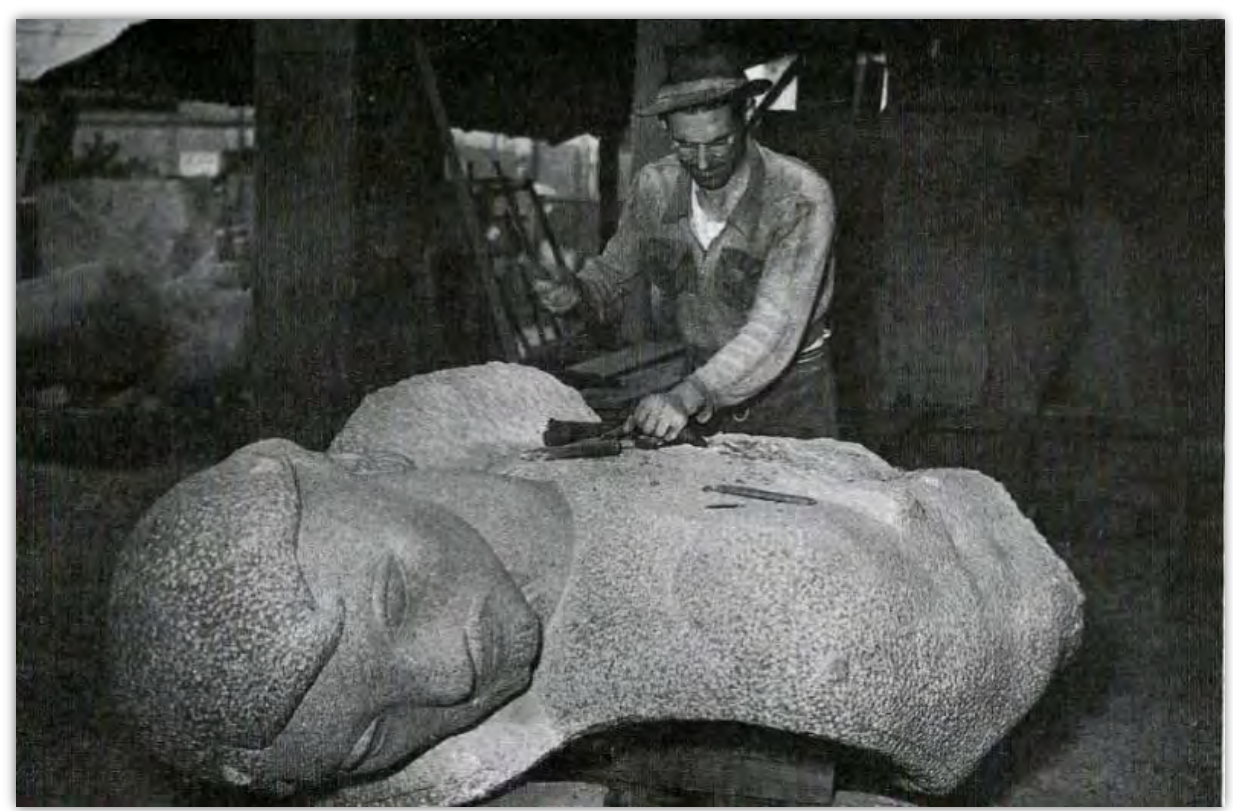

Figura 3.15 - Homem esculpindo fragmento do monumento, oficina Incerpi, anos 1940. Fonte: Bandeiras de Brecheret (1985), de Marta Rossetti Batista, p. 97.

A despeito da retomada das obras, "os bandeirantes de Brecheret parecem Prometeus acorrentados ao Cáucaso da burocracia paulistana”, afirma uma reportagem veiculada na revista Elite ao lembrar que, em 1943, o Estado transferira para a prefeitura terrenos no Ibirapuera, inclusive o do monumento, junto com a obrigação de finalizá-1o ${ }^{476}$. "Marchai, titãs de gesso!”, teria exclamado o escultor em 1940, mas sua obra seguia "aprisionada", segundo a mesma matéria ${ }^{477}$. Lourival Gomes Machado, em seu ensaio "Retrato da arte moderna no Brasil” (1947), faz coro aos lamentos, dizendo que ao público é proibido até saber o que e como Brecheret produz. "Ora, isso não corresponde aos fatos", retruca o Correio Paulistano, ao explicar que as visitas ao ateliê são isentas de burocracia, bastando que o escultor esteja presente para receber os visitantes ${ }^{478}$. A maquete em barro e as moldagens em gesso, ao contrário do monumento em granito, não resistiriam ao excesso de umidade e calor se ficassem expostas a céu aberto, por isso permaneciam no Ibirapuera dentro do ateliê do escultor ${ }^{479}$.

\footnotetext{
476 "O prisioneiro do parque do Ibirapuera". Elite, 1947, reproduzido em Pellegrini (1976, p. 83).

477 Ibidem, p. 80.

478 "Victor Brecheret, o escultor do Monumento às bandeiras". Correio Paulistano, nov. 1948, reproduzido em Pellegrini (p. 98).

479 Ainda assim, o jornal O Estado de S. Paulo queixa-se de que, "fechado no barracão de tábuas", faltava ao trabalho de Victor Brecheret espaço para ser visto a distância, cf. "Do Monumento das bandeiras às pedras", O Estado de $S$. Paulo, 1 dez. 1948, p. 5. Na etapa final da obra, o modelo em gesso 1:10 foi ampliado para 1:1 (tamanho natural), sendo numerado em 124 partes, algumas delas posteriormente subdivididas (BATISTA, 1985). "Em toda parte" era possível ver "cabeças gigantescas, troncos, braços, mãos”, relata um articulista da revista paranaense Guaíra, cf. “Brecheret”, Revista Guaíra, nov. 1949, reproduzido em Pellegrini (1976, p. 108).
} 


\subsubsection{Três décadas depois}

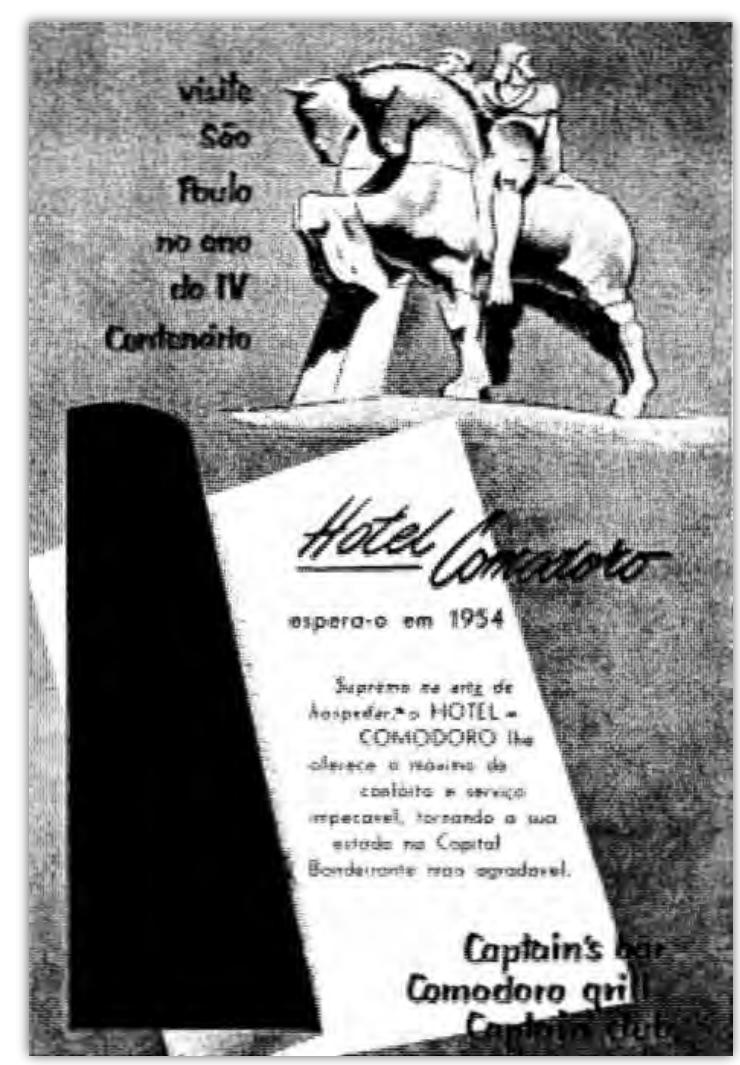

Figura 3.16 - Propaganda do hotel Comodoro, 1953.

Fonte: Catálogo da II Bienal do Museu de Arte Moderna de São Paulo (1953), s/p.

É somente durante os preparativos para as comemorações do IV Centenário, em 25 de janeiro de 1953, que a obra de Victor Brecheret é finalmente inaugurada. Ofertado à cidade por conta das comemorações do Centenário da Independência do Brasil, o Monumento às bandeiras é concretizado 31 anos depois da reabertura do Museu Paulista, sede oficial das comemorações paulistas de 1922. Aproveitando a ocasião, sua imagem é veiculada para divulgar as festas de 1954, como na propaganda acima do hotel Comodoro (ele mesmo inaugurado como um "presente" para a cidade aniversariante ${ }^{480}$, publicada no Catálogo da II Bienal do Museu de Arte Moderna de São Paulo,

480 "Dotado do que há de mais moderno da indústria hoteleira", o hotel Comodoro é inaugurado em 1952 como "um presente de aniversário à ciclópica cidade de São Paulo", anuncia a propaganda do próprio hotel. Entre outros, cf. "Hotel Comodoro". O Estado de S. Paulo, 25 jan. 1952, p. 7. 
exposição que contou com a participação de Brecheret em sua primeira edição, quando o escultor foi inclusive premiado ${ }^{481}$.

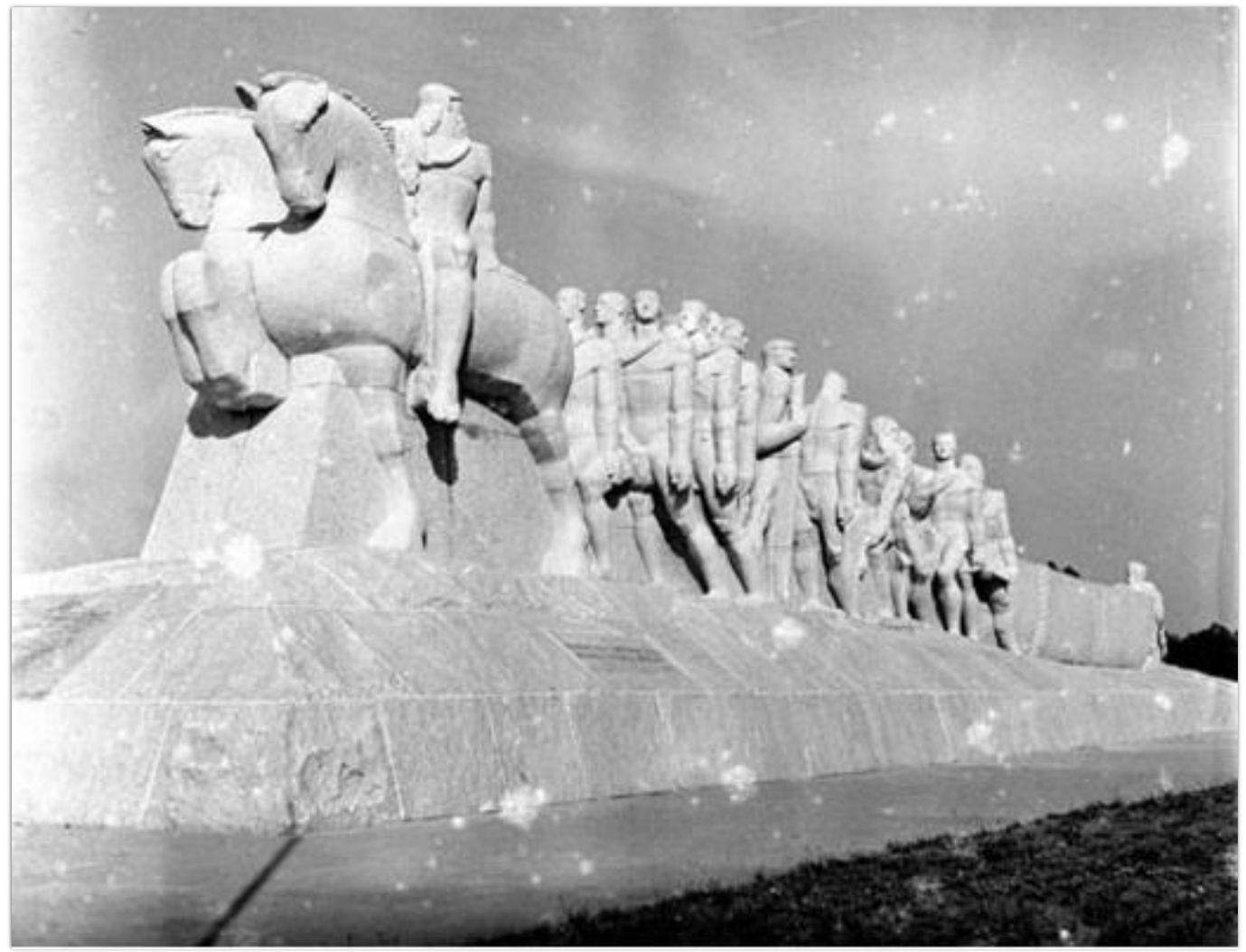

Figura 3.17 - Monumento às bandeiras, 1954.

Fonte: Acervo Fotográfico do Museu da Cidade de São Paulo | Foto: Benedito Junqueira Duarte.

Indagado pelo jornal Última Hora sobre o motivo que o levou a inaugurar sua obra um ano antes do IV Centenário, Brecheret teria respondido: "Você está louco? Quero ver meu trabalho pronto antes de morrer" ${ }^{482}$. Dois anos depois o escultor falece, mas seu nome perdura estampado na placa de uma rua próxima ao parque do Ibirapuera e à última de várias obras por ele esculpidas (embora tenha sido a primeira a ser esboçada) 483 . "Pretendi transformar isso [o Monumento às bandeiras] num Altar da Pátria”, explica Brecheret diante de uma população que se

\footnotetext{
${ }^{481}$ Victor Brecheret recebeu o Prêmio de Escultura Nacional, durante a I Bienal de São Paulo, pela obra O indio e a suaçuapara (1951).

482 “Trinta anos de trabalho no maior monumento do mundo". Última Hora, 21 nov. 1952, reproduzido em Pellegrini (1976, p. 111).

483 A rua Victor Brecheret tem seu nome oficializado pela lei $\mathrm{n}^{\circ}$ 5.278, de 8 de julho de 1957. Cf. Núcleo de denominação de logradouros públicos, AHMWL.
} 
multiplicava, "aqui se encontram o índio, o negro e o branco" ${ }^{484}$. Notemos que entre os anos 1950 e 1960, São Paulo ultrapassa demograficamente a capital federal, tornando-se a maior urbe brasileira $^{485}$. Como observa Paulo Garcez Marins (2003), Brecheret já não especifica o português ou o mameluco, como fizera antes, conferindo um caráter mais abrangente aos seus bandeirantes. Mas se o artista enfatiza que em sua obra estão esculpidas "todas as raças" que formaram o Brasil ${ }^{486}$, o monumento é frequentemente representado segundo uma convenção que o vê a partir da dianteira, dando destaque para os dois bandeirantes que cavalgam conduzindo hierarquicamente os demais

Nessa cavalgada, a obra de Brecheret é associada à "vitalidade" da "capital bandeirante", ilustrada por uma imagem, agora em cores (quando a recém-inaugurada televisão veiculava imagens em preto e branco), do Monumento às bandeiras, destacando aqui também sua parte frontal. Cercada por muitas flores vermelhas, e por uma sombra que cobre toda parte posterior do monumento, a obra tem sua imagem publicada em um suplemento da revista carioca O Cruæeiro, sobre os quatrocentos anos de São Paulo. Esta, a moderna cidade, com seu "espetacular e vertiginoso crescimento", é comparada aos "bandeirantes heroicos que empurram, na boca de seus bacamartes, o tratado de Tordesilhas até quase os contrafortes da cordilheira dos Andes" ${ }^{\text {"47 }}$. Na capa da mesma edição, temos ainda um retrato do padre José de Anchieta como fundador da cidade de São Paulo, pintado por Candido Portinari (1903-1962), lembrando que outras imagens disputavam o protagonismo das festas centenárias ${ }^{488}$.

484 “Trinta anos de trabalho no maior monumento do mundo". Última Hora, 21 nov. 1952, reproduzido em Pellegrini (1976, p. 111).

485 A população de São Paulo, que de acordo com o censo demográfico de 1950 somava aproximadamente 2,2 milhões de pessoas, irá aumentar para mais de 3,8 milhões no censo de 1960, devido sobretudo às correntes migratórias, em grande parte geradas na região Nordeste do país, estimuladas pela possibilidade de incorporação dos recémchegados nas fábricas ou na construção civil. São Paulo ultrapassa, assim, a população do Rio de Janeiro, que entre os dois censos aumentou de quase 2,4 milhões para 3,3 milhões de habitantes. Disponível em: <https://censo2010.ibge.gov.br/sinopse/index.php?dados=6\&uf=00>. Acesso em: 17 ago. 2017. Nota-se, para além de uma expansão considerável da mancha urbana, que o crescimento demográfico modificou a cidade em praticamente todos os seus aspectos, imprimindo-lhe "os contornos definitivos de metrópole", assim como "um perfil cosmopolita e moderno” (ARRUDA, 2015, pp. 52-55).

486 “O Monumento às bandeiras”. Gazeta, 31 dez. 1952, reproduzido em Pellegrini (1976, p. 112).

487 “São Paulo”. O Cruzeiro, 23 jan. 1954, p. 32.

488 Sobre a recorrência da imagem de José de Anchieta e do Pátio do Colégio como marcos fundadores da cidade de São Paulo durante as comemorações do IV Centenário, cf. Quarenta (2009), Canado Junior (2014) e Kuhn (2016). Já para um aprofundamento da discussão da imagem de uma cidade entre o passado e o futuro durante as comemorações paulistas dos quatrocentos anos de São Paulo, ver Lofego (2004). 

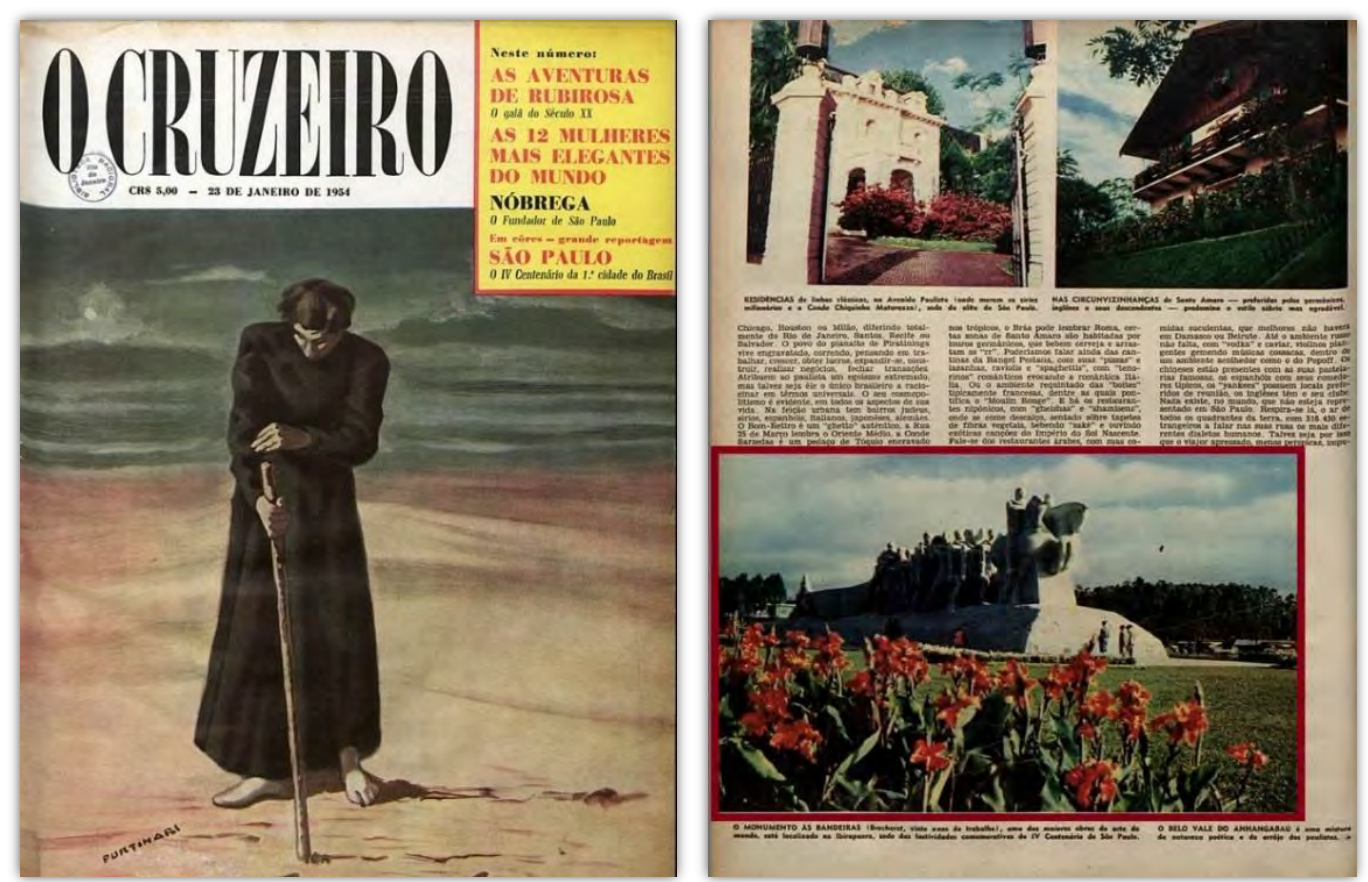

Figura 3.18 - Monumento às bandeiras durante as festas do IV Centenário.

Fonte: O Cruzeiro, 23 jan. 1954.

Os bandeirantes de Victor Brecheret estão associados não apenas ao passado, mas também ao progresso e à modernidade, enfatizados pelo próprio símbolo do IV Centenário, como é possível observar no editorial de outra revista carioca, a Manchete, igualmente publicada por ocasião das celebrações centenárias, cuja capa retrata o centro de São Paulo e seus edifícios por meio de uma fotografia aérea. Escrito em português e em inglês, o texto do editorial, acompanhado por uma fotografia noturna do monumento, também visto aqui a partir de sua dianteira, descreve o Ibirapuera como uma "nova cidade" que "abre seus portões para o mundo": "É um monumento à sua irmã mais velha, que reúne cerca de 3 bilhões de habitantes do alto do planalto de Piratininga" ${ }^{489}$. Criada por uma equipe sob o comando de Oscar Niemeyer (1907-2012) para integrar o conjunto arquitetônico do parque do Ibirapuera, a famosa espiral (ou "aspiral" ${ }^{490}$ ) desenhada no editorial evoca a pujança da cidade aniversariante ao apontar para cima, rumo ao futuro, "aspirando" a um progresso sem fim ${ }^{491}$.

489 “400 anos depois”. Manchete, edição especial do IV Centenário de São Paulo, 1954, s/p.

490 A "aspiral", segundo o Histórico da comissão do IV centenário de 1954, "significa pelo seu movimento, pelo seu ritmo ascensional, uma aspiração para o alto”. Símbolo do IV Centenário, ela foi reproduzida em um monumento erguido, por um breve período, na entrada do parque do Ibirapuera, mas "seu elegante desenho não condizia muito com a estática e ruiu" (SEGAWA, 1998, p. 102).

491 Importante ressaltar que embora Oscar Niemeyer se inspirasse constantemente no passado colonial brasileiro como nos numerosos painéis de azulejo e nas pedras Itacolomi do conjunto da Pampulha —, nas construções do 

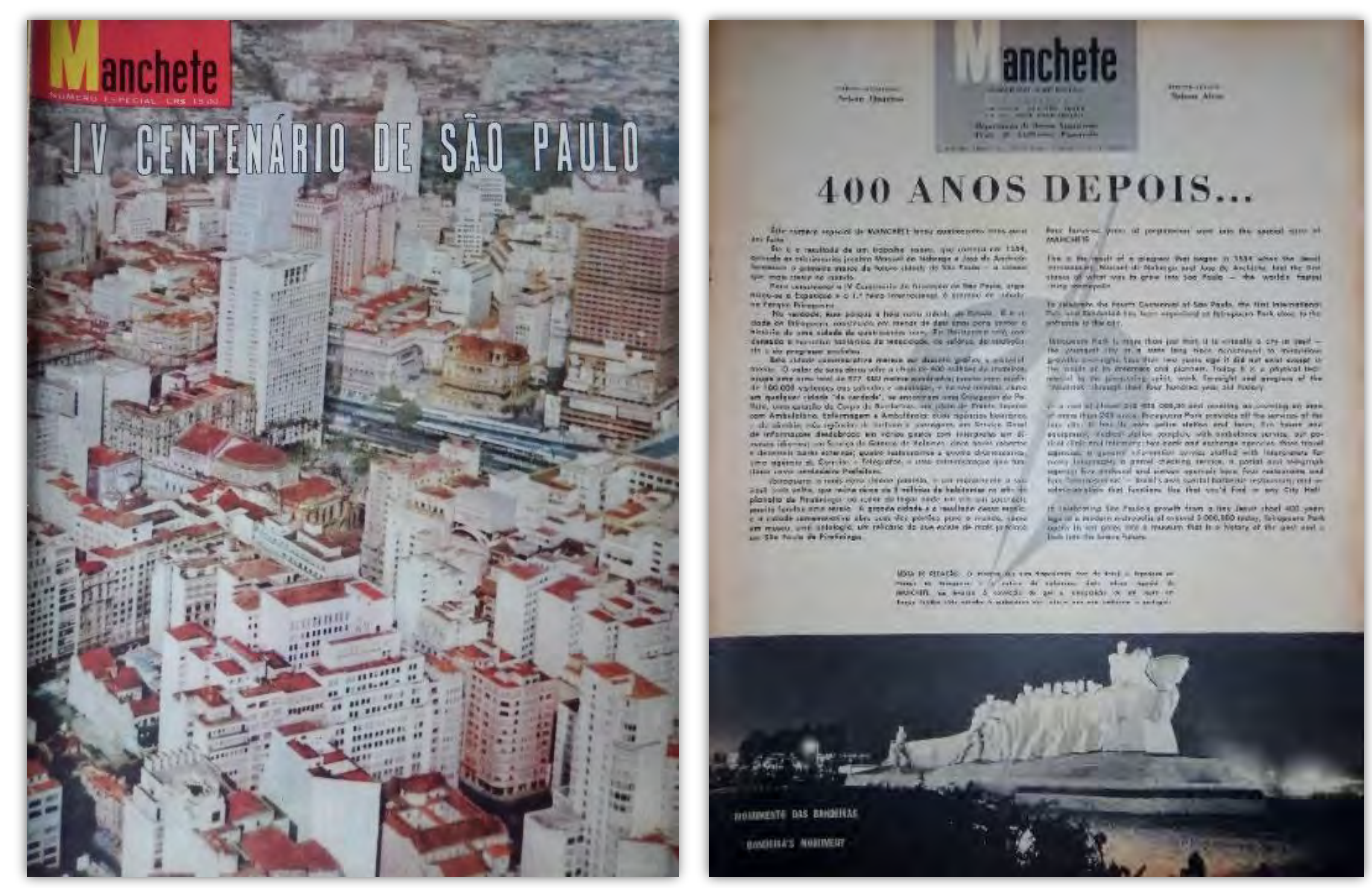

Figura 3.19 - Rumo ao futuro, revista Manchete, 1954.

Fonte: Acervo pessoal | Foto: Thaís Waldman.

Um ano depois de sua inauguração, o Monumento às bandeiras é praticamente reinaugurado em meio aos festejos dos quatrocentos anos da cidade. Em 1954, enquanto os versos da música "Quarto Centenário", composta pelo italiano Mario Giovanni Zandomeneghi, conhecido como Mario Zan, celebravam à exaustão nas rádios e nos toca-discos paulistanos o "progresso e glória" da "terra bandeirante", cujos edifícios "parecem chegar ao céu", o Monumento às bandeiras ocupava uma praça na entrada do parque do Ibirapuera, no qual ocorria a exposição comemorativa do aniversário de São Paulo ${ }^{492}$. Ao mesmo tempo, sua imagem replicava-se parque afora, fazendo com que o monumento se movimentasse pela cidade, protagonizando propagandas como as da General Electric. "Símbolo da excelência", a empresa multinacional estadunidense afirma em uma

Ibirapuera não há nenhuma remissão ligada ao passado paulista ou nacional, de modo que o passado aparece aqui como ponto de partida de uma escalada para o futuro (MARINS, 2003).

${ }^{492}$ Em carta a Guilherme de Almeida, presidente da comissão do IV Centenário, o diretor de relações públicas da mesma comissão chega a sugerir uma homenagem a Mario Zan, "artista do povo", reconhecendo a importância de sua obra. Apesar do sucesso da música de Zan, popularmente conhecida como o hino do IV Centenário, a proposta foi indeferida. Cabe notar que em 1952, de acordo com documentos do serviço de comemorações do IV Centenário, compositores "de renome” (como Heitor Villa-Lobos, Francisco Mignone e Camargo Guarnieri) já haviam sido contratados, embora não tivessem alcançado o mesmo sucesso. Cf. Fundo do IV Centenário, processo no 3206-54, caixa 123, AHMWL. 
propaganda, que traz estampado um desenho da parte frontal da obra de Brecheret, que "ao monumento do progresso que é São Paulo, se funde o monograma GE"493.

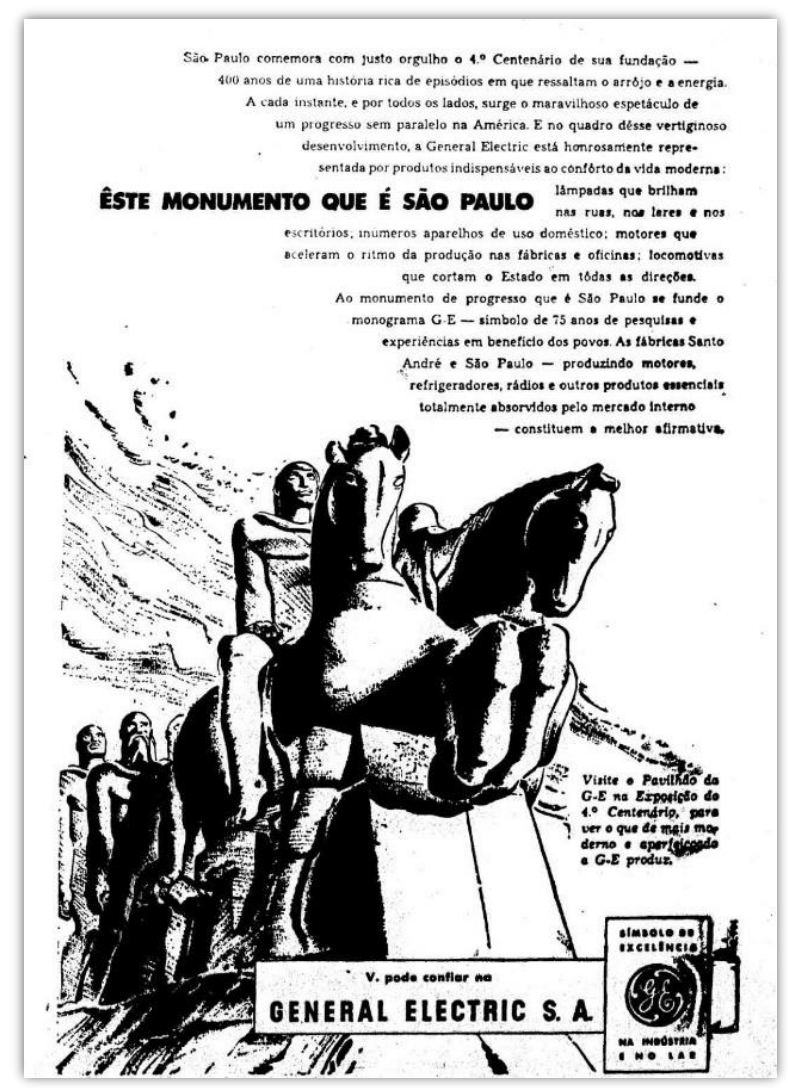

Figura 3.20 - Propaganda veiculada durante as celebrações do IV Centenário da cidade, 1954. Fonte: O Estado de S. Paulo, 25 jan. 1954, p. 93.

Ao povoarem, finalmente, a antiga praça dos Bandeirantes, renomeada em homenagem a Armando de Salles Oliveira, Victor Brecheret e os demais personagens de sua bandeira passam a ocupar uma região, assim como os arredores da Escola Estadual Fernão Dias Paes, tomada pela presença bandeirante. Nas proximidades do parque do Ibirapuera, diversos logradouros já haviam recebido nomes de bandeirantes nos anos 1930, como as ruas Domingos

493 Ainda que não esteja falando especificamente dos bandeirantes esculpidos por Victor Brecheret, Esmeralda Moura (1994) destaca a imagem do "bandeirante do progresso" ao analisar as propagandas veiculadas em 1954, durante as comemorações do IV Centenário, nos jornais A Gazeta, Diário de S. Paulo, Folha da Manhã e O Estado de S. Paulo. Se os anos 1950 representaram um momento particularmente significativo para a industrialização do estado e do país, a publicidade mostra que a indústria desbravaria caminhos como os dos bandeirantes, vide as propagandas da Philips, da Cia. Swift do Brasil, da Cia Cervejaria Brahma e da Indústria de Pneumáticos Firestone, analisadas por Moura, assim como a da General Electric apresentada acima. 
Leme, Leonardo Nardez, Lourenço Castanho, Baltasar da Veiga, Antônio Afonso, Mendes Pais, Domingos Fernandes, Januário Cardoso, Pais de Araújo, André Fernandes, Campos Bicudo, Jerônimo da Veiga e Pedroso Alvarenga, sem falar na praça Jacintho Moreira Cabral. Posteriormente, outras ruas na mesma região têm seus nomes oficializados, como a João Lourenço, mais uma homenagem a um bandeirante, nomeada no mesmo ano em que é inaugurado o Monumento às bandeiras ${ }^{494}$.

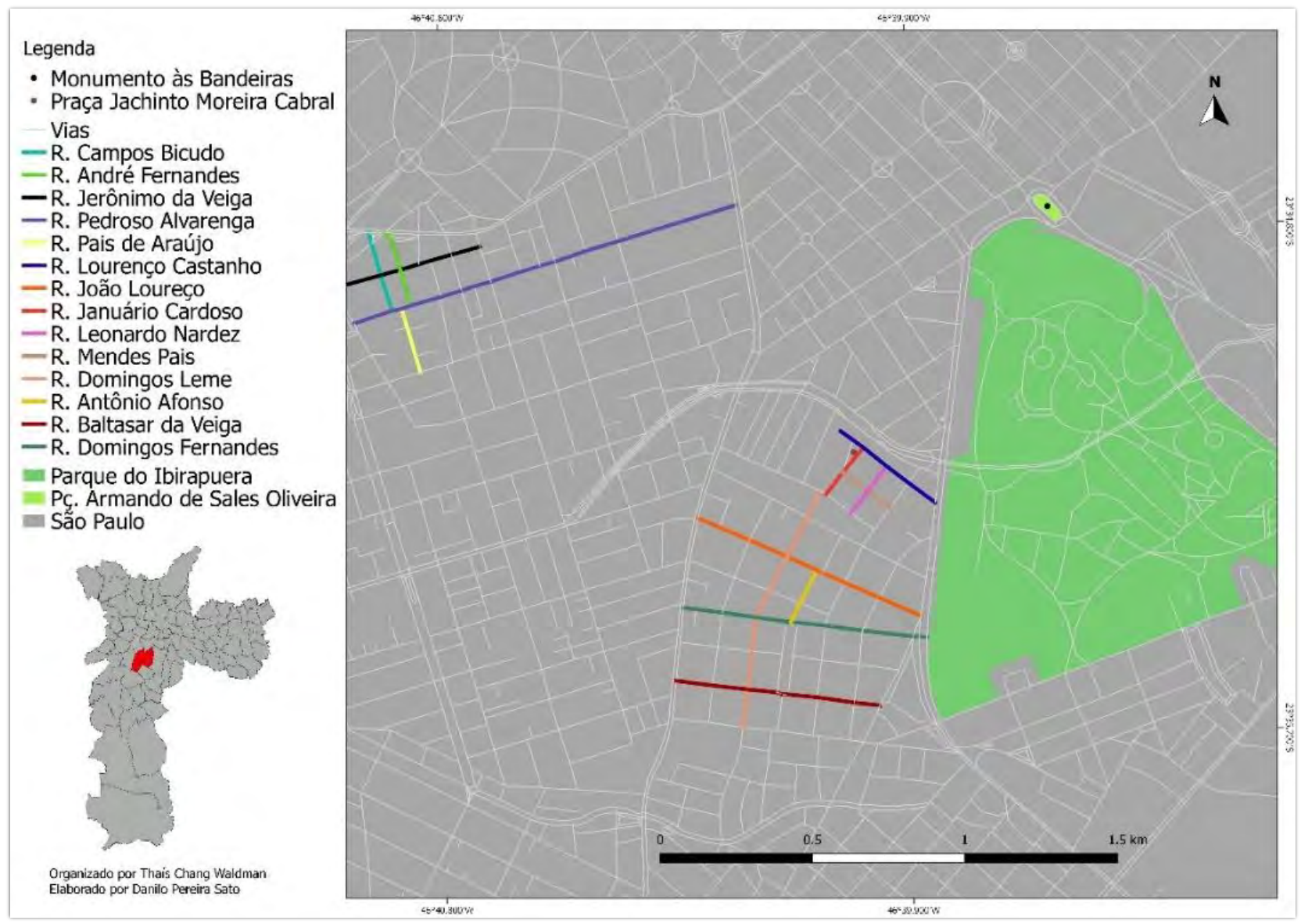

Figura 3.21 - Logradouros em homenagem a bandeirantes no entorno do parque do Ibirapuera. Fonte: GeoSampa: dados abertos geoespaciais ${ }^{495}$.

494 As ruas Baltasar de Veiga, Domingos Leme, Antônio Afonso e Domingos Fernandes tiveram seus nomes oficializados pela lei no 3.447, de 7 de janeiro de 1930. No mesmo ano, as ruas Januário Cardoso, Leonardo Nardez, Mendes Pais e Lourenço Castanho, mais a praça Jacintho Moreira Cabral, são nomeadas pela lei no 3.448, de 8 de janeiro de 1930. A rua Mendes Pais teve seu nome oficializado pelo ato $n^{\circ} 305$, de 4 de fevereiro de 1932, enquanto as ruas Pedroso Alvarenga, Pais de Araújo, André Fernandes, Campos Bicudo e Jerônimo da Veiga foram nomeadas pelo ato $\mathrm{n}^{\mathrm{o}}$ 562, de 12 de janeiro de 1934. A praça Armando de Salles Oliveira, por sua vez, teve seu nome oficializado pelo decreto $n^{\circ} 406$, de 11 de março de 1947. Já a rua João Lourenço foi nomeada pela lei $n^{\circ} 4.371$, de 17 de abril de 1953. Cf. Núcleo de denominação de logradouros públicos, AHMWL.

495 Disponível em: < http://www.prefeitura.sp.gov.br/cidade/secretarias/urbanismo/dados_abertos/> . Acesso em: 20 jun. 2017. 
Pensando ainda nessa espécie de geografia bandeirante, em meio à expansão da capital para a região sul, um dos limites do parque do Ibirapuera era a antiga estrada de Santo Amaro, que em 1954 passa oficialmente à condição de avenida, mantendo a denominação de Santo Amaro (referência ao bairro homônimo que deve sua origem a um aldeamento indígena chamado Ibirapuera). Cabe notar que o caminho que ligava a cidade de São Paulo ao então município de Santo Amaro, anexado à capital em 1935, cruzava o córrego da Traição e, sobre o leito desse curso d'água, após sua canalização, foi construída uma estrada que, em 1970, passa a ser chamada avenida dos Bandeirantes (por cima da qual passará o viaduto dos Bandeirantes). A avenida dos Bandeirantes, por sua vez, não só cruza a avenida Washington Luís - que quando presidente (1926-1930) tornou célebre a frase "governar é abrir estradas" —, como desemboca na avenida Afonso de Taunay ${ }^{496}$.

Convidado por Washington Luís, presidente honorário da comissão executiva do Monumento às bandeiras, para ser membro da comissão técnica que avaliaria o projeto da obra nos anos 1920, Afonso Taunay acompanhou toda a longa execução dos bandeirantes de Victor Brecheret ${ }^{497}$. Além de sugerir uma ânfora com águas do Tietê na maquete inicial de Brecheret, durante os preparativos para as comemorações paulistas do Centenário da Independência do Brasil, Taunay já realizava pesquisas para o seu Ensaio de carta geral das bandeiras paulistas (1922), mapa com oito metros quadrados de superfície, amplamente divulgado na época e, segundo ele, "o primeiro ensaio que no gênero se faz entre nós" (1926, p. 18) ${ }^{498}$. A imagem do mapa, exposto na época na sala de cartografia colonial do Museu Paulista, então sob sua direção, figura até hoje no frontispício do Monumento às bandeiras, gravando na pedra um a um os nomes dos bandeirantes responsáveis

\footnotetext{
496 A avenida dos Bandeirantes teve seu nome oficializado pelo decreto ${ }^{\circ}$ 9.160, de 25 de novembro de 1970, enquanto o viaduto dos Bandeirantes, pelo decreto no 15.777, de 29 de março de 1979. Afonso de Taunay, por sua vez, depois de sua morte irá nomear uma avenida de acordo com o decreto no 5.579, de 18 de fevereiro de 1963. Já a nomeação da avenida Washington Luís é posterior, remontando ao decreto no 27.437 , de 2 de dezembro de 1988. Cf. Núcleo de denominação de logradouros públicos, AHMWL.

${ }^{497}$ Junto a Wasth Rodrigues, Ramos de Azevedo, Aguiar de Andrade e Adolfo Pinto, Taunay deveria apresentar um laudo a respeito da maquete do Monumento às bandeiras, sob o ponto de vista artístico, histórico e orçamentário. Ofício dos secretários da Comissão Executiva do Monumento das bandeiras - Armando Prado, Menotti del Picchia, R. Moreira — para Afonso Taunay, 24 ago. 1920. APMP/FMP, pasta 110.

498 Após a primeira tiragem de seu mapa, Taunay explica, em carta ao secretário de Negócios do Interior, ter distribuído exemplares da obra para grupos escolares, ginásios e escolas normais do estado de São Paulo; para a inspetoria geral da instrução pública e para o comando geral da força pública; para as câmaras municipais; para os institutos históricos brasileiros; para as bibliotecas estaduais e para as "grandes bibliotecas do universo". Carta de Afonso Taunay a José Manuel Lobo, 15 out. 1926. APMP/FMP, pasta 128. Taunay também publica, em 1922, a Coletânea de mapas da cartografia paulista antiga, organizada por ele mesmo e lançada pela editora Melhoramentos.
} 
pela conquista do território brasileiro, tais como Fernão Dias, Borba Gato e Raposo Tavares (além do nome do próprio Taunay, autor do mapa ${ }^{499}$.

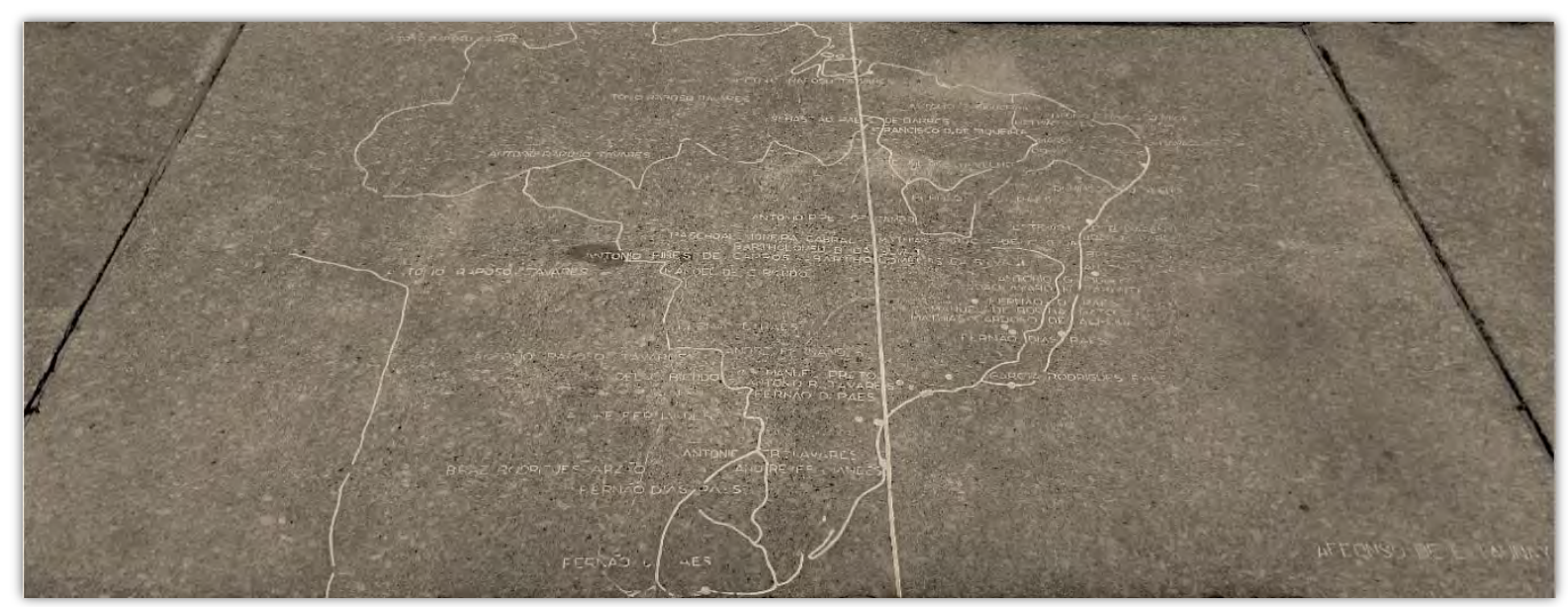

Figura 3.22 - Ensaio de carta geral das bandeiras paulistas, de Afonso Taunay, no Monumento às bandeiras, 2017.

Fonte: Acervo pessoal | Foto: Thaís Waldman.

Poucos meses antes da inauguração do Monumento às bandeiras, Brecheret recebera uma carta de Afonso Taunay propondo-lhe que não apenas gravasse seu Ensaio de carta geral das bandeiras paulistas na face frontal do pedestal da obra, como também inscrevesse no monumento uma citação de Auguste de Saint-Hilaire, datada do início do século XIX. Nesse texto, além de descrever os paulistas como uma "raça de gigantes" (expressão que seria repetida à exaustão anos depois ${ }^{500}$ ), o viajante e naturalista francês evoca "uma navegação gigantesca e prodigiosa" que partia da cidade de Porto Feliz e seguia rumo às minas de ouro de Cuiabá, causando espanto entre os europeus acostumados com "seus mesquinhos rios" ${ }^{\text {" }}$. Embora a sugestão da legenda não tenha sido acatada, o Monumento às bandeiras, desde seu modelo inicial, engloba tanto bandeiras terrestres quanto fluviais ${ }^{502}$.

499 Além desse ensaio, Taunay pretendia acrescentar, na sala de cartografia colonial, de acordo com suas próprias palavras, "curiosas cartas do nosso litoral, do século XVII de autoria de Pedro Teixeira, e das missões jesuíticas inéditos que recebi da Espanha, de um dos arquivos da Companhia de Jesus, etc" (1926, p.10). Desse modo, "dispersaria", em seus próprios termos, "todos os antigos materiais extrapaulistas que ali estavam por falta de material suficiente” (1926, p. 10).

500 Alfred Ellis Júnior, aluno de Taunay no curso ginasial do Colégio São Bento, irá tomar o termo "raça de gigantes" como título de seu livro publicado em 1926, cf. Abud (1985) e Ferreira (2002).

${ }^{501}$ Carta de Afonso Taunay a Victor Brecheret, 15 fev. 1953, reproduzida em Pellegrini (1976, p. 116).

502 As legendas escolhidas para serem inscritas no granito são de autoria de Guilherme de Almeida ("Brandiram achas e empurraram quilhas vergando a vertical de Tordesilhas”) e de Cassiano Ricardo (“Glória aos heróis que traçaram 
Caracterizadas no memorial que acompanha a primeira maquete da obra como "titãs da terra", e como "argonautas dos rios", as figuras esculpidas por Brecheret são apresentadas desde 1920 empurrando uma "canoa das monções", descrita como uma grande embarcação "destinada a singrar o Tietê histórico" ${ }^{\text {"503 }}$. Não parece estranho, portanto, que o Monumento às bandeiras seja ao mesmo tempo representado segundo uma convenção que o vê a partir da dianteira, e popularmente chamado de "empurra-empurra", "deixa que eu empurro" e "não empurra", três referências à canoa que ocupa a parte posterior da obra, da qual foram eliminadas a ânfora e os indígenas guardiões do monumento, presentes na maquete de $1920^{504}$.

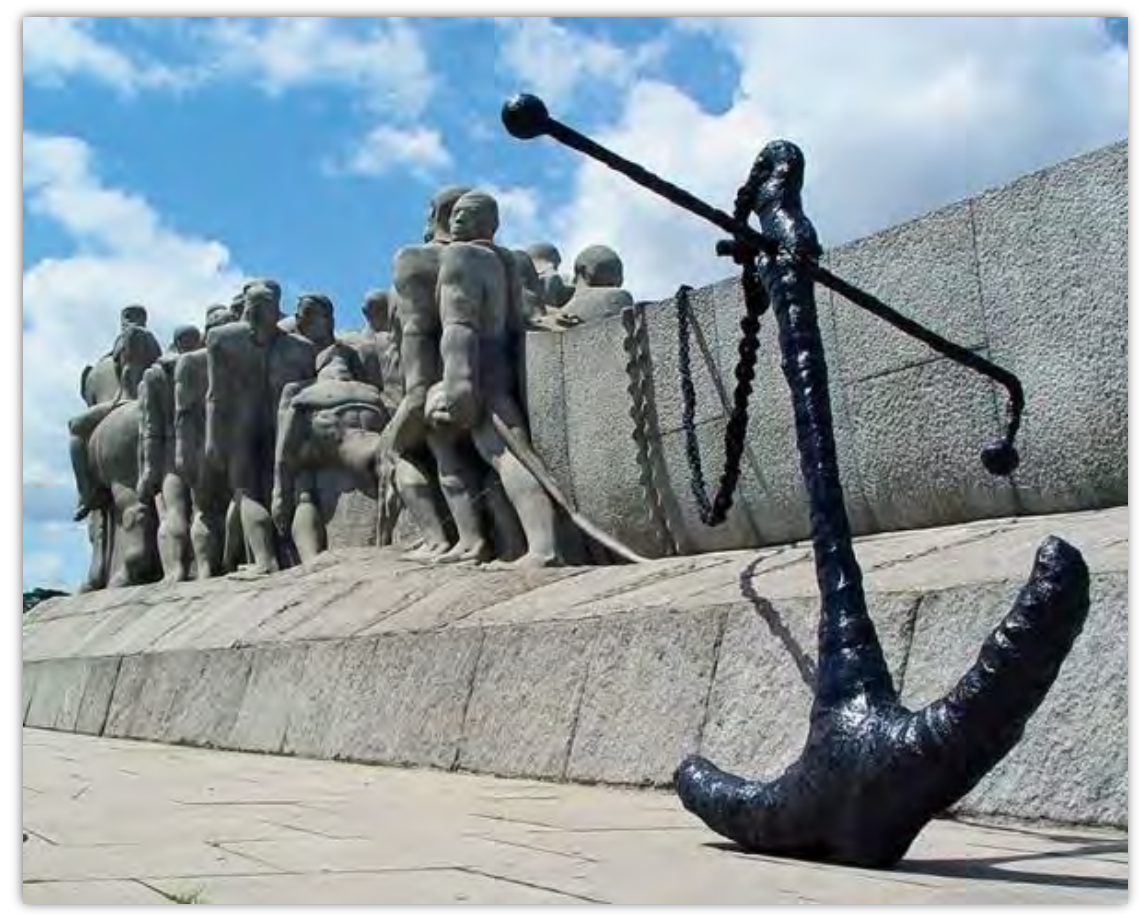

Figura 3.23 - Âncora, de Eduardo Srur, 2004.

Fonte: Acervo Eduardo Srur ${ }^{505}$.

Se o texto de Saint-Hilaire sobre a grande embarcação que partia de Porto Feliz não foi acatado por Brecheret, a imagem da canoa porto-felicense nele descrita segue disparando novas

o nosso destino em geografia do mundo livre, sem eles o Brasil não seria grande como é”), respectivamente gravadas nas faces laterais direita e esquerda do pedestal do Monumento às bandeiras.

503 “Monumento das Bandeiras". Correio Paulistano, 28 jul. 1920, p. 1.

$504 \mathrm{O}$ próprio site da prefeitura, em seu Inventário de obras de arte em logradouros públicos da cidade de São Paulo, ao apresentar o Monumento às bandeiras lhe atribui os três apelidos acima mencionados. Disponível em: $<$ http://www.prefeitura.sp.gov.br/cidade/secretarias/cultura/patrimonio_historico/adote_obra/index.php?p=4526>. Acesso em: 5 jul. 2017.

${ }^{505}$ Disponível em: <https://www.instagram.com/p/-kGmTJMHrO/?taken-by=eduardostur>. Acesso em: 5 jul. 2017. 
criações. Em 2004, por exemplo, uma intervenção artística acima de Eduardo Srur (artista que quatro anos depois vestiria as estátuas de Borba Gato e Anhanguera com coletes salva-vidas, como visto no capítulo precedente ${ }^{506}$ ) acoplou ao "monumento modernista que representa o desenvolvimento de São Paulo", nos termos de Srur, uma escultura em forma de âncora, feita de borracha EVA, madeira, massa asfáltica, pó de ferro, sisal e cabos de aço ${ }^{507}$. Integrada ao Monumento às bandeiras, a âncora parecia tornar a canoa mais fixa, como se estivesse afirmando que o monumento está parado e não pode sair dali.

\subsection{Outros caminhos das monções}

"Quando, à margem do rio Piratininga, na antiga várzea de
Guarepe, se puseram pela primeira vez a meditar acerca do
curso provável daquelas águas, estranhas e volumosas, que
nasciam tão perto do mar e corriam para o interior das
terras, que teria ocorrido à mente desses primeiros
povoadores do planalto? Para onde iria o misterioso caudal?
Para as terras dos monstruosos coruqueans ou dos
minúsculos guayazis? Dos inumeráveis matuyus, dos
gigantes de pés voltados para trás? Acaso atravessaria as
florestas de árvores de vidro e árvores de sabão, povoadas
de abentesmas e animais monstruosos? Ou antes: não se
dirigiria para as paragens prodigiosas do Eldorado?” (Afonso Taunay, 1926b, p. 85)

A imagem da canoa porto-felicense percorreu muitos caminhos. Vimos no primeiro capítulo que, entre as décadas de 1920 e 1930, um conjunto de vasos contendo pequenas quantidades de água retiradas in loco dos grandes rios do Brasil foi alocado por Afonso Taunay na

506 Âncora, ao contrário de Sobrevivência, não foi uma intervenção artística inicialmente autorizada: "Construí uma âncora velha de navio e instalei o objeto, em plena luz do dia, no monumento modernista que representa o desenvolvimento de São Paulo. Mesmo sem a aprovação da prefeitura, a âncora permaneceu três semanas no local. Durante uma tentativa de retirá-la, fui ironicamente impedido pela polícia que alegou defender o patrimônio histórico da cidade", explica Eduardo Srur. Disponível em: <http://www.eduardosrur.com.br/intervencoes/ancora >. Acesso em: 10 ago. 2017.

507 Disponível em: <http:// www.eduardosrur.com.br/intervencoes/ancora>. Acesso em: 5 jul. 2017. 
escadaria principal do Museu Paulista. Na mesma instituição, na sala das monções, além das telas com temática monçoeira e de uma ânfora similar à da primeira maquete do Monumento às bandeiras, com águas do Tietê colhidas em Porto Feliz, temos três âncoras e um pedaço de uma "canoa das monções" ${ }^{508}$.

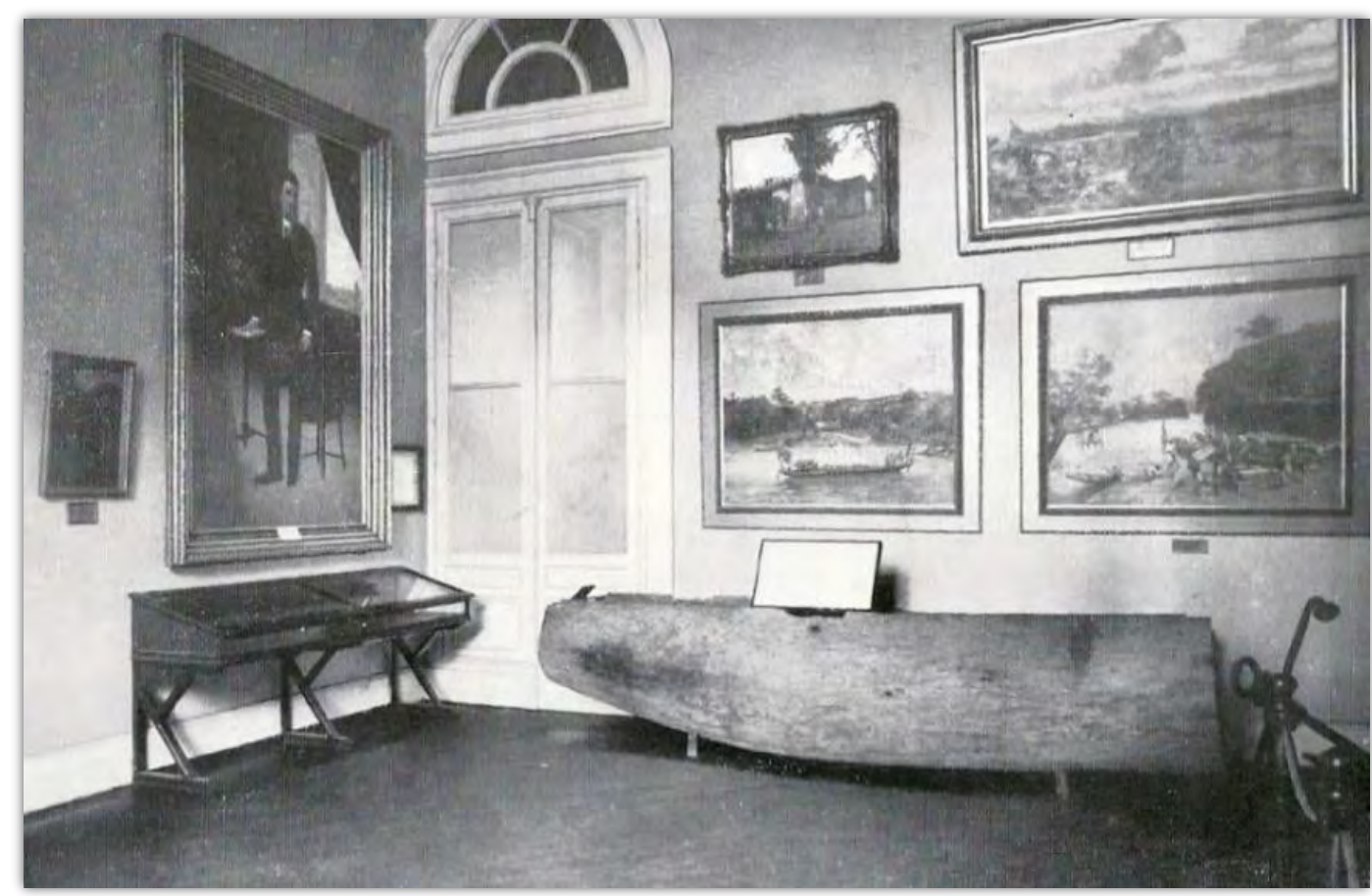

Figura 3.24 - Sala consagrada às monções, Museu Paulista, década de 1930. Fonte: Guia da sesão histórica do Museu Paulista (1937), Afonso Taunay, s/p.

O fragmento com cerca de 3,5 metros de comprimento havia sido transformado em cocho por um fazendeiro, mas seu corpo central transmitia o "arrojo" dos "intrépidos e aguerridos" bandeirantes por "confiarem a vida a tão bisonhas, toscas e mal seguras canoas" explica Eugênio Motta, então prefeito de Porto Feliz, antes de doar a embarcação, por ele descrita como uma "relíquia", ao Museu Paulista ${ }^{509}$. O outro pedaço de um "canoão" mencionado por Afonso Taunay, encontrado em 1910 nas barrancas do rio Tietê, permaneceu em Porto Feliz, atual região metropolitana de Sorocaba, atracado próximo ao local onde fora descoberto.

\footnotetext{
${ }^{508}$ Carta de Afonso Taunay a Alarico Silveira, 4 jan. 1924. APMP/FMP, pasta 121.

${ }^{509}$ Carta de Eugênio Motta a Afonso Taunay, 27 dez. 1917. APMP/FMP, pasta 104. Em carta ao proprietário da canoa, Taunay agradece pela "valiosa dádiva". Carta de Afonso Taunay a João Batista Portella, 5 dez. 1923. APMP/FMP, pasta 120 .
} 


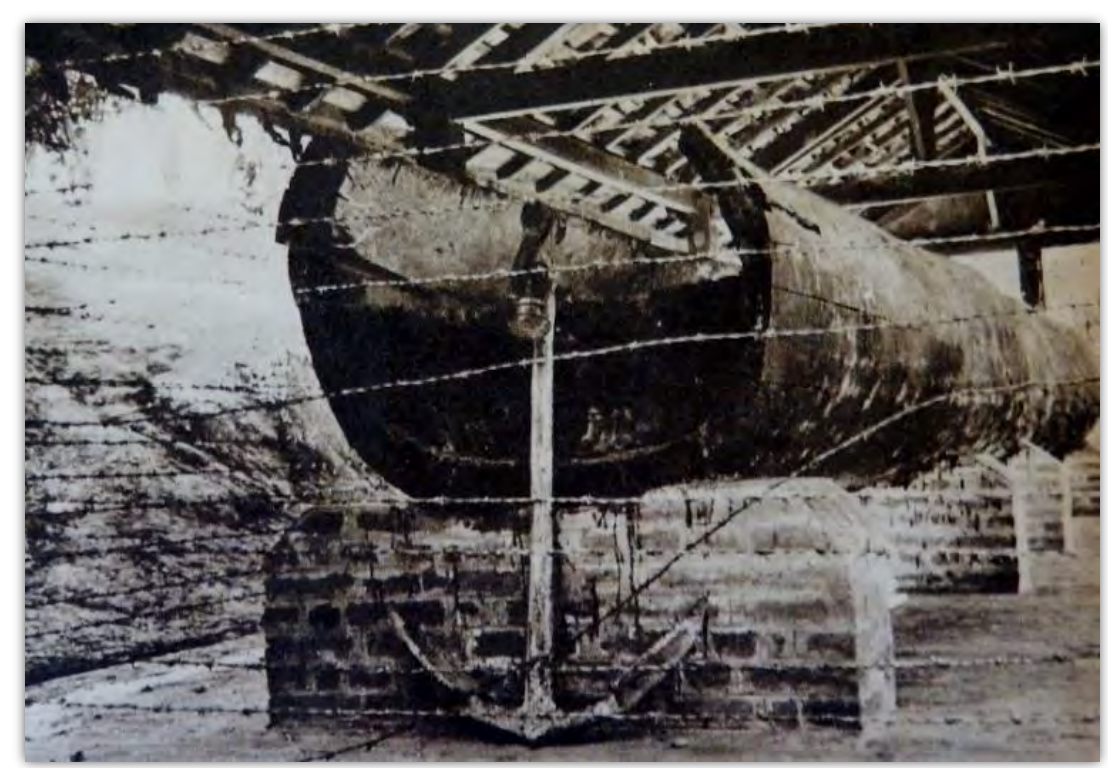

Figura 3.25 - Antiga canoa, parque das Monções, Porto Feliz, anos 1930. Fonte: S. Paulo, dez. 1936, n. 10, s/p.

Inicialmente, o fragmento foi oferecido ao Museu Paulista, mas, apesar do interesse da prefeitura em cedê-lo, as dificuldades de transporte até a cidade de São Paulo impediram a doação, devido aos limites impostos pelo peso, pelas dimensões e pelo volume do objeto. Sem uma estrada de ferro, seria impossível arcar com as despesas do deslocamento de um pedaço de canoa de quinze metros de comprimento, explica Eugênio Motta, em carta escrita em 1917, na qual relata a doação de uma âncora do período monçoeiro para o Museu Paulista. Por essa razão, um galpão foi planejado para acolher a "mal agasalhada" embarcação, protegendo-a do "rigor das intempéries", informa na mesma mensagem o prefeito de Porto Feliz ${ }^{510}$.

O abrigo do "canoão" seria construído no interior do futuro parque das Monções, cuja longa escadaria refaz o caminho do centro da cidade ao antigo porto de Araritaguaba, ligando Porto Feliz às margens do Tietê. O parque é inaugurado em abril de 1920, poucos meses antes da maquete do Monumento às bandeiras ser exposta na capital paulista, coincidindo com a abertura do ramal férreo que ligava Boituva a Porto Feliz. Depois de festejos na estação ferroviária, as comemorações seguiram rumo ao antigo porto, na "lendária Araritaguaba de onde partiam para suas arriscadas

510 Carta de Eugênio Motta a Afonso Taunay, 17 dez. 1917. APMP/FMP, pasta 104/ Carta de Eugênio Motta a Afonso Taunay, 23 jul. 1918. APMP/FMP, pasta 107. 
incursões [fluviais] pelo sertão os intrépidos bandeirantes paulistas", relata O Estado de S. Paulo ${ }^{511}$. Mencionada pela imprensa paulista, a inauguração do parque obteve destaque maior na mídia local, como nos periódicos Tribuna das Monções e O Novo Porto, embora a grande notícia do dia tivesse sido o ramal férreo ${ }^{512}$.

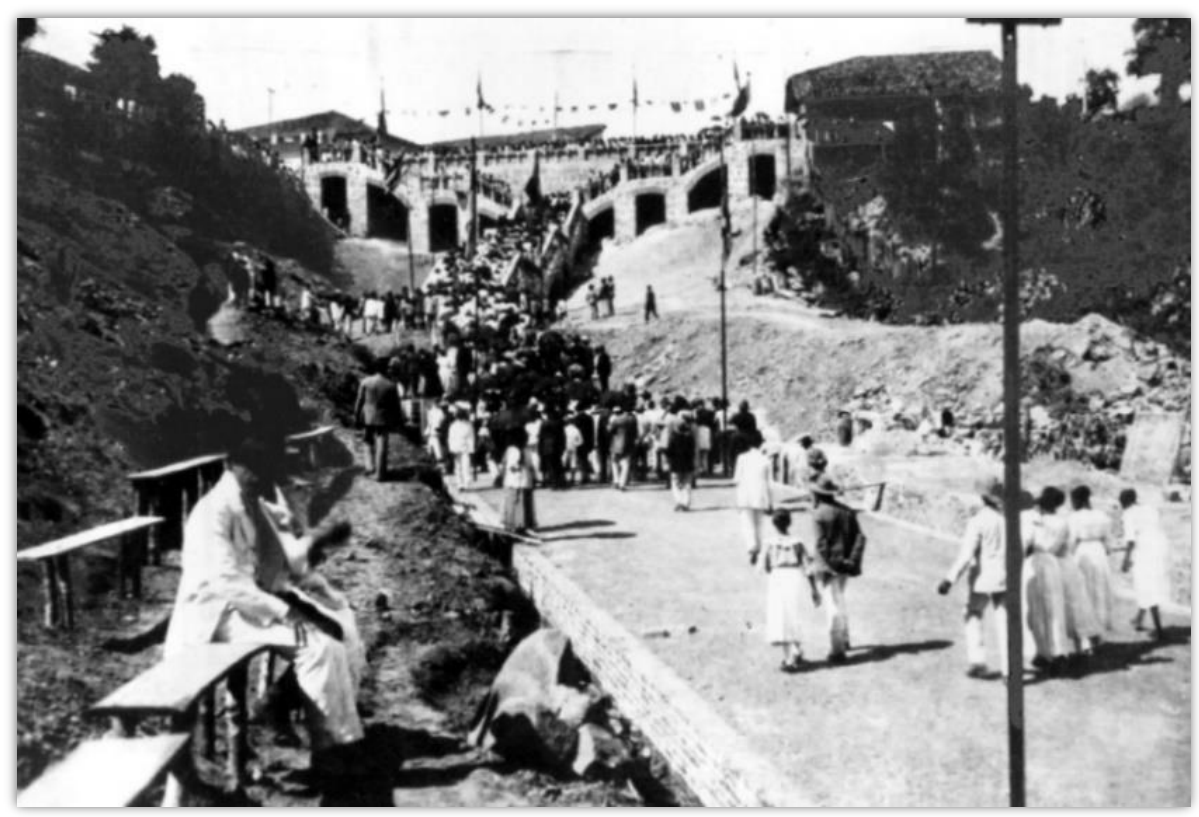

Figura 3.26 - Inauguração do parque das Monções, 1920.

Fonte: Iconografia monçoeira (2006), de Rodolfo Hessel, p. 36.

A inauguração do parque contou com a presença do governador de São Paulo, Altino Arantes, nos últimos dias de seu governo (1916-1920), do secretário da Agricultura do Estado, Cândido Motta (nascido em Porto Feliz), e de autoridades locais e convidados como Afonso Taunay, a quem coube a conferência de abertura, muito aplaudida, ainda segundo O Estado de $S$. Paulo. Intitulada A glória das monções, a palestra de Taunay foi publicada em livro no mesmo ano, exaltando essa "homenagem do presente ao passado" que "conserva o último destes grandes barcos que fizeram com que as terras de além-Paraná se conservassem brasileiras" (TAUNAY, 1926b, pp. 99-100). O galpão que serviria de abrigo para a canoa - e para uma âncora, revelando "o gênio expansionista da nossa raça”, nas palavras de Eugênio Motta ${ }^{513}$ — ficou pronto apenas três anos depois da inauguração do parque.

\footnotetext{
511 "Boituva a Porto Feliz". O Estado de S. Paulo, 28 abr. 1920, p. 6.

512 Para uma análise da inauguração do ramal férreo e do parque das Monções segundo a imprensa local, cf. Hessel (2006).

${ }^{513}$ Carta de Eugênio Motta a Afonso Taunay, 17 dez. 1917. APMP/FMP, pasta 104.
} 
Ainda que a embarcação tenha sido acolhida às margens do Tietê em 1923, sua imagem seguiu circulando parque afora, incorporada posteriormente ao brasão de armas da cidade de Porto Feliz, de acordo com outra sugestão de Afonso Taunay ${ }^{514}$.

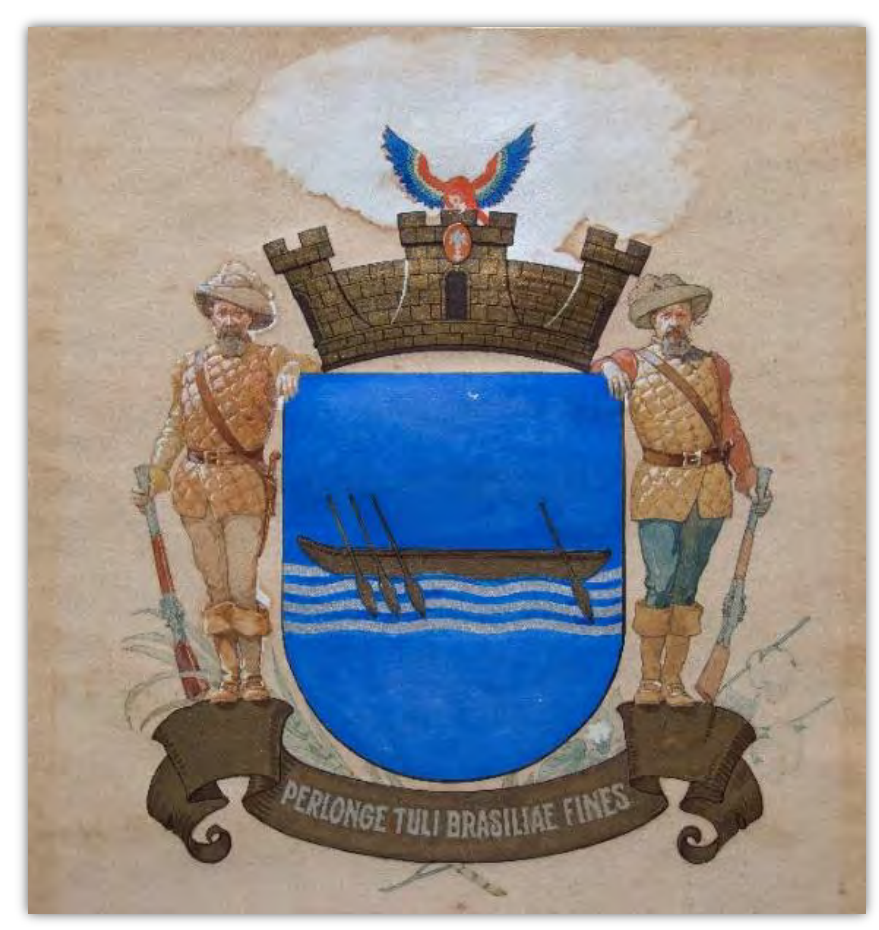

Figura 3.27 - Desenho em guache do brasão de armas da cidade de Porto Feliz, anos 1920. Fonte: Acervo do Museu Paulista da USP | Foto: Hélio Nobre/José Rosael.

$\mathrm{Na}$ imagem do brasão, que estampa ainda hoje a bandeira da cidade, veem-se duas figuras de bandeirantes praticamente idênticas, nas quais se altera apenas a cor de suas vestimentas e de seus acessórios ${ }^{515}$. Um espelhando o outro, os dois estão apoiados em um escudo, com uma canoa dourada e um rio desenhados em seu interior, sob a divisa "Perlonge tuli Brasiliae fines [Longe levei as fronteiras do Brasil]", lema igualmente sugerido por Taunay ${ }^{516}$. Acima do escudo, há uma coroa

${ }^{514}$ Em carta ao prefeito de Porto Feliz, Afonso Taunay explica: "Há cerca de uns quatro anos tive o prazer de compor um projeto para o brasão de Porto Feliz que tive a satisfação de ver honrado com a aprovação dos poderes municipais desta ilustre cidade (...). Mas não estou satisfeito com o meu projeto, penso que ele pode ser muito melhorado conservando integralmente o escudo com o canoão, a divisa, o timbre etc. Apenas desejo colocar, suportando o escudo, dois bandeirantes vestidos a caráter, o que dará um grande realce ao projeto”. Cf. carta de Afonso Taunay a Antônio Henrique Sampaio, 7 mar. 1925. APMP/FMP, pasta 123.

515 Como mencionado no primeiro capítulo, a imagem do brasão de Porto Feliz está também fixada no alto da caixa da escadaria principal do Museu Paulista, junto aos brasões de São Paulo e São Vicente que, segundo Afonso Taunay, conduziriam os brasões das mais antigas cidades do estado.

516 "A divisa é a verdade em relação às monções e à conquista”, dirá Afonso Taunay em carta ao prefeito de Porto Feliz. Cf. carta de Afonso Taunay a Antônio Henrique Sampaio, 12 jul. 1925. APMP/FMP, pasta 125. 
com uma arara, referência ao nome indígena Araritaguaba (junção do termo arara com ita, pedra, e guaba, lugar), dado ao local pelos guaianás que habitavam a região antes de serem escravizados pelos bandeirantes paulistas.

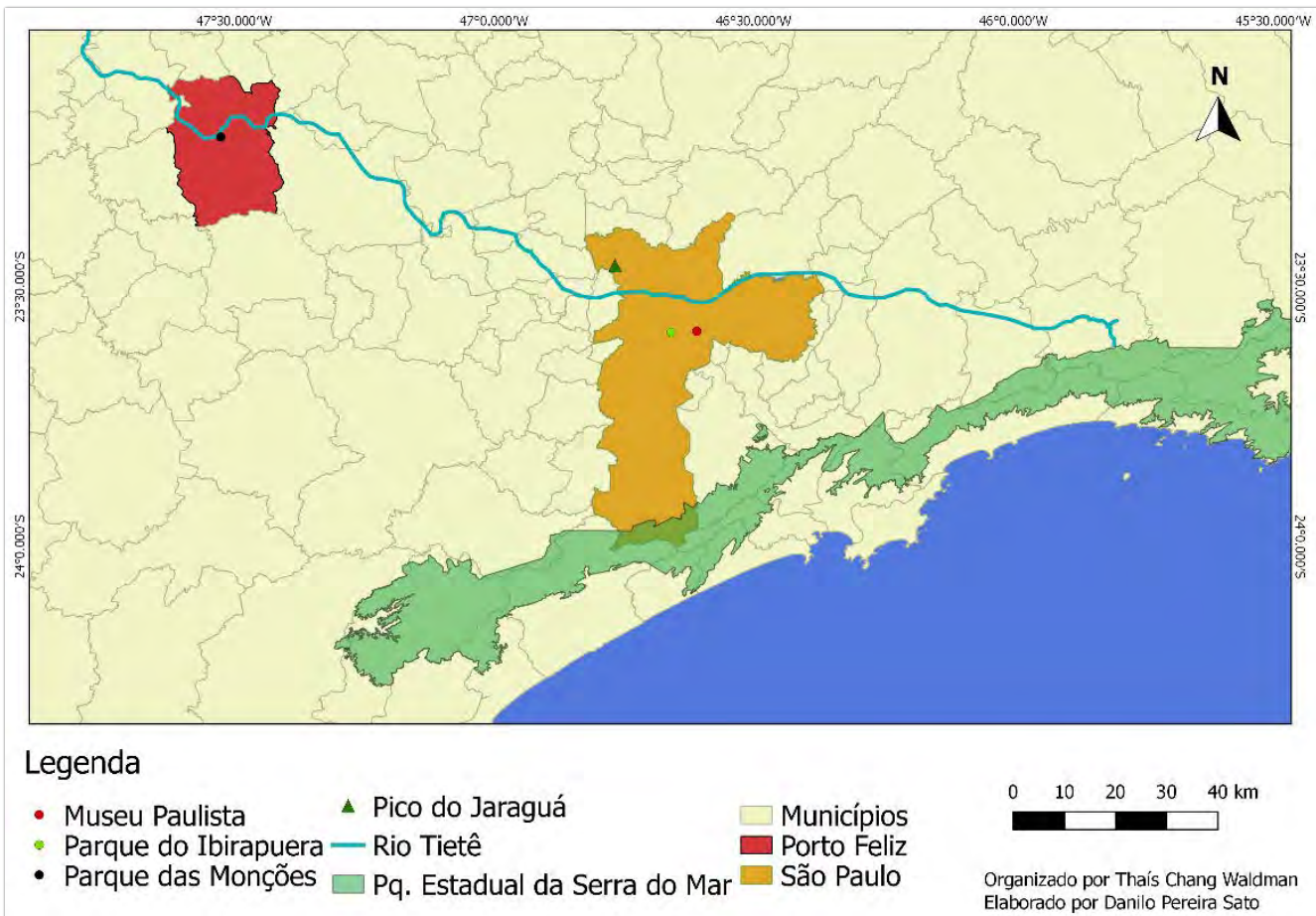

Figura 3.28 - Da Serra do Mar a Porto Feliz.

Fontes: Agência Nacional das Águas ${ }^{517}$ / Ministério do Meio Ambiente 518 / Instituto Brasileiro de Geografia e Estatística ${ }^{519}$.

Se para Afonso Taunay, as bandeiras terrestres têm entre os principais representantes bandeirantes como Fernão Dias, as fluviais enfatizam o seu meio de transporte, mais do que a algum monçoeiro específico: "Veículo essencial dos paulistas da última fase sertanizadora", eram essas canoas que traziam riquezas das minas cuiabanas, tão importantes quanto as de Minas Gerais e Goiás, com a diferença de que estas últimas utilizavam vias terrestres para chegar às suas jazidas (TAUNAY, 1927b, p. 382). Seguindo o curso do Tietê, essas grandes embarcações realizaram a “maior das viagens fluviais do universo", conclui Taunay (1953, p. 42). Não por acaso, foi seguindo uma sugestão do então diretor do Museu Paulista que Victor Brecheret incluiu uma ânfora, na

\footnotetext{
517 Disponível em: <http://hidroweb.ana.gov.br/HidroWeb.asp?TocItem=4100>. Acesso em: 10 jul. 2017.

518 Disponível em: <http://mapas.mma.gov.br/i3geo/datadownload.htm>. Acesso em: 10 jul. 2017.

519 Disponível em: < ftp://geoftp.ibge.gov.br/organizacao_do_territorio/malhas_territoriais/malhas_municipais/>. Acesso em: 10 jul. 2017.
} 
maquete de 1920, ânfora que deveria conter águas desse rio. Com a peculiaridade de nascer na Serra do Mar e correr para o interior, caberia ao Tietê o papel de orientador do movimento de expansão bandeirante. Até hoje esse caminho é divulgado turisticamente no site da prefeitura de Porto Feliz como o "roteiro dos bandeirantes" 520.

\subsubsection{Porto Feliz dos bandeirantes}

Em 1972, o parque das Monções (e a canoa que ele acolhe) é tombado pelo Condephaat ${ }^{521}$. Transformado em área de preservação depois da prefeitura municipal propor um projeto que previa a desapropriação e a demolição de uma rua tradicional em seu entorno — com "casas que foram familiares de nossos gloriosos bandeirantes que presenciaram os episódios ligados à navegação do Tietê”, nos termos do diretor do Museu Histórico e Pedagógico das Monções de Porto Feliz —, o parque passa a ser propagandeado como patrimônio bandeirista regional ${ }^{522}$. Por isso mesmo, o poder público local, que queria desapropriar e demolir a região, começa a investir no turismo histórico. $\mathrm{Na}$ época, inclusive, havia uma proposta municipal para reconhecer Porto Feliz como uma "cidade monumento", de acordo com o Plano Diretor Ambiental (2008) da cidade ${ }^{523}$.

520 O roteiro turístico dos bandeirantes engloba oito cidades paulistas ao longo de seus 180 quilômetros. Partindo de Santana do Parnaíba, ele passa pelas cidades de Pirapora do Bom Jesus, Araçariguama, Cabreúva, Itu, Salto e Porto Feliz, até chegar à cidade de Tietê. "São museus, fazendas, trilhas e caminhos dignos de serem explorados por novos desbravadores", anuncia o texto veiculado no site da prefeitura da cidade de Porto Feliz. Disponível em: $<$ http://www.portofeliz.sp.gov.br/content.php?t=content\&id=232\&idm=232>. Acesso em: 10 jun. 2017. Muitas dessas cidades também possuem monumentos públicos em homenagem aos bandeirantes.

521 O processo de tombamento informa que o parque abarcava toda a área relativa "ao embarque dos bandeirantes no Tietê, a saber: as escadarias com os canteiros de ambos os lados, o Monumento às monções, o abrigo com a parte do batelão remanescente dos tempos históricos da cidade, o paredão que deu origem ao nome antigo (Araritaguaba), a gruta de Nossa Senhora de Lourdes, o porto de embarque dos bandeirantes, bem como a velha casa do terreno fronteiro". Cf. Processo no 15559/69, Condephaat.

${ }^{522}$ Em carta ao presidente do Condephaat, Vicente Palma, diretor do Museu Histórico e Pedagógico das Monções de Porto Feliz, explica que no "quarteirão mais tradicional da cidade", que seria demolido e desapropriado pela prefeitura de Porto Feliz, “existem marcas urbanas vinculadas ao período monçoeiro”. Cf. Processo no 15559/69, Condephaat. O Museu Histórico e Pedagógico das Monções tem como sede uma construção em taipa de pilão, localizada no centro da cidade. Comprada pelo governo do estado em 1908, essa construção passa a abrigar, em 1963, o museu que, ao ser municipalizado em 1998, recebe o nome de Museu das Monções.

523 Ainda segundo o Plano Diretor Ambiental de Porto Feliz (2008), entre os bens não tombados, mas atualmente considerados pela prefeitura municipal como de interesse histórico, artístico e cultural, temos o condomínio residencial Portal dos Bandeirantes e o bairro Cidade Nova Bandeirante. O condomínio residencial Portal dos 
Cabe ressaltar que os anos 1970 foram pautados pela preservação de bens ligados à memória oficial, tanto no plano regional quanto nacional, como os bens relacionados à memória bandeirante (RODRIGUES, 1999, p. 100). Observa-se também que, entre os primeiros bens móveis tombados pelo Condephaat — órgão criado em 1968, durante um período de recrudescimento do autoritarismo do regime militar instaurado em $1964^{524}$ —, estão as obras de Benedito Calix to e de José Ferraz de Almeida Júnior, respectivamente em 1969 e 1970. Além dos trabalhos dos dois pintores, que contribuíram com a construção de narrativas visuais ligadas à temática bandeirante, em 1973 é tombada toda coleção artística do Museu Paulista e, em 1975, o próprio parque da Independência, no qual esse acervo está alocado; já nos anos 1980, temos não apenas o tombamento do Monumento às bandeiras, mas também do Mausoléu do soldado constitucionalista, da Serra do Mar e do parque do Jaraguá, para ficarmos em alguns exemplos ${ }^{525}$.

Anos antes do tombamento do parque, a Semana das Monções passa a ser divulgada pela imprensa paulista como a festa mais tradicional de Porto Feliz e um dos principais acontecimentos da região. A ideia do evento foi lançada ainda nos anos 1940, quando Sérgio Buarque de Holanda, no mesmo ano em que assume a direção do Museu Paulista, em 1946, esteve em Porto Feliz para uma tarde de autógrafos no porto da cidade, em função do lançamento de seu livro Monções $(1945)^{526}$. Mas é durante os preparativos para os festejos dos quatrocentos anos da capital paulista — quando é também publicada a coletânea Relatos monçoeiros, de Afonso Taunay ${ }^{527}$ — , que a Semana

Bandeirantes é um empreendimento imobiliário construído em 1995, cujas praças — como a Afonso Taunay, a Alcântara Machado, a Sérgio Buarque de Holanda, a Teotônio José Juzarte, a Washington Luís — e logradouros internos — como a avenida Hércules Florence e as ruas Adrien Taunay, Almeida Júnior, Langsdorff — também fazem referência a nomes ligados à temática bandeirante. Já o bairro Cidade Nova Bandeirante é um loteamento de casas populares que começou a ser construído em 1976, cujas ruas possuem nomes como Antônio Raposo Tavares, Bartolomeu Bueno, Borba Gato, Domingos Jorge Velho, Fernão Dias e Pascoal Moreira.

524 O Condephaat tem uma atuação marcada por "um profundo sentido cívico" e pelo "interesse em promover o turismo" (RODRIGUES, 1999, p. 30). Não à toa, sua criação ocorre na mesma década que à do Conselho Nacional de Turismo e da Empresa Brasileira de Turismo (Embratur).

525 Sobre o tombamento das obras de Benedito Calixto e de Almeida Júnior, da coleção artística do Museu Paulista, do parque da Independência, do Monumento às bandeiras, do Mausoléu do soldado constitucionalista, da Serra do Mar e do parque do Jaraguá, ver respectivamente os processos $\mathrm{n}^{\circ} 13996 / 69$, n $\mathrm{n}^{\circ} 17260 / 70, \mathrm{n}^{\circ}$ 00342/73 (tombamento exofficio), $n^{\circ} 08486 / 69, n^{\circ} 23074 / 84, n^{\circ} 20294 / 77, n^{\circ} 20868 / 79$ e no 20437/78, Condephaat.

526 Depois de ter publicado, em 1945, seu livro Monções, Sérgio Buarque de Holanda publica os ensaios “Os primórdios da expansão paulista no fim do século XVI e começo do século XVII" (1948) e "Índios e mamelucos na expansão paulista” (1949) que, junto a outros artigos menos extensos, são reunidos no livro Caminhos \& Fronteiras, de 1957.

${ }^{527}$ Além dos livros Relatos monçoeiros e Relatos sertanistas, de Afonso Taunay, a coleção Biblioteca Histórica Paulista, lançada pela Livraria Martins Editora em comemoração ao IV Centenário, (re)lançou diversos livros sobre a São Paulo colonial. Entre eles: Nobiliarquia paulistana histórica e genealógica, de Pedro Taques; Memórias para a história da capitania de São Vicente, de Frei Gaspar; Segunda viagem a São Paulo e quadro histórico da província de São Paulo, de Auguste 
das Monções, instituída em 1952, ganha impulso ${ }^{528}$. Descrita na ocasião pelo jornal O Estado de $S$. Paulo como uma "contribuição do histórico município de São Paulo ao IV Centenário", a Semana das Monções foi incluída na programação oficial dos festejos e contou, em 1954, com a presença do presidente da comissão do IV Centenário, Guilherme de Almeida ${ }^{529}$.

Lembremos que durante os preparativos para as festas centenárias o texto de Auguste de Saint-Hilaire, sugerido por Afonso Taunay, não foi gravado na obra de Victor Brecheret; mas os versos de Guilherme de Almeida estão até hoje inscritos no Monumento às bandeiras. Além disso, enquanto a cidade de Porto Feliz era aclamada na mesma época pelo Correio Paulistano como uma "relíquia histórica" ${ }^{530}$, na capital paulista Guilherme de Almeida dá início ao processo de conversão da Casa do Bandeirante em museu, transformando o antigo imóvel construído em taipa de pilão no século XVIII, no bairro do Butantã, em uma espécie de "relíquia do tempo dos bandeirantes", nos termos do jornal $A$ Gazeta ${ }^{531}$. Por meio de um acervo induzido, a obra realizada sob a orientação de Luís Saia, diretor do Instituto do Patrimônio Histórico e Artístico Nacional (Iphan) de São

de Saint-Hilaire; Informações sobre as Minas de São Paulo, de Pedro Taques; Apontamentos históricos, geográficos, biográficos, estatísticos e noticiosos da província de São Paulo, de Azevedo Marques; Peregrinação pela provincia de S. Paulo (1860-1861), de Augusto Emílio Zaluar; Viagem à província de São Paulo, de Auguste de Saint-Hilaire; e Memória sobre a viagem do porto de Santos à cidade de Cuiabá, de Luís D’Alincourt.

528 A Semana das Monções foi instituída por meio da lei municipal no 312, de 30 de junho de 1952, que estabelece uma semana anual comemorativa com início em 7 de outubro e encerramento no dia 13 do mesmo mês, no Dia das Monções, feriado municipal instituído pela mesma lei para comemorar a emancipação político-administrativa de Porto Feliz, cf. AHSBH.

529 “Abertura dos festejos da Semana das Monções”. O Estado de S. Paulo, 8 out. 1954, p. 11. Guilherme de Almeida assumiu a presidência da comissão do IV Centenário em março de 1954, substituindo o primeiro presidente, o ítalobrasileiro Francisco Matarazzo Sobrinho, mais conhecido como Ciccillo, cuja gestão estava mais focada no progresso industrial e material da cidade. Em entrevista, Ciccillo afirma não ter investido na evocação do bandeirante porque seu interesse estava em projetar o futuro e não o passado, cf. MIS, cd 21.A-A-0441. No entanto, explica Lofego (2004), em 1951 foi regulamentado por decreto que caberia à comissão municipal dos festejos comemorativos do IV Centenário promover um estudo relativo à história de São Paulo do século XVI até a atualidade. Mas as articulações travadas para as comemorações de 1954 indicam muitos atritos, visíveis por exemplo na proposta de um contrato com a Academia Brasileira de Letras (ABL) para a realização de um curso sobre a história paulista, sob a fiscalização da comissão do IV Centenário, quando o então presidente da ABL teria afirmado: "Escandaloso é pretender um cavaleiro de instrução rudimentar, e que mal se expressa na língua portuguesa, FISCALIZAR um curso promovido e dado por acadêmicos tidos e havidos como centro mais alto e requisitado das letras paulistas (...). [Ciccillo] não tem sequer preparo que lhe permita, nas esferas superiores da inteligência e do saber, o desempenho do elevado posto em que se meteram, minguando nas raízes de quatrocentos anos que o pudessem suster e prestigiar nesta gloriosa terra das bandeiras", cf. "A Academia Paulista de Letras e a Comissão do IV Centenário", A Gaz̧eta, 4 fev. 1953, p. 18.

530 "Porto Feliz: relíquia histórica". Correio Paulistano, 5 abr. 1953, p. 11.

531 “Testemunha arquitetônica dum passado grandioso - em plena zona residencial de São Paulo uma relíquia do tempo dos bandeirantes". A Gazeta, 1 jan. 1954. 
Paulo, buscou eliminar tudo aquilo que não correspondesse a um modelo arquitetônico colonial idealizado como luso-brasileiro ${ }^{532}$.

Além de prestigiar, em Porto Feliz, a Semana das Monções, a comissão presidida por Guilherme de Almeida planejou o transporte da antiga embarcação exposta no parque das Monções até o parque do Ibirapuera. "Da capital a Porto Feliz são 125 quilômetros totalmente por asfalto pela via Anhanguera", anunciaria na década seguinte o jornal O Estado de S. Paulo ${ }^{533}$. Nos anos 1910 o "canoão" não pode viajar devido à dificuldade de transporte; passadas quatro décadas, um ano após a inauguração da obra de Victor Brecheret, a enorme canoa é transportada até a capital para participar da exposição sobre a história de São Paulo do IV Centenário, organizada por Jaime Cortesão (1884-1960), com a consultoria técnica de Afonso Taunay e Sérgio Buarque de Holanda. No roteiro da exposição, consta que na seção destinada a São Paulo e à formação dos limites do Brasil haveria um "batelão das monções" ao lado de um "painel com lendas relativas ao Tietê" ${ }^{534}$.

Ainda que a primeira pista pavimentada da via Anhanguera tenha sido inaugurada no final dos anos 1940, o retorno do antigo batelão não parece ter sido tranquilo. O jornal O Estado de $S$. Paulo lamenta, nos anos 1960, o sumiço de dois pedaços da enorme embarcação durante as festas centenárias. "A mágoa de Porto Feliz", diz o subtítulo da matéria, ao lembrar que o governo de

\footnotetext{
532 A ideia era criar um cenário, explica Guilherme de Almeida, uma "casa viva, mobiliada e guarnecida por objetos de uso doméstico, tal qual como era uma casa de bandeirante", cf. Fundo do IV Centenário, processo no 3981/54, caixa 213, AHMWL. A Casa do Bandeirante faz parte de um conjunto de edificações protegidas devido a um esforço voltado para a construção de uma memória nacional e uma identidade paulista que ganharam visibilidade com a criação do atual Instituto do Patrimônio Histórico e Artístico Nacional (Iphan), em 1937. Frequentemente, o terreno onde se localiza o imóvel é confundido com uma propriedade vizinha, a fazenda Ybiatá, que teria pertencido a Afonso Sardinha, um dos primeiros bandeirantes da capitania de São Vicente. A Ybiatá, porém, foi construída um século antes, no local onde hoje estão instalados o Instituto Butantã e a Universidade de São Paulo. Já a atual Casa do Bandeirante parece ter sido propriedade de Antônio Corrêa de Morais e, após mudar algumas vezes de proprietário, foi doada em 1944 pela Companhia City à prefeitura. Hoje ela faz parte do Museu da Cidade de São Paulo, junto a outros imóveis de interesse histórico e arquitetônico distribuídos pela mal ha urbana do município. A Casa do Bandeirante foi tombada pelo Condephaat nos anos 1980, mesma década do tombamento do Monumento às bandeiras, ver processo no 22262/82, Condephaat. Sobre a Casa do Bandeirante, cf. Saia (1955), Mayumi (2008), Santos (2016) e Weimer (2015). Sobre as demais casas chamadas bandeiristas, catalogadas e tombadas no estado de São Paulo, cf. também Katinsky (1976), Saia (1972), Lemos (1999), Zanettini (2005) e Duarte (2016).

533 "Porto Feliz repete as monções dia 8". O Estado de S. Paulo, 29 set. 1967, p. 38.

534 Cf. Fundo do IV Centenário, processo no 4046/54, caixa 213, AHMWL. Jaime Cortesão, também nos anos 1950, irá publicar livros como A fundação de São Paulo: capital geográfica do Brasil (1955) e Raposo Tavares e a formação territorial do Brasil (1958), além de organizar e escrever a introdução dos Manuscritos da coleção de Angelis, entre eles Jesuitas e bandeirantes no Guairá (1594-1640), Jesuitas e bandeirantes no Itatim (1596-1760) e Jesuitas e bandeirantes no Paraguai (1703-1751).
} 
São Paulo serrou as duas pontas da canoa, devolvendo apenas o restante ${ }^{535}$. O fragmento da canoa se fragmentara ainda mais. Sua exposição no parque do Ibirapuera implicou perdas e, passados dez anos, ninguém sabia explicar onde estavam as duas peças serradas, enquanto a parte restante voltou ao seu abrigo, às margens do Tietê, e em seu interior foram ainda largadas vassouras velhas, latas de lixos, enxadas e baldes, denuncia a mesma matéria.

Mas a canoa teve seus momentos de reconhecimento e celebridade durante as festas centenárias, evocando o passado e ao mesmo tempo o futuro, assim como o Monumento às bandeiras, conforme sugere a inclusão do parque das Monções no álbum de figurinhas IV Centenário, publicado nos anos 1950 pela editora Aquarela.

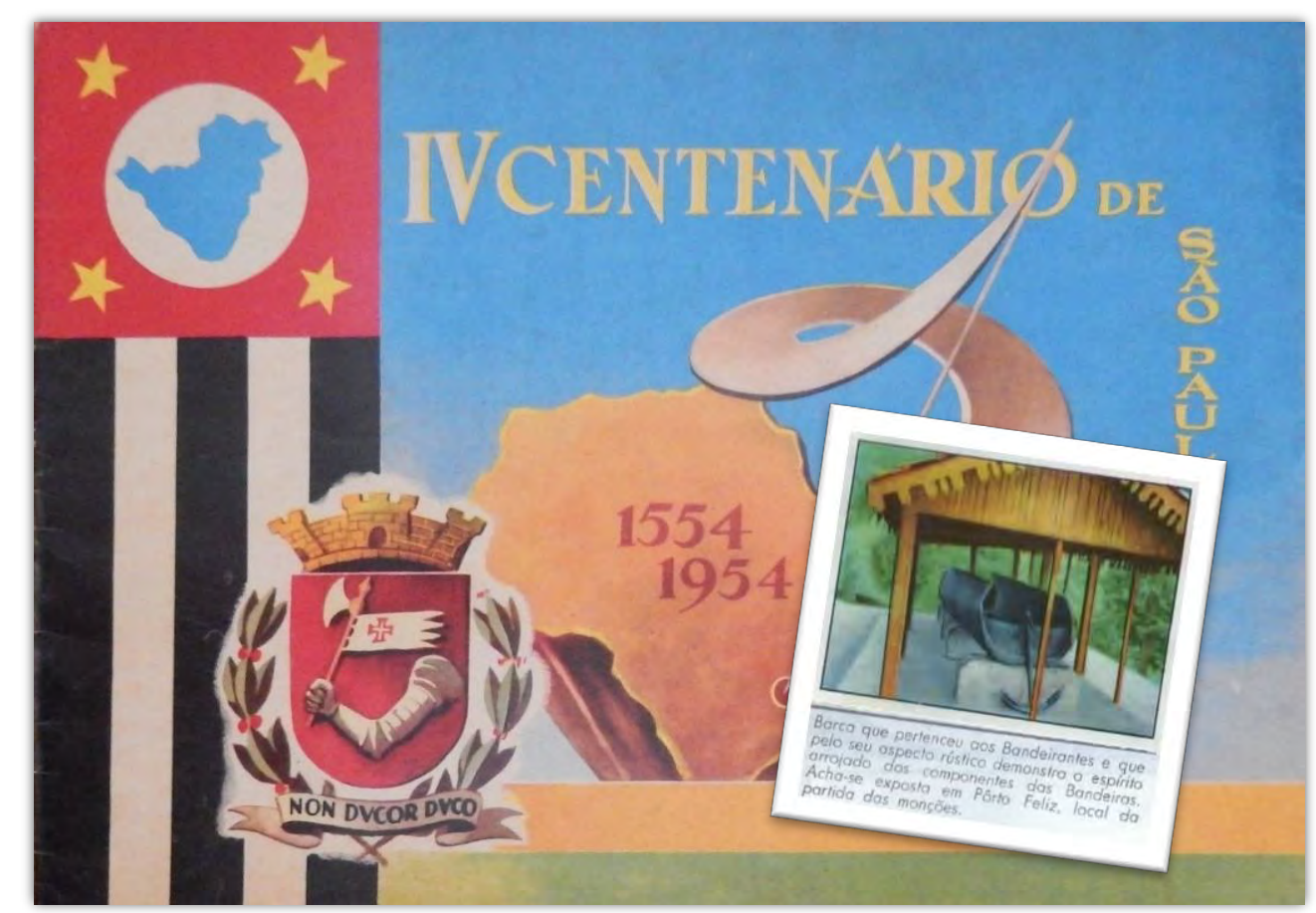

Figura 3.29 - Álbum de figurinhas IV Centenário de São Paulo (1954).

Fonte: Acervo pessoal | Foto: Thaís Waldman.

Impressas na avenida Cásper Líbero, no centro da capital paulista, uma figurinha com a imagem da canoa e outra de seu conterrâneo Monumento às monções (também chamado de Monumento ao bandeirante) ganham evidência no álbum, que tem como um de seus maiores destaques não apenas uma figurinha, maior que as demais em tamanho, com uma fotografia do Monumento às bandeiras, mas também uma capa ilustrada com uma imagem da "aspiral" saindo de um mapa do estado de 
São Paulo. Desde os anos 1920, a antiga embarcação convive em Porto Feliz com o Monumento às monções, inaugurado junto ao parque, algumas semanas antes da exposição da maquete do Monumento às bandeiras.

Idealizado por Afonso Taunay e realizado por Amadeo Zani — no mesmo período em que o escultor italiano recebe diversas encomendas para a escadaria do edifício do Ipiranga —, o Monumento às monções é uma das primeiras obras inauguradas no estado de São Paulo durante os preparativos para o Centenário da Independência do Brasil. Em sua parte superior, o monumento possui uma coluna rostral, espécie de edificação que costumava ser erguida para comemorar as vitórias militares navais romanas. Na ponta dessa coluna, feita em mármore, tal como uma esfera armilar (um importante elemento do brasão de armas português, utilizado nas bandeiras de várias colônias de Portugal, incluindo o Brasil), há um instrumento de astronomia utilizado em navegações, sugerindo o movimento dos astros. Já a base da obra é composta por um grande semicírculo construído em granito entalhado, no qual se encontram, em um painel de alvenaria, as reproduções em baixo-relevo de três obras que também ganharão destaque no Museu Paulista, como visto no primeiro capítulo: a tela A partida da monção (1894), de Almeida Júnior; e os desenhos Partida de uma expedição mercantil de Porto Felizpara Cuiabá (1826), realizado por Hércules Florence, e A partida da expedição Langsdorff, no rio Tietê (1826), de Aimé-Adrien Taunay.

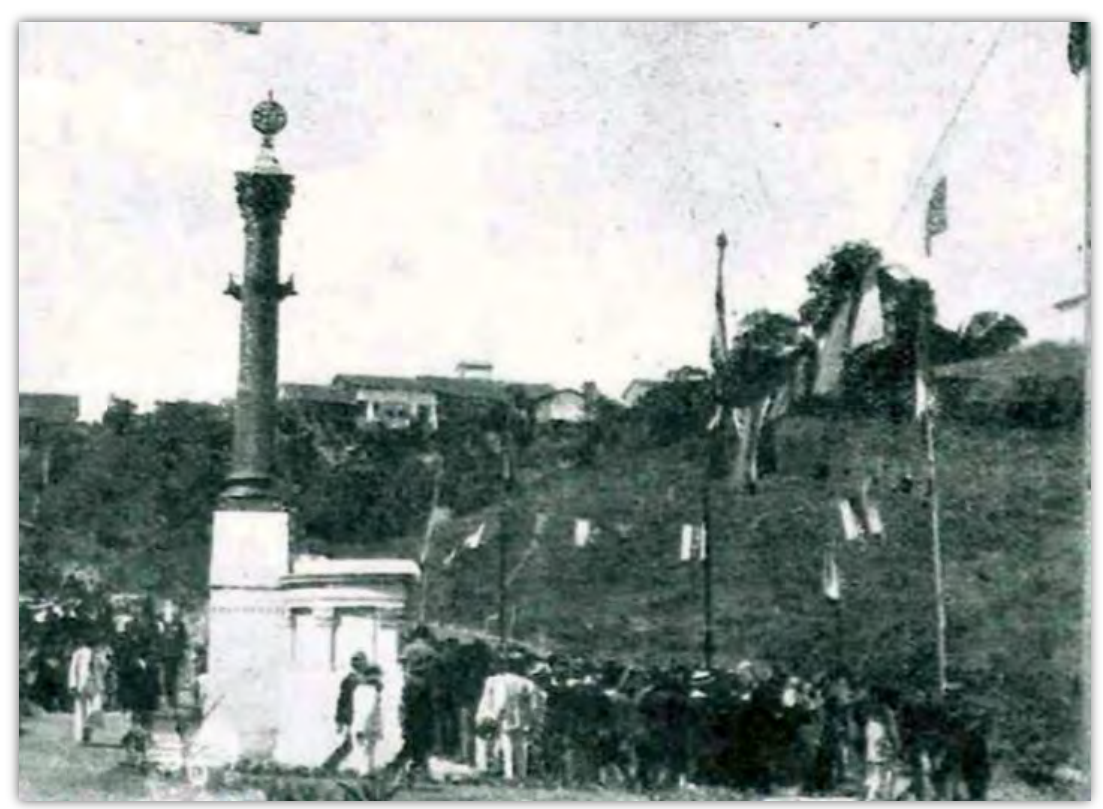

Figura 3.30 - Inauguração do Monumento às monções, parque das Monções, 1920. Fonte: Iconografia moncoeira (2006), de Rodolfo Hessel, p. 40. 
Em 1961, uma importante novidade é incorporada à Semana das Monções: a "partida simbólica de uma monção", interpretada pelos próprios porto-felicenses "caracterizados com trajes da época dos bandeirantes", anuncia O Estado de S. Paulo ${ }^{536}$. Tradicionalmente, o evento teatral ocorria dentro do parque das Monções, às margens do Tietê, perto da antiga canoa, mas hoje em dia costuma ser realizado na praça Matriz, como ocorreu em 2016, quando estive lá presente ${ }^{537}$.
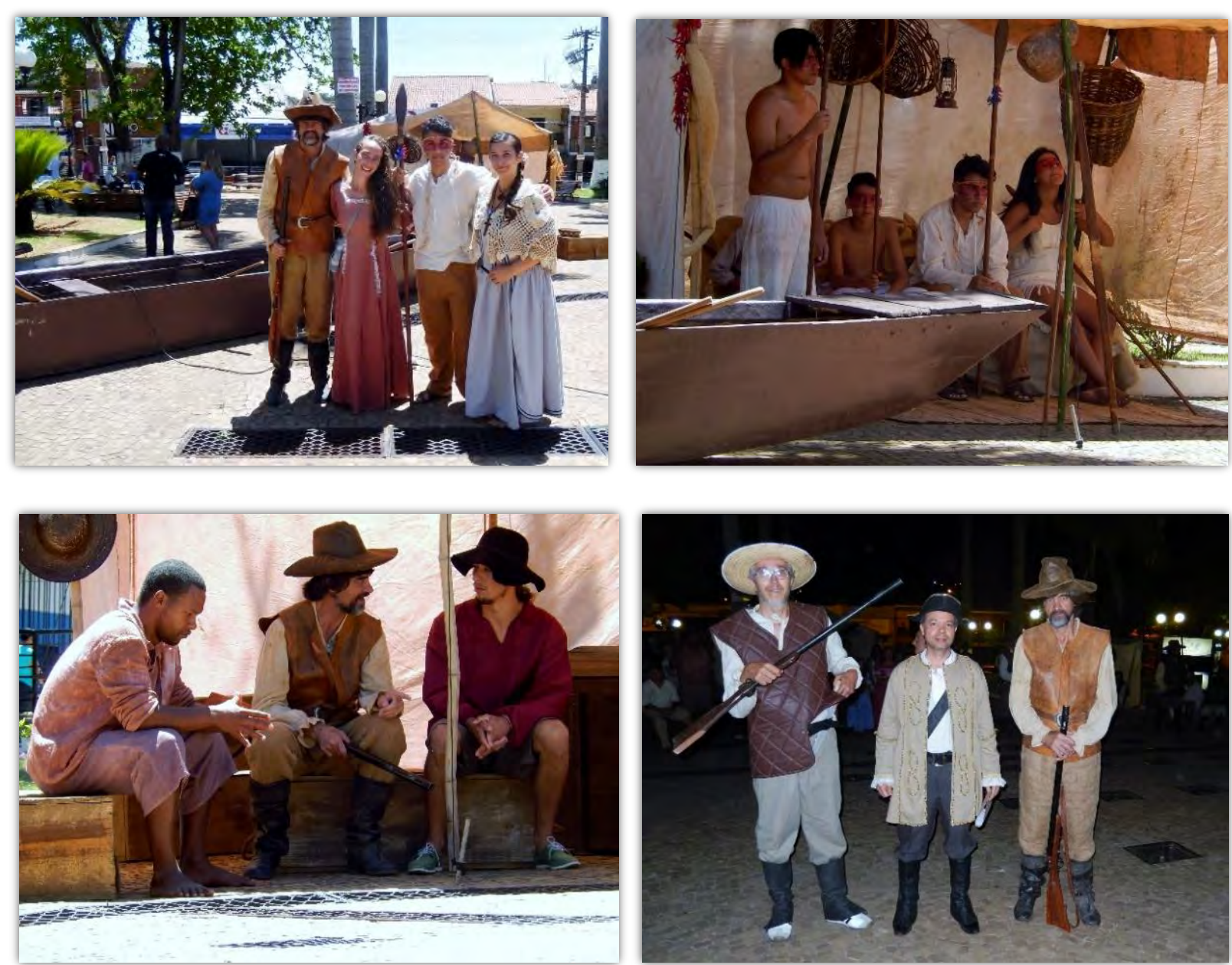

Figura 3.31 - 61 ${ }^{\mathrm{a}}$ Semana das Monções, praça Matriz, Porto Feliz, 2016.

Fonte: Acervo pessoal | Foto: Thaís Waldman.

536 "Partida simbólica de bandeirantes hoje em Porto Feliz". O Estado de S. Paulo, 10 out. 1961, p. 27. O próprio hino de Porto Feliz, elaborado especialmente por ocasião da primeira Semana das Monções, já exaltava a "terra das monções” e "sua gente varonill, "a conquista dos mais brutos e ínvios sertões”, seus "valentes heróis” e "a grandeza do Brasil”.

537 Ao que parece, falta o auto de vistoria do Corpo de Bombeiros para a liberação do parque das Monções para as encenações; em 2016, quando visitei a cidade, alguns avisos no próprio parque informavam também que havia uma infestação de carrapatos-estrela no local, por conta das capivaras. 
No final dos anos 1960, O Estado de S. Paulo descreve uma dessas partidas, quando uma canoa de dezoito metros de comprimento é empurrada pelas ruas, saindo do centro até chegar às margens do Tietê: "A nossa missão é fazer com que o povo admire cada vez mais os nossos valores positivos, sinta a importância dos bandeirantes", explica o professor de um colégio estadual da cidade ${ }^{538}$. De acordo com o site da prefeitura local, trata-se de um evento no qual "hábitos, indumentárias e meios de transporte da época são reconstituídos com total fidelidade pelos próprios moradores" 539 .

Há mais de cinquenta anos as encenações se tornaram um dos pontos culminantes da Semana das Monções (que até então se restringia, principalmente, à promoção de conferências e festas populares encerradas com um desfile de barcos), embora atualmente a cidade receba um número bem reduzido de turistas ${ }^{540}$. Mas se hoje são poucos os turistas em Porto Feliz, uma matéria publicada na revista O Cruæeiro informa que, em 1971, a cidade com cerca de 24 mil moradores recebeu aproximadamente 3 mil visitantes durante a Semana das Monções, evento que contou com mais de 250 figurantes. À frente da monção, rumo ao Tietê, o governador da capitania de São Paulo — “majestoso, passo firme, blusa de couro, chapéu de pluma, bacamarte ao ombro" - é seguido por bandeirantes, fidalgos, carregadores, remadores, mucamas e escravos (negros e indígenas). A reportagem o descreve como um "personagem fugido de um livro de história" que "parece desconhecer o que ocorre à sua volta: sons de bandas, bexigas coloridas, roupas domingueiras, casaizinhos sorridentes". "A festa é do povo", diz um dos subtítulos da mesma matéria; comerciantes, advogados, professores, lavradores, crianças, todos participam ${ }^{541}$.

\footnotetext{
538 "Monções têm cururu e iê-iê-iê". O Estado de S. Paulo, 11 out. 1968, p. 16. Também nos anos 1960, os bandeirantes e as monções são comentados Brasil afora, como no livro editado por Richard Morde quando professor em Yale, The bandeirantes: the historical role of the brazians pathfinders (1965), que apresenta um texto introdutório sobre a importância de se conhecer nos Estados Unidos os "pioneiros" da América portuguesa, tão semelhantes de certo modo aos da América do Norte. Morse também traduz as Monções de Sérgio Buarque de Holanda, além de textos como os de Afonso Taunay, Teodoro Sampaio e Alcântara Machado, cf. Castro (2013).

${ }^{539}$ Disponível em: <http://www.portofeliz.sp.gov.br/content.php?t=content\&id=225\&idm=220 > Acesso em: 25 jul. 2017.

540 Observação realizada pela autora em viagem a Porto Feliz durante a 61 ${ }^{\text {a }}$ Semana das Monções, em 2016. Cabe notar que um dos poucos hotéis da cidade é o hotel dos Bandeirantes, próximo à rua dos Bandeirantes, à imobiliária Monções, à pizzaria Monções, à Faculdade Porto das Monções, ao Arquivo Municipal Sérgio Buarque de Holanda e ao Museu das Monções, o que indica que a despeito do baixo número de turistas, a presença bandeirante ainda é forte na cidade, e não somente durante as comemorações da Semana das Monções.
}

541 “O Porto Feliz dos Bandeirantes”. O Cruzeiro, 22 nov. 1972, p. 78. 
As canoas já estavam à espera, descreve a mesma reportagem, e "trajados como mandava o figurino da época", os remeiros se preparam, enquanto indígenas, negros e bandeirantes se apressam para a viagem e lotam as embarcações. Uma das porto-felicenses que permaneceram às margens do Tietê agitando os braços em sinal de adeus foi Edna Fátima Righetto, ao interpretar a esposa de um bandeirante. Candidata a vereadora pelo Movimento Democrático Brasileiro (MDB), desde criança ela participa do evento teatral; mas se Edna se lembra com orgulho do primeiro vestido que usou na encenação - "todinho vermelho com rendas brancas", quando interpretou, aos nove anos de idade, a filha de um bandeirante —, os "personagens fugidos de livros de história" não agradaram a todos ${ }^{542}$.

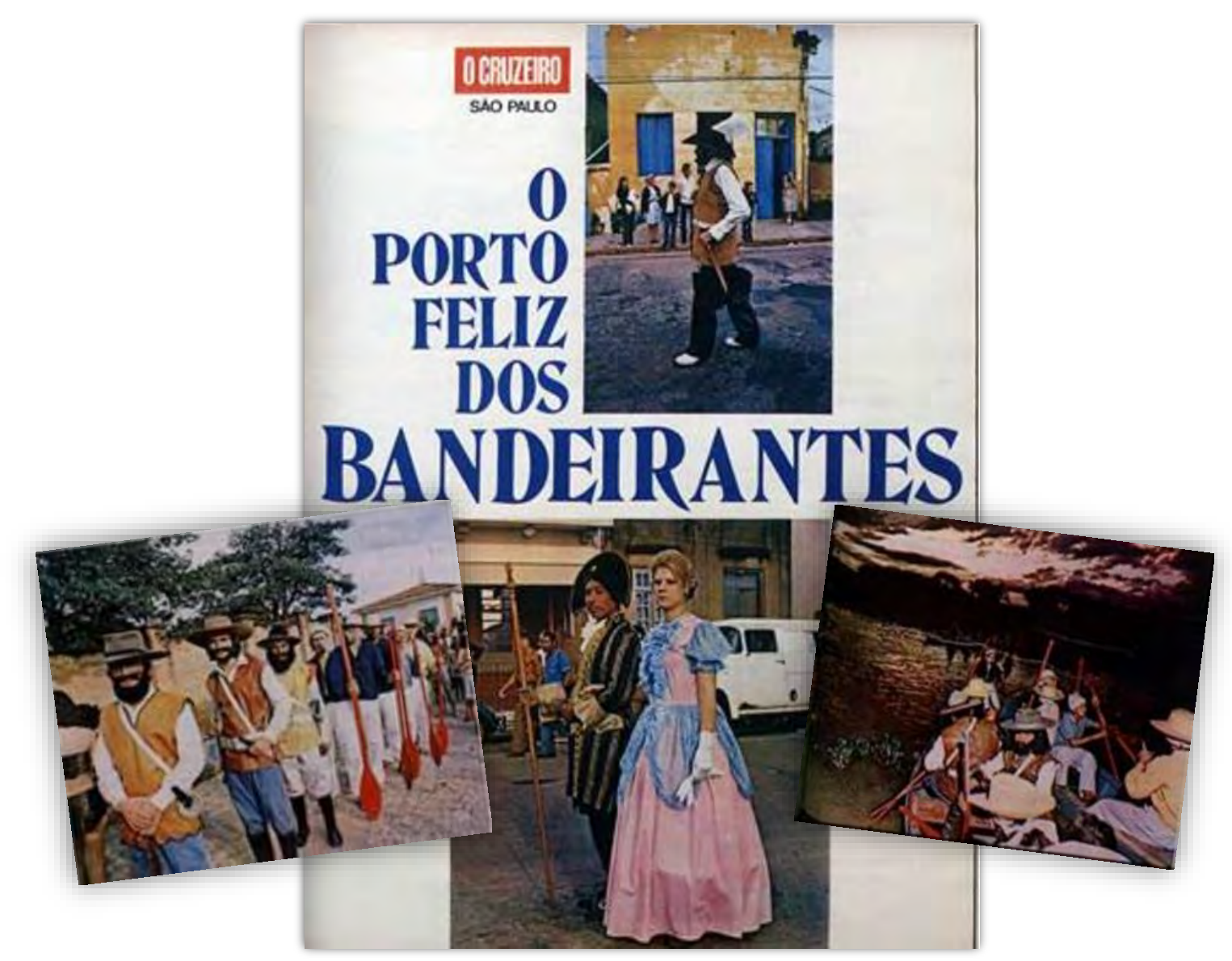

Figura 3.32 - A Semana das Monções na revista $\boldsymbol{O}$ Cruzeiro.

Fonte: O Cruzeiro, 22 nov. 1972.

${ }^{542}$ Ibidem, p. 77. 
Ainda que a festa fosse "do povo" e o próprio portofelicense vestido como um fidalgo na imagem central abaixo não fosse branco, a distribuição dos papéis não era tranquila, muitos negros, por exemplo, não queriam participar da Semana das Monções porque teriam que interpretar escravos. "Ninguém quer ser escravo", denuncia o título de outra reportagem, publicada nos anos 1980 no Jornal de Porto Feliz. ${ }^{43}$. Lembremos que no mesmo dia, mês e ano em que a Semana das Monções é oficializada por meio de uma lei municipal, outra lei irá proibir na cidade a congada, o batuque e "outros divertimentos congêneres" ${ }^{544}$. Também nos anos 1950, a comissão do IV Centenário rejeitará diversas vezes a proposta de se erguer na capital paulista a escultura Mãe Preta, vista no capítulo anterior ${ }^{545}$.

O número reduzido de intérpretes que aceitavam papéis na ala dos escravos parece até mesmo ter levado pessoas brancas a se pintarem de preto durante algumas procissões. Segundo o historiador Carlos Cavalheiro, no acervo do Museu das Monções, há anos fechado para reforma, existe uma fotografia que retrata nitidamente "uma pessoa pintada de preto representando um trabalhador escravizado na moagem de cana-de-açúcar" ${ }^{\text {"546 }}$. Cavalheiro indaga qual seria o papel do negro, do índio, do mestiço e do branco pobre durante as monções e constata que, nas festas, "a impressão que se tem é a de que seria possível contar a história das monções sem nos referirmos a esses personagens" ${ }^{\prime 547}$.

Em matéria publicada em 2013 no periódico Tribuna das Monções, Carlos Cavalheiro relata ainda que em 2005 o espetáculo teatral da Semana das Monções apresentou escravos negros presos a correntes "em atitude de franco desafio aos monçoeiros brancos (ou mamelucos, como deveriam ser muitos deles)" ${ }^{548}$. No ano seguinte, em 2014, o diretor Emílio Santana, então responsável pelas encenações da Semana das Monções, explica em uma reportagem publicada na revista Terraço que "viver é rasgar-se e remendar-se". Santana declara que, cansado de ouvir dos próprios artistas que "não aguentavam mais ser algemados e torturados", resolveu "desacorrentar

\footnotetext{
543 "Ninguém quer ser escravo". Jornal de Porto Feliz, 10-16 out. 1981, p. 6.

${ }^{544}$ Lei no 315 , de 30 de junho de 1952, cf. AHSBH.

545 A Mãe Preta só integrará as comemorações centenárias depois da divulgação de um abaixo-assinado a favor da obra, ver Lofego (2004).

546 “O imaginário do negro na Semana das Monções”. Tribuna das Monções, 6 abr. 2013, p. 11.

547 “O imaginário do negro na Semana das Monções”. Tribuna das Monções, 6 abr. 2013, p. 11.

548 Ibidem, p. 11. Em 2016, Carlos Cavalheiro publicou uma coletânea com esse e outros artigos, alguns inéditos, em um livro intitulado O negro em Porto Feliz:
} 
o negro", ao anunciar um espetáculo "sem aquele grande número de bandeirantes barbudos dando tiros" ${ }^{\prime 49}$.

\subsection{Tinha que acontecer}

"É preciso analisar a história e contar outra vez" (Flávio Cerqueira, por ocasião da exposição de sua obra Tinha que acontecer, em 2017)

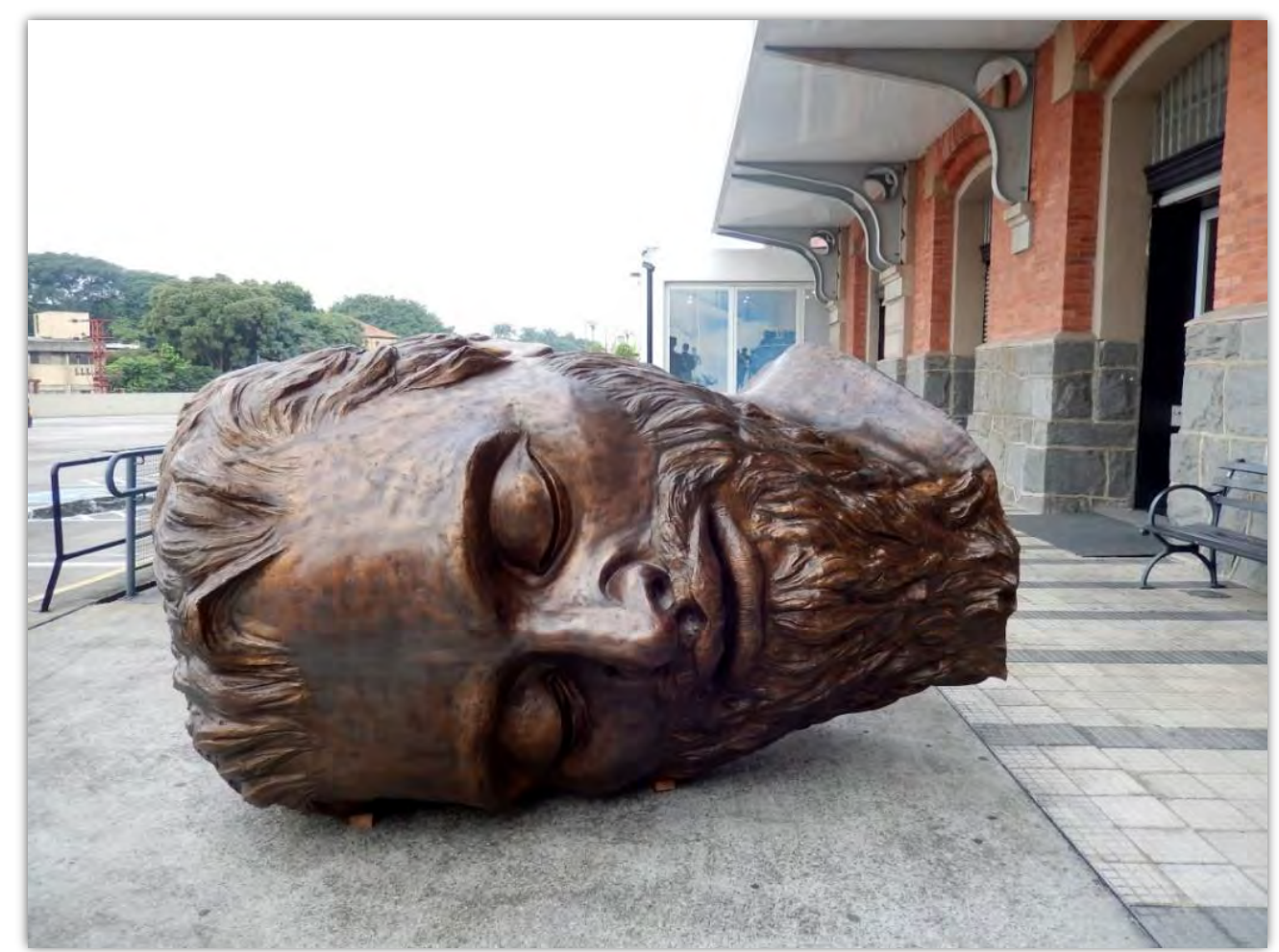

Figura 3.33 - Tinha que acontecer, de Flávio Cerqueira, Estação Pinacoteca, 2017. Fonte: Acervo pessoal | Foto: Thaís Waldman. 
Retornemos à cidade de São Paulo, ao antigo prédio do Departamento Estadual de Ordem Política e Social (Deops), atual Estação Pinacoteca (Pina Estação), no largo General Osório, centro da capital. Em 2017, durante a mostra "Metrópole: experiência paulistana", um artista negro lá expôs a escultura de um bandeirante decepado, uma cabeça em bronze de oitocentos quilos e 2,5 metros de diâmetro caída ao chão, chamada Tinha que acontecer (cabeça de bandeirante) ${ }^{550}$. Ao contar a história outra vez, o escultor paulista Flávio Cerqueira (1983- ), de acordo com o Jornal da USP, "decapitou os bandeirantes do corpo da história e tombou uma das cabeças entre os paulistanos" 551. Com os cabelos cacheados, as barbas longas e o nariz afinado (tal qual a maioria dos bandeirantes convencionalmente retratados na capital paulista, ressalta Cerqueira), a figura do anti-herói moldada em bronze (material resistente marcado por uma "carga de significados históricos", nos termos do artista) é disposta degolada na entrada posterior do museu, dispensando os bandeirantes da história da cidade, do estado e do país ${ }^{552}$.

Um ano antes, Tinha que acontecer (cabeça de bandeirante) havia sido exposta na mostra individual "Se precisar, conto outra vez”, na Casa Triângulo, região dos Jardins, decretando já então sua morte (anunciada desde os anos 1960 com a inauguração de Borba Gato, de Júlio Guerra) como tema para a produção escultórica monumental da capital ${ }^{553}$. Também na ocasião a obra foi disposta a céu aberto, caída ao chão, apontando o esgotamento de um modelo de leitura laudatório dos bandeirantes. Na calçada em frente da galeria, deitada de lado, diante de um estabelecimento de ensino, ela chamava a atenção não apenas pelas grandes dimensões da cabeça moldada com 3,5 toneladas de barro, e/ou pelo fato de ela estar decapitada, mas também por se tratar de uma escultura oca: as crianças que estudavam na escola de educação infantil do Club Athletico Paulistano, localizada em frente à Casa Triângulo, corriam nos intervalos das aulas para dentro da imensa obra, ocupando seu interior, relata um colunista carioca ${ }^{554}$.

\footnotetext{
550 Sobre a exposição "Metrópole: experiência paulistana”, cf. Chiarelli \& Bispo (2017).

${ }^{551}$ Disponível em: < http://jornal.usp.br/cultura/mostra-apresenta-os-sentidos-do-viver-em-sampa/> Acesso em: 1 out. 2017.

552 Depoimento de Flávio Cerqueira à autora em 11 out. 2017. Cabe notar que a maioria das obras do artista são moldadas em bronze. Muito utilizado nas esculturas tumulares, nos monumentos históricos e nos bustos de figuras emblemáticas da sociedade, o bronze é marcado por uma "carga de significados", me explicou Cerqueira, daí seu interesse em "trazer para esse contexto narrativas cotidianas com as quais as pessoas tenham uma maior identificação", de acordo com o artista no mesmo depoimento. Sobre a escolha do bronze para retratar homens públicos em bustos comemorativos, ver também Carvalho (2008).

${ }^{553}$ Fotografias da exposição "Se precisar, conto outra vez", assim como informações sobre as obras expostas, podem ser encontradas no site de Flávio Cerqueira. Disponível em: <http://flaviocerqueira.com/exposicoes/se-precisar-contooutra-vez/>. Acesso em: 1 out. 2017.

554 Disponível em: <http://www.zeronaldo.com/2016/flavio-cerqueira-na-casa-triangulo-em-sao-paulouma-exposicao-imperdivel/>. Acesso em: 1 out. 2017.
} 


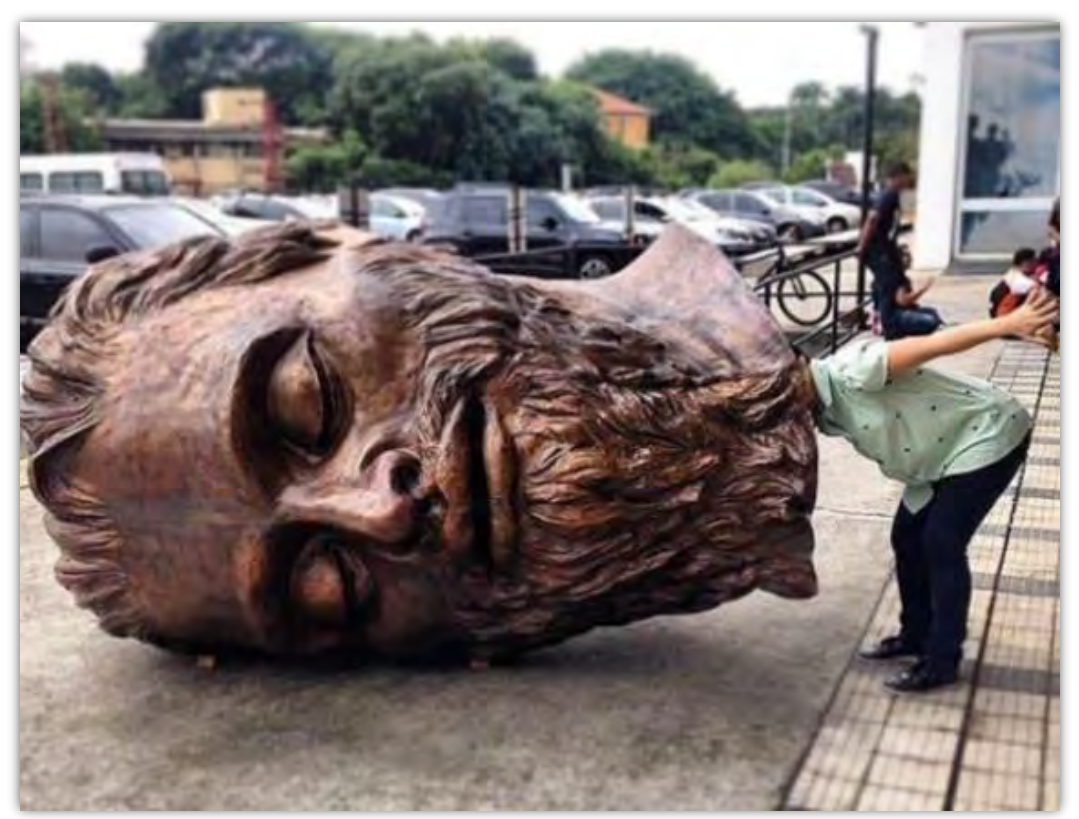

Figura 3.34 - Visitante interage com a obra Tinha que acontecer, Estação Pinacoteca, 2017. Fonte: Pinacoteca do Estado de São Paulo ${ }^{55}$.

O enorme vazio dentro da cabeça do bandeirante tampouco passou despercebido aos olhos dos visitantes da Estação Pinacoteca. Mas aqui, a cabeça degolada e oca foi tombada com a face voltada para o edifício que abriga a Secretaria da Cultura do Estado de São Paulo. Estratégica, sua localização era temporária, já que a obra não integra o acervo da Pinacoteca ${ }^{556}$. Nesse sentido, é impossível deixar de indagar qual seria o local mais adequado na cidade (que perde aqui seu famoso epíteto "capital bandeirante") para a instalação da escultura de Flávio Cerqueira. "Seria um sonho se esse trabalho fosse instalado ao lado do Monumento às bandeiras", declara o próprio artista, em uma das conversas que tivemos, “acredito que esse contraponto poderia colocar em questão a

${ }^{555}$ Disponível em: <https://www.instagram.com/pinacotecasp/?hl=pt-br>. Acesso em: 1 out. 2017.

556 Embora Tinha que acontecer (cabeça de bandeirante) não faça parte do acervo da Pinacoteca, no mesmo ano em que essa escultura é exposta na Casa Triângulo, outra obra de Flávio Cerqueira foi selecionada para compor a mostra "Territórios: artistas afrodescendentes no acervo da Pinacoteca", montada para comemorar os 110 anos da instituição. Antes que eu me esqueça (2013) é o nome da obra, adquirida pela Pinacoteca no mesmo ano de 2016, como parte de uma estratégia para a ampliação e atualização de seu acervo. Cabe notar que até a gestão de Emanoel Araújo (1992-2002), primeiro e único diretor negro do museu até o momento, essa instituição dedicada à arte brasileira contava com poucas obras de artistas negros. Sobre a exposição "Territórios: artistas afrodescendentes no acervo da Pinacoteca", ver Chiarelli, Silva \& Lopes (2016). 
presença heroica dos bandeirantes em nossa história e a minha ideia de anulação simbólica desses heróis se concretizaria de fato" ${ }^{557}$. Nota-se assim uma disputa pelas mesmas áreas simbólicas da cidade. Não por acaso, o Monumento às bandeiras é tomado como um dos pontos de partida dessa exposição que apresenta a obra Tinha que acontecer (cabeça de bandeirante) logo na entrada da Estação Pinacoteca, exposição que desde seu título sugere uma reflexão sobre experiências do viver na capital paulista.

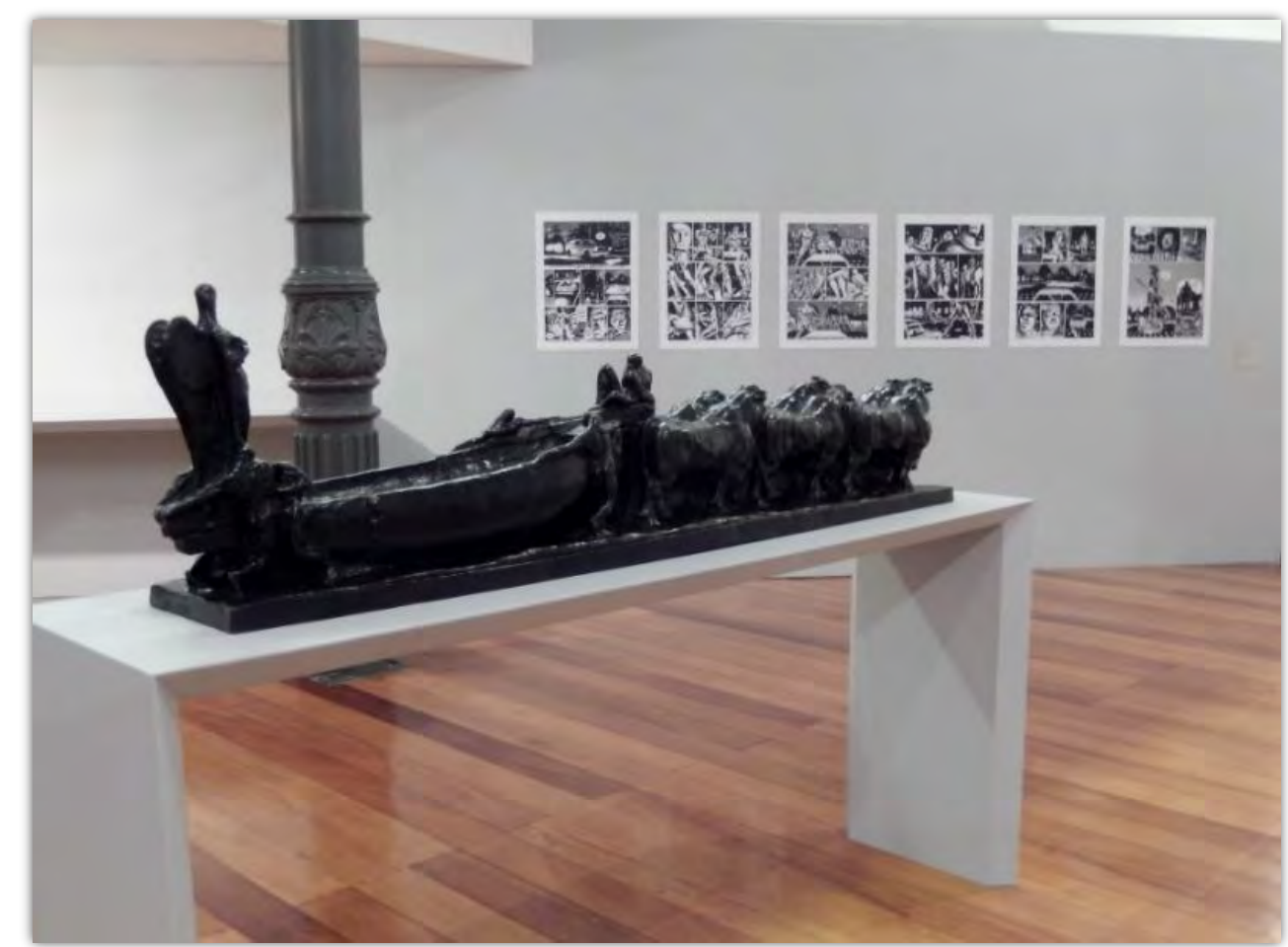

Figura 3.35 - Fragmento: Templo de minha raça, de Victor Brecheret, Estação Pinacoteca, 2017. Fonte: Acervo pessoal | Foto: Thaís Waldman.

Vimos no início deste capítulo que o Monumento às bandeiras possui uma relação antiga com a Pinacoteca, instituição que no começo dos anos 1920 acolhe a maquete exposta na Casa Byington. Tadeu Chiarelli, curador da mostra "Metrópole: experiência paulistana" e então diretor geral da instituição, explica que essa maquete do Monumento às bandeiras doada por Brecheret foi acidentalmente destruída em 1947, por isso em seu lugar optou por expor outro projeto do escultor que data da mesma época e faz parte do acervo da mesma instituição, o Fragmento: Templo de minha

${ }^{557}$ Depoimento de Flávio Cerqueira à autora em 11 out. 2017. 
raça. É possível "substituir uma peça por outra" se partirmos do pressuposto de que o Monumento às bandeiras é resultado de um processo em andamento, tomando assim o Fragmento: Templo de minha raça como um trabalho que integra esse mesmo processo, que ainda não estava concluído quando o escultor foi morar na Europa, explica Chiarelli (2017, p. 22).

Fundido em bronze em 1998, com dimensões (45 x 181 × $26 \mathrm{~cm}$ ) muito menores do que as do Monumento às bandeiras, o Fragmento: Templo de minha raça é parte de um projeto cuja maquete foi enviada ao Salão de Outono em 1921, em Paris, um ano depois da exposição da primeira maquete tornada pública do Monumento às bandeiras, doada à Pinacoteca (BATISTA, 1985). Mas ao contrário da maquete em gesso exposta em São Paulo, o projeto Fragmento: Templo de minha raça é passado para o bronze ${ }^{558}$. Cabe ainda observar que, embora nada mais reste da primeira maquete do Monumento às bandeiras, o Fragmento: Templo de minha raça não apenas remete à imagem do "Altar da pátria" evocada pelo escultor nos anos 1950 para descrever seus bandeirantes talhados em granito, como muito se assemelha ao estudo abaixo do Monumento às bandeiras, feito em nanquim pelo artista na mesma Paris dos anos 1920, reiterando o argumento de Tadeu Chiarelli de que o Monumento às bandeiras é resultado de um longo processo, do qual de certo modo fazia parte também o Fragmento: Templo de minha raça.

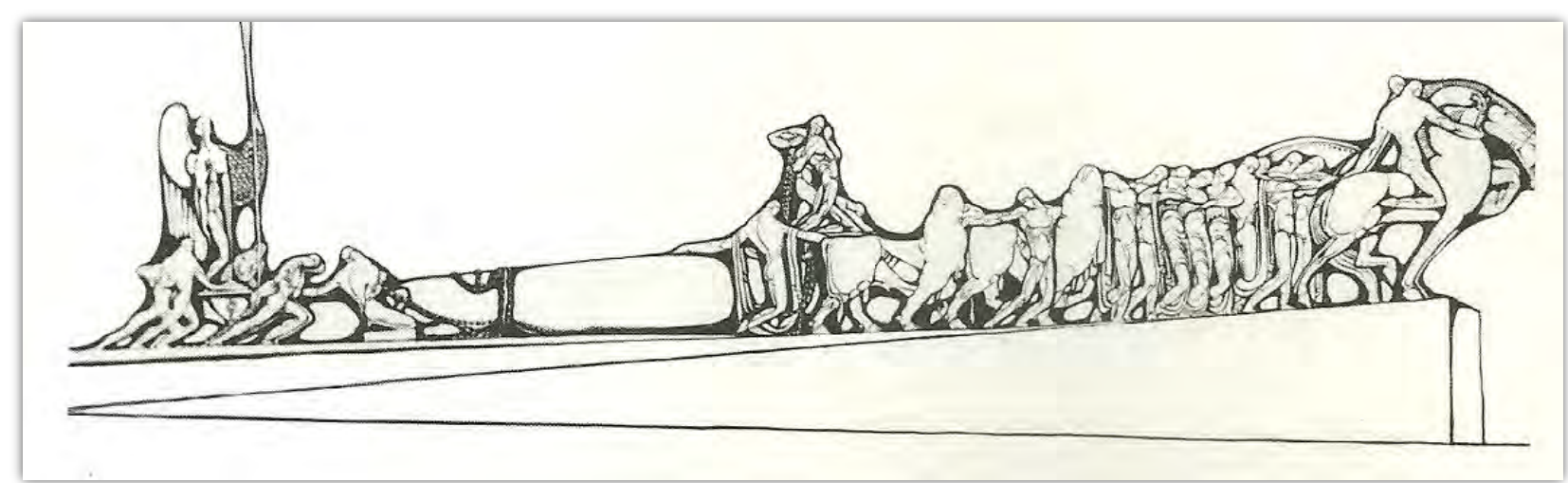

Figura 3.36 - Estudo para o Monumento às bandeiras, Paris, anos 1920.

Fonte: Victor Brecheret: obra de uma vida (2002), organizado por Sandra Brecheret Pellegrini, s/p.

558 Fragmento: Templo de minha raça foi fundido e adquirido em 1998 por meio de uma doação do Protocolo de Intenções entre a Pinacoteca do Estado de São Paulo, o Museu Nacional de Belas Artes, o Banco Safra e a filha do escultor, Sandra Brecheret Pellegrini. Já a obra em gesso que deu origem à peça em bronze exposta na Estação Pinacoteca, hoje pertencente à coleção do Banco Safra e, segundo a ficha catalográfica da Pinacoteca, é uma parte da escultura original, apresentada no Salão de Outono de Paris, em 1921. 
$\mathrm{O}$ andamento desse processo não apenas precede a inauguração do Monumento às bandeiras, como prossegue até os dias de hoje, na medida em que a obra e sua imagem são continuamente reinterpretadas e apropriadas para a produção de objetos variados ${ }^{559}$. Nesse sentido, se nos anos 1950 o monumento esculpido por Brecheret foi erguido como se partisse rumo ao Jaraguá, o Fragmento: Templo de minha raça, ao ser instalado dentro do prédio da Estação Pinacoteca, apontava justamente para a história em quadrinhos Entradas e bandeiras, reproduzida na parede do edifício. Vimos no capítulo anterior que, nesse livro de Luiz Gê, dedicado ao escultor, Borba Gato sai de seu pedestal, em Santo Amaro, e caminha pela cidade dos quadrinhos. No entanto, ao chegar no Ibirapuera, o Monumento às bandeiras parecia finalmente ter partido para o Jaraguá: no desenho, um dos indígenas da obra de Brecheret sinaliza o trânsito no cruzamento entre a avenida Brasil e a Brigadeiro Luís Antônio, dando passagem ao resto do seu pessoal.
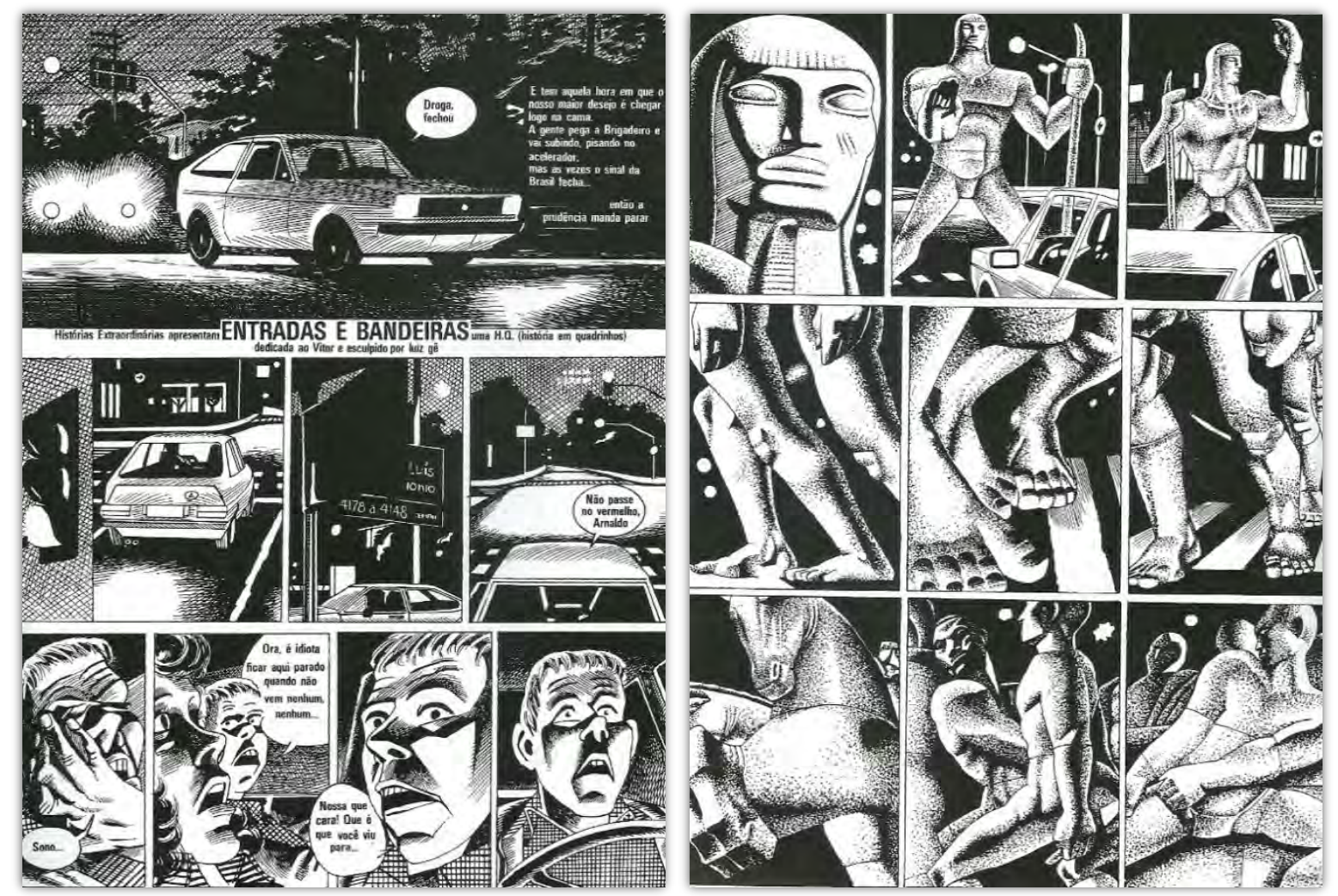

\footnotetext{
559 O próprio Tadeu Chiarelli, no catálogo da exposição "Metrópole: experiência paulistana”, enfatiza que "ainda está para ser realizado um estudo sobre como a população de São Paulo, nesses anos que nos separam de 1953, vem interagindo com o Monumento às bandeiras" (CHIARELLI, 2017, p. 24).
} 

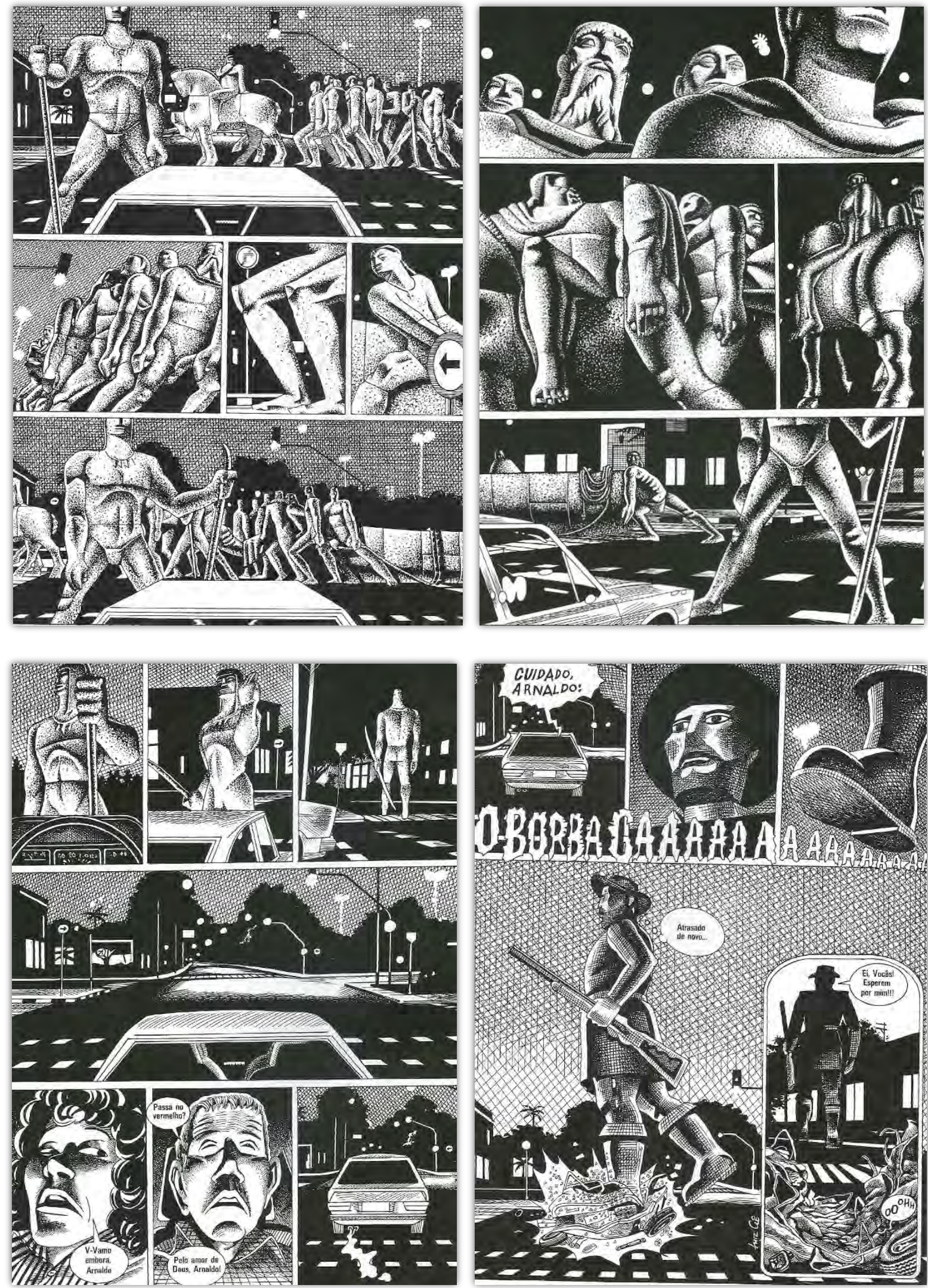

Figura 3.37 - Entradas e bandeiras (1985), de Luiz Gê.

Fonte: Chiclete com Banana, $\mathrm{n}^{\circ}$ 01, pp. 45-47. 
É possível observar minuciosamente cada parte do corpo (as cabeças e mãos, os braços, troncos, joelhos e pés) dos personagens de pedra desenhados por Luiz Gê, além de detalhes da canoa e dos cavalos ${ }^{560}$. Incrédulos, Arnaldo e sua companheira assistem do automóvel às figuras do monumento caminhando em marcha, figuras que cotidianamente passavam despercebidas sob seus olhares. Mas o motorista e a passageira — que até então viam o Monumento às bandeiras e a praça na qual ele está localizado como nada mais do que "uma rotatória com uma estátua no meio", nos termos do quadrinista (GÊ, 1993, p. 11) - mal têm tempo de assimilar o ocorrido. Quando o indígena libera a passagem, eis que o gigante Borba Gato, sem olhar para o chão, caminhando atrasado atrás do Monumento às bandeiras, os esmaga com sua enorme bota.

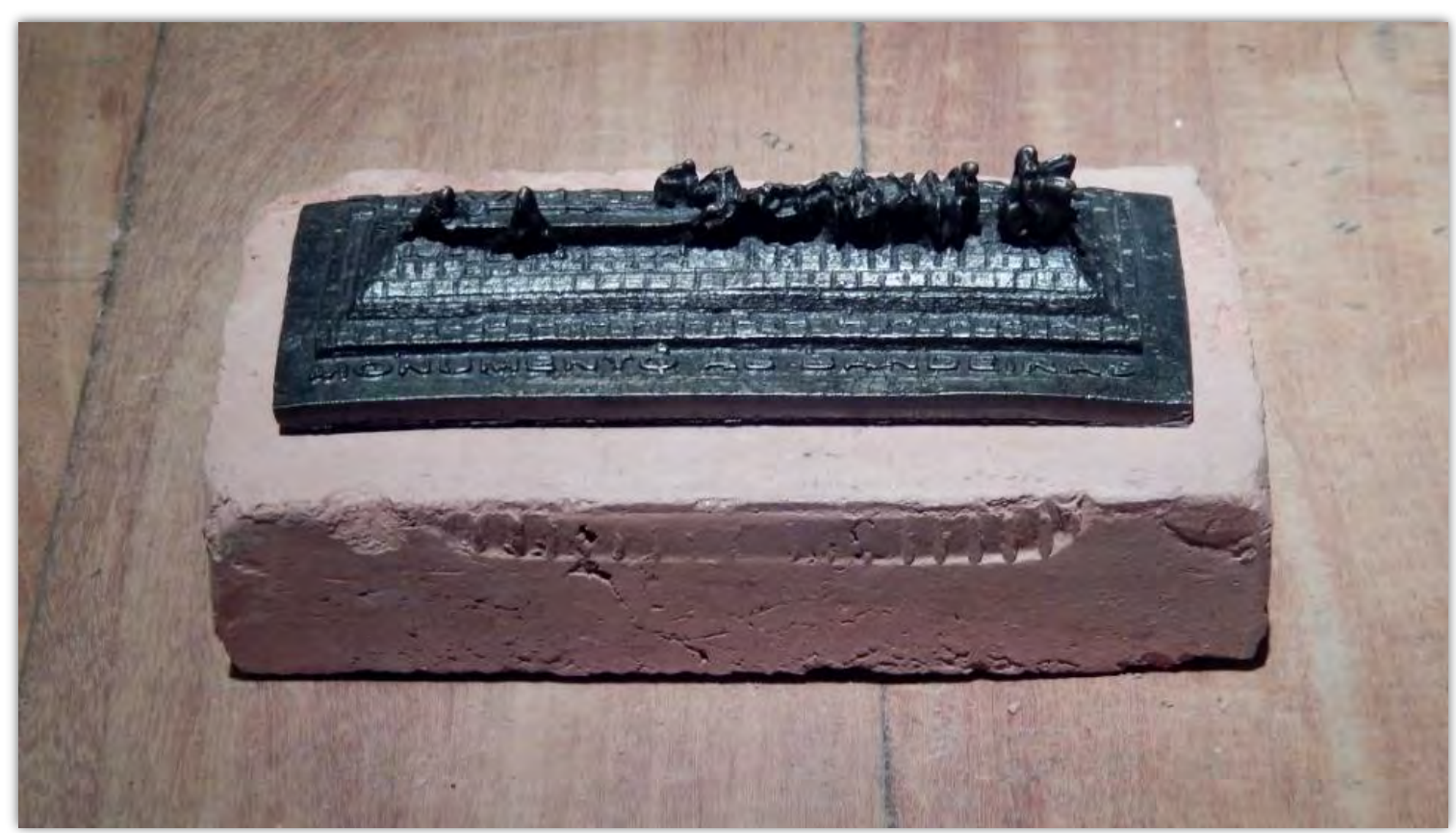

Figura 3.38 - Monumento às bandeiras, de Jaime Lauriano, Estação Pinacoteca, 2017. Fonte: Acervo pessoal | Foto: Thaís Waldman.

Enquanto nos quadrinhos o imenso Borba Gato pisa os passageiros do automóvel, em "Metrópole: experiência paulistana" os visitantes são praticamente convidados a pisotear o Monumento às bandeiras (2016) esculpido por Jaime Lauriano (1985-). Não foram poucos aqueles que, caminhando pela Estação Pinacoteca sem olhar para o chão, chutaram acidentalmente o

560 Anos depois, o diretor Gregorio Graziosi irá lançar o curta-metragem Monumento (2012), um documentário experimental que pretende contemplar cuidadosamente os detalhes de cada um dos personagens em pedra do Monumento às bandeiras. Disponível em: <https://vimeo.com/133488898>. Acesso em: 10 out. 2017. 
tijolo acima (material frágil se comparado ao granito) que servia de pedestal à obra do artista negro paulista, disposta no chão do segundo andar do edifício do antigo Deops sem nenhuma proteção, conforme me relatou uma das funcionárias encarregadas da segurança do local ${ }^{561}$. Definida por Lauriano como uma réplica em miniatura $(8 \times 18 \times 9 \mathrm{~cm})$ do monumento de Brecheret - e de todo seu repertório de "barbáries" —, a obra foi fundida em latão e restos de cartuchos de munições utilizadas pela Polícia Militar e pelas Forças Armadas brasileiras, sob uma base de tijolo vermelho ${ }^{562}$.

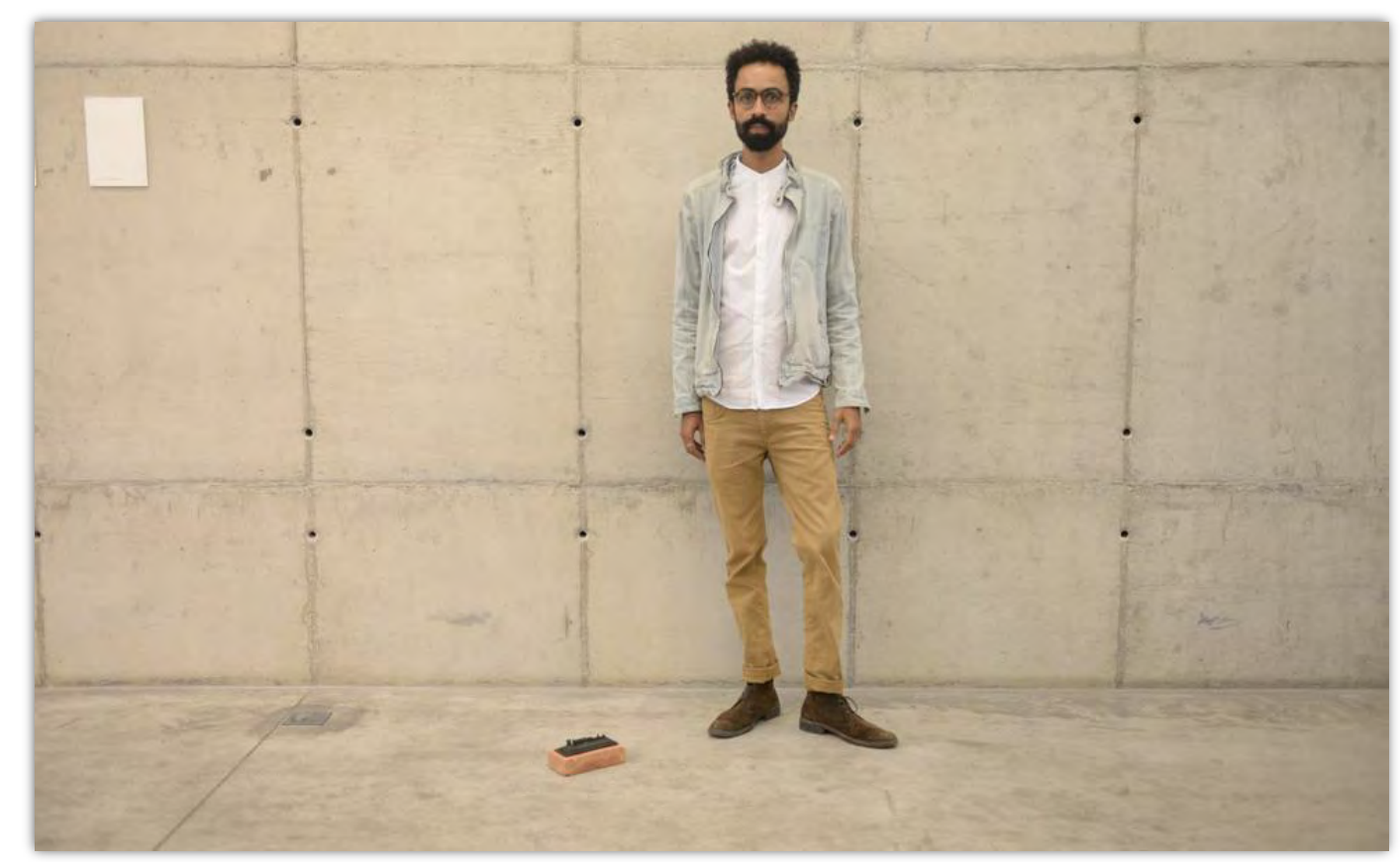

Figura 3.39 - Jaime Lauriano e seu Monumento às bandeiras, Galeria Leme, 2016. Fonte: Glamurama | Foto: André Ligeiro ${ }^{563}$.

O Monumento às bandeiras de Jaime Lauriano havia sido exposto em 2016 em uma mostra intitulada “Totemonumento", na galeria Leme, no bairro do Butantã (próxima à Casa

561 Conversa realizada entre a funcionária e a autora em 26 ago. 2017.

$562 \mathrm{O}$ Monumento às bandeiras, de Victor Brecheret, é um "totem à barbárie”, afirma Jaime Lauriano em depoimento a Tadeu Chiarelli. Trata-se de "um ídolo fálico que a todo momento nos lembra, ou relembra, que a construção do Brasil é uma construção de machos brancos, que chegavam violentando quem se opusesse à sua pulsão de desejo", explica o artista (apud CHIARELLI, 2017, p. 26).

563 Disponível em: <http://glamurama.uol.com.br/galeria/galeria-leme-abriu-duas-exposicoes-que-dialogam-com-a-cidade/\#21>. Acesso em: 10 out. 2017. 
Do Bandeirante $)^{564}$. Nas duas ocasiões, a obra foi igualmente deixada no chão sobre seu pedestal de tijolo. Nesse sentido, por suas dimensões e pelos materiais empregados, ela pode ser vista como "uma composição portátil para ser guardada — ou esquecida — no ambiente privado de uma casa, dentro de um móvel, em uma caixa sobre um guarda-roupa perdido, entre outras coisas", explica Alexandre Bispo (2017, p. 59) ${ }^{565}$. Ao mesmo tempo, ela é também pensada como uma arma, seja "um projétil lançado contra nossa visão edulcorada e obliterante do passado", afirma Márcio Seligmann-Silva (2016, s/p), ou um instrumento que pode ser pego e atirado contra "os novos bandeirantes", nos termos do próprio artista, que elenca entre os principais alvos de seu ataque a polícia e os grandes agropecuaristas (apud CHIARELLI, 2017, p. 26) 566 $^{56}$

\subsubsection{Cabeças de bandeirantes}

A escolha do edifício até recentemente conhecido como sede do antigo Deops para acolher a mostra "Metrópole: experiência paulistana" não parece ter sido aleatória. O prédio que hoje abriga a Estação Pinacoteca e o Memorial da Resistência foi tomado como um "marco paulistano" e escolhido como um dos eixos temáticos da exposição (assim como o Monumento às bandeiras). Um prédio associado a um repertório de "barbáries", tal qual os bandeirantes segundo a interpretação de Jaime Lauriano. Originalmente projetado pelo Escritório Técnico de Ramos de Azevedo para ser o armazém central e abrigar escritórios da Estrada de Ferro Sorocabana, o imponente edifício inaugurado nos anos 1910 começou, no final dos anos 1930, a ser ocupado pelo Deops, este

\footnotetext{
564 Sobre a exposição “Totemonumento”, ver Seligmann-Silva (2016). Fotografias dessa mostra (cujo título remete ao trabalho de Cildo Meireles, Tiradentes: Totem-monumento ao preso politico), assim como informações sobre as obras expostas, podem ser vistas no site da galeria. Disponível em: <http://galerialeme.com/expo/totemonumento/>. Acesso em: 10 out. 2017.

565 Em 2013, inclusive, uma reprodução em miniatura do Monumento às bandeiras começou a ser vendida em São Paulo. "Sempre que viajo trago miniaturas dos principais pontos. Tenho a Torre Eiffel, de Paris, e a Estátua da Liberdade, de Nova York, por exemplo, mas quem vinha a São Paulo não tinha o que levar”, explica o escultor Alexandre Leonato, que pediu autorização da família de Victor Brecheret para comercializar sua miniatura. Disponível em: < http:// saopaulo.estadao.com.br/noticias/geral,monumentos-viram-colecao-de-miniaturas-imp-,988074>. Acesso em: 10 out. 2017.

566 Depoimento de Jaime Lauriano a Tadeu Chiarelli em 28 mar. 2017.
} 
concebido desde sua origem como um órgão repressor ${ }^{567}$. Com a extinção do Deops em 1983, o prédio foi ocupado ainda pela Delegacia de Defesa do Consumidor, sendo definitivamente desativado como instalação policial em 1997, quando se torna responsabilidade da Secretaria da Cultura do Estado de São Paulo. Não à toa ele abriga, hoje, o Memorial da Resistência ${ }^{568}$.

Muito lembrado por sua atuação durante o regime militar, o Deops participou no final dos anos 1960 da criação da Operação Bandeirante (Oban), dando início a uma nova etapa (muito mais truculenta) na repressão às ações da esquerda e aos movimentos sociais, reunindo elementos das três Forças Armadas (Exército, Marinha e Aeronáutica), da Polícia Federal e da Secretaria de Segurança Pública ${ }^{569}$. Criada em 1969 — “com a missão de identificar, localizar e capturar os elementos integrantes dos grupos subversivos que atuam na área do II Exército, particularmente em São Paulo" ${ }^{770}$ —, a Oban é considerada um marco da repressão política, enquanto o seu sucedâneo, o sistema DOI-Codi, é tido como seu principal símbolo, já que em certa medida representa sua oficialização ${ }^{571}$. O próprio nome Operação Bandeirante, no Relatório da Comissão Nacional da Verdade, é associado à violência extrema utilizada em suas ações ${ }^{572}$.

Embora não fosse institucionalizada formal e juridicamente, a Oban mostrou-se eficiente, por isso seu escopo seria ampliado, disseminando um modelo semelhante pelo país ${ }^{573}$. Considerada o "centro de irradiação dos movimentos de contestação violenta ao governo" (FON, 1979, p. 16), a capital paulista é escolhida para acolher essa experiência piloto que, considerada pelos militares

\footnotetext{
${ }^{567}$ Criado em 1924, com a função de assegurar e disciplinar a ordem no país, o Deops passou por diversas mudanças ao longo de sua existência, mas foi sempre marcado por um caráter repressor, como mostram, por exemplo, os dossiês organizados por Aquino et al. (2001; 2002).

568 Sobre o Memorial da Resistência, ver Araujo \& Bruno (2009) e Neves (2012).

${ }^{569}$ Depois da instauração do regime militar, houve uma longa discussão a respeito da manutenção da segurança interna do país, um debate que durou cerca de cinco anos, do qual saiu vencedor o argumento dos setores militares favoráveis a um engajamento "total, ideológico e operacional das Forças Armadas contra a luta subversiva", que daria origem À Oban (FON, 1979, p. 15).

${ }^{570}$ Fundo Deops, dossiê 50-Z-9, pasta 74, Apesp.

${ }^{571} \mathrm{Em}$ 1970, a experiência da Oban, que se restringia a um conjunto de medidas administrativas internas, é integrada ao sistema oficial de segurança por meio da criação simultânea de dois órgãos diretamente ligados às Forças Armadas: o Destacamento de Operações e de Informações (DOI) e o Centro de Operações de Defesa Interna (Codi), dois órgãos distintos frequentemente associados na sigla DOI -Codi, o que reflete o caráter complementar de ambos. O primeiro era responsável pelas ações práticas de busca, apreensão e interrogatório de suspeitos, enquanto ao segundo cabia a análise de informações, a coordenação dos diversos órgãos militares, o planejamento estratégico do combate aos grupos de esquerda e a burocracia (JOFFILY, 2013).

572 Disponível em: <http://www.cnv.gov.br/>. Acesso em: 15 out. 2017.

573 Sobre a Oban, ver Joffily (2013) e o dossiê 50-Z-9 do Fundo Deops (Apesp).
} 
pioneira (tal qual os bandeirantes), se dissemina pelo país. Um dos gatilhos para sua criação, inclusive, foi a deserção, com armas e munições, do capitão Carlos Lamarca, então pertencente ao Regimento Raposo Tavares (no bairro de Quitaúna, em Osasco). Nesse sentido, passada a "febre" dos monumentos com temática bandeirante em São Paulo, a Oban pode ser vista como uma espécie de monumento imaterial aos bandeirantes.

Nos documentos do acervo do Deops, o estado de São Paulo já era evocado, antes mesmo da criação da Oban, como o "estado bandeirante" ou o "governo bandeirante", isso sem mencionar a "Milícia Bandeirante" (referência à Polícia Militar do Estado de São Paulo), igualmente mencionada nos registros, prenunciando assim o batismo da operação ${ }^{574}$. Vale ressaltar que a sede do governo do estado, o Palácio dos Bandeirantes ${ }^{575}$, havia sido inaugurada em 1965 na capital paulista, no bairro do Morumbi, pelo então governador Adhemar Pereira de Barros (um dos líderes civis do golpe de 1964, embora tenha sido afastado do governo de São Paulo pelos militares em 1966). Além de ter criado na mesma época uma comissão responsável por grandes empreendimentos rodoviários, como a rodovia dos Bandeirantes ${ }^{576}$, inaugurada nos anos 1970, Adhemar de Barros foi o segundo proprietário da rádio Bandeirantes ${ }^{577}$, que daria origem nos anos 1960 a Rede Bandeirantes de Televisão ${ }^{578}$, presidida pelo seu genro João Saad.

574 É oportuno lembrar as palavras do general José Canavarro Pereira, comandante do II Exército, para quem “a OPERAÇÃO BANDEIRANTE foi criada em um momento em que a subversão e o terrorismo ameaçavam a tranquilidade e a confiança do povo paulista". Nesse sentido, caberia ao "estado bandeirante", ao "governo bandeirante" e à "Milícia Bandeirante" acolherem essa operação homônima, que serviria de exemplo para todo país. Fundo Deops, dossiê 50-Z-9, pasta 43, Apesp.

575 Ainda na década de 1950, o edifício hoje conhecido como Palácio dos Bandeirantes tinha começado a ser construído para abrigar a Universidade Conde Francisco Matarazzo, projeto que não foi adiante. O imóvel foi então desapropriado e consagrado como sede definitiva do governo estadual e residência oficial do governador, sendo batizado como uma homenagem aos bandeirantes. Sua inauguração, nos anos 1960, abriu caminho para uma rápida ocupação do Morumbi, zona sul da cidade. Em 1977, ele foi aberto para visitação pública, quando assume também a vocação de museu. Atualmente, o Palácio abriga quatro secretarias de Estado, a Casa Civil, a Casa Militar, e parte do acervo artístico do governo. O acervo do local inclui telas como Os bandeirantes (s/d), na qual Henrique Bernardelli retrata sertanistas com vestimentas típicas da aristocracia europeia do século XVI, mas também outras que questionam esse tom laudatório, como a Grande estrutura branca simbólica - Alegoria ao bandeirante (1989), de Emanoel Araújo.

${ }^{576}$ No início dos anos 1940, Adhemar de Barros (nomeado interventor do governo de São Paulo por Getúlio Vargas) já havia iniciado as obras da rodovia Anhanguera, duplicada durante sua gestão como governador (1947-1951). Quando governador ele irá também criar o cinejornal Bandeirante na tela, ver Archangelo (2015).

577 A rádio Bandeirantes foi criada no final da década de 1930, mesma época em que Prestes Maia é nomeado prefeito da capital paulista por Adhemar de Barros, quando ambos inauguram a ponte das Bandeiras, mencionada no início deste capítulo.

578 Próxima ao Palácio dos Bandeirantes, no bairro do Morumbi, a Rede Bandeirantes de Televisão foi fundada pela família de imigrantes sírios Saad, produzindo pela primeira vez no Brasil uma programação em cores e com 
Algumas semanas após sua criação, no dia 7 de setembro, aniversário da Independência do Brasil, a Oban é instalada na rua Tutoia, próxima ao parque do Ibirapuera, em uma construção cuja entrada principal está voltada para o Monumento às bandeiras, como se com ele partisse rumo ao Jaraguá, compartilhando assim um mesmo projeto. A poucos metros dali, estava o quartel general do II Exército (atual Comando Militar do Sudeste), inaugurado em 1968 em um terreno dentro do qual, como vimos no capítulo anterior, é instalado no final dos anos 1980 o busto de Olavo Bilac, conhecido como o "patrono do serviço militar" (segundo os dizeres da placa disposta em seu pedestal). Banido na década de 1930 do antigo belvedere da avenida Paulista, o busto do poeta perdera a companhia da escultura dos bandeirantes que ocupam hoje o jardim da Escola Estadual Fernão Dias Paes, mas assim como elas acabou transferido para um local marcado pela presença bandeirante. Essa presença (e os projetos dela que não foram cumpridos em sua totalidade) não passou despercebida ao artista paulista Fernando Piola (1982- ) que, assim como Flávio Cerqueira e Jaime Lauriano, participou da exposição "Metrópole: experiência paulistana".

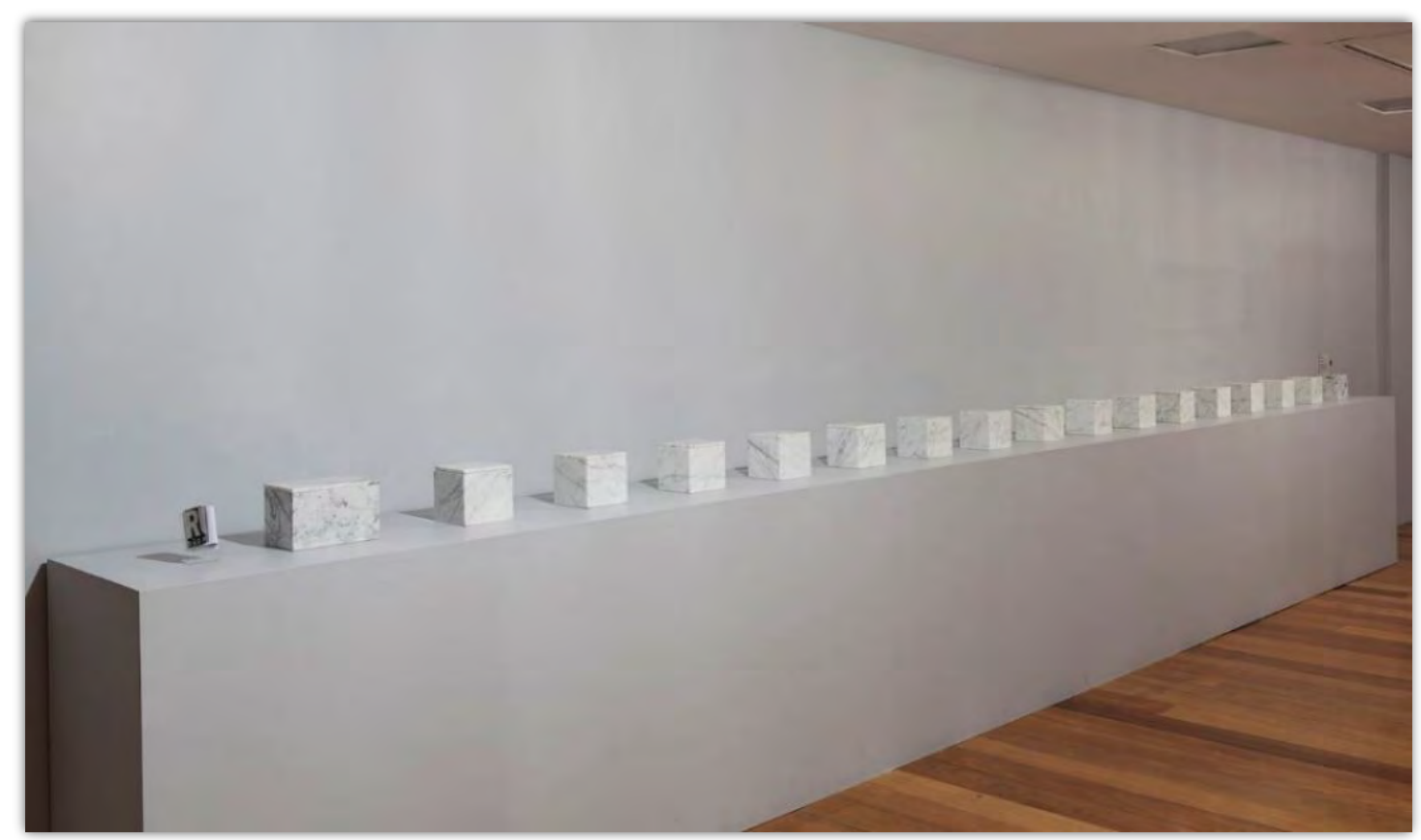

Figura 3.40 - Projeto São Paulo, Estação Pinacoteca, 2017.

Fonte: Acervo da Pinacoteca do Estado de São Paulo | Foto: Isabella Matheus.

transmissão via satélite. A rede entra no ar em 1967 sem intervalos entre os programas, e a separação das atrações era feita com a exibição do desenho "coelho bandeirante", mascote da nova emissora, um coelho com chapéu de abas largas e uma espingarda na mão. 
Piola expôs no segundo andar da Estação Pinacoteca o Projeto São Paulo (2010), um conjunto de pequenas caixas (urnas) feitas em mármore (material nobre, resistente e associado à permanência) contendo projetos para a cidade nunca realizados ou incompletos, apresentados durante diferentes gestões governamentais ${ }^{579}$. Entre eles: o Projeto Bandeiras, com diferentes propostas que não foram integralmente realizadas por Brecheret ao esculpir seu Monumento às bandeiras; o Projeto Tietê, que incluía na futura ponte das Bandeiras a construção do monumento em homenagem aos bandeirantes; e o Projeto Praça Vermelha, de autoria do próprio Piola, que previa uma intervenção paisagística em frente ao prédio do antigo Deops ${ }^{580}$.
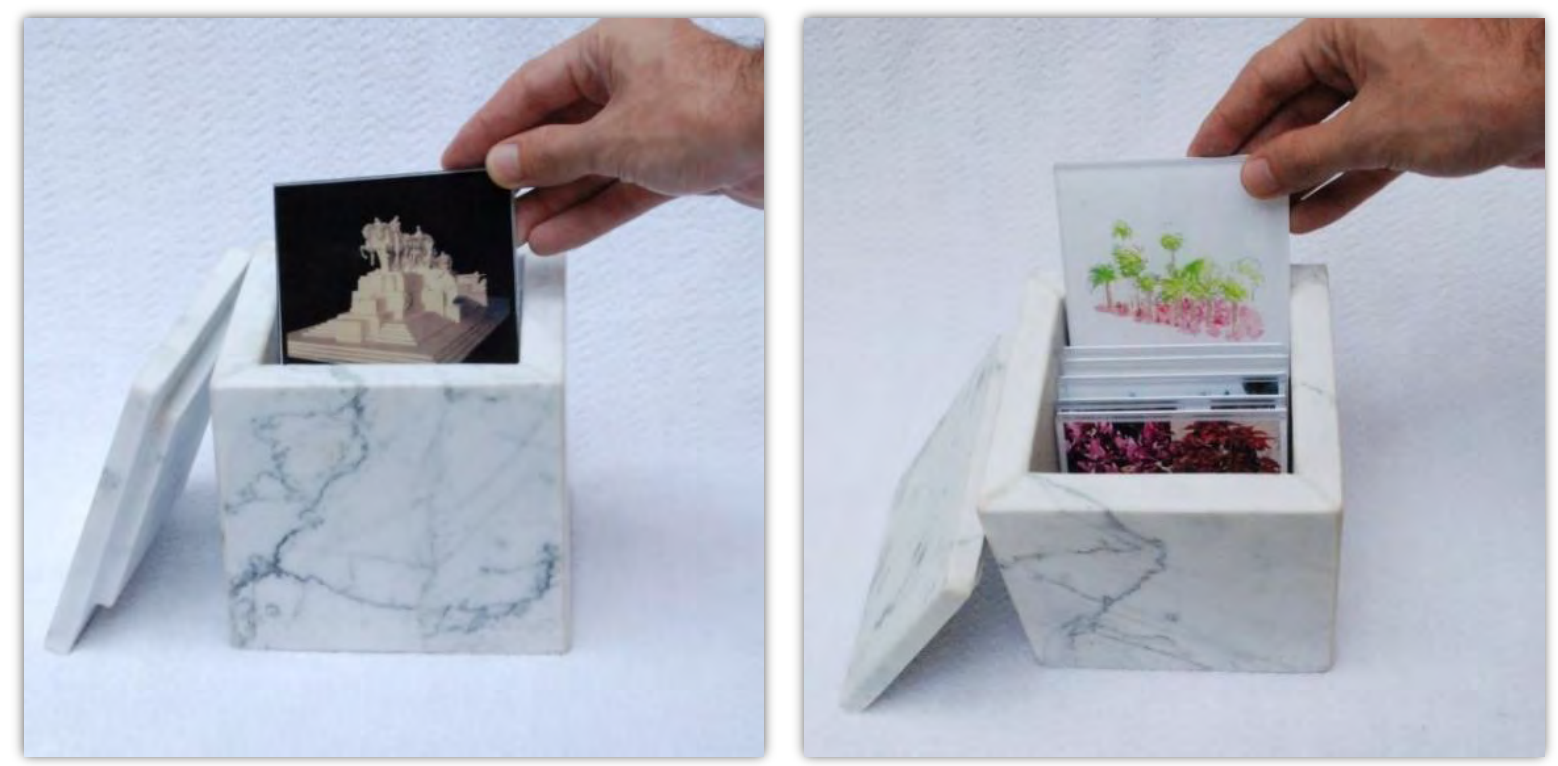

Figura 3.41 - Projeto Bandeiras e Projeto Praça Vermelha, detalhes do Projeto São Paulo (2010). Fonte: Acervo Fernando Piola | Foto: Fernando Piola.

A proposta do Projeto Praça Vermelha (2005/14) consistia no plantio de espécies de folhagens exclusivamente vermelhas no largo General Osório, em frente ao edifício do antigo

579 O Projeto São Paulo já havia participado em 2010 de uma exposição/intervenção no Monumento à Independência. Cf. site do artista. Disponível em: <http://fernandopiola.com/2010-Projeto-Sao-Paulo>. Acesso em: 16 out. 2017.

580 Vale observar que até hoje o Deops é associado à imagem do bandeirante. Não por acaso, em abril de 2017 foi promulgado um projeto de lei que acrescenta o nome de Romeu Tuma, delegado e diretor do Deops entre os anos de 1966 e 1983, à ponte das Bandeiras. Cf. Lei no 16.629, de 17 de abril de 2017, CMSP. Poucos meses depois, em setembro do mesmo ano, a Procuradoria da Câmara Municipal de São Paulo suspendeu a eficácia dessa lei até o julgamento final da ação, mas as placas de sinalização da ponte das Bandeiras mantiveram, até pelo menos o fim do ano de 2017, o nome Romeu Tuma inscrito. 
Deops. Iniciado um ano depois da inauguração da Estação Pinacoteca, o projeto buscou problematizar a ocupação do prédio escolhido para abrigar esse novo espaço da Pinacoteca, cujo "restauro" destruiu parte significativa da carceragem do Deops e descaracterizou as celas restantes (PIOLA, 2013, p. 60). A proposta, no entanto, foi recusada pelas autoridades do Depave (Departamento de Parques e Áreas Verdes da Subprefeitura Sé) dentre outros motivos, por ser considerada muito vermelha. Ao longo dos anos, outras tratativas institucionais foram tomadas na tentativa de realizar essa intervenção paisagística, que acabou ao lado de projetos que homenageiam bandeirantes paulistas, ao ser depositada em uma das urnas de mármore do Projeto São Paulo. Urnas que "encerram solenemente o futuro não cumprido" ao mesmo tempo que "funcionam como um busto alegórico de uma cidade não realizada", explica o artista (PIOLA, $2010 \mathrm{~b}, \mathrm{~s} / \mathrm{p})^{581}$.

Enquanto aguardava autorização para prosseguir com seu Projeto Praça Vermelha, Fernando Piola inicia a Operação Tutoia (2007/12). Se durante o regime militar o Deops ("órgão de repressão política”) e a Operação Bandeirantes (“centro integrador das forças que reprimiam aqueles que resistiam ao regime militar", nos termos do artista) realizavam operações de forma conjunta e coordenada, Piola se dirige até a atual $36^{a}$ Delegacia de Polícia, na rua Tutoia, para realizar paulatinamente outro plantio com folhagens vermelhas (PIOLA, 2010, pp. 27-28). Apresentando-se dessa vez como agente da Secretaria de Estado da Cultura de São Paulo, ele consegue permissão para cuidar do jardim da antiga sede da Oban, que com o passar dos meses acaba tomado pela folhagem recém-plantada. Vermelho é "símbolo de sangue, luta, morte", além de ser "a cor da revolução e do comunismo", recorda o artista (2013, p. 23) ${ }^{582}$. Não parece estranho que diante do novo paisagismo a delegacia tenha feito uma poda, atenuando o monocromatismo.

581 O processo dessa e das demais “obras/exercícios” de Fernando Piola, apresentados por meio de textos e imagens, podem ser acompanhados no site do artista. Disponível em: <http://www.fernandopiola.com/>. Acesso em: 16 out. 2017.

582 Durante a realização das obras Projeto Praça Vermelha e Operação Tutoia, o artista participou da primeira edição do programa de residência artística do Memorial da Resistência, apresentando como resultado dez “obras/exercícios" que refletem sobre diferentes tipos de repressão na cidade de São Paulo. Entre elas, além do Projeto Praça Vermelha e da Operação Tutoia, destaco a obra Rexistir (2005/13), uma caixa feita com o mármore remanescente do processo de restauração da estação Júlio Prestes e do antigo Deops, na qual se encontram registros das espécies que ainda resistem depois de plantadas durante o Projeto Praça Vermelha e a Operação Tutoia. Cf. Piola (2013) 

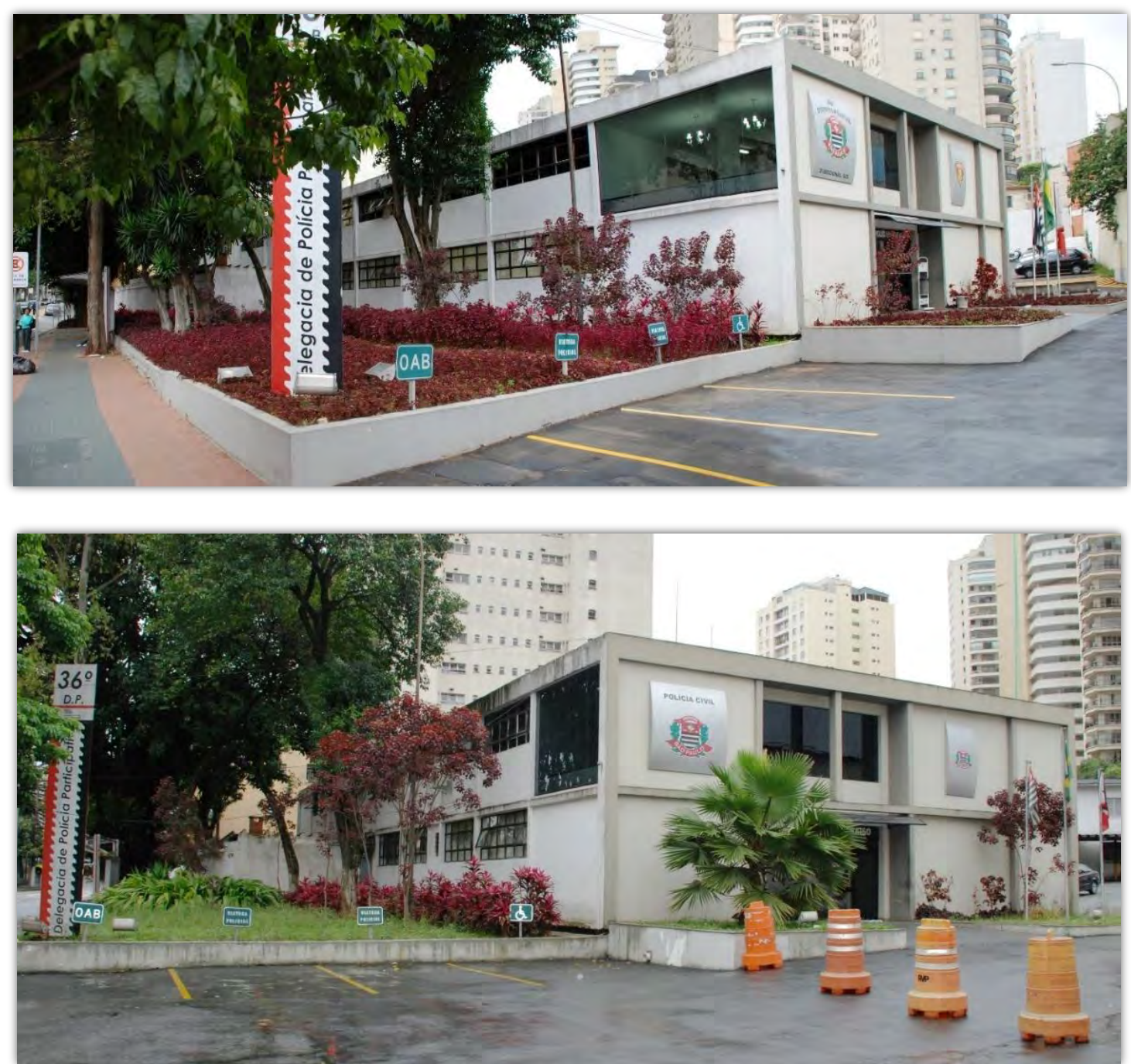

Figura 3.42 - Operação Tutoia, de Fernando Piola, 36 ${ }^{\text {a }}$ Delegacia de Polícia, 2008/2011. Fonte: Acervo Fernando Piola | Foto: Fernando Piola.

Fernando Piola elenca entre suas grandes referências o grupo 3Nós3 (1979-1982), coletivo formado por Hudinilson Júnior (1957-2013), Mario Ramiro (1957- ) e Rafael França (1957-1991). Pautado por um trabalho de intervenções urbanas, as quais denomina "interversões urbanas", o grupo funde as ideias de intervir na cidade com inverter a ordem das coisas, como na "interversão" Ensacamento (1979) que, assim como a Operação Tutoia, remete à tortura no Brasil durante a última ditadura militar. Ao longo de uma madrugada, em abril de 1979, com a liberdade ainda cerceada pelo regime militar, o 3Nós3 cobriu com sacos de lixo preto e corda a cabeça de uma série de esculturas e monumentos públicos a partir de um trajeto pré-estabelecido pela cidade e de um mapeamento dessas obras. Reproduziram assim, a céu aberto, na região central da capital paulista, um gesto típico dos torturadores da Oban e de seu sucedâneo DOI, registrado pelo grupo por meio 
de fotografias ${ }^{583}$. Entre as primeiras obras a serem fotografadas, estava o Monumento às bandeiras. Curiosamente, as imagens tiradas pelo grupo do conjunto escultórico de Brecheret foram as que apresentaram mais problemas, relata Mario Ramiro: além do adicional da clandestinidade, as fotografias foram tiradas durante a madrugada, o que impôs grandes limitações para "não fotógrafos" como eles ${ }^{584}$. Ademais, até os anos 1980, um equipamento de vídeo "portátil” era caro e difícil de transportar, "uma câmera enorme com um monte de cabo e uma mala onde estava o gravador”, descreve Ramiro (apud MESQUITA, 2008, p. 354) ${ }^{585}$.

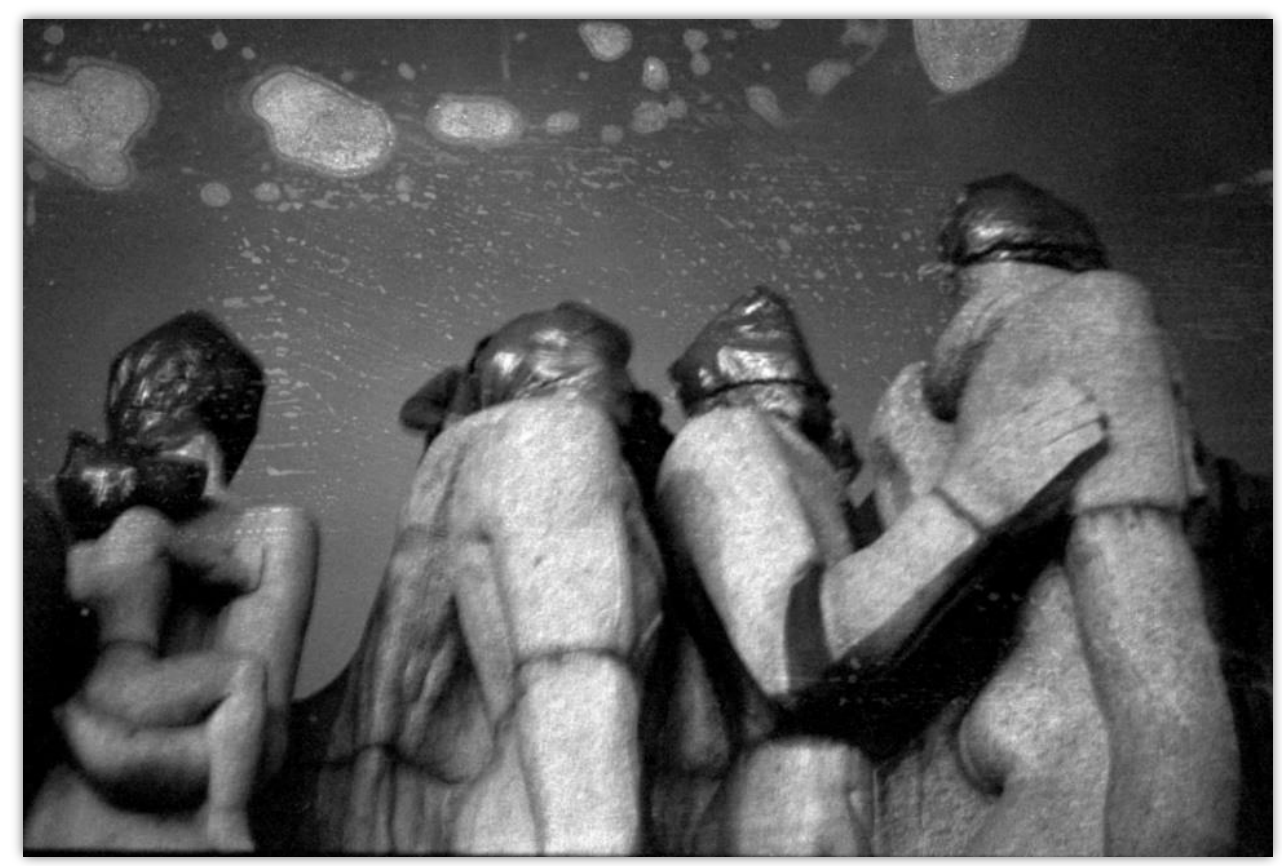

Figura 3.43 - Ensacamento do Monumento às bandeiras, 1979. Fonte: Acervo Mario Ramiro | Foto: 3Nós3.

Trabalhar com a mídia seria então uma forma prática e barata de registrar e disseminar essa operação efêmera. Por isso, na manhã seguinte, a imagem do Monumento às bandeiras ensacado não apenas gerou uma quebra no cotidiano da cidade, como foi documentada pela imprensa. Além de se apropriarem do espaço público, os ensacamentos ocuparam as páginas dos jornais. "Nem

583 Sobre as intervenções do 3NÓs3 ver Aldana (2006), Nichelle (2010), Pontes (2012) e o livro organizado por Ramiro (2017). Durante a escrita da tese, em 2017, fotografias de alguns desses ensacamentos foram expostas em São Paulo durante as mostras "Avenida Paulista”, no Museu de Arte de São Paulo, e “A construção do patrimônio", na Caixa Cultural da Sé, cf. os catálogos organizados por Pedrosa \& Toledo (2017) e Galvão \& Almeida (2017).

${ }^{584}$ Depoimento de Mario Ramiro à autora, em 18 abr. 2017.

585 Depoimento de Mario Ramiro a André Mesquita, em 22 fev. 2006. 
mesmo o imponente empurra-empurra" foi obstáculo a um obstinado "encapuzador" de estátuas que, nessa fria madrugada paulistana, deixou poucas cabeças ao relento, dirá em tom sarcástico o periódico Última Hora ${ }^{586}$. O título da matéria, ao fazer uma aproximação entre a obra de Brecheret e os sacos de lixo, ressalta ainda que a maneira de ver esse monumento e de se relacionar com ele havia mudado naquele dia. "A paisagem, em certos lugares, sofrera alteração", constata também a Folha da Tarde ${ }^{587}$.

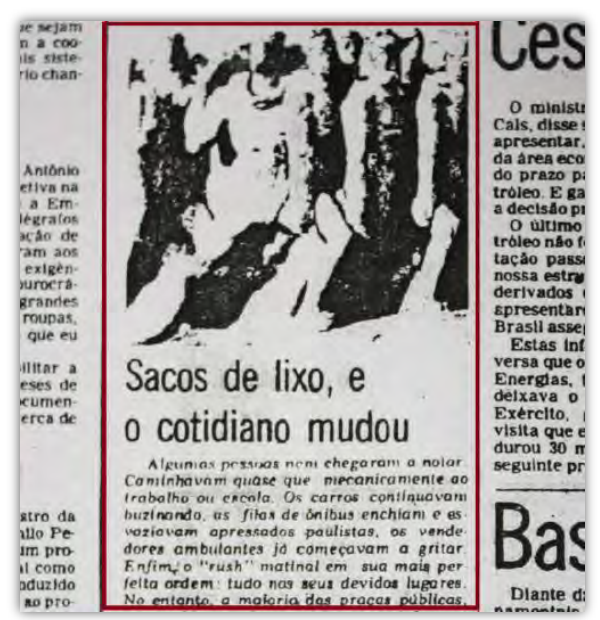

Figura 3.44 - Imagem do Monumento às bandeiras ensacado no jornal Última Hora. Fonte: Última Hora, 28 abr. 1979, p. 2.

Dissimulado, o 3nós3 entrou em contato com uma série de veículos da imprensa logo após os ensacamentos. Passando-se por moradores e transeuntes, o grupo indagou o motivo daquela estranha atitude tomada contra as esculturas e os monumentos públicos. Um dos integrantes do grupo, já dando o tom da notícia, teria ligado anonimamente para um jornalista e exclamado: "Por favor, mande urgente um médico aqui na praça, tem uma escultura que está com gripe, ela está toda coberta, coitada! Precisa levar ela para um hospital", conta Hudinilson Jr. (apud NICHELLE, 2010, p. 109 $)^{588}$. O Ensacamento tornou-se então um fato jornalístico, assumindo as mais diversas versões. O jornal Notícias Populares chegou a levantar a hipótese de que aquilo fosse algum tipo de manifestação dos coletores de lixo da cidade que, coincidentemente, na mesma noite em que o 3NÓs3 realizou sua ação, haviam entrado em greve. O periódico fez então uma associação entre o

\footnotetext{
586 “Sacos de lixo, e o cotidiano mudou”. Última Hora, 28 abr. 1979, p. 2.

587 “No centro da cidade, estátuas encapuzadas”. Folha da Tarde, 28 abr. 1979, p. 12.

${ }^{588}$ Depoimento de Hudinilson Jr. a Aracéli Cecília Nichelle, em 1 fev. 2010.
} 
centro da capital, que "está mesmo um lixo", e as estátuas cobertas com sacos de lixo ${ }^{589}$. Em dois boxes separados, na mesma página, ambos os eventos são publicados lado a lado, um deles estampando a imagem de vários montes de lixo largados em uma rua no centro da cidade, e o outro ilustrado com uma fotografia de uma das estátuas cobertas com sacos pretos. Mario Ramiro explica que os primeiros contatos com a mídia foram feitos com jornalistas da seção cidades e não dos cadernos de artes e, por conta disso, não houve especulação de que a intervenção fosse artística (apud NICHELLE, 2010) ${ }^{590}$.

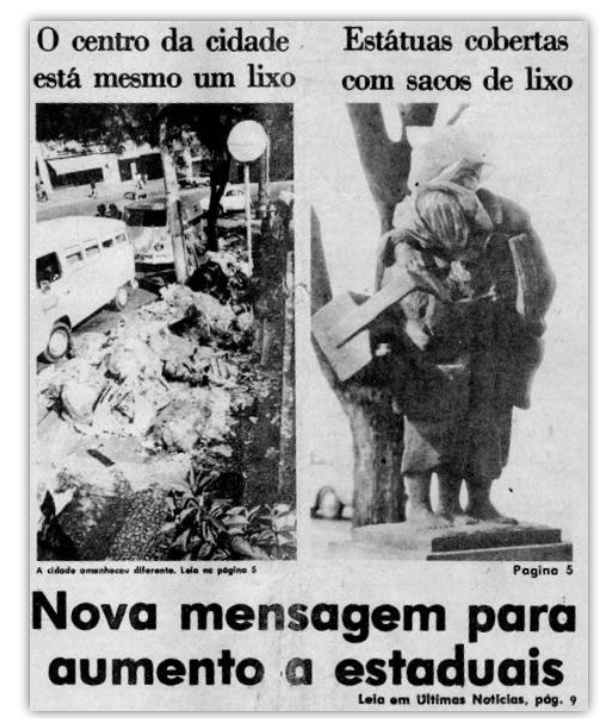

Figura 3.45 - Montes de lixo e estátuas cobertas com sacos de lixo no jornal Notícias Populares. Fonte: Notícias Populares, 28 abr. 1979, p. 5.

Entre as 68 estátuas ensacadas estava também o Anhanguera, de Luigi Brizzolara, cuja cabeça foi coberta pouco antes de o mesmo ocorrer com os bandeirantes esculpidos por Brecheret. " $\mathrm{O}$ primeiro monumento a ser encapuzado foi o Monumento à Independência, no Ipiranga, depois nos dirigimos para a avenida Paulista, onde tem a escultura Anbanguera, em seguida descemos para o Ibirapuera em direção ao Monumento às bandeiras, e depois para o centro da cidade”, explica Hudinilson $\mathrm{Jr}^{591}$. Percurso que lembra outros já percorridos nesta tese. O roteiro foi pensado e posto em prática a partir daquilo que era "acessível à nossa escala de trabalho", justifica Mario

\footnotetext{
589 “Estátuas cobertas com sacos de lixo”. Notícias Populares, 28 abr. 1979, p. 5.

590 Depoimento de Mario Ramiro a Aracéli Cecília Nichelle, em 11 nov. 2009.

591 Depoimento de Hudinilson Jr., 9 ago. 1984. Arquivo Multimeios/ CCSP.
} 
Ramiro (apud PONTES, 2012, p. 108) ${ }^{592}$. Até o Monumento às bandeiras, o roteiro foi percorrido de carro, mas na sequência os integrantes do grupo caminharam pelo centro a pé (o motorista, colega deles, desistiu de acompanhá-los). Igualmente esculpido por Brecheret, "o Duque de Caxias [com seus mais de quarenta metros de altura] escapou", informa ironicamente o jornal Última Hora, ao chamar o "encapuzador" de "principiante" ${ }^{593}$. Outras obras, como a Mãe Preta, não foram ensacadas pois havia muitos policiais no seu entorno (NICHELLE, 2010).
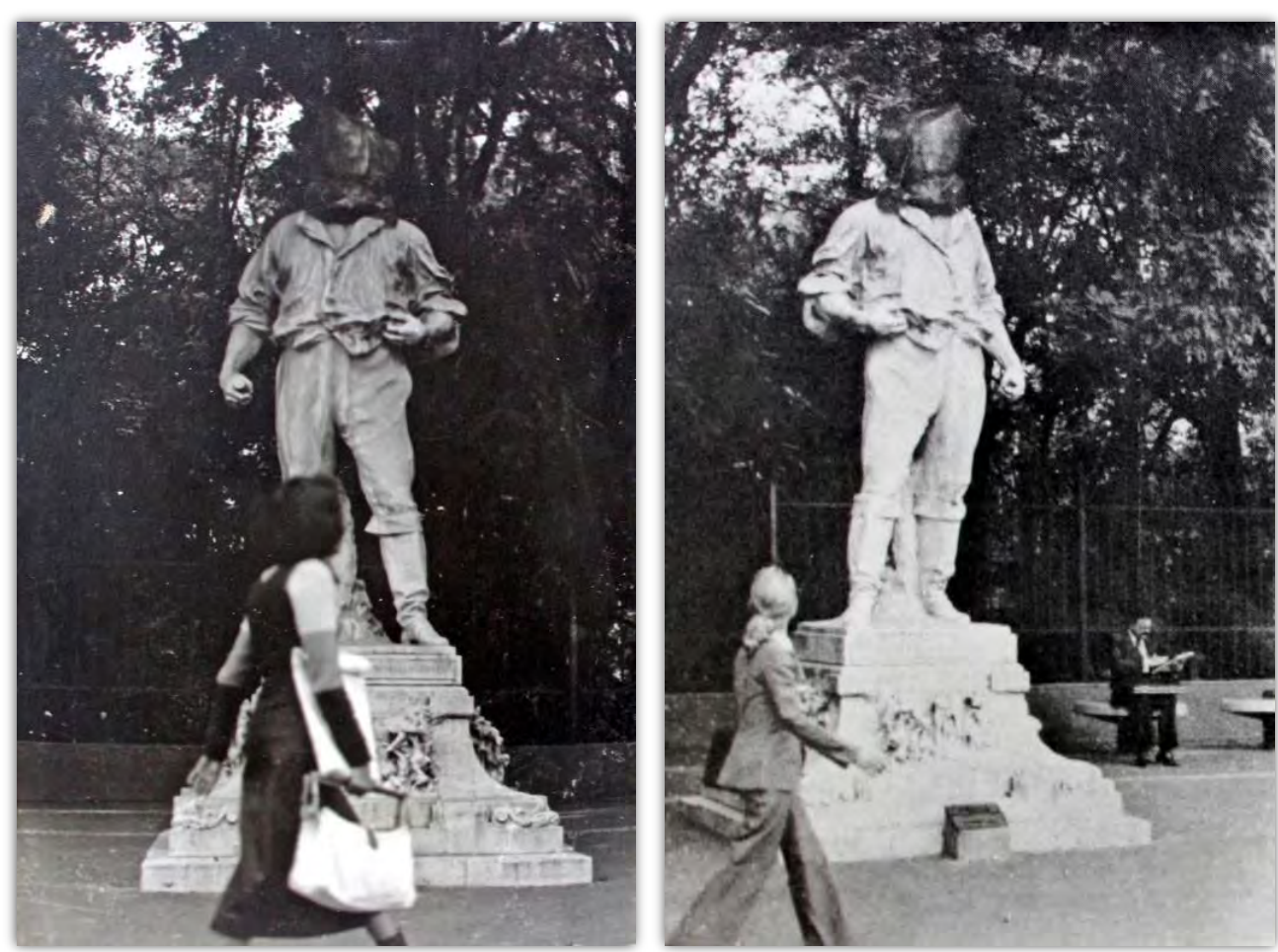

Figura 3.46 - Transeuntes observam a escultura Anhanguera ensacada, 1979. Fonte: Acervo Mario Ramiro | Foto: 3nós3.

As imagens do efêmero ensacamento do Monumento às bandeiras, assim como do Anhanguera e das demais obras, foram adquirindo certa autonomia enquanto produto impresso. Os registros fotográficos feitos pelo grupo e as notícias veiculadas na mídia deram origem ainda ao EncarteEnsacamento (1979), uma edição de artista, com tiragem de quinhentos exemplares, distribuídos pela rede de arte postal. Nesse período, explica Mario Ramiro, "tivemos um boom da arte postal, consequentemente as fotos se transformavam em xerox, colocava-se uma informação básica, fazia

\footnotetext{
592 Depoimento de Mario Ramiro a Maria Adelaide Pontes, em 31 jan. 2011.

593 “Sacos de lixo, e o cotidiano mudou”. Última hora, 28 abr. 1979, p. 2.
} 
um postal, e isso rodava o mundo" (apud MESQUITA, 2008, p. 354) 594 . Ao "rodar o mundo", o Encarte-Ensacamento chega também à XVI Bienal Internacional de São Paulo, no núcleo de arte postal, dois anos depois dos episódios em que as estátuas foram encapuzadas, período marcado pela redemocratização do país que culminou nas mobilizações pelas Diretas Já em 1984, mesmo ano em que irá circular um selo postal com uma fotografia do Monumento às bandeiras (ou melhor, dos dois cavaleiros, os "cabeças" da bandeira, o que parece enfatizar, mais uma vez, a ideia de uma convenção visual que toma o conjunto da obra por sua parte dianteira ${ }^{595}$ ).

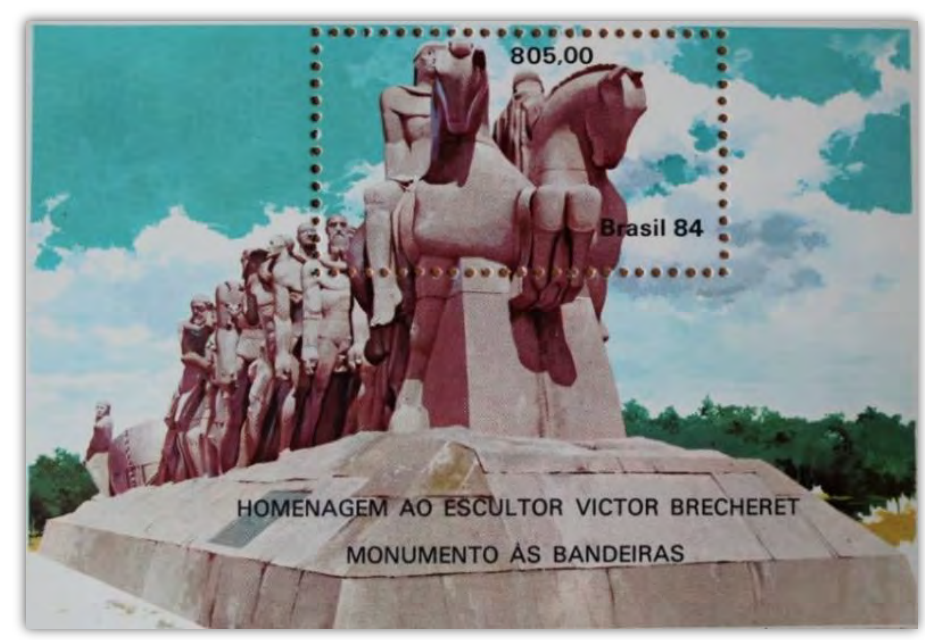

Figura 3.47 — Selo em homenagem a Victor Brecheret, 1984. Fonte: Acervo pessoal | Foto: Thaís Waldman.

Vale mencionar que, durante esse período de redemocratização — quando é também inaugurada a rodovia dos Bandeirantes ${ }^{596}$ —. Antônio Salim Curiati é nomeado prefeito em 1982,

${ }^{594}$ Depoimento de Mario Ramiro a André Mesquita, em 22 fev. 2006.

595 Notemos que essa associação entre os termos bandeirante e cabeça não é recente. Embora não haja nenhuma menção ao bandeirante no dicionário de Antônio de Moraes Silva, publicado em Lisboa em 1789, considerado um marco inicial da lexicografia em língua portuguesa, ao ser revisado e ampliado em sua segunda edição, de 1813, esse dicionário já então definia a bandeira (vocábulo que também não consta na primeira edição da obra) como "uma associação de homens que vão pelos sertões, debaixo de um cabeça, descobrir terra mineiras".

596 A rodovia dos Bandeirantes, que irá unir a capital a pontos do interior com seus 173 quilômetros de extensão, é inaugurada em 1978, pelo general-presidente Ernesto Geisel e pelo governador Paulo Egídio Martins. Se a via Anhanguera, que liga São Paulo à região norte do estado, tem sua primeira pista pavimentada inaugurada em 1948, atingindo sua capacidade máxima por volta de 1960, a rodovia dos Bandeirantes é construída visando justamente uma capacidade muito maior, como mencionado no capítulo anterior. Esse "sistema monumento" dará também nome a uma obra de Beto Shwafaty, Anhanguera/ Bandeirantes (2015), uma quimiogravura em baixo relevo que associa a imagem da estátua feita por Luigi Brizzolara nos anos 1920, Anhanguera, a imagem do Monumento comemorativo da rodovia dos Bandeirantes. Pude observar a obra de Shwafaty na exposição Empresa Colonial, mostra que ficou em cartaz 
pelo então governador Paulo Maluf (uma das autoridades presentes na criação da Oban), após Reynaldo de Barros se afastar da prefeitura para disputar a eleição para governador. Nessa ocasião, o Partido do Movimento Democrático Brasileiro (PMDB), o Partido Democrático Trabalhista (PDT) e o Partido dos Trabalhadores (PT) impetraram um mandado de segurança contra sua nomeação, mas este foi logo cassado pelo tribunal. Salim Curiati permaneceu à frente da prefeitura até 1983, tomando como logotipo de sua administração a imagem do Monumento às bandeiras ${ }^{597}$.

Quase uma década depois, durante o primeiro governo do PT na prefeitura de São Paulo, a imagem do mesmo monumento irá inspirar o logotipo da gestão de Luiza Erundina (1989-1992), junto a um slogan que havia sido usado no governo de Reynaldo de Barros (1979-1982), fato que chamou a atenção do jornal $O$ Estado de S. Paulo. "PT usa slogans de prefeitos malufistas para divulgar obras", denuncia a reportagem desde seu título, ao apontar que o Monumento às bandeiras e a frase "São Paulo para todos" já haviam sido utilizados pelos últimos dois prefeitos biônicos nomeados por Maluf no final do regime militar ${ }^{598}$. Paradoxalmente, o Monumento às bandeiras é tomado como símbolo tanto pela ditadura quanto por governos de orientação democrática, o que revela a complexidade da obra de Brecheret, apropriada para fins e interesses muito diversos.

O logotipo petista foi feito pelo artista plástico João Baptista da Costa Aguiar (1948-2017), que recebeu de Ermínia Maricato, secretária da Habitação da cidade de São Paulo, a tarefa de desenvolver uma marca para a prefeitura. "Procurei no Monumento às bandeiras, que é um esforço coletivo, dar, ao individualizar um personagem, um sentido de cidadania”, explica o artista à reportagem. Partindo da ideia de totalidade defendida por Brecheret, Costa Aguiar opta pela modificação de uma convenção, ao focar em um dos indígenas que penosamente arrasta a canoa das monções, escolha que pode indicar um importante deslocamento de interesses. Nesse sentido, é possível dizer que, enquanto a administração de Salim Curiati reproduz uma imagem convencional da obra, a gestão de Luiza Erundina escolhe um dos personagens em pedra da parte posterior do monumento. Quanto à frase "São Paulo para todos", segundo Costa Aguiar, ela lhe

entre 2015 e 2016 na Caixa Cultural da Sé, refletindo justamente sobre as correlações entre o período colonial, a ditadura militar e a atualidade, cf. o catálogo organizado por Toledo (2016).

${ }^{597}$ Em 2007, Antônio Salim Curiati (PPB) recebeu da Fundação Brecheret uma reprodução do Monumento às bandeiras feita em miniatura pelo artista Alexandre Leonardo Neto para ser entregue oficialmente às autoridades estrangeiras em visita ao estado de São Paulo. A homenagem foi feita pelo presidente da Assembleia, deputado José Carlos Vaz de Lima (PSDB). O ato contou com a presença do prefeito da capital, Gilberto Kassab (DEM), que também recebeu uma réplica da obra. Disponível em: <https://www.al.sp.gov.br/noticia/?id=275437>. Acesso em: 20 out. 2017.

598 “PT usa slogans de prefeitos malufistas para divulgar obras”. O Estado de S. Paulo, 9 out. 1990, p. 22. 
foi entregue pronta por Maricato que, ao ser indagada a respeito da escolha de um slogan utilizado por Reynaldo de Barros, teria afirmado que esse era um fato "insignificante" ${ }^{599}$.

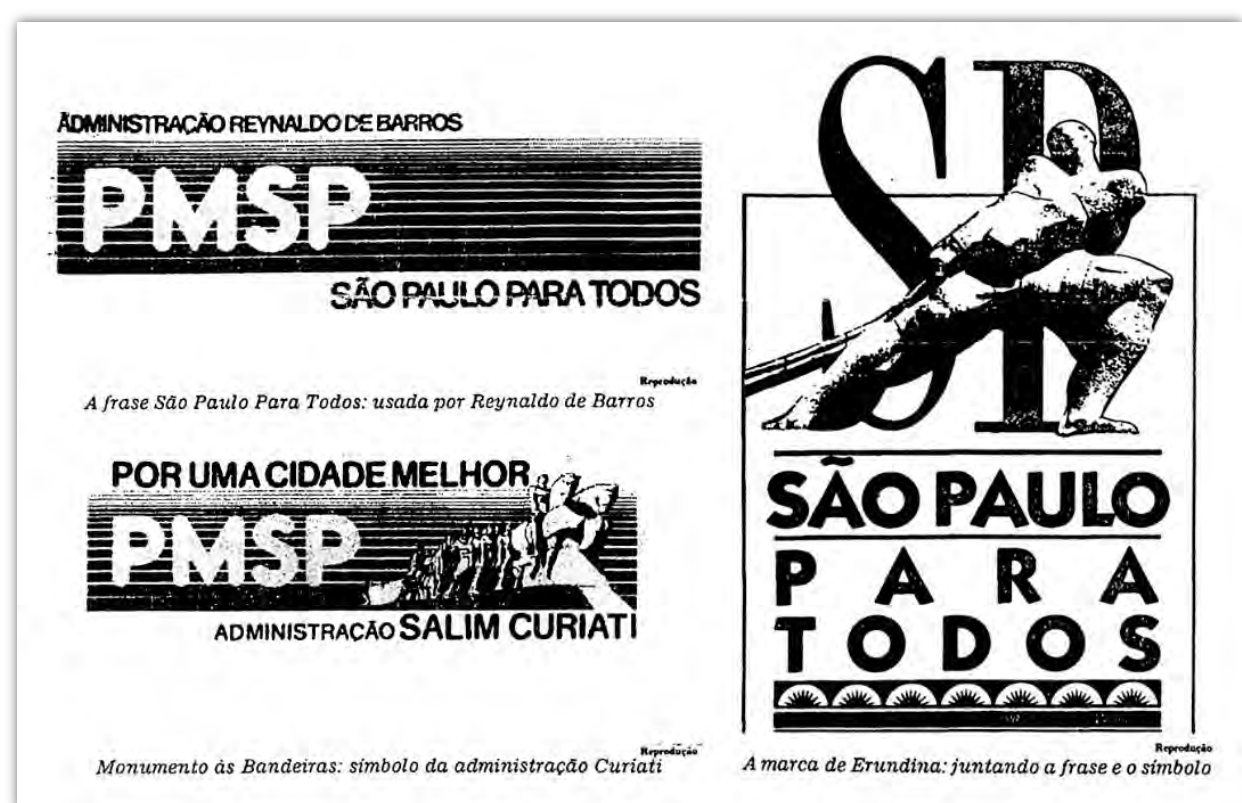

Figura 3.48 - Logotipos da prefeitura de São Paulo nas gestões Reynaldo de Barros, Salim Curiati e Luiza Erundina.

Fonte: O Estado de S. Paulo, 9 out. 1990, p. 22.

A imagem dos personagens esculpidos por Brecheret também irá ilustrar a capa e a contracapa do Plano Diretor de São Paulo: ao alcance de todos (1991), elaborado durante a gestão de Luiza Erundina, sob a coordenação de Paul Singer e Raquel Rolnik. Trata-se de uma obra, segundo o texto de apresentação publicado na contracapa do Plano Diretor de São Paulo, escrita "numa linguagem simples para que todos possam participar do Plano e da transformação da cidade". Tal como no logotipo da prefeitura petista, na capa do livro as figuras retratadas não são os dois "cabeças" da bandeira, mas os indígenas, negros e imigrantes por eles liderados. Os cavaleiros, no entanto, não são deixados de lado, já que na contracapa o monumento é apresentado a partir de uma imagem convencional de sua dianteira. Desse modo, o Plano Diretor parece querer explorar todos os seguimentos do monumento, com o objetivo de chegar não mais a novos territórios, mas "ao alcance de todos", referindo-se à população da cidade.

\footnotetext{
599 “O seu jornal está perdendo tempo com essa reportagem, pois esse é um fato insignificante”, teria dito Ermínia Maricato ao argumentar, na mesma matéria, que "a frase 'São Paulo para todos', de Erundina, nada tem a ver com a frase 'São Paulo para todos' de Reynaldo de Barros", pois na administração PT "é para todos mesmo", e "no tempo de Reynaldo era diferente", conclui a secretária. Cf. "PT usa slogans de prefeitos malufistas para divulgar obras". O Estado de S. Paulo, 9 out. 1990, p. 22.
} 

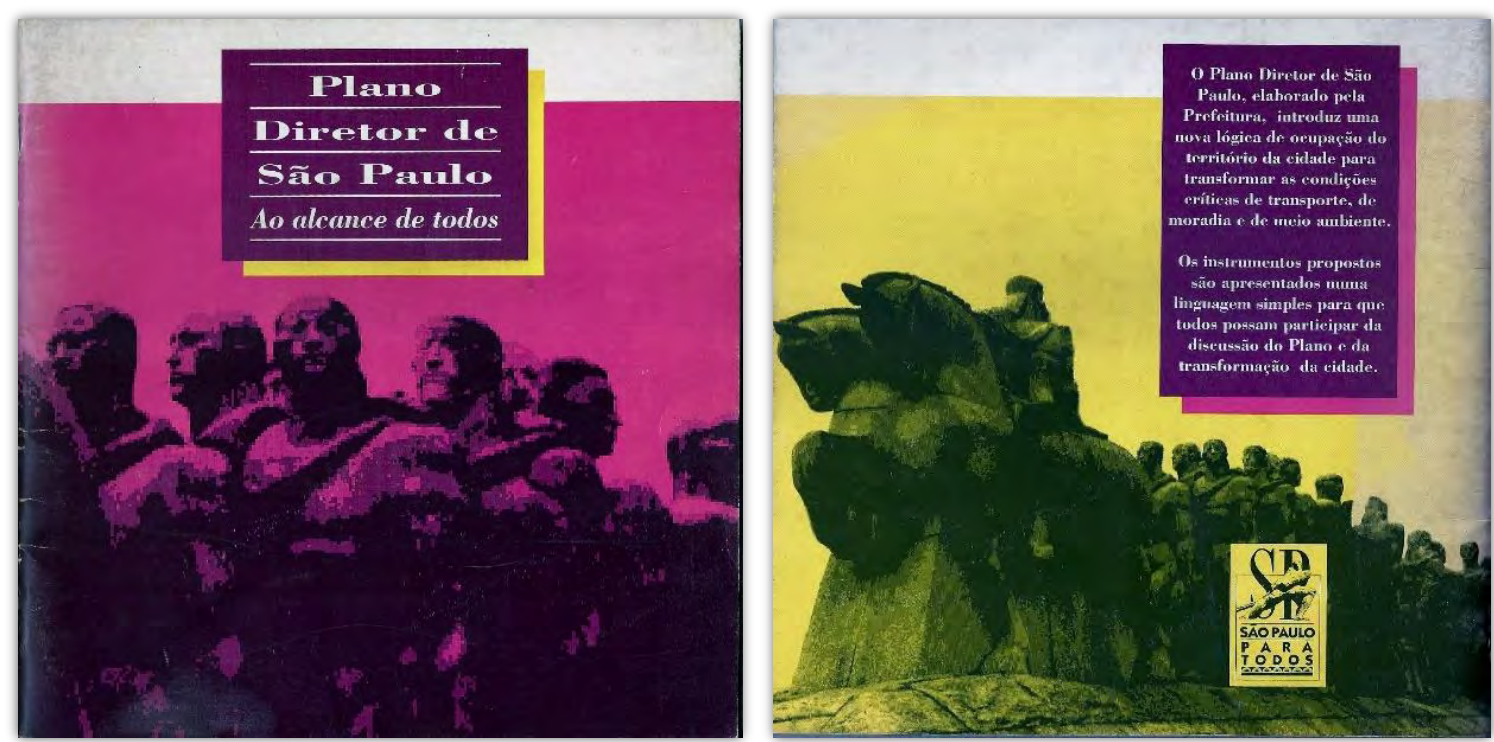

Figura 3.49 - Capa e contracapa do Plano Diretor de São Paulo: ao alcance de todos (1991). Fonte: Acervo pessoal | Foto: Thaís Waldman.

\subsubsection{Quando a pedra sangrou}

Quase cem anos depois de o Monumento às bandeiras ser idealizado, temos uma articulação entre povos indígenas brasileiros e diversas organizações e movimentos sociais que ganha reconhecimento em outubro de 2013, com a Semana Nacional de Mobilização Indígena, convocada pela Articulação dos Povos Indígenas do Brasil (Apib), durante o governo de Dilma Rousseff $(\mathrm{PT})^{600}$. Nessa ocasião, momento em que a constituição celebrava 25 anos de existência, as cabeças de muitas das figuras esculpidas por Victor Brecheret foram cobertas por tinta vermelha ${ }^{601}$. “Ocupado por nossos guerreiros xondaro, por nossas mulheres e crianças, esse novo monumento tornou viva a bonita e sofrida história de nosso povo, dando um grito a todos que queiram ouvir:

${ }^{600}$ A Semana Nacional de Mobilização Indígena surgiu como uma resposta à inação do Executivo quanto à demarcação das terras indígenas, às proposições do Legislativo que restringiam os direitos indígenas e à tese do "marco temporal' que tem sido aplicada pelo Judiciário anulando processos de demarcação, ver Ricardo \& Ricardo (2017).

${ }^{601} \mathrm{Em}$ um texto inspirador sobre um dos monumentos mais protegidos e inacessíveis do Rio de Janeiro, Emerson Giumbelli analisa a pichação, em 2010, do Cristo Redentor, quando os jornais informaram que, segundo os policiais que se infiltraram entre os pichadores, "alcançar a face da estátua" foi considerada uma "verdadeira proeza" (GIUMBELLI, 2013, p. 9). O autor retoma assim a ideia de "desfiguração", que dá título ao livro de Michel Taussig (1999), ao tomar como referência o corpo humano e o lugar proeminente que atribuímos à cabeça. 
que cesse de uma vez por todas o derramamento de sangue indígena no país!”, explica o guarani mbya Marcos Tupã $\tilde{c}^{02}$.

A manifestação começou quando cerca de 1,2 mil indígenas e quilombolas residentes no estado "encabeçaram a marcha", que saiu da avenida Paulista, de acordo com a Rede Brasil Atual" No caminho, entoando a palavra de ordem “Assassino! Assassino!”, os manifestantes cobriram a estátua Anhanguera com um tecido preto com grafismos indígenas ${ }^{604}$.
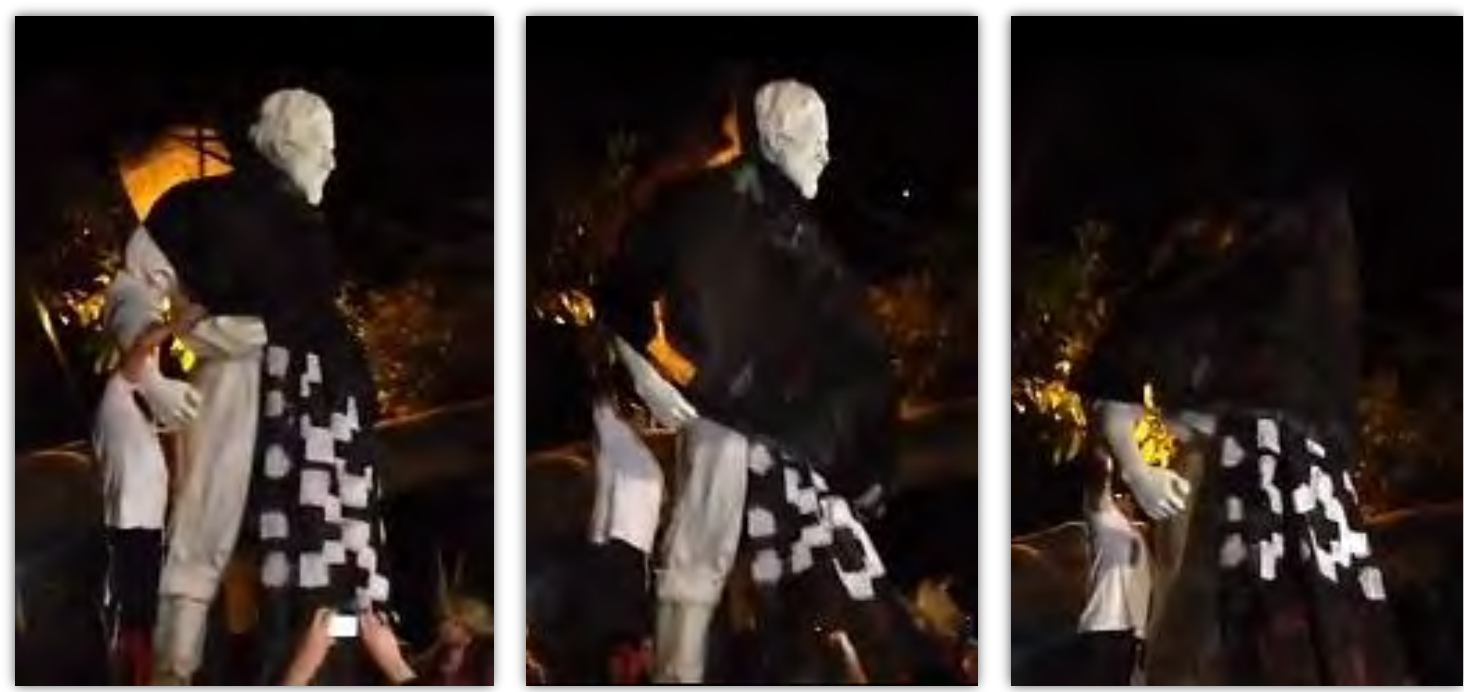

Figura 3.50 - Anhanguera é coberto com um tecido preto, avenida Paulista, 2013. Fonte: G1605.

Poucos dias antes, lembrando que a Terra Indígena do Jaraguá está localizada entre as atuais rodovias Anhanguera e dos Bandeirantes, os guarani já haviam interrompido o trânsito naquela

${ }^{602}$ Carta aberta de Marcos Tupã divulgada em 2013 durante a Mobilização Nacional Indígena. Disponível em: $<$ https://trabalhoindigenista.org.br/monumento-a-resistencia-do-povo-guarani/>. Acesso em: 23. out. 2017. Em 2016, a prática do xondaro - "movimento, dança, jogo, mas antes de tudo modo de vida e de luta que o povo guarani mbya tem aprimorado ao longo de séculos de convívio com os juruás, os 'brancos" — inspirou uma série de onze intervenções urbanas realizadas pela Cia Nova Dança na cidade de São Paulo, uma delas realizada no Monumento às bandeiras. Um caderno virtual dessas intervenções pode ser acessado no site do grupo. Disponível em: <http://ciaoitonovadanca.com.br/>. Acesso em: 23 out. 2017. Xondaro é também o nome de um livro em quadrinhos publicado em 2016, pelo quadrinista Victor Paciornik, que retrata, entre outras coisas, o dia em que os guarani tomaram o Monumento àa bandeiras em 2013. Sobre o xondaro, cf. também Keese (2017).

${ }^{603}$ Disponível em: < http://www.redebrasilatual.com.br/cidadania/2013/10/mobilizacao-chega-a-sp-com-marcha-de-guaranis-pelaavenida-paulista-7008.html>. Acesso em: 24 out. 2017.

${ }^{604}$ Disponível em: <https://www.socioambiental.org/pt-br/noticias-socioambientais/marcha-pelos-direitosindigenas-e-quilombolas-reune-cerca-de-mil-pessoas-na-av-paulista >. Acesso em: 24 out. 2017.

${ }^{605}$ Disponível em: <http://g1.globo.com/sao-paulo/noticia/2013/10/manifestantes-jogam-tinta-vermelha-nomonumento-bandeiras.html>. Acesso em: 24 out. 2017. 
região ${ }^{606}$. No trajeto da Paulista até o Ibirapuera, não faltaram faixas com os dizeres "Guarani resiste" e "Demarcação já", além de folhetos, distribuídos ao longo da marcha, com a inscrição "Os ruralistas de hoje são os bandeirantes de ontem"607. No final da passeata, alguns indígenas (segurando faixas, cartazes e um exemplar da constituição promulgada em 1988) tomaram a obra de Victor Brecheret, transformando-a no Monumento à resistência guarani.

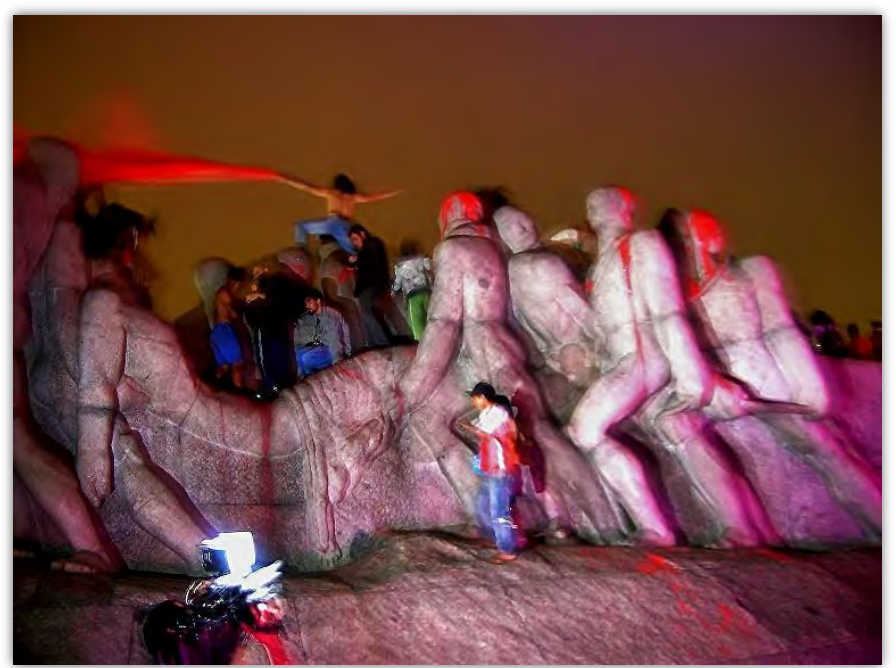

Figura 3.51 - Monumento às bandeiras se transforma no Monumento à resistência guarani, 2013. Fonte: $\mathrm{O}$ palco e mundo ${ }^{608}$.

Foi "um dia intenso para o Monumento às bandeiras", revelava desde seu título uma matéria publicada em O Estado de S. Paulo ${ }^{609}$. Enquanto hasteavam um grande pano vermelho — que remete ao "sangue dos nossos antepassados, derramado pelos bandeirantes", nos termos de Marcos Tupã ${ }^{610}$-, alguns apoiadores da pauta indígena jogaram tinta vermelha nas figuras esculpidas em granito. O filho do escultor aproveitou a ocasião para contar que seu pai sempre teve orgulho da "solidez" da sua obra e "costumava brincar que, mesmo que caísse uma bomba atômica em São

${ }^{606}$ Disponível em: < https://mobilizacaonacionalindigena.wordpress.com/2013/09/26/indios-guarani-fechamrodovia-dos-bandeirantes-em-sao-paulo/>. Acesso em: 24 out. 2017.

${ }^{607}$ A plataforma online Mapa Guarani Digital (<http://guarani.map.as/\#!/>) disponibiliza dados sobre a situação fundiária e a localização das aldeias guarani no Brasil, além de informações georreferenciadas sobre antigas ocupações (das quais os indígenas foram expulsos) e sobre os sítios arqueológicos de tradição tupi-guarani.

608 Disponível em: < http://opalcoeomundo.blogspot.com.br/2013/10/a-mobilizacao-nacional-indigena-em-sao.html>. Acesso em: 24 out. 2017.

609 Disponível em: <http://sao-paulo.estadao.com.br/blogs/edison-veiga/duas-entrevistas-o-filho-de-brecheret-e-o-pichador-domonumento-as-bandeiras/>. Acesso em: 23 out. 2017.

${ }^{610}$ Disponível em: <https://trabalhoindigenista.org.br/monumento-a-resistencia-do-povo-guarani/>. Acesso em: 23 out. 2017. 
Paulo, ela permaneceria intacta" ${ }^{611}$. Naquele dia, no entanto, nos termos de Tupã, longe de sair ileso o Monumento às bandeiras literalmente "sangrou" 112.

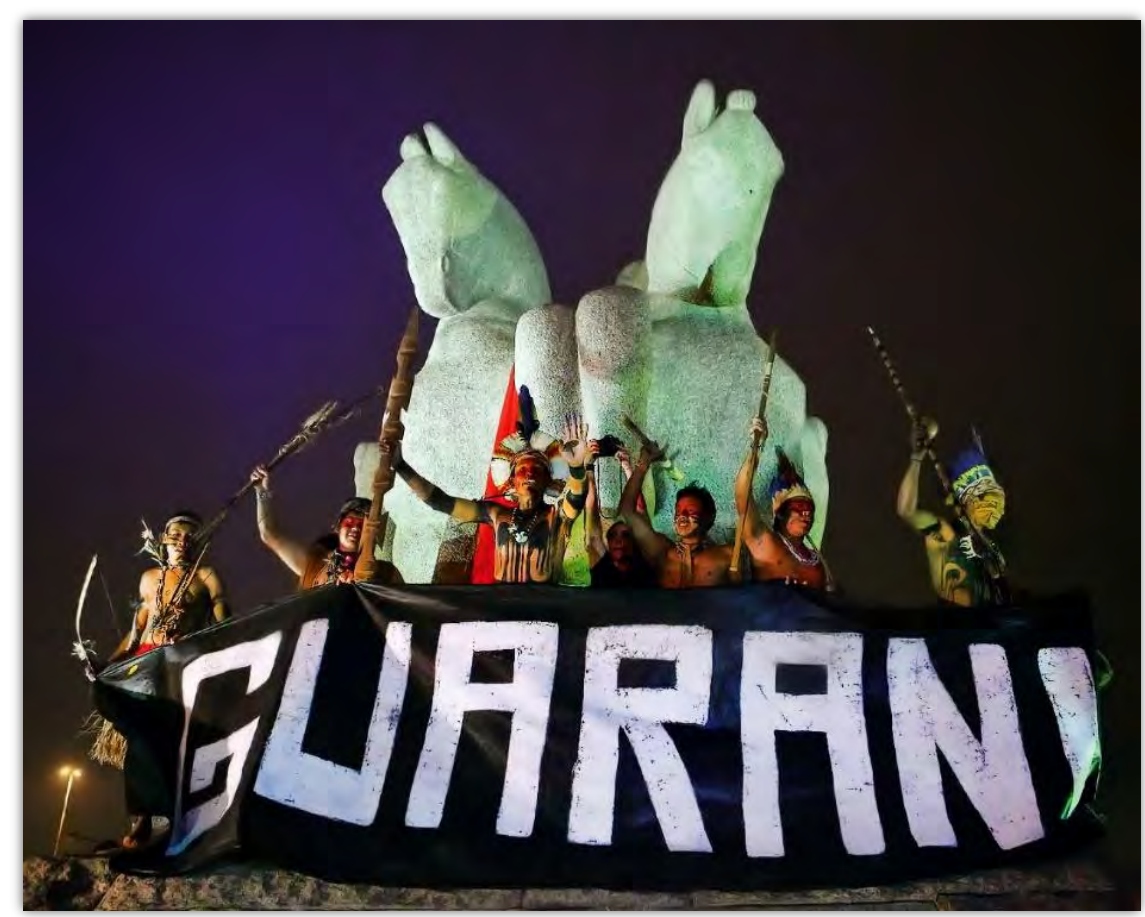

Figura 3.52 - Indígenas ocupam o Monumento às bandeiras, 2013. Fonte: Página do Facebook de Ian Packer | Foto: Ian Paker ${ }^{613}$.

"Para nós [povos indígenas], arte é outra coisa. Ela não serve para contemplar pedras, mas para transformar corpos e espíritos. Para nós, arte é o corpo transformado em vida e liberdade e foi isso que se realizou nessa intervenção", explica Marcos Tupã ${ }^{614}$. O Pixo Manifesto Escrito grupo de pichadores que realiza ataques políticos nos muros e ruas de São Paulo e abraçou a causa por ser contra "tudo que oprime a quebrada" inscrevendo na sua dianteira os dizeres "PEC 215 não" e "Bandeirantes assassinos". O objetivo do ato, segundo um dos pichadores, era chamar a atenção da imprensa sobre o tema. Assim como

611 Disponível em: <http://sao-paulo.estadao.com.br/blogs/edison-veiga/duas-entrevistas-o-filho-de-brecheret-e-o-pichador-domonumento-as-bandeiras/>. Acesso em: 23 out. 2017.

${ }^{612}$ Disponível em: < https://trabalhoindigenista.org.br/monumento-a-resistencia-do-povo-guarani/>. Acesso em: 23 out. 2017.

613 Disponível em: <https://www.facebook.com/ian.packer.92/photos>. Acesso em: 23 out. 2017.

${ }^{614}$ Disponível em: <https:/ /trabalhoindigenista.org.br/monumento-a-resistencia-do-povo-guarani/>. Acesso em: 23 out. 2017.

615 Disponível em: <http://vaidape.com.br/2017/05/conheca-o-pme-o-grupo-de-pixadores-que-organiza-ataques-politicos/> . Acesso em: 24 out. 2017. 
ocorreu, no final dos anos 1970, com o Ensacamento do 3nós3, fotografias do Monumento à resistência guarani ocuparam também a grande mídia.
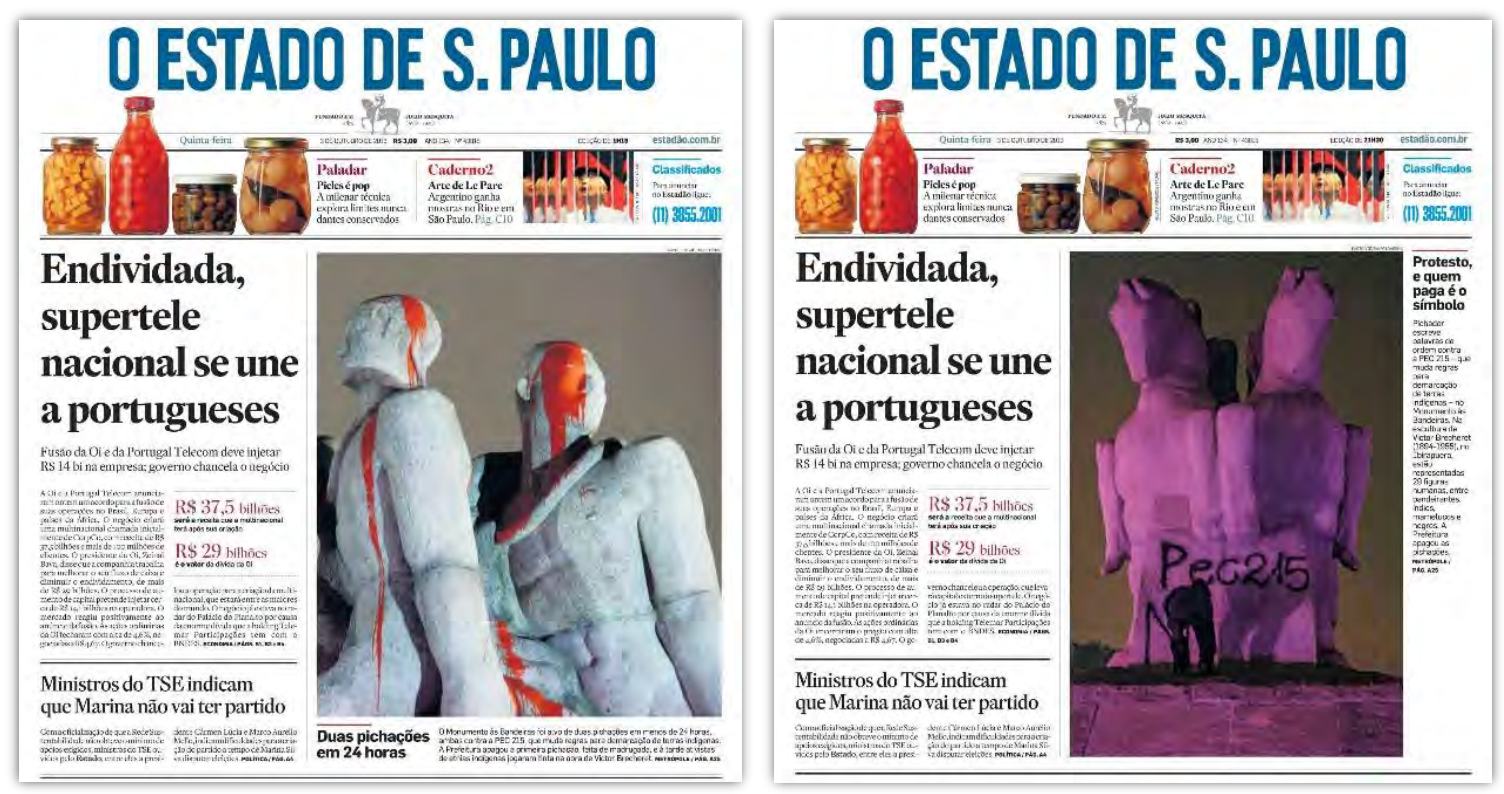

Figura 3.53 - Duas diagramações da mesma capa de $O$ Estado de $S$. Paulo.

Fonte: O Estado de S. Paulo, 3 out. 2013, p. 1.

As reações às pichações e à tinta vermelha jogada no monumento, apesar dos contextos distintos, lembram muito aquelas que vimos na introdução desta tese, quando às vésperas das últimas eleições municipais de São Paulo, em 2016, o Monumento às bandeiras e o Borba Gato amanheceram cobertos de tinta látex ${ }^{616}$. "Estamos vivendo um período de pré-barbárie", dirá Victor Brecheret Filho ${ }^{617}$; enquanto a diretora do Departamento do Patrimônio Histórico (DPH), Nadia Somekh, alerta que as tintas utilizadas nos protestos muitas vezes demandam solventes especiais, o que pode deteriorar o patrimônio público ${ }^{618}$. Marcos Tupã, por sua vez, indaga

${ }^{616}$ Poucas semanas antes das últimas eleições municipais, Benjamin Moser veio ao Brasil lançar seu último livro, Autoimperialismo (2016), composto por três ensaios sobre o país, um deles justamente sobre as esculturas bandeirantes, que tanto lhe chamaram atenção em suas viagens à capital paulista. O historiador norte americano as compara a atores amadores, imóveis e impotentes. Ignoradas pela cidade, no máximo, afirma Moser (alheio a potência dessas obras), elas seriam desdenhadas pelos cidadãos paulistas.

${ }^{617} \mathrm{O}$ filho do escultor sugere ainda a instalação de um detector de passagem no Monumento às bandeiras, com um feixe de luz capaz de acionar uma sirene. Disponível em: <http://sao-paulo.estadao.com.br/blogs/edison-veiga/duas-entrevistaso-filho-de-brecheret-e-o-pichador-do-monumento-as-bandeiras/>. Acesso em: 23 out. 2017.

618 "Limpeza do Monumento às bandeiras levará uma semana". O Estado de S. Paulo. 4 out. 2013, p. 15. Duas intervenções foram bastante lembradas pela mídia quando o Monumento às bandeiras foi pintado de vermelho: uma delas ocorrera no ano anterior, quando as unhas de um dos personagens esculpidos no monumento amanheceram pintadas com 
indignado: "Que tipo de sociedade realiza tributos a genocidas diante de seus sobreviventes? Apenas aquelas que continuam a praticá-lo no presente"; foi somente ao dar voz à "parcela originária da sociedade brasileira", dirá ainda ele, que a obra se tornou um verdadeiro patrimônio público ${ }^{619}$.

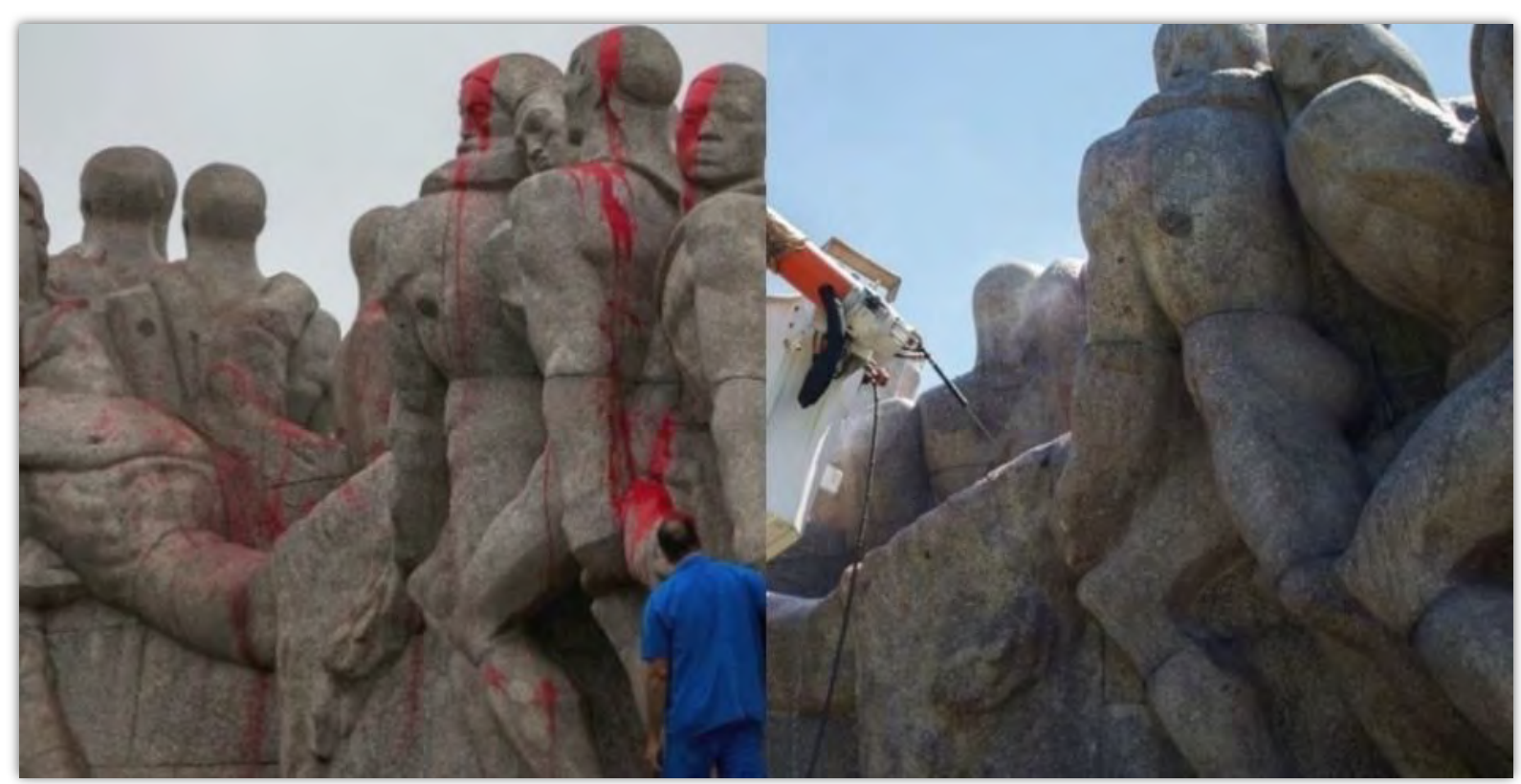

Figura 3.54 - Limpeza do Monumento às bandeiras.

Fonte: UOL Notícias ${ }^{620}$. Crédito fotográfico: Paulo Whitaker/Reuters.

"As imagens publicadas nos jornais falam por si só: com esse gesto, eles nos ajudaram a transformar o corpo dessa obra ao menos por um dia”, defende Marcos Tupã, para quem “a pintura não é uma agressão ao corpo, mas uma forma de transformá-lo”621. Após a limpeza, o Monumento às bandeiras não apenas "voltou a pintar como heróis os genocidas do nosso povo", conforme constata Tupã ${ }^{222}$, como ganhou novas camadas que, inclusive, lhe dão consistência biográfica.

tinta azul; a outra, no começo do ano de 2013, logo depois da morte do vocalista da banda Charlie Brown Jr., quando a obra amanheceu pichada em uma homenagem a ele.

${ }^{619}$ Disponível em: < https://trabalhoindigenista.org.br/monumento-a-resistencia-do-povo-guarani/ > . Acesso em: 23 out. 2017.

${ }^{620}$ Disponível em: < https://noticias.uol.com.br/album/2013/10/03/monumento-das-bandeiras-e-pichado-e-sujo-por-tintas.htm> . Acesso em: 24 out. 2017.

${ }^{621}$ Disponível em: <https://trabalhoindigenista.org.br/monumento-a-resistencia-do-povo-guarani/>. Acesso em: 23 out. 2017. Notemos que o próprio termo "desfiguração" é dicionarizado na última edição do diconário Honaiss como sinônimo de "alteração do aspecto exterior; transformação".

${ }^{622}$ Disponível em: < https://trabalhoindigenista.org.br/monumento-a-resistencia-do-povo-guarani/> Acesso em: 23 out. 2017. 


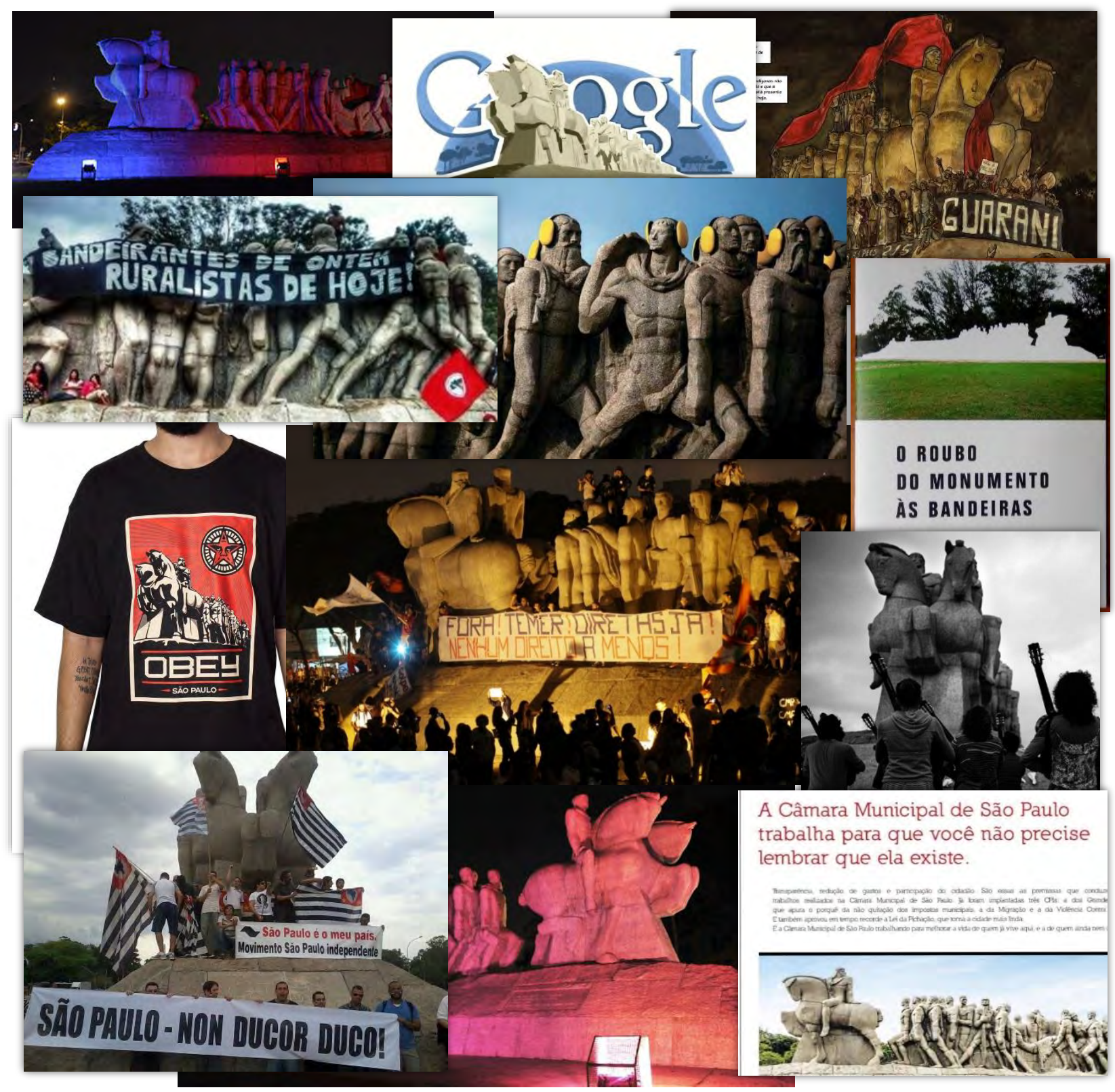

Figura 3.55 - Imagens e multiplicação de sentidos visuais, 2013/2017. Fonte: Acervo pessoal | Foto: Thaís Waldman.

Tenha sido em uma propaganda da empresa multinacional Google em homenagem ao $119^{\circ}$ aniversário de Victor Brecheret ${ }^{623}$; em um manifesto antirruralista ("Bandeirantes de ontem, ruralistas de hoje!’) organizado pelo Movimento dos Trabalhadores Rurais Sem Terra (MST) ${ }^{624}$; na

${ }^{623}$ Disponível em: <https://www.google.com/doodles/victor-brecherets-119th-birthday>. Acesso em: 25 out. 2017.

${ }^{624}$ Disponível em: <http://www.redebrasilatual.com.br/cidadania/2014/06/indios-fazem-novo-protesto-contra-pec-dos-ruralistassobre-demarcacoes-1960.html>. Acesso em: 25 out. 2017. 
obra do quadrinista Vitor Paciornik, Xondaro, uma história em quadrinhos sobre a luta dos guarani em São Paulo ${ }^{625}$; em uma homenagem às vítimas de um atentado terrorista em Paris, que matou mais de 120 pessoas ${ }^{626}$; em uma manifestação separatista a favor da independência de São Paulo (“São Paulo é meu país, movimento São Paulo independente”) 627; em uma intervenção urbana da Cia. Oito Nova Dança, chamada Esquiva ${ }^{228}$; em uma campanha de conscientização pela prevenção do câncer de mama, o "Outubro Rosa" ${ }^{229}$; em protestos contra o peemedebista Michel Temer (Fora! Temer! Diretas já! Nenhum direito a menos!) ${ }^{630}$; em um livro de Guto Lacaz, O roubo do monumento às bandeiras ${ }^{631}$; em uma camiseta da Obey, marca fundada por Shepard Fairey, criador dos famosos pôsteres de Barack Obama, quando candidato à presidência dos Estados Unidos ${ }^{632}$; em uma propaganda da Câmara Municipal de São Paulo633; ou em um ato organizado pela Associação Brasileira para a Qualidade Acústica, concebido com o objetivo de conscientizar a população sobre o ruído e seus efeitos na saúde, qualidade de vida e meio ambiente ${ }^{634}$ (isso sem falar no dia em que o monumento amanheceu colorido durante a última eleição municipal); os usos do Monumento às bandeiras e de sua imagem foram os mais variados e seguem se multiplicando desde que a pedra sangrou, como mostram as imagens acima.

Ainda que, nos termos de Marcos Tupã, a pedra de granito tenha sangrado por apenas um dia (a prefeitura agiu prontamente e logo removeu a tinta colorida e a pichação), a desfiguração do

${ }^{625}$ Disponível em: < https://www.nexojornal.com.br/entrevista/2017/01/13/Xondaro-a-luta-dos-Guarani-de-S\%C3\%A3o-Pauloem-quadrinhos>. Acesso em: 25 out. 2017.

626 Disponível em: <https://vejasp.abril.com.br/blog/pop/alguma-coisa-esta-fora-da-ordem-na-iluminacaofrancesa-do-monumento-as-bandeiras/>. Acesso em: 25 out. 2017.

${ }_{627}$ Disponível em: <https://www.facebook.com/pg/MSPIreal/photos/>. Acesso em: 25 out. 2017.

${ }^{628}$ Disponível em: <http://ciaoitonovadanca.com.br/intervencao-urbana-esquiva/>. Acesso em: 25 out. 2017.

${ }^{629}$ Disponível em: <https://noticias.bol.uol.com.br/fotos/imagens-do-dia/2013/10/09/imagens-do-dia---9-deoutubro-de-2013.htm?fotoNav=63\#fotoNav=66>. Acesso em: 25 out. 2017.

${ }^{630}$ Disponível em: <https://brasil.elpais.com/brasil/2016/09/11/politica/1473608606_494272.html>. Acesso em: 25 out. 2017.

631 Disponível em: <https://glamurama.uol.com.br/galeria/guto-lacaz-lanca-livro-no-qual-o-monumento-asbandeiras-e-roubado/>. Acesso em: 25 out. 2017.

${ }^{632}$ Disponível em: <https://notthesamo.co/2015/12/19/maze-apresenta-segunda-colecao-em-parceria-com-obey/>. Acesso em: 25 out. 2017.

633 Revista da Câmara Municipal de São Paulo, n. 24, mar./jun. 2017, p. 42. Cabe lembrar que em 1969, quando a Câmara Municipal de São Paulo é transferida para o viaduto Jacareí, seu atual endereço, o artista Clóvis Graciano foi convidado pela para fazer alguns murais no salão nobre do local, pinturas que até hoje lá se encontram, exaltando os bandeirantes no órgão legislativo paulista.

634 Disponível em: <http://www.proacustica.org.br/publicacoes/artigos-sobre-acustica-e-temas-relacionados/inad-desperta-saopaulo-para-o-incomodo-do-barulho.html>. Acesso em: 23 out. 2017. 
Monumento às bandeiras trouxe novas possibilidades de sentido para uma obra em constante movimento. A noção de desfiguração - ela própria sempre acompanhada por um processo de refiguração (TAUSSIG, 1999) — nos permite, portanto, pensar a complexidade da memória produzida pelos monumentos, como o de Victor Brecheret, já que ela não apaga, mas amplia a agência dos objetos, revelando seu caráter socialmente construído, ou seja, sua qualidade de artefato. 


\section{CONSIDERAÇÕES FINAIS}

No início desta tese, vimos a imagem de um grupo de indígenas comemorando a derrubada do enorme Borba Gato esculpido por Júlio Guerra, e de diversos bandeirantes que pareciam sair de seu corpo, estampada em lambe-lambes que fotografei ao andar pelas ruas do centro da cidade de São Paulo no final de 2016. Imagem que reencontrei, um ano depois, quando comecei a escrever essas últimas linhas; coincidentemente, soube por um amigo ${ }^{635}$ da existência de outra escultura em homenagem ao mesmo bandeirante, ereta sobre um estreito pedestal assinado por De Sordi, próxima a um dos muros ainda ocupados pelo que restava dos lambe-lambes colados no ano anterior pelo Comitê Paulista de Solidariedade à Luta pelos Tapajós.

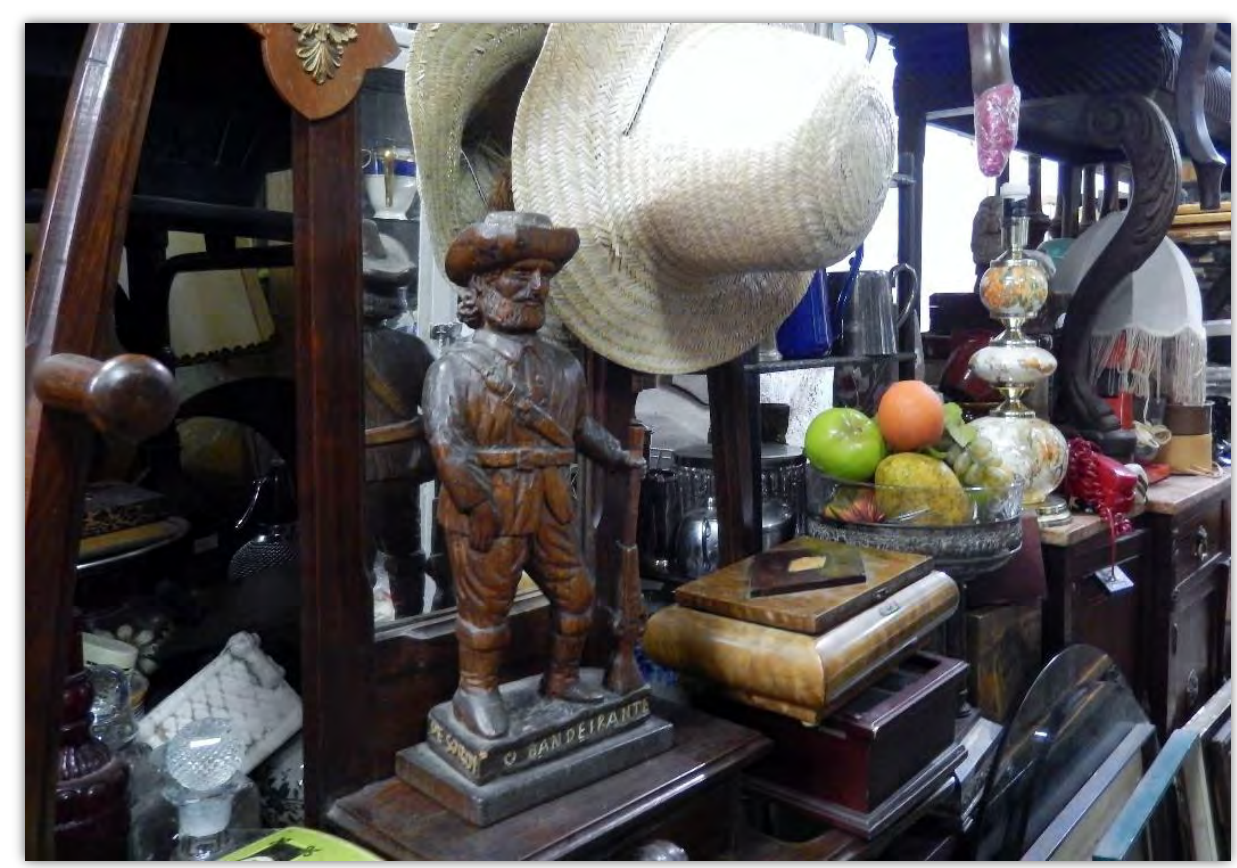

Figura 4.1 - Borba Gato, loja Brasil Antigo: móveis e objetos autênticos, 2017. Fonte: Acervo pessoal| Foto: Thaís Waldman.

635 Agradeço a Alexandre Araujo Bispo pela indicação dessa obra (e de tantas outras). 
Exibida discretamente entre quatro paredes, a estátua homônima estava rodeada por uma diversidade de peças, em cima de uma penteadeira, em um antiquário no bairro da Santa Cecília. O pequeno bandeirante com pose de rei (semelhante à imagem modelar de Domingos Jorge Velho e seu loco-tenente realizada pelo o pintor e historiador Benedito Calixto no início do século Xx), uma entre muitas obras à venda em uma loja chamada Brasil antigo, parecia ter sido esquecido no passado (e isso "tinha que acontecer", diria Flávio Cerqueira, remetendo ao título da cabeça decepada esculpida por ele em bronze nos anos 2010). Único bandeirante do antiquário (quase tão solitário quanto aquele retratado moribundo velado apenas por seu cão, doado na década de 1930 junto ao espólio de Henrique Bernardelli para o Museu Paulista, que dirigido à época por Afonso Taunay não expôs a obra), ele não recebia nenhum destaque em meio a uma variedade de objetos dispostos em móveis amontoados, embora seu pedestal indique se tratar de uma obra finalizada em 1953, um ano antes das comemorações do IV Centenário da cidade de São Paulo, contexto celebrativo no qual a exaltação da sua figura foi recorrente.

Medindo menos de meio metro de altura (pouco maior que o Monumento às bandeiras feito em 2016 por Jaime Lauriano com restos de cartuchos de munições sobre um pedestal de tijolo), o discreto Borba Gato pode ser visto nesse contexto como um contraponto à grandiosidade coletiva dos bandeirantes em granito de Victor Brecheret, inaugurados no Ibirapuera também em 1953. Nota-se ainda que, diferente das demais figuras acompanhadas nesta pesquisa, ele foi esculpido em madeira (material sujeito ao fogo, ao apodrecimento e aos ataques de cupim, como indica a canoa protegida desde os anos 1920 das intempéries dentro de um galpão no parque das Monções). Seu paradeiro anterior é desconhecido, segundo a administradora do estabelecimento localizado na rua São João (logradouro que poderia ser hoje chamado de avenida das Bandeiras, caso tivesse sido efetivada a alteração de seu nome cogitada nos anos 1930, período no qual a São João se destacava como uma das principais vias de circulação da "capital bandeirante", cujo epíteto a própria peça assinada por De Sordi, ao dar margem a usos e intenções contraditórios, irá problematizar). Por outro lado, se sua escultura parece estar perdida entre santos, mobílias e relíquias, a qualquer momento ela pode ser encontrada, comprada e inserida em ambientes diversos, como o domiciliar, incorporando assim outros significados e funções.

Idas e vindas como essas marcaram a escrita desta tese, que versou sobre uma série de movimentos que redefinem o bandeirante a todo momento, deslocando-se ela mesma entre planos e narrativas de naturezas diversos. Seus três capítulos - Desvios, Desterros e Desfigurações - se 
organizam de modo a qualificar os (des)caminhos propostos, sugerindo portas de entrada para uma cidade marcada, desde seus primórdios e até hoje, pela presença bandeirante. Criador e criatura de uma metrópole que ora o eleva e ora o derruba — ou as duas ações ao mesmo tempo —, o bandeirante não tem significados imutáveis. Ao longo de itinerários acidentados, o (re)encontrei em suportes e materiais que, apesar de distintos, se mostraram como elementos justapostos, ou camadas superpostas que se encobrem parcialmente umas às outras, deixando entrever aqui ou ali um terreno outro. Juntas, essas camadas, ou elementos, me permitiram flagrar múltiplos sentidos que constituem "os bandeirantes [que] ainda estão entre nós", como nos lembram os lambe-lambes espalhados por muros e postes da cidade.

No primeiro capítulo, tentei mostrar como os desvios são contemporâneos à imagem modelar elaborada do personagem. Para tanto, ingressei no Museu Paulista. Maior monumento erguido na cidade durante o Império, ele se transformou durante a gestão de Taunay (1917-1945) em um local também voltado à celebração da história de São Paulo. Além do então diretor da casa, acompanhei produções de artistas, políticos e historiadores do período, como: Benedito Calixto, Henrique Bernardelli, Rodolfo Amoedo, Capistrano de Abreu, Oscar Pereira da Silva, Luigi Brizzolara, Amadeo Zani, Wasth Rodrigues, José Ferraz de Almeida Júnior, Washington Luís, José de Alcântara Machado e Sérgio Buarque de Holanda. Brasileiros e estrangeiros, paulistas e cariocas, monarquistas e republicanos, eles mostraram não ser possível reduzir as disputas em torno dessas imagens e narrativas a simples oposições entre a monarquia e a república, entre o nacional e o estrangeiro, ou entre São Paulo e o Rio de Janeiro.

Percorrendo caminhos alternativos em um espaço (o museu) e em um período (a gestão Taunay) específicos, pude avistar, com a ajuda dos estudos existentes sobre essa instituição e seu acervo, a figura do bandeirante envelhecida e enferma, magra e maltrapilha, exausta e solitária, muitas vezes acompanhada por vigorosos indígenas que, em uma das imagens, o mata com uma flecha. Imagens que muitas vezes não foram concluídas; que algumas vezes foram concluídas, mas não aceitas; ou que não foram expostas. Vi- o também assassino em linha de combate e, ainda, caipira e monçoeiro esvaziados de heroísmo. Imagens que deram um jeito de se fazer presentes, permitindo entrever diferentes modos de pensar a história e de estar na história dentro de uma instituição que, erguida como um monumento para celebrar a separação entre Brasil e Portugal, se tornou também um local para celebrar a glória de São Paulo.

Essas imagens desviantes seguiram atravessando os demais itinerários deste trabalho após deixarmos a colina do Ipiranga para percorrer, entre tempos e espaços plurais, uma cidade marcada 
pela presença bandeirante. Fernão Dias Paes Leme, do escultor italiano Luigi Brizzolara, encomendado por Afonso Taunay para figurar no hall de entrada do Museu Paulista, me conduziu de início no segundo capítulo, no qual também acompanhei outras esculturas homônimas ou que cruzaram o seu caminho, e que simbólica ou literalmente perambularam pela cidade. Já o Monumento às bandeiras, do também italiano Victor Brecheret, obra que desde seu projeto original concentra e sobrepõe significações discordantes, foi quem me guiou no terceiro capítulo. Acompanhar essas flutuações e percursos trouxe à tona um personagem, mas também sujeitos e uma cidade em disputa que, de certa maneira, são construídos de forma concomitante, emprestando-se mutuamente traços e qualidades.

Os desterros acompanhados no segundo capítulo fizeram emergir uma multiplicidade de vozes para além das já mencionadas: Olavo Bilac e a Liga Nacionalista de São Paulo; o Movimento Terra Livre; o Centro Acadêmico XI de Agosto; a Associação Brasileira de Escoteiros; os estudantes secundaristas da Escola Estadual Fernão Dias Paes e os DJs MC Foice e Martelo; a Comissão PróHerma a Luiz Gama; escultores como o sueco William Zadig, o belga Adelbert Gresnigt, o santoamarense Júlio Guerra e o paulista Eduardo Srur; políticos de diversos períodos e filiações partidárias, como Geraldo Alckmin, Antônio da Silva Prado, Paulo Maluf, Getúlio Vargas e Jânio Quadros; Miguel Kruse, primeiro abade do mosteiro de São Bento; o ator Paulo César Pereio; a Polícia Militar; os guarani-kaiowá; os cartunistas Belmonte, Laerte Coutinho e Luiz Gê; o cineasta Humberto Mauro, entre outras. Atenta a todas elas, da colina do Ipiranga fui até o largo de São Bento, e de lá para a avenida Paulista, chegando a Santo Amaro - passando pelos depósitos municipais da Várzea do Carmo e do Canindé, pelo cineteatro Odeon, pelo Palácios dos Campos Elíseos e dos Bandeirantes, por um mosteiro, uma escola, ruas, praças e avenidas. Nesses trânsitos, foi possível vislumbrar a configuração de uma certa geografia bandeirante.

Já as desfigurações do terceiro e último capítulo trouxeram à tona inúmeras possibilidades de sentido para uma figura que, desde a sua concepção, se encontra em constante movimento. Novas vozes se misturaram àquelas dos capítulos anteriores: artistas e intelectuais envolvidos na realização da Semana de Arte Moderna; o grupo Pixo Manifesto Escrito; Francisco Prestes Maia e seu plano de avenidas; políticos como Armando Salles Oliveira, Adhemar de Barros, Reynaldo de Barros, Salim Curiati, Luiza Erundina e Dilma Rousseff; o guarani mbya Marcos Tupã; o escultor ítalo-brasileiro Nicola Rollo; os artistas negros Jaime Lauriano e Flávio Cerqueira; povos indígenas brasileiros e diversos movimentos e organizações sociais ligados à Semana Nacional de Mobilização Indígena; o artista Fernando Piola e o grupo 3Nós3. Vozes que vão se justapondo e se sobrepondo 
a novos lugares: o Deops, uma oficina de cantaria, o parque do Jaraguá, o Memorial da Resistência, o parque das Monções, a Pinacoteca, o parque do Ibirapuera, o quartel general do II Exército... Procurei mostrar de que maneira esses movimentos, que carregam consigo elementos e camadas muito variados, vão emprestando corpo e sentidos para o que é o bandeirante, para o que é São Paulo.

Os itinerários bandeirantes que esta tese buscou descrever nos colocam, portanto, diante da dimensão subversiva e criativa das práticas de memória, que podem ser despertadas por um desvio, por um desterro ou por uma desfiguração, três aspectos dos (des)caminhos propostos. (Des)caminhos que esboçam geografias urbanas (materiais e imaginárias) e contrariam temporalidades (seja o meu tempo de caminhar na rua e encontrar um lambe-lambe, o tempo do Centenário da Independência, o tempo das comemorações do IV Centenário, o tempo das ocupações das escolas estaduais por estudantes, o tempo da ditadura militar...) e registros ("populares" e "eruditos"), contribuindo para reavermos de outros ângulos um personagem bastante tratado pela historiografia interessada na compreensão do regionalismo paulista em momento preciso (as primeiras décadas do século Xx).

Tomar o bandeirante em função de seus usos mostra, entre outras coisas, como ele se descola de um contexto específico, habitando outros tempos e espaços. Ao longo de suas deambulações, seus sentidos se alteram: de encarnação da glória paulistana ele se converte em inimigo público, alvo de movimentos de contestação política de diversos tipos nos dias atuais, o que deixa ver sua presença viva na cidade de São Paulo e na sociedade brasileira até hoje. Mas o que talvez não fosse evidente é que a construção da imagem épica e gloriosa esteve acompanhada de seu avesso; o bandeirante desvalido e enfraquecido é contemporâneo à certa imagem modelar; o intrépido desbravador coetâneo ao matador de índios, que por isso mesmo o ataca. Bandeirantes plurais, encarnados e desencarnados, mas que conformam imagens essencializadas e estereotipadas e que, como tais, ensina Michael Herzfeld (1997), produzem efeitos sobre o mundo, mobilizando ações e sujeitos. 


\section{FONTES E REFERÊNCIAS BIBLIOGRÁFICAS}

\section{$\underline{\text { Arquivos e Acervos }}$}

Arquivo Histórico Municipal Washington Luís, São Paulo (AHMWL)

Arquivo Histórico Municipal Sérgio Buarque de Holanda, Porto Feliz (AHSBH)

Arquivo Multimeios do Centro Cultural São Paulo

Arquivo Permanente do Museu Paulista, Universidade de São Paulo (APMP)

Fundo Museu Paulista (FMP)

Arquivo Público do Estado de São Paulo (Apesp)

Assembleia Legislativa do Estado de São Paulo (Alesp)

Biblioteca Brasiliana Guita e José Mindlin, Universidade de São Paulo (BBM)

Biblioteca do Museu Paulista, Universidade de São Paulo

Biblioteca Florestan Fernandes, Faculdade de Filosofia, Letras e Ciências Humanas, Universidade de São Paulo

Biblioteca do Instituto de Estudos Brasileiros, Universidade de São Paulo

Biblioteca do Livro Didático, Faculdade de Educação, Universidade de São Paulo (BLD)

Biblioteca Mário de Andrade, São Paulo (BBA)

Biblioteca Nacional, Rio de Janeiro (BN)

Câmara Municipal de São Paulo (CMSP)

Conselho de Defesa do Patrimônio Histórico, Arqueológico, Artístico e Turístico, São Paulo (CONDEPHAAT)

Instituto Histórico e Geográfico de São Paulo (IHGSP)

Museu da Cidade de São Paulo (MCSP)

Museu da Imagem e do Som, São Paulo (MIS)

Museu Mariano Procópio, Juiz de Fora 
Museu Nacional de Belas Artes, Rio de Janeiro

Pinacoteca do Estado de São Paulo

\section{$\underline{\text { Sites consultados }}$}

http://almanaque.folha.uol.com.br/

https://www.al.sp.gov.br/

http://anonimatosa.blogspot.com.br/

https://www.argn.com/

http:/ /arquiamigos.org.br/blog/

http://www.atlasofurbanexpansion.org/

http://www.bandeirantes.org.br/

http://www.biblioteca.presidencia.gov.br

https://blogdosakamoto.blogosfera.uol.com.br/

https://www.brasil247.com/

https://www.brasildefato.com.br/

http://brasil.elpais.com/

http://www.brasilianaiconografica.art.br/

http://caci.rosaluxspba.org/\#!/

http://www.capital.sp.gov.br/

https://censo2010.ibge.gov.br/

http://ciaoitonovadanca.com.br/

http://www.cimi.org.br/

http://www.cnv.gov.br/

http://colegiodesaobento.com.br/

http://www.desvirtual.com/mda/

http:/ / www.dicionarioderuas.prefeitura.sp.gov.br/

http://www.ebc.com.br/ 
http://www.eduardosrur.com.br/

http://www.estadao.com.br/

https://extra.globo.com/

https://www.facebook.com/

http://www.fernandopiola.com/

http:/ / flaviocerqueira.com/

http://www.folha.uol.com.br/

http://www.funai.gov.br/

http://g1.globo.com/

http://galerialeme.com/

http://geoftp.ibge.gov.br/

http:/ /glamurama.uol.com.br/

https://www.google.com/doodles/

http://guarani.map.as/\#!/

http://hidroweb.ana.gov.br/

https://www.instagram.com/

http://jornal.usp.br/

https://julioguerradesantoamaro.wordpress.com/

https://www.loterofilia.com.br

http://www.mma.gov.br/

https://mobilizacaonacionalindigena.wordpress.com/

https://moburb.org/

http://mosteiro.org.br/

http://mp.usp.br/chamadas/estamos-aqui/

http:/ / ncanarede.blogspot.com.br/

https://www.nexojornal.com.br

https://noticias.bol.uol.com.br

https://noticias.uol.com.br/

http://opalcoeomundo.blogspot.com.br/

https://parqueibirapuera.org/ 
https://www2.planalto.gov.br/

http://portal.imprensanacional.gov.br/

http://www.portofeliz.sp.gov.br/

http://www.redebrasilatual.com.br/

https://www.revistaforum.com.br/

https://sampahistorica.wordpress.com/

http://www.saopauloantiga.com.br/

https://www.saopauloindependente.org/

http://smul.prefeitura.sp.gov.br/

http:/ / www.proacustica.org.br

https://www.socioambiental.org/pt-br

http://souinquerito.com.br/

https://www.terra.com.br/

http://www.terralivre.org/

https://trabalhoindigenista.org.br/

https://twitter.com/

http://vaidape.com.br/

http://vejasp.abril.com.br/

https://vimeo.com/

http://warburg.chaa-unicamp.com.br/

https://www.youtube.com/

http://www.yvyrupa.org.br/

http://www.zeronaldo.com/

\section{Periódicos}

\section{CHICLETE COM BANANA}

Chiclete com Banana, São Paulo, n. 01, pp. 45-47. 


\section{A CIGARRA}

MONumento da Independência, O. A Cigarra, São Paulo, 4 abr. 1920, p. 36.

\section{O COMBATE}

O Combate, São Paulo, 24 mar. 1923, p. 1.

\section{A Constituinte}

NOTICIÁRIO. A Constituinte, 13 maio 1880, p. 1.

VelHo, J. “Os Palmares”. A Constituinte, 16 maio 1880, pp. 2-3.

\section{CORREIO DA MANHÃ}

CARIOCA, J. “A musa do poeta”. Correio da Manhã, Rio de Janeiro, 10 jul. 1929, p. 5.

\section{Correio PaUlistano}

DANÇA das estátuas, A. Correio Paulistano, São Paulo, 14 nov. 1948, pp. 15/24.

Centenário, O. Correio Paulistano, São Paulo, 8 set. 1922, p. 4.

Chrysanthème. "O sacudir das cadeias”. Correio Paulistano, São Paulo, 7 set. 1922, p. 2.

DEL PICCHIA, M. “Brecheret”. Correio Paulistano, São Paulo, 26 fev. 1920, p. 1.

DEL PICCHIA, M. “O problema estético em face ao fenômeno ético paulista”. Correio Paulistano, São Paulo, 7 set. 1922 , p. 2.

ESTÁTUAS de bronze e pedra serão colocadas nos jardins públicos da capital. Correio Paulistano, São Paulo, 27 dez. 1947, p. 8.

Helios. "Monumento das Bandeiras”. Correio Paulistano, São Paulo, 27 jul. 1920, p. 3.

Helios. “Arte Nova”. Correio Paulistano, São Paulo, 29 jul. 1920, p. 3.

HELIOS. "Um monumento que não se ergueu”. Correio Paulistano, São Paulo, 30 mar. 1921, p. 3.

HELIOS. "Eva”. Correio Paulistano, São Paulo, 15 abr. 1921, p. 3.

HeLIOS. “A vitória de um patrício”. Correio Paulistano, São Paulo, 10 nov. 1921, p. 4.

MARTINS, I. "Trinta anos de vida junto do maior bloco de granito do mundo". Correio Paulistano, São Paulo, 21 dez. 1952, suplemento Pensamento e Arte, p. 16.

monumento das Bandeiras. Correio Paulistano, São Paulo, 28 jul. 1920, p. 1. 
MUSEu Paulista. Correio Paulistano, São Paulo, 5 maio 1926, p. 4.

NO país das sombras. Correio Paulistano, São Paulo, 6 abr. 1925, p. 4.

NOTAS. Correio Paulistano, São Paulo, 1 maio 1920, p. 1.

OLAVo Bilac. Correio Paulistano, São Paulo, 25 abr. 1920, p. 3.

PIZA, A. “Os Palmares”. Correio Paulistano, São Paulo, 28 fev. 1903, pp. 1-2.

PORTO Feliz: relíquia histórica. Correio Paulistano, São Paulo, 5 abr. 1953, p. 11.

SAlgado, P. “O nosso poema”. Correio Paulistano, São Paulo, 28 nov. 1922, p. 3.

SOUZA, A. “Jorge Velho”. Correio Paulistano, São Paulo, 9 mar. 1903, p. 1.

SOUZA, A. “Jorge Velho II”. Correio Paulistano, São Paulo, 10 mar. 1903, p. 1.

VICTOR Brecheret, o escultor do Monumento às bandeiras. Correio Paulistano, São Paulo, nov. 1948. In: PELLEGRINI, S. Brecheret: 60 anos de notícia. São Paulo: Melhoramentos, 1976, p. 98.

\section{O CRUZEIRO}

FERrEIRA, J. “São Paulo”. O Cruqeiro, Rio de Janeiro, 23 jan. 1954, p. 32.

PORTO Feliz dos Bandeirantes, O. O Cruzeiro, Rio de Janeiro, 22 nov. 1972, p. 78.

\section{DIÁRIO DE S. PAULO}

Amaral, T. “Uma visita a Brecheret”. Diário de S. Paulo, São Paulo, 10 abr. 1949, p. 10.

PARECE que via o Duque de Caxias nos instantes decisivos de sua vida solar. Diário de S. Paulo, São Paulo, 4 dez. 1941, p. 1.

\section{DIARIO ESPAÑOL}

OLAvo Bilac y el Centenario. Diario Español, 30 ago. 1922, p. 1.

\section{DIÁRIO NACIONAL}

URBAnO. "Monumentos". Diário Nacional, São Paulo, 4 maio 1925, p. 4.

\section{DIÁRIO OFICIAL DA UNIÃO}

EMENDAS apresentadas ao PL 424/2012. Diário Oficial da União, Brasília, 13 dez. 2013, p. 167. PORTARIA no 581, de 29 de maio de 2015. Diário Oficial da União, Brasília, 1 jun. 2015, p. 33. 
DECRETO no 94.221, de 14 de abril de 1987. Diário Oficial da União, Brasília, 15 abr. 1987, p. 5457. PORTARIA nº 683, de 15 de agosto de 2017. Diário Oficial da União, Brasília, 21 abr. 2017, p. 21.

\section{DiÁRIo POPULAR}

MAQUeTE dos Bandeirantes. Diário Popular, São Paulo, 31 jul. 1920, p. 1.

\section{DOM CASMURRO}

PACHECO, A. "São Paulo escreve no granito a história do Brasil". Dom Casmurro, Rio de Janeiro, 24 jan. 1942 , n. 235 , p. 7.

\section{ELITE}

GONÇALVES, V. “O prisioneiro do parque do Ibirapuera”. Elite, 1947. In: PELLEGRINI, S. Brecheret: 60 anos de notícia. São Paulo: Melhoramentos, 1976, pp. 80-82.

\section{A ÉPOCA}

PARA o segundo semestre do próximo ano a inauguração do Monumento das bandeiras. A Época, São Paulo, 28 jul. 1949, reproduzido em Batista (1985, p. 113).

\section{O ESTADINHO}

O Estadinho, 28 jul. 1920. In: Bandeiras de Brecheret: história de um monumento (1920-1953). São Paulo: Departamento do Patrimônio Histórico, 1985, p. 28.

\section{O ESTADO DE S. PAULO}

$392^{\circ}$ Aniversário da fundação da cidade de S. Paulo, O. O Estado de S. Paulo, São Paulo, 27 jan. 1946, p. 7.

Abertura dos festejos da Semana das Monções. O Estado de S. Paulo, São Paulo, 8 out. 1954, p. 11. Alencar, A. "Nós vencidos pela minoria”. O Estado de S. Paulo, São Paulo, 12 out. 2013, p. 2. ARTES e artistas O Estado de São Paulo. 1 jan. 1898, p. 1. . O Estado de S. Paulo, São Paulo, 15 jun. 1916, p. 4. BoItuva a Porto Feliz. O Estado de S. Paulo, São Paulo, 28 abr. 1920, p. 6. CEnTENÁRIO da Independência, O. O Estado de S. Paulo, São Paulo, 28 jun. 1920, p. 3. 
CentenÁrio da Independência, O. O Estado de S. Paulo, São Paulo, 5 dez. 1920, p. 5.

CEnTEnário da Independência, O. O Estado de S. Paulo, São Paulo, 8 set. 1922, p. 2.

Coelho, S. "Monções têm cururu e iê-iê-iêe". O Estado de S. Paulo, São Paulo, 11 out. 1968, p. 16.

DO monumento das bandeiras às pedras. O Estado de S. Paulo, São Paulo, 1 dez. 1948, p. 5.

DUAS pichações em 24 horas. O Estado de S. Paulo, São Paulo, 3 out. 2013, p. 1.

Escoteiros de Natal, Os. O Estado de S. Paulo, São Paulo, 5 set. 1923, p. 4.

“Hotel Comodoro”. O Estado de S. Paulo, São Paulo, 25 jan. 1952, p. 7.

“General Electric S. A.”. O Estado de S. Paulo, São Paulo, 25 jan. 1954, p. 93.

GONÇAlves, D. "Quem ama o feio, bonito lhe parece". O Estado de S. Paulo, São Paulo, 9 dez. 1966, p. 44.

Lobato, M. "Monumento aos Andradas". O Estado de S. Paulo, São Paulo, 19 set. 1920, p. 4.

LUCHETTI, A. "PT usa slogans de prefeitos malufistas para divulgar obras". O Estado de S. Paulo, São Paulo, 9 out. 1990, p. 22.

monumento a Caxias, O. O Estado de S. Paulo, São Paulo, 21 dez. 1955, p. 8.

monumento a Bilac, O. O Estado de S. Paulo, São Paulo, 10 nov. 1920, p. 3.

MONumENTO das Bandeiras. O Estado de S. Paulo, São Paulo, 29 jul. 1920, p. 4.

Monumento Comemorativo da Fundação da cidade de S. Paulo. O Estado de S. Paulo, São Paulo, 3 out. 1909 , p. 7.

MOreirA, A. "Paixão por Santo Amaro inspira escultor". O Estado de S. Paulo, São Paulo, 19 jan. 2001, p. 80.

PARTIDA simbólica de bandeirantes hoje em Porto Feliz. O Estado de S. Paulo, São Paulo, 10 out. 1961, p. 27.

PEDIDA a retirada da estátua. O Estado de S. Paulo, São Paulo, 8 out. 1966, p. 34.

PORTO FELIZ repete as monções dia 8. O Estado de S. Paulo, São Paulo, 29 set. 1967, p. 38.

PREFEITURA retira mais uma estátua da cidade. O Estado de S. Paulo, São Paulo, 19 nov. 1972, p. 64.

PROTESTO e quem paga é o símbolo. O Estado de S. Paulo, São Paulo, 3 out. 2013, p. 1.

Quintal da Boa Vista. O Estado de S. Paulo, São Paulo, 16 maio 1976, p. 11.

RiCARdo, C. "Brecheret e sua obra máxima”. O Estado de S. Paulo, São Paulo, 14 mar. 1970, p. 15.

VEIGA, E. "Limpeza do Monumento às bandeiras levará uma semana”. O Estado de S. Paulo, São Paulo, 4 out. 2013, p. 15.

XI de agosto quer a estátua. O Estado de S. Paulo, São Paulo, 19 out. 1966, p. 28. 


\section{EU SEI TUDO}

DORIA, E. “Aspectos de S. Paulo: o Ipiranga". Eu sei tudo, Rio de Janeiro, set. 1922, n. 64, pp. 2428.

\section{FOLHA DA NOITE}

EREÇão do busto da Mãe Preta, A. Folha da Noite, São Paulo, 30 jan. 1953, p. 1.

FESTAS, As. Folha da Noite, São Paulo, 8 set. 1922, p. 1.

Centenário, O. Folha da Noite, São Paulo, 7 set. 1922, pp. 2-3.

MOnumento a Olavo Bilac. Folha da Noite, São Paulo, 18 out. 1922, p. 1.

NOSSAS estátuas, As. Folha da Noite, São Paulo, 12 out. 1922, p. 1.

NOSSAS estátuas, As. Folha da Noite, São Paulo, 18 out. 1922, p. 1.

\section{FOLHA DA TARDE}

NO centro da cidade, estátuas encapuzadas. Folha da Tarde, São Paulo, 28 abr. 1979, p. 12.

\section{FOLHA DE S.PAULO}

BORBA GATO de 10m dominará Santo Amaro. Folha de S.Paulo, São Paulo, 7 abr. 1962, Ilustrada, p. 10.

COM $12 \mathrm{~m}$ de altura, a estátua de $40 \mathrm{t}$ tem seus prós e contras. Folha de S.Paulo, São Paulo, 7 fev. 1963, Ilustrada, p. 1.

ESTÁTUA do Borba Gato e Monumento às bandeiras são pichados. Folha de S.Paulo, São Paulo, 1 out. 2016, Eleições 2016, p. 2.

EZABELLA, F. “Srur veste coletes salva-vidas em estátuas de SP”. Folha de S.Paulo, São Paulo, 17 out. 2008, p. E6.

MARTí, S. “Memórias do subsolo”. Folha de S.Paulo, São Paulo, 27 jan. 2016, p. C1.

SALES, V. “A poluição através da paisagem”. Folha de S.Paulo, São Paulo, 18 mar. 1973, $1^{\circ}$ Caderno, p. 11.

VOCÊ sabe a última da estátua?. Folha de S.Paulo, São Paulo, 15 maio 1975, Local, p. 19.

\section{A GAZETA}

ALEIJÃo da avenida, O. A Gaẓeta, São Paulo, São Paulo, 7 nov. 1922, p. 1. 
monumento às bandeiras, O. A Gazeta, São Paulo, 31 dez. 1952. In: PELlegrini, S. Brecheret: 60 anos de notícia. São Paulo: Melhoramentos, 1976, p. 112.

PICCHIA, M. "Dois monumentos: os paulistas e os portugueses renderão uma homenagem a S. Paulo”. A Gaz̧eta, São Paulo, 28 jun. 1920, p. 1.

SEIXAS, A. "A Academia Paulista de Letras e a Comissão do IV Centenário". A Gareta, São Paulo, 4 fev. 1953, p. 18.

TESTEMUNHA arquitetônica dum passado grandioso — em plena zona residencial de São Paulo uma relíquia do tempo dos bandeirantes. A Gazeta, São Paulo, 1 jul. 1954.

VINGANÇA de Pan, A. A Gaz̧eta, s/d. In: Pellegrini, S. Brecheret: 60 anos de notícia. São Paulo: Melhoramentos, 1976, p. 76.

\section{GAZETA DE NOTÍCIAS}

EXPOSIÇÃo de Belas Artes. Gažeta de Notícias, 1 set. 1895, p. 2.

\section{GAZETA DE SANTO AMARO}

Gaz̧eta de Santo Amaro, São Paulo, 7 fev. 1963.

\section{GUAÍRA}

HOLANDA, J. "Brecheret". Revista Guaíra, nov. 1949. In: PELLEGRINI, S. Brecheret: 60 anos de notícia. São Paulo: Melhoramentos, 1976, p. 108.

\section{IL PASQuino Coloniale}

ARChitetTI Italiani in Brasile. Il Pasquino Coloniale, São Paulo, 9 set. 1922, p. 31.

ARTE italiana in Brasile. Il Pasquino Coloniale, São Paulo, 13 mar. 1926, p. 12.

L’ERoIsmo dei Bandeirantes. Il Pasquino Coloniale, São Paulo, 9 set. 1922, p. 28.

IL DubBIO di Billac! Il Pasquino Coloniale, São Paulo, 28 out. 1922, p. 4.

IL Monumento a Carlos Gomes. Il Pasquino Coloniale, São Paulo, 15 maio 1920, p. 15.

MOnumento das Bandeiras. Il Pasquino Coloniale, São Paulo, 1 ago. 1920, p. 22.

UN’ALTRA testa tagliata! Il Pasquino Coloniale, São Paulo, 30 jan. 1926, p. 2.

\section{ILUSTRAÇÃO BRASILEIRA}

ANDrade, M. "De São Paulo”. Ilustração Brasileira, Rio de Janeiro, nov. 1920, p. 37. 


\section{O IMPARCIAL}

PEDERNEIRAS, R. “Bronzes paulistas”. O Imparcial, Rio de Janeiro, 18 jan. 1923, p. 2. PRÓ-ITÁLIA. O Imparcial, Rio de Janeiro, 2 abr. 1936, p. 8.

\section{JORNAL DE PORTO FELIZ}

NINGUÉm quer ser escravo. Jornal de Porto Feliz, Porto Feliz, 10-16 out. 1981, p. 6.

\section{JORNAL DO COMMERCIO}

GALERIA do Museu Paulista. Jornal do Commercio, Rio de Janeiro, 6 jun. 1943, p. 2.

NOTAS sobre Arte. Jornal do Commercio, Rio de Janeiro, 8 set. 1895, p. 2.

\section{JORNEGRO}

CARTAS. Jornegro, São Paulo, maio 1978, p. 2.

\section{MANCHETE}

400 ANOS depois. Manchete, Rio de Janeiro, edição especial do IV Centenário de São Paulo, 1954, $\mathrm{s} / \mathrm{p}$.

400 ANOS sem rugas. Manchete, Rio de Janeiro, 23 jan. 1954, pp. 14-18.

\section{A NOITE}

CIDADE espera as estátuas das Bandeiras e de Caxias, A. A Noite, Rio de Janeiro, 19 abr. 1947. In: PELLEgrini, S. Brecheret: 60 anos de notícia. São Paulo: Melhoramentos, 1976, p. 79.

CARvalho. J. "Surpresa e Comoção". A Noite, Rio de Janeiro, 5 nov. 1939. In: Pellegrini, S. Brecheret: 60 anos de notícia. São Paulo: Melhoramentos, 1976, p. 56.

"Notas de Arte". A Noite, 9 jul. 1916, p. 3.

\section{NotíCIAS POPULARES}

eStátuas cobertas com sacos de lixo. Notícias Populares, São Paulo, 28 abr. 1979, p. 5. 


\section{NOVA ESCOLA}

MARTINS, A. R. Mudou a imagem. Título original: Bandeirantes: heróis ou vilões? Nova Escola, ed. 217, out. 2008.

\section{O PAÍZ}

PALESTRA. O Paír, Rio de Janeiro, 8 set. 1895, p. 2.

\section{PROGRESSO}

COsTA. J. E. “Nosso dever”. Progresso, 26 set. 1929, p. 1.

GuEdes, L. “O ‘Progresso”'. Progresso, 23 jun. 1928, p. 1.

\section{REVISTA DO BRASIL}

Lobato, м. “O momento”, Revista do Brasil, n. 83, nov. 1922, p. 195.

\section{S. PAUlo}

S. Paulo, São Paulo, jan. 1936, n. 1, s/p.

S. Paulo, São Paulo, abr. 1936, n. 4, s/p.

S. Paulo, São Paulo, jun. 1936, n. 6, s/p.

S. Paulo, São Paulo, jul. 1936, n. 7, s/p.

S. Paulo, São Paulo, ago. 1936, n. 8, s/p.

S. Paulo, São Paulo, dez. 1936, n. 10, s/p.

\section{REVISTA DA CÂMARA DE SÁO PAULO}

Revista da Câmara Municipal de São Paulo, n. 24, mar./jun. 2017, p. 42.

\section{ReVista do INSTituto HistóRICo e GEOGRÁfico de SÃo PAULO}

RELATÓRIO dos trabalhos e ocorrências sociais no ano de 1932, apresentado pelo diretor em sessão de 5 de maio de 1933. Revista do Instituto Histórico e Geográfico de São Paulo, v. 30, 1935, pp. 115-118. 


\section{TERRAÇO}

DESCONSTRUindo para construir. Terraço, Porto Feliz, out. 2014, pp. 18-20.

\section{TRIBUNA}

BRECHERET. Tribuna, 22 jun. 1920. In: PELLEGRINI, S. Brecheret: 60 anos de notícia. São Paulo: Melhoramentos, 1976, pp. 16-20.

\section{TRIBUNA DAS MONÇÕES}

Cavalheiro, C. "O imaginário do negro na Semana das Monções". Tribuna das Monções, Porto Feliz, 6 abr. 2013, p. 11.

\section{ÚLTIMA HORA}

MARTINS, I. "Trinta anos de trabalho no maior monumento do mundo". Última Hora, Rio de Janeiro, 21 nov. 1952. In: PELLEGRINI, S. Brecheret: 60 anos de notícia. São Paulo: Melhoramentos, 1976, p. 111.

SACOS de lixo, e o cotidiano mudou. Última Hora, Rio de Janeiro, 28 abr. 1979, p. 2.

\section{$\underline{\text { Materiais didáticos }}$}

s/a. História do Brasil — curso preliminar. São Paulo: Livraria Salesiana, 1922.

BRAGA, C. Breves lições de história do Brasil. São Paulo: Tipografia Piratininga, 1922.

HERMIDA, A. Compêndio de história do Brasil: para a primeira e a segunda séries do curso médio. $53^{\mathrm{a}}$ ed. São Paulo: Companhia Editora Nacional, 1968.

LIMA, A. Noç̃es de história do Brasil. Porto Alegre: Livraria do Globo, 1942.

magalHães, B. História do Brasil. São Paulo: Livraria Francisco Alves, 1952.

POMBO, R. História do Brasil. São Paulo: Edições Melhoramentos, 1943.

. História do Brasil. São Paulo: W. M. Jackson Inc., 1953.

SILVA, J. História do Brasil — 1a série do curso ginasial. São Paulo: Companhia Editora Nacional, 1958. SOUtHeY, R. História do Brasil, v.3. São Paulo: Obelisco, 1965.

TAPAjÓs, V. História do Brasil. 11ª ed. São Paulo: Companhia Editora Nacional, 1963. 


\section{$\underline{\text { Dicionários }}$}

FRANCO, F. Dicionário de bandeirantes e sertanistas do Brasil. São Paulo: Comissão do IV Centenário, 1954.

FREIRE, L. Grande e novíssimo dicionário de língua portuguesa. Rio de Janeiro: A noite, 1939-1944, 5v.

HOUAISS, A. Dicionário Houaiss da língua portuguesa. Rio de Janeiro: Objetiva, 2009.

SILVA, A. M. Dicionário da lingua portuguesa composto pelo padre D. Rafael Bluteau, reformado, e acrescentado por Antônio de Moraes Silva natural do Rio de Janeiro. Lisboa: Simão Tadeu Ferreira, 1789.

Dicionário da lingua portuguesa recopilado dos vocabulários impressos até agora, e nesta segunda edição novamente emendado, e muito acrescentado, por Antônio de Moraes Silva natural do Rio de Janeiro oferecido ao Muito Alto, e Muito Poderoso Principe Regente N. Senhor. 2a ed. Lisboa: Tipografia Lacerdina, 1813.

VIEIRA, D. Grande dicionário português; ou, Tesouro da lingua portuguesa, pelo frei Domingos Vieira, dos eremitas calçados de Santo Agostinho; publicação feita sobre o manuscrito original, inteiramente revisto e consideravelmente aumentado. Porto, Rio de Janeiro, Pará: editores Ernesto Chardron e Bartholomeu de Moraes, Cruz Coutinho, Antônio Rodrigues Quelhas, 1871.

\section{Catálogos de exposições}

CATÁlogo: trigésima Bienal de São Paulo, a iminência das poéticas. Bienal de São Paulo/MinC: São Paulo, 2012.

CATÁlogo da II Bienal do Museu de Arte Moderna de São Paulo. São Paulo: Ediam, 1953.

CHIARELLI, T.; BISPO, A. (orgs.) Metrópole: experiência paulistana. São Paulo: Pinacoteca de São Paulo, 2017.

Chiarelli, T.; Silva, C.; LOPES, F. (orgs.) Territórios: artistas afrodescendentes no acervo da Pinacoteca. São Paulo: Pinacoteca de São Paulo, 2016.

ESCOla nacional De Belas ARTES. Catálogo da Exposição Geral de Bellas Artes. Rio de Janeiro: Typ. De J. Villeneuve, 1890.

Galvão, A.; AlmeIdA, L. F (orgs.). A construção do patrimônio. Rio de Janeiro/ São Paulo: Instituto Pedra, 2017.

GUilhotTi, A.; LiMA, S.; Meneses, U. (orgs.) Às margens do Ipiranga (1890-1900): exposição do centenário do edifício do Museu Paulista da USP. São Paulo: Museu Paulista/UsP, 1990; 
IHERING, H. Guia pelas Coleções do Museu Paulista. São Paulo: Cardozo Filho, 1907.

LEVY, C. R. Exposições gerais da Academia Imperial e da Escola Nacional de Belas Artes. Perído Monárquico. Catálogo de Artistas e Obras entre 1840 e 1884. Rio de Janeiro: Arte Data, 2003.

Pedrosa, A.; TOledo, T. (orgs.) Avenida Paulista. São Paulo: Masp, 2017.

PELLEGRINI, S. Victor Brecheret: obra de uma vida. São Paulo: [s/n], 2002.

PICCOLI, V.; PITTA, F. (orgs.) Coleçẽes em diálogo: Museu Paulista e Pinacoteca de São Paulo. São Paulo: Pinacoteca de São Paulo, 2016.

PIOLA, F. Projeto São Paulo. São Paulo: [s.n.], 2010b. (org.) 10 exercícios de aproximação/ representação de SP. São Paulo: Pinacoteca do Estado de São Paulo/Memorial da Resistência de São Paulo, 2013.

TAunAy, A. Guia da secção histórica do Museu Paulista. São Paulo: Imprensa Oficial do Estado, 1937. TOLEDO, T. Empresa colonial. São Paulo: Caixa Cultural da Sé, 2016.

\section{$\underline{\text { Relatórios e documentos do governo }}$}

BRASIL. Presidente (1930-45; 1951-54: Getúlio Vargas). Cruzada rumo ao oeste. Goiânia, 8 ago. 1940. Disponível em: <http://www.biblioteca.presidencia.gov.br/presidencia/ex-presidentes/getuliovargas/discursos/1940/25.pdf/view>. Acesso em: 12 nov. 2017.

MAIA, P. Estudo de um plano de avenidas para a cidade de São Paulo. São Paulo, Melhoramentos, 1930.

OLIVEIRA, A. Mensagem apresentada pelo governador Armando de Salles Oliveira à Assembleia Legislativa de São Paulo. São Paulo: Empresa gráfica da Revista dos Tribunais, 1936.

PIRES DO RIO, J. Relatório de 1926 apresentado pelo Dr. J. Pires do Rio - Prefeito do Município de São Paulo. São Paulo: Seção de obras d'O Estado de S. Paulo, 1927.

PLANO diretor ambiental de Porto Feliz: levantamento histórico e elaboração de diretrizes para preservação e valorização do patrimônio cultural e paisagístico do Município. Porto Feliz: Marcos Carrilho Arquitetos, 2008.

RELATÓRIO circunstanciado de delimitação e identificação da Terra Indígena Jaraguá. Portarias 659/2009, 1178/2009 e 1415/12. Ministério da Justiça: fundação Nacional do Índio: 2002.

RELATÓRIO da Comissão Nacional da Verdade. Brasília: CNV, 2014.

Secretaria Municipal de Planejamento (Sempla). Plano diretor de São Paulo ao alcance de todos. São Paulo: Prefeitura do Município de São Paulo/Secretaria Municipal do Planejamento, 1991. 


\section{$\underline{\text { Livros e artigos }}$}

ABREU, C. Capitulos de história colonial. Rio de Janeiro: Orosco, 1907.

Caminhos antigos e povoamentos do Brasil. São Paulo: Livraria Briguiet, 1930.

. Ensaios e estudos: crítica e história. 4a série. Rio de Janeiro: Civilização Brasileira, 1976.

ALmeIDA, G. Raça. $2^{\mathrm{a}}$ ed. Rio de Janeiro: José Olympio, 1972.

Americano, J. São Paulo naquele tempo (1895-1915). São Paulo: Saraiva, 1957.

ANDRADE, M. Últimas conferências e discursos. Rio de Janeiro: Livraria Francisco Alves, 1924. Losango cáqui. São Paulo: Casa Editora, 1926.

O Monumento das Bandeiras. In: Catálogo da exposição Victor Brecheret. São Paulo: FAU/USP, 1962.

. "O Movimento Modernista". In: Aspectos da literatura brasileira. $5^{a}$ ed. São Paulo: Martins, 1974, pp. 231-55.

BELMONTE. No tempo dos bandeirantes. São Paulo: [gráfica da prefeitura], 1939.

BILAC, O. Poesias. Rio de Janeiro: Garnier, 1902.

BOSI, E. Lembranças. In: Memória e sociedade, lembranças de velhos. $3^{\text {a }}$ ed. São Paulo: Companhia das Letras, 1994.

BRUnO, E. Histórias e tradições da cidade de São Paulo. $3^{\text {a }}$ ed., v. 3, São Paulo: Hucitec, 1984.

CALIXTO, B. Capitanias paulistas: São Vicente, Itanhém, São Paulo. São Paulo: Gráfica Rossetti, 1924.

CASTElo branco, R. Domingos Jorge Velho e a presença paulista no Nordeste. São Paulo: T. A. Queiroz, 1990.

CARLOS, F. Sonata fantasma bandeirante. 2016 [inédito].

CEPElos, M. Os bandeirantes. São Paulo: Tipografia de Fanfulha, 1906.

CORTESÃO, J. Jesuitas e bandeirantes no Guairá (1594-1640). Introdução, notas e glossário por Jaime Cortesão. Rio de Janeiro: Biblioteca Nacional/Divisão de Obras Raras e Publicações, 1951 (Manuscritos da coleção de Angelis, v. 1).

- Jesuitas e bandeirantes no Itatim (1596-1760). Introdução, notas e glossário por Jaime

Cortesão. Rio de Janeiro: Biblioteca Nacional/Divisão de Obras Raras e Publicações, 1952 (Manuscritos da coleção de Angelis, v. 2). 
Antecedentes do Tratado de Madri: jesuítas e bandeirantes no Paraguai (1703-1751). Introdução, notas e glossário por Jaime Cortesão. Rio de Janeiro: Biblioteca Nacional/Divisão de Obras Raras e Publicações, 1955 (Manuscritos da coleção de Angelis, v. 6).

. A fundação de São Paulo: capital geográfica do Brasil. Rio de Janeiro: Livros de Portugal, 1955b.

e da Cultura, 1958.

Raposo Tavares e a formação territorial do Brasil. Rio de Janeiro: Ministério da Educação

ELLIS JR., A. Raça de gigantes. São Paulo: Hélios, 1926.

. O bandeirismo paulista e o recuo do meridiano. $2^{\text {a }}$ ed., Companhia Editora Nacional, 1934.

ELLIS JR., A.; PICCHIA, M. del. Tesouro de Cavendisch. São Paulo: Companhia Editora Nacional, 1928.

FLORENCE, H. Viagem fluvial do Tietê ao Amaronas: de 1825 a 1829. São Paulo: Melhoramentos, 1941.

FREITAS, A. Tradicões e reminiscências paulistanas. Belo Horizonte: Itatiaia, 1985.

GÊ, L. Território de bravos. São Paulo: Editora 34, 1993.

GÊ, L. Interatividade, ambiente, corpo: novas proposições em uma história em quadrinhos tridimensional. In: Congresso Internacional Artes e Novas Tecnologias: Caminhos da Arte para o Século XXI. São Paulo: USP, 2007, pp. 145-147.

GUERRA, J. Barbeiro Anédes, um livro igual à estátua de Borba Gato: também diferente/Anédes Nemendes de Aragóia y Navaja: ex barbeiro da Real Casa de Bascelar 1850-1930. [S.l.: s.n., s/d].

HOlAndA, S. B. Monções. Rio de Janeiro: Casa do Estudante do Brasil, 1945.

Caminhos \& fronteiras. Rio de Janeiro: José Olympio, 1957.

IHERING, H. História do Monumento do Ipiranga e do Museu Paulista. Revista do Museu Paulista, v. 1, pp. 9-31. São Paulo: Typ. A Vapor de Hennies Irmãos, 1895.

LACAZ, G. O roubo do Monumento às bandeiras: tragédia rupestre. [S.l.: s.n.], 2016.

Luís, W. Na capitania de São Vicente. São Paulo: Livraria Martins Editora, 1956.

MACHADO, A. La divina increnca. Livro di Prupaganda da Literatura Nazionale [por] Juó Bananére Candidato à Gademia Baolista de Letras. $7^{a}$ ed. São Paulo: Livraria do Globo/Irmãos Marrano, 1924.

Machado, A. Brás, Bexiga e Barra Funda: notícias de São Paulo. São Paulo: Editora Helios, 1927.

MACHAdO, J. Vida e morte do bandeirante. $2^{a}$ ed. São Paulo: Revista dos Tribunais, 1930. . Vida e morte do bandeirante. $3^{a}$ ed. São Paulo: Martins, 1943.

MAGALHÃES, C. O Selvagem. Trabalho preparatório para o aproveitamento do Selvagem e do solo por ele ocupado no Brasil. Rio de Janeiro: Typographia da Reforma, 1876.

MiLliet, s. "Introdução". In: MACHADO, J. Vida e morte do bandeirante. São Paulo: Martins, 1943. 
MOnBeIG, P. Pioneiros e fazendeiros de São Paulo. $2^{a}$ ed. São Paulo: Hucitec, 1998.

MORSE, R. Formação histórica de São Paulo: uma biografia. São Paulo: Comissão do IV Centenário, 1954.

The bandeirantes: the historical role of the brazians pathfinders. New York: Knopf,

1965.

Moser, B. Pornografia bandeirante. In: Autoimperialismo: três ensaios sobre o Brasil. São Paulo: Planeta, 2016.

PACIORNIK, V. Xondaro. São Paulo: Fundação Rosa Luxemburgo/Elefante, 2016.

PAUla sOUZA, J. Os Palmares: romance histórico. Rio de Janeiro: Laemmert, 1885.

POWELL, B. Scouting for Boys. London: Horace Cox, 1908.

- Manual do escoteiro: guia de educação cívica para portugueses e brasileiros. Lisboa: empresa Lusitana, 1915.

PICCHIA, M. del. Juca Mulato. $5^{\text {a }}$ ed. São Paulo: Monteiro Lobato, 1925.

- A longa viagem: da revolução modernista à revolução de 1930. São Paulo: Martins,

1972.

PINTO, A. A cidade de São Paulo em 1900: impressões de viagem. Rio de Janeiro: Imprensa Nacional, 1900.

O Centenário da Independência. Revista do Brasil, v. 1, n. 1, jan. 1916.

PIOLA, F. Operação Tutoia / Projeto Praça Vermelha / Carandiru. Teoria e debate, n. 89, pp. 27/30. São Paulo: Fundação Perseu Abramo, 2010.

POMBO, R. São Paulo e suas grandes legendas. Revista do Brasil, v. 2, n. 7, jul. 1916.

PRADO, P. O momento. Revista do Brasil, v. 22, n. 88, pp. 290-2, abr. 1923.

. Paulística: história de São Paulo. São Paulo: Monteiro Lobato, 1925.

. A carta a René Thiollier. O Estado de S. Paulo, São Paulo, 23 ago. 1927.

Retrato do Brasil: ensaio sobre a tristeza brasileira. São Paulo: Duprat-Mayença, 1928.

QUEIROZ, D. A muralha: romance comemorativo do IV Centenário da Fundação de São Paulo. Rio de Janeiro: José Olympio, 1954.

RAMIRO, M. (org.). 3Nós3, intervenções urbanas. São Paulo: Ubu, 2017.

RICARDO, C. Brasil no original. 2a ed. São Paulo: Coleção Cultural da Bandeira, 1937. . "O Estado Novo e o seu sentido bandeirante". Cultura Política, pp. 111-132, 1941.

1962.

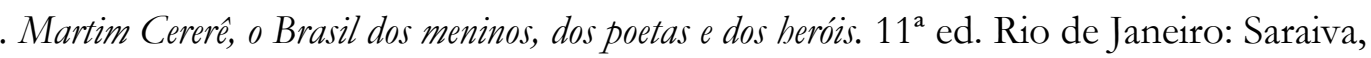


. Marcha para Oeste: a influência da "bandeira" na formação social e política do Brasil. Rio de Janeiro: José Olympio, 1970.

Rodrigues, J. H. (org.) Correspondência de Capistrano de Abreu. Rio de Janeiro: Civilização Brasileira, 3v., 1977.

ROQuetTe-PINTO, E. Recepção do Sr. Afonso Taunay. Revista da Academia Brasileira de Letras, ano 21, n. 103, pp. 243-303, jul. 1930.

SAIA, L. A Casa Bandeirista: uma interpretação. São Paulo: Comissão do IV Centenário, 1955. . Morada paulista. São Paulo: Perspectiva, 1972.

SAINT-HILAIRE, A. Viagem à provincia de São Paulo. Belo Horizonte: Itatiaia, 1972.

TAUnAy, A. A missão artística de 1986. Rio de Janeiro: Instituto Histórico e Geográfico Brasileiro, 1912.

- A glória das monções. São Paulo: Casa Editora O Livro, 1920.

Cie, 1921.

. São Paulo no século XVI: História da vila de Piratininga. São Paulo: Tours e Arrault \& . "Reabertura do Museu Paulista". Correio Paulistano, São Paulo, 3 set. 1922, p. 3.

1922.

. A propósito da estátua de Antônio Raposo Tavares. Revista Nacional, n. 13, pp. 3-11, . Na era das bandeiras. $2^{\mathrm{a}}$ ed. São Paulo: Melhoramentos, 1922b.

t. XIII, 1923.

. Relatório de atividades referente ao ano de 1920. Separata da Revista do Museu Paulista,

História geral das bandeiras paulistas. São Paulo: Typ. Ideal. 1924, t. 1.

. “Quadros históricos”. Correio Paulistano, São Paulo, 24 mar. 1924b, p. 2.

. Relatório de atividades referente aos anos de 1921, 1922, 1923. Separata da Revista do Musen Paulista, t. XIV, 1926.

. Indios! Ouro! Pedras! São Paulo: Melhoramentos, 1926b.

L. Canton, 1927.

História antiga da abadia de São Paulo (1598-1772). São Paulo: Tipografia Ideal; Heitor

. Duas cartas anchietanas. Anais do Museu Paulista, t. III, pp. 375-87, $1927 \mathrm{~b}$.

$1927 c$.

J. Capistrano de Abreu: in memorian. Anais do Museu Paulista, t. 3, pp. XIII-XXXIX, . "Identificação dos diversos Domingos Jorge Velho". Correio Paulistano, São Paulo, 10 jan. 1928, p. 3. 
A propósito do curso de história da civilização brasileira na Faculdade de Filosofia, Ciências e Letras. Anuário da FFCHL da USP, Revista dos Tribunais, 1934/35.

12 set. 1939.

O método confuso em nossas artes. Revista da Academia Paulista de Letras, pp.61-71, . "História de um filme”. Jornal do Commercio, Rio de Janeiro, 22 set. 1940, p. 3.

. Amador Bueno e outros ensaios. São Paulo: Imprensa Oficial, 1943.

. Galeria do Museu Paulista. Mensário do Jornal do Commercio, t. XXII, v. 2, pp. 487-91,

1943.

. O bandeirismo e os primeiros caminhos do Brasil. In: Curso de bandeirologia. São Paulo: Departamento Estadual de Informações, 1946, pp. 7-28.

. Iconografia paulista vetustíssima. Anais do Museu Paulista, n. 13, pp. 30-45. São Paulo: Museu Paulista, 1949.

. Relatos monçoeiros. São Paulo: Comissão do IV Centenário, 1953.

. Relatos sertanistas. São Paulo: Comissão do IV Centenário, 1953 b.

Quatro séculos paulistanos. São Paulo: Gráfica Municipal, 1954.

. História das bandeiras paulistas. $2^{\mathrm{a}}$ ed., 3v. São Paulo: Melhoramentos, 1961.

vargas, G. A nova politica do Brasil, v. 5. São Paulo: José Olympio, 1938.

VASCONCELOS, J. La raza cósmica: misión de la raza iberoamericana, Argentina y Brasil. México:

Espasa-Calpe Mexicana, 1948.

vianna, O. Populações meridionais do Brasil. $6^{\mathrm{a}}$ ed. Rio de Janeiro: Paz e Terra/Governo do Estado do Rio de Janeiro/UfF, 1973.

VICTOR, M. Os dramas da floresta virgem. $5^{a}$ ed. São Paulo: Livraria Editora Alberto de Azevedo, 1941.

WANDERLEY, M. Domingos Jorge Velho. São Paulo: Irmãos Ferraz, 1930.

\section{Bibliografia geral}

ABUD, K. O sangue intimorato e as nobilíssimas tradições (a construção de um símbolo paulista: o bandeirante). 1985. Tese (Doutorado em História Social). Faculdade de Filosofia, Letras e Ciências Humanas, Universidade de São Paulo, São Paulo.

ALDANA, E. Interventions into Urban and Art Historical Spaces: The Work of the. Artist Group 3nós3 in Context, 1979-1982. Tese (doutorado). University of Texas at Austin, 2008. 
ALmeIDA, A. Os visitantes do Museu Paulista: um estudo comparativo com os visitantes da Pinacoteca do Estado e do Museu de Zoologia. Anais do Musen Paulista: História e Cultura Material, v. 12, pp. 269-306. São Paulo: Museu Paulista, 2004.

ALMEIDA, B. O olhar de quem faz: o paulistanismo sob a ótica do operariado paulista durante a Revolução Constitucionalista de 1932. 1999. Dissertação (Mestrado em História Social). Faculdade de Filosofia, Letras e Ciências Humanas, Universidade de São Paulo, São Paulo.

ALMEIDA, C. O cinema como "agitador de almas": Argila, uma cena do Estado Novo. São Paulo: Annablume, 1999.

ALmeIDA, F. O Franciscano Ciccilo. São Paulo: Pioneira, 1976.

ALmeIDA, M. Estado Novo: Projeto político pedagógico e a construção do saber. Revista Brasileira de História, 18(36), pp. 137-159, 1998.

ALMEIDA, V. A Caipirinha. (1880-1928): representações do caipira na peça teatral de Cesário Motta Jr. 2011. Dissertação (Mestrado em História Social). Faculdade de Filosofia, Letras e Ciências Humanas, Universidade de São Paulo, São Paulo.

ALMEIDA, V. O Brasil pelas minisséries: A gente se vê por ali? Um estudo sobre a minissérie A Muralha. 2012. Tese (doutorado). Instituto de Filosofia e Ciências Sociais, Universidade Federal do Rio de Janeiro, Rio de Janeiro.

ALvES, A. M. O Ipiranga apropriado: ciência, política e poder (o Museu Paulista, 1893-1922). São Paulo: História Social USP/Humanitas, 2001.

ALVES, C. Benedito Calixto e a construção do imaginário republicano. Bauru: Edusc, 2003.

Amaral, A. Artes plásticas na Semana de 22. 5ª ed. São Paulo: Editora 34, 1998.

. Tarsila, sua obra e seu tempo. $3^{\text {a }}$ ed. São Paulo: Editora 34/Edusp, 2003.

. Um olhar sobre a cidade. In:

Textos do Trópico de Capricórnio. V. 2. Circuitos de arte na América Latina e No Brasil. São Paulo: Editora 34, 2006. pp. 365-374.

Amaral, A. B. O bairro de Pinheiros: história dos bairros de São Paulo. São Paulo: Prefeitura Municipal/Secretaria de Educação e Cultura, 1969.

História dos velhos teatros de São Paulo: da Casa da Ópera à inauguração do Theatro Municipal. São Paulo: Imprensa Oficial do Estado de São Paulo, 2006.

ANHEZINI, K. Museu Paulista e trocas intelectuais na escrita da História de Afonso de Taunay. Anais do Museu Paulista, São Paulo, v. 10/11, pp. 37-60, 2003.

Unesp, 2011.

Um metódico à brasileira: a história da historiografia de Afonso de Taunay. São Paulo:

AQUino, M. A. (et. al.). Dossiês Deops/SP: radiografias do autoritarismo republicano brasileiro. Arquivo do Estado, Imprensa Oficial do Estado: São Paulo, 2001/2002, 5 vol.

Araujo, M.; Bruno, M. C. (orgs.) Memorial da Resistência de São Paulo. São Paulo: Pinacoteca do Estado, 2009. 
araujo, M.; Camargos, M. Pinacoteca do Estado: a história de um museu. São Paulo: Pinacoteca, 2007.

ARAujo, E.; LAudAnnA, M. De Valentim a Valentim: a escultura brasileira. São Paulo: Imprensa Oficial: 2010.

ARAújo, O. Enquistamentos étnicos. Revista do Arquivo Municipal, v. 65. São Paulo: Departamento de Cultura Municipal, mar. 1940. pp. 227-246.

ARAÚJO, R. B. Ronda noturna: narrativa, crítica e verdade em Capistrano de Abreu. Estudos Históricos, n.1, Rio de Janeiro: FGV, pp. 28-54, 1988

ARCHANGelo, R. Um bandeirante nas telas de São Paulo: o discurso adhemarista em cinejornais (19471956). São Paulo: Alameda, 2015.

ARGAN, G. História da arte como história da cidade. São Paulo: Martins Fontes, 1992.

ARrudA, M. A. Metrópole e cultura. São Paulo: Edusp, 2015.

ASSMANN, A. Espaços da recordação: formas de transformações da memória cultural. Campinas: Unicamp, 2011.

BANDECCHI, B. A Liga Nacionalista. Revista do Instituto Histórico e Geográfico de São Paulo, LXXIII. São Paulo: IHGSP, 1977. pp. 325-348.

BARBOSA, J. Revista do Instituto Histórico e Geográfico Brasileiro, n. 1, pp. 9-17, 1839.

BARbuy, H. O Brasil vai a Paris em 1889: um lugar na Exposição Universal. Anais do Museu Paulista: História e Cultura Material, v. 4, n. 1, pp. 211-261. São Paulo: Museu Paulista, 1996.

. (org.). Um monumento no Ipiranga: história de um edifício centenário e sua recuperação. São Paulo: Fiesp/Ciesp/Sesi/Senai/IRS, 1997.

BARONE, A. C. Ibirapuera: parque metropolitano (1926-1954). 2007. Tese (Doutorado em Arquitetura e Urbanismo). Faculdade de Arquitetura e Urbanismo, Universidade de São Paulo, São Paulo.

BARRo, M. O caçador de diamantes: o primeiro roteiro cinematográfico brasileiro completo. São Paulo: Imprensa Oficial, 2004.

BARro, M.; BACELli, R. Ipiranga: história dos bairros de São Paulo. São Paulo: Secretaria Municipal da Cultura, 1979.

BARTHES, R. "La tour Eiffel” [1964] In: OEuvres complètes, Tomo1, 1942-1965. Édition établie et présentée par Éric Marty. Paris, Éditions du Seuil, 1995.

BAtista, M. R. Bandeiras de Brecheret: história de um monumento (1920-1953). São Paulo: Departamento do Patrimônio Histórico, 1985.

São Paulo e a arte nos espaços públicos, 1900-1925. In: LIMA, A. (org.). Escritos sobre arte e modernismo brasileiro. São Paulo: Prata Design, 2012. pp. 263-276.

BATISTA, M. R.; LIMA, Y.; LOPEZ, T. Brasil: $1^{0}$ tempo modernista - 1917-1929. São Paulo: IEB, 1972. 
BAXANDALL, M. O olhar renascente: pintura e experiência social na Itália da Renascença. Rio de Janeiro: Paz e Terra, 1991.

BAZIN, A. O que é o cinema? São Paulo: Cosac Naify, 2014.

Beiguelman, G. "Memória da Amnésia". In. Da cidade interativa às memórias corrompidas: arte, design e patrimônio histórico na cultura urbana contemporânea. 2016. Tese (Livre-docência em Arquitetura e Urbanismo). Faculdade de Arquitetura e Urbanismo, Universidade de São Paulo, São Paulo.

Beiguelman, G.; FARia, N. A empresa política: história e energia. A chegada da Light. São Paulo: Eletropaulo, 1986.

BELluZzo, A. M. A expedição do Barão Langsdorf, 1822-1829. In: O Brasil dos viajantes, v. 2. São Paulo: Metalivros, 2006.

BERARDI, M. H. Santo Amaro: história dos bairros de São Paulo. São Paulo: Secretaria Municipal de Cultura, 1981.

BICudo, V. Atitudes raciais de pretos e mulatos em São Paulo. São Paulo: Editora Sociologia e Política, 2010.

BISPO, A. "Borrando os limites da cor: negros e brancos na Pinacoteca de São Paulo". In: CHIARELli, T.; BISPO, A. (orgs.) Metrópole: experiência paulistana. São Paulo: Pinacoteca de São Paulo, 2017.

BitTencourt, C. M. Pátria, civilização e trabalho: o ensino da história nas escolas paulistas (19171939). São Paulo: Edições Loyola, 1990.

BLAJ, I. A trama das tensões. São Paulo: Humanitas, 2002.

Borrego, M. A. A teia mercantil: negócios e poderes em São Paulo colonial (1711-1765). São Paulo: Alameda, 2010.

Bottmann, D. G. Padrões explicativos da historiografia brasileira. Curitiba: Aos Quatro Ventos, 1999. BRefe, A. O Museu Paulista: Affonso de Taunay e a memória nacional. São Paulo: Unesp, 2005.

BRITO, M. História do modernismo brasileiro: antecedentes da Semana de Arte Moderna. $6^{\text {a }}$ ed. Rio de Janeiro: Civilização Brasileira, 1997.

CAIUbY NOVAeS, S. Imagem, Magia, Imaginação - Desafios ao Texto Antropológico. Mana, v. 14, pp. 455-475. Rio de Janeiro: UFRJ, 2008.

Camarante, A. (org.). Mães em luta - dez anos dos crimes de maio de 2006. São Paulo: Nós por Nós Editora, 2016.

Camargo, J. F. Crescimento da população no estado de São Paulo e seus aspectos econômicos. São Paulo: IPE/USP, 1981.

Campos, A.; Medeiros, J.; RiBeiro, M. Baderna: escolas de luta. São Paulo: Veneta, 2016.

CAMPOS, C. M. Os rumos da cidade: urbanismo e modernização. São Paulo: Senac, 2002. 
Construção e desconstrução do centro paulistano. Sociedade Brasileira para o Progresso da Ciência. v. 56, n. 2. São Paulo: Unicamp, 2004.

CAMPOS, E. Arquivo histórico de São Paulo: história pública da cidade. São Paulo: Imprensa Oficial, 2011.

CANADO JÚNIOR, R. Embates pela memória: a reconstrução do conjunto jesuítico do Pátio do Colégio (1941-1979). 2014. Dissertação (Mestrado em Arquitetura e Urbanismo). Faculdade de Arquitetura e Urbanismo, Universidade de São Paulo, São Paulo.

CANDIDO, A. Os parceiros do Rio Bonito. Rio de Janeiro: José Olympio Editora (Coleção Documentos Brasileiros), 1964.

. "Os poetas da inconfidência". IX Anuário do Museu da Inconfidência. Ouro Preto: Ministério da Cultura, Instituto Brasileiro do Patrimônio Cultural, 1993.

. Literatura e sociedade. $8^{a}$ ed. São Paulo: T.A. Queiroz, 2002.

CANO, W. Raízes da concentração industrial em São Paulo. Rio de Janeiro: Difel, 1977.

CAPelato, M. H. O Movimento de 1932: a causa paulista. São Paulo: Brasiliense, 1981.

CARPINTÉRO, M. Em busca da imagem: a cidade e seu figurino (São Paulo: 1938-1954). 1998. Tese (Doutorado em História). Instituto de Filosofia e Ciências Humanas, Universidade Estadual de Campinas, Campinas.

CARruthers. M. A técnica do pensamento: meditação, retórica e a construção de imagens (400-1200). Campinas: Unicamp, 2011.

CARvalho, J. M. A formação das almas: o imaginário da República no Brasil. São Paulo: Companhia das Letras, 2006.

Carvalho, P. C. A. O Museu Sertório: uma coleção particular em São Paulo no final do século XIX (primeiro acervo do Museu Paulista). Anais do Musen Panlista: História e Cultura Material, v. 22, n. 2, pp. 105-152. São Paulo: jul-dez. 2014.

CARVALHO, V. Gênero e artefato: o sistema doméstico na perspectiva da cultura material — São Paulo, 1870-1920. São Paulo: Edusp, 2008.

CASALECCHI, J. E. O Partido Republicano Paulista: política e poder (1889-1926). São Paulo: Brasiliense, 1987.

Castro, A. C. A São Paulo de Menotti del Picchia: arquitetura, arte e cidade nas crônicas de um modernista. São Paulo: Alameda, 2008.

Um americano na metrópole [latino-americana]: Richard Morse e a histórica cultural urbana de São Paulo, 1947-1970. 2013. Tese (Doutorado em Arquitetura e Urbanismo). Faculdade de Arquitetura e Urbanismo, Universidade de São Paulo, São Paulo.

CASTRO, C. Demarcadores e objetos em campanha: a comissão brasileira demarcadora de limites e a fabricação de fronteiras. São Paulo: Cultura Acadêmica, 2014.

CAVAlHeiro, C. O negro em Porto Feliz: Sorocaba: Crearte, 2016. 
CERri, L. F. A ideologia da paulistanidade. São Paulo: Cone Sul, 1997.

CEZAR, T. Lição sobre a escrita da história: historiografia e nação no Brasil do século XIX. In: Diálogos, v. 8, n. 1. Maringá: DH/UEM, 2004. pp. 11-29.

. Varnhagen em movimento: breve antologia de uma existência. Topoi, v. 8. Rio de Janeiro: UFRJ, 2007. pp. 159-207.

CHIARELLI, T. "Anotações sobre arte e história no Museu Paulista”. In: FABRIs, A. (org.). Arte e política: algumas possibilidades de leitura. Belo Horizonte: Editora Fapes/Editora C/Arte, 1998. pp. 21-46.

. "Andar por São Paulo faz com que São Paulo também ande em nós". In: CHIARELLI, T.; BISPO, A. (orgs.) Metrópole: experiência paulistana. São Paulo: Pinacoteca de São Paulo, 2017.

CHRISTO, M. Bandeirantes na contramão da história: um estudo iconográfico. Projeto História, n. 24, pp. 307-335. São Paulo, 2002.

2002b.

. Bandeirantes ao chão, n. 30, pp. 33-55. Estudos Históricos. Rio de Janeiro: CPDOC,

Representações oitocentistas dos índios no Brasil. In: PARANHOS, K. et al. História e imagem: textos visuais e práticas de leituras. Minas Gerais: Fapemig/Mercado das Letras, 2010.

Aires, n. 3, dez. 2013.

Desbravadores do Brasil Colônia: disputas iconográficas. Revista Caiana. Buenos

CORREIA, T. A gestão do tempo e a organização da cidade moderna. Sinopses, n. 33, pp. 22-32. São Paulo: USP, 2000.

COSTA, R. O corpo indígena ressignificado: Marabá e $\mathrm{O}$ último tamoio de Rodolfo Amoedo e a retórica nacionalista do final do Segundo Império. 2013. Dissertação de Mestrado (História da Arte). Instituto de Filosofia e Ciências Humanas, Universidade Estadual de Campinas, Campinas.

CUTI, E. E disse o velho militante José Correia Leite. São Paulo: Secretaria Municipal de Cultura, 1992.

DAmante, H. Nova Paulística. São Paulo: Imprensa Oficial, 1971.

DAVIDOFF, C. Bandeirismo: verso e reverso. 8ª ed. São Paulo: Brasiliense, 1994.

DAZZI, C. A produção dos professores e alunos da Escola Nacional de Belas Artes na Exposição de Chicago de 1893. 19 \& 20, v. VI, n. 4. Rio de Janeiro, 2011.

DEAN, W. A industrialiqação de São Paulo (1880-1945). $4^{\text {a }}$ ed. Rio de Janeiro: Bertrand Brasil, 1991.

De CerTeau, M. A invenção do cotidiano: artes de fazer. Petrópolis: Vozes, 1994.

- A escrita da história. Rio de Janeiro: Forense, 2011.

DE LUCA, T. R. A Revista do Brasil: um diagnóstico para a (N)ação. São Paulo: Unesp, 1999.

- O Centenário da Independência em São Paulo. História. Debates e Tendências (Passo

Fundo), v. 4, n. 2, pp. 136-150. Passo Fundo, 2003. 
DE PAULA, J. 1932: imagens construindo a história. Campinas/Piracicaba: Unicamp/Unimep, 1998. DeRTÔNIO, H. O bairro do Bom Retiro: história dos bairros de São Paulo. São Paulo: Secretaria de Educação e Cultura, 1971.

DIAS, E. A representação da realeza no Brasil: uma análise dos retratos de D. João VI e D. Pedro I, de Jean-Baptiste Debret. Anais do Museu Paulista, v. 14, pp. 243-261. São Paulo: Museu Paulista, 2006.

Paisagem e academia: Félix Émile Taunay e o Brasil (1824-1851). Campinas: Unicamp,

2009.

. Os Retratos de D. Pedro I e de D. João VI no acervo do Museu Paulista. In: VALLE, A.; DAZZI, C.; PORTELLA I. (orgs.) Oitocentos: intercâmbios culturais entre Brasil e Portugal, tomo 3. Seropédica: UFRRJ, 2013, v. 3, pp. 177-188.

DIDI-Huberman, G. A imagem sobrevivente: história da arte e tempo dos fantasmas segundo Aby Warburg. Rio de Janeiro: Contraponto Editora, 2013.

Di Giovanni, J. Seattle, Praga, Gênova: política anti-globalização pela experiência da ação de rua. 2007. Dissertação (Mestrado em Antropologia Social). Faculdade de Filosofia, Letras e Ciências Humanas, Universidade de São Paulo, São Paulo.

DOMINGUeS, P. “Os Pérolas Negras: a participação do negro na Revolução Constitucionalista de 1932”. Afro-Ásia, n. 29/30, pp. 199-245. Salvador, 2003.

. "A aurora de um grande feito: a herma a Luiz Gama". Anos 90, v. 23, n. 43, pp. 389416. Porto Alegre, 2016.

DUARTE, M. As transformações da cidade e o distanciamento de seu passado. In: ALMEIDA (org.). Territórios de Ururay. São Paulo: Movimento Cultural Penha, 2016.

ELIAS, M. De monumento a monumento-museu. In: GUILHOTTI, A.; LIMA, S.; MENESES, U. (orgs.) Às margens do Ipiranga (1890-1900): exposição do centenário do edifício do Museu Paulista da USP. São Paulo: Museu Paulista/UsP, 1990. pp. 22-23.

Musen Paulista: memória e história. 1996. Tese (Doutorado em História Social). Faculdade de Filosofia, Letras e Ciências Humanas, Universidade de São Paulo, São Paulo.

EREMITES DE OLIVEIRA, J. Para compreender os conflitos pela posse da terra indígena Nande Ru Marangatu no estado de Mato Grosso do Sul, Brasil. Revista da Anpege, v. 11, pp. 333-340, 2015.

FABRIS, A. Cândido Portinari. São Paulo: Edusp, 1996.

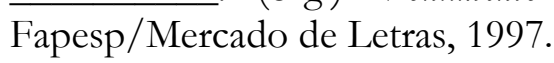

(org.) Monumento a Ramos de Azevedo: do concurso ao exílio. São Paulo:

FAusto, B. Conflito social na República Oligárquica: a greve de 1917. Estudos Cebrap, n. 10, pp.79-109. São Paulo: Cebrap, 1974. . (org.) História geral da civilização brasileira. Rio de Janeiro: Difel, 1977.

FEDERICO, M. E. Meio ambiente e degradação cultural. São Paulo: Humanitas/Fapesp, 2005. 
FERNANDES, F. Caracteres rurais e urbanos na formação e desenvolvimento da cidade de São Paulo. In: Mudanças sociais no Brasil. Aspectos do desenvolvimento da sociedade brasileira. $2^{\mathrm{a}} \mathrm{ed}$. São Paulo: Difel, 1974.

FERREIRA, A. A epopeia bandeirante: letrados, instituições, invenção histórica (1870- 1940). São Paulo: Unesp, 2002.

FERREIRA, B. O nobre e antigo bairro da Sé: história dos bairros de São Paulo. São Paulo: Secretaria de Educação e Cultura, 1971.

FERRETTI, D. A construção da paulistanidade: identidade, historiografia e política em São Paulo (18561930). 2004. Tese (Doutorado em História). Programa de Pós-Graduação em História Social, Departamento de História da Faculdade de Filosofia, Letras e Ciências Humanas, Universidade de São Paulo, São Paulo.

FERRETTI, D. Z.; CAPELATO, M. H. R. "João Ramalho e as origens da nação: os paulistas na comemoração do IV Centenário da descoberta do Brasil”, Tempo, n. 8, 1999.

FLYNN, M. H. Concursos públicos para o Monumento do Ipiranga. In: GUILHOTTI, A.; LIMA, S.; MENESES, U. (orgs.) Às margens do Ipiranga (1890-1900): exposição do centenário do edifício do Museu Paulista da USP. São Paulo: Museu Paulista/USP, 1990, p 14.

FON, A. C. Tortura: a história da repressão política no Brasil. São Paulo: Global, 1979.

FOnt, M. Coffee, Contention and Change in the Making of Modern Brazil. Cambridge: Basil Blackwell, 1990.

FRANÇOZO, M. "O Museu Paulista e a história da antropologia no Brasil entre 1946 e 1956". Revista de Antropologia, v. 48, n. 2. São Paulo: USP, 2005. pp. 585-612.

FREHSE, F. O tempo das ruas na São Paulo de fins do Império. São Paulo: Edusp, 2005.

2011.

. O da rua! O transeunte e o advento da modernidade em São Paulo. São Paulo: Edusp,

FREIRE, C. Além dos mapas: os monumentos no imaginário urbano contemporâneo. São Paulo: Annablume/SESC, 1997.

FRUGOLI, H.; ANDRADE, L.; PEIXOTO, F. (orgs.) As cidades e seus agentes: práticas e representações. Belo Horizonte: PUC Minas/Edusp, 2006.

GELL, A. Art and Agency. Oxford: Clarendon Press, 1998.

"A rede de Vogel: armadilhas como obras de arte e obras de arte como armadilhas". Arte e Ensaios. n. 8, pp. 174-191, 2001.

63, 2005[1992].

"A tecnologia do encanto e o encanto da tecnologia". Concinnitas, v. 1, n. 8, pp. 41-

GIUMBELLI, E. O Cristo pichado: sacralidade e transgressão de um monumento urbano. Ponto.Urbe, v. 12. São Paulo: USP, 2013. 
GIUMBeLli, E.; BOsIsIO, I. A política de um monumento: as muitas imagens do Cristo Redentor. Debates do NER, v. 18, pp. 173-192. Rio Grande do Sul: UFRGS, 2010.

GLEZER, R. Um museu para o século XXI: o Museu Paulista e os desafios para os novos tempos. Anais do Museu Paulista: História e Cultura Material, São Paulo, v. 10-11, pp. 9-21, 2003.

Chão de terra e outros ensaios sobre São Paulo. São Paulo: Alameda, 2007.

GOMES, A. História e historiadores. Rio de Janeiro: FGV, 1996.

GOMES, P. E. Humberto Mauro, Cataguases, Cinearte. São Paulo: Perspectiva/usP, 1974.

GOnÇALves, J. R. Antropologia dos objetos: coleções, museus e patrimônio. Rio de Janeiro: Departamento de Museus e Centros Culturais, 2007.

GONÇALVES, T. C. Fernão Dias: uma trajetória cinematográfica. 1999. Dissertação (Mestrado em Multimeios). Universidade Estadual de Campinas, Campinas.

GORELIK, A. Historia de la ciudad e historia intelectual. Prismas: Revista de História Intelectual, n. 3, pp. 209-223. Buenos Aires: UNQ, 1999.

gorelik, A.; PeiXoto, F. (orgs.) Ciudades Sudamericanas como Arenas Culturales. Artes y medios, barrios de élite y villas miseria, intelectuales y urbanistas: cómo ciudad e cultura se activan mutuamente. Buenos Aires: Siglo Veintiuno, 2016.

GOYENA, A. "O sorriso irônico dos Budas: demolição e patrimônio no vale sagrado de Bamiyan”. In: GONÇAlves, J. R.; GUIMARÃES, R.; BITAR, N. A alma das coisas. Rio de Janeiro: Mauad/Faperj, 2013.

GROLA, D. A memória nas arcadas: construção material simbólica e ideológica do edifício da Faculdade de Direito do largo de São Francisco. São Paulo: Humanitas, 2012.

GRosteIn, M. Periferias: loteamentos ilegais e forma de crescimento. In: CAMPOS, C.; GAMA, L.; SACCHETTA, V. (orgs.) Metrópole em trânsito: recursos urbanos e culturais. São Paulo: Senac/sP, 2004, v. 1. pp. 130-137.

GUILHOTTI, A.; LIMA, S.; MENESES, U. (orgs.) Às margens do Ipiranga: um monumento-museu. In: Às margens do Ipiranga (1890-1900): exposição do centenário do edifício do Museu Paulista da USP. São Paulo: Museu Paulista/USP, 1990. pp. 22-23.

GUIMARÃES, L. Da Escola Palatina ao silogeu: Instituto Histórico e Geográfico Brasileiro (1889-1938). Rio de Janeiro: Museu da República, 2007.

GUIMARÃES, M. S. Nação e civilização nos trópicos: o Instituto Histórico e Geográfico Brasileiro e o projeto de uma história nacional. Estudos Históricos, v. 1, n. 1. pp. 4-27. Rio de Janeiro: FGV, 1988.

HALL, M. Imigrantes na cidade de São Paulo. In: PORTA, P. (org.). História da cidade de São Paulo. A cidade na primeira metade do século XX, v. 3. São Paulo: Paz e Terra, 2004. pp. 121-151.

HANSEN, P. Golpes de memória: usos políticos de Olavo Bilac no século XX. Revista do IEB, n. 61, pp. 122-139. São Paulo: IEB, 2015. 
HARTOG, F. Regimes de historicidade: presentismo e experiências do tempo. São Paulo: Autêntica, 2013.

HERZFELD, M. Cultural Intimacy: Social Poetics in the Nation-State. New York/London: Routledge, 1997. . Anthropology: Theoretical Practice in Culture and Society. Oxford: Blackwell, 2001.

HESSEL, R. Iconografia monçoeira: imagens e ideologia. 2006. Dissertação (Mestrado em História). Programa de Estudos Pós-Graduados em História, Pontifícia Universidade Católica de São Paulo, São Paulo.

HObSBawm, E.; RAnger, T. A invenção das tradições. Rio de Janeiro: Paz e Terra, 1987.

Homem, M. C. O palacete paulistano. São Paulo: Martins Fontes, 1996.

HOSKINS, J. “Agency, Biography and Objects". In: TILLEY et al (ed.). Handbook of Material Culture. London: Sage Publications, 2006. pp. 74-84.

IGLESIAS, F. Historiadores do Brasil: capítulos de historiografia brasileira. Rio de Janeiro: Nova Fronteira/Belo Horizonte: UFMG, 2000.

INGOLD, T. (ed.). Aesthetics is a Cross-Cultural Category. In: Key Debates in Anthropology. London: Routledge, 1994. pp. 249-294.

INVEntário de Obras de Arte em Logradouros Públicos da Cidade de São Paulo. São Paulo: Departamento do Patrimônio Histórico, [s/d].

JOFFILY, M. No centro da engrenagem: os interrogatórios na Operação Bandeirante e no DOI de São Paulo (1969-1975). São Paulo: Edusp, 2013.

KATINSKY, J. R. Casas bandeiristas: nascimento e reconhecimento da arte em São Paulo. São Paulo: USP, 1976.

KEESE, L. A esquiva do xondaro: movimento e ação política entre o Guaranu Mbya. 2017. Dissertação (Mestrado em Antropologia Social). Faculdade de Filosofa, Letras e Ciências Humanas, Universidade de São Paulo, São Paulo.

KOSELLECK, R. Futuro passado: contribuição à semântica dos tempos históricos. Rio de Janeiro: Contraponto/PUC-RJ, 2006.

KUHN, J. C. Resistências sagradas: Pátio do Colégio, secularização e reconstrução. 2016. Dissertação (Mestrado). Faculdade de Arquitetura e Urbanismo, Universidade de São Paulo, São Paulo.

KUNIGK, M. C. Nicola Rollo (1889-1970): um escultor na modernidade brasileira. 2001. Dissertação (Mestrado). Escola de Comunicações e Artes, Universidade de São Paulo, São Paulo.

LAgrou, E. Arte ou artefato? Agência e significado nas artes indígenas. Revista Proa, $\mathrm{n}^{\circ}$ 2, vol. 1, 2010.

LANNA, A. L.; PEIXOTO, F.; LIRA, J.; SAMPAIO, M. R. (orgs.) São Paulo, os estrangeiros e a construção das cidades. São Paulo: Alameda/Fapesp, 2011. 
LATOUR, B. O que é iconoclash? Ou, há um mundo além das guerras de imagem? Horizontes Antropológicos, ano 14, n. 29, pp. 111-150. Porto Alegre: UFRGS, 2008.

LATOUR, B.; YANEVA, A. "Donnez-moi un fusil et je te ferai bouger tous les batîments: le point de vue d'une fourmi sur l'architecture" In: GEISER, R. (ed). Explorations in Architecture: Teaching, Design, Research. Basel: Birkhäuser, 2008. pp. 80-89.

LEE, F. Henrique Bernardelli. 1991. Monografia (Dissertação de Graduação). Faculdade de Arquitetura e Urbanismo, Universidade de São Paulo, São Paulo.

LEME, M. C. Revisão do plano de avenidas: um estudo sobre planejamento urbano. 1990. Tese (Doutorado em Arquitetura e Urbanismo). Faculdade de Arquitetura e Urbanismo, Universidade de São Paulo, São Paulo.

LEMos, C. Casa Paulista: história das moradias anteriores ao ecletismo trazido pelo café. São Paulo: Edusp, 1999.

Lima, S.; CARVAlHo, V. São Paulo Antigo, uma encomenda da modernidade: as fotografias de Militão nas pinturas do Museu Paulista. Anais do Museu Paulista, v. 1, pp. 147-98. São Paulo: Museu Paulista, 1993.

LIMA, V. A viagem de um pintor de história: Debret e sua obra. In: CHRISTO, M. (org.). Dossiê Pintura de História. Anais do Museu Histórico Nacional, v. 39. Rio de Janeiro: MinC/Ibram, 2007.

LIMA JUNIOR, C. Um artista às margens do Ipiranga: Oscar Pereira da Silva, o Museu Paulista e a reelaboração do passado nacional. Dissertação (Mestrado). 2015. Instituto de Estudos Brasileiros, Universidade de São Paulo, São Paulo.

LOfEgo, S. IV Centenário da cidade de São Paulo: uma cidade entre o passado e o futuro. São Paulo: Annablume, 2004.

LOPES, A. C. Tradição, nacionalismo e modernidade: o Monumento Duque de Caxias. São Carlos: Edufscar, 2017.

LOPES, F. Cenografia e paisagem urbana: um estudo de caso da cidade de São Paulo. 2012. Dissertação (Mestrado em História). Faculdade de Filosofia e Ciências Humanas, Universidade Estadual de Campinas, Campinas.

LOPES, M. A. "As representações sociais da mãe negra na cidade de São Paulo. Patrimônio e Memória. São Paulo: Unesp, 2007.

LOPES, M. M.; FIGUEIRÔA, S. F. A criação do Museu Paulista na correspondência de Hermann von Ihering (1850-1930). Anais do Museu Paulista: História e Cultura Material, São Paulo, v. 10-11, n. 1, pp. 23-35, 2003.

Lourenço, M. C. Revendo Almeida Júnior. 1980. Dissertação (Mestrado). Escola de Comunicações e Artes, Universidade de São Paulo, São Paulo.

LOVE, J. A locomotiva: São Paulo na federação brasileira 1889-1937. Rio de Janeiro: Paz e Terra, 1982.

LYRA, M. Memória da Independência: marcos e representações simbólicas. Revista Brasileira de História, v. 15, n. 29, pp. 173-206, 1995. 
MACHADO, L. Retrato da arte moderna no Brasil. São Paulo: Departamento de Cultura, 1947.

MACHAdO, R. São Paulo em movimento. A representação cinematográfica da metrópole nos anos 1920. 1989. Dissertação (Mestrado). Escola de Comunicações e Artes, Universidade de São Paulo, São Paulo.

MACIEL, D. António de Alcântara Machado e a criação de São Paulo: personagens, espaços e experiências. 2017. Dissertação (Mestrado em Antropologia Social). Faculdade de Filosofa, Letras e Ciências Humanas, Universidade de São Paulo, São Paulo.

MAKINO, M. A construção da identidade nacional: Afonso de E. Taunay e a decoração do Museu Paulista (1917-1937). 2003. Tese (Doutorado em História). Faculdade de Filosofa, Letras e Ciências Humanas, Universidade de São Paulo, São Paulo.

Ornamentação do Museu Paulista para o primeiro Centenário: construção de identidade nacional na década de 1920. Anais do Museu Paulista, v. 10/11, pp. 167-195. São Paulo: Museu Paulista, 2003b.

MArCílio, M. L. A cidade de São Paulo: povoamento e população. São Paulo: Pioneira, 1973.

MARINS, P. O Parque do Ibirapuera e a construção da identidade paulista. Anais do Museu Paulista, v. 6/7, pp. 9-36. São Paulo: Museu Paulista, 2003.

Nas matas com pose de reis: a representação de bandeirantes e a tradição da retratística monárquica europeia. Revista do IEB, n. 44, pp .77-104. São Paulo: IEB, 2007.

. San Pablo. La avenida Paulista de la Belle Époque: élites en disputa. In: GORELIK, A.; PEIXOTO, F. (orgs.) Ciudades Sudamericanas como Arenas Culturales. Artes y medios, barrios de élite y villas miseria, intelectuales y urbanistas: cómo ciudad e cultura se activan mutuamente. Buenos Aires: Siglo Veintiuno, 2016.

- A identidade da terra evocada por suas águas: os vasos dos rios brasileiros do Museu Paulista como metáfora nacional. In. PICCOLI, V.; PITTA, F. (orgs.) Coleções em diálogo: Museu Paulista e Pinacoteca de São Paulo. São Paulo: Pinacoteca de São Paulo, 2016b, pp. 113-118.

O museu da paz: Sobre a pintura histórica no Museu Paulista durante a gestão Taunay. In: OLIVEIRA, C. H. (org.) O Museu Paulista e a gestão de Afonso Taunay: escritas da história e da historiografia, séculos XIX e XX. São Paulo: Museu Paulista da USP, 2017, pp. 159-191.

MARTINS, L. G. Criação intermidiática: espaço e interatividade numa HQ tridimensional. Anais do III Fórum de Pesquisa FAU-Mackenzie. São Paulo: Faculdade de Arquitetura e Urbanismo da Universidade Presbiteriana Mackenzie, 2007.

MATTOS, C. Imagem e palavra. In: OLIVEIRA, C.; MATTOS, C. (orgs.) O brado do Ipiranga. São Paulo: Edusp, 1999.

- "Da palavra à imagem: sobre o programa decorativo de Affonso Taunay para o Museu Paulista". In: Anais do Museu Paulista, v. 6/7, pp. 123-145. São Paulo: Museu Paulista, 2003.

MAYUMI, L. Taipa, canela-preta e concreto. Estudo sobre o restauro de casas bandeirista. São Paulo: Romano Guerra, 2008. 
MAUSS, M. Uma categoria do espírito humano: a noção de pessoa, a de "eu". In. Sociologia e Antropologia. São Paulo: Cosac \& Naify, 2003. pp. 367-398.

MENESES, U. Benedito Calixto como documento: sugestões para uma releitura histórica. Benedito Calixto: memória paulista. São Paulo: Pinacoteca do Estado, 1990, pp. 37-47.

. “O Museu Paulista”. In: Estudos Avançados, v. 8, n. 22, pp. 573-8. São Paulo: IEA/USP,

1994. Como explorar um museu histórico. São Paulo: Museu Paulista, [s.d.].

MESQUITA, A. Insurgências poéticas: arte ativista e ação coletiva (1990-2000). 2008. Dissertação (Mestrado em História Social). Faculdade de Filosofia, Letras e Ciências Humanas, Universidade de São Paulo, São Paulo.

MICELI, S. Intelectuais e a classe dirigente no Brasil. São Paulo: Difel, 1979. . Nacional e estrangeiro. São Paulo: Companhia das Letras, 2003.

MICELI, S.; RUBinO, S. A metrópole e a arte. São Paulo: Prêmio, 1992.

MONTEIRO, J. Tupis, tapuias e a história de São Paulo. Novos Estudos Cebrap, v. 38, pp. 125-35. São Paulo: Cebrap, 1992.

. Negros da terra. São Paulo: Companhia das Letras, 2009.

Monteiro, M. Fundação de São Paulo, de Oscar Pereira da Silva: trajetórias de uma imagem urbana. 2012. Dissertação (Mestrado em Arquitetura e Urbanismo). Faculdade de Arquitetura e Urbanismo, Universidade de São Paulo, São Paulo.

. São Paulo na disputa pelo passado: o Monumento à Independência de Ettore Ximenes como lugar de memória. 2017. Tese (Doutorado em Arquitetura e Urbanismo). Faculdade de Arquitetura e Urbanismo da Universidade de São Paulo, São Paulo.

MORAES, F. R. Uma coleção de história em um museu de ciências naturais: o Museu Paulista de Hermann von Ihering. Anais do Museu Paulista, v. 16, n. 1. São Paulo: Museu Paulista, 2008. pp. 203-233.

MORETTIN, E. Quadros em movimento: o uso das fontes iconográficas no filme Os Bandeirantes (1940), de Humberto Mauro. Revista Brasileira de História, vol. 18, n. 35, pp. 105-131. São Paulo: USP, 1998. . Humberto Mauro, cinema, história. São Paulo: Alameda, 2013.

MORSE, R. Formação histórica de São Paulo. São Paulo: Difusão Europeia do Livro, 1970.

As cidades "periféricas" como arenas culturais: Rússia, Áustria, América Latina. Estudos Históricos, v. 8, n. 16, pp. 205-225. Rio de Janeiro: CPDOC, 1995.

MOTTA, M. A nação faz 100 anos: a questão nacional no centenário da Independência. Rio de Janeiro: FGV/CPDOC, 1992. 
MOURA, E. Bandeirantes do progresso: imagens do trabalho e do trabalhador na cidade em festa. São Paulo, 25 de janeiro de 1954. Revista Brasileira de História, v. 14, n. 28. pp. 105-131. São Paulo: Anpuh/Marco Zero, 1994.

MOurA, I. A cidade e a festa: Brecheret e o IV Centenário de São Paulo. 2010. Tese (Doutorado em História). Programa de Estudos Pós-Graduados em História, Pontifícia Universidade Católica de São Paulo, São Paulo.

MIYOSHI, A. Os princípios de uma galeria de arte de São Paulo: relações entre o Museu Paulista e a Pinacoteca do Estado de São Paulo no início do século XX. In: MALTA, M. (org.). Novas perspectivas para o estudo da arte no Brasil de entre os séculos XIX/XX. Rio de Janeiro: EBA/UFRJ, 2012.

NASCIMENTO, A. P. Espaços e a representação de uma nova cidade: São Paulo (1895-1929). 2009. Tese (Doutorado em Arquitetura e Urbanismo). Faculdade de Arquitetura e Urbanismo, Universidade de São Paulo, São Paulo.

NAVES, R. Almeida Jr: o sol no meio do caminho. Novos Estudos, n. 73, pp. 135-148. São Paulo: Cebrap, 2005.

NEEDELL, J. Belle Époque tropical: sociedade e cultura de elite no Rio de Janeiro. São Paulo: Companhia das Letras, 1993.

NERY, P. Arte, pátria e civilização: a formação dos acervos artísticos do Museu Paulista e da Pinacoteca do Estado (1893-1912). 2015. Dissertação (Mestrado em Museologia). Interunidades em Museologia, Universidade de São Paulo, São Paulo.

NEVES, K. "Memorial da Resistência de São Paulo: uma perspectiva museológica processual”. In: FERreira, M. L.; Michelon, F. Memória e esquecimento. Pelotas: Ed. da Universidade Federal de Pelotas, 2012. pp. 35-66.

NICHELle, A. C. O que está dentro fica/ O que está fora se expande: 3nós3, Coletivo de Arte no Brasil. 2010. Dissertação (Mestrado em Artes Visuais). Centro de Artes da Universidade do Estado de Santa Catarina, Florianópolis.

NORA, P. Entre memória e história: a problemática dos lugares. Projeto História, São Paulo, n.10, pp.7-28, dez. 1993.

OLIVEIRA, C. H. O espetáculo do Ypiranga: mediações entre história e memória. 1999. Tese (Livre-docência em história). Museu Paulista, Universidade de São Paulo, São Paulo.

Delimitação do lugar do grito: propostas e contradições. In: Museu Paulista: um monumento no Ipiranga (História de um edifício centenário e de sua recuperação). São Paulo: Federação e Centro das Indústrias do Estado de São Paulo, 1997.

. Museu Paulista: espaço de evocação do passado e reflexão sobre a história. Anais do Museu Paulista, v. 10/11, pp. 105-126. São Paulo: Museu Paulista, 2003.

(org.) O Museu Paulista e a gestão de Afonso Taunay: escritas da história e da historiografia, séculos XIX e XX. São Paulo: Museu Paulista da USP, 2017.

Oliveira, C. H.; MAtTos, C. (orgs.) O brado do Ipiranga. São Paulo: Edusp, 1999.

Oliveira, G. H. O Espólio Bernardelli no Museu Paulista e o pensamento museológico de Afonso de Escragnolle Taunay: estudos teórico-metodológicos em museologia e a historicidade do fenômeno museal. 
2000. Trabalho de Conclusão de Curso (Especialização em Museologia). Museu de Arqueologia e Etnologia, Universidade de São Paulo, São Paulo, 2000.

Oliveira, L. L. A questão nacional na Primeira República. São Paulo: Brasiliense, 1990.

A conquista do espação: sertão e fronteira no pensamento brasileiro. In: História, ciências, Saúde: Manguinhos, v. 5 (suplemento), pp. 195-215. Rio de Janeiro: Fiocruz, 1998.

- Americanos: representações da identidade nacional no Brasil e nos EUA. Belo Horizonte: UFMG, 2000.

. Nós e eles: relações culturais entre brasileiros e imigrantes. Rio de Janeiro: FGV, 2006.

OLIVEIRA, M. Crítica, método e escrita da história em João Capistrano de Abreu. Rio de Janeiro: FGV, 2013.

OLIVEIRA FILHO, J. C. O Monumento à Independência: registros de arquitetura. Anais do Museu Paulista, v. 10/11, pp. 127-147. São Paulo: USP, 2003.

Oliveira júNIOR, P. Affonso d'E. Taunay e a construção da memória bandeirante. 1994. Dissertação (mestrado). Instituto de Filosofia e Ciências Sociais, Universidade Federal do Rio de Janeiro, Rio de Janeiro.

PAOLI, M. C. São Paulo operária e suas imagens, 1900-1940, n. 33, ano XI, pp. 27-41. São Paulo: Espaço e Debates, 1991.

PAOLI, M. C.; DUARTE, A. São Paulo no plural: espaço público e redes de sociabilidade. In: PORTA, P. (org.). História da cidade de São Paulo. A cidade na primeira metade do século XX, v. 3. São Paulo: Paz e Terra, 2004. pp. 53-99.

PASsos, M. L. A cidade em que as estátuas andam. Revista do Arquivo Municipal. São Paulo, v. 197. pp. 55-63, 1986.

PECCININI, D. A saga da arte de Victor Brecheret: novas perspectivas da origem do modernismo à modernidade nos cenários de São Paulo e da Escola de Paris. Postais: Revista do musen Correios, ano 3, n. 4. pp. 34-95. Brasília: 2015.

PEIXOTO, F. “As cidades nas narrativas sobre o Brasil”. In: FRUGOLI JR., H.; ANDRADE, L.; PEIXOTO, F. (orgs.) As cidades e seus agentes: práticas e representações. Belo Horizonte: Edusp/PUC Minas, 2006. pp.177-197.

A viagem como vocação - Itinerários intelectuais, experiência social e formas de conhecimento. São Paulo: Edusp, 2015.

PEIXOTO, F.; BISPO, A. San Pablo. El edifício Martinelli e la euforia vertical. In: GORELIK, A.; PEIXOTO, F. (orgs.) Ciudades Sudamericanas como Arenas Culturales. Artes y medios, barrios de élite y villas miseria, intelectuales y urbanistas: cómo ciudad e cultura se activan mutuamente. Buenos Aires: Siglo Veintiuno, 2016.

PELLEGRINI, S. Brecheret: 60 anos de notícia. São Paulo: Melhoramentos, 1976.

PEREIRA, D. Descobrimentos de Capistrano. A História do Brasil "a grandes traços e largas malhas". Rio de Janeiro: Apicuri, 2010. 
PEREIRA, L. "Situação territorial dos Kaiowá e Guarani hoje”. In: RICARDO, B.; RICARDO, F. (orgs.) Povos indígenas no Brasil 2011/2016. São Paulo: Instituto Socioambiental, 2017.

PERISSINOTO, T. Classes dominantes e hegemonia na República Velha. Campinas: Unicamp, 1994.

PERUTTI, D. C. Almeida Júnior, gestos feitos de tinta. São Paulo: Alameda, 2011.

PETRONE, M. T. As migrações transoceânicas. In: FAUSTO, B. (org.). História geral da civilização brasileira. O Brasil Republicano. Sociedade e Instituições (1889-1930). Tomo III, v. 2. Rio de Janeiro: Bertrand Brasil, 1977. pp. 93-133.

PIMENTEL, S. Violação dos direitos humanos e a luta pela terra Guarani-Kaiowá. In: VENTURI, G.; BOKANY, V. (orgs.) Indígenas no Brasil: demandas dos povos e percepções da opinião pública. São Paulo: Perseu Abramo, 2013. pp. 85-100.

PIMENTEL, S.; MONCAU, J. Guarani Kaiowá: genocídio surreal. In: RICARDO, B.; RICARDO, F. (orgs.) Povos indígenas no Brasil 2006-2010. São Paulo: Instituto Socioambiental, 2011. pp. 692-696.

PITTA, F. Um povo pacato e bucólico: costume, história e imaginário na pintura de Almeida Júnior. 2013. Tese (Doutorado em Artes Visuais). Escola de Comunicações e Artes, Universidade de São Paulo, São Paulo.

. Os pincéis escrevem a bistória no "Teatro da Memória": o trabalho artístico, intelectual e político de Benedito Calixto nas encomendas de retratos históricos do Museu Paulista (1900-1906). Relatório de pesquisa de pós-doutorado, 2014 [inédito].

PONTES, M. A. A documentação nas práticas artística dos grupos Arte/ Ação e 3nós3. 2012. Dissertação (Mestrado em Artes). Instituto de Artes da Universidade Estadual Júlio de Mesquita Filho, São Paulo.

PORTA, P. (org.). História da cidade de São Paulo. 3 v. São Paulo: Paz e Terra, 2004.

PRADO, A. 1922: itinerários de uma falsa vanguarda. Os dissidentes, a Semana, o integralismo. São Paulo: Brasiliense, 1983.

PRAdo, M. L. A democracia ilustrada: o partido democrático de São Paulo, 1926-1934. São Paulo: Ática, 1986.

PRADO, N. Antônio Prado no Império e na República. Rio de Janeiro: F. Briquet \& Cia., 1929.

PRADO JúnIOR, C. $A$ cidade de São Paulo: geografia e história. $2^{a}$ ed. São Paulo: Brasiliense, 1989.

QUARENTA, E. O apóstolo pregresso e as alegorias da fundação: Anchieta, um mito fundador no IV Centenário da cidade de São Paulo. 2009. Tese (Doutorado em História Social). Faculdade de Filosofia, Letras e Ciências Humanas, Universidade de São Paulo, São Paulo.

QUEIROZ, M. I. Ufanismo paulista: vicissitudes de um imaginário. Revista USP, n. 13. pp. 78-87. São Paulo: USP, 1992.

REgO, A. O sertão e a geografia. Revista do IEB, n. 63, pp. 42-66. São Paulo: IEB, 2016.

REIS, N. Os caminhos de Anhanguera. São Paulo: Via das Artes, 2014. 
REIS FILHO, N. Sobre o local do Museu Paulista. In: GUILHOTTI, A.; LIMA, S.; MENESES, U. (orgs.) Às margens do Ipiranga (1890-1900): exposição do centenário do edifício do Museu Paulista da USP. São Paulo: Museu Paulista/usp, 1990. pp. 23-24.

- São Paulo e outras cidades: produção social e degradação dos espaços urbanos. São Paulo: Hucitec/Edusp, 1994.

RELATÓRIO de violências contra os povos indígenas. Brasília: Cimi, 2015.

RIBEIRO, A. Tradição, nacionalismo e modernidade: o monumento Duque de Caxias. 2006. Dissertação (Mestrado em História da Arquitetura e Urbanismo). Programa de Pós-Graduação em Arquitetura e Urbanismo, Escola de Engenharia de São Carlos/Universidade de São Paulo, São Carlos.

RIBEIRO, B. Cartografias cruzadas: os caminhos do samba e os traçados do Plano de Avenidas em São Paulo (1938-1945). 2018. Dissertação (Mestrado em Antropologia Social). Faculdade de Filosofa, Letras e Ciências Humanas, Universidade de São Paulo, São Paulo.

RICARDO, B.; RICARDO, F. (orgs.) Povos indígenas no Brasil 2011/2016. São Paulo: Instituto Socioambiental, 2017.

RIEGL, A. O culto moderno dos monumentos: a sua essência e a sua origem. São Paulo: Perspectiva, 2014.

RODRigues, J. H. Explicação. In. ABREU, C. Capitulos de história colonial. $7^{\mathrm{a}}$ ed. Belo Horizonte: Itatiaia/ São Paulo: USP, 1988, pp. 11-41.

RODRIGUES, M. Imagens do passado: a instituição do patrimônio em São Paulo (1969-1987). São Paulo: Unesp, 1999.

RODrigues, R. Da Galeria Collectio ao Banco Central do Brasil: percursos de uma coleção de arte. 2015. Dissertação (Mestrado em Artes). Instituto de Artes, Universidade de Brasília, Brasília.

ROLNIK, R. Cada um no seu lugar! São Paulo, início da industrialização, geografia do poder. 1981. Dissertação (Mestrado em Arquitetura). Faculdade de Arquitetura de Urbanismo, Universidade de São Paulo, São Paulo.

Romano, C. A igreja de Santa Cecília e as representações do bandeirante na obra de Benedito Calixto: percalços eclesiásticos em São Paulo, na Primeira República. Revista Brasileira de História das Religiōes, n. 4, maio, pp. 61-84. São Paulo: ANPUH, 2009.

ROSSI, M. Circulação e mediação da obra de arte na Belle Éppoque paulistana. Anais do Museu Paulista, v. 6-7, pp. 83-119. São Paulo: Museu Paulista, 2003.

SALIBA, E. Juó Bananére, o raté do modernismo paulista? Revista de História (USP), v. 126, n. 137, pp. 113-122. São Paulo: USP, 1997.

. Histórias, memórias, tramas e dramas da identidade paulistana. In: PORTA, P. (org.). História da cidade de São Paulo. A cidade na primeira metade do século XX, v. 3. São Paulo: Paz e Terra, 2004. pp. 555-585.

Santos, A. M. A Casa do Bandeirante como espaço museológico (1954-1964). 2016. Dissertação (Mestrado). Interunidades em Museologia, Universidade de São Paulo, São Paulo. 
SANTOS, R. HQs de bumor no Brasil: variação da visão cômica dos quadrinhos brasileiros (1864-2014). Porto Alegre: EDIPUCRS, 2014.

SCHNEIDER, A. Os paulistas e os outros: fama e infâmia na representação dos moradores da capitania de São Paulo nas letras dos séculos XVII e XVIII. Projeto História, v. 57, pp. 84-107. São Paulo: Puc, 2016.

SCHUSTER, S. História, nação e raça no contexto da Exposição do Centenário em 1922. In: História, ciências, saúde: Manguinhos, n. 21, v. 1. Rio de Janeiro: Fiocruz, 2014.

SCHVArZMan, S. Humberto Mauro e as imagens do Brasil. São Paulo: Unesp, 2004.

SCHWARCZ, L. O espetáculo das raças: cientistas, instituições e questão racial no Brasil, 1870-1930. São Paulo: Companhia das Letras, 1993.

Questões de fronteira: sobre uma antropologia da história. Novos estudos, n. 72, p. 119-135. São Paulo: CEBRAP, 2005.

O sol do Brasil. São Paulo: Companhia das Letras, 2008.

SEGAWA, H. Fantasia brasileira: o balé do IV Centenário. São Paulo: Sesc, 1998.

- Prelúdio da metrópole: arquitetura e urbanismo em São Paulo na passagem do século XIX ao XX. São Paulo: Ateliê Editorial, 2000.

. São Paulo, veios e fluxos: 1872:1954. In: PORTA, P. (org.). História da cidade de São Paulo. A cidade na primeira metade do século XX, v. 3. São Paulo: Paz e Terra, 2004. pp. 341-385.

SELIGMANN-SILVA, M. Por uma estética do precário: antimonumentos e a arte de "desesquecer". Fórum Permanente, v. 4, n. 7. Funarte: 2016.

SEVCENKO, N. Rio de Janeiro y San Pablo: desarrollo social y cultural comparativo, 1900-1930. In: HARDOY, J.; MORSE, R. (orgs.) Nuevas perspectivas en los estudios sobre historia urbana latinoamericana. Buenos Aires: Instituto Internacional de Medio Ambiente, 1989.

Museu Paulista: história, mito, crítica. In: GUILHOTTI, A.; LIMA, S.; MENESES, U. (orgs.) Às margens do Ipiranga (1890-1900): exposição do centenário do edifício do Museu Paulista da USP. São Paulo: Museu Paulista/usP, 1990. pp. 22-23.

. Orfeu extático na metrópole: São Paulo, sociedade e cultura nos frementes anos 20. São Paulo: Companhia das Letras, 1992.

SILVA, R. Sobre taipas e textos: um estudo sobre as narrativas a respeito da cidade de São Paulo. São Paulo: Alameda, 2013.

SILVA-NIGRA, D. C. A Ordem dos Beneditinos na cidade de São Paulo. In: Ensaios paulistas. São Paulo: Anhambi, 1958. pp. 124-137.

SIMIONI, A. P. "Eternamente amadoras: artistas brasileiras sob o olhar da crítica (1885-1927)". In: FABRIS, A. (org.). Crítica e modernidade. São Paulo: ABCA/Imesp, 2006.

SIMIONE, A. P; LIMA JUNIOR, C. Heroínas em batalha: figurações femininas em museu em tempos de Centenário: Museu Paulista e Museu Histórico Nacional, 1922. Revista do programa da pós-graduação 
em ciência da informação da Universidade de Brasília. Museologia \& Interdisciplinaridade, v. 7, n. 13, pp. 31-54. Brasília: UNB, 2018.

SINGH JÚNIOR, O. "A partida da monção", de Almeida Júnior. 2004. Dissertação (Mestrado em História). Universidade Estadual de Campinas, Campinas.

SOUZA, L. Vícios, virtudes e sentimento regional: São Paulo, da lenda negra à lenda áurea. Revista de História, n. 142-143, pp. 261-276. São Paulo: UsP, 2000.

STRATHERn, M. “The decomposition of an event”. Cultural Anthropology, vol. 7, n. 2, pp. 244-254, 1992.

Artefatos da história: os eventos e a interpretação de imagens. In. O efeito etnográfico e outros ensaios. São Paulo: Cosac Naif, 2014. pp. 211-229.

STUMPF, L. A terceira margem do rio: mercado e sujeitos na pintura de história de Antônio Parreiras. Dissertação (Mestrado). 2014. Instituto de Estudos Brasileiros, Universidade de São Paulo, São Paulo.

TAUSSIG, M. Mimesis and Alterity: a particular history of the senses. Londres: Routledge, 1993. Defacement. Stanford: Stanford University Press, 1999.

TOledo, B. L. O Caminho do Mar. Revista do Instituto de Estudos Brasileiros, n. 1, pp. 37-51. São Paulo: IEB/USP, 1966. - Anhangabaú. São Paulo: Federação das Indústrias de São Paulo, 1989.

Artes, 1996. . Prestes Maia e as origens do urbanismo moderno em São Paulo. São Paulo: Empresa das

TORRES, M. C. Ibirapuera: história dos bairros de São Paulo. São Paulo: Secretaria de Educação e Cultura, 1977.

TOTA, A. P. O amigo americano: Nelson Rockfeller e o Brasil. São Paulo: Companhia das Letras, 2014. TREECE, D. Exilados, aliados, rebeldes. São Paulo: Edusp, 2008.

TREnTo, A. Do outro lado do Atlântico: um século de imigração italiana no Brasil. São Paulo: Nobel, 1989.

VAinfas, R. Texto introdutório. In. SAnTIAgO, S. (Org.). Intérpretes do Brasil, v. 2. Rio de Janeiro: Nova Aguilar, 2000, pp. 3-23.

VALENTINI, L. Um laboratório de antropologia: o encontro entre Mário de Andrade, Dina Dreyfus e Claude Lévi-Strauss. São Paulo: Alameda, 2013.

Valladares, C. Arte e sociedade dos cemitérios brasileiros. Rio de Janeiro: Conselho Federal de Cultura/MEC, 1972.

VILLA, M. A. 1932: imagens de uma Revolução. São Paulo: Imprensa Oficial, 2008. 
VELloso, M. O mito da originalidade brasileira: a trajetória intelectual de Cassiano Ricardo (dos anos 20 ao Estado Novo). 1983. Dissertação (Mestrado). Departamento de Filosofia, Pontifícia Universidade Católica do Rio de Janeiro, Rio de Janeiro.

A brasilidade verde-amarela: nacionalismo e regionalismo paulista. Estudos Históricos, vol. 6, n. 11, pp. 89-112. Rio de Janeiro: FGV/CPDOC, 1993.

VERnANt, J. P. Mito e pensamento entre os gregos. Rio de Janeiro: Paz e Terra, 1990. Mito e sociedade na Grécia antiga. Rio de Janeiro, José Olympio, 1999.

VIANY, A. Humberto Mauro: sua vida/ sua arte/ sua trajetória no cinema. Rio de Janeiro: Editora Artenova/Embrafilme, 1978.

WARBURG, A. Histórias de fantasma para gente grande: escritos, esboços e conferências. São Paulo: Companhia das Letras, 2015.

Waldman, T. Moderno bandeirante: Paulo Prado entre espaços e tradições. São Paulo: Alameda, 2014.

WeIMER, G. A Casa do Bandeirante: uma revisão de suas origens. Revista do Instituto Histórico e Geográfico do Rio Grande do Sul, n. 149, Porto Alegre. pp. 89-104, 2015.

WeINSteIn, B. The Color of Modernity: São Paulo and the Making of Race and Nation in Brazil. Durham: Duke University Press, 2015.

YATES, F. A arte da memória. Campinas: Unicamp, 2007.

ZANETTINI, P. E. Maloqueiros e seus palácios de barro: o cotidiano doméstico na Casa Bandeirista. 2005. Tese (Doutorado em Arqueologia). Museu de Arqueologia e Etnografia da Universidade de São Paulo, São Paulo.

ZUQUIM, J.; CYTRYNOWICZ, R. Notas para uma história do escotismo no Brasil: a "psicologia escoteira" e a teoria do caráter como pedagogia de civismo (1914-1937). Educação em Revista. Belo Horizonte, n. 35, 2002. pp. 43-58. 